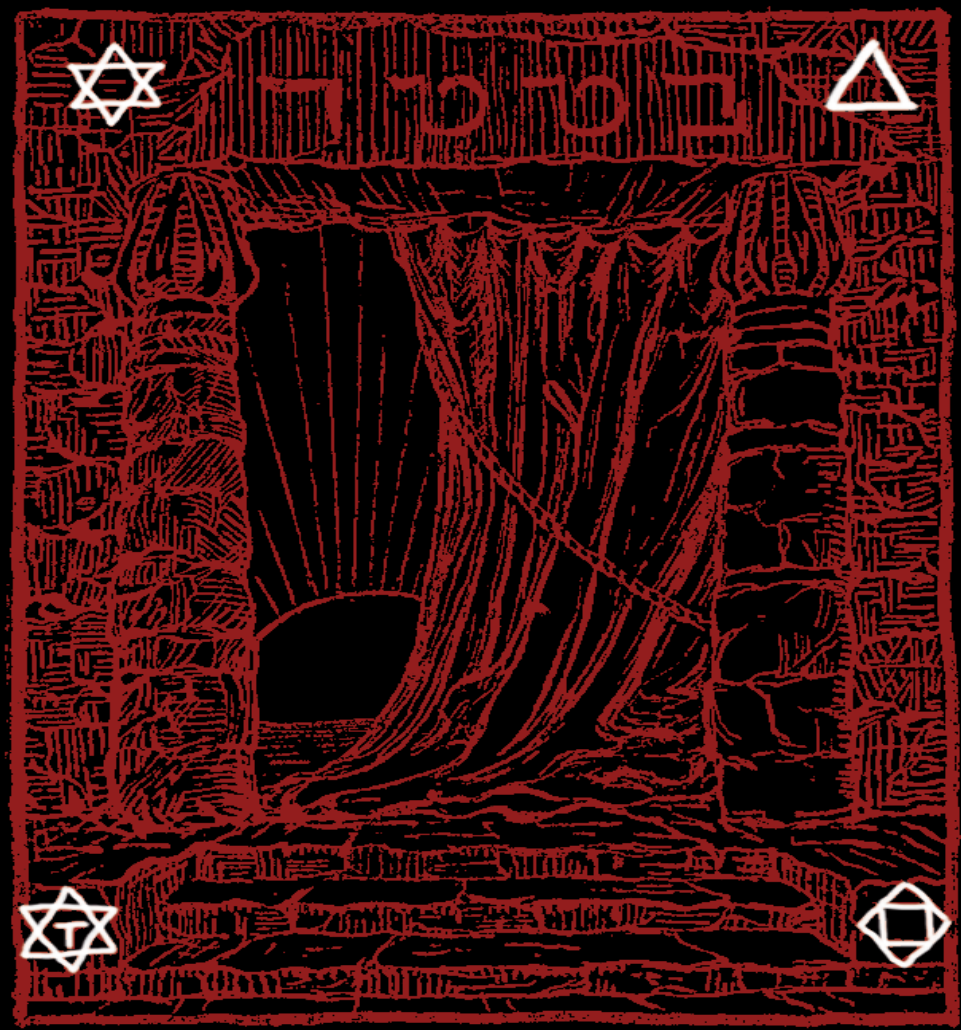

\title{
The NEW AGE of RUSSIA OCCULT AND ESOTERIC DIMENSIONS
}
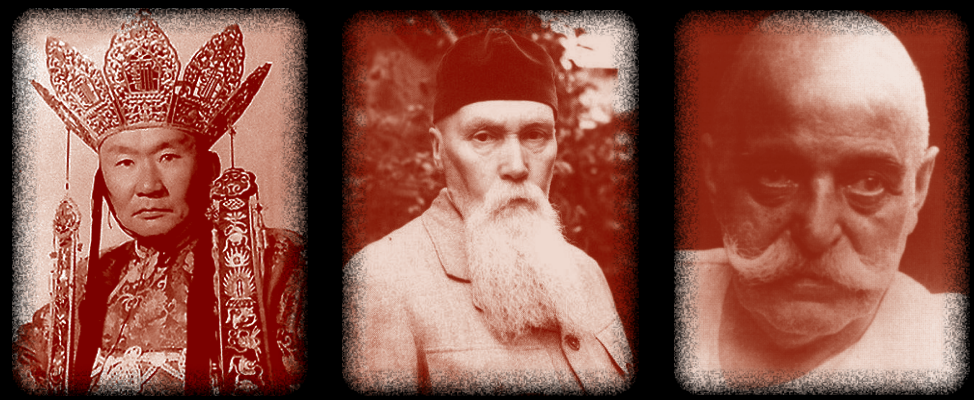

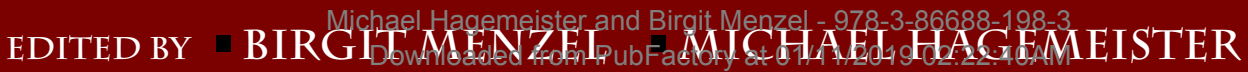
BERNICE GLATZER ROSENTHALE access 
The New Age of Russia

Occult and Esoteric Dimensions

Michael Hagemeister and Birgit Menzel - 978-3-86688-198-3

Downloaded from PubFactory at 01/11/2019 02:22:40AM

via free access 
Michael Hagemeister and Birgit Menzel - 978-3-86688-198-3

Downloaded from PubFactory at 01/11/2019 02:22:40AM

via free access 


\title{
THE NEW AGE OF RUSSIA OCCULT AND ESOTERIC DIMENSIONS
}

\author{
EDITED BY \\ BIRGIT MENZEL, \\ MICHAEL HAGEMEISTER AND \\ BERNICE GLATZER ROSENTHAL
}

Verlag Otto Sagner · München-Berlin 2012 


\section{Studies on Language and Culture in Central and Eastern Europe Edited by Christian Voß, Volume 17

Bibliographic information published by the Deutsche Nationalbibliothek The Deutsche Nationalbibliothek lists this publication in the Deutsche Nationalbibliografie; detailed bibliographic data are available in the Internet at http://dnb.d-nb.de (C) 2012 by Kubon \& Sagner GmbH

Heßstraße 39/41

80798 München (Germany)

www.kubon-sagner.de

«Verlag Otto Sagner» is an imprint of Kubon \& Sagner GmbH.

All rights reserved, including the rights of translation. No part of this book may be reproduced in any way without the permission of the publisher.

Layout: robert jones

Cover: Christopher Triplett

Printed in Germany by: Difo Druck

ISSN: $1868-2936$

ISBN: 978-3-86688-197-6

ISBN (eBook): 978-3-86688-198-3 


\section{CONTENTS}

$\begin{array}{ll}\text { Acknowledgements } & 7\end{array}$

Note on Transliteration $\quad 8$

$\begin{array}{lr}\text { Illustrations } & 9\end{array}$

$\begin{array}{ll}\text { Introduction } & 11\end{array}$

Birgit Menzel

\section{Prerevolutionary Roots and Early Soviet Manifestations}

The Occult and Popular Entertainment in Late Imperial Russia

Julia Mannherz

The History of Esotericism in Soviet Russia in the 1920s-1930s

Konstantin Burmistrov

The Occultist Aleksandr Barchenko and the Soviet Secret Police (1923-1938)

Oleg Shishkin

From Synarchy to Shambhala: The Role of Political Occultism and Social Messianism in the Activities of Nicholas Roerich Markus Osterrieder

Konstantin Tsiolkovskii and the Occult Roots of Soviet Space Travel Michael Hagemeister

\section{Manifestations in the Soviet Period (1930-1985)}

Occult and Esoteric Movements in Russia from the 1960s to the 1980s Birgit Menzel

Away from the Globe. Occultism, Esotericism and Literature in Russia during the $1960 \mathrm{~s}-1980 \mathrm{~s}$

Leonid Heller

Guests from Outer Space. Occult Aspects of Soviet Science Fiction Matthias Schwartz 
Totalitarian Utopia, the Occult, and Technological Modernity in Russia: The Intellectual Experience of Cosmism

Marlène Laruelle

III The Occult Revival in Late and Post Soviet Russia (1985 to the Present)

Occult and Esoteric Doctrines after the Collapse of Communism

Demyan Belyaev

Occult Dissident Culture: The Case of Aleksandr Dugin

Mark Sedgwick

The Rodnoverie Movement: The Search for Pre-Christian Ancestry and the Occult

Marlène Laruelle

Through an Occult Prism: The Bolshevik Revolution in Three Post-Soviet

Novels

Marina Aptekman

Shamanism in the Russian Intelligentsia (Post-Soviet Space and Time)

Natalia Zhukovskaia

Competing Legacies, Competing Visions of Russia:

The Roerich Movement(s) in Post-Soviet Russia

John McCannon

On the Way from Border Conflicts: Transpersonal Psychology in Russia Boris Falikov

\section{Comparative Aspects, Continuity and Change}

Occultism as a Response to a Spiritual Crisis

Bernice Glatzer Rosenthal

On Reading Russian Mystical Literature Upside-Down

Jeffrey J. Kripal

Select Bibliography

Michael Hagemeister

About the Contributors 


\section{ACKNOWLEDGEMENTS}

This book grew in part out of the research conference „The Occult in 20th Century Russia. Metaphysical Roots of Soviet Civilization," which was held on 11-13 March 2007 in Berlin, organized by Birgit Menzel, in cooperation with the Deutsche Gesellschaft für Osteuropakunde (DGO) and the Harriman Institute at Columbia University, New York. We would like to thank all participants of the conference for their presentations, in particular Catharine TheimerNepomnyashchy, Mikhail Epstein, Michael Eskin, Renata von Maydell, Tatyana Meira-Kochetkova, Valentin Nikitin, Arkady Rovner and Rebecca Jane Stanton. Special thanks go to the intrepid translator of the Russian contributions (Burmistrov, Shishkin, Heller, Zhukovskaya, Belyaev, Falikov), Josephine von Zitzewitz. Grateful acknowledgement is made to both institutions, as well as the Deutsche Forschungsgemeinschaft (DFG), which funded that conference. These agencies are not responsible for the findings of this conference or for any of the interpretations therein. 
Transliteration follows the Library of Congress system except that the familiar English spelling is used for well-known persons and terms such as:

Andrei Bely

Elena Blavatsky

Fedor Dostoevsky

Nikolai Gogol

Maxim Gorky

Gurdjieff, Gurdjieffian, Gurdjievist movement

Nicholas and Elena Roerich

Vladimir Soloviev

Peter Tchaikovsky

Lev Tolstoy

Leonid Vasiliev

Boris Yeltsin

Kabbalah

Shambhala

The Library of Congress transliteration is used in the footnotes. 


\section{ILLUSTRATIONS}

On the cover

1. Ex libris from Grigorii O. Möbes (1910-1920s) (private collection K. Burmistrov);

2. Bidia Dandaron (private archive Vladimir Montlevich);

3. Nicholas Roerich (courtesy of the Nicholas Roerich Museum, New York).

p. 35 "The Spiritualist Appearance" as an optical illusion (1883).

p. 36 The Woman-Spiritualist.

p. 38 Psychographology.

p. 47 Married by Satan (1917) (N.I. Baburina, Plakat nemogo kino, Moscow, 2001).

p. 49 Ornal'do hypnotizing audiences in the ring and front rows (1930s).

p. 83 Aleksandr Barchenko (private archive O. Shishkin)

p. 86 Symbol of Diunkhor (private archive O. Shishkin)

p. 90 Gleb Bokii (1918) (private archive O. Shishkin)

p. 150 Konstantin Tsiolkovskii, Palekh lacquer miniature, ca. 1980, postcard (private archive M. Hagemeister)

p. 159 Cover of the Samizdat zhurnal Okkul'tizm i ioga (private archive K. Burmistrov)

p. 174 Dzhuna Davitashvili in one of the special clinics in Moscow (early 1980s) (private archive Russell Targ)

p. 178 “Tosha” from the book Sergei Beliaev, Ostrye kunty. Put' russkogo mistika. Tosha-russkii Budda (St. Petersburg, 2002) (www.ark.ru) 
Michael Hagemeister and Birgit Menzel - 978-3-86688-198-3

Downloaded from PubFactory at 01/11/2019 02:22:40AM

via free access 


\title{
INTRODUCTION
}

\author{
BIRGIT MENZEL
}

This book is not about what the Orthodox Church and traditional religions regard as sects. It is not about magicians, superstition and folk beliefs, although pagan double-belief ${ }^{1}$ (dvoeverie) and some traditional folk beliefs in Russia lived well into the $20^{\text {th }}$ century. It is not about traditional Asian religions, including Buddhism and Shamanism, although much is borrowed from them, and Russian mixtures sometimes come closer to their original spheres than in Western countries. And it is not about popular entertainment or the spiritual marketplace, although many formerly exclusive concepts and experiences have entered main-stream commercialized culture since the 1990s in both East and West. This book is about non-conformist spiritual seekers, about individual quests beyond the dogmas of both the political and the religious powers that ruled Russia throughout its history, especially in the $20^{\text {th }}$ century. It is about Russians, mostly intellectuals, who, with a problematic experience of modernity in an atheist and post-atheist society, turned to non-conventional metaphysical quests and practices. These generally unknown phenomena in Russian society are relevant to an understanding of the post-Soviet present.

In early $20^{\text {th }}$ century Russia, ambivalence about the new world and the uncomfortable recognition of the ultimate uncertainty of all human knowledge, which neither scientific nor legal experts nor the churches could resolve, intensified the desire for wholeness, harmony and synthesis and led many people unhappy with modernity to embrace the new occult doctrines. ${ }^{2}$ Soviet rule, especially in Stalin's time, attempted to eliminate all metaphysical thought.

1 Double-belief is a term for a long-living mixture of Christian-orthodox and pagan belief systems in Russia. See Iurii Lotman, Boris Uspenskii, "The Role of Dual Models in the Dynamics of Russian Culture (Up to the End of the Eighteenth Century)," In: Iu. Lotman, B. Uspenskii, The Semiotics of Russian Culture, ed. Ann Shukman (Ann Arbor: University of Michigan, 1984), 3-35 (Russ. in B. Uspenskii, Izbrannye stat'i v 2 tomakh, t. 1 (Moscow, 1994), 219253.

2 See Isabel Wünsche, Harmonie und Synthese. Die russische Moderne zwischen universellem Anspruch und nationalkultureller Identität (Munich: Fink, 2008). See also, Corinna Treitel, A Science for the Soul. Occultism and the Genesis of the German Modern (Baltimore and London: Johns Hopkins University Press, 2004), 246, 248. 


\section{Birgit Menzel}

People engaged in occult or esoteric thinking and practices had to go underground or were sent to the GULag. Yet, we must not forget that there were uses of the occult by the Soviet state. These ranged from trading the life of the theosophical Buddhist mystic Nicholas Roerich in exchange for U.S. dollars and Soviet propaganda abroad in the 1920s and 30s to experiments with mind control and psychic warfare for political and military reasons, which was also practiced in the U.S. ${ }^{3}$ The end of the Soviet Union and the breakdown of a bipolar world-order have affected concepts of history, as well as the sciences and humanities. It has brought a reconsideration of boundaries and paradigms of rationality. Coming to terms with the global experiment of communism has revealed shadows of modernity and enlightenment. Post-colonial approaches have re-evaluated perspectives beyond traditional hierarchies and the asymmetries of power and have helped develop holistic concepts that integrate Eastern and Western philosophies, religions, artistic practices and life-styles. Quantum physics and mechanics have expanded basic notions in the sciences and opened up new dialogues with religion and the humanities. Seen from today's post-modernist perspective some phenomena from early $20^{\text {th }}$ century recur. For example, Theosophical and Anthroposophical associations were refounded in the 1990s and reestablished their international networks. ${ }^{4}$ Other phenomena are altogether new, but all have become part of a new context that challenges conventional paradigms.

Since the fall of communism, and even before, there has been a marked return of religion in both the East and in the West. It can be seen in the sense of a reverence for the great established religions, but also in a wide range of quests for new spiritual orientations. This yearning has been manifested on all levels of society, in high culture as well as in popular culture and everyday life.

One of the fastest growing areas involved is an immersion in the ideals and practices of the occult and esoteric. Many Western scholars of contemporary Russia have encountered this prevalence of occult and esoteric ideas and topics

3 For Roerich see Robert C. Williams, "Mysticism and Money: Nicholas Roerich," In: Russian Art and American Money. 1900-1940 (Cambridge/Mass.: Harvard UP, 1980), 111-147. For Russia see Henry Gris, William Dick, The New Soviet Psychic Discoveries (Englewood Cliffs, N.J.: Prentice Hall, 1978), chapter 3. For the U.S. there are numerous studies. One of the first was José M.R. Delgado, Physical Control of the Mind. Toward a Psychocivilized Society (New York: Harper \& Row, 1969); Alex Constantine, Virtual Government, CIA, Mind Control Operations in America (Venice, CA.: Feral House, 1997); John Marks, The Search for the 'Manchurian Candidate'. The CIA and Mind Control (New York: Norton, 1991).

4 For the revival of theosophy see Bernice Rosenthal, "The Occult in Modern Russian and Soviet Culture. An Historical Perspective,” In: Theosophical History 4 (1992-93), 252-259. 
in post-Soviet culture either through the vast literature or simply by visiting bookstores and street vendors in Moscow and St. Petersburg, as well as other cities, such as Kazan', Novosibirsk and Khabarovsk. It is almost impossible to understand contemporary Russian literature without being equipped with an encyclopedia of the occult. ${ }^{5}$ In the 1990s no less than 36 percent of all nonfiction publications in the humanities dealt with occult-esoteric topics. ${ }^{6}$ Some former Soviet thick journals, such as Literaturnoe obozrenie and Nauka i religiia, have adopted a whole new profile with publications on aspects of the occult.

This revival has been described by some Western scholars, for instance, Eliot Borenstein, Valentina Brougher and Holly deNio Stephens, as a phenomenon of popular culture, and one might be quick to assume that it represents a primarily one-way import of New Age ideas and publications flooding into commercialized Russia from the West. ${ }^{7}$ We will argue, that the occult revival in Russia is by no means simply a question of popular culture. The fascination with esoteric, supernatural and non-orthodox spirituality, with popular utopian and pagan folk traditions in post-Soviet Russia can be found on all levels of intellectual and artistic life, including the sciences and politics. One can discern a considerable impact of esoteric ideas and ideologies not only in the humanities, but also on the sciences: newly established organizations based on "Russian cosmism," a hybrid ideological concept of human self-

5 See Birgit Menzel, “The Occult Revival in Russia Today and Its Impact on Literature,” In: The Harriman Review, vol. 16, no. 1 (Spring 2007).

6 For an empirical study on esoteric orientations of the population in Russia today see Demian Belyaev's chapter in this volume. In 1993-2001, 63\% of the $76 \%$ who declared themselves as Orthodox, believe in supernatural powers present in life, 35\% of them believe in magic and $30 \%$ in fortunetelling, although only $8 \%$ had once been active and only $3 \%$ are still actively involved in magic. See Iurii Sinel'nikov, Izmenenie religioznosti naseleniia Rossii. Pravoslavnye, musul'mane, suevernye povedenie Rossiian (Moscow: Nauka, 2006). Also see the rich body of material on non-traditional religions and belief systems in M. Burdo [Bourdeaux], Sergei Filatov, Sovremennaia religioznaia zhizn'v Rossii. Opyt sistematicheskogo opisaniia, 4 vols. (Moscow: Logos, 2005).

7 Valentina G. Brougher, "The Occult in Russian Literature of the 1990s," Russian Review 56, (1997), 1, 111-124; Holly deNio Stephens, "The Occult in Russia Today," In: The Occult in Russian and Soviet Culture, ed. Bernice Glatzer Rosenthal (Ithaca/London: Cornell UP, 1997), 357-76; Bernice Glatzer Rosenthal, “Russia’s Occult Revival,” In: East-West Church and Ministry Report, August 1,1999; Eliot Borenstein, "Suspending Disbelief: 'Cults' and Postmodernism in Post-Soviet Russia," In: Consuming Russia: Popular Culture, Sex, ad Society Since Gorbachev, ed. Adele Marie Barker (Durham: Duke University Press, 1999), 437-62; idem, "Survival of the Catchiest. Memes and Post-Modern Russia," Slavic and East European Journal, 48 (2004), 3, 462-83. 


\section{Birgit Menzel}

perfection and salvation, such as the Association for a Complex Survey of the Russian Nation (Assotsiatsiia po kompleksnomu izucheniiu russkoi natsii, $A K I R N$ ), which has ties with several Pan-Slavist circles, closely collaborates with the Slavic International Union of Aviation and Aeronautics (Slaviakosmos), the Mir Station, and the Museum of the History of Aviation and Aeronautics. ${ }^{8}$ The sheer number of conferences and research projects, university course offerings and college textbooks on supernatural powers, from bioenergy theories, the so-called "torsionic" fields, to UFO's and cosmic consciousness, produced by scientists at the highest academic ranks has been so disturbing that in 2002 a commission within the Russian Academy of Sciences (RAN) was founded to warn and propagate against the spread of "obscure pseudoscience." The occult is also connected to the healing sciences. Shamanism as an alternative medicine has entered scientific discourses in Russia and in the West. ${ }^{10}$ In July 2005 and July 2010, the International Congress of Transpersonal Psychology was held in Moscow for the first time. Transpersonal psychology, a branch of professional psychology, was founded in the 1960s by the Czech-American psychiatrist Stanislav Grof and the American psychologist Ken Wilber and is based on an esoteric approach and worldview, accepting paranormal experience as a reality. ${ }^{11}$ We will show that today's occult revival should be seen, first of all, as the result of seven decades of the forceful suppression of metaphysical thought in Russia. The spiritual vacuum caused by

8 See, for instance, the $8^{\text {th }}$ Pan-Slavist Convention in April 2001, held on the initiative of the Pan-Slavist Council of N. I. Kikechev. The AKIRN was founded by Evgenii Troitskii. See Marlène Laruelle, "Futuristic Religion and Air Space Conquest: The Conception of the Universe (Kosmos) in the Russian Cosmism Ideology," paper delivered at the ICCEES, July 28, 2005, Berlin.

9 See "Obskurantizm v postsovetskuiu èpokhu," In: Rossiia: Tret'e tysiacheletie. Vestnik aktual'nykh prognozov, no. 8, vol. 2 (Spetsvypusk 'Nauka v Rossii': Stsenarii razvitiia 46-161), ed. Eduard Krugliakov (Ekspertnyi Sovet RAN pri administratsii Prezidenta po bor'be s lzhenaukoi) ( Moscow, 2004).

10 See Dagmar Eigner, Ritual, Drama, Imagination. Schamanistische Therapie in Zentralnepal, Habilitationsschrift Medizin (Vienna: Universitätsverlag, 2001); Bol'shaia èntsiklopediia narodnoi meditsiny (Minsk, 1999).

11 See the Russian Transpersonal Psychology and Psychotherapy Association (www.atpp.ru), which was founded in 2002. For a report on the conference "Human Consciousness, Human Values in an Interconnected World; A Transpersonal Approach," see www.transpersonalcentre.co.uk/moscoweurotas.htm. See also Boris Falikov's chapter in this volume. For a basic study on this see Irreducible Mind. Toward a Psychology for the $21^{\text {st }}$ Century, ed. Edward Kelly, Emily Williams Kelly et al (Boulder/New York: Rowman\&Littlefield, 2007, 2010). 
the downfall of Communism together with a traditionally strong desire to believe helps to explain the impact of belief systems outside the established religions. As Mikhail Epstein writes, "many more people now exit atheism than enter the churches. They exit atheism without arriving, they stay somewhere at the crossroads." 12 The Russian people have a desire for wisdom, unity and a holistic being, which reaches out beyond the dogmas and traditions of the established religions:

Imagine a young man from a typical Soviet family who for three or four generations has been completely cut off from any religious traditions. And now that he hears a calling, the voice of God from above, this young man is unable to determine into which church, under which roof he should take cover. All historical religions are equally alien to him. He seeks belief and finds only religious confessions [veroispovedaniia]. [...] And it is precisely in this gap between [the yearning for] belief and [traditional] confessions that the poor religion emerges, one without dogma, books, or rituals. [...] This crossroads is in fact the crucial point, where all paths merge. A point of common belief, equally accepting all belief systems as leading to one unified belief. [...] Simply belief, belief in the Good, [...]. Poor religion is a religion without further definition. ${ }^{13}$

For Epstein, this particular search for spiritual reorientation which he calls "poor religion" or "religious modernism", is a uniquely post-atheist phenomenon, and thus inseparably linked with the Soviet past. While all believers had formerly been equal in relation to the monolithic atheist state, the negative sign has now been turned into a positive one in the same totalizing undistinguished way. This uniqueness, however, is open to question, if the religious renaissance is seen in a broader international context. Wouter Hanegraaff, professor of the History of Hermetic Philosophy and Related Currents at the University of Amsterdam, argues that "the emergence of modernity itself is intertwined with the history of esotericism." However, "surviving examples [...] of western esoteric currents are not recognized as an integral part of our collective cultural heritage and are insufficiently documented, studied and preserved." ${ }^{14}$

12 Mikhail Epshtein, Na granitsakh kul'tur. Rossiiskoe-Amerikanskoe-Sovetskoe (New York: Slovo-Word, 1995), 315.

13 Ibid.

14 Wouter Hanegraaff, Masonic \& Esoteric Heritage. A NewPerspective for Art and Conservation Policies, http://www.amsterdamhermetica.com; and quoted from Mark Sedgwick, Against the Modern World. Traditionalism and the Secret Intellectual History of the Twentieth Century (Oxford: Oxford University Press, 2004), 13. 
It is commonly maintained that during the Soviet period occult traditions were cut off. This book offers material to revise such opinions. Soviet civilization defined itself as a purely rational ideocratic society, based on work, on science, and empirical knowledge, yet its cult of the rational was taken to such an extreme that one could speak in terms of a "rationalistic religion." In the 1920 s and again in the late 1950s and early 1960s, when science merged with utopian thinking, when during the proclaimed "cosmic era" borders shifted between science and science fiction, certain disciplines, for example, telepathy, hypnosis and parapsychology-three topics traditionally connected with spiritual and occult thought—all experienced a boom. Commissions at the Academy of Science explored the phenomena of alien intelligence, intergalactic UFOs, the Tungus meteorite in Siberia and anthropoids (the Abominable Snowman/Yeti) in the Tibetan Himalayas. ${ }^{15}$ Nuclear submarines were commissioned to find the mythical "blue continent" Atlantis on the bottom of the sea, Khrushchev declared 1960 in New York, that human reason can nowadays create miracles to be possible, and Iurii Gagarin was paralleled with Christ's ascension to and return from heaven. ${ }^{16}$ All these projects evoked strong popular interest and were accompanied by extended discussions in popular scientific journals. ${ }^{17}$ Paradoxically, with its strictly defined borders of science-the humanities seen as part of science-its borders were at the same time much less strictly defined, so that phenomena excluded from the Western scientific paradigm were studied or declared scientific within the Soviet academic system.

Since the 1960s and 1970s, there has been a marked reaction against this 'cult of the rational' and countervailing concepts became popular in both artistic practice and everyday life. Expressions of reaction against "Soviet-speak" include the playful undermining of the official rituals or political selfrepresentation by mystical circles and sects in the two capitals and in other

15 On parapsychology and the Abominable Snowman see Informatsionnye materialy Komissii po izucheniiu voprosa o 'snezhnom cheloveke', 4 vols. (Moscow, 1958-59). On the hypotheses about the Tungus meteorite, see N. Vasil'ev, Tungusskii meteorit. Kosmicheskii fenomen leta 1908g. (Moscow, 2004), 256-266. See Matthias Schwartz' chapter in this volume.

16 On Atlantis see for instance Ekaterina Khagemeister, "Udivitel'noe skhostvo dat geologicheskoi istorii Atlantidy s noveishimi dannymi o lednikovom periode," Tekhnika-molodezhi, No. 12 (1956), 17-18; Khrushchev quoted in Vladimir L'vov, "Na zare kosmicheskoi èry (Malaia kosmicheskaia èntsiklopediia)," Vokrug sveta no. 10 (1961), 4; V. Mezentsev, "V gostiakh u bogov," Znanie-sila, no. 9 (1962), 2.

17 See Matthias Schwartz, Die Erfindung des Kosmos. Zur sowjetischen Science Fiction und populärwissenschaftlichen Publizistik vom Sputnikflug bis zum Ende der Tauwetterzeit (Frankfurt: Lang, 2003), 83-104. 
cities; a rediscovery of eastern religious concepts and philosophy; and experiments with drugs and transcendental practices that expand consciousness. The occult opened up paths of metaphysical exploration, spiritual growth, and individual self-empowerment.

All this raises questions, such as: What are the effects of the idiosyncratic Russian expressions of reactions against Soviet order and reality (i.e. to be found in such cults as an obsession with trash $\left.{ }^{18}\right)$ ? Where can one pinpoint connections or divergences between the old (Soviet) cults and various new ones? How have the borders between established religions, such as orthodox Christianity, Islam, Buddhism/Hinduism, Judaism and unconventional religious practices to be found in Shamanism and other esoteric beliefs, shifted in this recent turn to religion? How did occult ideas influence, shape or merge with Soviet science, politics, culture and society which explicitly declared themselves as atheist and anti-metaphysical? How did popular occult uses change after the Revolution? And how did they change after Perestroika? How and by whom were modern, $20^{\text {th }}$ century scientific and technological tools applied in the Soviet period? How were they used to deconstruct other belief systems?

While the return of traditional religions has been studied extensively, ${ }^{19}$ superstition, sects and magic have been analyzed, ${ }^{20}$ and recent studies on $20^{\text {th }}$ century Russia have reconsidered paradigms of rationality focusing on emo-

18 See Mikhail Epshtein, Cries in the Wilderness (Philadelphia: Paul Dry Books, 2002), russ. Novoe sektantstvo. Tipy religiozno-filosofskogo umonastroeniia $v$ Rossii (1970-1980), ed. Roman Levin (Holyoke: New England, 1993; and Moscow, 2005).

19 See for instance Kimmo Kääriäinen, Dmitri Furman, "Religiosity in Russia in the 1990s," In: Religious Transition in Russia, ed. Matti Kotiranta (Helsinki: Kikimora, 2000), 28-75; Kathrin Behrens, Die russische orthodoxe Kirche: Segen für die ,neuen Zaren'? Religion und Politik im postsowjetischen Russland (1991-2000) (Paderborn: Schöningh, 2002); John and Carol Garrard, Russian Orthodoxy Resurgent. Faith and Power in the New Russia (Princeton/Oxford: Princeton University Press, 2008).

20 See Sergei Filatov, Sovremennaia Rossiia i sekty, Inostrannaia literatura, no. 8, 1996 (http://magazines.russ.ru/inostran/1996/8/filatov.html). Faith Wigzell, Reading Russian Fortunes (Cambridge, 1998); Aleksandr Panchenko, Khristovshchina i skopchestvo. Fol'klor i tradistionnaia kul'tura russkikh misticheskikh sekt (Moscow: OGI, 2002); Laura Engelstein, Castration and the Heavenly Kingdom. A Russian Folktale (Ithaca: Cornell University Press, 1999); Aleksandr Etkind, Khlyst (Sekty, literatura i revoliutsiia) (Moscow: NLO, 1998); William F. Ryan, The Bathhouse at Midnight. Magic in Russia (University Park: Pennsylvania State University Press, 1999). See also the excellent study of Leonid Heller/Michel Niqueux, Geschichte der Utopie in Russland (Bietigheim-Bissingen: ed. tertium, 2003); much shorter Histoire de l'Utopie en Russie (Paris: PUF, 1995). 
tions and the irrational, in conditioning individuals by State dogma as well as shaping a specific type of Soviet civilization, ${ }^{21}$ it is quite remarkable how little scholarly attention has been given to spiritual and occult practices and thought in Soviet and post-Soviet society. Reasons for this reluctance can be found both in the specific historical conditions and in problems met by scholars.

In Russia, the borders between science and religion and the Occult have differed from those in the West for several reasons: Russian Orthodox Christianity, rooted in the Byzantine, i.e. Eastern tradition, has always been open to mystic experience and esoteric knowledge. Mystical, utopian and pagan roots in religious and intellectual belief systems and more generally in Russian folk culture were stronger than in modern Western societies and had a pervasive influence throughout the twentieth century. Asian philosophy and religions, including indigenous Shamanism and Sufism, have been part of the Empire, transferred by Siberian, Buriat, Caucasian and Central Asian traditions, and survived into the $20^{\text {th }}$ century, offering alternatives to European Russians.

Research on this topic also faces methodological problems. There is a great variety of material which at the same time is extremely scattered, with sources hardly accessible, often unreliable, and the scholar is faced with mystifications and mythologizing. Last, but not least, research faces terminological challenges, especially when Russian and Western scholars try to cooperate. So explanation of the terminology in this book is necessary.

\section{Terms}

All terms to describe the phenomena presented in this book have been controversial. Most of them are not terms the practitioners would use to describe themselves. Likewise, the academic field established in the West has offered definitions which did not always find the approval of the authors of this volume and the Russian scholars involved in its production. The terms Occult and New Age have been rejected by most Russian members of, what I will call here the occult underground. Russian adherents of cosmism for instance strongly reject any connection with the occult or the esoteric, ${ }^{22}$ although by Western

21 See Oleg Kharkhordin, The Collective and the Individual in Russia. A Study of Practices (Berkeley/Los Angeles: University of California Press, 1999); Caryl Emerson, "Soviet civilization. Its Discontent, Disasters, Residual Fascinations”, The Hudson Review, 44 (Winter 1992), 4, 57484; Corliss Lamont, Soviet Civilization (Kessinger, 2007); Stephen Kotkin, Magnetic Mountain: Stalinism as a Civilization (Berkeley/CA., 1995).

22 Information from Anastasiia Gacheva (Fedorov-museum in Moscow) by e-mail (12.1.2009). 
academic definition they certainly would be included. There are also newly coined terms such as Russian Sannyasin, a Hindu term for wandering monks who dedicate their entire life to spiritual pursuits. Since the 1990s the term esotericism (ezoterizm) has been emphasized by academic scholars to distinguish it from mass cultural popular uses which are called ezoterika. The History of Esotericism (istoriia ėzoterizma) has even become an academic program for universities as part of the new subject of Religious Studies. ${ }^{23}$

The disagreement on terms defined in the West, can in part be seen as a consequence of historical conditions and confusion in the just emerging field of academic research in Russia. For several reasons, terms defined in Western scholarship need modification or further explanation when applied to Russian material. Many terms, which were originally quite specific, have become catchalls dictated by the state, still argued about, and inaccurate. Thus, the term commonly used in Russia for a wide range of phenomena related to the spiritual realm is mysticism (mistitsizm). Although mysticism and occultism have little in common, especially since the occult particularly in Russia has always claimed to be rational, scientific and part of evolutionism, irreligious or even antireligious, Soviet officials, however, confused this term by polemically denouncing most diverse phenomena as mysticism: metaphysical religious philosophers (such as Sergei Bulgakov, Vladimir Soloviev and Lev Losev), as well as what they saw as occultism in the sciences, popular traditions of both Christian Orthodox religion, folk beliefs and Siberian Shamanism.

It is not the aim of this book to offer new theoretical approaches or advance a single coherent theory of the occult, esoteric or New Age. What it offers is a collection of material, information and exchange of ideas between scholars of different countries and disciplines, in the aim of providing a documentary foundation and, by bringing different discourses together, advancing this field of knowledge. It is more descriptive than conceptualizing; for the latter much more research is needed. ${ }^{24}$ In assembling this volume, the editors, mindful of the problems of terminology, and for pragmatic reasons, asked all contributors

23 Curricula were developed already since 1994. As an independent course on the 'History of Esotericism', it was taught since 2000 and became mandatory only since 2007. A basic curriculum was developed at the Russian Humanitarian University in Moscow (RGGU). See Diskursy ezoteriki. Filosofskii analiz, ed. Larissa Fesenkova (Moscow, 2001).

24 For a fascinating discussion of an array of paranormal phenomena, including mysticism, the occult, and parapsychology, see Jeffrey Kripal, Authors of the Impossible. The Paranormal and the Sacred (Chicago/London: University of Chicago Press, 2010). For the first time, it brings the Sacred and the Occult into a serious dialogue which inspires an application to Russia. 
to follow the same basic assumptions in order to establish some common understanding of terms. These assumptions are:

The term New Age (OF Russia) is used first of all as a metaphor pointing to the challenge of naming; but it also suggests application of George Chryssides's term (in Kemp and Lewis' Handbook of New Age) to Russia: as a "theoretical construct", a "segmented polycentric integrated network" (Ferguson), lacking a unified worldview, ideology and organization, which comprises various areas as education, religion, ecology, health care and medicine. For the contributors, despite many differences, there are several common features based on:

- the goal of self-improvement, or self-empowerment, by way of self-education to get in touch with the divine essence in oneself and ultimately achieve selfdeliverance;

- the unity of physical, spiritual and mental, the emphasis being on first-hand spiritual experience;

- the ecological worry of preserving nature threatened by destruction and of the future fate of the earth and cosmos, which are perceived as a unity;

- the conviction of the effect of energetic and psychic powers and the belief in a transformation of the earth and the cosmos into a new age (Aquarius), which can be achieved by the collective effort of a fundamentally changed way of life; the hypostasis of the feminine. The future age is seen as a female one. ${ }^{25}$

The term esotericism, which, from the Greek word esoterikós (inward), i.e. secret teaching, can be traced back to Greek philosophy of the $3^{\text {rd }}$ century A.D., and can be applied to all cultures. Today, in a semantic context shaped since the late $19^{\text {th }}$ century, esoteric is used in two different senses: (1) as a general term for occult practices, teachings and communities, and (2) as an "inner path" to certain spiritual experiences that go beyond following dogmas in an external or formal manner, and which is connected with tradition, secrecy and initiation.

Nothing is naturally esoteric. Esotericism is a designation of the historical role of certain ideas and methods within a culture rather than a description of their intrinsic characteristics. As an adjective, esoterical describes a culture's attitude towards ideas rather than the ideas themselves. ${ }^{26}$

25 George Chryssides, "Defining the New Age," In: The Handbook of New Age, ed. Daren Kemp/James R. Lewis (Leiden/Boston: Brill, 2007), 5-24.

26 Joseph Dan, Western Esotericism and the Science of Religion. Selected Papers presented at the $17^{\text {th }}$ Congress of the International Association for the History of Religion (Mexico City, 1995); Gnostica 2, ed. Antoine Faivre and Wouter Hanegraaff (Leuven: Peeters, 1998), 128. 
The term esotericism is used here according to Antoine Faivre's definition, as a "mode of thought" that can be recognized by four intrinsic and two nonintrinsic characteristics:

1. a belief in invisible and non-causal 'correspondences' between all visible and invisible dimensions of the cosmos;

2. a perception of nature as permeated and animated by a divine presence or lifeforce;

3. a concentration on the religious imagination as a power that provides access to worlds and levels of reality intermediary between the material world and God;

4. the belief in a process of spiritual transmutation by which the inner man is regenerated and re-connected with the divine; the non-intrinsic, frequent but not always present characteristics are:

5. the belief in a fundamental concordance between several or all spiritual traditions and

6. the idea of a more or less secret transmission of spiritual knowledge. ${ }^{27}$

The Occult has been the most controversial term. As "concealed wisdom" (Latin: hidden, secret), it is here seen as linked to, though not identical with mysticism as "secret experience," 28 but also to the term esoteric. ${ }^{29}$ The occult is generally considered "higher knowledge" in the East in the sense of Buddhism, Shintoism, Hinduism etc., but "lower knowledge" in the West. As "hidden teachings" it should be seen together with the inner circle of many religions and religious belief systems. This means, it is usually connected to a holistic (in terms of connecting body, mind and soul) world view, a spiritually oriented belief system, and practices of harnessing and making use of basic forces in many fields. The occult is about power.

Based on Maria Carlson's definition, the occult “embraces the whole range of psychological, physiological, cosmological and spiritual phenomena and applies the study of all arcane sciences (astrology, alchemy, the mystic traditions of the main religions, Kabbalah, Sufi, Vedanta, Zen, etc.) to these phenomena. Secondly: the occult always comprises both a certain theoretical or philosophical concept and a number of practices which are supposed to lead

27 Antoine Faivre, Access to Western Esotericism (Albany: SUNY Press, 1994), 10-15; Dictionary of Gnosis \& Western Esotericism, ed. Wouter Hanegraaff (Leiden/Boston: Brill, 2006), 336340 .

28 See "mysticism," Robert Galbreath, "A Glossary of Spiritual and Related Terms," In: The Spiritual in Art. Abstract Painting, 1890-1985, ed. Edward Weisberger (Los Angeles/New York: Abbeville Press, 1986), 376-377.

29 All three terms, occult, mystic and esoteric, are often used synonymously, although referring to different historical and ideological contexts. 


\section{Birgit Menzel}

the person involved to an experience of higher, ultimately divine knowledge and consciousness." ${ }^{30}$ This is considered a path to deliverance and divination within the human life.

However, sometimes the occult is not used to achieve higher consciousness or divine knowledge, but to deliberately make practical use of self-serving or "dark", evil forces. A special affinity between the occult, mysticism and literature has always stemmed from a similar belief in the magical power of the Word. Language as a literary device may then be chosen for its magical effect or its symbolism, rather than as an aesthetic value or for explaining ideas. In this sense, the occult can be seen as a relative term applied to the uses of the Soviet state and also as a term to denote an underground with exclusive access to secret knowledge and power.

Just as the term esoteric, the occult can be seen as a certain perspective; a culture's attitude rather than certain phenomena and ideas themselves. Some examples may illustrate the problem and considerations of the editors to include certain topics or perspectives and exclude other ones: The Tungus meteorite discussed in Matthias Schwartz's chapter is certainly a topic of popular mythmaking and legend and it can be a topic of cryptogeography, but it is not necessarily a topic of the occult in the concept suggested above. The same applies to superstition, fin-de-siècle spiritualism or telepathy, which can also be analyzed within conventional sciences such as psychology and sociology (fashions of popular culture). But they can be related to the occult, if viewed and discussed in the context of "magical thinking", or harnessing power and control, which applies not only to popular culture, but to philosophy and orthodox religion, or linguistics, as in phenomena such as "imiaslavie" (the belief in the magic and mystic qualities of the name of God). Another example of applying magical thinking and energy theories to language is the assumption of a destructive effect on speakers using "mat"-language (curse words).

Neither the religious aspects of Russian philosophy nor the relations between canonical Western and Russian philosophy will be part of this discussion on the occult. However, Soviet science can be related to the occult, in that in certain research beyond the mainstream scientific paradigm, particular scientists and scientific communities perceived a world-view as a form of metaphysics, reaching out for a hidden meaning, an ancient source of holistic knowledge or teaching, perhaps a spiritual redemption or a new form of gnosis.

30 Maria Carlson, No Religion Higher Than Truth. A History of the Theosophical Movement in Russia, 1875-1922 (Princeton University Press, 1993), 10, 15. 
Shamanism is foremost a topic of ethnography and anthropology. It has also become, if only in the past few decades, a topic of both conventional and non-conventional medical science and pharmacology. Shamanism can, however, be related to the occult, if it is seen and discussed, as in Natalia Zhukovskaia's chapter, with regard to the need for a holistic (in the eyes of the shaman), spiritually based belief of people in arcane powers in the modern world, ${ }^{31}$ which is connected with either healing forces and practices or, less frequently, with evil forces, "mysticism of violence" and demonizing practices.

Mind control is first of all a topic of political science. But it becomes a topic of the occult, if viewed in the context of manipulating those with a belief in the occult, hidden uses of technology and science, policing, and using hidden forces and knowledge for exerting or combatting political power.

Literature, philosophy, bio-political utopias, research about cosmic influences and reference to cosmic powers-the line could be continued-can be related to the occult, if they are connected with a belief in an integrated and lively magic power to transform and redeem the world, and if this can be identified as the driving force of one or several Russian writers, scientists, philosophers, artists or political leaders.

\section{Contributions}

This book is in part based on a conference on The Occult in $20^{\text {th }}$ Century Russia held in Berlin in March 2007 and brings together scholars from Germany, Russia, France, England, America, and Canada, most of whom have explored relational metaphysical aspects of Soviet and post-Soviet society from different disciplines—anthropology, history, literary scholarship, psychology—for many years.

Proceeding from the research that has been done, above all extending Bernice Rosenthal's book The Occult in Russian and Soviet Culture, the main issue discussed in this book is whether today's rejection of the rational and reference to irrational and anti-rational sources represents a radical break with past Soviet society or to what extent it represents a continuation of the anti-rational reaction to it, and thus an intensification of elements in what has been called Soviet civilization. Most contributors argue that the contemporary scene is a continuation, however weak and distorted the connections may be. Cosmism and Roerich were the main channels of influence connecting the early, late and

31 Both Eastern and Western or mostly Western - a question to be asked if discussing the Russian/Soviet/post-Soviet context. 


\section{Birgit Menzel}

post-Soviet periods. However, some contributors, such as Burmistrov and Aptekman, describe this new era as a break, while others, such as Falikov, describe altogether new developments. New occurances are, above all, organized forms of the occult including international networks. Lines of conflict occurred wherever traditions were maintained, such as Shamanism or secret societies. A mixture of rational and mystical elements, which Julia Mannherz finds in the publications of popular occult print media before the Revolution, has in fact been a feature which many contributors have identified in their chapters. While Stalin tried to suppress metaphysical and religious movements, the political occult has nevertheless been an important driving force from the 1920s to the end of the Soviet period. Examples appear in Burmistrov's, Shishkin's, Osterrieder's, Hagemeister's, McCannon's and Sedgwick's chapters. An indirect consequence of the political dimension is the sacralization of forbidden knowledge, which is addressed by Leonid Heller but can be traced throughout the occult Soviet underground. Since different aspects reoccur in different times or contexts, some overlappings are inevitable. They have been marked by cross-references. Wherever possible, comparative perspectives help to avoid specifying certain phenomena as typically Russian or Soviet and thus projecting exclusiveness where there is none, or ignoring specifics by overstressing similarities. $^{32}$

There are three parts, loosely structured chronologically: 1. Prerevolutionary roots and early Soviet manifestations; 2 . Material related to spiritual practices from the 1930s to late Soviet society, and 3. Material on the Occult Revival in Late and post-Soviet Russia (1985 to the Present). However, some chapters give a general overview or treat specific aspects or earlier manifestations of the occult and esoteric and their subsequent reception. Some chapters focus more on the political aspects, others on the cultural and literary aspects in different time periods.

Julia Mannherz analyzes the prominent role of the occult in popular entertainment of the late tsarist empire. Whereas previous scholars have asserted that modern media such as newspapers and forms of entertainment such as fun fairs, the theatre and the cinema propagated rational views that debunked "superstitions", she argues that the messages of these institutions were mixed. Reports about gullible spiritualists were usually printed in the same issue as articles that stressed the power of mysterious forces to influence the lives of ordinary Russians. Similarly, some allegedly occult journals taught secret tech-

32 This refers, for instance, to certain marginalized parts of both Western and Soviet sciences, main-stream historiography, astro- and space physics. 
niques, while simultaneously satirizing them. Mannherz concludes that a widely shared uncertainty about the forces that governed individual fates existed among contemporaries, an uncertainty that was by no means resolved in the wake of the Bolshevik revolution of 1917.

Konstantin Burmistrov discusses occultism in the drastically changed conditions of the 1920s. He focuses on the members of four underground esoteric societies-The Order Emesh Redivivus, the Order of the Moscow Rosicrucians and Manichaeists (Orion-Khermorion), who called themselves neo-Rosicrucians, the Order Lux Astralis, and the Moscow Templar Order. Especially interested in Hermeticism, Magic, and Kabbalah, they believed that their occult studies would be accepted by the society and would benefit all humanity. Most of them perished in the GULag.

Oleg Shishkin shows some early Soviet uses of the political occult. Based on archival materials, it reveals the attempts of Aleksandr Barchenko (1881-1937), a doctor and a mystic, to study "brain rays" or what today would be called mental telepathy. He was a writer and a member of a Rosicrucian Order, then broke with it in order to organize a secret society of the Kremlin and the OGPU-NKVD elite. This was done by his disciples, Ivan Moskvin and Gleb Bokii (formerly Lenin's personal secretary). Barchenko himself continued his research at the Neuro-Energetic Laboratory, until 1937, when he was accused of belonging to a Masonic society, arrested and executed. Although he was not a member, the society did exist and was connected with the mystical quests of some high-ranking Bolsheviks.

Markus Osterrieder introduces Nikolai Roerich (1874-1947) and his wife Elena who developed an esoteric system called Agni Yoga. Their ultimate objective was to establish a vast "new country" in Central Asia, as the earthly expression of the invisible kingdom of Shambhala (the "holy place" where the earthly world is linked to the highest states of consciousness), thereby preparing humanity for a New Age of peace and beauty. He led two missions in search of Shambhala, but after Stalin declined to support his project, Roerich turned his attention to prominent Americans.

Michael Hagemeister's chapter illustrates the fusion of Soviet science and the occult by presenting a new perspective on Konstantin Tsiolkovskii (18571935), who is considered the "father of Soviet space travel." His thought was rooted in a "cosmic philosophy," a unique syncretism of vitalism, panpsychism, and monadology, with aspects of Gnosticism, Theosophy and Spiritualism. Tsiolkovskii's goal was to open the cosmic way to the transfiguration and perfection of humanity, and finally to immortality and eternal salvation. Space travel was only a means to achieve this goal. 
Birgit Menzel traces the seeds of the post-Soviet occult revival back to the 1960s. She explores occult ideas in official publications on literature, culture, and science; esoteric groups and teachings in the artistic milieu of Moscow and Leningrad; occultism in scholarly study of Eastern religious mysticism and mythology; and uses of the occult in secret political and scientific institutions. Unlike Theosophy in the early $20^{\text {th }}$ century and unlike the contemporary Western New Age movement, the Russian occult underground of the 1960s and 1980s did not imagine the future as a hypostasis of the feminine and did not emphasize sexual liberation.

Leonid Heller describes a parallel universe, mostly underground, of esoteric literature. This was a complex entity composed of three elements: esoteric literature per se, science fiction (which he calls "cosmic opera"), and "mythological prose" (stories about the flowering and decline of ancient and exotic civilizations). Throughout, he finds echoes of the occult and esoteric literature of the Silver Age and the 1920s, and of the Fedorovian theme of immortality.

Matthias Schwartz focuses on "alien encounters" in Soviet science fiction the most popular literary genre and the key literary channel for occult topics. Works about alien encounters appealed to readers on all levels of Soviet society, including the so-called scientific intelligentsia, because it encrypted taboo spiritual and religious practices. By reflecting alien encounters, science fiction explored the unknown, concealed, and mysterious aspects of human existence. In a society emerging from feudalism and geared to the future, this was a mainspring of the ideology.

Marlène Laruelle discusses cosmism, a doctrine constructed in the 1920s and reinforced by the recent conquest of space. She limns cosmism's roots in Western and Russian thought and argues that cosmism reflects a unique experience of modernity, because of its emphasis on technology, not so much for its own sake, but as a means to totally transform humanity.

Demian Belyaev focuses on the resurgence of traditional religions since the 1990s which up to now is accompanied by interest in occult and esoteric doctrines and alternative religions. Works by Blavatsky, Roerich, Gurdjieff, and Daniil Andreev were published legally and more and more people consulted healers, sorcerers, and astrologers. Based on a wide-spread representational survey, this chapter presents esoteric theories and teachings, originating in a post-Soviet Russian subculture, which are based on experience and result in practices that had a major impact on a number of individuals.

In the 1980s, Aleksandr Dugin (b. 1962) belonged to an occultist dissident group that studied the teachings of Georgii Gurdjieff. Mark Sedgwick shows how he became primarily a Traditionalist (a school that originated in early 
20th century France that totally rejects the modern world). Dugin's version of Traditionalism was especially appealing to persons who had experienced and reacted against Soviet reality, the cults of science and progress. At the end of the Soviet period, Dugin modified his views and incorporated aspects of Eurasianism.

Marlène Laruelle connects a new religion, Rodnoverie (a form of neopaganism) to the post-Soviet search for identity. She describes Rodnoverie as an alternate spirituality, rooted in Asian religions, esotericism, occultism, astrology, and UFO research. Here, too, a marked difference to Western paganism and the New Age movement is the absence of a female element and a marked emphasis on national uniqueness.

Marina Aptekman reveals the occult element in post-Soviet counterhistory by examining three novels: Ilia Masodov's The Devils, Vladimir Sorokin's Be Like Children, and Polina Dashkova's The Source of Happiness. All three novels treat the Russian Revolution not as a political but an occult process, an alchemical Great Work aimed at reworking mortal material into an immortal synthesis of the soul, matter, and consciousness. Although these authors have different perspectives, they all use the motif of eternal life and its significance in the occult tradition and in Soviet mythology to link Russia's past and present and to recreate and mythologize 20th century Russian history.

Natalia Zhukovskaia treats Russian intelligenty's perceptions of Shamanism. They regard it as a world view and as a practice that offers physical and spiritual healing, reveals the future, explains the present by way of the past, makes it possible to connect with dead ancestors, reach other worlds, stave off misfortune, and even remove the threat of death. It is this practical aspect that links Shamanism and the Occult, that particularly interests the urban intelligentsia.

John McCannon shows that the "amazing elasticity" of Agni Yoga has enabled it to influence contemporary Russian cultural and political life in various ways. The Moscow based International Center of the Roerichs espouses a hagiographic and messianic view. Other centers have a more academic and slightly more universalist stance. His chapter also touches on the ways that the ideals of Agni Yoga have been co-opted by political thinkers, environmentalists, other modern esotericists, artists, and the general public.

Boris Falikov recounts attempts by Russians interested in Transpersonal Psychology (which originated in the United States at the end of the 1960s and reached Russia in the early 1970s) to "russify" the discipline by connecting it to the early 20th century occult and religious revival. Their attempt failed, partly because the Orthodox Church criticized Transpersonal Psychology's supposed 
occult underpinnings. As a reaction to these recent campaigns adherents of Transpersonal Psychology chose the ambivalent strategy to promote their teachings through popular culture as the least ideologically controlled sphere of post-Soviet society.

Two concluding chapters comment on comparative aspects.

Bernice Glatzer Rosenthal points out that occultism surges during periods of spiritual crisis, i.e. periods when the dominant ideal of a society loses its luster, leading people to search for "something else." Examples of such periods include prerevolutionary and early Soviet Russia; Russia after Khrushchev's deStalinization; late Soviet and post-Soviet Russia; and the United States since the 1960s. The dominant ideals were very different, and they faded for different reasons, but the response-a turn to the occult-was the same. The occultism of each period, addressed contemporary concerns and reflected the cultural legacy.

Jeffrey J. Kripal, an expert in American esotericism, views the Russian materials in the mirror of the American materials and vice versa. He emphasizes the boundary erasing aspect of mysticism and the global networks of mystics that developed, while also noting nationalistic and messianic aspects in Russia mysticism. He then turns to and suggests to adress the "gap" that existed, in both countries, between persons who have had a mystical experience and those who have not, to the "silences" on these personal experiences, which result in "secrets" that have existed in both countries, on different levels, for different reasons.

There are several topics missing in this volume: Rasputin's role in the impact of esoteric and mysticism in connection with sexuality in Russia; Anthroposophy and its influence on literature, the healing sciences, and theater, the work of Leonid Vasiliev on extra-sensory perception (ESP), the interrelations of Russia with occult and esoteric dimensions in other countries of Central and Eastern Europe. This research would have to be based on material in archives hitherto inaccessible, that Russian scholars have collected, and on research presented on countries, such as Bulgaria, Poland, Hungary, Romania and Ukraine. 


\title{
THE OCCULT AND POPULAR ENTERTAINMENT IN LATE IMPERIAL RUSSIA
}

\author{
JULIA MANNHERZ
}

The occult featured prominently in Russian popular entertainment in the last decades of the nineteenth and at the beginning of the twentieth century. Mainstream newspapers entertained their readers with reports about mysterious events, cheap pamphlets advertized the recreational qualities of magical practice, while theatres and in particular film made use of the newest technological developments to show the supernatural in action. Jeffrey Brooks has argued that authors of popular texts "felt a duty to enlighten their less well-educated readers and free them from superstitions that limited their understanding of their modern world." 1 This article revisits the seemingly incongruous affinity between stories about supernatural forces and the quintessentially modern media of mass consumption. It argues that the relationship between the occult and the public sphere was much more complex than previously suggested and characterized by ambiguity.

Leisure-time pursuits in fin-de-siècle Russia were exemplary modern phenomena. The rise of commercial literature as well as the increasing popular success of theatre productions and of film screenings owed much to the rapid process of urbanization and to the relaxation of censorship regulation in the Russian empire of the post-reform period. While five daily newspapers were printed in St. Petersburg in 1860, this number rose to 22 in $1880 .^{2}$

One of the most successful newspapers, which also frequently reported supernatural events, was The Petersburg Flyer (Peterburgskii listok). The sheet was aimed at a poorly educated audience of ordinary workers and employees. Founded at the height of the reform period in 1864, The Petersburg Flyer increased its numbers of weekly issues from the original four to five in 1871 and to seven in 1882. It attained a circulation of 9,000 in 1870 , a number that rose

I wish to thank Ian Forrest for commenting on this article.

1 Jeffrey Brooks, When Russia Learned to Read: Literacy and Popular Literature, 1861-1917 (Princeton, 1985), 247.

2 The comparative numbers for Moscow are 2 (1860) and 7 (1880). Louise McReynolds, The News under Russia's Old Regime: The Development of a Mass-Circulation Press (Princeton, 1991), 293. 
to 24,000 in 1895 and to 30,000 in $1900 .^{3}$ This expansion was quite typical for periodicals generally, which benefited from innovations such as the telegraph, improved print technology and railways. Newspapers disseminated their information to provincial towns and historians have estimated that by 1914 every second or third adult in Russia had regular contact with a newspaper. ${ }^{4}$

Similar developments took place in other areas too. The imperial monopoly on theatres ended in 1882 and as a consequence, popular theatres mushroomed all over the country. By the turn of the century, the theatrical landscape had dramatically diversified as had the composition of the audience: ordinary Russians including factory workers now rubbed shoulders with the urban elites at playhouses. ${ }^{5}$ At the turn of the century, popular entertainment was revolutionized by the invention of moving images. By 1900, cinemas had become an important aspect of Russian cultural life. Indeed, cinemas were established at such a fast rate that in 1908 the authorities felt compelled to introduce an upper limit to the number of cinemas allowed to operate in some cities. $^{6}$ In 1912, there were 134 cinemas in St. Petersburg, 76 in Moscow and 1,412 in the empire as a whole. ${ }^{7}$ Films reached huge audiences and, like newspapers such as The Petersburg Flyer, they shocked many educated observers with the simple entertainment they provided. ${ }^{8}$

Leisure-time pursuits as mass activities shaped by commercial mechanisms, then, were features of modern life and intrinsically linked to urbanization, political liberalization and technological advances. But the changing concept of entertainment itself was also a novelty. As Louise McReynolds has noted, “'free' time, or hours not spent at work or doing domestic chores, was not intrinsically new, 'leisure' time however-time spent in activities intended for

3 Russkaia periodicheskaia pechat', 1703-1895: Spravochnik (Moscow, 1957); McReynolds, The News, 297.

4 Manfred Hagen, Die Entfaltung politischer Öffentlichkeit in Russland, 1906-1914 (Wiesbaden, 1982), 144-149.

5 I. Petrovskaia, Teatr i zritel' provintsial'noi Rossii vtoraia polovina XIX veka (Leningrad, 1979), 144-145.

6 Jay Leyda, Kino: A History of the Russian and Soviet Film (Princeton, 1983), 28.

7 Richard Stites, Russian Popular Culture: Entertainment and Society since 1900 (Cambridge, 1992), 30.

8 On early Russian cinema see B. S. Likhachev, Kino v Rossii (1896-1926) (Leningrad, 1927); Leyda, Kino; Paolo Cherchi Usai, Yurii Tsivian, et al., eds., Silent Witnesses: Russian films, 1908-1919 (London, 1989); Stites, Russian Popular Culture; Yurii Tsivian, Early Russian Cinema and its Cultural Reception (London and New York, 1994); Louise McReynolds, Russia at Play: Leisure Activities at the End of the Tsarist Era (Ithaca and London, 2003). 
'self-actualization through the arts'-was." These modern trends were deeply bound up with the supernatural in ways that transcended mere diversion. The new developments also pointed towards new understanding of the individual self and the creation of a shared culture that accepted diversity.

\section{The Occult and Popular Literature}

Numerous stories published by Russian newspapers or as slim and inexpensive pamphlets asserted, as Brooks claims, a rational worldview and entertained their readers by ridiculing those who believed in supernatural forces. One such case was the article entitled The witch's trial (Sud nad ved'moi) published by The Petersburg Flyer in 1909. As the newspaper informed its readers, a rumour spread among the inhabitants of the town of Bolkhov that a witch was living in their midst who took on animal form at night. One evening, three drunken townspeople encountered a pig in the dark and concluded that the swine must be the transformed witch in question. They caught the witch/the pig, passed a "formal" judgment over her and punished her by cutting off her ears and tail. After daybreak, the tradesman Kalmykov "found his sow in a horribly disfigured state, barely alive. [He] instituted legal proceedings against the culprits for pig mutilation and attempted murder." 10 The ironic tone of The Petersburg Flyer suggests that the newspaper expected to entertain its readers by debunking the superstitions of provincials.

Similar accounts could be found frequently in the pages of this popular daily. A rather typical story was published 1893. It told the story of a superstitious estate owner who, of course, held a subscription to the well-known and expensive spiritualist journal Rebus. In a state of complete drunkenness, so the story goes, the old man saw a large number of threatening devils. The superstitious peasants who were with him also claimed to see them. Only the young and educated Vervitskii did not believe in the demons and is portrayed as the only modern and rational character in the tale. The account introduced a theme that was a frequent ingredient in diverting stories about the supernatural: the juxtaposition of the gullible and wealthy nobleman which is opposed to the young and educated rationalist. In 1895, the same newspaper published a story by D. K. Lamanchskii that praised the rational worldview of a certain engineer Kozlov. Kozlov and his family had just moved into a new apartment in St. Petersburg when inexplicable events began to take place. Objects moved

9 Ibid., 9.

10 "Sud nad ved'moi," Peterburgskii listok, March 3, 1909, no. 60, 6. 
around and fell from chests and wardrobes, and strange noises were heard. These events echoed reports about haunted houses that featured prominently in late imperial publishing and which interpreted such events in the context of folkloric and spiritualist notions. ${ }^{11}$ The narrator of the article in The Petersburg Flyer did not forget to mention famous Russian spiritualists such as Nikolai Petrovich Vagner and Aleksandr Nikolaevich Aksakov; two men who were known for their investigations into haunted houses and reports about troubled dwellings in Rebus. Kozlov, however, who was not a spiritualist but an engineer and hence a practical man, soon discovers the cause of the troubles: after he smoked out the hollow space below the floorboards, hundreds of rats flee. Everything is quiet from that time on. ${ }^{12}$

The topic of the allegedly haunted, but in reality entirely ordinary, house, was long-lived, as is illustrated by "The Enigmatic House", published again by The Petersburg Flyer in 1913. It told the story of a poor tenant who successfully stages supernatural phenomena in his living quarters in order to get a reduction in rent from a spiritualist landlord. ${ }^{13}$ These stories, then, poked fun at spiritualists' enthusiasm for haunted houses and their inclination to interpret moving objects as items touched by invisible spirit hands.

Stories debunking the supernatural "would not have appeared in such numbers and for so long had they not found a ready readership."14 These narratives also contained an aspect of social criticism as they contrasted their rational, urban heroes with gullible, privileged spiritualists or backward provincials. This theme was also expressed in other newspapers. An allegedly factual account published in The Moscow Kopeck Gazette (Moskovskaia gazeta kopeika), reported on a poor gypsy fortune-teller Smirnova, who predicted and influenced the future of her clients by inspecting and casting spells on their jewellery. Her magical technique, so Smirnova told her customers, requires her to wrap the precious objects in cloth bundles that ought not to be touched for three days for the spell to work. In actual fact, Smirnova robbed gullible ladies of valuable items worth hundreds of rubles. ${ }^{15}$ We can only assume that the urban lower-class readers of The Petersburg Flyer and The Moscow Kopeck Gazette enjoyed identifying with clever engineers such as Kozlov or rascals

11 Julia Mannherz, “Slukhi o ‘nepokoinom' dome v Rossii v ėpokhu moderna,” In: Igor' Narskii, ed., Slukhi v Rossii XX veka: neformal'naia kommunikatsiia i "krutye povoroty" rossiiskoi istorii (Cheliabinsk, 2011) 218-230.

"Proisshestviia: Gadalka," Gazeta kopeika (Moskva), 1909, no. 58, 3. 
such as Smirnova, and they probably relished the schadenfreude generated by reading stories about gullible affluent spiritualists.

The portrayal of belief in the supernatural as naive superstition by the popular press was, however, not universal. Some pamphlets dealing with apparitions of the dead tried to convince readers that the phenomena described were beyond doubt. In the story The Dead Husband Appears to his Wife Forty Days after His Death (Iavlenie umershego muzha zhene na sorokovoi den' konchiny), the religious and superstitious wife is vindicated in her belief about life after death, while the more sceptical husband has to experience the beyond before he can be convinced..$^{16}$ Books like On Life in the Beyond: Apparitions from the Other World (O zagrobnoi zhizni. (Iavleniia s togo sveta)) and The Dead Appear to the Living from the Beyond (Iavlenie umershikh zhivym iz mira zagrobnogo) collected stories of this kind and presented them in a way that underscored their alleged factuality. ${ }^{17}$ Their claim to veracity was supported by Christian beliefs about life after death, on which such publications based their claims.

Not only pamphlets with a Christian mission described the supernatural as a real force to be reckoned with. The same popular newspapers that debunked spiritualist belief also published seemingly trustworthy depictions of the supernatural. Articles reporting From the Mysterious World (Iz mira tainstvennogo) were regular features in popular newspapers such as The Petersburg Flyer, The Moscow Kopeck Gazette and The Russian Flyer (Russkii listok). The Petersburg Flyer started its successful series Iz mira tainstvennogo in 1899 and articles under this title appeared-with some interruption-until 1907. These reports on the unknown covered about half of one newspaper page and were often comprised of more than one account. The prominence and the relatively long period of the series' publication suggest that it had a considerable appeal among readers. ${ }^{18}$ Iz mira tainstvennogo included accounts of prophetic dreams, apparitions, haunted houses, supernatural curses, mysterious marks appearing on the bodies of the living, ghost photography and inexplicable, sudden deaths. These stories entertained because they portrayed events which contradicted a rational worldview and which, because of their inexplicability, created a sense

16 Geine iz Tiflisa, Iavlenie umershego muzha zhene na sorokovoi den' (konchiny) (Moscow, 1910).

17 O zagrobnoi zhizni. (Iavleniia s togo sveta) (St. Petersburg, 1903); ed., Iavlenie umershikh zhivym iz mira zagrobnogo (Moscow, 1915).

18 One of many examples is "Iz mira tainstvennogo: Fotografiia dukha," Moskovskaia gazeta kopeika, August 2, 1910, no. 62 (417), 4. 
of insecurity and dread. Often, the scariness and the alleged reality of such stories was heightened by referring to localities known to readers. In 1903, one of these accounts told the story of Mr. Z., who lived on Pushkin Street in Petersburg. One morning, relatives fond him sitting on his bed, staring with frightened eyes into empty space. Z., it turned out, was paralyzed and unable to speak. A mysterious mass and the remains of a completely demolished armchair are discovered next to him. Moreover, the icon in Z.'s room is removed from its original place and a mysterious note with illegible scribbling in Latin letters (Latin usually being associated with the devil) lies on his bedside table. The family doctor, a representative of the urban educated professional intelligentsia-commonly portrayed as deeply sceptical of everything mysterious-, suggests that some supernatural power must be implicated in the events. A few days later, Z. was found dead and his bereaved family are impatient to move into another dwelling. ${ }^{19}$ The setting of this tale in the centre of St. Petersburg near Moscow station, a sight representing technological progress and rational prowess, added to the thrill it provided for readers.

Another, similar account told a story of a traveler relishing a conversation with two students in his hotel room on Nevskii Prospekt, St. Petersburg's central avenue, when they suddenly grow transparent and eventually disappear. It is later established, so the author claimed, that they were visitors from the beyond. ${ }^{20}$ Stories of that kind seem to have been highly popular, for publishers had difficulties meeting demand. Numerous stories appeared more than once or were reprinted in slightly different version, an indication that editors rushed such accounts into print. In some cases, publishers took a mysterious tale, changed the location and the names of the characters and had a new story ready. $^{21}$

None of these allegedly factual accounts provided rational explanations for the mysterious events they reported. Instead, they meticulously refuted physical explanations and insinuated that supernatural forces lay at the source of such occurrences. These powers, however, were never clearly named and thus remained suggestive and elusive. Nonetheless, such newspaper accounts implied that supernatural powers had a bearing on the lives of Petersburgers. This form of reasoning questioned the hold of the rational mind over reality and linked the accounts of the Iz mira tainstvennogo series to the many gothic novels

19 -v, "Iz mira tainstvennogo," Peterburgskii listok, December 7, 1903, no. 336, 5.

20 Volkhv, "Iz mira tainstvennogo," Peterburgskii listok, December 4, 1905, no. 309, 2.

21 P. M., "Iz mira tainstvennogo," Peterburgskii listok, January 15, 1906, no. 14, 5; P.M., "Iz mira tainstvennogo," Peterburgskii listok, March 15, 1907, no. 72, 5. 
which newspapers also published. The Petersburg Flyer, for example, serialized two of Vera Kryzhanovskaia's occult novels: The Wizard's Daughter: An Occult Novel (Doch' kolduna (Okkul'tnyi roman)) and In the Kingdom of Darkness ( $V$ tsarstve t'my). ${ }^{22}$ Popular newspapers aimed at a mass audience, then, sent mixed messages about the forces that influenced contemporaries' lives. On the first page of a newspaper, reports about political, foreign and local events commonly occupied the top two-thirds. They expressed a rational view of the world but frequently sat above serialized occult novels to which the lower third was devoted. On page two, a satirical account might ridicule supernatural belief, while a story under the heading Iz mira tainstvennogo, usually printed on page 5, might again suggest that scientific explanations failed to grasp important events.

Belief and disbelief were most ambiguously combined in occult instruction manuals. On the one hand, such publications operated on the assumption that contact with another, supernatural world was possible. On the other hand, numerous of these "how-to" manuals, while advertising the experiences of the beyond, simultaneously subverted belief in another world by poking fun at it. Instruction manuals enticed potential buyers by stressing the entertainment value of traditional fortune-telling practices and of spiritualist séances in their titles. The first part of the lengthy title of Moldavanin's publication is typical: Extraordinarily Interesting and Exceptionally Intriguing Domestic Magic Booklet for Familial Spiritualist Séances in the Evenings (Chrezvychaino-interesnaia $i$ neobyknovenno-zabavnaia dlia semeinykh vechernykh spiriticheskikh seansov Domashnaia Volshebnaia Knizhka). ${ }^{23}$ Another similar publication was Yuletide: The Wonders of Striped Magic or the Fate of every Man and Wo-Man (Sviatki: Chudesa polosatoi magii ili sud'ba kazhdogo cheloveka i chelovechitsy), which evoked the fun and humour to be discovered within its covers through

22 The last installment of $V$ tsarstve t'my informed readers that the publication had to be discontinued "due to reasons beyond the editors" control, another hint at dark forces. V. Kryzhanovskaia, "V tsarstve t'my," Peterburgskii listok, February 20, 1913, no. 50; Muireann Maguire, "Ghostwritten: Reading Spiritualism and Feminism in the Works of Rachilde and Vera Kryzhanovskaia-Rochester," Modern Language Review; forthcoming 2011.

23 Anti-spirit Alkhazar-Tovii Moldavanin, Chrezvychaino-interesnaia $i$ neobyknovennozabavnaia dlia semeinykh vechernykh spiriticheskikh seansov Domashnaia volshebnaia knizhka: Knizhka volshebnitsa, po kotoroi mozhno pokazyvat' teni (prividenii) zhelaemykh lits, khotia by oni vo vremia seansa byli $v$ otsutstvii za neskol'ko tysiach verst ili uzhe umerzhie, uznat' imena i leta sovershenno neznakomykh lits. Krome togo po etoi knizhke mozhno uznat', skol'ko kto imeet pri sebe v karmane deneg ili u sebia $v$ dome, nesmotria uzhe i na to, chto esli-by takoe litso bylo ot svoego doma na rasstoianii za neskol'ko sot ili tysiach verst. (Moscow, 1883). 
the un-grammatical neologism, wo-man (chelovechitsy). The pamphlet delves into Petersburg gossip, advising readers to "go to Filippov's bakery (or to any other baker versed in the art of flying out of the chimney)" to buy a French roll and throw crumbs onto a diagram in to book which "will reveal your future." The book's prophetic revelations, too, expressed an air of playfulness and humour, telling diviners that "The Catholic Pope worries about you" or "the savings-bank misses you". ${ }^{24}$ Other booklets were exclusively geared towards play and games. One divinatory device allowed fortunetellers to "foresee" the grotesque face of one's future spouse by rubbing a piece of paper with heatsensitive colour near one's heart. ${ }^{25}$ Another included the optical illusions $A$ Spiritualist Apparition (Spiriticheskoe iavlenie), advertized with the headline: "No medium required: Everybody can summon ghosts!" (fig.1 $)^{26}$

\section{СПИРИТИЧЕСКОЕ ЯВЛЕНІЕ.}
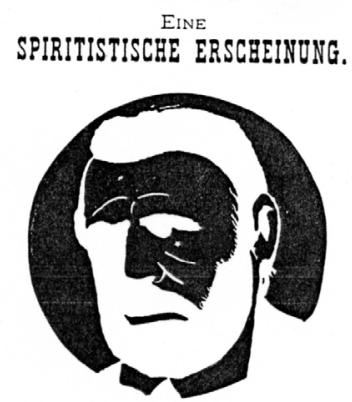

Каждый можетъ призывать духовъ бевъ медіума.

Iiein Medium mehr nöthig, da Jedermann Geister citiren kann.

Fig. 1: "The Spiritualist Appearance" as an optical illusion (1883)

24 Sviatki: Chudesa polosatoi magii ili sud'ba kazhdogo cheloveka i chelovechitsy (St. Petersburg, 1905). Other booklets that radiated a similar air of fun, humour and playfulness include Noveishii Peterburgskii orakul: chut' ne 1.000 interesneishikh voprosov i otvetov na Peterburgskie zloby dnia (St. Petersburg, 1893). on the starlet in the middle of the image for 30-40 seconds. Then look quickly at the wall or the ceiling, after 10-20 seconds the apparition will appear. [...] If it does not work immediately, repeat the procedure and you will certainly be successful." 
Uncertainty about occult events, then, was expressed both in secular newspapers and in instruction manuals allegedly teaching occult practices. The occult periodical The Cinematographer: Weekly Illustrated Magazine of Secrets and Horrors (Kinematograf: ezhenedel'nyi illiustrirovannyi zhurnal tain $i$ uzhasov) was equally ambiguous. This is startling in light of the journal's program, which was after all to teach readers black magic, white magic, occult sciences, the interpretation of dreams, astrology, Indian 'fakirizm', spiritualism and chiromancy. ${ }^{27}$ Yet despite this clear occult mission, the journal published caricatures in 1910 which suggested that reference to the supernatural was a mere rhetorical device employed by women eager to cheat on their husbands or get hold of their spouse's money. As figures 2 and 3 suggests, "spirit" was a euphemism for lovers, while fortune-telling was a way of obtaining money. ${ }^{28}$

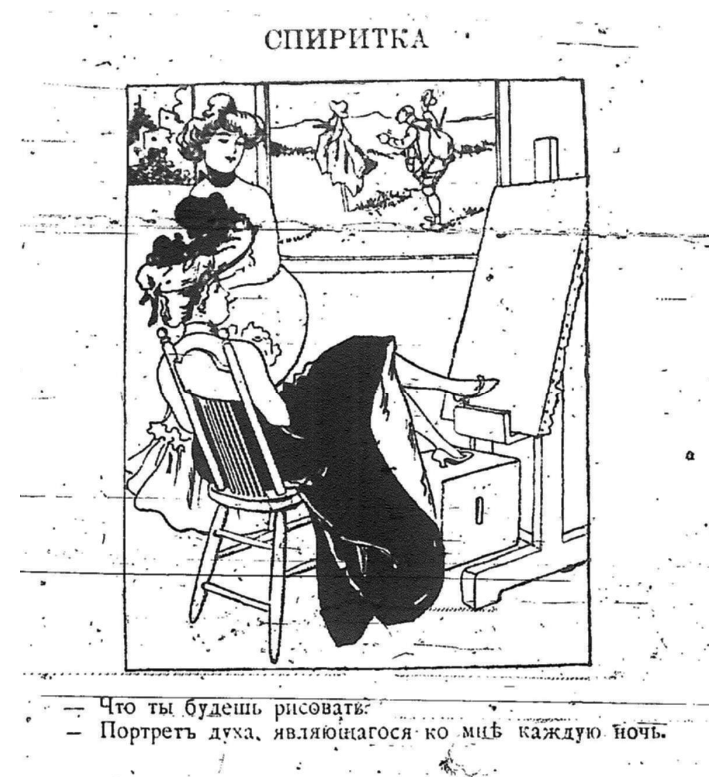

Fig. 2: The Woman-Spiritualist: "-What are you going to paint? -A portrait of the spirit who appears to me every night".

27 Kinematograf: Ezhenedel'nyi illiustrirovannyi zhurnal tain i uzhasov (St. Petersburg, 1910).

28 "Opasnoe predskazanie," Kinematograf: ezhenedel'nyi illiustrirovannyi zhurnal tain i uzhasov (11), 1910, 8-9. 


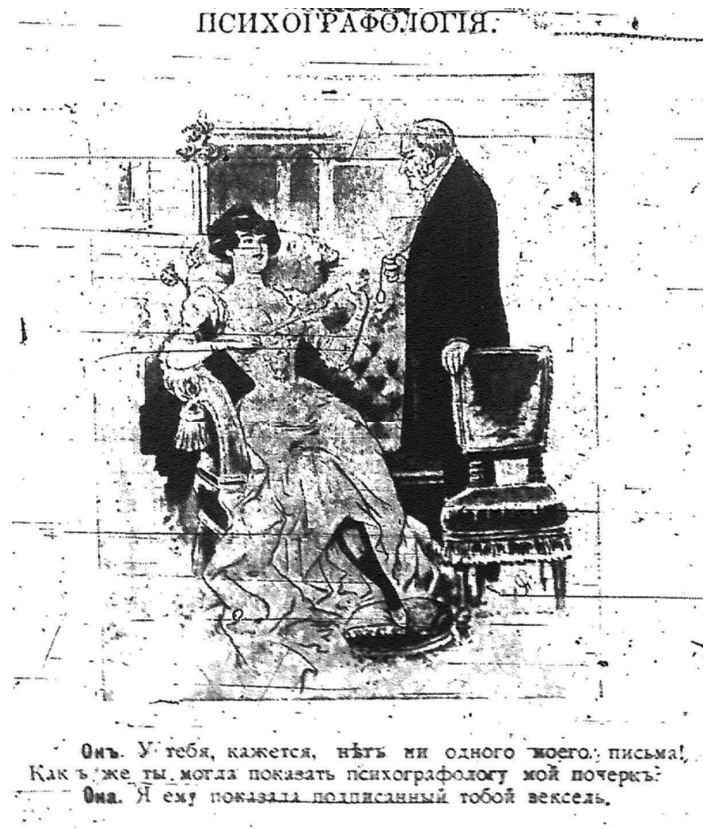

Fig. 3: "Psychographology. -It seems you don't have a single piece of writing by me. How did you show the psychographologue my handwriting? -I showed him a bill you signed."

Accounts making fun of superstitions, then, appeared alongside stories that were more sympathetically inclined towards the supernatural. Indeed, without serious treatments of the occult, satirical articles would not have had such a wide audience and reception. Even instructions manuals and occult journals mirrored the same ambivalent attitudes towards supernatural past-time activities. While articles debunking belief in the occult and those suggesting the reality of occult phenomena existed in the same media outlets, the borders between natural and supernatural were even more blurred in the circus arena, on stage or on the silver screen. In the performing arts, the rational and the mysterious merged within single productions.

\section{Fun Fairs, Circuses and Theatres}

Fun fairs and circuses transported the occult from pleasure gained during individual reading into the domain of shared recreation. The supernatural had been present in popular leisure-time pursuits for a long time, especially at fun 
fairs. Narodnye gulianiia, folk fairs or folk festivals were seasonal events with provenance in folk games, pagan and Christian rites and the traditions of minstrel companies. Fun fairs offered fairbooth burlesques, sleigh rides and ice hill sledding, carrousels, dancing bears, food stalls, and general drinking and merrymaking. ${ }^{29}$ The fairbooth, or balagan, staged the supernatural in one of its most popular plays: Petrushka, which told the story of the rogue Petr Ivanovich Uksusov who was ultimately dragged to hell by the devil himself. ${ }^{30}$ In the late nineteenth century, the supernatural was promoted from minor element to featured attraction. Whereas the supernatural was only a subsidiary plot device in Petrushka, showmen now attracted audiences with entertainments devoted solely to showcasing the mysterious. Séances were performed on fun-fair platforms and in puppet shows, and hypnotists displayed their powers. ${ }^{31}$

Allusions to the supernatural were also widespread in the circus ring. Soviet commentators later ascribed this to the "bourgeois" intelligentsia's fascination with the occult. Considering that circus shows were attended by members of all social strata, it seems more likely that allusions to the mysterious appealed to ordinary Russians as well. "Many illusionists took on an air of mysteriousness, mentioned their relationships with 'supernatural' powers and claimed that they had gained their powers from Indian fakirs or Egyptian sages." ${ }^{2}$ Others compared their feats to the notorious eighteenth-century magician and adventurer Cagliostro. ${ }^{33}$ Allusions to life after death were common in circuses, as one routine, known as "the living dead", illustrates. In this act, the nose and mouth of the "deceased" was stopped up with cotton wool and taped over before his head was wrapped in a scarf and he was laid in a glass coffin. The coffin was then lowered into a tomb. After 15 minutes, the dead was resurrected with ether. $^{34}$

29 Stites, Russian Popular Culture.

30 On Petrushka see Catriona Kelly, Petrushka: The Russian Carnival Puppet Theatre (Cambridge, 1990); A.F. Nekrylova, Russkii narodnyi kukol'nyi teatr "Petrushka" v zapisakh XIX-XX vekov: Avtoreferat dissertatsii uchenoi stepeni kandidata iskusstvovedeniia (Leningrad, 1973); eadem, Russkie narodnye gorodskie prazdniki, uveseleniia i zrelishcha (Leningrad, 1984); eadem, N.I. Savushkina, ed., Folklornyi teatr (Moscow: Sovremennik, 1988); eadem, N. I. Savushkina, ed., Narodnyi Teatr (Moscow: Sovetskaia Rossiia, 1991). In some versions of this play, the devil was replaced by a huge dog.

31 "Razoblachennyi 'volshebnik'," Peterburgskii listok, July 6, 1911, no. 184, 2; "Kratkie zametki," Rebus 5(2), 1886, 24. Much to the disdain of serious spiritualists, staged séances were common European folk festival attractions. S. E-1, “Zhurnalistika,” Rebus 2(34), 1883, 302-304.

32 Emil' Fedorovich Renard-Kio, Fokusy i fokusniki (Moscow, 1958).

33 "Novosti v tsirke Modern," Peterburgskii listok, December 1, 1911, no. 330, 16.

34 “Novosti sezona," Khronika, no. 2965, 1914, cited in Renard-Kio, Fokusy, 10. 
Indian fakirs were particularly popular figures when it came to entertaining audiences with allusions to mysterious powers. The exoticism of the enigmatic East added to their appeal. Circus programmes included numerous stunts by alleged Indian sages and these were so popular that instructions on how to become a fakir could be purchased. ${ }^{35}$ Not surprisingly, some of these fakirs were not at all of very exotic background: the fakir Nen Saib, for example, turned out to be a peasant named Karlinskii. ${ }^{36}$ Notwithstanding such profane disguises, "Indians" toured the empire and performed breathtaking acts of "positive horror" (polozhitel'nyi uzhas), as one critic called it. ${ }^{37}$ They were joined by Persians and Tatars, and their routines were greeted with resounding cheers. Fakirs also merged alleged Eastern mysticism with Western spiritualism. In 1912, the Moscow Art Theatre allocated one part of its foyer to Indian fakirs, who advertized their show with a banner extolling: "The visiting performance of two spiritualists! There have been cases of death." 38

Magicians in the circus arena and in fun fair booths used spiritualist vocabulary and settings to make their shows more appealing to audiences, thereby fusing Eastern mysticism with spiritualists' claims about the existence of supernatural beings and rationally Thus the programme of one illusionist included a "spiritualist materialization", a "spiritualist candle" and a trick to illustrate "the power of magnetism [i.e. hypnotism]." ${ }^{39}$

This fusion of the rational and the supernatural was furthermore underscored by the endorsement of modern technology during performances of

35 S. M. Makarov, "Iskusstvo fakirov v Evrope XIX-nachala XX veka," In: E. V. Dukov, ed., Razvlekatel'naia kul'tura Rossii XVIII-XIX vv. Ocherki istorii i teorii (St. Petersburg: Dmitri Bulanin, 2000), 464-480; Otzyvy Russkoi pressy po povodu zagadochno-porazitel'nogo seansa Indiiskikh fakirov g-zhi Saadi-Dzhebbari i g-zha Solimana Ben-Saida imeiushchego byt' u nas $v$ gorode (Khar'kov, 1904); "Novosti v tsirke Modern"; Paul Sedir, Indiiskii fakirizm ili prakticheskaia shkola dlia razvitiia psikhicheskikh sposobnostei. S prilozheniem slovaria terminov indusskogo fakirizma (St. Petersburg, 1909). On the appeal of exoticism generally see Stites, Russian Popular Culture, 21.

Renard-Kio, Fokusy, 9.

Otzyvy (1904); Otzyvy Russkoi pressy po povodu zagadochno-porazitel'nogo seansa Indiiskikh fakirov (Vil'na, 1905); Otzyvy Russkoi Pressy po povodu zagadochno-porazitel'nogo seansa Indiiskikh fakirov (Kazan', 1907).

Liudmila Il'inichna Tikhvinskaia, Kabare i teatry miniatiur v Rossii, 1908-1917 (Moscow, 1995), 16.

Starshii Prof. magii Pevzer, Noveishii katalog chernoi i beloi magii (St. Petersburg, 1891). In one instance, a magician allegedly became a medium after discovering the reality of his tricks. Critics of spiritualism claimed that all mediums were tricksters and that illusionists therefore found the "career change" not very difficult. See Mikhail Petukhov, "Prevrashchenie fokusnika v mediuma," Rebus 2(15), 1883, 139. 
magic at fun fairs and circuses. Illusionists used electricity and played with such new inventions as telegraphs and cameras. The fusion of magic with technology ultimately made inroads not only into public but also into private entertainment. The Melamed company produced apparatus for illusionists that reworked technological innovations and could be used both for public performances and for private entertainment. ${ }^{40}$ Technology and the occult were thus intertwined, suggesting that an uncertainty lingered about both technological inventions and occultists' claims to factuality. Indeed, some spectators expected "real" supernatural events at fun fairs, not just illusions. In 1911, one wizard hypnotist found himself in court on a charge of deception. He had illustrated the force of hypnosis on his assistant, whose body-so the illusionist claimed-acquired such a strong state of catalepsy that she was able to sit in thin air after he had pulled the chair from underneath her. When spectators discovered that the assistant was in reality simply wearing a metal harness, they angrily brought the magician before a justice of the peace. ${ }^{41}$

Theatres, though more elitist than fun fairs and circuses, were also touched by the fascination with the supernatural. Like newspapers, the attitude towards the occult that stage productions expressed was equivocal. One anti-spiritualist play was Lev Tolstoy's The Fruits of Enlightenment (Plody prosveshcheniia). ${ }^{42}$ Tolstoy's piece, written in 1890, echoed the rational stories debunking superstitions in popular newspapers. Plody prosveshcheniia tells the story of the servant Tania who stages spiritualist phenomena in the house of her superstitious employer, the wealthy Leonid Fedorovich Zvezdintsev. The "spirits" successfully talk Zvezdintsev into selling land to peasants from Tania's home village, property which they desperately need for their livelihoods. Like some accounts in The Petersburg Flyer, Tolstoy ridiculed the wealthy as irresponsible fools who, blindly following foreign fashions, were impervious to rational arguments and easily duped. His depiction of peasants, however, was more positive than

40 Kazhdyi mozhet byt' fokuznikom. Mgnovennyi fotograf ili magicheskaia plastinka (St. Petersburg, 1885); Fokusy (St. Petersburg, 1887); Potainyi sunduchok Kartusha. Magicheskii apparat sobiraiushchii, dlia razvlecheniia publiki, grivenniki i publiki (St. Petersburg, 1893); TelegrafGerkules ili elektricheskaia lenta. Porazitel'noe usovershenstvovanie (St. Petersburg, 1893); Shutka kassira ili kak nazhit' million (St. Petersburg, 1893); Zhivaia plastinka ili sredstvo udvoit' svoe nasledstvo; Alkhimiia XX-go veka (St. Petersburg, 1893); Pechatnyi stanok charodeia Fausta (St. Petersburg, 1893); Dve plity Kheopsa: Egipetskii volshebnyi apparat, naidennyi $v$ tainike drevnei piramidy (St. Petersburg, 1893). Something similar was advertized by Didagtomat: Elektricheskii pribor, daiushchii otvety na voprosy (Moscow, 1889).

41 "Razoblachennyi 'volshebnik'".

42 L.N. Tolstoi, Sobranie sochinenii v dvadtsati tomakh (Moscow, 1963), vol. 11, 119, vol. 11, 228. 
the images of rural dwellers that popular newspapers painted. Faithful to his romantic views about Russia's former serfs, Tolstoy juxtaposed gullible nobles and their silly scientist friends with ordinary peasants. The latter were serious, hard-working and grappling with real economical-not imagined supernatural-problems. The play was premiered in April 1890 in Tula; a year later, the eminent director Konstantin Stanislavskii staged it in Moscow and himself played Zvezdintsev. 1891 saw further popular productions in Moscow and at St. Petersburg's Aleksandrinskii theatre. The painter Il'ia Repin, who attended a performance in the capital, remembered that "after the first act, the audience was so fervently demanding [to see] 'the author!' that a gentleman in tails had to come out and inform everyone from the stage that the author was not in the theatre building." 43 The play was staged 238 times in Moscow and St. Petersburg before 1917 and remained prominent on the programmes of Russian theatres after the revolution. ${ }^{44}$

Despite the success of anti-spiritualist plays such as Plody prosveshcheniia, productions suggesting that the supernatural was real dominated the imperial stage. As one historian of Russian theatre noted, "theatres were not drawn towards depictions of social and everyday realities, but they were attracted by the fantastical." ${ }^{45}$ Especially popular were the special effects which the theatre could stage and this again linked the mysterious in entertainment to technological progress. As early as the late 1850 s, a provincial theatre advertized its mise-en-scène of Ioann Faust, or the Sorcerer (Ioann Faust, ili Chernoknizhnik) with the promise to provide breathtaking effects. Their staging, the advertisement claimed, was "A great tragedy in 5 acts, in verse, including the necessary magical phenomena, will-o'-the-wisps, flying flames, metamorphoses, traps, shadows, monsters from hell, flying dragons, skeletons and other scares. [...] The scenery in the fifth act includes jaws from hell lit by red Bengal fires." 46 Although productions with such effects became less common in the years that followed, the fascination with supernatural phenomena on stage was to return with fin-de-siècle culture.

Many of the titles of plays staged around 1900 suggest supernatural involvement. One such play was The Sorceress (Charodeika), by Shpazhinskii,

43 I.E. Repin and L.N. Tolstoi, Perepiska, vol. 1, Moscow and Leningrad, 1949, 39. Cited in L.N. Tolstoi, Sobranie sochinenii v 22 tomakh (Moscow, 1982), 496.

44 E. R. Kholodov, ed., Istoriia russkogo dramaticheskogo teatra, 1862-1881 (Moscow, 1980), vol. 6, 484, vol. 7, 483; Tolstoi, Sobranie sochinenii v 22 tomakh, 407.

45 Kholodov, ed., Istoriia russkogo dramaticheskogo teatra, vol. 6, 145.

46 Petrovskaia, Teatr i zritel', 62. 
"one of the most frequent plays in the repertoire" although artistically unenticing. ${ }^{47}$ Others included The Domovoi Jokes (Domovoi shalit), Into the Beyond (Na tot svet), the comedy The Spiritualists (Spirity), The Secret Power (Tainstvennaia sila), and The Vii (Vii), based on a story by Gogol'.48 The latter was staged in 1900 at the Russian Dramatic Theatre in St. Petersburg. It left a lasting impression on audiences, especially because of its moving scenery (still a novelty at the time), apparitions of the dead, a flying coffin and because of its portrayal of Vii, a vampire, who came on stage in the last act. The production was so popular that it was repeated over forty times. ${ }^{49}$

Because depictions of the supernatural on stage evoked impressions of fear, the otherworldly was soon associated with horror. On 4 January 1909, the impresario V. A. Kazanskii opened the Liteinyi, his third theatre in St. Petersburg. While his other two theatres treated audiences to comedies and displays of electrical apparatus, the Liteinyi aimed at "scaring people" with the help of the supernatural and portrayed itself as a "theatre of strong impressions" (teatr sil'nykh oshchushchenii). ${ }^{50}$ Before the premiere, organizers asked people with weak nerves to stay at home because of "the extraordinary terror" exhibited in the show. And indeed, the theatre staged "murders, guillotining, stabbing of knifes into breasts and pouring of hydrochloric acid over faces." ${ }^{1}$ The acts on the Liteinyi's first bill are a perfect example of how the supernatural was employed to scare audiences: "they included a psychiatrist raping his hypnotized patient," who retaliated with hydrochloric acid. The theatre became an immediate sensation, causing one critic to deplore that "shrouds have become the most fashionable dress, and corpses the stars of the season." ${ }^{2}$ The popularity was not to last very long, however. "Despite a wild first two months, enthusiasm for the horrors wore off with the novelty, and by 1909 the same critic could write that 'corpses can now return to their graveyards." 53 Still, spectres were to remain on the stage of the Liteinyi and on that of other houses.

Ghosts however retained a satirical quality alongside the horror they provoked. In 1912, the Liteinyi staged The Stock-Brokeress (Birzhevka), which told the story of a rich student who dabbled in spiritualism. This sober-minded

\footnotetext{
47 Kholodov, ed., Istoriia russkogo dramaticheskogo teatra, vol. 6, 75.

48 Ibid. vol. 6, 452-501; vol. 7, 453-496

49 I. Petrovskaia, V. Somina, Teatral'nyi Peterburg: Nachalo XVII veka - Oktiabr' 1917 goda (St. Peterburg, 1994), 231.

50 Tikhvinskaia, Kabare, 137-149; Petrovskaia, Somina, Teatral'nyi Peterburg, 323-325.

51 Tikhvinskaia, Kabare, 137.

52 McReynolds, Russia at Play, 220.

53 Ibid., 220.
} 
youth is so eager to experience the realm between life and death that he enacts the following agreement with his secretary: he will shoot himself and inform her about everything he sees while dying. But however hard the secretary tries, she is unable to make any sense of his groans and moans. ${ }^{54}$

\section{The Silver Screen}

The medium that captured the supernatural most convincingly in late imperial entertainment was film. Initially, the Russian market was influenced by foreign, mainly French companies, but from 1908 Russian filmmakers produced melodramas, films on bandits, historical films from Russia's past, comedies and enigmatic films delving into the supernatural.

Film was indeed an appropriate medium for the portrayal of the supernatural, since the novelty of the medium "itself was already something mysterious." ${ }^{5}$ Film showings evoked the "uncanny feeling that films somehow belonged to the world of the dead [...] the presence of movement made the image look strikingly life-like, while the absence of sound and colour turned it into a haunted frame." ${ }^{56}$ It is indicative, that Kinematograph was the title of the above mentioned occult journal. Symbolist writers described films as "phantasmagorical moonlit visions which conveyed the [...] sense of a veiled and occult reality of which the visible world was merely a shadow." For the poet Alexander Blok, cinema was part of the "city mystery". ${ }^{57}$ But films were associated with magic in other ways as well. "Familiar faces on the screen would evoke the motive of doubles and duality with the traditional accessories of magic mirrors and haunted portraits." 58

For audiences, the darkened film theatre added to the obscure atmosphere and evoked the darkened rooms of spiritualist séances, which were further mirrored in the white apparitions on screen that echoed spirit manifestation. Technological accidents or interferences, too, were interpreted as supernatural events. "Flickering movies" or the "vibration" of the picture could be explained in a theosophical vein as the "penetrating oscillations" with which the Cosmic Will communicated to earthly souls. Similarly, the frozen image evoked a mys-

\footnotetext{
54 Tikhvinskaia, Kabare, 140.

55 Ibid., 219.

56 Tsivian, Early Russian Cinema, 6.

57 Tim Gunning. "Foreword," in ibid., xix.

58 Ibid., 4.
} 
tical chill of death that emanated from the screen. ${ }^{59}$ Films were seen as literally spellbinding, as exerting a "hypnotic and trance like fascination over viewers." ${ }^{60}$

The very medium of film, then, conjured up supernatural notions. This was further heightened in the case of films that featured supernatural content. Pushkin's novella The Queen of Spades (Pikovaia dama), for instance, was made into a film in 1910 and again in 1916; both versions elaborated on supernatural aspects of the plot. The first screen adaptation by Petr Chardynin, which was accompanied by Tschaikowsky's music, thrilled viewers by employing a trick that caused characters to appear and disappear. In this film, the story's anti-hero German has multiple visions of the murdered countess and of the fatal cards, which the audience sees appearing mysteriously. When the countess's ghost appears during a game of cards, none of German's fellow officers sees her, but cinema-goers do. Her sudden appearance and disappearance creates a thrilling chill-even for today's viewer. ${ }^{61}$ Chardynin's Pikovaia dama was the first Russian film to win critical acclaim on artistic grounds. ${ }^{62} \mathrm{Six}$ years later, the outstanding film director Iakov Protazanov offered a second version of Pikovaia dama. This remake has an eerie scene in which a French magician, count Saint Germain, is shown in his alchemy laboratory disclosing the secret of the three cards to the then-young countess. Later, we also see the dead countess appear to German in a white dress, and a special effect projects her moving face onto the queen of spades, which German is holding in his hand. Through these technological effects, the film creates gripping thrills and suspense.

Russian films also incorporated folkloric sprites. 1910 saw the production of The Mermaid (Rusalka), which made use of several supernatural notions and incorporated traditional notions of water nymphs into the modern medium of film. It told the story of a girl who, having been rejected by her lover, commits suicide by drowning herself in the mill pond, a traditional dwelling place for sprites. Her ghost appears twice at the banquet celebrating the young man's marriage to another woman and again in the young couple's bed chamber. As in Chardynin's Pikovaia dama, the ghost appears as suddenly as it vanishes and is seen only by the young man and the audience. The spectral appearances spoil the man's marriage, and viewers are told that even after eight

59 Tsivian, Early Russian Cinema, 109-111.

60 Gunning. "Foreword," xxi.

61 Usai et al., eds., Silent Witnesses, 108-111.

62 Leyda, Kino, 40. 
years, no intimacy has developed between the spouses. Instead, "an unknown force" (nevedomaia sila), a common euphemism for a supernatural power, draws the husband to "the sad shore" where his former love ended her life. According to folklore, young women who committed suicide turned into water nymphs, and in this case we see the girl dancing with other rusalki at the pond's shore. The last scene shows the underwater palace in which the rusalki live: in this magical scene, which highly impressed audiences, the dead lover lies in state, surrounded by mermaids. ${ }^{63}$

In an ironical turn of fate, the staunch anti-occultist Tolstoy posthumously became the hero of a film with a supernatural quality. The Departure of a Grand Old Man (Ukhod velikogo startsa) featured the apparition of a living person, a supernatural phenomenon that greatly occupied spiritualists at the time.$^{64}$ In the movie, Tolstoy, despondent about his life in Iasnaia Poliana, is attempting suicide when the apparition of a nun, whom we later see him visit, prevents the novelist from putting the rope around his neck. At the end of the film, Tolstoy, having eventually died a natural death, is received in heaven by Jesus. They are shown in this last frame as radiant white figures conspicuously resembling spiritualist materialization photographs. ${ }^{65}$

Spectres, and the technological possibilities to depict them, remained prominent features of prerevolutionary cinema. In 1915, one of Russia's great prerevolutionary directors, Evgenii Bauer, shot After Death (Posle smerti). In this film, a young scientist rejects the love of an actress, who soon afterwards commits suicide. The young man sees her spirit several times and is driven to the brink of madness. ${ }^{66}$ The supernatural and madness were also linked in Midnight at the Cemetery, or A Fatal Bet (V polnoch' na kladbishche, ili rokovoe pari). This film told the story of a young man who loses a bet and thus has to spend a night at a cemetery. As proof of his presence, the hero must drive his

63 Usai et al., eds., Silent Witnesses, 112-115.

64 On spirits of the living see Alexander Aksakow, Animismus und Spiritismus: Versuch einer kritischen Prüfung der mediumistischen Phänomene mit besonderer Berücksichtigung der Hypothesen der Halluzination und des Unbewussten. Als Entgegnung auf Dr. E. v. Hartmanns Werk "Der Spiritismus". Zweite verbesserte Auflage (Leipzig, 1894); Edmund Gurney, Frederic W. H. Myers, Frank Podmore, Phantasms of the Living (London, 1883).

65 There is, however, some confusion as to whether this film was actually shown in imperial Russia. Notes accompanying the collection of prerevolutionary films by the British Film Institute claim that only the ending, which the censors regarded as blasphemous, had to be cut for Russian audiences, while Leyda asserts that the film was only shown abroad. Leyda, Kino, 51.

M. V. Lodyzhenskii, Vragi Khristianstva: Doklad, chitannyi v Petrograde na religioznom sobranii v dome E.G. Shvarts 28 Dekabria 1915 g. (Petrograd, 1916); Usai et al., eds., Silent Witnesses, 286-290. 
dagger into a grave. Everything goes well until his coat accidentally gets stuck to a cross. "When he wants to leave, he feels that someone is keeping him back. The horror makes him go mad." ${ }^{\prime 7}$

The popularity of supernatural characters continued until the revolution and beyond. 1917 saw the premiere of Satan Triumphant (Satana likuiushchii), a horror picture, as well as the first screening of the even more thrilling Married by Satan (Venchal ikh Satana) (fig. 4). ${ }^{68}$

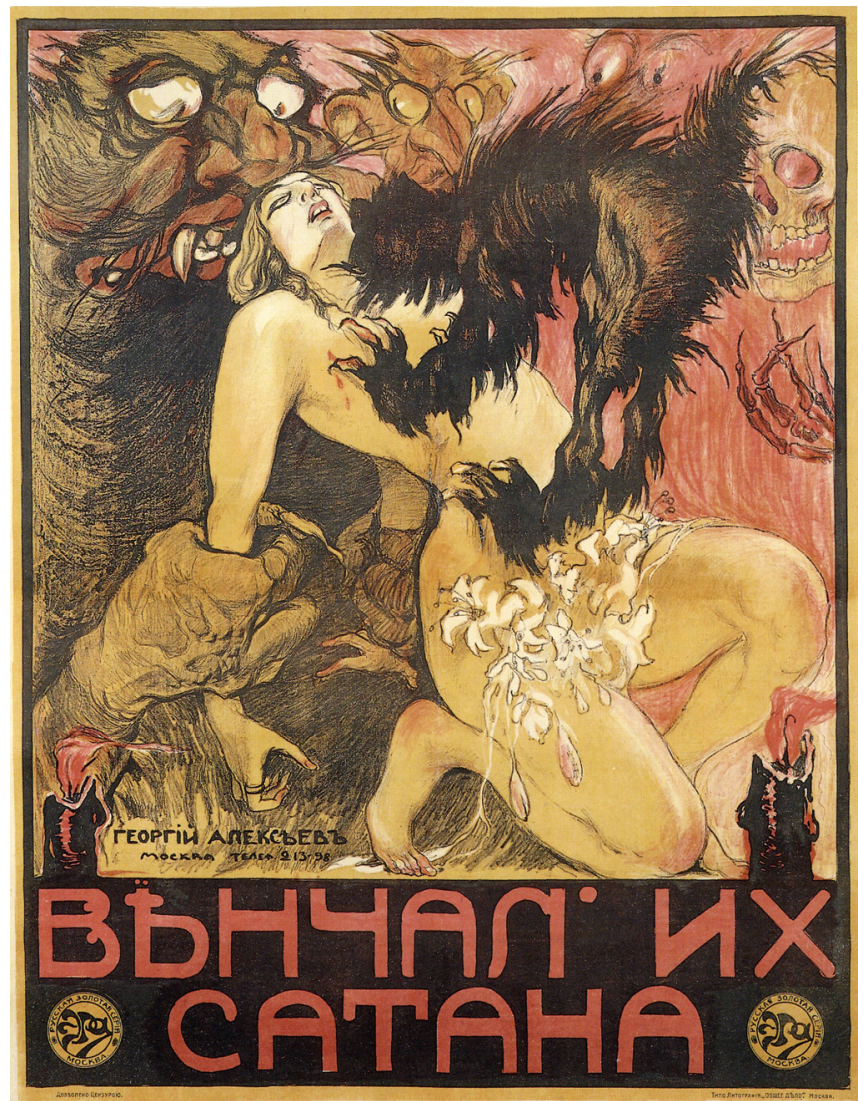

Fig. 4: Married by Satan (1917).

67 Likhachev, Kino $v$ Rossii, 67-68.

68 Ibid., 133-134. Poster by Georgii Alekseev. Taken from N.I. Baburina, Plakat nemogo kino (Moscow, 2001), no. 37. 
The plot of Venchal ikh Satana was taken from the novel Hell's Delights (Adskie chary), by the theosophist writer and medium Vera Kryzhanovskaia whose occult novels had appeared in the pages of The Petersburg Flyer. The film told the story of beautiful young Elena, who

is in love with Prince Basargin, but he prefers another. On the advice of her maid, Elena goes to see Sibilla the fortune teller, who "by the power of Great Source", unites her soul with the prince. They are wed by Satan (we actually see this!), the prince then asks for Elena's hand in the conventional way and marries her. True, it seems to her that he smells like a corpse and that there is a skeleton beside her. [...] Next Elena falls in love with her childhood friend Ivnev, and is unfaithful to her husband. But the fortune-teller helps out here too: she whispers something to Sa$\tan [\ldots]$ and some time later disaster befalls the prince. Six months pass and Elena marries Ivnev [...]. But the ghost of the late Prince Basargin begins to torment her. Once again, the fortune-teller wants to help Elena, but alas!-Elena's heart gives out, unable to cope with the nightmares of reproach. And this is where the picture ends. ${ }^{69}$

Although educated critics were adamant about the low artistic quality of films such as Married by Satan, film scripts that treated the occult were very popular with the audiences. Some of these films left the public with the impression that ghosts and devils really existed, while others-much like in popular literature-had a rational denouement. In 1914, The Mysterious Someone (Tainstvennyi nekto) and The Unknown World (Nevedomyi mir) were shot in the style of a horror story. The latter's plot was "taken from the mysterious world and [made use of] the notion of life in 'the beyond'. On the background of mystical yearning, the heroes' drama evolves but is ended by the triumph of science." ${ }^{\prime 70}$ The triumph of rational reasoning was also celebrated in 1915 in The Adventures of I.D. Putilin, the Renowned head of the Petrograd CID (Prikliucheniia znamenitogo nachal'nika petrogradskoi sysknoi politsii I. D. Putilina), which was a great success at the box office. In this detective story, the clever policeman appears to a murderer as the ghost of his victim and thereby extracts the much needed confession. ${ }^{71}$

69 Kino gazeta, 1918, No. 15, 7. Cited in Usai et al., eds., Silent Witnesses, 382.

70 "Nevedomyi mir,"Vestnik „Ekler“: Organ kinematografii 6, 1914, 21.

71 Alternative titles of this film were Phantoms of the Past (Prizraki proshlogo), On Murderer's Trails (Po sledam ubiits) and The Russian Sherlock Holmes (Russkii Sherlok Kholms). Usai et al., eds., Silent Witnesses, 290-292. 


\section{Post-revolutionary Continuities}

The appeal of the supernatural in light entertainment was so prevalent that it did not stop immediately after the Bolshevik Revolution of 1917. Indeed, Jay Leyda has argued that there was little change to film production in the first months after the Bolshevik revolution; sensational and macabre subjects continued to thrill audiences. ${ }^{72}$ The Face of Fate (Litso sud'by, 1918), for example, turned on the curse of an Indian Brahmin and thus also continued the prerevolutionary fascination with Asian mystical exoticism. It told the story of Leonid, who inherits a talisman mask that his father had received from an Indian sage. Before long, the mask turns into a threatening object, the ghost of the Brahmin appears and Leonid eventually finds refuge only in madness. ${ }^{73}$ Only in the early twenties did the mysterious slowly fade from Soviet cinema.

The supernatural, especially in the form of hypnosis remained a common feature in Soviet circuses until the 1930s. Special renown has been attributed to Ornal'do, also known as Nikokai Aleksandrovich Smirnov, who quite literally hypnotized his audiences, a routine which gained him much fame (fig. 5).$^{74}$

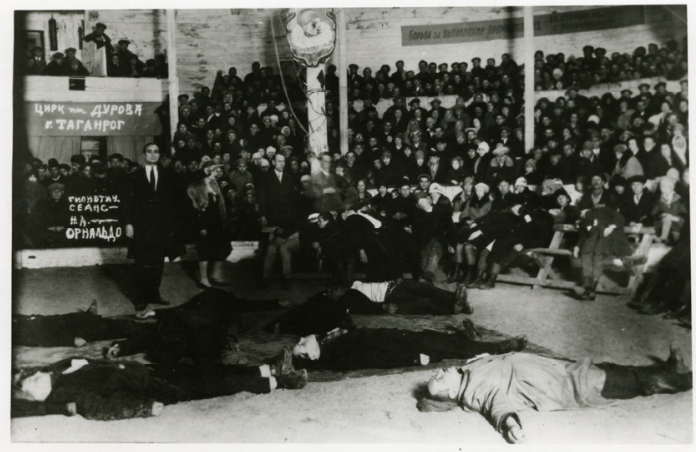

Fig. 5: Ornal'do hypnotizing audiences in the ring and front rows (1930s).

\footnotetext{
72 Leyda, Kino, 12.

73 Usai et al., eds., Silent Witnesses, 214, 408. Other films dealing with the supernatural included Kaliostro, Belye goloby (1918), Masony, Legenda ob Antikhriste (1919), Faust (1919). Ibid., 214, 408, 450-452, 470-472, 512, 506-508.

74 Muzei tsirkogo iskusstva.
} 
One of Ornal'do's stunts included the catalepsia of his female assistant, whereby the lady's body would become so stiff that she could be laid on the backs of two chairs, one supporting her heels, the other supporting her head. This feat echoed the trick of the hapless prerevolutionary fairground magician and his assistant in a mental harness and thus continued another older tradition. Even much later, when anything alluding to the occult was officially banned from Soviet mass entertainment, an aura of mystery seems to have lingered in Russian circuses. The Soviet illusionist Kio remembered that hypnosis was especially popular with female circus goers, who frequently asked to be put to sleep in this manner. Kio's reminiscences are also full of encounters from the 1950s in which respectable Soviet women begged him to read their fortunes. $^{75}$

\section{Conclusion}

The hidden forces of the supernatural featured prominently in late nineteenthand early twentieth-century entertainment. Newspapers reported supernatural events, instruction manuals advertised the diverting qualities of spiritualist séances and of fortune-telling, fun fairs and circuses staged hypnotic sessions while theatres and film used the latest technological innovations to make vampires fly through the air and ghosts appear on the silver screen. Consumer culture called for entertainment that involved supernatural forces and, as court cases and newspapers suggest, some illusionists were able to earn a living by displaying their "mediumistic abilities" or "hypnotic forces." The occult was thus not only a means of inexpensive self-entertainment; it became highly marketable. Serious money could be earned by publishers, at book-stalls, box offices and in shops that sold technical devices for magicians. The mysterious in entertainment fascinated contemporaries in the late imperial era and remained an undercurrent to official culture for much longer.

The message of newspapers, pamphlets, fairbooths, circuses, theatres and films regarding the occult was mixed. Parodies of gullible spiritualists were printed or staged alongside factual reports about supernatural engagement in human affairs. Popular entertainment blurred the borders between lighthearted satire and rational demystification on the one hand, and the acknowledgment of the existence of higher powers on the other. In popular entertainment, the explicable and predictable laws of physics coalesced with hypnosis, horror, madness, ghosts and death. The late nineteenth- and early twentieth- 
century Russian press along with other vehicles of public communication, such as the stage and the cinema, then, was far from embracing the rationalizing, enlightening mission which historians have commonly attributed to these intelligentsia organs. Instead, their pronouncements suggested a widely shared uncertainty on the part of contemporaries about the forces that governed individual fates. This uneasiness cannot be captured with labels such as "secularization" or "religious revival", the two terms commonly employed in regard to late nineteenth- and early twentieth-century worldviews. Instead, Russian popular culture suggests that a mood of uncertainty was prevalent, which was open to numerous possible denouements.

Of course, we do not know how individual consumers reacted to the opposing messages they encountered in print, on stage and on the silver screen. It is possible, that contemporaries-depending on personal opinions and preconceptions-choose to follow and believe in either rational or supernatural accounts. Even if this should have been the case, it does not change the fact that single news outlets, such as The Petersburg Flyer, The Cinematographer, theatres and cinemas expressed contradictory messages, in the case of newspapers at times even in one single page. The close association of pronouncements supporting and debunking supernatural forces suggest that neither traditional institutions such as religious institutions, nor the new, nineteenth-century authority of the scientific and technological community was in a position to assert a dominant worldview. Instead, supernatural notions coexisted with scientific teaching and also incorporated other, folkloric notions. The symbiosis of these different strands was not free of conflict. It was this conflict, which informed the character of the supernatural. Without serious spiritual search, parody would not have been possible; and technological imports allowed the supernatural to retain its contemporary relevance. In incorporating these diverse notions newspapers, theatres and cinemas truly became organs of mass culture.

One is tempted to surmise that this polyphony, which can be seen as the basis for ideological tolerance, was overcome after the revolution through staunch Soviet materialism. But as the magician Kio's reminiscences indicateas do the subsequent articles in this book-this presumption is misleading. Russian culture of the nineteenth and twentieth centuries remained open to various worldviews and interpretations, even if the spheres in which this openness was expressed changed. 


\title{
THE HISTORY OF ESOTERICISM IN SOVIET RUSSIA IN THE 1920S-1930S
}

\author{
KONSTANTIN BURMISTROV
}

\section{Esoteric movements in post-revolutionary Russia: main characteristics}

Esotericism in early Soviet Russia (1920s-1930s) constitutes an interesting chapter in the history of Russian thought that remains underappreciated and very little researched. The exuberant surge of interest in esoteric doctrines and practices of the first two decades of the $20^{\text {th }}$ century did not abate during the years of the Revolution and the bloody Civil War (1917-1922), although these events triggered profound changes in all areas of life. During these few years the centuries-old traditional order of Russian life was almost completely destroyed and the social structure of society underwent fundamental changes. It is not surprising that these changes should have affected the esoteric organizations that were now forced to organize their activities under new and wholly different socio-political and ideological conditions. Particularly significant is the fact that in pre-revolutionary Russia, the majority of esoteric organizations (Masons, pseudo-masons, Martinists, spiritualists etc) had been either branches of respective Western European organizations or maintained close ties with them. However, the Revolution rendered these contacts impossible, and any attempts to establish ties with foreign organizations incurred suspicions of espionage. As a result, esoteric groups in Soviet Russia faced increasing isolation from Western European schools of esotericism, and their doctrines and rituals inevitably became more and more "self-sufficient".

Another important factor that had a significant impact on Russian esotericism after the Revolution was the fact that a large proportion of Russian educated society (nobility, university professors, civil servants, army officers et al.) fled the country during these years. As a result, many members of esoteric groups found themselves in emigration and resumed their activity in their new countries (Turkey, Bulgaria, Serbia, Czechoslovakia, the Baltic States, France, China et al.) as early as the 1920s. Those esotericists who remained in Soviet Russia now recruited members for their new or rehabilitated groups (groups that had lost members in huge numbers since the Revolution) mainly from the intelligentsia of non-noble background and the working classes, a fact that 
inevitably found reflection in the respective organization's ideology. And while previously it had been the Orthodox Church that had exerted pressure on the Russian esoteric schools (although the Church's ability to exert pressure was sharply curtailed by the abolition of ecclesiastical censorship in 1905), now, after the Revolution, any interest in mystical or occult questions attracted the suspicion of the new authorities, who were preaching a militant atheism.

On the other hand, the renewed interest in certain aspects of esoteric knowledge was often related to the new scientific or pseudo-scientific theories that were rapidly gaining popularity after the Revolution and were used by the communists in their attempts to create a surrogate for religion. The newly formed worldview was based on the concepts of technocracy, cosmism and a boundless faith in man and his ability to change and subdue nature. ${ }^{1}$ These concepts included telepathy, telekinesis, the perfection of human nature, the prolongation of life and even the resurrection of the dead. ${ }^{2}$ Consequently, the Soviet occultists concentrated on experimental methods, including magic, in their quest to learn, first and foremost, how to exert influence on nature and man, while the esotericists in tsarist Russia had been mostly preoccupied with personal spiritual growth, the study of the most subtle manifestations of the human psyche etc.

Esoteric groups in Soviet Russia differed in their attitude towards the Soviet regime, state politics and communist ideology. Some of them, especially at the beginning of the 1920s, tried to legalize their activities and convince the communists that their teachings were fully commensurate with communist doctrine and that they could be of great use to the new regime. However, the most serious occult groups were operating underground and avoided attracting attention, partly because they distrusted the Soviet regime, or harbored an openly negative attitude towards it, and partly because of their strongly hierarchical and traditional "initiatory" character, which did not foresee any proselytizng or even the disclosure of doctrines and practices.

1 See Anthony J. Vanchu, “Technology as Esoteric Cosmology in Early Soviet Literature,” In: Bernice G. Rosenthal, ed., The Occult in Russian and Soviet Culture (Ithaca: Cornell University Press, 1997), 203-222.

2 See Michael Hagemeister, „Die Eroberung des Raums und die Beherrschung der Zeit. Utopische, apokalyptische und magisch-okkulte Elemente in den Zukunftsentwürfen der Sowjetzeit,“ In: Jurij Murašov, Georg Witte, eds., Die Musen der Macht. Medien in der sowjetischen Kultur der 20er und 30er Jahre (Munich: Fink, 2003), 257-284; idem, „'Unser Körper muß unser Werk sein.' Beherrschung der Natur und Überwindung des Todes in russischen Projekten des frühen 20. Jahrhunderts, "In: Boris Groys, Michael Hagemeister, eds., Die Neue Menschheit. Biopolitische Utopien in Rußland zu Beginn des zwanzigsten Jahrhunderts (Frankfurt am Main: Suhrkamp, 2005), 19-67. 
Be that as it may, the majority of mystic and occult groups that operated in the 1920s and 1930s did not constitute successor institutions or branches of earlier esoteric groups, either Russian or foreign. Instead, they were created by the will of their founders and under the influence of literature. Their founders were often charismatic leaders and autodidacts who had independently (often following a paranormal experience) taken upon themselves the burden of "initiation". Subsequently, their first preoccupation was the acquisition of an esoteric genealogy, legends and traditions for the organizations they had founded. Often they referred to this activity as reconstruction or revival of ancient traditions (e.g. Gnostic, Templar, Rosicrucian). While there certainly was some continuity of pre-revolutionary schools, these connections were artfully concealed, and we have little to no trustworthy information about them.

Noticeable materialist tendencies and attempts to classify esoteric theory and practice as a specific stage in the development of a scientific worldview that was wholly unrelated to religious issues notwithstanding, it would be erroneous to consider the participants in esoteric movement atheists. Some of them were sympathetic to Christian mysticism, others were hostile to Christianity as a whole, yet all of them were heavily influenced by Gnostic ideas. Gnostic texts, which were available in translation into European languages, were carefully studied in esoteric circles and sometimes became important sources for a given group's legends, traditions and liturgical texts. One can even say that Gnosticism was regarded as the primary religion that had been destroyed by Christianity and needed to be restored as an original alternative to Christianity.

We must briefly comment on the sources providing information about the activities of esoteric groups in early Soviet Russia. Practically all surviving information can be found in the investigation files and documents compiled by the repressive organs, first and foremost in the archival investigation files of the OGPU-NKVD-MGB-KGB. ${ }^{3}$ Unfortunately, most of the archives pertaining

3 The principle material was deposited in the Central Archive of the Federal Security Service (FSB) of the Russian Federation, as well as in the archives of regional FSB sections. Some documents are in personal files held in the Russian State Archive of Literature and Art (RGALI) and the State Literature Museum in Moscow. To the present moment the researcher who has made the biggest contribution to the collection and publication of documents relating to secret esoteric societies in Soviet Russia during the 1920s-1930s is Andrei Leonidovich Nikitin (1935-2005), a well-known historian, archaeologist, literary scholar, publicist and the author of numerous works of the archaeology, history, palaeography and historical ecology of Eastern Europe. Owing to the fact that his father, the artist Leonid Nikitin (1896-1942) was an active member of the Templar Order (as a result of which he suffered repressions twice and 
to this organization remain closed to researchers to the present day. Moreover, while some documents relating to investigations, as well as information about sentences passed, were accessible in the 1990s, when the denunciation of political repression was at its height, and were subsequently published, the theoretical papers and literature of esoteric groups, which were confiscated by the intelligence services but had no relation to politics whatsoever, failed to attract attention and remain unstudied. As a result we know quite a lot about the history of certain groups (their membership profile, structure and practical activities), while knowing next to nothing about their doctrine. Self-censorship features prominently on the list of factors that complicate the reconstruction of the worldview of the Russian esotericists of this period: for obvious reasons there were many things they did not entrust to paper, and we must assume that the most significant aspects of their doctrines and practices (in particular everything to do with the use of ceremonial magic) did not find entry into the surviving documents.

It is significant that, as a rule, even those esotericists who survived the repressions told nothing about the organizations of which they had been members. Yet another problem is the question to which degree we can trust the statements of people who were under investigation by Stalin's repressive organs-after all it is from confessions of this kind that we glean most of the information about our subject. It is glaringly obvious that those arrested under suspicion of having committed grave crimes against the communist authorities would adopt all kinds of strategies, ranging from attempts to express their views as fully as possible in order to convince the investigators of their innocence or pass on these views to posterity, to complete mystification, defamation etc. ${ }^{4}$

died in prison), his son received permission to access the closed collections of the Central Archive of the FSB. The result of his many years of painstaking work are five volumes in the series "Mystical Societies and Orders in Soviet Russia" (Misticheskie obshchestva i ordena v sovetskoi Rossii) (Moscow: Minuvshee, 2003, 2004, 2005) and numerous books and articles.

4 Until December 1934 (i.e. until the assassination of Sergei Kirov) investigators usually followed correct procedure (with the exception of the provincial borderlands) and the case materials contain valuable data on both the history and the teachings of esoteric groups. Between 1935 and 1940 the task of the repressive organs was to force those under investigation to denounce themselves, which then entailed the sentence of death by firing squad. The case files of this period contain very little information about esoteric movements, as the investigators were focussing on indictments on political grounds (terror, sabotage, anti-Soviet agitation and propaganda). No more information is to be found in the archival investigation files compiled during the third wave of repression, which followed in 1948-1951, when those who had a previous sentence according to article 58 of the Penal Code were hunted down all over the 
It is also important to bear in mind that from the early 1920s on the publication of texts on esoteric issues became impossible, even in periodicals. Of course the rich literature on different aspects of occultism that had been published in Russia from the late $19^{\text {th }}$ century onwards remained accessible. Moreover, the esoteric circles self-published large amounts of foreign articles and books in translation, original new texts and different kinds of technical literature (statutes, by-laws etc) that they circulated anonymously in manuscript or typescript (print run between 10 and 100 copies). ${ }^{5}$

\section{Esotericism in Russia in the 1910s}

There were some links, ideological as well as organizational, between esoteric groups in Soviet Russia and pre-revolutionary esoteric circles and those esoteric leaders who remained in Russia after the Revolution. The best-known and most influential among them was Grigorii Ottonovich Mebes [Miobes, Möbes] (1868-1934), a lecturer in mathematics, physics and French, as well as one of the most outstanding Russian theorists of occultism and a prominent figure in the esoteric movement. ${ }^{6}$ At the end of the 1910s he became Inspector General

country and once again sent to concentration camps or "eternal exile". These were purely formal trials and the case files contain no new information.

5 A good impression of the breadth of the topic of "occult samizdat" can be gleaned from Mikhail Artem'ev's (real name Mikhail Brendsted) article, published in the 1930s in several issues of the newspaper Rassvet (Dawn) which appeared in Chicago; see Mikhail Artem'ev, "Podpol'naia literature v sovetskoi Rossii," Rassvet (Chicago), 1930, nos. 233-235. For example: "...they all vie with each other, searching for the innermost, secret, internal, original, eternal, absolute, divine, true... in one word, a thicket of 'philosophy', 'ontology', 'metaphysics', 'mysticism' and other areas, which had previously triggered in the young political propagandists and agitators condescending disdain and arrogant pity for the 'reactionary way of thought'." One can also find an extremely important information on the underground occultists movements in the early Soviet Russia and their libraries in two papers by Aleksandr Aseev (1902-1993), editor-in-chief of the esoteric journal Okkultizm i Ioga (Occultism and Yoga, Belgrade, Sofia, Asuncion, 1933-1977), published by Nikolai Bogomolov: Aleksandr Aseev, "Initiatory orders: Freemasonry, Martinism, and Rosicrucianism” (Posviatitel'nie ordena: masonstvo, martinizm $i$ rozenkreitserstvo), "Occult movement in Soviet Russia" (Okkul'tnoe dvizhenie v sovetskoii Rossii), In: Nikolai Bogomolov, Russkaia literatura nachala XX veka i okkul'tizm (Moscow: NLO, 1990, 429-443.

6 On him, see Andrei Serkov, Istoriia russkogo masonstva v XX veke, t. 1 (St. Petersburg: izd-vo im. N.I. Novikova, 2009), 117-122; Viktor Brachev, Okkul'tisty sovetskoi épokhi. Russkie masony XX veka (Moscow: Bystrov, 2007), 11-14. Cf. also the recently published edition of Mebes's lectures on the arcana of the Tarot that he gave in 1912 and 1921 (G.O.M[ebes], Kurs 
of the St Petersburg branch of the French Martinist Order (Ordre Martiniste). At the same time he was giving his famous lecture course on the Arcana of the Tarot in which he, in many aspects following Papus, interpreted Martinist doctrine by combining concepts pertaining to the Martinist Kabbalah with the Tarot. Soon afterwards these lectures were published in mimeograph under the name A Course in the Encyclopaedia of Occultism given by G.O.M. in the academic year 1911-1912 in St Petersburg (Kurs entsiklopedii okkul'tizma chitannyi G.O.M. v 1911-1912 akademicheskom godu v gorode Sankt-Peterburge, St. Petersburg, 1912). In the same year Mebes declared the independence of the Russian Martinists ${ }^{7}$ after founding, in Petersburg, the "Autonomous Detachment of Martinism of the Russian Rite" (Avtonomnyi razriad martinizma russkogo poslushania), after 1916 called "Martinist Order of Eastern Rite" (Orden martinistov Vostochnogo poslushania), ${ }^{8}$ which maintained close ties to the most important Russian periodical on occultism, "Izida" (1909-1913) and the eponymous publishing house. The Martinist groups in pre-revolutionary Russian had in many respects the most defining influence on the esoteric groups of the 1920s, the majority of whose leaders and activists were linked to Mebes and his system in one way or another. The Order continued to be active throughout the Civil War and the first years of the Soviet regime.

Potentially the most interesting of these groups were the "Society for the Revival of Pure Knowledge" (Obshchestvo vozrozhdeniia chistogo znaniia, 1916) and the Martinezist Order (a branch of the Martinist Order), both founded by Mariia Nesterova (Erlanger, 1878-after 1932), Mebes's wife and

entsiklopedii okkul'tizma (Moscow: Aenigma, 2003); G.O.M[ebes], Meditatsii na Arkany Taro. Dopolneniia k Éntsiklopedii okkul'tizma: lektsii 1921 goda (Moscow: Aenigma, 2007).

7 The Russian Martinist lodge was founded in 1899 by Count Valerian Valerianovich Murav'evAmurskii (1861-1922), a prominent diplomat and Russian military agent in France. In 1910 the Polish count Czesław Czyński (1858-1932) took over his place, a member of the Supreme Council of the Martinist Order and General Delegate to Russia (he was also initiated to a high stage in the Ordo Templi Orientis [O.T.O.] and the Église catholique Gnostique). After the schism of 1912 the Moscow group of the Martinist Order under the leadership of P.M. and D.P. Kaznacheev remained faithful to the Paris center and continued their activities until 1923. See Serkov, Istoriia russkogo masonstva v XX veke, t. 1, 109-126.

8 The leadership of the Order was a Chapter consisting of seven people. Its General Inspector was the historian, journalist and bibliographer Ivan Kazimirovich Antoshevskii (1873-1917), the director of the publishing house and journal Izida; for more information on him, see Ivan Antoshevskii, Derzhavnyi orden sviatogo Ioanna Ierusalimskogo... Orden Martinistov (Moscow: GPIB, 2001), 3-26. After his death the position was taken over by Vasilii Bogdanov (1877 - after 1926), a disciple of Mebes who studied at the Theological Institute and served as a clerk in the State Bank in the 1920s. Mebes himself was the "invisible master" of the Order. 
close associate. A special group for intensive theoretical and practical training, "The Promethean Group" (Gruppa Prometeia), which was closed to the uninitiated, was set up within the latter Order. During the Civil War years (19181922), Mebes and his colleagues gave a lecture course for their closest followers in the context of this group. The lectures concerned the doctrine of the Kabbalah (Mebes), the history of religion (Nesterova) and the history of Freemasonry (Boris Astromov); the leaders also held practical training sessions in telepathy and psychometrics, as well as collective meditations.

The lawyer Boris Astromov (Kirichenko, 1883-1941?), a disciple of Cesare Lombroso, who had joined a Masonic lodge in Italy in 1909, played an important and rather deplorable role in the history of occult circles in the 1920s. ${ }^{9}$ In 1919 Mebes appointed him Inspector General of the Martinist Order, but, Astromov left the Order after a conflict in 1921 to found the "Autonomous Russian Freemasons" (Russkoe avtonomnoe masonstvo), and then the "Grand Lodge Astreia" (Velikaia lozha Astreia). In 1925 he contacted the OGPU, offered his services as an informer and provided the officials with substantial information on various esoteric groups in Soviet Russia, including the Martinist Order. Thus he prepared the ground for the wave of repression that swept the scene in 1926 and led to the arrest of dozens of Russian esotericists, led by Mebes, in what became known as the Case of the Leningrad Freemasons (Delo Leningradskikh masonov). ${ }^{10}$

There were several other esoteric organizations that had been active in the Russian capital in the years preceding the Revolution and remained operative for some time after the Revolution. Among them was Georgii Loboda's society "Sphinx"11, the "Order of the Knights of the Holy Grail" (Orden rytsarei svia-

9 See Andrei Nikitin, Ezotericheskoe masonstvo v Sovetskoi Rossii. Dokumenty 1923-1941 gg. (Moscow: Minuvshee, 2005), 16-30, Brachev, Okkul'tisty sovetskoi épokhi, 10-72.

10 The materials of the case are published in: Nikitin, Ezotericheskoe masonstvo $v$ Sovetskoi Rossii, 7-245. See also Viktor Brachev, ed., "Leningradskie masony i OGPU (protokoly doprosov, veshchestvennye dokazatel'stva)," Russkoe proshloe. Istoriko-dokumental'nyi al'manakh, book 1 (Leningrad, 1991), 252-279.

11 The chairman of the society, Georgii Osipovich Loboda (1876-?), subsequently participated in the work of a commission for the study of psychological phenomena at the Brain Institute (1923-1924). In 1926 he was arrested and exiled. The society "Sphinx", created for the study of occultism, existed from 1916-1918. Among its active members were Semiganovskii and Barchenko, who will be mentioned below. In 1917 Loboda published a collection which constitutes a faithful representation of the interests entertained by the members of the society: Sphinx. A collection of articles on spiritism, occultism, theosophy, hypnosis et al. compiled by the chairman of the "Sphinx" society G. Loboda (Sfinks. Sbornik statei po spiritizmu, okkultizmu, teosofii, gipnotizmu i proch. Sost. pred. o-va "Sfinks" G.L., Petrograd, 1917). 
togo Graalia), founded by Aleksei Gaucheron de la Fosse (1888 - after 1930) ${ }^{12}$, Antonin Semiganovskii's circle "Inner Esoteric Church" (Vnutrenniaia ezotericheskaia tserkov) ${ }^{13}$, the circle "United Labor Brotherhood" (Edinoe trudovoe bratstvo), headed by the doctor, science-fiction writer and occultist Aleksandr Barchenko (1881-1938) ${ }^{14}$, the Russian branch of the French occult order of the "Philalethes"15 et al.

The abovementioned groups exerted a significant amount of influence on those esoteric organizations that emerged in the 1920s and were forced to operate in radically different conditions. The impossibility of pursuing their activities openly and publishing the results of their work, combined with political and ideological pressure, forced them deep underground. Below we will describe some of the groups that we consider to be the most distinctive and representative of this stage in the history of Russian esotericism.

\section{The Order "Emesh Redivivus"}

The order "Emesh Redivivus" was founded in 1926 in Moscow by the economist and "professional" occultist Evgenii Karlovich Teger (1890 - after 1940) and Vadim Karlovich Chekhovskii (1902-1929), a meteorologist and physicist who was especially interested in telepathy and parapsychology. ${ }^{16}$ According to

12 The Order was founded in 1916 and destroyed by the OGPU in 1927. See Brachev, Okkul'tisty sovetskoi eppokhi, 72-79.

13 Antonin (Antonii) Nikolaevich Semiganovskii-Dienti (1888-?), a graduate of Moscow University and the Moscow Archaeological Institute; member of the Martinist Order, since 1916 leader of the lodge "Zodiak". In 1919 excluded from the Order by Mebes. Subsequently founded the "Christian Esoteric Order" (Khristianskii ézotericheskii orden) (1920-1923). Since 1922 member of the Renovated ("Living") Church, since 1923 a bishop in the Renovated Church in the Baikal region. Was a professor at the Moscow Theological Academy of the "Living" Church and there gave a lecture series on "The History of Religions".

14 On Barchenko and his cooperation with the OGPU, see Brachev, Okkul'tisty sovetskoi eppokhi, 199-226.

15 See Viktor Brachev, ed. "Peterburgskie martinisty 1910-1925 godov. Dokumenty Arkhiva Ministerstva bezopasnosti Rossiiskoi Federatsii," Otechestvennaia istoriia, 1993, no. 3, 192.

16 The main information about the structure, history and teachings of the Order can be found in the witness statements of Chekhovskii, who consciously tried to give a detailed explanation of his views to the OGPU and tried to convince his investigators that he was in the right and harmless, as well as in the statements of Vasilii Preobrazhenskii (1883 - after 1931), who gave very detailed information about the internal work of the Order, its magic practices and the hostile attitudes of its leaders towards the Soviet government. Teger gave practically no statements. See Andrei Nikitin, ed., Rozenkreitsery v Sovetskoi Rossii. Dokumenty 1922-1937 gg. (Moscow: Minuvshee, 2004), 30-99. 
one of the Order's members, its name- "אמש Redivivus"-denoted the reborn (renewed) unity of the three planes of being-mental, astral and physical,symbolized by the three "letter-mothers" of the Jewish mystic treatise "Sefer Yetzirah" (the letters aleph, mem and shin, together making up the acronym Emesh). ${ }^{17}$

By origin, the organization was directly linked to the pre-revolutionary Martinist Order led by Czesław Czyński and Mebes. According to certain data, a secret group called "Emesh" had existed in Petersburg in the 1900s-1910s , and it was from this group that the Moscow Order received its initiation and the necessary literature in the 1920s. The members of the Order referred to themselves as Rosicrucians and to their organization as a "branch of the Russian branch of the Kabbalistic Order of the Rose and Cross with its center in France", in Russia led by Mebes. ${ }^{18}$ The Order sought to "surpass all existing occult organizations, including Masonic ones, that is, apart from theory it set itself the aim 'to realise theory in practice by attaining power that enables implementation'. This expression must be considered as the 'endeavour to establish initiation to magic on a worldwide scale"'. ${ }^{19}$ According to Teger, the magicians leading the Order "must be higher than the spiritual and secular authorities" in the entire world. ${ }^{20}$

The Order's ambitious goals aptly reflect the utopian mindset and atmosphere of intellectual recovery typical of post-revolutionary Russia: its members hoped to be able to combine the new achievements of contemporary science with the esoteric knowledge of the ancients, to create-or re-create-real and efficient magic that would allow them to exert influence not only on the material world, but also on all the planes of being in the entire universe. The "brain center" of the Order was the scholar and experimenter Chekhovskii, a specialist in the field of physics and chemistry, who spent years carrying out experiments establishing the influence of colored light on the human psyche and telepathy (he worked with the State Brain Institute, headed by Vladimir Bekhterev, and the Society for the Study of Psychology, Neurology and Hypnology

17 See Sefer Yetzirah, mishna III: "Three primary letters: Alef, Mem, Shin - a great secret, hidden and ineffable, and sealed with six seals. And from it goes out fire, and water and air, and it is divided into male and female", Allison P. Hayman, Sefer Yesira. Edition, Translation and TextCritical Commentary (Tübingen: Mohr Siebeck, 2004), 111; on the 'three mothers' see ibid., 110-127; cf. also Nikitin, Rozenkreitsery v Sovetskoi Rossii. Dokumenty 1922-1937 gg., 93.

18 I.e. Ordre Kabbalistique de la Rose Croix, founded by Stanislas de Guaita (1861-1897) in 1888. Cf. Nikitin, Rozenkreitsery v Sovetskoi Rossii. Dokumenty 1922-1937 gg., 87. Ibid., 91. Ibid. 
in Leningrad). Teger also played an important role; he was one of the most outstanding Russian specialists in the field of occultism and familiar with virtually all the existing esoteric schools and traditions. It is significant that the majority of the organization's members were Germans or Poles by birth, graduates of the well-known Evangelical Reformed school of the Holy Apostles Peter and Paul ${ }^{21}$ in Moscow, and that nationalist and anti-Semitic views were rife among them. Moreover, the leaders of the Order had a wide contact network in both the occult and the academic scenes. ${ }^{22}$

This is not the place for a detailed history of the Order, but let us note that the organization was exposed in February 1928, entirely by chance, as the result of a misunderstanding, although the flat that served as headquarters was situated right next to the NKVD building on the Lubyanka. Be that as it may, the Order's members were sentenced to prison terms and internal exile. Chekhovskii, who was sent to the labor camp on the Solovetskii islands, was executed soon afterwards for his active involvement in the preparation of a prisoner breakout, while Teger spent the remaining years of his life in exile and imprisonment (nothing is known of his fate after 1942).

There were different levels of initiation to the Order, as in any esoteric organization, so as a consequence the majority of its members were ignorant of the organization's ultimate goals. As occult organizations were forbidden in the USSR, the leaders of the Order concealed their activities. The Order had been granted the legal status of a scientific laboratory for research into the subject of telepathy, closely collaborating with the Brain Institute of the Soviet Academy

\section{Ibid, 25.}

22 Teger was a disciple of Mebes, while his wife was a sister of Mikhail Sizov (1883-1956), a wellknown biologist, chemist, anthroposophist, Rosicrucian and Templar. Chekhovskii collaborated with the famous Russian psychiatrist Vladimir Bekhterev and the biophysicist Aleksandr Chizhevskii. In 1922 Chekhovskii spent most part of the year in Germany, where he was in contact with anthroposophists, including Nikolai Belotsvetov (1892-1950). In Russia, Belotsvetov, a Russian officer, poet and mystic had been a member of an underground occult circle and lodge; in 1920 he had fled abroad and written the seven-volume documentary novel "Michael", in which he talked about the complex relations between occultists and the Cheka after the revolution, the flirtation of the "magi" with the regime, and the Bolsheviks' attempts to use occult forces to strengthen their power. The author destroyed his sensational and profoundly autobiographical novel at the request of his former "colleagues" (it is possible that one of the reasons was the fact that the authors made a link between the Bolsheviks' occult interests and a Jewish group within the party and the Cheka). Only a few fragments were published in the book "The Proletarian Missionaries' Commune" (Kommuna proletarskikh missionerov, Berlin, 1921), but even these fragments contain many facts not mentioned in any other source. 
of Sciences. ${ }^{23}$ Some of the participating scholars knew nothing about the occult and magical motifs underlying the group's activity. The goal of the Order's secret activity, on the other hand, was the mastery of occult methods for controlling the elemental spirits, the so-called "elementalia". In the underground laboratory that was situated in the basement of a house on the Malaia Lubianka, 16, they studied ways of calling upon and "coagulating" elementalia with the help of narcotics and strong hallucinogenic substances. In order to carry out these experiments the Order's members searched for wild magical and medicinal herbs in the outskirts of Moscow and made plans for growing them in dedicated plantations. The place for the laboratory had been chosen deliberately: its close proximity of the cellars of the OGPU, in which people were being tortured and shot, was supposed to make it easier to trap the "elementalia" and "liarvy" (larvae) ${ }^{24}$ that had been attracted by the suffering and the blood of the victims. ${ }^{25}$ We know also that Chekhovskii used the laboratory to carry out experiments in envoltation, that is, a mental attack accomplishing by a ceremonial magic ritual, the result of which "could be... either death or complete mental depression, or illness." 26

The theoretical sessions that were held on the same premises comprised lectures on practical magic, arcanology, cabbalistics, graphology, astrology and other occult disciplines, as well as organic and inorganic chemistry, botany and medicine. The main sources of instructions were handwritten brochures received from the Order's leader Lev Martiushev (1880-1937) in Leningrad, a military chemical engineer and member of the pre-revolutionary occult Order "Emesh" (Order name "Aleph") 27. Mebes's Course in the Encyclopaedia of Oc-

23 See Chekhovskii's statement "My meta-psychological activities in the Brain Institute" (Moia metapsikhicheskaia deiatel'nost'), In: Nikitin, Rozenkreitsery v Sovetskoi Rossii. Dokumenty 1922-1937 gg., 60-62, 66.

24 Liarva (lat. larva-mask, guise) - harmful substances; the spirit of an evil person who has not found rest after death and is wandering about on earth. In occultism: an evil wish that has not been accomplished but has taken on astral form.

According to the former Orthodox priest V.V. Preobrazhenskii, Chekhovskii's closest associate in the field of practical magic, the site of the laboratory had been chosen specifically for its situation next to "the cellars of the OGPU, where the blood of the executed is shed. As we know, the blood of the deceased is necessary for the feeding of liarvas, who are forming a reign of shadows and darkness, which must be destroyed by the currents of light from the magical operations carried out in the generator of the cellar...", Nikitin, Rozenkreitsery $v$ Sovetskoi Rossii. Dokumenty 1922-1937 gg., 92. Nikitin, Rozenkreitsery v Sovetskoi Rossii. Dokumenty 1922-1937 gg., 17. Transport; he was shot in 1937. According to Chekhovskii, Martiushev only slowly and reluc- 
cultism was also actively used, alongside various other handbooks on occultism (for example the lithographic edition of Sar Dinoil ${ }^{28}$, Karl Brandler-Pracht's Occultism [St. Petersburg, 1910], the books of Swami Vivekananda et al.). According to Chehovskii,

...there were four different levels in our organization. The first was... for individuals who did not know about the existence of the organization. The second was for... people who, while following the course, had begun to suspect the existence of an unknown occult organization with a magical bias. The third was for... people who knew about the existence of the organization and had formed some understanding about its aims, but did not know its name, structure or main positions. The fourth level comprised people (only men) who were familiar with the name and aims of the organization and had the right to acquaint themselves with all materials at the organization's disposal. At the same time, members at this level did not have the right to have in their personal possession material and information relating to other similar organizations, if they had dealt with them beforehand. ${ }^{29}$

Moreover, Chekhovskii identified nine levels or stages of promotion for the Order's members:

1. the scientific study of metapsychical phenomena that find expression mostly in works on telepathy and clairvoyance; 2 . a course on arcanology and the beginning of occult training; 3 . occult magical practice; 4 . the center "Emesh Redivivus", which does not pretend to have attained the fullness of occult possibilities; 5. the same, after the creation of an appropriate base for serious occult and magical practice over a number of years; 6 . the same, after the attainment of certain results and after the

tantly passed on the magic and occult manuscripts from the archive of the earlier order (ibid., 69).

28 Sar Dinoil, the pseudonym of Leonid von Fölkersam (Leonid Leonidovich fon Fel'kersam), an occultist and astrologist and member of the French "Société magnétique", the "Centre ésotérique de France" and other similar organizations. He was the author of several books on the practice of occultism and astrology, including The Building of the Human Being. Our Hidden Abilities and how to Develop Them (Stroenie chelovecheskogo sushchestva. Nashi skrytye sposobnosti i ikh razvitie, St. Petersburg, 1912), What is Astrology. The Stars and the Human Life (Chto takoe astrologiia. Svetila i zhizn' cheloveka, Petrograd, 1916). In the early 1910s he gave a course on "how to develop hidden mental forces" in St. Petersburg and held consultations, during which he combined the methods of astrology with graphology, physiognomy, palmistry and magnetic, as well as preparing items for use in practical occultism (crystals, magnets, biometers, screens). He published his works in the journal Izida.

29 Nikitin, Rozenkreitsery v Sovetskoi Rossii. Dokumenty 1922-1937 gg., 79. 
beginning of the creation of a world centre for occult magic, either on the territory of the USSR or abroad; 7. a world center for occult magic that has full control of the astral plane; 8. the same, with full control of the mental plane; 9. the same with full control of the divine plane. The nine levels were divided into three groups, each consisting of three consecutive stages according to criteria: the first was concerned with the periphery, the second with the centre (Emesh Redivivus) as a tool for the creation of a world center for the occult that would have complete mastery of all occult knowledge and the opportunity to put this knowledge into practice; finally, the third group was concerned with the world centre for occult magic that would command these opportunities and use them to serve the cultural process and all humanity... ${ }^{30}$

Thus the Order's goals were hugely ambitious and extended to the attainment of world supremacy. In the USSR it was not possible to attain anything beyond the fourth stage, the creation of "Emesh Redivivus". Later, the Order's leaders entertained serious plans to flee abroad and implement their activities in more favorable conditions; however, their plans were foiled by the state security organs at an early preparatory stage. ${ }^{31}$

Our knowledge of the Order's doctrine is limited, mainly to the information Chekhovskii himself gave the investigators, trying to convince them of the usefulness of Rosicrucian ideas for the Soviet authorities. As we can easily see, the Order's cosmology and anthropology are re-workings and adaptations of the ideas of Stanislas de Guaita, Papus and Mebes. The universe consists of five layers or planes, which Chekhovskii characterized with the help of concepts pertaining to different religious and esoteric traditions:

1. The divine plane is the finest, most immaterial, perfect plane of being; the Olam ha-Aziluth of the Kabbalah (the World of Radiance), Ein sof (the upper abyss) - God, the real pole of being. The Salamander-firethe radiant state. 2. The mental plane, the letter Aleph (=1), Olam ha-Briah (The World of God's Creation), the world of transcendental reason, the world of primary causality. The ten sephiroth of the Kabbalah, the ten names of God; the Spirit of the Christian hermits. 3. The astral plane. Mem (=40), Olam ha-Yetzirah (The World of Spiritual Hierarchies), the world of transcendental emotional origins. The world of secondary causalities, the Seven "planets" and 12 "signs of the zodiac".

30 Ibid., 78-79; cf. also 68-69.

31 Only the leaders of the Order (Teger, Chekhovskii and Preobrazhenskii) reached the fourth stage out of nine. 
The "Soul" of the Christian hermits. Undines-water-the liquid state. 4. The physical or material plane, Shin $(=300)$, Olam ha-Asiah ("The World of the Elements"), the material or physical world; the illusory world. The "Maya" of the Indians, the "body" of the Christian hermits. Gnomes-earth-the solid state. 5. the lower abyss. ${ }^{32}$

The eclecticism of this scheme is no accident. Pretending to universality and convinced that the Order would revive the ancient knowledge of the dwellers of Atlantis, Chekhovskii "categorically declared" that "this scheme encompasses all religions... and found entry into a number of philosophical currents and scientific classifications." 33

The aim of the experiments carried out within the Order was not just the perfection, but rather the radical transformation of the entire human being. By his nature and in his present state "man consists of three planes and carries within himself the individual eternal spark of the higher plane", although he is not aware of this. "All occult-mystical currents are striving after the awareness and mastery of these planes", however, the Order's task was more radical yetnamely, the restoration of the state in which the dwellers of Atlantis existed. In Atlantis "man had a united four-plane consciousness and exercised divine power in the four worlds" and because of that, the Order teaches, "the task of contemporary man is reintegration, ${ }^{34}$ the restoration of unity, the mastery of lost perfection. This can be achieved by different paths. For example the mystical-passive one or the occult-[active] one, such as the path of the Templars, 'who took heaven by storm'." ${ }^{35}$ According to Chekhovskii, freedom, equality, joyful delight in life, boundless creativity and individual immortality would reign supreme in the occult-cabbalistic world of the future. This is what he tirelessly tried to explain to his jailers.

\section{The Order of Orion-Khermorion (Order of the Moscow Rosicrucians and Manichaeists).}

The occult "Order of Orion" was founded before the Revolution, in 1916. It received its new name, "The Order of Orion-Khermorion" in 1926, after a restructuring. In 1933 the Order was exposed, rooted out, and destroyed by the

32 Nikitin, Rozenkreitsery v Sovetskoi Rossii. Dokumenty 1922-1937 gg., 45-46.

33 Ibid., 46.

34 A clear parallel with the eponymous Martinist conception dating back to the Traité sur la réintégration des êtres of Martines de Pasqually.

35 Nikitin, Rozenkreitsery v Sovetskoi Rossii. Dokumenty 1922-1937 gg., 46-47. 
NKVD; however (and this was very uncharacteristic of that time), the NKVD failed to confiscate its large archive, which was preserved as part of a private collection. ${ }^{36}$ Some members of the Order continued their activities until the 1970s. ${ }^{37}$

As a result, we possess a sizable amount of information on the doctrine and internal practices of this organization, unlike in the case of the majority of occult groups from this time, where all we know is taken from the investigation file. The members of this strictly clandestine Order ("Knights") studied the theory of occultism and magic, as well as actively practicing ceremonial magic. In particular, they developed special methods for collective magical operations, work with the elements (using aromatic substances, herbs, stones, metals etc), and ways of achieving lasting contact with the astral plane (the so-called "twinconsciousness").

The head of the order was the probably most charismatic and talented occultist of his time, the 'Russian Saint Germain', Vsevolod Viacheslavovich Beliustin (1899-1943?). ${ }^{38}$ The doctrine he developed was based not on the Martinist tradition in the version propagated by Mebes, but instead on an original occult doctrine created by Vladimir Alekseevich Shmakov (died 1929), one of the most enigmatic figures in the history of Russian occultism. Shmakov, the generally accepted spiritual leader of various Rosicrucian organizations in the early 1920s, was the son of Aleksei Semenovich Shmakov (18521916), a well-known lawyer, monarchist, member of the Black Hundreds and anti-Semite. A railway engineer by profession, Vladimir Shmakov gained fame as a theorist of occultism and expert in arcanology and kabbalistics even before the Revolution. He was also the author of the fundamental study The Sacred Book of Thoth. The Major Arcana of the Tarot. The Absolute Principles of the

36 Among other things it contains notebooks with magic texts, prayers, incantations, descriptions of rituals, magic alphabets, esoteric astronomy etc.

37 Thus Mariia Vadimovna Dorogova (von Mengden; 1889-1981/82) held a prominent place both in the Order of Orion and in the Templar Order, held session in the knights' study groups, translated large amounts of foreign literature and distributed "mystical Samizdat". About her, see Nikitin, Rozenkreitsery v Sovetskoi Rossii. Dokumenty 1922-1937 gg., 313-315.

38 A philologist and teacher of foreign languages. In the 1920s he worked in the People's Commissariat of Foreign Affairs as a translator. He was arrested several times and died in a prison in Central Asia. Cf. Nikitin, Rozenkreitsery v Sovetskoi Rossii. Dokumenty 1922-1937 gg., 220222; Andrei Nikitin, Tainye ordeny $v$ Sovetskoi Rossii. Tampliery i rozenkreitsery (Moscow: Veche, 2006), 198-217; Brachev, Okkul'tisty sovetskoi épokhi, 355-374. See also Beliustin's last investigation file from 1940-1941 in: Nikitin, Ezotericheskoe masonstvo v Sovetskoi Rossii, 297-392. 
Synthetic Philosophy of Esotericism. (Sviashchennaia kniga Tota. Velikie arkany Taro. Absoliutnye nachala sinteticheskoi filosofii ėzoterizma, Moscow, 1916). In 1922 he managed to publish, at his own expense, a work that was even more significant for the Russian esoteric movement: The Foundations of Pneumatology. The Theoretical Mechanics of the Formation of the Spirit (The System of Esoteric Philosophy) (Osnovy pnevmatologii. Teoreticheskaia mekhanika stanovleniia dukha [Sistema ėzotericheskoi filosofii], Moscow [Sergiev Posad], 1922). This was probably the last book on esoteric issues to appear in Soviet Russia. ${ }^{39}$

Although Shmakov is mentioned in the witness statements and memoirs of many contemporary occultists, we know about his fate during the postrevolutionary years mainly from the statements made by Beliustin during his final arrest in 1940-1941. Beliustin and Shmakov met in May 1923. In the early 1920 s, a circle for the study of the occult sciences regularly met in Shmakov's flat. Its members included Father Pavel Florenskii (1882-1937), the wellknown art historian A.A. Sidorov (1891-1978), the already mentioned Bishop A.N. Semiganovskii, the anthroposophist M.I. Sizov, and others who were known in Russian esoteric circles. ${ }^{40}$ Some of those attending the study group were experienced occultists already and had been members of various esoteric organizations even before the Revolution, others were intellectuals and artists, groups in which the interest in the topic ran particularly high. In the last months of the circle's existence it was Beliustin, considered Shmakov's successor by the latter, who gave the lectures on the theory of the occult sciences. According to Beliustin, Shmakov left the USSR in summer 1924 (with the help of his friend Tomáš Masaryk, the President of Czechoslovakia), spent some time in Prague and then left for Buenos Aires, where he spent the last years of his life. ${ }^{41}$ Although the study group stopped meeting after he left, the Rosicrucian "Order of Orion-Khermorion", founded by Beliustin in 1926, continued the group's work in an original way.

This Order, relatively small in terms of membership (not more than 20 people), counted a few of those who had attended Shmakov's study group among its members. All of them were "professional occultists" and belonged to various secret organizations: among them were Templars (Mariia Dorogova,

39 Already after the collapse of the Soviet Union yet another, probably more important work of Shmakov that had survived in Samizdat was published: The Law of Synarchy and the Teaching about the Dual Hierarchy of Monads and Multitudes (Zakon sinarkhii i uchenie o dvoistvennoi iearkhii monad i mnozhestv, Kiev: Sofiia, 1994).

40 See Nikitin, Rozenkreitsery v Sovetskoi Rossii. Dokumenty 1922-1937 gg., 218.

41 Ibid., 216-219. 
Fedor Verevin), Freemasons (A.A. Sidorov), Anthroposophists (N.B. Vurgaft, M.I. Sizov) et al. This allowed Beliustin to receive all information about the esoteric underground and probably even to orchestrate this activity without giving himself away. The Order offered different stages of initiation. During the first stage, apprenticeship, the neophyte studied literature under the supervision of a mentor and wrote his own essays on occult topics. After that the new member of the Order was initiated to become a Squire (oruzhenosets), followed by two "Knight" stages_- "Knight of the Outer Castle" and "Knight of the Inner Castle". At the top of the hierarchy were the different stages of spiritual initiation held by the members of the Order's Supreme Chapter. The Order's ultimate goal was to prepare its members for the attainment of the magical abilities of the ancient Rosicrucians with the help of long training sessions, the re-structuring of consciousness in a certain direction, and the use of occult knowledge in conjunction with alchemy and astrology.

The idea of resurrecting a Rosicrucian order had occurred to Beliustin already at the time when he was in contact with Shmakov, i.e. in 1923-1924. At that time he discussed his idea with Teger and Fedor Verevin (1899 - after 1967), two experienced occultists mentioned above. However, when it came to practical questions, their opinions differed. Teger, an atheist who regarded magic as a variation of scientific knowledge, considered the goal behind the restoration of the ancient occult tradition to be the mastery of its practical aspects. Beliustin, on the other hand, was convinced that without the serious study of the theory of occult knowledge, learning to use its practical aspects would prove impossible. At the same time they evidently continued to appreciate each other. The annihilation of the Order "Emesh Redivivus", the arrest of Teger and the multiple interrogations of Verevin in 1926 entailed no serious consequences for Beliustin: although he spent three months in custody, he was released in the end because the arrested never mentioned him.

As a result, Beliustin's Order was able to operate underground for another seven years, until the spring of 1933. The Order's members created a huge number of manuscripts that make up an entire archive, the remains of which were preserved by the youngest Rosicrucian, the artist Valentin Monin (19041972), who managed to avoid arrest. ${ }^{42}$ The documents detail the Order's doc-

42 This archive, consisting of dozens of manuscript and typescript books, was handed over to Monin for safekeeping by Beliustin himself; Monin and his wife carefully preserved it. In the 1970s-1980s it was studied by the members of the occult underground, however its traces were lost in the 1990s. A few documents that were copied from this archive are published in: Nikitin, Rozenkreitsery $v$ Sovetskoi Rossii. Dokumenty 1922-1937 gg., 241-307. 
trine and history, describe the history of occultism in Russia, and record the Order's legends. Some are dedicated to arcanology, symbolism and the special alphabets (the orionic, cabbalistic, magical) that were used for magical rituals; ${ }^{43}$ also preserved were the formulae for incantations and prayers written in these languages. As the basis of the Order's arcanology, the "alphabet of esotericism", the Kabbalah had a particularly high status in the Order's teachings. The Kabbalah constituted the "United Knowledge of the Cosmos", "Higher Mathematics of the Cosmos-the Science of Live Numbers in the endless combinations of current Stages and Paths of the Creativity of God, Man and the Universe". ${ }^{4}$ Thus the widespread use of Hebrew in the Order's literature and ritual texts, as well as the frequent references in these texts to various cabbalistic and occultkabbalistic concepts, is no accident. As an example of the magic practiced by the Order's member we cite below the surviving text of a collective rite called "The Great Mystery of the Elements", that was intended to summon elemental ghosts and capture their powers. ${ }^{45}$ As we will see, it resembles in many ways the rituals that were practiced in the "Order of the Eastern Templars" (Ordo Templi Orientis, O.T.O.) and in other European initiatory organizations of the late $19^{\text {th }}$ - early $20^{\text {th }}$ century The document gives a detailed description of the preparatory conditions needed for the ritual (magic objects, substances etc). The hymn cited below was written and pronounced in this special "orionic" language. The ceremony began with a general blessing for all those present by the High Priest (i.e. Beliustin), and also the "Great Incantation of the Most Reverend Thelema." It was followed by the "collective singing of the sacred hymn, inherent to the Pentagram of the Great Elements":

O Great Thelema, Spirit-Matter of the manifest Universe! ${ }^{46}$ Your element encompasses the boundless abysses of the Cosmos and dwells within me, for the Universe and I are one. Oh Great Fire, Principle of Life! You are burning in each atom of being and consciousness of the

43 See: Evgenii Lazarev, "O sviashchennykh iazykakh rossiiskikh arkanologov," In: Nikitin, Rozenkreitsery v Sovetskoi Rossii. Dokumenty 1922-1937 gg., 421-429.

44 Ibid., 272

45 It forms part of the manuscript "The Rituals of the Order of Khermorion. The Cycle of Great Operations-Mysteries Within the Terner אמש" (Ritualy ordena Khermoriona. Tsikl velikikh operatsii misterii po terneru אמש). Terner (ternary) is a principle of triplicity or triality representing the unity and mutual correspondence of the three principles-active, passive, and equilibratory.

46 In the original: "Eà Zaròl Orselèth Haathà-Mâaträ Joralët Orim. Hàr Bròa iosirg Athiòrs Abïdèks Oribaöm tizàrsä me eme utir Orim tie m sieth Orbaö...” 
Existing and are ablaze within me as the inextinguishable spark of Life... Oh Great Air, Principle of Creation! You lock the Worlds into a circle of light-ideas and preserve them as an inmost Secret.... Oh Great Water, principle of Origin! You enter into the interior of all things and flow within me as a scarlet current... Oh Great Earth, principle of Death and Rebirth! You devour Matter in order to open to the Spirit the Gates of Freedom... We bless and glorify you, Unuttered Pentagram of Elements, dwelling within the Great Pentagram of Man and awakening its rays to the eternal Creation in God, Man and Universe!..

After the reciting of the hymn in the sacred language the "Great Call of the Lords of the pentagram of the Elements" was carried out. The manuscript reads further:

The room plunged into darkness. Those present bow their knees and sink into meditative contemplation of a silver disc. Fixation of possible visual perceptions. The room is lit. Those present rise, approach the throne and seal a magic circle around it. Presentation of the cult objects (cross, staff, sword, chalice, pentacle, magic mirrors-square, black frosted ones, censer). Great Incantation of the Lords of the pentagram of the Elements. Those present break the magic circle and, after bowing to the High Priest, return to their place. The room is once again plunged into darkness (personal ecstasy of those present, who bow). Possible mental images. The room is lit. The High Priest blesses those present with the cult objects. Those present rise and, beginning with the youngest and finishing with the eldest, bow, and, after bowing to the High Priest, return to their place. Sacred Prayer, inherent to the Pentagram of the Great Elements. Those present, beginning with the youngest and finishing with the eldest, approach the throne, holding the sword in their right, lowered hand. They fall on their knees before it, rise and, headed by the High Priest, one after the other walk around it and around the small thrones and then, after bowing to the High Priest, return to their place. This symbolises the mystical ritual of the betrothal of the present adepts to the Elements... ${ }^{47}$

As will become evident from the manuscript tract on metahistory, "The First Transitional Circle of Reason of Hermes" (Pervyi perekhodnyi krug razuma Germesa), the Rosicrucian-Orionists considered the history of the Earth, the history of mankind and the history of Russia as a field of battle between the

47 Nikitin, Rozenkreitsery v Sovetskoi Rossii. Dokumenty 1922-1937 gg., 300-301. 
forces of Light and Darkness. In particular, they used this standpoint for the interpretation of the history of Ancient Rus' and Tsarist Russia, identifying an irreconcilable struggle between the infernal, Satanist forces of the Union of the Great Dark Fraternities and the forces of light, embodied in certain Russian saints and tsars. Thus the Rosicrucians shared the Gnostic and Manichean idea of the world as a field of battle between two principles, Good and Evil. At the same time they were aware that the higher forces with whom they tried to establish contact through magic (the Lords of the Astral Element and Lucifer himself, as the principle which is "eternally balanced and balancing... indifferent both to Good and Evil"48), were in their essence neither good nor evil and that it was the decision of the adept whether he wanted to use these forces for evil purposes or in order to do good. For this reason the Order maintained that every Rosicrucian had to undergo two initiations-one "light" and one "dark" (the so-called White and Black initiations) in order to be able to direct the forces of the dark without falling under their spell. "In the astral realm the eternal, never-ending battle between light and dark forces is taking place, with each side gaining the upper hand from time to time. The present moment belongs to the reign of the dark forces, i.e. forces that interrupt our evolutionary progress by enslaving consciousness to matter. The liberation from the bonds of matter is achieved when we acknowledge the illusory nature of the physical plane and direct our conscience towards the world of ideas." ${ }^{49}$ As was mentioned above, the profoundly clandestine nature of the Order meant that some of its members were able to avoid being arrested and thus preserve the Order's archives, while other members were subject to some degree of repression yet persisted in their esoteric activities for a long time to come, albeit under radically new conditions. Thus the well-known occultist Fedor Verevin, Beliustin's closest assistant and a "Knight of the Outer Castle", who was arrested in April 1933, spent only two months under arrest before being released. We know that he preserved his entire archive and pursued occult activities until the second half of the 1960s. The fate of Mariia Dorogova is even more successful. She was simultaneously among the leading members of both the Orionist and the Templar Orders. Arrested in April 1933, she was released

48 Ibid., 280.

49 From the witness statement of Sergei Polisadov (1933) (Nikitin, Rozenkreitsery $v$ Sovetskoi Rossii. Dokumenty 1922-1937 gg., 228). Cf. also: "We distinguish between the 'current of the Light' and the 'current of the Darkness'. The white Initiation, based on the 'current of Light', furthers the evolutionary ascent into the area of the opening of consciousness and the achievement of perfection. The black Initiation, based on the 'current of the Darkness', pulls one into the area of matter and clouds consciousness, thus hindering evolution." (ibid). 
after two months; after a second arrest in 1935 and a sentence of three years of internal exile for "anti-Soviet activities" she was also released immediately and never subject to repression again. Dorogova continued her occult activities right up to her death (in 1981 or 1982); in the 1950s-1970s she hosted groups for the study of Theosophy.

\section{The Order Lux Astralis}

This neo-Rosicrucian organization was fundamentally different from the two groups described above. Its history depends entirely on one man, Boris Zubakin (1894-1938), ${ }^{50}$ a poet, sculptor, archaeologist and ethnographer who spent all his life trying to organize groups for the study of secret knowledge in order to attract like-minded people. Although Zubakin himself claimed that he had founded the Order "Lux Astralis" in 1911 and named Aleksandr Kordig as his teacher, one should treat his stories about the organization's history before 1916 with a degree of suspicion. Throughout his life Zubakin proved that he was a skilled mystifier: he made up entire mystical brotherhoods, awarded himself the most astonishing titles and ranks and forged documents in his attempts to find spiritual allies and recruit comrades-in-arms for what he considered the chief purpose of his life-the resurrection of the spirit of ancient Rosicrucianism. Steeped in the humanities, Zubakin was a religious mystic but not a magician, and he had no interest in contemporary science. This radically distinguished him from the leaders of the Orders discussed above. It is no accident that most of Zubakin's followers were representatives of the creative professions.

Zubakin himself confessed, after being arrested in 1922, that when he discovered as a child that among his ancestors "there were 'spiritual knights', 'princes of the Kabbalah' and 'mystics and freemasons"', ${ }^{51}$ he decided to dedicate his life to the study of the secret sciences. According to his own words, as early as 1911 he founded, together with some of his peers, the occult circle "Lux Astralis". A decisive role in its development was played by the already mentioned Aleksandr Kordig (died 1916), a Rosicrucian and Martinist, who taught Zubakin the Kabbalah, hermetism and "mystical philosophy" in 19151916. Upon returning from the front, Zubakin began his indefatigable activity

50 On him, see ibid., 368-420; Aleksandr Nemirovskii, Viktoriia Ukolova, Svet zvezd, ili poslednii russkii rozenkreitser (Moscow: Progress-kul'tura, 1994); Brachev, Okkul'tisty sovetskoi épokhi, 149-198.

51 Nikitin, Rozenkreitsery v Sovetskoi Rossii. Dokumenty 1922-1937 gg., 376. 
towards the creation of "a community of like-minded people to share communal life, rituals, mysteries etc". He would preach his ideas about brotherhood wherever he happened to be and created cells of his Order in Nevel, Minsk, Smolensk, Rzhev, Moscow and Petrograd. Zubakin established contact with the most diverse people (suffice it to mention the film director Sergei Eisenstein (1898-1948), whom he accepted into the Order, and Maxim Gorky (1868-1936), with whom he corresponded), however, the composition of his groups kept changing, and by the end of the 1920s he was surrounded by only a few of his most devoted followers, including his closest associate, the writer Anastasiia Tsvetaeva (1894-1993), sister of the famous Russian poet Marina Tsvetaeva (1892-1941). In 1929, Zubakin was exiled to Arkhangelsk, and throughout the 1930s his group operated exclusively underground, but nonetheless all its members were arrested in 1937 and Zubakin himself was shot.

Zubakin's teachings are known from his own witness statements and the statements of members of his Order who were arrested at different times, as well as from memoirs that mention him. He himself composed prayers, hymns, rituals, legends, as well as creating sacred objects for ritual practice, thinking that he could thus resurrect the spirit of the Order of the ancient Rosicrucians. It is evident (and this constitutes the difference between him and other Russian esoteric leaders of his time), that he did not consider himself the historical successor of a more ancient organization-his initiation was "spiritual" rather than related to real historical time. This is precisely why he so often had recourse to mystifications and even provocations, which he concealed from his closest disciples. Because of this, his teachings were not "occult" or "esoteric" in the proper sense of the word-he preached his ideas openly, gave lectures and papers and prepared the ground for the foundation of his own occult brotherhood. With this brotherhood he envisioned retreating to a life of isolation somewhere deep in the provinces in order to fully devote himself to the practical aspects of restoring the Rosicrucian path. Unfavourable historical circumstances prevented him from doing so.

\section{The Moscow Templar Order}

The Templar movement, which in 1920 formed the Eastern Detachment of the Templar Order, had a much larger scope, and its activities were more strictly goal-oriented. Its founder was Apollon Karelin (1863-1926), an economist, lawyer and prominent theorist of anarchism, who returned to Russia in 1917 after more than ten years in emigration. Unlike the previous orders and societies with their propensity for occultism and magic, the Templar movement was 
clearly oriented towards Gnosticism, ${ }^{52}$ which is evident from the surviving body of the Order's legends and the memoirs of the participants in its many study groups. ${ }^{53}$

The Templars had set themselves two main tasks, namely to work towards the perfection of the self as a way of serving man and society, and to pursue the combined mystic and scientific knowledge of the world, something they considered a constituent part of the universal struggle of the light of knowledge against the darkness of ignorance. The first task, they held, could be solved with the help of Christian ethics, the second by uniting the principles of ancient gnosis with the contemporary scientific cognition of the world. These tasks also defined the composition of the movement itself, whose members had to possess not only certain moral and ethical qualities, but also a rather wide general education and culture. The Templar doctrine was practically devoid of the occult and magical component that was so important to the Rosicrucians and Martinists. Moreover, they did not share in the exaggerated worship of experimental science and medicine, since the tasks that the Order set before its members were above all ethical and socio-political in nature and required work on one's inner self, as well as spiritual self-perfection. According to one member of the Order, the mathematician Evgenii Smirnov (1891-1937), the Order's aims were

...of purely ethical order: the moral self-perfection of the individual through the perception of the Christian basics and the fostering of knightly Christian virtues within the self. A Knight is an ethical concept that denotes a person who is carrying out moral deeds. Separating the Christian basics from dogmas that have accumulated over centuries and are clouding the face of Christ the knight, and in some cases also from the deception committed by the Church-these are the Order's aspirations. The legends lift up the spirit and heart of the student and nourish him morally... In my case, the combination of the ethical and aesthetic moment has always ennobled my soul. The ritual aspect of the Order accompanied us on the way to self-perfection, although it was of secondary importance. ${ }^{54}$

52 Cf. Evgenii Lazarev, “Gnosticheskaia obraznost' v nasledii russkikh tamplierov XX veka," In: Rossiia i gnozis. Materialy konferentsii (Moscow: VGBIL, 1996), 69-75.

53 The history and teachings of the Templar Order are fully documented. See the three-volume edition of the investigation file, documents and works of the Templars, published by Andrei Nikitin, Orden rossiiskikh tamplierov. Vols. 1-3 (Moscow: Minuvshee, 2003). See also: idem, Tainye ordeny v Sovetskoi Rossii, 38-188; Brachev, Okkul'tisty sovetskoi épokhi, 283-314.

54 Andrei Nikitin, ed., Orden rossiiskikh tamplierov, t. 2: Dokumenty 1930-1944 gg. (Moscow: Minuvshee, 2003), 131-132. 
Compared to the Rosicrucian groups, the Templar Order pursued a much larger range of activities. The Templars founded a large number of study groups scattered over the entire country that actively recruited young people, a wide spectrum of intellectuals; they even used propaganda methods in the print media. ${ }^{55}$ The membership represented the cream of the contemporary intelligentsia working in the humanities. Suffice it to list the theatre actors and directors Iurii Zavadskii, Ruben Simonov, Valentin Smyshliaev, Arkadii Blagonravov, Mikhail Astangov (Ruzhnikov), the cinema actresses Vera Zavadskaia and Iuliia Bystritskaia, the writers Georgii Shtorm, Ivan Novikov, Pavel Arenskii, the literary scholars Vladimir Nilender and Nikolaii Kiselev, the art historians Dmitrii Nedovich and Aleksei Sidorov, the philosopher Diodor Debol'skii, the Orientalists Iurii Shchutskii and Fedor Rostopchin, the composer Sergei Kondrat'ev, the singer Viktor Sadovnikov and many others.

Karelin's main associate and successor was Aleksei Aleksandrovich Solonovich (1887-1937), a poet, mathematician, philosopher and theorist of mystical anarchism. ${ }^{56} \mathrm{He}$ had been studying the occult sciences since his youth, and written his first book, the mystical-symbolist tract "The Wanderings of the Spirit" (Skitaniia dukha), ${ }^{57}$ in 1914. In form and content it resembled the works of Saint-Yves d'Alveydre and was clearly composed under the influence of Andrei Belyi's "Symphonies". Subsequently Solonovich taught mathematics and mechanics at different grammar schools throughout Moscow, later at the Bauman Technical High School. After Karelin's death he organized a number of anarcho-mystical circles and gave public lectures in the Kropotkin Museum, which became the center of the movement of Moscow anarchists in the 1920s. Solonovich was arrested in 1930, given a camp sentence and died in a labor camp in 1937.

Solonovich became the main theorist of mystical anarchism and the creator of a Gnostic meta-historical doctrine, which he expressed in his main work, the three-volume "Bakunin and the Cult of Yaldabaoth" (Bakunin i kul't Ial'dobaofa) (unpublished; the manuscript was confiscated and has never been found) and a large number of lectures. The proto-archon (first ruler) and

55 Naturally these were Russian editions published abroad. First and foremost we are talking about the newspaper Dawn (Rassvet) and the journal Awakening (Probuzhdenie), which was founded in the USA by Eugeny Dolinin (Moravsky, alias Robert Ermand, 1898-1938), the secretary of the All-Russian Federation of the Anarchist Communists, and published the writings of a number of Moscow Templars (A.A. Solonovich, A.S. Pastukhov, E. Moravskii, L.A. Nikitin et al.)

56 About him, see Nikitin, Orden rossiiskikh tamplierov, t. 2, 140-143.

57 Moscow: Sfinks, 1914. 
demiurge Yaldabaoth, well known from Gnostic texts ${ }^{58}$, is presented by Solonovich as a rebel angel, the embodiment of Satan, one of the faces of the devil. In his view, the Bolsheviks who seized power were possessed by "the demons of power" and "the principle of power is ingrained in humanity like a disease such as syphilis." "...larvae crawl in Yaldabaoth's tracks and demonic filth soils the souls of people and their lives...Among the most strongest fanatics of power, for whom the end justifies the means, we find Ivan IV, Philipp II, Loyola, Torquemada, Lenin, Marx and others. All of them were directly led by the angels of Yaldabaoth in some form and to some degree", Solonovich wrote. "Having suppressed the revolution ... and trampled underfoot all elements of public initiative ... they thus identified and isolated themselves to form a new brigade of foreign conquerors, merciless without precedent and profoundly reactionary."

Solonovich provided a ruthless analysis of the processes defining his time and perceptively predicted the direction in which things were going. It is not surprising that this metaphysical rejection of the new powers (members of the communist party were not allowed to join the Order) entailed cruel repressions, not only against the author himself, but also against his audience and readers.

We can identify three main periods in the history of the Templar movement in Soviet Russia. The first is associated with the activities of Apollon Karelin, the commander of the Eastern Detachment of the Order. A man of commanding influence and authority who was a member of the All-Russian Central Executive Committee, i.e. the government of the country at the time, he regularly gave lectures and headed public initiatives, and thus had the opportunity to recruit new members for the Order. He attracted many prominent figures from the fields of theater, literature and science, who became the first "knights" and accepted initiation with the goal of subsequently heading their own groups (Aleksei Solonovich was one of them).

In his public speeches Karelin often told legends and parables about knights, the spirit world, boundless universes and the spiritual origin of man, whose physical body, according to the Templars' teaching, is merely a means of existence enabling the development of the spiritual essence locked within it, an essence that actively participates in the evolution and the process of introducing order into the chaos of the Universe. Among these legends were the legends of Atlantis, of Ancient Egypt, the Gnostics and first Christians, whose

58 E.g. in Ophites. Cf. Birger A. Pearson, “Ophites,” In: Wouter J. Hanegraaff, ed., Dictionary of Gnosis and Western Esotericism (Leiden: Brill, 2005), 895-898. 
traditions preserved the ancient wisdom of the Orient... Many of these legends are known to us now thanks to the fact that they were written down and circulated in Templar circles. The surviving members of the movement began to collect and classify them as early as in the 1950s-1960s. To the present day more than one hundred legends have been published. ${ }^{59}$ Some of them are evidently translations of the French texts Karelin brought back from emigration, others were composed on the basis of various occult and Gnostic works by himself and his closest disciples. ${ }^{60}$

These legends were widely used in the Order's rituals, which resembled both Masonic rituals and medieval knighting ceremonies known from historical sources. Overall there were eight levels of initiation to the Order. A new member would listen to the three first fundamental legends about the Golden Ladder of the Cosmos, Atlantis and Ancient Egypt. The subsequent cycles of 10-12 legends each prepared him for the next level of initiation, which was accompanied by a special ritual. The legends are of crucial importance as a source of information about the teachings of the Templar Order. According to Andrei Nikitin, ${ }^{61}$ it is possible to divide the overall body of legends into three cycles. Firstly, there are the cosmological legends, evidently based on certain Gnostic legends (more specifically, on the interpretation of these legends in $19^{\text {th }}$-century European esotericism). The second cycle comprises historical (or quasi-historical) tales about the Order's origins (beginning with Atlantis and leading through Ancient Egypt, the events of the New Testament, and from the Crusades to the $20^{\text {th }}$ century). The third cycle, the properly mystical one, tells about the worlds of high spirits that correspond to the hierarchies of the Christian heavenly powers and hosts. The latter group of legends, which was in all likelihood composed after the Revolution, displays the influence of the new natural-scientific and technocratic ideas, as well as the social ideals of anarchism. The Templar legends of the "mystical" type constituted a very important tool for educating students in the spirit of the Order's commandments, especially with regard to questions of both spiritual and everyday life. In many respects they resembled similar didactic writings of medieval European Chris-

59 See Andrei Nikitin, ed., Orden rossiiskikh tamplierov, t. 3: Literatura tamplierov. Literatura Ordena (Moscow: Minuvshee, 2003).

60 Some of the possible sources could have been Theodor Merzdorf's monograph on the Templars (Theodor Merzdorf, Die Geheimstatuten des Ordens der Tempelherren nach der Abschrift eines vorgeblich im Vatikanischen Archive befindlichen Manuscriptes [Halle: Schwetschke, 1877]) and Carl Schmidt's translations into German of gnostic texts (Carl Schmidt, Koptisch-gnostische Schriften [Leipzig: Hinrichs, 1905]).

61 Andrei Nikitin, Tainye ordeny v Sovetskoi Rossii, 133-134. 
tianity, while the historical and cosmological legends had the function of forming the Templar's worldview. Thus the study of legends was supposed to foster the overall development of the adept's personality.

The second period in the development of the Templar movement began in late 1923-the period of expansion: groups and "daughter organizations" sprang up all over the country, in particular the "Order of Light" (Orden sveta) and the "Temple of Art" (Khram iskusstv) in Moscow, the "Order of the Spirit" (Orden dukha) in Nizhnii Novgorod, student circles and divisions of the Order in Leningrad, Sverdlovsk, the Northern Caucasus, Tashkent and Batum.

Precisely at this time the Order began to actively distribute its "Samizdat": collections of the lectures given in individual study groups as well as the Order's legends and numerous translations and original articles, published in foreign anarchist periodicals. The Templars were especially active in the State Institute of the Word (Gosudarstvennyi institut slova), the Oriental Institute, the Institute of Living Oriental Languages, the Bauman Technical High School in Moscow, the Moscow Conservatory, the State Academy of Artistic Science, the $2^{\text {nd }}$ Belorussian State Theater, the Evgenii Vakhtangov $2^{\text {nd }}$ Moscow Art Theater, the P.A. Kropotkin Museum, the Tolstoy Society.

The Order had a clearly defined hierarchical structure. It consisted of separate study groups and "sub-Orders" at different levels ("Order of Light", "Order of Spirit", "Temple of the Arts" etc), which were governed by the four final stages of the Templar Order proper. Strict secrecy reigned in the higher echelons: as a rule, the group members knew only their immediate leaders, and met the other higher-ranking knights only during the next initiation, when passing from one study group to another or when changing their spiritual director. Alongside the training sessions that took place once or twice a week, the members of Templar study groups gathered in groups of eight to ten people for meetings to greet neophytes, initiations to the next stage or the Order's feast days (Christmas, Resurrection [Easter], the Memorial Day for St. John the Baptist and the Feast of the Archangel Michael).

The central organization of the Templars in Soviet Russia was the "Order of Light", founded in Moscow at the very end of 1923. The commander of the Order was Aleksei Solonovich. About this group we have detailed information at our disposal from the investigation file compiled in $1930 .{ }^{62}$ Its members were for the most part representatives of the creative intelligentsia-writers, actors, musicians, artists (artists and art historians made up a special subsection within the Order, the "Temple of the Arts", whose members were called

62 Published in: Nikitin, Orden rossiiskikh tamplierov, t. 2, 6-190. 
"priests" $[$ zhretsy]). They were active as teachers and educators in higher education institutions, studios, science institutes, and simultaneously in secret study groups within the Order. The Order was in contact with intellectuals from the arts and sciences in Moscow, Leningrad, Nizhnii Novgorod, the Northern Caucasus, Batum and Tashkent. The Order's ideas also widely circulated among other esoteric organizations and mystical brotherhoods, in particular among Tolstoyans, Theosophists and Anthroposophists. The repressions against individual branches of the Order (the anarcho-mystical organization "Order of the Spirit" in Nizhnii Novgorod, the group "Order of the Templars and Rosicrucians" in the town of Sochi et al.) began at the end of 1929. In the autumn of 1930s the Moscow center was rooted out and destroyed.

The 1930s constitute the third and last period in the history of the Templars in Soviet Russia, of which we know comparatively little. ${ }^{63}$ During these years the ideas of the Templars circulated in closed study groups that were frequented almost exclusively by academics-orientalists, mathematicians, meteorologists, biologists. Almost all of them were physically annihilated during the Great Terror in 1937-1938. In the 1950s the surviving members of the "Order of the Light" (Georgii Gorinevskii, Boris Vlasenko, Viktor Pikunov) tried to restore the Order's activities, however, in the new historical circumstances this proved impossible.

\section{Conclusion}

As we have seen, the history of esotericism during the first two decades after the 1917 Revolution and the seizure of power by the Bolsheviks represents a special stage that is distinct from both the preceding 150-year period, during which the esoteric movement in tsarist Russia evolved, and the subsequent revival of interest in the occult sciences during the 1960s-1980s. The heterogeneous character of the different esoteric schools and currents notwithstanding (and this article fails to mention a number of Russian esoteric groups of the time, such as the Masonic lodge "Garmonia" and the Masonic section of the Russian National Union, ${ }^{64}$ Georgii Tiufiaev and Vladimir Labazin's "Brotherhood of True Service" (Bratstvo istinnogo sluzheniia) ${ }^{65}$ as well as the Anthropo-

63 Cf. the investigation files of Iurii Shchutskii, Aleksei Siniagin and Dmitrii Nedovich (19371944) in: Nikitin, Orden rossiiskikh tamplierov, t. 2.

64 See Nikitin, Ezotericheskoe masonstvo v Sovetskoi Rossii, 246-291.

65 See Brachev, Okkul'tisty sovetskoi épokhi, 79-85. 
sophist and Theosophist groups operating underground ${ }^{66}$ ), we must note that most of them displayed a faith in science as a transformative (magical) force that was in many respects similar to the perception of science in Europe during the $16^{\text {th }}$ and $17^{\text {th }}$ centuries. Moreover, only in that period were all occult organizations in Russia preoccupied with the solution of socio-political tasksfrom combating the Soviet regime with the help of magic to cooperating with it in the subjection of nature. Neither before nor afterwards has anything similar been seen. At the same time these groups remained faithful to the principles of esotericism even when engaging in public propaganda, preserving the strict hierarchy and, what was especially important in the conditions of the day, the secret character of their internal institutions. Moreover, this period saw radical changes in the attitude of the occultists towards religion: while previously they had been persecuted as heretics, now they were turning, in the eyes of the regime and society, into obscurantists and reactionaries (the name of the last investigation against the occultists in 1940-1941, which brought the history of esoteric movements in Stalin's Russia to an end, was "The Case of the Obscurantists" [Delo mrakobesov ${ }^{67}$ ). All this turns Russian esotericism of that time into an original and highly interesting phenomenon, which is doubtlessly in need of further, more detailed investigation that considers archival materials that are still inaccessible to researchers today.

66 See Mariia Zhemchuzhnikova, "Vospominaniia o Moskovskom antroposofskom obshchestve (1917-1923)," Minuvshee. Istoricheskii al'manakh, vol. 6 (Moscow: Phoenix, 1992), 7-53; Brachev, Okkul'tisty sovetskoi epokhi, 273-283.

67 The case materials are published in: Nikitin, Ezotericheskoe masonstvo v Sovetskoi Rossii, 292503. 


\title{
THE OCCULTIST ALEKSANDR BARCHENKO \\ AND THE SOVIET SECRET POLICE (1923-1938)
}

\author{
OLEG SHISHKIN
}

In the 1990s and 2000s a number of works and monographs appeared in Russia on a seemingly impossible and exotic subject-the existence of esoteric and occult groups in the USSR and their impact on society. The most outstanding among these studies and materials are the publications prepared by Andrei Leonidovich Nikitin. ${ }^{1}$ Just as remarkable are the publications of the Petersburg-based scholar Aleksandr Andreev, ${ }^{2}$ the director of the Kozlov Museum. Other important publications include Aleksandr Nemirovskii's and Viktoria Ukolova's Starlight or the Last Russian Rosicrucians (Svet svezd ili poslednii russkii rozenkreitser), devoted to Boris Zubakin. ${ }^{3}$ Very interesting is also Sergei Valianskii and Irina Nedosekina's Diviner of Secrets, Poet and Astrologer (Otgadchik tain, poet $i$ zvezdochet), on the revolutionary and mystic Nikolai Morozov. ${ }^{4}$ I will pay particular attention to the fifth part of this book.

The year 1924 marked the death of Lenin. It was also the year of the boldest dream ever entertained by the leaders of the Communist International-the dream of a universal federation. At this time, one of the strategic counsels of the late Kremlin leader, published the year before in the main Soviet newspaper was still fresh in their mind:

In the last analysis, the outcome of the struggle depends on the fact that Russia, India, China et al. represent the vast majority of the population. And, in recent years, this majority has become involved with unusual

1 Andrei Leonidovich Nikitin (1935-2005) was a Soviet Russian historian, archeologist, writer, literary scholar, journalist and archivist. See Konstantin Burmistrov's chapter in this volume.

2 Aleksandr Andreev, Okkul'tist Strany Sovetov: Taina doktora Barchenko (Moscow: EksmoJauza, 2004); idem, Ot Baikala do sviashchennoi Lkhasy. Novye materialy o russkikh èkspeditsiiakh v Tsentral'nuiu Aziiu v 1-oi polovine 20-go veka (Buriatiia, Mongoliia, Tibet) (St. Petersburg, Samara, Prague, 1997); idem, Vremia Shambaly. Okkultizm, nauka i politika v sovetskoi Rossii (St. Petersburg, Moscow, 2002; 2nd edition 2004); idem, Soviet Russia and Tibet: The Debacle of Secret Diplomacy, 1918-1930s (Leiden, Boston: Brill, 2003).

3 Aleksandr Nemirovskii and Viktoriia Ukolova, Svet svezd ili poslednii russkii rozenkreitser (Moscow, 1994).

4 Sergei Valianskii and Irina Nedosekina, Otgadchik tain, poèt i zvezdochet (Moscow, 2004). 
speed in the struggle for its own liberation. Thus in this respect there can be not the slightest doubt about the final outcome of the world struggle. $^{5}$

All the Kremlin notables thought exactly the same and did not hide their dreams from the world. Nikolai Bukharin expressed these ideas with particular clarity:

In these conditions, when the masses are revolting against foreign imperialists and foreign oppressors who pursue their goals with an iron hand, we must bear in mind that China has 430 million inhabitants, plus our Soviet Union with more than 130 million and, if the events in India develop further, that country has more than 200 million. ${ }^{6}$

Of course, the revolutionaries had their secret addresses hidden passages, an intelligence network and fighters who were prepared to take to the streets in Europe. However, the arithmetic of the political geography noted by both Lenin and Bukharin pointed in the opposite direction-eastwards. And the East was a "sphinx", a continent of ancient civilizations and possibly elements of class struggle that were completely different from the ones on which the Comintern relied in Europe. This is why the Soviet leaders were so interested in certain exotic projects that will be examined below.

The man who was destined, by fate or maybe by nature, to become the founder of a large Soviet project concerned with finding Shambhala, ${ }^{7}$ was not a

5 Pravda, 4 March 1923. From Lenin's article "Luchshe men'she, da luchshe".

6 "Revolutsionnyi vostok," 1927, 1, 9.

7 In Mahayana-Buddhism, the term Shambhala has several meanings: it is a secret territory somewhere in Tibet or the Himalayas from where allegedly the 25th Emperor is expected to come and cleanse the world of non-believers. The Shambhala-myth can be traced back to the 10th century when it was first mentioned in the mystical Kalachakra-tantra-text. According to the prophecy, the decisive battle between the powers of good and evil, Buddhist believers and their enemies will come under the 25th tsar. After the good has unconditionally won, the future Buddha Majtreya will appear. The legends of Shambhala became so popular that guidebooks began to appear in Buddhist monasteries which promised to lead to this enigmatic, promised land. According to other Buddhist teachings, Shambhala is a particular territory, a mystical realm which cannot be entered physically. Being an inner reality, it is accessible only to the most illuminated and ascetic. In a political sense, Shambhala is the source of liberation from the Chinese occupation for groups and peoples from Mongolia living on the territory of the former Empire of Chinghiz Khan. Historically, three countries have officially been declared to be Shambhala. Before the October revolution legends about a white Shambhala in the North were popular. In the myth of its arrival, the Buddhists of the Asian north took this as 
member of the Bolshevik party, but a mystic seeker and a scholar: Aleksandr Vasil'evich Barchenko (1881-1938), a doctor, writer and psychic (fig.1).

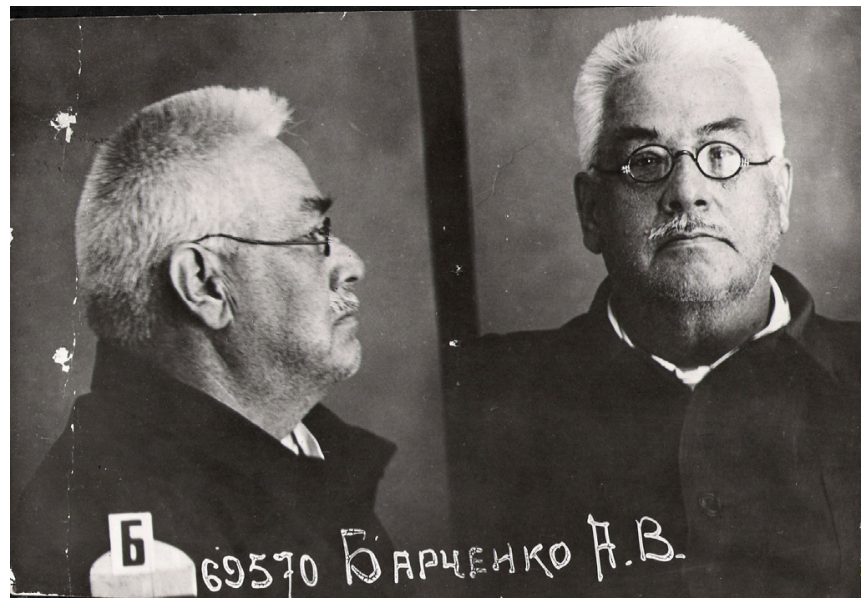

Fig. 1: Aleksandr Barchenko (1881-1938)

Even before the October Revolution, he had been a visible figure among the mystics, freemasons and Rosicrucians of Petrograd. A graduate of the medical faculties of Kazan' and Dorpat (today Tartu) Universities, he was just as seriously interested in astrology, palm-reading and magic as in medicine and science. He subsumed all occult knowledge under the term "ancient science" and regarded it as a legacy left to us by extinct civilizations of the past, which perished as a result of global cataclysms, but managed to preserve their knowledge in hidden caves at the top of the highest mountain ranges, out of the reach of the worldwide flood. In his extensive written instructions to the members of the "United Workers' Brotherhood", an occult secret society, Barchenko summarized his views as follows:

the Russian Empire. After 1917, powerful rumors spread in Tibet and Western China about Soviet Russia as a Bolshevik Shambhala. And when finally Japan annexed parts of China creating the state of Manchukuo, Shambhala began to designate the land of the rising sun, and became a symbol of pan-Mongolism. However, at the end of the 19th century, Shambhala became important in Theosophical doctrines. The founder Elena Blavatsky maintained that in this cave-land hidden in the Himalayas lived the wise teachers, powerful telepathic leaders of mankind who direct the development of civilization and preserved ancient science in their catacombs. See Markus Osterrieder's chapter in this volume. 
a) The next flood will destroy the last traces of black civilization in its decadent form, that is, Africa will probably be hit hardest.

b) The white race will apply the sociological ideal of Universal Knowledge in its highest, 'sunny' form, that is, in the form of a World Federation of Peoples, on the basis of a pure communism that is in harmony with nature, rather than in the form of the highly refined theocracy of Ramidom, where the heights of knowledge are concealed and severe class limitations reign, allowing rule by tsars and emperors.

c) After the flood, one should think, the white race will complete the eight millennia of the Golden Age of the great Golden Age, and under its knowledge culture will fluctuate in its development within the limits of the period between-the-floods, because by the next flood (after 1,200 years) the white race will have settled everywhere in the world, and after the bottom of the Atlantic Ocean will have been raised, all the lowlands of Europe, America and Asia, where so-called 'culture' is concentrated today, will perish, alongside the steppes of China and Mongolia. But the mountain ridges and plateaus of Eurasia, which are completely settled by the white race (Afghans, Kaffirs, Mountain Tadzhiks, Kurds, the peoples of Baluchistan, Persia, Azerbaidjan, Transcaucasia and the Himalayas with Shambhala and Sadzha) will probably survive. Thus the white race will be in the majority after the next flood. And since the nationalities mentioned above are organized and practically control the associations that know 'sunny' science and that the Europeans regard as 'pitiful sects of savages' (the Akhl-i-Khakk sect, the 'People of Truth', Zer-deshti, Yezidi, Sufi, Jains, Jacobites et al.), it will not be particularly difficult to implement the sociological ideal of this science and devise new ones that are entirely based on this science. ${ }^{8}$

Even a superficial analysis of Barchenko's views reveals the rootedness of his ideas in the works of Elena Blavatsky (The Secret Doctrine, 1884-1891) and Marquis Saint-Yves d'Alveydre, the author of several books in the same spirit (Mission de l'Inde en Europe. Mission de l'Europe en Asie, 1886, L'Archéomètre, 1910). At the centre of the world order suggested by Barchenko lies the cave region Shambhala-Agartha, populated by all-powerful telepaths, from which important information enters the world via messages given to travellers, as well as by telepathic means.

8 "Pamiatka dlia chlenov ETB" (Instructions to the Members of the United Workers' Brotherhood), (place 1924). Archive of the Tron'ion-Barchenko family. The complete document is published in the appendix to Oleg Shishkin, Bitva za Gimalai. NKVD: magiia i shpionazh (Moscow, 1999). 
He first came into contact with them through his acquaintance with Aleksandr Sergeevich Krivtsov, ${ }^{9}$ who told him that during a trip to Paris

he became acquainted with some Indians through the well-known mystic and occultist Saint-Yves d'Alveydre; these Indians claimed that in pre-historic times there existed a very great culture in North-Western Tibet, and that this culture knew of some astonishing synthetic method that represented the highest level of universal knowledge, and that the propositions of European mysticism and occultism, including freemasonry, constituted a distorted rehash and echo of ancient science. ${ }^{10}$

\section{Barchenko remembered:}

What Krivtsov told me was the first stimulus directing my thinking towards a search that was to determine my entire life. Assuming the possibility that remains of this pre-historic science had survived in some form or other, I began to research ancient history and the culture of mystical teachings and gradually entered mysticism. My fascination with mysticism went so far that in 1909-1911, having studied the handbooks, I started to practice chiromancy-I read people's hands. ${ }^{11}$

Later, in his message to the Buriat orientalist Gombozhab Tsybikov, ${ }^{12}$ Barchenko refers to the "synthetic method" or "ancient science" as Diunkhor, designated it with the enigmatic signs and linked it to the secret orgiastic practices of the Tantrists. "The strongest, most irrefutable and convincing tool in

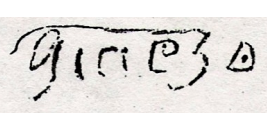
this effort is the evidence that the East still knows, in virtually untouched form, not only the accidentally preserved practical formulae of tantric science, but also its entire rationally based theory." (fig. 2$)^{13}$

9 Aleksandr Krivtsov (1868-1910) was a Russian Jurist and a professor of Roman Law at Dorpat university with a degree from Moscow and Berlin University.

10 TsA FSB (FSB Central Archive). Transcript of the interrogation of A.V. Barchenko, 10 June 1937.

11 Ibid.

12 Gombozhab Tsybikov (1873-1930) was a well-travelled ethnographer, orientalist, professor and translator who worked for the Russian and Soviet government and the Peoples' Commissariat for Education. He was also the first known photographer of Lhasa and Central Tibet, author of guide-books to Tibet (1899-1902). See Buddhist-pilgrim of Sacred Places in Tibet (Petrograd, 1919).

13 NARB [National Archive of the Republic Buriatiia], f. 1 (p), op. 1, d. 966, 125. 


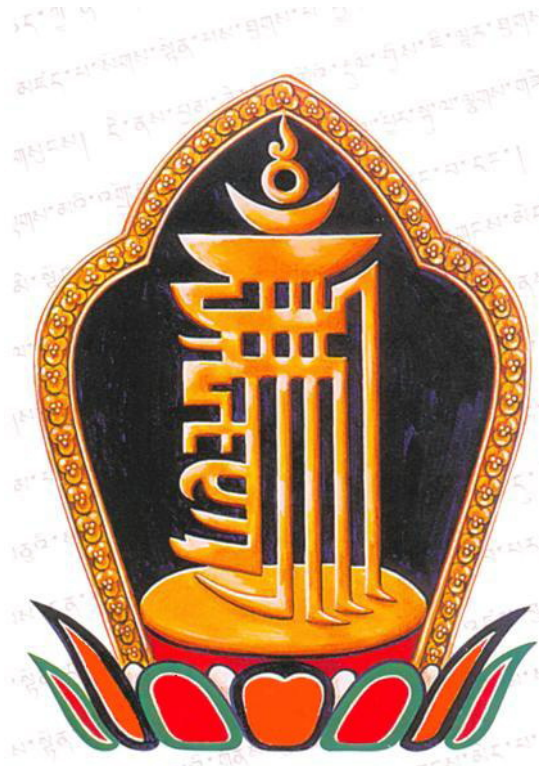

Fig. 2: Symbol of Diunkhor

In 1911, convinced of the practical value of ancient science, Barchenko carried out experiments to determine the nature of telepathy or, as it was then called, "brain rays". In his article The Transmission of Thought over a Distance (Peredacha mysli na rasstoianie), Barchenko describes the original contraption he used for his paranormal experiments:

With the help of a cheap air pump one can build variations of an apparatus that replace Joire's "sthenometer". Inside a thin glass cap with a drop of dammar varnish, Canadian balsam or glass fluidized with borax, we suspend a dry thin silk thread, to the end of which we tie and then balance a thin dry straw that serves as a pointer. On the end of the straw we fluff out a tiny wisp of hydroscopic cotton wool. The disc of the pump is covered with a thin layer of salt. The opening of the pump is protected by a piece of dry cardboard with holes in it and a small edge so that the salt is not blown off. Then, the air is evacuated and the device is ready to be used. Concentrate your gaze on the wisp of cotton wool and you can turn the pointer with your gaze. ${ }^{14}$

14 Aleksandr Barchenko, "Peredacha mysli na rasstoianie," Priroda i liudi, part II, vol. 32 (1911). 
Saint-Yves d'Alveydre, the French mystic author, whom Barchenko had chosen as his occult mentor, was also known for his work Archéomètre in which he tells of the invention of a special magic device that enables people to predict history and fatal events in the future. The same author was also the founder of the occult political concept of Synarchy. ${ }^{15}$ The essence of his theory was the idea that in the depths of Asia there exists an inaccessible underground country called Agartha, populated by political telepaths and magic leaders, who are able to influence life on earth using incantations and the power of thought. These powerful creatures allegedly live in caves in the Himalayas and from time to time send out emissaries to the powerful of this world. Saint-Yves d'Alveydre claimed that the existence of this brotherhood in the heart of Asia had been known to the mystical sects of ancient times and to the Templars. It was this claim of the French occultist, in Barchenko's re-telling, which would later become the starting point of the research carried out under the auspices of the OGPU. Long before Lenin's speech What is Soviet Power? and the first workers' soviets in Ivanovo, Saint-Yves d'Alveydre had introduced the concept of the council as the ruling political organ, central to the Synarchic Supreme Board, that is, an organ exercizing total, unlimited power. For d'Alveydre, the words "council" and "dictatorship" were practically synonymous. In his many books, entitled Missions, we encounter the Council of Prophets, the Council of Priests and the Council of Emperors. At the same time, the idea of the new order itself that is expressed in the concept of Synarchy is addressed to the hegemon of the Revolution, i.e. the workers, to whom d'Alveydre turns in his book The Mission of the Proletariat (Mission des Ouvriers, 1882).

The Bolshevik Revolution put a temporary stop to Barchenko's research in the field of telepathic connections and a direct link to the Synarchic brotherhoods of Asia. During the Civil War, like many other scientists, he gave educational lectures on the ships of the Baltic Fleet in the hope of getting a ration card. In these lectures he permitted himself to mention the powerful country of Shambhala.

In his mystical presumption he reckoned that the key to the solution of social problems was to be found in Shambhala-Agartha, this conspiratorial Eastern site, where elements survived of the knowledge and experience of a society that had reached a higher stage of social, material and technical development than contemporary society. And because of that it was very important to find ways to reach Shambhala and establish ties with it. The people best suited to this task were probably

15 See Markus Osterrieder's chapter in this volume. 
those who were free from any attachment to material things, property, personal enrichment, free from egoism, that is, people who had reached the heights of moral perfection. ${ }^{16}$

His public appearances were so inspirational that a group of sailors expressed the desire to join the scientist in forcing a way into Tibet and, once they had reached Shambhala, establishing ties with the great leaders of the world. The sailors wrote several letters to various officials, including to the People's Commissariat for Foreign Affairs, but received no answer. ${ }^{17}$

In 1920, Barchenko was invited by the Petrograd Institute for BrainResearch and Psychic Activity to give a series of conference papers. His paper The Spirit of Ancient Teachings from the Point of View of Contemporary Natural Science (Dukh drevnikh uchenii v pole zreniia sovremennogo estestvoznania) was considered worthy of publication in the Institute's Newsletter. At that time Barchenko was working on the creation of a universal doctrine of rhythm (gamma) that could be applied in cosmology, cosmogony, geology, mineralogy and crystallography, as well to social life and the bio-psychological manifestations of the individual. Later he would call his discovery a "synthetic method based on ancient science". The doctrine would be expounded, in compressed fashion, in the author's treatise Diunkhor.

The Institute for Brain-Research hosted a special Learned Commission, which invited not only scientists as speakers, but also mystics and members of secret societies. Barchenko was not the only such mystic. There was also Leonid Vasil'ev, ${ }^{18}$ a psychologist and psychiatrist and corresponding member of the Academy of Medical Sciences of the USSR, who would later publish two books in the USSR on paranormal phenomena. ${ }^{19}$ This is what Leonid Vasil'ev remembers about the "commission for psychic research" at the Institute for Brain-Research:

The most significant feature of this commission was the fact that it was composed of representatives of science as well as of adepts of occultism-

16 TsA FSB From the transcript of the interrogation of A.V. Barchenko, 10 June 1937.

17 AVP RF [Foreign Policy Archive of the Russian Federation] f. 100, op. 1, d. 1, 1. 8 ff.

18 Leonid Leonidovich Vasil'ev (1891-1966), Russian psychophysiologist. Graduate of the Faculty of Natural Sciences of St. Petersburg University. Head of the physiology laboratory at the Institute for Brain-Research. Professor of physiology and zooreflexology. In 1932 he began to research the possibilities of telepathy.

19 Leonid Vasil'ev, Tainstvennye iavleniia chelovecheskoi piskhiki, (Moscow: Gospolitizdat, 1959); idem, Zametki fiziologa (Moscow: Gospolitizdat, 1962). 
spiritists Nilov, G. O. Loboda, the medical doctor Aleksandr I. Iablonskii), theosophists (Likhov, who was also in charge of the Institute's premises and hosted the commission's sessions); other occultists also sometimes attended Pogorel'skii, also a medical doctor, the biologist Antonovskii and the journalist (Barchenko)."20

In late 1923, Barchenko attracted the attention of the OGPU in Petrograd, at first because the secret police habitually observed various occult associations whose sessions Barchenko sometimes attended. The secret police was worried by the existence in Petrograd of organizations such as the "Order of the Holy Grail” (Orden' sviatogo graalia), "Russian Autonomous Masons" (Russkoe avtonomnoe masonstvo), "Resurrection" (Voskresen'e), "Brotherhood of True Service" (Bratstvo istinnogo sluzheniia), "Order of the Light" (Orden' sveta), "Order of the Spirit" (Orden' dukha), "Order of Templars and Rosicrucians" (Orden' tamplierov i rozenkreitserov), and "Order of Martinists" (Orden' martinistov). The OGPU aimed to be informed about everything that was going on at these sessions, especially since participants summoned spirits from the netherworld who predicted political dramas to come: the impending death of Trotskii at the hand of a woman and the impending reign of Nicholas III. Consequently, Barchenko received a confidential visit by secret police officers.

They were rather sympathetic to Barchenko's tales about his research in the field of paranormal phenomena and the possibility of applying his discovery to enhance the Soviet Union's defence capability, and even more so about his plans to organize an expedition to Tibet to visit the keepers of the secrets of ancient science. Barchenko remembers: "The comrades told me that my work was so significant that I had to write a report to the government and to the chairman of the Supreme Council for the National Economy, comrade [Feliks] Dzerzhinskii. On their advice I wrote to Dzerzhinskii and told him about my work." ${ }^{21}$

The path to Dzerzhinskii's office was not an easy one. The OGPU workers spent a long time discussing different possibilities and decided that the shortest way was through the Special Section (Spetsotdel) —an institute headed by Gleb Ivanovich Bokii, ${ }^{22}$ and that Bokii himself was the person who had the power to realize their secret project. (fig.3)

20 Cited after Andreev, Okkul'tist strany Sovetov, 123.

21 TsA FSB, transcript of the interrogation of A. Barchenko, 23 May 1937.

22 Gleb Ivanovich Bokii (1879-1937), Communist Party activist and prominent apparatchik of the Cheka/OGPU/NKVD, Commissar of State Security third class (1935). One of the founders of the GULag system of labor camps. Shot on 15 November 1937. Rehabilitated in 1956. 


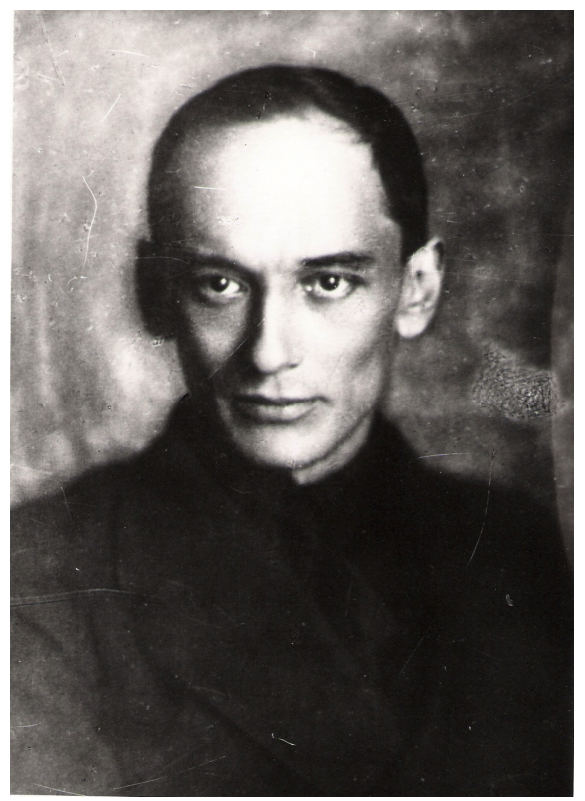

Fig. 3: Gleb Ivanovich Bokii (1879-1937)

The secret police who visited Barchenko knew Bokii very well. In the autumn of 1918, when Bokii had been the head of the Petrograd Cheka, they had all worked in counterintelligence and were the harshest investigators of the era of the Red Terror. It did not take the well-wishers long to deliver Barchenko's letter to the head of the OGPU, Dzerzhinskii himself, while a copy of the document ended up on the desk of Iakov Agranov, the deputy director of the Secret Section and Lenin's former secretary. He was responsible for a particularly important set of operations concerned with secret societies.

Only a few days after he sent the letter, Barchenko was invited to a secret location of the OGPU on Krasnykh zor' Street where Agranov awaited him. The fact that Agranov had travelled from Moscow for this confidential conversation indicates how excited he was by the news. He took in every word Barchenko uttered. Barchenko remembers that "in the conversation with Agranov I explained to him in detail my theory of the existence of a closed scientific collective in Central Asia and my project for establishing contact with the owners of this knowledge. Agranov reacted positively to my report." ${ }^{23}$

23 TsA FSB, transcript of the interrogation of A. Barchenko, 23 December 1937. 
The meeting made a striking impression on the high-ranking OGPU official, although he didn't tell Barchenko anything concrete. However, the Petrograd OGPU asked Barchenko to write an official letter directly to the board of the Central Apparatus of the OGPU, the weekly meeting of the leaders of the Soviet Union's repressive apparatus. The man who was to deliver the letter was the graphologist Konstantin Vladimirov, ${ }^{24}$ a member of the Special Section of the OGPU. Barchenko remembered:

When he returned to Leningrad a few days later, Vladimirov told me that our affairs were going well, that I should travel to Moscow in order to explain our project to the leading OGPU members there. In Moscow, Vladimirov put me in touch with Agranov once again, whom we visited in his flat that was near the OGPU building. I did not make a note of the exact address. ${ }^{25}$ During this meeting Agranov told me that it was intended to present my report about the closed scientific collective to the meeting of the Board of the OGPU. My proposal to establish contact with the keepers of the secrets of Shambhala in the East stood a chance of being approved and from now on I would need to maintain a business connection with the OGPU board member Bokii in this matter. ${ }^{26}$

Iakov Agranov's invitation to visit him at home was a great honor for Barchenko and a sign of trust. The detached house on Miliutinsk Street was under close surveillance, constantly being watched by the secret police. The surveillance was carried out from the surrounding houses, in a neighbourhood that was home to many secret police workers.

Barchenko's message to Bokii contained a resumé of the mystical teachings of Diunkhor-Kalachakra, the central theme of which was Shambhala. In addition, Barchenko also presented his plan for expeditions to the enigmatic Shambhala. Fedor Leismer-Shvarts, another OGPU worker from Petrograd who had helped Barchenko, remembered: Barchenko handed me a parcel to bring to Bokii, which I did. Then I went to Moscow on my own. Vladimirov had left for Moscow the day before. I met him the next day and then we went to see Bokii together, where Vladimirov supplemented my information on Barchenko." 27

24 Konstantin Vladimirov (1883-1929) was an occultist and graphologist working for the VChK. In 1927, he was put under trial and executed in 1929. He has never been rehabilitated.

25 It was the house for high-ranking staff members on 9 Miliutinskii Street.

26 TsA FSB, transcript of the interrogation of A. Barchenko, 23 December 1937.

27 UFSB po SPB i Lenoblasti. [FSB Administration for St Petersburg and the Leningrad Region]. Protocol of the interrogation of K.F. Shvarts, 3 July, 1. 79. 
As we can see, Barchenko's acquaintance with Bokii was preceded by the Petrograd secret police painstakingly working with the Special Section itself, which was subordinated to the Party Central Committee. The Special Section's main area of activity was cryptography, but it also oversaw wide-ranging research carried out by the USSR's repressive organs. The scientific expedition proposed to them was not just a revolutionary measure for destabilizing Central Asia. This caravan also had exotic goals. And it was possible that the Central Committee and the OGPU Board would not understand these goals. But nevertheless Bokii made a decision. He was willing to support Barchenko's idea.

On the same day or the next day Vladimirov took me to Bokii, who subsequently put my paper on the agenda of the OGPU Board. The Board meeting was taking place late at night. Everyone was very tired so they did not pay attention to what I said. They were in a hurry to finish with the questions as soon as possible. As a result I managed to achieve, with the support of Bokii and Agranov, a positive resolution to the effect that Bokii would be instructed to study my project in detail and extract any value that might be in it. ${ }^{28}$

The Board meeting and the approval of the decision were chaired by Dzerzhinskii. From this moment on, Barchenko no longer worked exclusively on expedition projects, but also in the OGPU's secret science centers. In the spring of 1925, the preparations for the expeditions to Shambhala were in full swing. Barchenko remembers: "With the help of Bokii I was able to win approval for an expedition to Afghanistan. The expedition was also due to travel to India, Sintszian and Tibet, and Bokii managed to receive around 100,000 roubles in funding (USD 600,000; O. Sh.)." ${ }^{29}$

The money was allocated by the All-Union Council for National Economy on the orders of Feliks Dzerzhinskii himself, who displayed great enthusiasm for the enterprise. The money came from the illegal foundation of the Special Section, as mentioned subsequently by Bokii. Later, he also said:

As I was myself working on the knowledge of absolute truth (the absolute understanding of good and evil) when I met Barchenko, I took an interest in his tales about the existence of the synthesis of absolute scientific knowledge. In the same year, in 1925, I tried to organize a trip to 
Afghanistan for Barchenko so that he could establish contact with the keepers of this ancient science from there. ${ }^{30}$

The political commissar on the expedition was supposed to be Iakov Bliumkin, a subversive agent and organizer of terrorist acts, notorious for the murder of the German envoy, Baron Mirbach, in 1918, and for the preparation of terrorist acts in British Palestine in 1923. The central base for the preparation of the expedition was a secret sanatorium for the families of OGPU leaders who formed part of the large household controlled by the Liubianka. It was here that some of the future travellers learned English and Urdu, attended indispensable lectures and received practical instructions. Every day, all participants in the march to Shambhala practiced their horse riding skills in the shady alleys of the old park.

All preparations were basically finished by the end of July 1925 . Now came the most important moment-it was necessary to have the paperwork approved by several bureaucratic agencies. In order to prevent an unwanted reaction by Georgii Chicherin, the People's Commissar for Foreign Affairs, Bokii instructed Barchenko to approach the latter through a recommendation from Vladimir Zabrezhnev, a former member of the Comintern section for international relations, who was an illegal OGPU activist, hypnotiser, member of the lodge "Grand Orient de France" and went by the title "maître vénérable". 31 The People's Commissar had once been a freemason himself, and Bokii knew how much authority the society had over him. Barchenko remembered: "To begin with, Chicherin's reaction to my plans was positive..." 32

In order to cement their success, Bokii, Barchenko and Evgenii Gopius, the head of the Special Section's laboratory, went to see Chicherin at his office. After a short conversation the People's Commissar authorised the planned expedition. Bokii reported to the head of the Soviet diplomatic service that the expedition members' documents had been submitted to the visa service of the Afghan embassy a while ago and that the date of departure had already been fixed. However, this expedition was not meant to happen. It fell victim to an intrigue within the OGPU, hatched by Dzerzhinskii's deputies against Bokii

30 Arkhiv UFSB po SPB i Lenoblasti. [Archive FSB Administration for St Petersburg and the Leningrad Region]. Protocol of the interrogation of Bokii from 17-18 May 1937.

31 TsA FSB, transcript of the interrogation of A.Barchenko, 23 December 1937. In the personal file of Zabrezhnev, held in the documents of the Society of Political Prisoners [Obshchestvo politkatorzhan], he personally confirms that he belongs to the French freemasons: GARF [State Archive of the Russian Federation], f. 533, op. 3, d. 1051, 1. 34.

32 TsA FSB, transcript of the interrogation of A. Barchenko, 10 June 1937. 
himself. Under their pressure, only a day after authorizing it, Chicherin, completely changed his view on the expedition. As a result of his protest, it was cancelled at the last moment. In his new resolution for the Politburo of $1 \mathrm{Au}-$ gust Chicherin wrote:

There can be no talk of an expedition to Afghanistan. Not only will the Afghan authorities not allow our Chekists to look for any secret brotherhoods, but their very appearance could cause serious trouble and lead to a press campaign in England that would inevitably present this expedition in a totally different light. We will create trouble for ourselves without the slightest practical advantage because, naturally, our Chekists will not be allowed to search for any secret brotherhoods." ${ }^{33}$

However, despite this unfortunate result, Barchenko continued to work at the OGPU's secret laboratory, which was situated at the Energy Institute in Moscow. Apart from his research, Barchenko was working towards the foundation of the occult "United Workers' Brotherhood" and involved Bokii in this task, for whom he became over time an indisputable guru. This is how Bokii, head of the Special Section, described Barchenko: "Barchenko called himself a disciple of the ancient society, claiming that he had been initiated into all of this by a secret envoy of that society's religious and political centre, with whom he had managed to establish contact." ${ }^{34}$ Gleb Bokii's subsequent description of the events, most likely given under torture, seems almost incredible, but here it is:

I remember the following two events: In 1925, I organized Barchenko's trip to the Altai Mountains, where Barchenko was supposed to establish contact with the sects of "White Water" (Belovod'e ${ }^{35}$ ), religio-mystical circles in Central Asia who are very close to our centre "Shambhala in their mystical teachings. As a result of Barchenko's trip a number of persons from among the local sectarians were designated to undertake regular pilgrimages to this mystical centre abroad. In 1926-27, Barchenko visited Bakhchisarai in the Crimea, where he established contact with the members of the Muslim order "Sandi-Eddini-Dzhibabi". Subsequently he invited the son of the sheikh (the head) of this order to Moscow and brought him to me. At approximately the same time he travelled to Ufa and Kazan, where the established contact with the dervishes of the "Haksh-Bendi" and "Khalidi" orders. In addition, Barchenko

33 APRF [Archive of the President of the Russian Federation] f. 3, op. 65, d. 739, 1. 57.

34 Arkhiv UFSB po SPB i Lenoblasti [Archive FSB Administration for St Petersburg and the Leningrad Region]. Protocol of the interrogation of Bokii, 17-18 May, 1937.

See Markus Osterrieder's chapter in this volume. 
undertook various trips to contact sects in Samara region and Kostroma. In 1926, Barchenko travelled to Kostroma in order to meet representatives of our "Shambhala" order, who were due to arrive from abroad."36

With the transfer of the Brotherhood's activities to Moscow, and also because of Barchenko's move to a new workplace, the structure of the Brotherhood's Supreme Council changed. Its members were Gleb Bokii, the head of the Special Section of the OGPU, Ivan Moskvin, first candidate for, then member of the Bolshevik Party's Central Committee, who worked in the apparatus of the Central Committee and was a member of the Commission for Soviet Control Mironov, an engineer and friend of Bokii's from their time at the Mountain Institute, working at the People's Commissariat for Agriculture, Kostrinkin, an engineer and also a friend of Bokii's from the Institute, B. Stomoniakov, the deputy People's Commissar for Foreign Affairs and Gopius. And the Brotherhood itself was now called the "United Workers' Brotherhood" (Edinoe Trudovoe Bratstvo). In spring 1927, Bokii approved a scientific expedition. The director of this enterprise was, once again, Barchenko. All applications by those wishing to work with Barchenko were approved by Bokii and Gopius, the laboratory director. But their resolutions were a pure formality-in the eyes of the leaders of the Special Section, the indisputable authority was Barchenko.

The base of the expedition was Bakhchisarai. Barchenko and his coworkers were staying in 4 Aziz Street. Having collected the necessary information, they left for the cave towns of the Crimea to search for the remains of civilizations such as the one that had at some point flourished on the Kol'skii peninsula. The legendary Goths had lived in these mountains only two hundred years ago. They had disappeared and now-so Barchenko believed-only a few stone pillars and the labyrinths of the caves reminded of the ancient architects who had possibly been sheltered here from a great flood.

On 24 March, Vladimir Korolev, the Soviet Consul to Mongolia and also a member of the "United Workers' Brotherhood", arrived in Bakhchisarai. He was due to set off to work in the Soviet-Mongol border town of Altan-Bulak and at the same time take a trip to Urga. Barchenko handed Korolev drawings depicting sacred symbols, including the Rosicrucians' Rosy Cross. These were distinctive passwords, meant to be shown to Khaian Khirve, the head of the State Armed Guard and to Nikolai Roerich, who may have been in Mongolia at the time. The signs were a token of belonging to the "United Workers' Brotherhood". And Korolev was entrusted with yet another secret mission: he had to

36 Ibid. 
pass a confidential message to the Buriat scholar Tsybikov in Ulan-Ude. The letter contained several pieces of secret information that must not fall into the hands of outsiders, lest there be an inevitable scandal.

The information was sensational and concerned the highest Kremlin bureaucrats privy to the secret of Shambhala. ${ }^{37}$ In 1928, Bokii had asked Barchenko to sketch a project for the Soviet government to call upon the occult and mystic organizations of the East. ${ }^{38}$ This proposal had come from somewhere within the Central Committee. And although Bokii did not disclose exactly who issued the order, suspicion fell on Avel' Enukidze, the secretary of the Presidium of the Central Executive Committee and a special minister of the Kremlin. The appeal was intended to convene a conference of occult and mystical organizations in Moscow, around 1929. Many of these groups lived in the territory of the British Colonies; evidently the Kremlin thought that in the case a revolutionary movement emerged in these territories, the assistance of the mystic leaders would be indispensable.

Right up until the time of repression the members of the "United Workers' Brotherhood", headed by Barchenko, continued to meet and hold séances at which they summoned the spirits of the dead or tried to establish contact with the netherworld. The content of these responses from the world beyond were shocking - almost all of them pointed to the mystic years 1937-1938, and every one of them told of death.

In the 1930s Barchenko and his work were still a state secret. In 1935 he transferred from the laboratory of the Energy Institute to another institution created by Stalin and Gorky, which was just as mysterious-the All-Union Institute for Experimental Medicine. Here, many different and, as a rule, secret experiments were carried out. In the chart detailing the structure and staff of the Institute's scientific departments, Aleksandr Barchenko was listed as a "research associate first class" and simultaneously as a "research and technical associate" working under Doctor Grigorii Kaminskii, the head of the neuroenergetic laboratory. ${ }^{39}$ The Institute executed highly important commissions by the Party, the government and the NKVD. The infamous Doctor Grigorii Maironovskii, who carried out experiments with poisons and narcotics on political prisoners who had been sentenced to death, was listed at the same agency, but on a different page. ${ }^{40}$

37 NARB [National Archive of the Republic Buriatiia], f. 1 (p), op. 1, d. 966, 1. 20.

38 TsA FSB, transcript of the interrogation of A.V. Barchenko, 23 December 1937.

39 GARF, f. r-6742, op. 1, d. 56, 1. 2.

40 Ibid., 1.11 (ob.). 
But on 16 May 1937 a fatal event took place. On this day, Bokii, the director of the consolidated department of the fourth administration of the NKVD (which until 1934 had been the OGPU Special Section), was summoned by Nikolai Ezhov, the People's Commissar of Internal Affairs. Ezhov demanded from Bokii compromising material on several members of the Central Committee and high-ranking communists. It was no accident that he addressed this request to Bokii.

As a result of reforms within the OGPU-NKVD, the Special Section was gradually losing its previous resources and even entire departments. Bokii, the USSR's main informer and secret agent, was losing more and more of his powers and turn ing into the ordinary director of a cryptographic department that was fulfilling essentially technical functions. Sooner or later he would cede the remaining levers of his former power and simply be a powerless veteran of the communist party. And now the day had come when the head of the NKVD, Ezhov, asked Bokii to hand over all the compromising materials he had accumulated. At the very beginning of the conversation Ezhov, anticipating Bokii's reaction, warned: "This is an order by Comrade Stalin." At this point Bokii exploded and replied: “I don't care about Stalin, Lenin himself has assigned me to this position!" These words put an end to both his career and his life. The "black book"-the black dossier on Bokii was to become the reason for the liquidation of all those who knew of its existence.

For a long time, the materials relating to Barchenko's research were kept in Bokii's office. However, shortly before the arrest of the members of the Special Section in the spring of 1937, Bokii's deputy, Evgenii Gopius, had taken the boxes with the files from Barchenko's laboratory home with him. But Gopius, too, was arrested soon after, and when his flat was searched, the documents vanished into the abyss of the NKVD.

Almost all members of the secret society, "United Workers' Brotherhood", were captured and shot. Bokii was the first to perish. He was to receive a bullet in the back of the head on 15 November 1937. Twelve days later the former Central Committee member Ivan Moskvin fell from grace. After that it would have been Barchenko's turn. However, unlike the others, he spent a whole year in prison, which gave him the opportunity to write a petition to Ezhov, in which he explained the essence of his discoveries. 
To Nikolai Ivanovich Ezhov, People’s Commissar for Internal Affairs. Confidential.

Prisoner of Lefortovo prison. Cell No. 76.

Aleksandr Vasil'evich Barchenko

24 December 1937

I have been told that the investigation of my case is over. I have disarmed completely and, leaving myself no loophole for digression, told the investigators all the details, events and names from my past that I could remember. I am aware that I am responsible for my past. I do not consider myself competent to look for attenuating circumstances in my past, even if there are any.

May I draw your attention to what follows below: in my time I was able to discover a physical phenomenon that is not described by contemporary science. Since the revolution I have devoted the majority of my life interests and time to the elaboration of this discovery.

At the time of my arrest I had almost finished setting up a laboratory at the All-Union Institute of Experimental Medicine for expanding the practical verification of my scientific constructions, which have already successfully been tested in an experiment in my former laboratory at the Energy Institute in 1935 and in domestic experiments. From the materials that were confiscated during my arrest it is known that I was forced to destroy part of the scientific materials, including the sketches that illustrate the practical application of my discovery, about two years prior to my arrest.

It is also known that before my arrest I had recourse to the assistance of certain people, including Professor Timiriazev, in order to promptly involve well-known specialists in the evaluation of the practical applicability of the concrete results of my scientific work, which were illustrated in the very materials that were destroyed. This process was interrupted by my arrest. Thus, I and the most reliable persons among my coworkers are at the moment deprived of the opportunity to completely explain the genuine social value of my discovery and the concrete perspectives for applying it for defence purposes. May I draw your attention to the fact that at the time of my arrest, the following propositions among those illustrated by the abovementioned discovery had been fully explored theoretically, and to a significant degree experimentally, so that they could be immediately verified in collective experiments:

1) As a result of studying the energetic factors of the structure of live matter, I discovered the means by which protozoa, including bacteria, regulate the energy of their vital functions. The further elaboration of these means can provide contemporary science with a very powerful 
tool for the therapy, prophylaxis and disinfection of a number of diseases, including epidemics, as well as for defence against biological warfare.

2) As a result of studying the energetic factors of the structures of the vital functions of matter, I discovered the energy regulation of hyperplasia (cell growth), which has not been considered by contemporary science in the fight against malignant tumours. As a result of the parallel study of the factors of heightened resistance (mechanical) of live matter I discovered a concrete mathematic projective-geometrical (mechanism), which enables us to select the most advantageous architectural and building constructions, including those that allow us to finally build earthquake proof buildings.

3) This is not because of mystical miracles, but because the vibrational -vortical (a quantum wave process) and unrecorded features that my discovery revealed are the universal root of absolutely every instance of energy modification. The practical application of this discovery is in principle universal. I have studied, to a significant level, the mechanism of dialectical degrees of outwardly differentiate practical applications of the discovery to various areas of science and technology not just in theory, but also in practice. ${ }^{41}$

Aleksandr Barchenko was shot on 25 April 1938 and buried in the Sovkhoz Kommunarka, a special purpose object. However, we must also mention that one of the members of the "United Workers' Brotherhood", Shishelov, managed to avoid the NKVD clampdown. He fled from Moscow to the town of Borovichi in the Novgorod region, where he lived until the 1970s. In the 1950s he began a correspondence with Barchenko's widow. The letters, which reveal many details of Barchenko's scientific and spiritual search, as well as the reason behind the "United Workers' Brotherhood", are in his family's archive.

On the basis of this information Barchenko's son Sviatozar requested his father's scientific papers from the KGB archive, but his request was rejected. However, by unofficial channels the leadership of the KGB informed him, through Fedor Nikolaevich Petrov, ${ }^{42}$ a former superior and friend of Barchenko, that these papers are still significant. ${ }^{43}$

41 TsA FSB. File of A. Barchenko.

42 Fedor Nikolaevich Petrov (1876-1997), Soviet scientist and Party activist, twice awarded the title Hero of Soviet Labor (1961, 1971), professor. Graduated from Kiev University, Faculty of Medicine (1902). Active in the revolutionary movement since 1894. Head of Glavnauka (state agency coordinating scientific research, translator) from 1923-1927. From 1929-1933 chairman of the All-Union Society for Cultural Links Abroad (VOKS). Deputy editor-in-chief of 
It is possible that these were the papers that Leonid Vasil'ev, the abovementioned professor, had in mind when he talked to the American researchers Sheila Ostrander and Lynn Schroeder, the authors of the book Psychic Discoveries behind the Iron Curtain. Iurii Aleksandrovich Voronov, an Academician in medical science, told me how once, in the late 1950s, Leonid Vasil'ev, at the time a professor at the Bekhterev Institute, had convened his closest allies, who included Voronov, and told them about a conversation he had had at his home in Moscow with Marshal Rodion Malinovskii, the Soviet Union's Minister of Defence. The Minister had suggested financing a programme of research into telepathy and parapsychology, earmarking one billion roubles from his ministry's budget for that purpose. The sum in itself was so impressive that the scientist was taken aback and decided to consult with his co-workers, having promised to think it over. Barchenko's work remains enigmatic to the present day.

the first edition of the Great Soviet Encyclopaedia (1927-1941), from 1959-1973 member of the editorial board for science at the "Bol'shaia sovetskaia entsiklopediia" publishing house, editor-in-chief and member of the editorial board for many encyclopaedias and dictionaries.

Barchenko's son, Sviatozar Aleksandrovich Barchenko, told me about this conversation. 


\title{
FROM SYNARCHY TO SHAMBHALA: THE ROLE OF POLITICAL OCCULTISM AND SOCIAL MESSIANISM IN THE ACTIVITIES OF NICHOLAS ROERICH
}

\author{
MARKUS OSTERRIEDER
}

Since the mid-1920s, the Russian painter and occultist Nicholas Roerich (Nikolai Konstantinovich Rerikh, 1874-1947) and his wife Elena Ivanovna, née Shaposhnikova (1879-1955), created a spiritual system called "Agni Yoga”, or the "Teaching of Living Ethics" (Zhivaia ètika), incorporating Theosophical doctrines as its basis. A decade later, there were important Agni Yoga groups in New York, London, Paris and Riga (Latvia), as well as in the exile home of the Roerichs in Naggar near Kulu, India. During the 1980s, Perestroika and Glasnost' allowed the Roerich movement, which had existed underground in the Soviet Union, to surface. Agni Yoga has since become an influential and exceedingly popular element in the esoteric scene of post-communist Russia. Today, there are several Roerich museums (in New York City, Moscow and Naggar) and various competing Roerich centers.

The opening of archives as well as the recent publication of various diaries and personal papers of the Roerichs and several of their closest collaborators eventually revealed the amazing scope and messianistic ambition of the 'spiritual geopolitics' (John McCannon ${ }^{1}$ ) which was the driving force behind the activities of the couple. Their ultimate objective-usually referred to as the 'Grand Plan' (Velikii Plan)_-was to establish a pan-Buddhist, transnational 'New Country' (Novaia Strana) stretching from Tibet to southern Siberia, including territory that was governed by China, Mongolia, Tibet, and the Soviet Union. This 'New Country' was conceived as the manifest, earthly expression of the invisible Kingdom of Shambhala, "the Holy Place, where the earthly world links with the highest states of consciousness". ${ }^{2}$ Roerich's ambition was nothing less than to prepare the coming of a New Age of peace and beauty, which would be ushered in by the earthly manifestation of Maitreya, the Buddha of the Future. Only a small inner circle of confidents and supporters in

1 See John McCannon, "By the Shores of White Waters: The Altai and its Place in the Spiritual Geopolitics of Nicholas Roerich," Sibirica 2 (2002), 166-189.

2 Nikolai Rerikh, Serdtse Azii (Southbury, Cn.: Alatas 1929), part 2, Shambala, list 10. 
New York was initiated in the full extent of the beliefs and aspirations of the Roerichs.

While Roerich always argued for the supreme importance of Culture and its manifestation in "Beauty" in the evolution of mankind, his initiative "Banner of Peace", addressed to the leaders of states, and the underlying ideology of Obshchina ("Community") - with its odd fusion of Buddhist spirituality, a quasi-communist social order and American capitalist money under the guidance of a enlightened Leader-was reminiscent of the French occultist Alexandre Saint-Yves d'Alveydre and his concept of a reform of social life called Synarchy. Saint-Yves wrote in 1886 about a spiritually and technologically far advanced society hidden in the mountains of Asia where Synarchy had been realized long ago.

Recent research has increasingly focused on the political aspects of N.K. Roerich's expeditions to Central Asia from 1925-1928 and from 1934-1935. ${ }^{3}$ This new interpretation of Roerich's background and motives has sparked off an ongoing polemical debate in Russia and has led to bitter divisions within the Roerich movement and its followers. Especially the Moscow-based Mezhdunarodnyi Tsentr Rerikhov under vice-president Liudmila Shaposhnikova has vowed to defend the legacy against any "traitors" from within the movement and "liars" and "slanderers" from outside. First the MTsR staged a witchhunt against the view that Nicholas Roerich might have been an active spy for the Soviet intelligence in Central Asia; ${ }^{4}$ then the MTsR tried to prove that Vladimir Rosov's ground-breaking Ph.D. thesis, in which much new material covering

3 Oleg Shishkin, Bitva za Gimalai: NKVD - magiia i shpionazh (Moscow: Olma-Press, 1999, 2nd printing 2000; Vladimir Rosov, Nikolai Rerikh: Vestnik Zvenigoroda. Ékspeditsii N.K. Rerikha po okrainam pustyni Gobi. Kniga 1: Velikii plan (St. Petersburg: Aleteiia, 2002), Kniga 2: Novaia strana (St. Petersburg, Moscow: Aleteiia, Ariavarta, 2004). For a bigger geopolitical, diplomatic and spiritual context see: Aleksandr Andreev, Soviet Russia and Tibet: The Debacle of Secret Diplomacy, 1918-1930s (Leiden: Brill, 2003); idem, Okkultist Strany Sovetov: Taina doktora Barchenko (Moscow: Eksmo-Iauza, 2004); idem, Gimalaiskoe bratstvo: Teosofskii mif i ego tvortsy. St. Petersburg: Izd. S.-Peterburgskogo Universiteta, 2008; Anita Stasulane, Theosophy and Culture: Nicholas Roerich (Rome: Pontificia Università Gregoriana, 2005); Andrei Znamenski, Red Shambhala. Magic, Prophecy, and Geopolitics in the Heart of Asia (Wheaton, Ill., Quest Books, 2011).

4 Roerich was always under suspicion by the British SIS. This has been taken up by Shishkin, Bitva za Gimalai and his articles in Segodnia (October 29, 1994; November 19, 1994; and December 10, 1994); and Anton Pervushin, Okkultnye tainy NKVD i SS (Moscow: Olma-Press, 1999). See for example the refutal by A.V. Stetsenko, "Byl li Nikolai Rerikh sotrudnikom specsluzhb?," Pravda, June 6, 2003, www.pravda.ru/print/science/planet/human-being/31713shambala-0 (accessed February 26, 2010). 
Roerich's political activities was published, had supposedly compromising scientific flaws. ${ }^{5}$ For this purpose, a whole series of apologetic volumes have been published. ${ }^{6}$

\section{2}

The publication of Elena Roerich's diaries, ${ }^{7}$ which contain the supposedly transcribed messages received between 1920 and 1944 from the "astral plane" and transmitted by spiritual Masters of the so-called "Great White Brotherhood", to whom the Roerichs devoted themselves and their work, confirm that the Roerichs did not consciously act as imposters who used the common vocabulary and ideals of the Theosophical Movement as a means to conceal very mundane purposes. It cannot be denied that they seriously interpreted and understood themselves and their "mission" as part of some larger spiritual Plan that ultimately should serve the advance of human evolution, especially since "Master Allal Ming" warmed them up by revealing their illustrious previous incarnations, thereby tempting personal vanity and a rather lofty arrogancecharacter traits which certainly do not occur exclusively in esoteric circles, but find an especially fertile ground among "chosen adepts" - and politicians. ${ }^{8}$

5 “'Staroe pod maskoi novogo'. Gruppa vidnykh uchenykh o dissertatsii V.A. Rosova," Novaia gazeta, no. 89, November 23, 2006; "Kul'tura, ne politika... K voprosu o neudachnoi dissertatsii o Nikolae Rerikhe," Literaturnaia gazeta, no. 20, September 26, 2006; "Ėtika lzhenauki," Special'nyi vypusk Novaia gazeta, no. 89, November 23, 2006.

6 Rerikhovskoe dvizhenie, Aktualnye problemy sohraneniia i zashchity naslediia Rerikhov $v$ istoricheskom kontekste. Materialy Mezhdunarodnogo obshchestvenno-nauchnogo simpoziuma 2002 goda (Moscow 2002); Zashchitim imia i nasledie Rerikhov. Tom 3: Dokumenty Publikatsii v presse ocherki mezhdunarodnyi Tsentr Rerikhov (Moscow 2005).

7 The diaries are preserved at the Amherst Centre for Russian Culture (Amherst, Ma.), Roerich Collection. Digital facsimiles (djvu-files) can be accessed at urusvati.agni-age.net.

8 On May 9, 1921 Elena Roerich was told that she had been as a former empress of Mexico married to Allal Ming; other incarnations included-apparently eternally female-Nofretete, king Solomon's wife, an Indian empress and a priestress in Carthago. Nikolai's credentials were quite impressive, too: $\mathrm{He}$ - eternally male-figures as a Chinese and ancient Slavonic priest, as the 5th Dalai Lama Lozang Gyatso (1617-1682), and, last but not least, as Chinese emperor under the name of Fu-Yama-Tsin-Tao. This corresponded to the spiritual name received by Roerich: Fuyama. ("Soobshcheniia, poluchennye v Londone s III po VIII m[esiats] 1920. NewYork, Nov. 1920-21 g, po 31-e maia," Elena Rerikh, Dnevnik, tetrad’ 1, 24.03.1920-31.05.1921, 79-81. See also Zinaida Fosdik's diary entries for July 29, 1922 and August 14, 1928, in: Z.G. Fosdik, Moi uchitelia: Vstrechi s Rerikhami. Po stranitsam dnevnika, 1922-1934 [Moscow: Sfera 1998], 77, 289.) As A. Andreev pointed out, the "revelation" of an alleged Lozang Gyatso incarnation was of paramount importance for all further dealings of N. K. Roerich, as Lozang 
Then again, as one enters the sphere of occultism, one has to be aware that there are, like in politics, many diverging and conflicting views, interests and objectives. One discovers very soon, how easily the spheres of occultism and politics interpenetrate. In the context of the Anglo-Russian contest for hegemony over Central and Inner Asia, the Russian and later Soviet intelligence could indeed rely on the help of agents, who in some cases were at the same time spiritual or even religious dignitaries and whose interests coincided to some extent with those of Russian imperial policy. Thus, the German traveller Wilhelm Filchner claimed in 1924 (in agreement with the British) that the Buriat lama Agvan Dorzhiev (1854-1938)-famous propagator of Tibetan Buddhism, assistant tutor and diplomat in the services of the 13th Dalai Lama Thubden Gyatso (1876-1933) - held close contact with the Tsarist foreign office and intelligence as early as 1885 , when Britain and Russia faced each other on the brink of war in Afghanistan, and that he trained other Buriat and Kalmyk lama-agents. ${ }^{9}$ While this has been disputed by others, ${ }^{10}$ there is enough evidence to suggest that Dorzhiev was indeed entrusted with political missions not only by Lhasa, but also by the Tsarist Government, even if he wasn't a "spy" in conventional terms. ${ }^{11}$ If Dorzhiev was ready to work in the service of the Tsarist government, he did it for the sake of the spiritual and political interests of Tibet, when her spiritual leaders believed it necessary to engage Russia as protective power. ${ }^{12}$

Gyatso was the first Dalai Lama to wield effective political power over central Tibet. He initiated the construction of the Potala Palace in Lhasa and was known for unifying the country under the leadership of the Gelugpa (aka the "Yellow Hat" sect) school of Tibetan Buddhism, after defeating the rival Kagyupa sect (belonging to the "Red Hat" sects) and a secular ruler, the prince of Tsang. Gyatso also established warm relations with Gushi Khan, a powerful Mongol military leader, and with the Shunzhi Emperor of China, the second emperor of the Qing Dynasty. Since there was a doubt about the legitimacy of the Dalai Lama's sixth incarnation, Roerich could claim that he was the continuation of the true lineage disrupted in the 17th century. Andreev, Soviet Russia and Tibet, 295.

9 Wilhelm Filchner, Sturm über Asien: Erlebnisse eines diplomatischen Geheimagenten (Berlin: Neufeld \& Henius, 1924), 5.

10 John Snelling, Buddhism in Russia: The Story of Agvan Dorjiev Lhasa's Emissary to the Tsar (Shaftsbury, Dorset; Rockport, Ma.: Element Books, 1993), 39.

11 Aleksandr Andreev, "Indian Pundits and the Russian Exploration of Tibet: An Unknown Story of the Great Game Era," Central Asiatic Journal 45/2 (2001): 163-80; idem, Soviet Russia and Tibet, 21; Tatiana Shaumian, Tibet: The Great Game and Tsarist Russia (Oxford: Oxford University Press, 2000), 38-40.

12 Tat'jana Shaumian: "Agvan Dorzhiev: les missions tibétaines auprès du tsar (1900-1901)," Slavica Occitania 21 (2005), 135--152. 
According to Theosophical tradition, the "Masters" were beings of ineffable spiritual development and wisdom; the most famous ones were Koot Hoomi and Morya, supposedly residents of Shigatse in Tibet. At the same time, already Elena Petrovna Blavatsky (hereafter referred to as HPB) claimed that they were incarnated, mortal men in flesh and blood. In this, the Roerichs, who joined the Theosophical Society in London in 1920, made no exception. They claimed to have met the Master Morya for the first time on March 24, 1920, in London's Hyde Park, the same spot where HPB also met her Asian teacher. Since this initial encounter, the Roerichs claimed to have received regular messages from "Morya"; indeed, on the same day, Elena Ivanovna began to note down the content of the spiritual messages transmitted to her. ${ }^{13}$ They came to believe that their Guide (they used the English word), who preferred to call himself Allal Ming or "A-Lal-Ming "14, was "the spiritual teacher of Tibet"15 and the "spiritual leader of the Pamir [region]". ${ }^{16}$

As in the case of HPB and other leaders of the Theosophical Society, the researcher is confronted with methodological choices: The first is to dismiss such "communications" as pure bluster and to range them altogether in the realm of fantasy or as an expression of some mental illness like "a special form of epileptic mania" ${ }^{17}$ Nevertheless, the source material does suggest that throughout the 1920s and 1930s the main inspiration for the Grand Plan remained the steady flow of the alleged "astral communications" transmitted by Elena Roerich, who acted as a medium. Even if there is reason to question the origin of these communications, one has to admit, as John McCannon has remarked, that "it is incredible just how much of his plan Roerich was able to accomplish", ${ }^{18}$ including the securing of fundings and diplomatic permissions for two expeditions into a highly sensitive area-the core region of the Great Game, as well as the building of a vast network of followers and financers ranging from Paris to New York and Harbin.

13 V.L. Krymov, in whose London flat the first séances took place, later wrote that Elena Ivanovna originally introduced her husband to spiritism to brighten up his deeply melancholic mood. Vladimir Krymov, Liudi v pautine (Berlin: Petropolis, [1929]), 209.

14 Dnevnik, t. 23: 13.08.1926-12.04.1927, March 13, 1927.

15 Listy sada Morii, kn. 1, September 23, 1922, in: Uchenie Zhivoi Etiki, vol. 1 (St. Petersburg: Prosveshchenie, 1993), 83.

16 Dnevnik, t. 2: 01.06.1921-05.09.1921, August 10, 1921.

17 Such is the opinion of Andreev: Gimalaiskoe bratstvo, 393-395.

18 McCannon, "By the Shores of White Waters," 179. 
On the other hand, if one assumes that "communication" actually took place-which the Roerichs perceived as their reality and as the motivating source of their actions-, did the medium (i.e. Elena Roerich) then distort the "messages" through personal defaults or ambition? Or did the "communicator" have a concealed identity and a quite different agenda from what was transmitted to the Roerichs? These are the key questions on which the further investigation in this paper is based. A similar approach has been attempted by scholars such as K. Paul Johnson and Joscelyn Godwin who in their respective research tried to shed a light on the mystery of the true "real life" identity of the Theosophical Masters and their "communications" with Elena Blavatsky. ${ }^{19}$

\section{4}

The rising influence of Eastern spirituality among Europeans and Americans was closely related to burning political questions such as the condemnation of imperialism, social and economic reform in the colonies and in contested areas like Central and East Asia, national and religious autonomy. For instance, both HPB and Annie Besant, like many Theosophists, were politically rather on the left and very strongly engaged in emancipatory causes. ${ }^{20}$ Besides, it has been recognized by a growing number of scholars that the phenomenon of occultism must be rescued from its status as an "irrational indulgence" as well as from rather partial concepts of "rationality" and "consciousness", and that on the contrary an involvement with the occult was an important driving force of the intellectual avant-garde. ${ }^{21}$ The attraction exerted by Buddhist, Hindu or

19 K. Paul Johnson, The Masters Revealed: Madam Blavatsky and the Myth of the Great White Lodge (Albany, NY: State University of New York Press, 1994); idem, Initiates of the Theosophical Masters (Albany, NY: State University of New York Press, 1995); Joscelyn Godwin, The Theosophical Enlightenment (Albany, NY: State University of New York Press, 1994).

20 The theosophical doctrines about "root races" are too often in a rather superficial way interpreted as a proof for racist, right-wing leanings by many researchers. Godwin suggested however that HPB's "Theosophy owed as much to the skeptical Enlightenment of the 18th century as it did to the concept of spiritual enlightenment with which it is more readily associated" (Godwin, The Theosophical Enlightenment, xi). John Zavos described how various religious reform movements including the Theosophical Society sought to mobilize Hindus by presenting particular ideas of what it meant to be a Hindu. It was in these movements that the ideology of Hindu nationalism began to be articulated. John Zavos: The Emergence of Hindu Nationalism in India (Oxford: Oxford University Press, 2002).

21 See for instance the affirming studies of Alex Owen, The Place of Enchantment: British Occultism and the Culture of the Modern (Chicago, Il.: University of Chicago Press, 2004); Godwin, The Theosophical Enlightenment; Antoine Faivre: Accès de l'ésotérisme occidental, 2 vols. (re- 
Muslim spirituality cannot be exhaustively explained in the context of 19th century racial theories and the notion of racist "Aryan superiority". ${ }^{22}$

In the case of Russia, the importance of the social factor, the idea that Asia was destined to be a potential ally in the fight against the oppression of the fossilized European imperialist powers, grew ever stronger in the course of the 19th century. In the culture and religion of the Eastern Slavs there existed already in the pre-Christian period a strong Iranian (and this also includes a Zoroastrian and later Manichaean) subtext, demonstrated by linguistic influences, ${ }^{23}$ which continually surfaced especially in numerous chiliastic folk beliefs, legends and sectarian cosmogonies. ${ }^{24}$ However, a similar influence can be discerned in several schools of Mahayana Buddhism, Shi'ite and Ismaili Islam. ${ }^{25}$ One can add that it was a common topic among occult and esoteric groups in East and West that the 19th century had come to an end by closing

vised ed. Paris: Gallimard, 1996); Corinna Treitel, A Science for the Soul: Occultism and the Genesis of the German Modern (Baltimore: The Johns Hopkins University Press, 2004); Arthur Versluis, The Esoteric Origins of the American Renaissance (Oxford: Oxford University Press, 2001); Hanegraaff et al., Dictionary of Gnosis \& Western Esotericism.

22 For an exploration of this latter aspect see Marlène Laruelle, Mythe aryen et rêve impérial dans la Russie du XIX siècle (Paris: CNRS Editions, 2005).

23 Aleksander Gieysztor, Mitologia Słowian (Warszawa: Wydawnictwo Artystyczne i Filmowe, 1982); Evel Gasparini, Il matriarcato slavo. Antropologia culturale dei protoslavi (Firenze: Sansoni, 1973); André Meillet, "Le Vocabulaire slave et le vocabulaire indo-iranien," Revue des études slaves 6 (1926), 165-174; Karl H. Menges, "Early Slavo-Iranian Contacts and Iranian Influences in Slavic Mythology," in Symbolae in honorem Z.V. Togan (Istanbul: Maarif Basımevi, 1955), 468-479; Max Vasmer, Russisches etymologisches Wörterbuch, 3 vols. (Heidelberg: Winter, 1953); Leszek Moszyński, Die vorchristliche Religion der Slaven im Lichte der slavischen Sprachwissenschaft (Cologne: Böhlau, 1992).

24 Mircea Eliade, Von Zalmoxis zu Dschingis-Khan. Religion und Volkskultur in Südosteuropa (Cologne-Lövenich: Hohenheim, 1982), 85-138; Mykhailo Dragomanov, Notes on the Slavic Religio-Ethical Legends: The Dualistic Creation of the World. Bloomington, In.: Indiana University Press, 1961); Ugo Bianchi, Il dualismo religioso. Saggio storico ed etnologico (Roma: L'Erma di Bretschneider, 1958), 42-43; Mikhail Seriakov: "Golubinaia kniga”: Sviashchennoe skazanie russkogo naroda (Moscow: Aleteiia, 2001); Georgii Fedotov: Stikhi dukhovnye: Russkaia narodnaia vera po dukhovnym stikham (Moscow: Progress 1991).

25 The ancient Zoroastrian eschatology influenced not only millenarist concepts in the muslim Shia (Henry Corbin, Corps spirituel et terre céleste: de l'Iran mazdéen à l'Iran shîite [Paris: Buchet-Chastel, 1979]), but also had a lasting impact on Buddhism in Tibet (Boris Kuznetsov, Drevnii Iran i Tibet: Istoriia religii Bon [St. Petersburg: Evraziia, 1998]; idem, Tibetika. Sbornik statei [St. Petersburg : Evraziia, 2003]) and the millenarist movements among Western and Eastern christians (Alain Besançon, Les Origines intellectuelles du Léninisme [Paris: CalmannLévy, 1977]; Mikhail Agursky, "L'aspect millénariste dans la révolution bolchevique," Cahiers $d u$ monde russe et soviétique 29 (1988), 487-513). 
the Dark Age or Kali Yuga, that a New Age of spiritual Enlightenment and social reform would dawn, although some details and especially the interpretation of the spiritual consequences varied drastically. In the same period, religious millenarism had reached a peak, most of all in regions of the world where political conflict, ethnic or social oppression and injustice created the necessary climate for revolt.

When, after the European rediscovery of the Zend-Avesta in the later part of the 18th century, ${ }^{26}$ the Zoroastrian legends about the eternal struggle of the agricultural peoples of Iran against the nomadic peoples of Turan ${ }^{27}$ spread across Europe, they were embraced by the Russian intelligentsia as a fitting description of the social situation in the Tsarist Empire. They could be interpreted in terms of a historic dualism between the agricultural soil and the steppe, especially following the conquest of the Central Asian territories in the mid-19th century. But whereas Dostoevsky still spoke in terms of a White Man's Burden, the mission of the Russian khristianin - krest'ianin ("Christianpeasant"-in Russian the words sound almost identical) to carry agriculture into the nomadic regions of Asia, ${ }^{28}$ outlooks began to shift in the 1860 s, when among the radical Left, the first hopes appeared for a renovation of Russia on the basis of her association with the Asian East. For such thinkers in their nascent Eurasianist mood, "Europe-Iran" turned into a synonym of stagnation and the old world. "Asia-Turan", on the other hand, became the symbol for the chaotic ferment that was necessary to overthrow the rigid tyranny, the krivda (injustice and lie) of the Tsar and to create a new, just world built upon pravda (justice and truth). Even Aleksandr Herzen (1812-1870), after his disappointment in the revolutionary Europe of 1848 and his resultant ideological

26 Michael Stausberg, Faszination Zarathushtra. Zoroaster und die Europäische Religionsgeschichte der Frühen Neuzeit, 2 vols. (Berlin: Kohlhammer, 1998); idem, “Zoroaster im 18. Jahrhundert: Zwischen Aufklärung und Esoterik," Aufklärung und Esoterik, ed. Monika Neugebauer-Wölk (Hamburg: Meiner, 1999), 117-139.

27 Concerning Iran-Turan see: Carsten Colpe et al.: "Altiranische und zoroastrische Mythologie," Wörterbuch der Mythologie, ed. H.W. Haussig, vol. I/4 (Stuttgart: Klett, 1986), 448-450; Markus Osterrieder, Durchlichtung der Welt: Altiranische Geschichte (Kassel: Pädagogische Forschungsstelle, 2008), 67-94; Marlène Laruelle, "La question du « touranisme » des Russes. Contribution à une histoire des échanges intellectuels Allemagne-France-Russie au XIX ${ }^{\mathrm{e}}$ siècle," Cahiers $d u$ monde russe, 45/1-2 (2004), 244-266.

"In Europe we are but parasites and slaves, but to Asia we shall come as masters." Fedor Dostoevskii, Polnoe sobranie sochinenii, vol. 11 (St. Petersburg: Panteleev, 1891), 515. See as well Markus Osterrieder, "Zarathushtra bei den Slaven: Die iranische Grundlage des slavischen Geisteslebens. Die Kultur des slavischen Ostens und der Schatten von Turan," Das Goetheanum 79 (2000), 577-581, 608-610, 633-636. 
approach to Russia's Slavophiles, pointed out that the focus of the world revolution would lie not in Europe but in the Turanian East, whose peoples, wrote Herzen, had received from Western civilization nothing but unhappiness, and who therefore would rise against the entire Teutonic-Latin world. Eventually Herzen came to bless in his paper Kolokol in 1860 the influence of the potentially revolutionary Turanian ethnic elements on Russia, even stating (from his London exile) that the Mongol yoke had protected Russia against Roman Catholicism and had saved the village community (mir) from destruction. ${ }^{29}$

Similar views could be found among narodniki such as Sergei Iuzhakov (1849-1910) who in 1885 spoke of the impending collision of Russia and Britain in a struggle for Asia in terms of a struggle of peasant Russia against shopkeepers' England. The colonial exploitation by the British would result in nothing less than the death of Asia. ${ }^{30}$ Another vostochnik ("Easterner") and champion for the Asian cause, prince Ésper Ukhtomskii (1861-1921), ${ }^{31}$ be-

29 Kolokol, April 1, 1860, quoted by Emanuel Sarkisyanz, Rußland und der Messianismus des Orients (Tübingen: Mohr, 1955), 207-208. See also Nicola Fumagalli: Cultura politica e cultura esoterica nella sinistra russa (1880-1917) (Milano: Barbarossa, 1996).

30 Quoted by Sarkisyanz, Rußland und der Messianismus des Orients, 208-209.

31 See David Schimmelpenninck van der Oye, Toward the Rising Sun: Russian Ideologies of Empire and the Path to War With Japan (DeKalb, Il.: Northern Illinois University Press, 2001), 42-60; Laruelle, Mythe aryen et rêve impérial, 156-168; Johnson, The Masters Revealed, 125-137. One of the most important cradles of the concept of modern Pan-Turanism was the Kingdom of Hungary, where it was popularized by literates like Sándor Székely de Aranyosrákos und Mihály Vörösmarty. One should not overlook at roughly at the same time, the idea of a Turanian empire was propagated amongst the Ottoman Turks by Ármin Vámbéry (Hermann Wamberger, 1832-1913), a Hungarian Professor, philologist and traveller who worked as an advisor to the Ottoman Sultan between 1857-1863, who was also doing intelligence work for Lord Palmerston of the British Foreign office. Vámbéry's thesis was based on the observation that as much of Central Asia used Turkic languages as their main vernacular (except Persian speaking Tajikistan), this then necessitated the formation of "Turan," which he saw as a political entity stretching from the Altai Mountains in Eastern Asia to the Bosphorus. It has been speculated that Vámbéry's mission was to create an anti-Slavic racialist movement among the Turks that would divert the Russians from the "Great Game" which they were involved in against Britain in Persia and Central Asia. Cf. M. Kemal Oke, "Prof. Arminius Vambery and Anglo-Ottoman Relations 1889-1907" Bulletin of the Turkish Studies Association 9/2 (1985), 15-28; H.B. Paksoy, "Basmachi': Turkestan National Liberation Movement 1916-1930s," Modern Encyclopedia of Religions in Russia and the Soviet Union, vol. 4 (Gulf Breeze, Fl: Academic International Press, 1991), 5-20; Geoffrey Miller, British Policy towards the Ottoman Empire and the Origins of the Dardanelles Campaign (Hull: University of Hull Press, 1997); Serge Zenkovsky, Pan-Turkism and Islam in Russia (Cambridge, Ma.: Harvard University Press, 1960); Michael de Fernandy, "Die Mythologie der Ungarn," Wörterbuch der Mythologie, ed. H.W. Haussig, vol. I/2 (Stuttgart: Klett, 1973), 209-260, here 231-232. 


\section{Markus Osterrieder}

lieved at the time of the Boxer Rebellion (1900) that "in the community of Russia and Asia is contained the future solution of the Oriental question". He also thought that "the bonds that unite our part of Europe with Iran and Turan, and through them with India and the Celestial Empire, are so ancient and lasting that, as yet, we ourselves, as a nation and a state, do not fully comprehend their full meaning and the duties they entail on us, both in our home and foreign policy." 32 Ukhtomskii was acquainted with Theosophy and a practicing Buddhist from the age of 15 . His links with Buriats and Tibetans were surrounded with secrecy. While he was in no way disloyal to Tsar Nicholas II, to whom he introduced Agvan Dorzhiev in 1898, he saw the Tsar as a potential liberator of the Asian peoples because of the way Russia was treated and rejected by the Western powers.

And there will come a day, when the Orient shall arise from its slumber, awakened and irritated by the stormy elements of the oppressing white race. Like our mythical Ilya Muromets, the Orient shall then feel a mighty power in itself and shall demand to say its word. [...] And Europe shall tremble. But neither threats nor violence nor accidental victories shall be able to accomplish anything [...]. In the eternal conflict between Europe and Asia, Russia shall decide in favor of Asia. Another judgment is not possible where the judge is the brother of the complainant. ${ }^{33}$

Like other Buddhists who were inspired by the teachings of Tibetan lamas and were familiar with the legends associated with the Kālachakra Tantra ("Wheel of Time Tantra") ritual, Ukhtomskii referred to the messianic advent of the so-called "Last King of Northern Shambhala. "This "Shambhala of the North" was considered to be a mythical land, thought to be situated somewhere far to the north of Tibet, ${ }^{34}$ a "Land of Quietness." On his travels through Central Asia in 1845-1846, the French Catholic Abbé Huc (Évariste Régis Huc, 1813-1860) came across an occult brotherhood under the command of the

32 Ésper Ukhtomskii: Travels in the East of Nicholas II Emperor of Russia when Cesarewitch 18901891, vol. 2 (London: Archibald Constable, 1896), 35.

33 Ėsper Ukhtomskii, $K$ sobytiiam v Kitae: Ob otnosheniiakh Rossii $k$ Vostoku (St. Petersburg: Vostok, 1900), 44-45 and 48 and 79.

34 G.A. Combe, A Tibetan on Tibet. Being the Travels and Observations of Mr. Paul Sherap (Dorje Zodbo) of Tachienlu (London: Unwin, 1926), 41-42. As an introduction to the Shambhala myths see Edwin Bernbaum: The Way to Shambhala (Garden City, NY.: Anchor, 1980). As seen from an Agni Yoga perspective: Natal'ya Kovaleva, Shambala - èto ne mif (Moscow: Ripol, 2002). 
Panchen Lama called the Kelan. Their members believed that their leader would be reborn in the future in a country north of Tibet between the TienShan and the Altai range, and that this country was connected to the prophecies of Shambhala. After the future Chinese conquest of Tibet, so it was told, the New Country in the North would be the cradle of the renewal of Buddhism, the dead would be resurrected, and the Panchen Lama as the Universal Ruler would then crush the forces of evil and spread Buddhism over the entire earth. ${ }^{35}$ Many elements of this tale would later resurface in the spiritual instructions of the Buriat Lama Agvan Dorzhiev and of "Allal Ming" and the Roerichs.

Another tale from Tibet foretold that the King would be reborn as the Tashi (Panchen)-Lama at a time when Lamaism has declined and become impotent. In this future incarnation, the ruler of Northern Shambhala was expected to lead the Lamaistic peoples into the last and decisive combat against the enemies of righteousness. In a special prayer the faithful asked to be reborn as fighters of Shambhala's armies against the opponents of truth, to prepare the advent of the realm of Maitreya, the Future Buddha, whose coming Lamaism was also expected from the far north. ${ }^{36}$ Then, a new Golden Age would dawn: "Grain shall then flourish on the fields without the necessity of ploughing." ${ }^{37}$

The political implications of this hope that the White Tsar from the Aryan North $^{38}$ as the potential liberator of Buddhist Asia could satisfy "yearnings for

35 M. Huc, Souvenirs d’un voyage dans la Tartarie, le Thibet, et la Chine pendant les années 18441846, vol. 2 (2nd ed. Paris: Adrien LeClère, 1853), 278-280.

36 As early as 1848, the first Russian educated Buriat Dordji Banzarov formulated-under the immediate impression of the revolutions in France, Germany, and Austria-a Mongol if not Lamaist view of the revolutionary crisis into the following words: "The inhabitants of the Occident now have a period of turmoil. They have expelled their lords and khans and have become hostile to one another. It seems such also were the times in which Kesar was born into this world. Judging by the character of the present epoch, will not Kesar appear again? Then we will have the possibility to be among his thirty-three companions." D. Banzarov's letter to Bobrovnikov, dated April 12, 1848. D. Banzarov, Chernaia Vera ili shamanstvo u mongolov $i$ drugiia stat'i (St. Petersburg: Imp. Akad. Nauk, 1891), 111. Although distinct from the Shambhala idea in literary origin, the expectations about the rebirth of Kesar (Gesar), the famous hero of Tibetan and Mongolian epics, do seem to converge with those about the Last King of Shambhala in the messianic and millennial expectations common to both of them. Thus, the hero king Kesar is expected to be reborn in Northern Shambhala. See Emanuel Sarkisyanz, "Communism and Lamaist Utopianism in Central Asia," The Review of Politics, 20/4 (1958), 623-33, here 626627.

37 Sarkisyanz, "Communism and Lamaist Utopianism”, 623-625.

38 Marlène Laruelle, “'The White Tsar': Romantic Imperialism in Russia’s Legitimizing of Conquering the Far East," Acta Slavica Iaponica 25 (2008), 113-134. 


\section{Markus Osterrieder}

truth and justice on Earth"39 were promoted at the court in St. Petersburg by Asia oriented intellectuals (vostochniki) like Ukhtomskii or the Buriat practitioner of Tibetan medicine Petr (Zhamsaran) Badmaev (1851?-1920) who suggested to his godfather Alexander III the annexation of Mongolia, China and Tibet. He later was suspected of having been a secret envoy of the Teshu Maru brotherhood. ${ }^{40}$ But they did not really depend on a specific type of government in Russia; ${ }^{41}$ the "White Tsar" as a mythical leader could also have a proletarian background. For this reason, there was no contradiction, if Buriat Lama Agvan Dorzhiev first put his hopes in the Russian Tsar, but after 1917 would court the Bolshevik leadership by stressing the compatibility of Buddhism and Communism. The same strategy was taken up by the Roerichs to whom the Himalayan Masters explained the evolutionary necessity of Communism.

\section{5}

It was the French occultist Joseph-Alexandre Saint-Yves d'Alveydre (18421909) who in the 1870s and 1880s joined the tales circulating in the occultist underground of Europe about a Master Lodge in the East, a superior underground society and social messianism by advocating a reform of social life that he called Synarchy. He was able to promote it thanks to his excellent social connections among the ruling dynasties of Western Europe, Scandinavia and

39 In the words of the offical Ivan Balashev in 1902; Schimmelpenninck van der Oye, Toward the Rising Sun, 198. See as well Dany Savelli, "Penser le bouddhisme et la Russie," Slavica Occitania 21 (2005), 9-88; Marlène Laruelle, "La place du bouddhisme dans les discours nationalistes russes du XIX ${ }^{\mathrm{e}}$ siècle," Slavica Occitania 21 (2005), 225-242.

40 Boris Gusev, Petr Badmaev: Krestnik imperatora, tselitel', diplomat (Moscow: Olma-Press, 2000). Petr Badmaev, Za kulisami tsarizma. Vospominaniia. Memuary (Moscow, Minsk; AST, 2001); Tat'iana Grekova, Tibetskaia meditsina $v$ Rossii. Istoriia $v$ sud'bakh u litsakh (St. Petersburg: Aton, 1998), 22-167; eadem, "Pëtr Badmaev (1851-1920), "médecin tibétain» converti à lorthodoxie. (Réflexions d'un biographe)," Slavica Occitania 21 (2005), 187-200. Concerning the occult allegations see Alexandre de Dánann, Les secrets de la Tara Blanche: Lettres d'un Lama occidental à Jean Reyor (Milano: Archè, 2003), 14-20; Louis de Maistre, L'énigme René Guénon et les "Supérieurs Inconnus ": Contribution à létude de l'histoire mondiale "souterraine " (Milano: Archè, 2004), 568-569. See also Birgit Menzel's chapter in this volume.

41 The idea of a Pan-Buddhist state even inspired Baron von Ungern-Sternberg's secret offers to the Dalai Lama in 1921-1922. Leonid Iuzefovich, Samoderzhets pustyni: Fenomen sud'by barona R.F. Ungern-Shternberga (Moscow: Ėllis Lak, 1993), 193; Andreev, Soviet Russia and Tibet, 153. Ungern-Sternberg was declared to be a Mahakala incarnation by the 13th Dalai Lama; Mahakala (Sanskrit maha "great" and käla "time") is a Dharmapala ("protector of dharma"). 
Russia (Alexander III). ${ }^{42}$ In 1877 he revealed the synarchical system for the first time in his book Clefs de l'Orient and he developed it during the following years in a series of "Mission"-pamphlets, Mission actuelle des souverains, Mission actuelle des ouvriers (1882) und Mission des juifs (1884). Saint-Yves explained how at the present stage of human evolution it had become necessary to adopt a threefold differentiation of human society along the three main spheres of social activity: Thus he suggested that there should be a European Council of National Communities as a central institution for finance, banking and trade representatives; a European Council of National Estates taking care of legal and political questions; and finally a European Council of National Churches for the representatives of religions, higher education and the arts. ${ }^{43}$ In 1885 (the year of the Anglo-Russian crisis), when Saint-Yves met a certain oriental initiate by the name of Hardjji Scharipf (or Haji Sharif), he began to refer to an Asian origin of Synarchy. Sharif claimed to be the "Guru Pandit of the Great Agarthian School”, from the hidden "Holy Land of Agartha" below the surface of the earth in the mountains of Asia, the residence of the "Master of the Universe". On June 8, 1885, Haji Sharif started to teach Saint-Yves the mysterious language and alphabet of Vattan. ${ }^{44}$ The result of this encounter was Saint-Yves' book Mission de l'Inde, written not before 1886 but published only

42 In 1877, in England he married Marie de Riznitch, Comtesse de Keller (1827-1895), a Polish noble woman with mediumistic capacities from Odessa and a good friend of the Danish queen Louise. The couple was always well received at the Copenhagen court. A daughter of Louise was married to the Prince of Wales and later King Edward VII, another daughter to Tsar Alexander III. These high-placed connections should prove very efficient for Saint-Yves to promote the concepts of Synarchy. They also contributed to the forging of the Franco-Russian entente in 1894 which gave Russia "the power to unleash a major European war whenever this might suit Russian purposes." George F. Kennan, The Fateful Alliance: France, Russia, and the Coming of the First World War (New York: Pantheon, 1984), 252. Kennan contributed another thorough study: The Decline of Bismarck's European Order: Franco-Russians Relations, 1875-1890 (2nd ed. Princeton, NJ: Princeton University Press, 1980.

43 Jean Saunier, Saint-Yves d'Alveydre ou une synarchie sans énigme (Paris: Dervy, 1981); idem, La Synarchie (Paris: Culture-Art-Loisir, 1971); Jacques Weiss, La Synarchie: l'autorité face au pouvoir depuis la préhistoire jusqu’à la prochaine paix selon Saint-Yves d'Alveydre (Paris: Dervy, 1967); Geoffroy de Charnay, Synarchie (Paris: Éditions Médicis, 1946); Yves-Fred Boisset, À la rencontre de Saint-Yves d'Alveydre et de son ceuvre, vol. 1: La synarchie (Paris: Éditions SEPP, 1996); Olivier Dard, La Synarchie, ou, Le mythe du complot permanent (Paris: Perrin, 1999).

44 Joscelyn Godwin, "Saint-Yves d'Alveydre and the Agarthian Connection," The Hermetic Journal, no. 32 (1986), 24-34; no. 33 (1986), 31-38; idem, "La genèse de l'Archéomètre. Documents inédits de Saint-Yves d'Alveydre," L'Initiation, no. 2-3 (1988), 61-71. 
in 1910, in which he used Agartha ${ }^{45}$ as an model illustration for a potential synarchical order. ${ }^{46}$

The synarchic ideas of Saint-Yves were carried on especially by founding members of the Ordre Martiniste (established in 1888) like Papus (Gérard d'Encausse), ${ }^{47}$ François-Charles Barlet aka Albert Faucheux (1838-1921) ${ }^{48}$ and Pierre-Augustin Chaboseau (1868-1946). ${ }^{49}$ The Martinists and their associates became ardent advocates of a Franco-Russian rapproachment, not only because of their deep dislike of Bismarckian Germany, but also because according to their views, Russia was a key country in the present cycle of social revolution, the avant-garde of a new world order ${ }^{50}$ and in any case ripe for synarchy.

45 Once more it was Aleksandr Dugin with his close contacts to the French Nouvelle Droite and to the followers of occult traditionalism as taught by Guénon or the Martinists, who began to spread in 1993 the rumour that among the military intelligence GRU (Glavnoe Razvedyvatel'noe Upravlenie) existed a secret Order under the name of "Agartha." Cf. Dugin, Konspirologiia.

46 A. Saint-Yves d'Alveydre, Mission de l'Inde en Europe. Mission de l'Europe en Asie (Paris 1886 [edition withdrawn], Paris 1910, Reprint Nice: Belisane, 1995).

47 Marie-Sophie André and Christophe Beaufils, Papus: Biographie: la Belle Epoque de loccultisme (Paris: Berg International, 1995); Philippe Encausse, Sciences occultes, ou, 25 années d'occultisme occidental: Papus, sa vie, son oeuvre (Paris: Ocia, 1949).

48 Barlet, also a member of the Hermetic Brotherhood of Luxor and "cornerstone of all the [occult] groups" (Emmanuel Lalande) showed a particularily strong interest in sociological questions. "The revolutions which have so deeply modified Europe over the last century and those which seem to threaten her even more give a special importance to the art of governing people." F.Ch. Barlet, Sociologies et synarchie. La société de l’avénir (Paris: L'Écho de l’Au-délà, 1900), 5. "It was understood, at first, that Martinism's sole purpose was to prepare its members for entry into an Order that could confer an authentic initiation [...] this was none other than the H.B. of L., of which Barlet had become the official representative for France." René Guénon, "F.-Ch. Barlet et les sociétés initiatiques," Le Voile d'Isis 30/64 (April 1925), 217-221, here 220. See as well Jean-Pierre Laurant, L'Esotérisme chrétien en France au XIX siècle (Lausanne: L'Age d'Homme, 1992), 135.

49 Chaboseau was conservateur adjoint at the library of the Musée Guimet in Paris where he promoted Buddhist studies; with Chaboseau's support, Agvan Dorzhiev could celebrate on 27 June 1898 a ritual in the Museum. Later, during World War I, Chaboseau became special secretary to Aristide Briand and was sent on diplomatic missions to the Balkans, because "most of the Balkan princes [...] were in 1914 Martinists" (Victor-Émile Michelet, Les Compagnons de l'hiérophanie. Souvenir du mouvement hermétiste à la fin du XIXe siècle. [Paris 1937, Reprint Nice: Dorbon-Ainé, 1977], 102).

50 Papus said in an esoteric lecture in 1908: "I shall remind you that in 1848, we have entered the period of English domination. This will end at the moment when the cannon shot has been given - so they say in the Western esoteric circles - which means that Papistry will be destroyed by England, and she herself will be defeated by Germany allied to Russia and perhaps even to France. Then there will be the Prussian domination, but later, Russia will rule over the 
Some insiders even thought that Papus not only helped to forge the FrancoRussian entente, but also contributed to heighten the expectations for a coming social revolution in Russia. ${ }^{51}$

\section{6}

According to some researchers, Roerich became a member of the Ordre Martiniste already in his days in St. Petersburg at the eve of World War I. ${ }^{52}$ Some of his social contacts make this seem likely. He certainly shared the conviction held by many occult orders and societies that Russia (a reborn RussiaZvenigorod) was destined to have a great future, that it would become a Saviour of the nations. Roerich first met Agvan Dorzhiev and heard his instructions about Shambhala in 1909, when he was a member of the construction

world. In this last period, France will enter another very brilliant cycle as harbinger of civilization of other nations, thanks to her alliance with the other countries of Latin tongue." Encausse, Sciences occultes, 200.

51 The occultist Gary de Lacroze, a former classmate of Papus at the Collège Rollin, remarked how quickly Martinism spread among the Russian aristocracy and the intelligentsiia and how it showed the same effects as the earlier Martinism at the eve of the French Revolution. He thought therefore that among the circles of Russian Martinists "the doctrine and the plan of the Russian Revolution will be defined." During his last meeting with Papus shortly before the latter's death in 1916, Papus said to Lacroze: Martinism "develops and enters the level of political realizations. I entrusted the Lodges with a social program that knows a lot of success: the obligatory civil service." Lacroze added: "This is the germ of Sovietism." Encausse, Sciences occultes, 96-97.

52 According to this version, which is vehemently denied by the followers of the MTsR (see S.V. Skorodumov, I.M. Sebeleva: "Nazad v budushchee (Vosvrashchenie v 1937 goda?): Otkrytoe pis'mo," Gazeta Sodruzhestvo, no. 11, July-October 2003, www.roerichs.com/Sodr/N11/6-1.htm (accessed February 26, 2010), N.K. Roerich - in the footsteps of his father Konstantin - joined the Martinist lodge of Grigorii O. Mëbus under the mystical name Fuyama a few years before the war and received his intitiation from the "Sovereign Delegate" of the Russian Martinist Order Czesław Czyński (mystical name "Punar Bhava"), who was appointed in 1913 by Papus as "Legat de l'Église Gnostique Universelle en Russie" (in 1910, he became also X O.T.O. [Ordo Templi Orientis] member for the Slavonic territories). Zapiska po 1-mu otdeleniiu Osobogo otdela Departamenta politsii "ob Ordene martinistov" ot 01.1911 g., quoted by O.A. Platonov, "Ternovyi venets Rossii". Tainaia istoriia masonstva, 1731-2000 (Moscow: Russkii vestnik, 2000), 707-708). See also Shishkin, Bitva za Gimalai, 18-23; “Jubilee edition” of the Oriflamme, Bad Schmiedeberg (June 1, 1912): 14. For a survey of the Russian Martinist Order see Andrei Serkov, Istoriia russkogo masonstva 1845-1945 (St. Petersburg: Izd. imeni N.I. Novikova, 1997), 67-90; Viktor Brachev, Chekisty protiv okkultistov (Okkul'tno-misticheskoe podpole v SSSR) (Moscow: Iauza, 2004), 41-61, 89-126. 
committee of the new Buddhist Kālachakra Tantra sanctuary in St. Petersburg. ${ }^{53}$

Likewise, Roerich's affinities to Martinism and Synarchy were avisible in his link with Harvey Spencer Lewis's order Antiquus Mysticusque Ordo Rosae Crucis (AMORC). He was introduced to the Lewises possibly by an American AMORC member from Chicago spending some time in Shanghai in the early 1920s and who organized AMORC's participation in the Roerich Peace Pact. AMORC was affiliated with both the Ordre Martiniste et Synarchique ${ }^{54}$ and the Ordre Martiniste Traditionnel. ${ }^{55}$ When Roerich set off for his Central Asian expedition, Lewis was keen on making him a legate of AMORC for Tibet, which apparently Roerich never was, in spite of his rather close relationship with Spencer Lewis. ${ }^{56}$ Nevertheless, AMORC claims until the present day that

53 Aleksandr Andreev, "Iz istorii Peterburgskogo buddiiskogo khrama," Minuvshee. Istoricheskii almanakh 9 (1992), 380-408, here 387; idem, "La Maison du Bouddha dans le Nord de la Russie (Histoire du temple bouddhique de Saint-Pétersbourg)," Slavica Occitania 21 (2005), 153-178; idem, Khram Buddy v Severnoi stolitse (St. Petersburg: Nartang 2004).

54 One of the oldest surviving regular Martinist Orders which has had a continual existence since its founding in 1918 by Victor Blanchard (Sar Yesir).

55 Conceived to be a rival order to Blanchard's OMS, the Traditional Martinist Order was established in 1931, with Victor-Émile Michelet as Grand Master and Chaboseau as deputy Grand Master. Though he had received his martinist initiations in the OMS, AMORC Imperator Ralph Maxwell Lewis was asked by the OMT in 1939 to import martinism to the U.S.A. and he was given the necessary charters and other documents.

56 There is a membership certificate inducting Nicholas Roerich into AMORC's OMCE (Order Militia Crucifera Evangelica, originally created by AMORC and the British Martinist Order) dated November 18, 1929. It is signed by H. Spencer Lewis and counter-signed by Ralph Lewis, but it was left unsigned by Roerich. Gary Stewart-the former Imperator and President of the Board of AMORC from 1987 to 1990, founder of the Confraternity of the Rose Cross (CR+C) in 1996, Knight Commander of the OMCE and the Sovereign Grand Master of the British Martinist Order-stated: "Roerich was never a member of AMORC. However, he was closely associated with both $\mathrm{H}$. Spencer Lewis and Ralph Lewis over a span of about 25 years in that there was considerable correspondance between them. The earliest correspondance I can find from Roerich to HSL is dated May 10, 1922 and refers to the sending of an article entitled 'Rigor Mortis' meant for publication in the AMORC magazine of that time. Over the years he sent a number of articles, some of which, quite sadly, were highly edited by AMORC to make it appear he was a member as well as to change some of the content. About half of the articles submitted by Roerich were published. Roerich also sent a number of items to the AMORC museum most of which were of a Tibetan nature. One was a coral ring. In turn, AMORC was, if not the first, one of the first, organizations in the United States to fly Roerich's Banner of Peace." Gary Stewart, posting on the Google Groups Rosicrucian list, August 25, 2006, groups.google.com/group/rosicrucian/msg/47f68b5ef4727246?hl=de\& (accessed February 26, 2010). 
Roerich communicated certain occult techniques from Tibet, which were since integrated in the AMORC teachings. ${ }^{57}$ Lewis proudly mentioned the correspondence he received from Roerich's second expedition. ${ }^{58}$

The Altai mountains-and, more widely, Siberia-were at the very core of the Great Plan, an indispensable component of the "New Country", because Roerich believed the Altai would become a double for Shambhala-as the fabled land of Belovod'e, or the Land of White Waters, celebrated in numerous Russian folk legends, especially among sectarians such as the Beguny. ${ }^{59}$ Roerich was also intrigued by all the stories about the tunnels and caverns that existed below the earth. Therefore, one of the Altai legends that most excited Roerich was the tale of a vast tangle of tunnels purported to honeycomb the underground realms deep beneath the mountains. Drawing upon the tales of the underground Agartha (or Agarthi), Roerich envisioned an intricate network of tunnels and chambers linking the Altai with the Himalayas. Even the Dalai Lama was drawn into Roerich's speculations, for, as he thought, the tunnels in the Altai led all the way to Lhasa and the Potala Palace. ${ }^{60}$

Another occultist in early Soviet Russia who tried to synthesize Saint-Yves's social utopia with natural science, Bolshevism, the fascination for Tibet and Buddhist spirituality, and the search for Shambhala was Aleksandr Barchenko

57 Christian Rebisse, "Histoire du rosicrucianisme des origines jusqu'à nos jours," www.rosecroix.org/histoire/histoire_rc_19.html (accessed February 26, 2010). See also idem, "Rosicrucian History from Its Origins to the Present, part XVIII," Rosicrucian Digest 84/1 (2006), 25-26. The US citizen Joseph J. Weed, who affiliated with AMORC in 1932 and eventually was appointed as Grand Councilor with responsibility for the North Atlantic States, continued his study in the teachings of Agni Yoga and the Arcane School, was a Trustee of the Nicholas Roerich Museum, and became a Director of the Agni Yoga Society. He was not the only AMORC member in NYC who was at one time also active in Agni Yoga.

58 "I am happy to say that on Monday, March 20th, the day of our New Year anniversary, I received a personal registered letter from our great Brother who is the international representative of the Great White Brotherhood. I refer to Nicholas Roerich. His letter came from the monastery in the Himalayas where he spends a part of each year in personal contact with the highest representatives of the Great White Brotherhood. From this sacred place came his message to us for the New Year, and with it a special article of inspiration and helpfulness to be published in the next issue of our Rosicrucian Digest. In his personal letter he states that he would warn all of us to be watchful at this very critical period of transition from the old cycle to the new, and from the old race of thinking men and women to the newer race of evolving beings, and to watch out for the last and most desperate forces of evil to try to destroy or prevent the activities of goodness and truth." The Rosicrucian Forum, vol. 3, no. 5 (April 1933), 130.

59 Kirill Chistov, Russkaia narodnaia utopiia (genezis i funktsiia sotsialno-utopicheskikh legend), 2. ed. (St. Petersburg: RAN, 2003), 279-384.

60 McCannon, "By the Shores of White Waters," 172-176. 
(1881-1938). ${ }^{61}$ After his arrest in 1937 by the GPU, Barchenko "confessed" during the interrogations how he had been approached in 1923 by two members of what he called the "Great Brotherhood of Asia", supposedly an occult umbrella organization for the whole of Inner Asia, uniting diverse Mongolian and Tibetan brotherhoods, Muslim and Dervish orders and even Jewish Hasidic and Christian sectarian groups. ${ }^{62}$ The first of the two men was the Lama Naga Naven, "the representative of the centre Shambhala" ${ }^{63}$ who lived at that time in the house of the Tibetan mission in Leningrad and who explained to Barchenko that he came to Moscow for negotiations with the Bolshevik leaders in order to "advance a rapproachment between West Tibet and the USSR". The lamas of Western Tibet under the leadership of the Panchen Lama disagreed with the policy of the Dalai Lama who after 1904 got on more friendly terms with the British. The second was Khayan Khirva, member of the TsK of the Mongolian People's Party. Both were pressing the Soviet government for close political and cultural relationships between the USSR and West-Tibet via South Mongolia. ${ }^{64}$

\section{7}

The wooing of the Soviet leadership by representatives of Tibetan Buddhism, in the rival services of both the Dalai Lama and the Panchen Lama, had reached a peak in the mid-1920s. Dorzhiev, still loyal to the Dalai Lama, called

61 See Oleg Shishkin's chapter in this volume. Andreev, Soviet Russia and Tibet, 108-109; Andreev, Okkultist Strany Sovetov.

62 Protocol of Barchenko interrogation, 10 June 1937; Shishkin, Bitva za Gimalai, 368-369; Andreev, Okkul'tist Strany Sovetov, 166-167. That such a "working community" was actually possible, in spite of the deep aversion within the Kālacakra Tantra tradition against Muslims, is for example confirmed by the existence of the Sufi Tarîqah Yasawiya in the Ferghana Valley and Kafiristan. Its members were always looked upon in a suspicious way by other more orthodox Sufi communities because of their close ties with Tibet and China. According to John G. Bennett, the Yasawis taught Gurdjieff a lot about sacral music and dance. John G. Bennett, Gurdjieff: Making a New World (London: Turnstone Books, 1973), chapter 4; see also De Dánann, Les secrets de la Tara Blanche, 174-177; Thierry Zarcone, Secrets et sociétés secrètes en Islam: Turquie, Iran et Asie centrale, XIX ${ }^{e}-X X^{e}$ siècles. Franc-Maçonnerie, Carboneria et confréries soufies (Milano: Archè, 2002); Musulmans et Soufis du Tibet, ed. Thierry Zarcone (Milano: Archè, 2005).

63 Statement by A.A. Kondiain, June 1937, Arkhiv UFSB SPb. and Lenoblast', D P-26492, 1.18; quoted by Andreev, Okkultist Strany Sovetov, 168.

64 Protocol of Barchenko interrogation, 10 June 1937, Arkhiv FSB, delo A.V. Barchenko; Shishkin, Bitva za Gimalai, 368-369; Andreev, Okkul'tist Strany Sovetov, 166-167. 
for the abolition of the khubilgan or tulku worship cult and the prohibition of divination by both Buriat and alien lamas. This caused a dramatic split of the clergy in Buriatia and Kalmykia. ${ }^{65}$ On their side, the Roerichs would, on their first expedition in 1928, blame the 13th Dalai Lama for the ultimate degradation of Buddhism and the schism into separate Western and Eastern traditions, and would correspondingly praise the 9th Panchen Lama Thubten Choekyi Nyima (1883-1937) as the true and unique Ruler of Tibet. ${ }^{66}$ The Panchen Lama, following his escape to Inner Mongolia in 1924 after a dispute with the Dalai Lama, sensed that he might face threat after his own monastery's monks were being prohibited from holding any office in the Central Tibetan government and his officials were locked up in Lhasa. He sought Chinese protection, spoke in favour of the Chinese revolutionary leader Sun Yat-sen (1866-1925) and advocated the union of Tibet with China in the context of a larger FiveNationalities-Confederation. ${ }^{67}$

Still, even Dorzhiev clearly favored Soviet influence over the British, and he implied in his autobiography that the Buddhist teachings were generally in harmony with the recently introduced system of Communism in Russia. Under the benign patronage of the Bolshevik regime, Russia would become a land worthy of the noble title "Supreme Place": one, in which the Buddhist religion thrives. ${ }^{68}$ Some of his followers went even further and declared that Buddhism had prefigured the ideals of Bolshevism, that Shakyamuni Buddha had been some sort of proto-Bolshevik and that his spirit lived on in Lenin. ${ }^{69}$

The Buddhists were not the only religious group who sought to reconcile spiritual messianism and new political order. Upon the establishment of Soviet power over Russia rumors also followed about the coming of Antichrist, the Second Advent of Christ and the End of the World, ${ }^{70}$ Even the Bolsheviks

65 Andreev, Soviet Russia and Tibet, 159-160.

66 Idem, 315. See Dnevnik, t. 22, 21.05.1925-12.08.1926, April 13, 1926: "The ray showed how the Tashi Lama becomes the chief of the buddhists without the Dalai Lama."

67 Fabienne Jagou, Le $9^{e}$ Panchen Lama (1883-1937). Enjeu des relations sino-tibétaines (Paris: École Française d'Extrème Orient, 2004), 137-210; Parshotam Mehra, Tibetan Polity 19041937: The Conflict Between the 13th Dalai Lama and the 9th Panchen. A Case Study (Wiesbaden: O. Harrassowitz, 1976); Melvyn C. Goldstein, A History of Modern Tibet, 1913-1951: The Demise of the Lamaist State. Berkeley, CA.: University of California Press, 1989), 252-264.

68 Snelling, Buddhism in Russia, 205-206; Andreev, Soviet Russia and Tibet, 160-161.

69 Snelling, Buddhism in Russia, 205.

70 "Sostoianie antireligioznoi raboty na dannom ètape," Pod znamenem Marksizma (nov./dec. 1931): 193-195; cited by Manuel Sarkisyanz: "Milleniarism in the Soviet Revolution," Filosofskii vek. Almanakh. Vyp. 13: Rossiiskaia utopiia épokhi Prosveshcheniia i traditsii mirovogo utopizma 
themselves proclaimed the old revolutionary phrase: My Staryi mir razrushim do osnovan'iia, a zatem my nash, my Novyi mir postroim! ("We shall destroy the Old World to the foundations, then we shall build our New World!").

By now it is time to ask once more how to evaluate the possible meanings of the "communications" transmitted by Elena Roerich since 1920? Is there a possible connection to the recurrent claim in Russian, Polish and French occultist circles that there existed a hidden "great Asian brotherhood" with a spiritual-political agenda of its own $?^{71}$ Who or what was behind the so-called "Tibetan Master" "Djwahl Khul", who was known to be one of the Theosophist's "Ascended Masters" and who at the same time, since the 1920s, allegedly spoke "through the astral light" to another medium, the founder of the Lucis Trust and the Arcane School of Alice Bailey? ${ }^{72}$

Roerich was not only lured by the "Masters" with obvious and rather lavish flattery, for example, making him believe that his paintings contained a deeper meaning for the future and contained a spiritual power, ${ }^{73}$ or that his Karma was to glorify Russia ("Karma vasha - Rossiiu proslavliat"). ${ }^{74}$ It was also stated that the rebirth of Russia meant the rebirth of the whole world, ${ }^{75}$ since she was "the mother of the small nations" and would "defeat the nations attacking

ed. T. V. Artem'eva and M.I. Mikeshin, (St. Petersburg: Sankt-Peterburgskii Tsentr istorii idei, 2000), 307-319, here 315.

71 The French engineer and occultist Jean Calmels (d. 1961), former Martinist Supérieur Inconnu, who got initiated into esoteric lamaism by the Buriat physician Włodzimierz N. Badmaieff (Vladimir N. Badmaev 1884-1961, a nephew of Petr Badmaev) in Warsaw between the wars, thought that the region between Ferghana, Kashmir and Nepal served, simlilar to the People's Republic of Tannu Tuva with its capital Kyzyl, as a corridor of interaction between Muslim and Lamaist spirituality, even if there were violent confrontations in the outer world, which had no great importance for the deeper occult exchange. Letter from Jean Calmels to Jean Reyor (Marcel Clavelle), June 25, 1943, De Dánann, Les secrets de la Tara Blanche, 116-117. See also Louis de Maistre, Dans les Coulisses de l'Agartha. L'Extraordinaire Mission de Ferdinand Anton Ossendowski en Mongolie (Milan, Archè, 2010).

See Alice Bailey and Djwhal Khul, The Externalization of the Hierarchy. Section II: The General World Picture ([1938-1939] New York: Lucis, 2001), 133. It seems that Alice Bailey initially tried to win the Roerichs for a possible cooperation (Fosdik, Moi uchitelia, November 25, 1929, 537), but Elena Roerich would always warn her followers not to get involved with Bailey and her Arcane School, established in 1923. See Phillip Lindsay, "Alice A. Bailey, H.P. Blavatsky and Helena Roerich. Cleavages Between the Followers of Three Traditions: The Theosophical Society, The Arcane School, The Agni Yoga Society," (2004), www.esotericastrologer.org/EAauthor Essays/AABHPBHR.htm (accessed February 26, 2010).

Dnevnik, t. 1, 24.03.1920-31.05.1921. 
her" ${ }^{76}$ In early 1921, the Master still uttered the opinion that the Bolsheviks would be overthrown within the next two and a half years, that there would be a coalition government in a constitutional monarchy and that the Caucasus, Ukraine, Finland and even Poland would be reunited with within the next seven years. ${ }^{77}$ All these predictions turned out to be more or less wrong, but it didn't seem to shake the Master's authority when he started to encourage the Roerichs after 1922 to embrace Communism and Lenin as the necessary preparation for the impending rising of Shambhala: "Lenin is with Us"78 and the Roerichs should "work for Communism", so that the hidden name of the highest Planet might be revealed. "Communism is necessary for the evolution, therefore glory is to Russia for her first step" ${ }^{79}$ However, before he could fully serve the cause of the Masters, so it was said, Lenin had to undergo in his postmortem existence some sort of transformation in a Kama-Loka sphere: "Lenin will be transformed for cooperation. There is so much blood on him! Like on Saul. On Christ is more blood. Lenin did not look for blood and was delighted about every newcomer. - [Question:] Where is he now? - [Answer:] He is now reposing in a purging sphere. - [Q.:] When will he be transformed? - [A.:] I think, by 1931." ${ }^{\circ 0}$ It was the duty of the Roerichs "to help Russia", because Lenin was misunderstood. ${ }^{81}$ For only to them was given the Silver Key, the secret word "M[aitreya] is Communism [...] Maitreya is Community". ${ }^{82}$ As a consequence, in the 1927 version $^{83}$ of the Agni Yoga volume Obshchina, Lenin was presented as a messenger of the Masters and a servant of the Evolution. ${ }^{84}$

76 Dnevnik, tedrad' A - Knigi i ustavi, 04-05.1921.

77 Dnevnik, tedrad' A - Knigi i ustavi, 04-05.1921.

78 Dnevnik, t. 22: 21.05.1925-12.08.1926, May 29, 1925.

79 Dnevnik, t. 22: 21.05.1925-12.08.1926, June 28, 1925.

80 Dnevnik, t. 22: 21.05.1925-12.08.1926, June 28, 1925.

81 Dnevnik, t. 22: 21.05.1925-12.08.1926, December 12, 1925.

82 Dnevnik, t. 22: 21.05.1925-12.08.1926, January 17, 1926. Fittingly, the Central Committee used during the same period rhetorical elements from the epistles of St. Paul by declaring: "Lenin is alive in the soul of each individual Party member." Also: "Every member of our Party is a particle of Lenin. Our entire Communist community is a collective embodiment of Lenin." Benno Ennker, Die Anfänge des Leninkults in der Sowjetunion (Cologne: Böhlau, 1997), 90.

83 In the 1936 edition published in Riga, which is the one commonly in print today, all references to Lenin are deleted or missing altogether.

84 "I already said that our representatives [of the "Masters"] visited Marx in London and Lenin in Switzerland. Evidently the word Shambhala was uttered." Obshchina, part III, II-26. See the apologetic essays of the Roerich followers Iurii Kliuchnikov, Put' $k$ obshchine: Agni Ioga o Lenine, revoliutsii, sud'bakh Rossii i Mirovoi Obshchine (Novosibirsk, 1991); Valentin Sidorov, Rerikh i Lenin (2nd ed. Voronezh, 1995). 
He had become a Mahatama; a great soul. ${ }^{85}$ The East would venerate Lenin "for the clarity of the construction and the dislike of convention and for the faith in the children as symbols of evolving mankind". ${ }^{86}$

In early 1924, when the Roerichs had settled in Darjeeling, Nikolai Konstantinovich was recognized by some Tibetan lamas from the Moru monastery as the incarnation of the Great Fifth Dalai Lama, and he also learnt about the Panchen Lama's secret flight from Tibet. Then, apparently, another meeting with a flesh and blood version (or at least an "avatar" [vessel-manifestation]) of Master M. aka Allal Ming took place. This initiated the preparation of the first expedition to Inner Asia and Siberia. In late 1924, Roerich was at the Soviet embassy in Berlin where he told the polpred (plenipotentiary) Nikolai Krestinskii about the anti-Soviet activities of the British in the Himalayan borderlands. He left such an impression that Krestinskii reported to People's Commissar of Foreign Affairs Georgii Chicherin (incidentally Roerich's university classmate) in Moscow, Roerich had "absolutely pro-Soviet leanings, which looked somewhat Buddho-Communistic". ${ }^{87}$

In early 1925 Roerich travelled to Paris to meet the Bolshevik "Minister of Finance", the newly appointed political representative Leonid Krasin. ${ }^{88}$ Originally an engineer, ${ }^{89}$ Krasin was in the early days before the War intimately involved with the campaign of bank robberies and other illicit means used to finance the revolutionaries, while at the same time (at least from 1896 to 1902) acting as a Secret Police informant. ${ }^{90} \mathrm{He}$ also had connections through his Masonic affiliation to the Grand Orient de France. ${ }^{91}$ One purpose of Roerich's visit was to obtain from the Soviets the mining and agricultural concessions in the Altai area as a first condition for the founding of the utopian "New Country".$^{92}$ But Krasin was not only a trade spokesman of the Soviets, he also was,

85 Obshchina (Urga, 1927), part II, XII-2.

86 Obshchina, part III, I-12.

87 Krestinskii to Chicherin, March 31, 1925, Arkhiv Vneshnei Politiki Rossiiskoi Federatsii, f. 04, op. 13, 87, d. 50117, 1. 14; Andreev, Soviet Russia and Tibet, 296.

88 He arrived at about the same time as the Tibetan delegation, from which the future Polairesmember Jean-Claude Rivière allegedly received his initiation.

89 Timothy O'Connor, The Engineer of Revolution: L.B. Krasin and the Bolsheviks, 1870-1926 (Boulder, Co.: Westview Press, 1992); Michael Glenny, "Leonid Krasin: The Years before 1917. An Outline," Soviet Studies 22/2 (1970): 192-221

90 Spence, Trust No One, 84 .

91 Osobyi Arkhiv (OA), f. 92, op. 5, d. 15, 1. 38; Oleg Platonov, Istoricheskii slovar' rossiiskikh masonov XXVII-XX vekov (Moscow: Arina, 1996), 65.

92 Andreev, Soviet Russia and Tibet, 296; Rosov, Velikii plan, 138. 
together with Lunacharskii, in charge of the commission that had planned and built the Lenin mausoleum. ${ }^{93}$ It was Krasin who made the proposal to turn the mausoleum into a people's tribune, a place from which Lenin was to speak to future generations through the mouths of his successors. ${ }^{94}$ Already in 1921, Krasin, a great admirer of Nikolai Fedorov's speculations about a future science that can reveal the means to overcome death, was convinced that through the future advances of Science "one will be able with the help of the elements of Life of a human being to reconstruct the physical human being itself". ${ }^{95}$

Under the guidance of the Master, the Roerichs were thus ready to add to the nascent Lenin cult a crucial mystical and chiliastic aspect 'borrowed' from Buddhist spirituality, which should help, like the spiritual recommendations by lamas like Agvan Dorzhiev, to win the Buddhist world for the Soviet cause (or was it the other way around?). Thus, when the expedition reached Urumchi in April 1926, the Soviet Consul General A.E. Bystrov reported from his meeting with Roerich to Moscow that there were "letters from the Mahatmas for Comrades Chicherin and Stalin. The task of the Mahatmas supposedly is to unite Buddhism and Communism and to create a great Eastern Union of Republics." They wanted to join the Tashi (Panchen) Lama, he added, in Mongolia "to set out in a spiritual procession for the liberation of Tibet from the British yoke." When the Roerichs eventually arrived in Moscow on 9 June 1926, they brought a little casket with earth from Buddha's birthplace for Lenin's Tomb as well as several paintings depicting the coming Buddha Maitreya and a Mahatma, whose face resembled Lenin's. On April 21, 1926, Allal Ming had communicated that he shared the Roerichs' joy about Lenin, who represented their bridge and a source of light: "You still could help in building the Lenin memo-

93 Nina Tumarkin, Lenin Lives! The Lenin Cult in Soviet Russia (Cambridge, Ma: Harvard University Press, 2nd ed. 1997).

94 Ennker, Die Anfänge des Leninkults, 234; Michael Hagemeister, Nikolaj Fedorov. Studien zu Leben, Werk und Wirkung (Munich: Otto Sagner, 1989), 285; Olga Velikanova, Making of an Idol: On Uses of Lenin (Göttingen: Muster-Schmidt, 1996). According to Konstantin Mel'nikov, the architect who designed Lenin's sarcophagus, "the general idea" of permanently preserving and displaying Lenin's body originated with L.B. Krasin. (Tumarkin, Lenin Lives, 181.) Krasin wrote in Izvestiia one week after the funerals that the world significance of Lenin's grave would surpass Mecca and Jerusalem. He suggested that as an inscription on the mausoleum there should be simply LENIN. It was Krasin's idea as well to use the mausoleum as a speaker's tribunal. (Tumarkin, Lenin Lives, 191, 193.)

95 Mikhail Ol'minskii: “Kriticheskie stat'i i zametki," Proletarskaia revoliutsiia, no. 1 (1931): 149150; quoted by Hagemeister, Nikolaj Fedorov, 285.

96 Andreev, Soviet Russia and Tibet, 297. 


\section{Markus Osterrieder}

rial. To find the red stone, a square in the foundation and, of course, the signs of the Soviets and the happy Tibetan signs. I recommend the inscription: 'Lenin-great Teacher' in seven languages." 97

On 18 March 1926, Allal Ming had dictated the letters that were presented to the "Moscow Communists" in June. Therein the Masters asserted that "measures should be urgently taken to introduce Communism worldwide as a step towards the necessary evolution." ${ }^{\text {" }}$ Maitreya was nothing else than the symbol of Communism, the negation of God was seen as a natural phenomenon in Buddhism. Eventually "Europe will be shattered by the union of Buddhism and Communism." 99

\section{8}

Yet it seems unlikely that the Roerichs acted consciously as Soviet agents. It was rather the other way around: as "agents" of "Allal Ming" and his "occult politics", ${ }^{100}$ they tried to make use of the Soviet leadership for the higher cause of the "coming of Maitreya". But after the withdrawal of Soviet engagement in Inner Asian affairs around 1930, Allal Ming and the Roerichs seemed less convinced of the efficiency of the Bolsheviks and began to turn towards the United States to gain support for the realization of the "Grand Plan" in the course of a second expedition, officially with the purpose of setting up an agricultural cooperative in Inner Mongolia, a cooperative bank and cultural establishments. ${ }^{101}$ American financial support had been assured through the Roerich Museum in New York and rich patrons like Charles Crane and Louis Horch ever since 1921. ${ }^{102}$ From 1933, they had an enthusiastic supporter in the Secretary for Agriculture, Henry A. Wallace (1888-1965), who was himself deeply immersed in all kinds of spiritual and occult matters: séances, symbols, secret

\footnotetext{
97 Dnevnik, t. 22: 21.05.1925-12.08.1926, April 21, 1926.

98 Rosov, Velikii plan, 180.

99 Dnevnik, t. 22: 21.05.1925-12.08.1926, March 18, 1926; Rosov, Velikii plan, 148. Andreev, Soviet Russia and Tibet, 298.

100 "Allal Ming's" true identity as an individual or a like-minded group cannot be resolved in this paper; and about Barchenko's "Great Brotherhood of Asia", the last word has not yet been spoken.

101 For details see Rosov, Novaia strana.

102 Robert C. Williams, Russian Art and American Money, 1900-1940 (Cambridge, Ma.: Harvard University Press, 1980).
} 
societies, rituals, astrology, Native American and Oriental religions. ${ }^{103}$ Wallace had attended meetings of the Theosophical Society since 1919, joined the Liberal Catholic Church associated with Theosophy, and became a Scottish Rite and a Blue Lodge Mason until he received the $32^{\circ}$ degree in 1928. By 1929, his search had led him to Roerich who became in the early 1930s his revered "Guru" until the abrupt and complete public break during autumn 1935. But up to this moment, Roerich's suggestive power was considerable. When Wallace suggested in 1934 that the symbol of the Great Pyramid from the Great Seal of the United States would be appropriate for the dollar bill, he was probably convinced by the arguments of none other than Nicholas Roerich. ${ }^{104}$

103 Graham White and John Maze, Henry A. Wallace: His Search for a New World Order (Chapel Hill, NC: University of North Carolina Press, 1995); John C. Culver and John Hyde, American Dreamer: The Life and Times of Henry A. Wallace (New York: W.W. Norton, 2000).

104 Williams, Russian Art and American Money, 111. This is also the point of view of the Franklin D. Roosevelt American Heritage Center Museum: "Nicholas Roerich was also influential in FDR's administration, and was the pivotal force behind placing the Great Seal of the United States on the dollar bill." www.fdrheritage.org/fdr_museum_preview.htm (accessed February 26, 2010). Wallace later used to point out the Masonic background of his idea: "In 1934 when I was Sec. of Agriculture I was waiting in the outer office of Secretary [of State Cordell] Hull and as I waited I amused myself by picking up a State Department publication which was on a stand there entitled, 'The History of the Seal of the United States.' Turning to page 53 I noted the colored reproduction of the reverse side of the Seal. The Latin phrase Novus Ordo Seclorum impressed me as meaning the New Deal of the Ages. Therefore I took the publication to President Roosevelt and suggested a coin be put out with the obverse and reverse sides of the Seal. Roosevelt as he looked at the colored reproduction of the Seal was first struck with the representation of the 'All Seeing Eye, a Masonic representation of The Great Architect of the Universe. Next he was impressed with the idea that the foundation for the new order of the ages had been laid in 1776 but that it would be completed only under the eye of the Great Architect. Roosevelt like myself was a 32nd degree Mason. He suggested that the Seal be put on the dollar bill rather than a coin and took the matter up with the Secretary of the Treasury. When the first draft came back from the Treasury the obverse side was on the left of the bill as is heraldic practice. Roosevelt insisted that the order be reversed so that the phrase 'of the United States' would be under the obverse side of the Seal... Roosevelt was a great stickler for details and loved playing with them, no matter whether it involved the architecture of a house, a post office, or a dollar bill." (Wallace to Dal Lee [editor of Astrology Guide and Your Personal Astrology], 6 February 1951, Henry A. Wallace Papers, University of Iowa, Correspondence). "I was struck by the fact that the reverse side of the Great Seal had never been used. I called it to Roosevelt's attention. He brought it up in Cabinet meeting and asked James Farley [Postmaster General and a Roman Catholic] if he thought the Catholics would have any objection to the All Seeing Eye' which he as a Mason looked on as a Masonic symbol of Deity. Farley said 'no, there would be no objection." (Wallace to George M. Humphrey, Secretary of Treasury, December 10, 1955 (Henry A. Wallace Papers, University of Iowa, Correspondence). See as well M.L. Lien, 
With a little help from Wallace, the Roerichs were eventually able to approach the President himself and to win Franklin Delano Roosevelt for their Banner of Peace initiative, which obligated nations to respect museums, cathedrals, universities and libraries, as they did hospitals; to become a part of the United Nations organizational charter. This was consistent with FDR's policy of hemispheric coordination and cooperation in the Americas, as well as with FDR and Secretary of State Cordell Hull's "good neighbour" foreign policy. ${ }^{105}$ The Roerich Peace Pact was signed by Wallace, representing the USA, and by all the members of the Pan-American Union as a treaty in the White House, in the presence of President Franklin Delano Roosevelt, on April 15, 1935. Of course Roerich never mentioned that "the initiated ones" expected the coming of Maitreya Buddha and the dawning of Shambhala for the year 1936 or later, and that this would be-according to the Kālachakra-Tantra tradition as well to the instructions given by Allal Ming-accompanied by great turmoil and war.

FDR was no stranger to mysticism; he always had a strong interest in the occult. Moreover, his receptivity was limitless and his curiosity enormous. ${ }^{106}$ According to the Wallace papers, the real mystic was perhaps the President rather than Wallace. ${ }^{107}$ A mason since 1911, Roosevelt became a member of the high grade Scottish Rite in 1929 (where he received the $32^{\circ}$ degree) and a member of the Imperial Council of the Shrine (Ancient Arabic Order of the

"Two Sides But Only One Die: The Great Seal of the United States," The Retired Officer (June 1982), 33.

105 An autograph letter in FDR's own handwriting, written to Secretary of State Cordell Hull, says: "Dear Cordell:/ As you know I am very [underlined] keen about the Roerich Peace Pact and I hope we can get it going via 'the Americas'-Will you and Henry Wallace talk this over and have something for me when I get back?/ FDR." Facsimile on the website of the Franklin D. Roosevelt American Heritage Center Museum, www.fdrheritage.org/fdr_museum_preview.htm (accessed February 26, 2010). The Roerich Pact and Banner of Peace movement grew rapidly during the early 1930s, with centers in a number of countries. There were three international conferences, in Bruges, Belgium, in Montevideo, Uruguay, and in Washington, D.C. Needless to say, this recalls very much of the present 14th Dalai Lama's "Kālacakra Tantra for World Peace" initiative. The public celebrations of the Kălacakra Tantra initiation rituals in the West by the Dalai Lama are said to contribute spiritually to the approaching "world peace" through the advent of Shambhala. See the extremely critical analysis of Tibetan spiritual politics in Victor Trimondi and Victoria Trimondi, Der Schatten des Dalai Lama: Sexualität, Magie und Politik im tibetischen Buddhismus (Düsseldorf: Patmos, 1999).

106 Frank Freidel, Franklin D. Roosevelt: Launching the New Deal (Boston: Little, Brown 1973), 75.

107 Torbjörn Sirevåg, The Eclipse of the New Deal and the Fall of Vice-President Wallace, 1944 (New York: Garland Publishing, 1985), 522-524. 
Nobles of the Mystic Shrine for North America). Eventually FDR was appointed as Honorary Grand Master of the New York Order of DeMolay on April 13, 1934 at the White House. ${ }^{108}$ FDR was equally deeply fascinated by the geography and history, the cultures and religions, of Inner Asia, from Tibet to the Siberian border- "the chess board of international politics". ${ }^{109}$ Because his maternal grandfather was linked with China, ${ }^{110}$ he always attributed a far greater importance to China than did many other U.S. politicians. In 1942, inspired by James Hilton's 1933 novel Lost Horizon about a utopian lamasery high in the Himalayas in Tibet whose inhabitants also enjoy longevity, Roosevelt named his new retreat in the Catoctin Mountain Park, Camp Hi-Catoctin (today's Camp David), Shangri-La.

This attitude is reflected in the series of eight letters addressed to the president by Elena Roerich and written between late 1934 and early 1936. While none of this correspondence, which is preserved in the Franklin D. Roosevelt Presidential Library in Hyde Park N.Y., stems from the pen of Roosevelt, the letters evolve into an indirect dialogue and suggest that FDR must have positively responded (E. Roerich refers several times to his "transmitted messages"). The diaries during this period reveal how Elena Ivanovna was constantly admonished by the Master to focus her thoughts on FDR. Although he was leaning towards her, ${ }^{111}$ the Master said, "Roosevelt has not yet understood the essence of the deal, but we shall still give him some time". ${ }^{112}$ But according to Henry Wallace, the strongest bond between FDR and Roerich was the President's mother Sara Delano Roosevelt. ${ }^{113}$ This is confirmed by the diaries, where the Master repeatedly suggests approaching the President's mother in order to gain an influence over FDR. ${ }^{114}$

108 Folder Roosevelt Family Masonic Papers, 1935. Franklin D. Roosevelt Presidential Library, Hyde Park, NY.

109 Robert Dallek, Franklin D. Roosevelt and American Foreign Policy, 1932-1945 (Oxford: Oxford University Press 1979), 117.

110 During a period of twelve years in China, Warren Delano II made a fortune first in the tea trade and, after 1860, in the highly profitable opium trade. It was rare for anyone even to mention China to FDR in a gathering without his launching into a long discourse about his ancestors' involvement in the China trade. James MacGregor Burns and Susan Dunn, The Three Roosevelts: Patrician Leaders Who Transformed America (New York: Grove Press 2002), 355.

111 Dnevnik, t. 40: 15.08.1934-03.02.1935, December 27, 1934.

112 Dnevnik, t. 39: 01.05.1934-14.08.1934, May 26, 1934.

113 Culver and Hyde, American Dreamer, 136.

114 Dnevnik, t. 38: 30.10.1933-30.04.1934, January 28, 1934. 


\section{Markus Osterrieder}

After the exchange of letters had begun, the "Master" instructed Elena Ivanovna to "speak about the meaning of the potential of Asia" and that "the New Russia could be the best friend of America". In the meantime, Roerich should keep during his expedition "the famous secrecy" in Japan and Mongolia, because "they love secrecy" there. ${ }^{115}$ In her letters, Elena Roerich addressed FDR as "not only the Ruler but the true great Leader" who had the singular choice to accept "the Highest Help and the Fiery Messages" "at the threshold of reconstruction" of the entire world, when "the fate of many countries is being weighed on the Cosmic Scales". ${ }^{116}$ Since the President had "so beautifully accepted the Message [...] free from prejudice", Elena Ivanovna started "to unfold before You gradually the entire Plan of the New Construction, in which You and Your Country are destined to play such a great part". ${ }^{117}$ FDR was warned of the preparations for war "from the land in the East" (by which she meant, according to the diaries, Japan ${ }^{118}$ ) and "from the land beyond the ocean, on the pretext of protection of China"119 (England). FDR was addressed as an integral part of "the Construction of Light" where "nobody can replace him". ${ }^{120}$ The "Master" transmitted to the President that "a Great State will be created in the East. This beginning will bring that equilibrium, which is so urgently needed for the construction of the great Future. America was since long linked with Asia. [...] Thus one must accept that the peoples occupying the larger part of Asia are destined to respond to the friendship of America. [...] The alliance of the nations of Asia is decided, the union of tribes and peoples will take place gradually, and there will be a kind of Federation of countries. Mongolia, China and the Kalmuks will constitute a counterbalance to Japan and in this alliance of peoples, Your Good Will is needed, Mr. President.” FDR was advised to keep the US well-armed against all future provocations, while the Master communicated to Elena that Japan was set to unleash a war against America out of her lust for conquest. ${ }^{121}$

115 Dnevnik, t. 38: 30.10.1933-30.04.1934, January 28, 1934.

116 Elena Roerich to FDR, October 10, 1934, Roosevelt Papers Official File (OF) 723, folder “Roerich Peace Pact, 1933-1945," Franklin D. Roosevelt Presidential Library, Hyde Park, NY.

117 Elena Roerich to FDR, November 15, 1934, Roosevelt Papers OF 723.

118 Dnevnik, t. 40: 15.08.1934-03.02.1935, November 10, 1934: “One attempt will be effected through a provocation by Japan; the other attempt through an instigation of England on the pretext of protection of China."

119 Elena Roerich to FDR, November 15, 1934, Roosevelt Papers OF 723.

120 Elena Roerich to FDR, December 27, 1934, Roosevelt Papers OF 723.

121 Dnevnik, t. 40: 15.08.1934-03.02.1935, November 10, 1934. 
Ironically, it was because of the growing suspicion of Roerich's apparent pro-Japanese activities and contacts to the Japanese War Ministry and Foreign Office that FDR and Wallace both cut off all personal relations after 1935. However, this doesn't mean that Roosevelt despised Roerich altogether after that date. When Elizabeth Avinoff-Shoumatoff ${ }^{122}$ (1888-1980), painter of Russian origin, started her watercolor sketches for her famous unfinished portrait of Roosevelt in July 1943, executed in FDR's final hours, she and her brother Andrei were invited to lunch at FDR's estate in Hyde Park. According to her description, the two men soon discovered a common interest in the occult. And Andrei was struck by the bust of Nicholas Roerich, which he saw prominently perched on Roosevelt's shelf. ${ }^{123}$

Indeed, Roerich seemed to keep all options open. When Nikolai Konstantinovich came from Tokyo to Manchuria in June 1934, it seemed as if Roerich was professing his approval of the Japanese military advances on the Asian mainland, and he had constantly expressed his admiration for Japanese art and culture. ${ }^{124}$ Moreover, Heinrich Müller, in charge of Gestapo section (Amt) IV in the Nazi Reichssicherheitshauptamt (RSHA), seems to have claimed during alleged interrogations in 1948 (which however may very well never have taken place and were forged at a later date) that Roerich was known to the Gestapo under the code word "Lama" and that he had contacted the Nazi regime in 1934 to ascertain whether they were interested in supporting his undertakings in Inner Asia. ${ }^{125}$ Allal Ming insisted throughout the 1930s that the main objec-

122 Elizabeth emigrated to the United States in 1917 with her husband Lev A. Shoumatoff [Shumatov, before 1916 Schumacher], then a representative of Aleksandr Kerenskii's provisional government, who later played host to Gurdjieff in the US. Her extraordinary talent for portraiture brought commissions from some of the most illustrious families in America, Great Britain and Europe. President Roosevelt was sitting for her in Warm Springs when he suffered a fatal cerebral hemorrhage on April 12, 1945.

123 See www.fdrheritage.org/fdr_museum_preview.htm (accessed February 26, 2010).

124 White and Maze, Henry A. Wallace, 88-89.

125 Gregory Douglas: Geheimakte Gestapo-Müller: Dokumente und Zeugnisse aus den USGeheimarchiven. Berg am Starnberger See 1995, 50-51 (translation of: Gestapo Chief: The 1948 Interrogation of Heinrich Müller. From Secret U.S. Intelligence Files. Los Angeles, Cal. 1995). Concerning the Nazi Tibet expedition in the 1930s see: Christopher Hale: Himmler's Crusade: The True Story of the 1938 Nazi Expedition into Tibet (London: Bantam 2004); Thomas Hauschild, Lebenslust und Fremdenfurcht: Ethnologie im Dritten Reich (Frankfurt/M.: Suhrkamp, 1995), 168-199; Trimondi and Trimondi, Der Schatten des Dalai Lama, 115-174. As a well-documented fact, Tibetan leaders like regent Reting Rinpoche (who discovered the incarnation of the present 14th Dalai Lama) and the 9th Panchen Lama addressed in the 1930s "under the sign of the Swastika" very sympathetic greeting messages to the "King of Germany 
tive remained the establishment of the Kingdom of Shambhala under Russian leadership, the creation of the New Country: "The Kingdom of Shambhala is the hegemony of Russia. This formula is the corner stone. [...] There was never so much talk about Russia - in such a unique way the Path of Shambhala is in creation. One should not speak about it, as Satan doesn't sleep, but you can perceive how the Path of Russian [Rossiiskoi] Asia consolidates. Already now every map is witness to the might of Russia. But add in your thoughts Turkey and Persia, and you will get the new borders of Shambhala." 26

By 1938, Dorzhiev and Barchenko, like many other "political occultists" of their generation, had tragically perished during the Stalinist purges. Roerich's second expedition to Inner Mongolia, Manchuria and China, financed by the U.S. Department of Agriculture with the purported aim to study plants, ethnology and to collect rare seeds, had failed. But still, in 1991, N.K. Roerich's son Sviatoslav Nikolaevich told Vladimir Rosov that the "Altai is a very important centre, a centre of a big future" and that Zvenigorod remained "a great reality and a great dream". ${ }^{127}$

\section{9}

Since the 1970s, the work of the Roerichs found a steadily increasing recognition in the Soviet Union, culminating in the meeting between Sviatoslav Roerich and the couple Mikhail and Raisa Gorbachev in the Kremlin on May 14, 1997. ${ }^{128}$ This paved the way for the establishment of the MTsR on the exquisite premises of the Lopukhin estate in downtown Moscow. The rich repertoire of facts, lies and rumors about occult politics and secret brotherhoods was rediscovered in the early 1990s among the ever-growing followers of the neoEurasians movement. Pre-eminent in this movement is the above-mentioned Aleksandr Dugin with his rather close links to both the European rightwingers and "esoteric traditionalists" (adepts of Saint-Yves, Papus, Evola, Guénon et al.), who began to spread the rumour about the alleged existence of a

Mr. Hitler." The "supreme chief of the Buddhists in China," reform monk T'ai-Hsu (1890-1947) proposed in a 1937 letter to Hitler that Buddhism was the ideal religion for the German people united under the "Führer." See Trimondi and Trimondi, Der Schatten des Dalai Lama, 318-321.

126 Dnevnik, t. 42: 19.10.1935-11.06.1936, April 4, 1936.

127 Rosov, Novaia strana, 280.

128 Both, but especially Raisa, favoured the resumption of activities of the Roerich foundation on the territory of the Soviet Union. Gorbachev commented on the May meeting: "This meeting is our oldest wish. When you consider the roots of Soviet-Indian relations, the first germs of friendship between the two countries are linked to the Roerich family." Pravda, May 15, 1987. 
secret brotherhood Agartha in the ranks of the GRU. Franco-Romanian writer Jean Parvulesco (Pârvulescu) even added that Vladimir Putin had to be seen as an envoy of this order. ${ }^{129}$

In the meantime, the Roerich Society could count on some political support and influence, for example by former prime minister Evgenii Primakov, a trained orientalist and from 1977 to 1985 Director of the Institute of Oriental Studies of the Academy of Sciences, who attended the Roerich Jubilee Conference on October 9, 1999 in Moscow. ${ }^{130}$ The disaster of the flawed and shady economic policy conceived by the so-called 'Harvard Boys' and the Chubais clan during the early 1990s under the presidency of Boris Yeltsin ${ }^{131}$ helped to create a social climate in which further "Westernization" found an increasingly strong opposition and provoked calls for a "patriotic period of reform" as the only safeguard against the forces of fundamentalism. ${ }^{132}$ Aleksandr Dugin promoted "Eurasianism" as a universal opposition to Western-inspired globalisation, avant-garde of the anti-globalist movement and the foundations of a future pan-Asian alliance. ${ }^{133}$

With regard to foreign policy, the signing of the Treaty on Deepening Military Trust in Border Regions in Shanghai on April 26, 1996 by the heads of states of Russia, Kazakhstan, the People's Republic of China, Kyrgyzstan and Tajikistan was a big step in this direction. The Treaty has led to the creation of the Shanghai Five grouping. In 2001, the five member nations first admitted Uzbekistan (thereby transforming it into the Shanghai Six). All six heads of state signed on June 15, 2001 the Declaration of Shanghai Cooperation Organization, aiming to realize a higher level of cooperation. In July 2001, Russia and

129 Jean Parvulesco, "Vladimir Poutine et l'empire eurasiatique de la fin," Synergies Européennes, Secrétariat Européen, Bruxelles, Juni 29, 2000, evrazia.info/modules.php?name=News\&file= article\&sid=271 (accessed February 26, 2010). See as well Jean Parvulesco, Putin i Evraziiskaia imperiia St. Petersburg: Amfora, 2006.

130 "Primakov at the Jubilee Roerich Conference," Moscow, October 9, 1999, web.archive.org/web/ 20080621110539/http://sangha.net/Photos/Conf-091099.html (accessed February 26, 2010).

131 Janine R. Wedel, "U.S. Aid To Russia: Where It All Went Wrong. Testimony before the Committee on International Relations, U.S. House of Representatives," September 17, 1998, http:// web.archive.org/web/20051125131205/http://www.ukar.org/wedel01.html (accessed February 26, 2010); eadem, "The Harvard Boys Do Russia," The Nation, June 1, 1998; eadem, Collision and Collusion: The Strange Case of Western Aid to Eastern Europe (New York: Palgrave Macmillan, 2001); Marshall I. Goldman, The Piratization of Russia: Russian Reform Goes Awry. (London: Routledge 2003).

132 This was announced by Mikhail Leont'ev in Segodnia, November 24, 1994.

133 Aleksandr Dugin, Osnovy geopolitiki. Geopoliticheskoe budushchee Rossii (Moscow: ArktogeiaTsentr, 1999), 190, 214-249. 


\section{Markus Osterrieder}

the PRC, the organization's two leading nations, signed the Treaty of GoodNeighborliness and Friendly Cooperation. Among other nations of the region, Mongolia became the first country to receive observer status at the 2004 Tashkent Summit, followed by Pakistan, India and Iran at the 2005 SCO summit in Astana, Kazakhstan. Mongolia, Pakistan, and Iran have since applied for full membership to the organization. The SCO has also encouraged India to join the organization, saying that they would properly consider a membership application should it decide to join the group. As of June 2011, following the 10th summit meeting of the SCO in Astana, India has indeed announced that she would make strong efforts in obtaining a full membership status, sharing regional security concerns with the SCO and also work closely with the SCO in Afghanistan. ${ }^{134}$ All this fits in the geopolitical Grand East (Bol'shoi Vostok) strategy that was pushed during the second presidency of Vladimir Putin (2004-2008), as a full-blown "return of Russia to the East" (vozvrashchenie Rossii na Vostok). Such an outspoken 'orientation' of foreign policy would certainly have pleased a prince Ukhtomskii. ${ }^{135}$

In this context, it doesn't seem altogether accidental when the full extent of the dealings of the Roerichs emerges today in Russian bookshops and newspapers, like some glaring spotlight pointing once again the path to Rossiiskaia Aziia or a Shambhala version of Evraziia. Indeed, the Kremlin has learnt how to make use for diplomatic purposes of the considerable prestige the names of the Roerichs enjoy in various parts of Asia. When the newly elected President of the Russian Federation granted a 50-minutes interview to the editors of India Today and The Russia Journal in October 2000, he referred to Nicholas Roerich as the prime example of "the spiritual closeness that binds all people" -foremost Russia and India. ${ }^{136}$ And while on December 4, 2002 in New Delhi,

134 "SCO on an Upswing: India Calling”, Russia \& India Report, June 14, 2011, http://indrus. in/articles/2011/06/14/sco_on_an_upswing_india_calling_12639.html (accessed July 15, 2011).

135 S.G. Luzianin: Vostochnaia politika Vladimira Putina: Vozvrashchenie Rossii na Bolshoi Vostok (2004-2008 gody) (Moscow: AST, Vostok-Zapad, 2007), 430-436.

136 AG: "I've been associated with Russia a long time. Almost everyone I meet here has some kind of a personal memory of India - movies, songs, actors... What are your associations with India?" - Putin: "First, I'd remember an artist well known in both Russia and India - Nikolai Roerich. Roerich's life was an amazing life, a marvel of creativity and astonishing example of spiritual closeness that, perhaps doesn't lie on the surface, but is nevertheless the spiritual closeness that binds all peoples." "No prospect for return to totalitarian system", The Russia Journal, no. 81, September 30, 2000, beta.russiajournal.com/node/3954 (accessed February 26, 2010); "Interv'iu indiiskim sredstvam massovoi informatsii i rossiiskomu telekanalu RTR”, October 1, 
Putin was discussing future collaboration between the intelligence agencies and Special Forces of the two countries, his wife Liudmila was opening an exhibition called "The Himalaya Saga" with paintings of Nikolai Konstantinovich. ${ }^{137}$

As a countermove, the Indian prime minister Atal Bihari Vajpayee offered in May $2001 \$ 200,000$ to the International Roerich Memorial Trust (IRMT) for the preservation of Roerich's home near Nagar in the Kullu Valley (Kashmir) by announcing he would act as "Chief Patron of the trust" in honour of the "great saint". ${ }^{138}$ In early November 2001, Vajpayee was on a diplomatic visit in St. Petersburg and gave a speech, in which he stressed the importance of the city for the mutual relations between the two countries. He underlined the continuity that could be traced from the pioneering discoveries of Afanasii Nikitin (who was the first Russian to "discover" India in the 15th century) to the plans of Peter the Great for securing a maritime access on the shores of the Indian Ocean, and finally to the birth of Nicholas Roerich in St. Petersburg. Vajpayee added that Nikitin's travels opened the path perceived nowadays by Russia, India and Iran "as a strategic axis for Eurasia": "Our three countries signed an agreement in September to develop this corridor." ${ }^{139}$

Finally, on the webpage of the embassy of the Russian federation in New Delhi, one could access an interview given in 2002 by ambassador Aleksandr Kadakin, a well-known orientalist and indologist, who was friendly with the family of Sviatoslav Nikolaevich Roerich and the former Indian prime minister Rajiv Gandhi. When he was asked by the journalist about the future of India and whether the recent events in Afghanistan could be interpreted in terms of Huntington's Clash of Civilizations, Kadakin, who by the way serves also as Deputy Director of the International Roerich Memorial Trust (IRMT) and

2000, archive.kremlin.ru/appears/2000/10/01/0000_type63379_128104.shtml (accessed February 26,2010$)$.

137 Strana.ru, 4 December 2002, travel.ru/news/2002/12/05/20933.html (accessed February 26, 2010).

138 The prime minister added: "Coming here again today has filled me with a special sense of satisfaction and elation. For this is not an ordinary museum, it is the karma bhoomi of one of the world's greatest artist-intellectuals of the 20th century." "Prime Minister Atal Bihari Vajpayee donates Rupees Ten million to International Roerich Memorial Trust," Press Release, Moscow May 29, 2001 www.roerichtrust.org/home.htm??IRMT.htm?IRMT_files/visits/270501 /vis270501.htm\& (accessed February 26, 2010). Cf. New Trends in Indo-Russian Relations, ed. V.D. Chopra (New Delhi: Kaipaz Publications on Behalf of International Institute for AsiaPacific Studies, 2003), 154, 274-275, 280-281.

139 Tarun Basu, “The Importance of St Petersburg in the Vajpayee Itinerary," Indo-Asian News Service, November 5, 2001, www.rediff.com/news/2001/nov/05russia.htm (accessed February $26,2010)$. 
curator of the Roerich manor in Nagar (India) ${ }^{140}$ answered enigmatically, as if he were quoting Allal Ming: "BM: China is predicted to have [sic!] a future of a superpower. Does the future also belong to India? What is your attitude towards the latest developments in Afghanistan, India's neighbour? What is it - a clash of religions or civilisations? - Kadakin: No doubt the three Asian giants Russia, China, India - have a great future. People justly say: 'Light will dawn in the East."."141

140 Natalya Benukh, "Life dedicated to India," The Voice of Russia, February 10, 2010, english. ruvr.ru/2010/02/10/4339938.html (accessed February 26, 2010).

141 The Embassy of the Russian Federation in the Republic of India: "Light will Dawn in the East: Interview with Alexander M. Kadakin," Ambassador's Interviews, Speeches and Articles, March 15, 2002, web.archive.org/web/20031205144854/http://www.india.mid.ru/india/sp_05.html (accessed February 26, 2010). Replying to the question of a journalist of Times of India, "What are your views on the growing axis between China, Russia, India and Iran?", Kadakin said on Juni 13, 2002: "This is only a reflection of the convergence of our stands. All four countries share the same attitude to terrorism. They share the same vision of a new world order. Of course there are problems between India and China but we felt, why not focus on areas where there is no conflict?" Rashme Sehgal, "Core of Terror," The Times of India, June 13, 2002. The original webpage has been removed since, but is still available at web.archive.org/web /20040419083618/http://www.meadev.nic.in/govt/kadakin-toi-13june2002.htm (accessed February 26, 2010). Kadakin, who is fluent in Hindi and Urdu, parted for Sweden in 2004, but returned to his post as Ambassador Extraordinary and Plenipotentiary of the Russian Federation in India, his proclaimed Karma Bhumi ("Land of Destiny"), in late 2009. Cf. Vladislav Kuzmichev, "Ambassador Alexander Kadakin: Karma Bhoomi: It’s like coming back home," Russia Beyond the Headlines, January, 11, 2010, www.rbth.ru/articles/2010/01/11/110110_kharma .html (accessed February 26, 2010). Kadakin: "I kept coming to India, each time for a higher post in the Embassy, interacting with more and more Indian friends and familiarising myself with ever new facets. [...] I could not help processing through my soul everything I was associated with - from the Himalayan saga of the Roerichs to the Nehru-Gandhi family's tragedies and triumphs of Aeschylean or Shakespearean magnitude." Aleksandr Kadakin, "My Passage to Many Indias: The Coexistence of Multiple Realities", Russia Beyond the Headlines, December, 25 2009, www.rbth.ru/articles/2009/12/25/251209_passage.html (accessed February 26, 2010). 


\title{
KONSTANTIN TSIOLKOVSKII AND THE OCCULT ROOTS OF SOVIET SPACE TRAVEL
}

\author{
MICHAEL HAGEMEISTER
}

The word "occult" has two meanings: firstly, it means "hidden" or "concealed", but it can also mean "esoteric" and "supernatural", relating to the transcendental, magic preternatural world. Both meanings apply to "the occult roots of Soviet space travel": the previously hidden, repressed, and therefore unconscious roots of the Soviet space program and its connection with the world of the supernatural.

Konstantin Eduardovich Tsiolkovskii (1857-1935), a nearly deaf schoolteacher of physics and mathematics in the then obscure provincial town of Kaluga, is considered to be the "father" or even "grandfather" of Soviet space travel. His patriarchal status rests on a series of path-breaking ideas-all being developed and published before the Bolshevik revolution-such as the expansion into outer space by means of liquid-propellant rockets, plans for manned space stations as well as the description of survival conditions in spacecraft. ${ }^{1}$

Already during his lifetime, the shy "eccentric from Kaluga" (kaluzhskii chudak), as he was called, was made into a hero by Soviet propaganda. In November 1921, while the luminaries of "bourgeois science" were starving or driven out of the country, the Council of People's Commissars granted the provincial autodidact (samouchka) a lifelong honorary pension. In reality though, as Asif Siddiqi has pointed out, ${ }^{2}$ the material and institutional support

1 See James T. Andrews, Red Cosmos: K. E. Tsiolkovskii, Grandfather of Soviet Rocketry (College Station: Texas A\&M University Press, 2009). This is the only monograph on Tsiolkovskii's life and work written by a non-Russian author. Unfortunately the description remains rather superficial and conventional, awkward and disputed themes are neglected. Russian biographies, intended for a broad audience, always create a highly idealized picture; see most recently Valerii Demin, Tsiolkovskii (Moscow: Molodaia gvardiia, 2005), published in the popular series "Zhizn' zamechatel'nykh liudei". The author (1942-2006) was a "cosmist philosopher" who wrote science fiction stories and supported the pseudoscientific "Hyperborean" or "Aryan" idea. Any attempt at a critical study on Tsiolkovskii hits a wall of resistance in his home country; this applies especially to the books by Gelii Salakhutdinov, Blesk i nishcheta Tsiolkovskogo (Moscow: AMI, 2000) and Mify o tvorchestve K. E. Tsiolkovskogo (Moscow: AMI, 2003).

2 See Asif A. Siddiqi, The Red Rockets' Glare: Spaceflight and the Soviet Imagination, 1857-1957 (Cambridge: Cambridge University Press, 2010), 51-55. Siddiqis monograph, based on extensive archival research, contains the only critical portrayal of Tsiolkovskii in the context of 


\section{Michael Hagemeister}

from the state was insignificant. During the 1920s and early 30s Tsiolkovskii still lived in poverty and obscurity. As an amateur he was ignored by the academic scientific community and denied access to research facilities and to current literature. He financed his research and publications out of his own pocket and aimed to publicize them with his broad self-created network of space enthusiasts and science writers. It was only in his last years that he received the official recognition for which he yearned. On his $75^{\text {th }}$ birthday he was awarded the distinction of the Order of the Red Banner of Labour. He was deeply moved and wrote to Stalin just before his death, bequeathing all his "work on aviation, rocket travel, and interplanetary communications" to the party of Bolsheviks and to the Soviet authorities. ${ }^{3}$ But it was the era of space travel that truly made this self-taught theorist and visionary a cult figure. Tsiolkovskii was feted as "one of the greatest Russian scientists", "a brilliant son of the people" and "a prophet of a new era". A huge monument was built in Moscow in front of the Hotel Kosmos in his honour; his modest wooden house in Kaluga was turned into a museum; his portrait appeared on stamps, medals and postcards; streets and schools and a large crater on the far side of the moon were named after him; and the story of his life became the basis for a film, with the poet Evgenii Evtushenko playing the lead role. ${ }^{4}$

Although Tsiolkovskii's technical and scientific texts and his literary works were widely distributed and are well-known, at least among the specialists, it is less well known that the "father of Soviet space travel" had developed a unique "cosmic philosophy" (kosmicheskaia filosofiia), and that the cosmonautical calculations and sketches that made him famous emanated from this philosophy. ${ }^{5}$

Russian-Soviet culture in any western language. See also idem, "Imagining the Cosmos: Utopians, Mystics, and the Popular Culture of Spaceflight in Revolutionary Russia," In: Michael D. Gordin, et al., eds., Intelligentsia Science: The Russian Century, 1860-1960 (Chicago, Ill.: University of Chicago Press, 2008), 260-288.

3 Siddiqi, Red Rockets' Glare, 69-70. For more details idem, “Nauka za stenami akademii: K. Ė. Tsiolkovskii i ego al'ternativnaia set' neformal'noi nauchnoi kommunikatsii," Voprosy istorii estestvoznaniia i tekhniki, 2005, no. 4, 137-154. Tsiolkovskii's much quoted letter to Stalin probably came about without his involvement. He only added his signature to it.

4 On the canonization of Tsiolkovskii and the resurrection of his legacy, see Andrews, Red Cosmos.

5 In Andrews' recent monograph (Andrews, Red Cosmos) Tsiolkovskii's cosmic philosophy is not even mentioned. 
Tsiolkovskii's philosophical writings, according to Siddiqi, "form a corpus of work that easily exceeds in size his combined works on aeronautics, rocketry, and space travel". ${ }^{6}$ Between 1914 and 1931, Tsiolkovskii himself published some of these writings in Kaluga in the form of small booklets. Having only small print-runs, they soon became bibliographic rarities, although they were never forbidden. Only upon the emergence of the so-called "Russian cosmism" (russkii kosmizm) in the 1970s, did Tsiolkovskii's "cosmic philosophy" attract greater attention. The most important forum for their presentations and discussions were the Tsiolkovskii Lectures (Tsiolkovskie Chteniia), which took place annually in Kaluga from1966 on. In addition to providing a setting for hero-worship they also served as a meeting point and platform for nonconforming thinkers and mystics. ${ }^{7}$ One of the first who pointed to Tsiolkovskii's 'cosmic philosophy' in a broad public way was the always trendconscious Evgenii Evtushenko in his novel Wild Berries (Iagodnye mesta, 1981). Since the mid-1980s Tsiolkovskii's philosophical and social-utopian writings have been published together with previously unknown works from the archive. ${ }^{8}$ Only recently collections of Tsiolkovskii's 'theological' writings have been released, including the extensive comments on the four Gospels from the positions of his "scientific faith" (nauchnaia vera) and a demythologizing description of the life of Jesus. ${ }^{9}$ A real breakthrough occurred in 2008 when the Russian Academy of Sciences made Tsiolkovskii's entire personal archive available online. ${ }^{10}$

Tsiolkovskii regarded his philosophy as the work of a genius and redeemer and did not shy away from comparisons with Jesus Christ (or as he always

6 Siddiqi, Red Rockets' Glare, 81.

7 One of the sections of the Lectures was dedicated to „philosophical problems of the conquest of space"; in this section alone hitherto more than 500 papers have been presented. Large parts have been published in collected volumes. However, these had such an extremely small amount of copies that only very few made their way into Western libraries.

8 The most important editions are: Konstantin Tsiolkovskii, Kosmicheskaia filosofiia, eds., Tatiana Zhelnina, Valentina Mapel'man (Moscow: Éditorial URSS, 2001); idem, Genii sredi liudei, eds., Leonid Golovanov, Elena Timoshenkova (Moscow: Mysl', 2002). A selection of his philosophical writings appeared in German translation in Boris Groys, Michael Hagemeister, eds., Die Neue Menschheit. Biopolitische Utopien in Russland zu Beginn des 20. Jahrhunderts (Frankfurt a. M.: Suhrkamp, 2005), 236-390.

9 Konstantin Tsiolkovskii, Evangelie ot Kupaly (Moscow: Samoobrazovanie, 2003); idem, "Shchit nauchnoi very". Sbornik statei (Moscow: Samoobrazovanie, 2007). Tsiolkovskii's demythologizing of the New Testament message is far from being inventive as it draws heavily from David Friedrich Strauss and Ernest Renan.

10 http://www.ras.ru/ktsiolkovskyarchive/about.aspx. 
collegially called him the "Teacher from Galilee"). Just like Thomas Carlyle, Friedrich Nietzsche or Edouard Schuré, Tsiolkovskii was enthralled by the great charismatic leaders of mankind-Buddha, Plato, Jesus, Newton-and obviously he had no doubt about himself being one of these intellectual giants, who had shown mankind paths towards a radiant future. It is clear that space exploration for Tsiolkovskii was ultimately only a means-a technical instrument for the self-perfection of humanity and to the achievement of "eternal bliss" (vechnoe blazhenstvo). ${ }^{11}$

Initially, for Tsiolkovskii the emancipation from the Earth and expansion into outer space was a matter of securing the continued existence of humanity. Since in his view, life on Earth was endangered by overpopulation and by geological and cosmic catastrophes (explosion of the inner core of the Earth, impact of an asteroid, extinction of the sun), humans must leave Earth and emigrate to outer space in order to save their species. The "reactive vehicle" will ensure the "salvation of the human species". ${ }^{12}$ By conquering the interplanetary and intergalactic spheres, man could, according to Tsiolkovskii, overcome damaging cosmic conditions, discover new habitats and sources of energy and become indestructible. However, emancipation from the Earth was intended not merely to expand human powers and ensure the survival of the human

11 For a competent and critical view of Tsiolkovskii's philosophy, Nikolai Gavriushin, "Kosmicheskii put' k ,vechnomu blazhenstvu'. (K. Ė. Tsiolkovskii i mifologiia tekhnokratii),"Voprosy filosofii, 1992, no. 6, 125-131 (also in English Nikolai Gavriushin, "The Cosmic Route to 'Eternal Bliss'. K. E. Tsiolkovskii and the Mythology of Technocracy," Russian Studies in Philosophy, 1995, no. 34, 36-47); idem, "Prozreniia i illiuzii russkogo kosmizma," In: Filosofiia russkogo kosmizma, eds., Aleksandr Ogurtsov, Liudmila Fesenkova (Moscow: Fond "Novoe tysiacheletie", 1996), 96-107; Salakhutdinov, Blesk i nishcheta, 193-205; a thorough overview, albeit apologetic, Vladimir Kaziutinskii, "Kosmicheskaia filosofiia K. E். Tsiolkovskogo," In: Filosofiia russkogo kosmizma, 108-132; Demin, Tsiolkovskii, 166-282; Vera Alekseeva, "Religioznye sochineniia Tsiolkovskogo," In: Tsiolkovskii, Evangelie ot Kupaly, 223-248; eadem, K. E. Tsiolkovskii: filosofiia kosmizma (Moscow: Samoobrazovanie, 2007). See also Michael Hagemeister, "The Conquest of Space and the Bliss of the Atoms - Konstantin Tsiolkovskii," In: Eva Maurer, Julia Richers, Monica Ruethers, Carmen Scheide, eds., Soviet Space Culture Cosmic Enthusiasm in Socialist Societies (Houndmills, Basingstoke: Palgrave Macmillan, 2011), $27-41$.

12 Konstantin Tsiolkovskii, Issledovanie mirovykh prostranstv reaktivnymi priborami (Moscow: Mashinostroenie, 1967), 98-100. 
species but also to rebuild the human body in order to accommodate it to the conditions of life in the cosmos.

The controlled selection of the fittest, ${ }^{13}$ their artificial reproduction, and the liquidation of all inferior beings would, in Tsiolkovskii's view, give rise to a species of super-humans, who were infinitely superior to today's humans in all respects: physically, morally, and aesthetically. Tsiolkovskii condemned sexual reproduction as "humiliating", as it is based on "low animal passions", which only lead to decay. ${ }^{14}$ According to him, it should be replaced by artificial fertilization or parthenogenesis. The biblical "legend" of the birth of Jesus from the Virgin Mary he interpreted as an "ideal of the future woman, who will provide children, but will not be subject to animal passions". ${ }^{15}$

As the cosmic evolution developed, the perfected human race, which would inhabit the entire universe, would lose its corporeality and turn into a kind of energy or radiation (luchistoe chelovechestvo), and thus become "immortal in time and infinite in space". ${ }^{16}$ As early as 1911, Tsiolkovskii wrote: "There is no end, neither for life nor for the intelligence and the refinement of man. It will eternally advance. And if that is the case, there also can be no doubt about its achieving immortality." 17

However, Tsiolkovskii's belief in progress had terrible consequences: Since every atom carries in itself the quest for perfection and happiness, the "ethics of the cosmos" demands that there should not be one single trace of disease,

13 The procedure is described in detail in Gore i genii (Kaluga: izd. avtora, 1916); "Ideal'nyi stroi zhizni," [1917] Samoobrazovanie, 1998, no. 2, 4-22.

14 Konstantin Tsiolkovskii, Prichina kosmosa. Konspekt. Avgust 1925g. (Kaluga: izd. avtora, 1925), 14-15; idem, Monizm Vselennoi (Kaluga: izd. avtora, 1931), 21.

15 Tsiolkovskii, Evangelie ot Kupaly, 23. Auguste Comte had already praised parthenogenetic reproduction and the "vierge-mère" as "female utopias".

16 Aleksandr Chizhevskii, „Teoriia kosmicheskikh èr”, In: idem, Aeriony i zhizn'. Besedy s Tsiolkovskim (Moscow: Mysl', 1999), 659-678, here 667, 677 (first published with substantial differences in Khimiia $i$ zhizn', 1977, no. 1, 23-32). In September 1992 I took part in the $27^{\text {th }}$ Tsiolkovskii Lectures, which took place in the large plenary hall of the provincial council in Kaluga. One discussed with striking passion the characteristics of the "radiant superhumanity" (luchistoe sverkhchelovechestvo) predicted by Tsiolkovskii. Nowadays such ideas are resurfacing in the post-humanist, neo-gnostic technoeschatologies of the liberation of the 'pure' spirit from the natural and thus decrepit body and a perfect virtual and potentially immortal existence in cyberspace. See, e.g., Hans Moravec, Mind Children. The Future of Robot and Human Intelligence (Cambridge, Mass.: Harvard University Press, 1988); Frank J. Tipler, The Physics of Immortality. Modern Cosmology, God, and the Resurrection of the Dead (New York: Doubleday, 1994).

17 Tsiolkovskii, Issledovanie mirovykh prostranstv, 100. 
suffering and irrationality "anywhere in the entire universe". ${ }^{18}$ Man as the "manifestation of the will of the universe" has been granted the task of eliminating all imperfect, useless and harmful forms of life-that is, all victims and sources of suffering-, among which Tsiolkovskii includes all animals (he was a vegetarian himself ${ }^{19}$ and most plants, as well as physically and morally defective humans, and populating the planets with his perfected race. ${ }^{20}$ "It is", he explains, "as if a gardener were to destroy all the useless weeds and only allow the best vegetables to grow!"21

Tsiolkovskii's world-redeeming "cosmic philosophy" is not based exclusively on the belief in unfettered progress with its monstrous consequences. It also is constructed from a bricolage of ideas drawn from very different philosophical, para-scientific and occult traditions. ${ }^{22}$ Tsiolkovskii called himself a "biocosmist"23 and "panpsychist" as he believed-apparently drawing on Ernst Haeckel (1834-1919) and Gustav Theodor Fechner (1801-1887) ${ }^{24}$ and maybe

18 Idem, Nauchnaia ètika (Kaluga: izd. avtora, 1930), 19, 44.

19 See Peter Brang, Ein unbekanntes Russland. Kulturgeschichte vegetarischer Lebensweisen von den Anfängen bis zur Gegenwart (Cologne: Böhlau, 2002), 293-295.

20 Konstantin Tsiolkovskii, Liubov' $k$ samomu sebe, ili istinnoe sebialiubie (Kaluga: izd. avtora, 1928), 36-37; idem, “Zhivaia Vselennaia” [probably 1918], Voprosy filosofii, 1992, no. 6, 135158, here 151; idem, Volia Vselennoi. Neizvestnye razumnye sily (Kaluga: izd. avtora, 1928), $2-4$.

21 Idem, Nauchnaia ettika, 45; cf. idem, Volia Vselennoi, 5. Here Tsiolkovskii is in the tradition of "rational egoism" (razumnyi egoizm) of Dmitrii Pisarev and Nikolai Chernyshevskii, whereas his gardening metaphors quite overtly draw on the language of totalitarian utopias.

22 See also Michael Hagemeister on the following, "Russian Cosmism in the 1920s and Today," In: Bernice G. Rosenthal, ed., The Occult in Russian and Soviet Culture (Ithaca, London: Cornell University Press, 1997), 185-202, here 196-198; idem, „Die Eroberung des Raums und die Beherrschung der Zeit: Utopische, apokalyptische und magisch-okkulte Elemente in den Zukunftsentwürfen der Sowjetzeit," In: Jurij Murašov, Georg Witte, eds., Die Musen der Macht. Medien in der sowjetischen Kultur der 20er und 30er Jahre (Munich: Fink, 2003), 257-284, here 275-283.

23 Lev Kassil', Zvezdoplavatel' i zemliaki, In: K. É. Tsiolkovskii. Sbornik Aerroflota (Moscow: Aèroflot, 1939), 159-172, here 165.

24 On the esoteric character of Haeckel's monism and Fechner's panpsychism, see Robert Matthias Erdbeer, Die Signatur des Kosmos: Epistemische Poetik und die Genealogie der Esoterischen Moderne (Berlin: de Gruyter: 2010), esp. 507-580. Haeckel's „unique and exciting mixture of science and philosophy" had, according to Alexander Vucinich, "an inordinately wide circulation" in Russia. Alexander Vucinich, Darwin in Russian Thought (Berkeley, Los Ange- 
also influenced by contemporary Russian secular panpsychism ${ }^{25}$-that all matter, organic as well as inorganic, is alive and animated and spoke of "lively and happy atoms-spirits" (zhivye i shchastlivye atomy-dukhi). In inorganic bonds the atom sleeps-dreamlessly and timelessly, as if in state of deep unconsciousness. If the atom enters a plant or animal, it takes on the ability to feel or sense (chuvstvitel'nost'). It lives the life of the organism and experiences happiness and sorrow. In the brain of a highly developed form of life, the atom becomes conscious, ${ }^{26}$ and in the brain of the most highly developed being it ultimately turns into an "irreversible form of a special energy, which has a cosmic and telepathic conscience". ${ }^{27}$

Man is nothing more than a temporary albeit complex "realm" (gosudarstvo) or "common home" (obshchezhitie) of indestructible—that is, immortal"atoms-spirits", which are scattered at death only to be reconfigured, according to the cosmic law of evolution and the quest for happiness, into more perfect, blissful "realms".

Death is one of the illusions of the weak human mind. Death does not exist... [...] The universe is constructed in such a way that not only itself is immortal, but also all of its parts, in the form of living, blessed beings. There is no beginning and no end to the universe, and thus no beginning and no end to life and to bliss. ${ }^{28}$

les: University of California Press, 1988), 195. Tsiolkovskii owned Haeckel's The Riddle of the Universe (Die Welträtsel) and Lectures on Science and Philosophy in the Russian editions of 1906 and 1913; see Alekseeva, K. E. Tsiolkovskii, 42-44, 134-135, 138. A Russian translation of Fechner's famous Little Book of Life After Death (Das Büchlein vom Leben nach dem Tode) appeared in 1915.

25 Represented by Aleksei Kozlov (1831-1901), Lev Lopatin (1855-1920), and Nikolai Losskii (1870-1965), Russian panpsychism regarded all being in the universe as psychic and conscious. Individual psychic substances were seen as parts of a cosmic system striving towards perfection and harmony. Kozlov like Tsiolkovskii was concerned with the improvement of the human breed and "argued that 'mediocre' people may be used as 'manure' to promote the flowering of great men”. See James P. Scanlan, "Russian Panpsychism: Kozlov, Lopatin, Losskii," In: Gary M. Hamburg, Randall A. Poole, eds., A History of Russian Philosophy 1830-1930: Faith, Reason, and the Defense of Human Dignity (Cambridge: Cambridge University Press, 2010), 150-168 (quotation 156).

26 Konstantin Tsiolkovskii, Monizm Vselennoi. Konspekt. Mart 1925g. (Kaluga: izd. avtora, 1925), 9.

27 Chizhevskii, “Teoriia kosmicheskikh èr," 677

28 Tsiolkovskii, Volia Vselennoi, 7; see also idem, Nauchnaia ètika, 24-32. The poet Nikolai Zabolotskii (1903-1958) was an avid reader of Tsiolkovskii's philosophical tracts: however he contended that the belief in the immortality of matter would not satisfy the quest for individ- 
Tsiolkovskii's conception comes close to the idea-developed by some of the Theosophists—of the "permanent atom" which passes from one incarnation to another. ${ }^{29}$

The universe was for Tsiolkovskii an "ocean of bliss" (okean schast'ia), ${ }^{30}$ created by an almighty and benevolent, but for humans incomprehensible "cause" (prichina), which he saw as a "most kind and rational living being" (zhivotnoe), as a "living organism", whose rationality and "absolute will" also defined the actions of mankind and its quest for happiness and reason-driven perfection..$^{31} \mathrm{He}$ also believed in the existence of immortal beings, who were much more developed than humans and almost bodiless, "ethereal" (éfirnyi) and therefore hardly visible to humans. ${ }^{32} \mathrm{He}$ also believed that these alien beings-which are similar to angels or spirits in his description-constructively intervene into the lives of humans, read their thoughts and send them messages through "heavenly signs" (nebesnye znameniia). And he assured that he had seen such signs himself several times. ${ }^{33}$ Viktor Shklovskii reports a conver-

ual immortality. Zabolotskii, like Tsiolkovskii, termed himself a „monist“, making no distinction between the spiritual and the material, but in sharp contrast to the latter dreamed of the "humanization" of animals and the reconciliation between man and nature. See Darra Goldstein, Nikolai Zabolotsky. Play for Mortal Stakes (Cambridge: Cambridge University Press, 1993), 143-148.

29 For Tsiolkovskii's atomism, see Nikolai Gavriushin, "Mistik-tekhnokrat (K. Ė. Tsiolkovskii)," In: Vladislav Lektorskii, ed., Filosofiia ne konchaetsia. Iz istorii otechestvennoi filosofii. XX vek (Moscow: ROSSPĖN, 1998), 702-717; idem, “Tsiolkovskii i atomistika," Trudy sed'mykh chtenii, posviashchennykh razrabotke nauchnogo naslediia $i$ razvitiiu idei $K$. E. Tsiolkovskogo [1972] (Moscow: IIET AN SSSR, 1973), 36-50; idem, “Antichnyi kosmos v tvorchestve K. $\dot{E}$. Tsiolkovskogo, "Voprosy istorii estestvoznaniia i tekhniki, 1989, no. 4, 11-16.

30 Konstantin Tsiolkovskii, "Kosmicheskaia filosofiia” [1935], In: idem, Kosmicheskaia filosofiia, 348-354, here 349.

31 Tsiolkovskii, Volia Vselennoi, 5. The ancient atomists (e.g. Lucretius in his poem De rerum natura) as well as Renaissance philosopher Giordano Bruno saw the universe as a living being which had to be born and die. In modern Western New Age thinking the idea of Earth or the whole universe as an animated self-regulating organism occurs in the so called "Gaia" hypothesis.

32 A specimen of an "ethereal being" (éfirnoe sushchestvo) is displayed together with models of aliens and UFOs in the planetarium of Kharkiv (Ukraine), see: http://planetarium-kharkov. org/?q=gumanoid-ephirniy (accessed September 11, 2010).

33 Tsiolkovskii, Volia Vselennoi, 9, 22-23; idem, Nauchnaia ètika, 37, 39-43; idem, "Fatum, sud'ba, rok," 47-51, here 50. Referring to Tsiolkovskii, Soviet scientists in the 1970s delevoped ancient astronaut theories and tried to establish such para-sciences as paleovizitologiia and paleokontaktologiia. See Iurii Morozov, Vladimir Rubtsov, "K otsenke sovremennogo sostoianiia problemy paleovizita," Trudy chetyrnadtsatykh chtenii, posviashchennykh razrabotke nauch- 
sation with Tsiolkovskii in the 1930s, in which Tsiolkovskii admitted that he frequently talked to angels. ${ }^{34}$

The influence of Gnostic, Theosophical and spiritualist teachings on the philosophical work of Tsiolkovski has been hardly researched up to now because it was to a large extent taboo in the Soviet Union..$^{35}$ The provincial town of Kaluga, in which Tsiolkovski lived, was-as Maria Carlson has demonstrated-the most important center after St. Petersburg of the Russian Theosophical movement at the beginning of the $20^{\text {th }}$ century. ${ }^{36}$ It can now be regarded as certain that Tsiolkovskii knew the writings of the Theosophists, of which many were published since 1905 in the Kaluga 'Lotos Publishing House', and incorporated several of their ideas and formulas-such as "cosmic thought", "cosmic consciousness", "citizen of the universe" or the description of the "heavenly worlds and their inhabitants"-into his "cosmic philosophy", an essential component of which was the aspiration to achieve a "holistic worldview" (tsel'noe mirovozzrenie), a "synthesis of science, religion and philosophy" ${ }^{37}$. Indeed, Tsiolkovskii's claim that he received messages from super-

nogo naslediia i razvitiiu idei K. E. Tsiolkovskogo [1979] (Moscow: IIET AN SSSR, 1980), 2650. See also, Ben Finney, Vladimir Lytkin, „Tsiolkovsky and Extraterrestrial Intelligence, Acta Astronautica, 46 (2000), nos. 10-12, 745-749.

34 Viktor Shklovskii, "Konstantin Ėduardovich Tsiolkovskii," In: idem, Zhili-byli (Moscow: Sovetskii pisatel', 1966), 519-528, here 525. The assumption of the existence of extraterrestrial intelligent beings which had gained a growing popularity not only among spiritualists (Johann Heinrich Jung-Stilling, Allan Kardec et al.), but also among scientists since the $19^{\text {th }}$ century is conflicting with both, Christianity's anthropocentric doctrine of salvation, and equally anthropocentric Historical Materialism. For Aleksandr Bogdanov, however, the objective laws of evolution were valid not only for societies on Earth but also for societies on other planets, Mars in particular. See his Krasnaia zvezda (1908) and Inzhener Menni (1912).

35 Even in more recent publications, as the 300-page monograph on Tsiolkovskii and the philosophy of cosmism by Alekseeva from 2007 (see note 11) there is not the slightest mention of this aspect.

36 See Maria Carlson, "No Religion Higher Than Truth". A History of the Theosophical Movement in Russia, 1875-1922 (Princeton, NJ: Princeton University Press, 1993), 62-65. Kaluga's attraction for cosmists and occultists has been explained by the impact of a meteor on the outskirts of the city. Vladimir Lytkin, vice-director of the Tsiolkovskii State Museum for the History of Cosmonautics in Kaluga, personal communication, Kaluga, 18 May 1992.

37 So the subtitle of Elena Blavatsky's Secret Doctrine. On the influence of Theosophy and occult teachings on Tsiolkovskii's view of the world, see Gavriushin, „Kosmicheskii put'," 127-129; idem, "Mistik-tekhnokrat," 712-715; Demin, Tsiolkovskii, 118-122, 254-255. The "cosmic" attribute can be found in the works of mystics and occultists since the late $19^{\text {th }}$ century (Max Théon, Blavatsky, Annie Besant, Petr Uspenskii) as well as in Anglo-American philosophies of evolution (John Fiske, Outlines of Cosmic Philosophy Based on the Doctrine of Evolution, 1874; Richard M. Bucke, Cosmic Consciousness. A Study in the Evolution of the Human Mind, 1901). 
evolved beings is remarkably similar to the alleged communication with the "Mahatmas" or "Ascended Masters", whom Madame Blavatsky claimed to consult.

Tsiolkovskii's notion that part of humanity would become highly developed and ultimately turn into luminous rays is a central motive in the Gnostic myth as it was popularized in Russia through the "secret doctrines" of the Theosophists and later the Anthroposophists: According to these teachings it is the goal of the earthly process to free the bright and divine part of the human soul from the dark and suffering earthly body and let it rise to the celestial realm of light. The inferior, earthly, decaying beings, on the other hand-and especially the animals - should be pushed back and obliterated. This recalls less Spencer's and Darwin's "natural selection" or "survival of the fittest" than Blavatsky's and Steiner's highly fanciful—and dangerous—-speculations about the ascent of higher races and the destruction of the racial "failures of nature". ${ }^{38}$

While Tsiolkovskii's views most heavily reflected a Theosophical influence, his ideas on nonterrestrial life may also have developed from his reading of the esoterically minded French astronomer Camille Flammarion (1842-1925) and the cosmic-spiritualist philosopher and natural scientist Carl du Prel (18391899), whose works were wide-spread in Russian translation around the turn of the $20^{\text {th }}$ century. ${ }^{39}$ In his Philosophy of Mysticism $(1885)^{40}$ the Bavarian private scholar outlined a peculiar synthesis of Darwinism and occultism in an attempt to determine the "status of humans in the universe" and their cosmic tasks. Expecting the end of the Earth, he forecasted a "cosmic expansion" of the history of mankind. ${ }^{41}$ According to him "cosmic traffic" opens the possibility that even after the cold death of the Earth "the achievements of the earthly culture can be preserved". ${ }^{2}$ By applying the principle of evolution and selec-

See, e.g., Nikolai Gavriushin, “Kosmicheskaia filosofiia’ Dzhona Fiska (1842-1901),” Trudy odinnadtsatykh chtenii, posviashchennykh razrabotke nauchnogo naslediia i razvitiiu idei K. $\dot{E}$. Tsiolkovskogo [1976] (Moscow: IIET AN SSSR, 1978), 117-123.

38 See Harald Strohm, Die Gnosis und der Nationalsozialismus (Frankfurt a. M.: Suhrkamp, 1997).

39 For a summation of Flammarion's and du Prel's views, see Michael J. Crowe, The Extraterrestrial Life Debate, 1750-1900: The Idea of a Plurality of Worlds from Kant to Lowell (Cambridge: Cambridge University Press, 1986), 378-386, 426-427 and passim.

40 In Russian: Filosofiia mistiki, ili dvoistvennost' chelovecheskogo sushchestva (St. Petersburg, 1895). See also the bibliography of the Russian versions of the works of du Prel in Carlson, "No Religion Higher Than Truth", 260.

41 Carl du Prel, Die Philosophie der Mystik (Leipzig: Günther, 1885), 509.

42 Ibid., 511. 
tion to the cosmic sphere, du Prel-as well as Tsiolkovskii-, believed it was not only possible "that on Earth itself man could be replaced by an even higher form of organization", but also "that the initiative to start cosmic history was triggered by inhabitants of another star". ${ }^{43}$

It is quite remarkable, and fully deserves further investigation, that it was the esoteric teachings of redemption and escape from this world which motivated Tsiolkovskii in his concrete research and technical developments. These in turn formed the basis of the Soviet space program and its propagation ${ }^{44}-\mathrm{a}$ program that was supposed to open the cosmic way to the transfiguration and perfection of humanity, and finally to immortality and eternal bliss. ${ }^{45}$

Tsiolkovskii is probably the most important, but by no means the only, founder of space flight with strong occult inclinations. It is remarkable that the prominent German rocket pioneers, the engineers Hermann Ganswindt (1856-1934), Hermann Oberth (1894-1989), and Max Valier (1895-1930) were also engaged in extensive metaphysical and occult speculation, and were fascinated by paranormal phenomena. Valier not only developed powerful rocket engines but also followed the pseudoscientific cosmic ice theory (Welteislehre) and published an extensive Occult Doctrine of the Universe (Okkulte Weltallslehre, Munich 1922), in which he-like Tsiolkovskii-described the universe as well as the atom as a "living and besouled organism", in accordance with the Hermetic doctrine of the analogy between microcosm and macrocosm. ${ }^{46}$ The eminent rocket pioneer John Whiteside Parsons (1914-1952), whose research was central to the United States rocket program in the 1930s and 1940s and who-again, like Tsiolkovskii-has a crater on the dark side of

43 Ibid.

44 Literary scholar Michael Holquist has gone so far as to claim that "Tsiolkovsky's great achievements in science were in fact exercises in applied philosophy." And "... without Tsiolkovsky there would have been no Soviet space program." Michael Holquist, "The Philosophical Bases of Soviet Space Exploration," The Key Reporter, 51 (1985), no. 2, 2-4, here 3, 4.

45 Asif Siddiqi refers to the link between technological utopianism and the Russian mystical occult tradition in the Soviet dream of spaceflight in the 1920s, see "Imagining the Cosmos", 260-288.

46 See Christian Thiel, "Zur Dynamik von Wissenschaft, Grenzwissenschaften und Pseudowissenschaften in der Moderne," Zeitschrift für Parapsychologie und Grenzgebiete der Psychologie, 30 (1988), nos. 1-4, 152-171, here 163-169. See also Hermann Oberth's tract Research and the Other World (Forschung und Jenseits), published in 1932. 
the moon named in his honour, was also an avid practitioner of the hermetic and magical sciences, and for several years, the leader of the US branch of Aleister Crowley's Ordo Templi Orientis (O.T.O.). ${ }^{47}$

We can only speculate about the reasons for the partiality these pioneers of space travel felt for occult doctrines. This partiality most likely has its roots in the mythological importance that heaven, and thus outer space, has had since the era of Aristotelian-Ptolemaic cosmology: as the realm of perfection, gods and paradise, and the eternal home of blessed mankind. The assault on heaven (shturm neba) would therefore open the road to humanity's self-perfection (samosovershenstvovanie) and self-deification (samoobozhestvlenie), including the realization of immortality. ${ }^{48}$ Since the conquest of heaven will be achieved through science and technology, these fields are given esoteric qualities and magical functions. Esoteric knowledge differs from modern-that is, postmetaphysical and empirical-knowledge in its aim to be holistic (tsel'noe), integrated (edinoe) and lively (zhivoe znanie), and-in the tradition of Gnosticism-in its alleged magic power to transform and redeem the world.

A magical, Gnostic understanding of science and technology was widespread among Tsiolkovskii's contemporaries. What had previously been the business of magicians, sorcerers and alchemists became the task of scientists and engineers, namely: the conquest of natural laws, the transmutation of species and elements, the absolute domination over space and time, the advance into new dimensions, and the creation of an omnipotent and immortal superhuman. ${ }^{49}$

47 See George Pendle, Strange Angel: The Otherworldly Life of Rocket Scientist John Whiteside Parsons (Orlando: Harcourt, 2005); Francesco Dimitri, Comunismo magico. Leggende, miti e visioni ultraterrene del socialismo reale (Rome: Alberto Castelvecci, 2004), 417-425.

See, e.g., David F. Noble, The Religion of Technology. The Divinity of Man and the Spirit of Invention (New York: Knopf, 1997). As Ryan J. McMillen has demonstrated in his excellent dissertation (which unfortunately I discovered only after finishing this manuscript), the dream of space colonization, as it stretches back to Isaac Newton and his contemporaries, also has deep roots in the Christian apocalyptic fantasy of the "rapture" - the supposed ascension of the chosen and blessed part of humanity into heaven - and the imminent destruction of the Earth. The technology of rocketry, according to McMillen, provides the apocalyptic end to history, both in its liberating power of departure from the Earth and its destructive power of Earth annihilation. See his Space Rapture: Extraterrestrial Millennialism and the Cultural Construction of Space Colonization, PhD. Diss., University of Texas at Austin, 2004, unpublished manuscript. Online at http://74.125.155.132/scholar?q=cache:_JVQd-j6xuwJ:scholar.google. com/+Space+Rapture:+Extraterrestrial+\&hl=de\&as_sdt=2000 (accessed September 11, 2010).

See Hagemeister, „Die Eroberung des Raums“; Dimitri, Comunismo magico, 167-219. Already in 1916, Nikolai Berdiaev had pointed to the magic origins of natural sciences and technology, 
A few examples may suffice: ${ }^{50}$ Aleksandr Bogdanov (1873-1928) and Valerian Murav'ev (1885-1932 [?]) attempted to create a "universal science", a kind of mathesis universalis, bringing the various strands of diverse findings together into one grand unified theory. This theory would be useful not only for attaining total command of the world but also for perfecting it. Psychologists, biologists, and physicists such as Naum Kotik (1876-1920), Piotr Lazarev (1878-1942), Leonid Vasil'ev (1891-1966), and Aleksandr Chizhevskii (18971964), the latter being a close friend of Tsiolkovskii, tried to uncover a hitherto concealed, all-powerful psycho-physical, nervous or cosmic radiation. Bogdanov's famous experiments in mutual blood transfusion, aiming to create a powerful superhumanity (sverkhchelovechestvo), are based on deeply archaic notions of blood as the site of the vital force (as in vampirism) and on the ability of blood to build and maintain a sense of community (as in Holy Communion). Bogdanov's magic vitalism could well have been influenced by Rudolf Steiner's lectures on "occult medicine" ${ }^{51}$ Perhaps the clearest example of the combination of modern (rational) science and technology with esoteric (irrational, mystical, Gnosticist) knowledge is the work of the priest, sophiologist, scientist, and engineer Pavel Florenskii (1882-1937): recall his speculations about "organ projection", "bio-technology" and "bio-industry", the alchemy of synthetic resin, the magic energies of names and numbers, or his efforts to employ the theory of relativity to prove the existence of the empyreum, the realm of Platonic ideas, the abode of God and the heavenly host. ${ }^{52}$ What Ger-

see his Smysl tvorchestva. Opyt opravdaniia cheloveka (Moscow: G. A. Leman, 1916), chap. XIII: “Tvorchestvo i mistika. Okkul'tizm i magiia”. On the close connections between Gnosticism and Soviet Dialectical Materialism, see Boris Groys, „Elemente des Gnostizismus im Dialektischen Materialismus (sowjetischen Marxismus), “In: Peter Koslowski, ed., Gnosis und Mystik in der Geschichte der Philosophie (Zurich, Munich: Artemis, 1988), 352-367.

50 For the following, see Michael Hagemeister, „'Unser Körper muß unser Werk sein.' Beherrschung der Natur und Überwindung des Todes in russischen Projekten des frühen 20. Jahrhunderts, "In: Groys, Hagemeister, eds., Die Neue Menschheit, 19-67.

51 According to uncertified information, while in Europe, Bogdanov attended Steiner's lectures on „occult medicine“, in which he talked about the magic meaning of blood. See Aleksandr Eliseev, „Krasnye mistiki,“ Nezavisimaia gazeta - religii, 14 November 2001; Oleg Odnokolenko, „S pritselom na voskreshenie, “Itogi, 22 March 2006.

52 See Michael Hagemeister, „Wiederverzauberung der Welt - Pavel Florenskijs Neues Mittelalter," In: Norbert Franz, Michael Hagemeister, Frank Haney, eds., Pavel Florenskij - Tradition und Moderne. Beiträge zum Internationalen Symposium an der Universität Potsdam, 5. bis 9. April 2000 (Frankfurt a. M.: Peter Lang, 2001), 21-41; also in Russian: „Novoe srednevekov'e Pavla Florenskogo," In: Modest Kolerov, ed., Issledovaniia po istorii russkoi mysli. Ezhegodnik za 2003 god (Moscow: Modest Kolerov, 2004), 86-106 (a pirate translation appeared in 
man sociologist Niklas Luhmann has described as "the differentiation of the systems"-namely the separation of modern science, metaphysics, and religion (including their institutions and discourses) - is reversed by these theories (or is considered never to have taken place).

A magical-esoteric understanding of science and technology is still prevalent in today's Russia. This can be seen by "Russian cosmism", a hybrid ideological concept, of which Tsiolkovskii was later declared as one of its founders, along with philosopher Nikolai Fedorov (1829-1903), geochemist Vladimir Vernadskii (1863-1945), and the already mentioned heliobiologist Aleksandr Chizhevskii. ${ }^{53}$ In reality, however, "Russian cosmism"-which is a typical case of the "invention of a tradition" (also with intent to support a tradition of invention)-originated in the late Soviet period and has fed into a nationalist discourse about Russian identity in post-Soviet Russia. ${ }^{54}$

Zvezda, 2006, no. 11, 130-144). See also L. I. Vasilenko, “O magii i okkul'tizme v nasledii o. Pavla Florenskogo," Vestnik Pravoslavnogo Sviato-Tikhonovskogo Gumanitarnogo universiteta 3 (2004), 81-99. Florenskii's attraction to the occult, magic, Gnosticism and neo-Platonism was already criticized by his contemporaries.

Tsiolkovskii has often been called a disciple of Fedorov. This, however, raises serious questions, since Tsiolkovskii's 'solution' of the death problem is incompatible with Fedorov's central idea of personal resurrection by technological means. According to Andrews, Red Cosmos, 17, Tsiolkovskii joined "a group of scientists who saw themselves as Fedorov's disciples, amateur philosophers called the Biocosmists". In reality, this group, which according to Andrews included Vladimir Vernadskii, Leonid Krasin, and Valerian Murav'ev, never existed. There was, however, a group called the "Biocosmists", but it was an ephemeral assortment of anarchists and poets. Boris Groys is definitely mistaken in stating that Tsiolkovskii conducted his research on rocketry in the tradition of Fedorov "with the aim to bring the awakened ancestors to other planets”. Boris Groys, „Unsterbliche Körper, oder die materialistische Metanoia, “In: Vittoria Borsò, et al., eds., Benjamin - Agamben. Politik, Messianismus, Kabbala (Würzburg: Königshausen \& Neumann, 2010), 49-58, here 57. For a highly fanciful depiction of "Nikolai Fedorov's cosmism" (including Fedorov's alleged influence on Stalin), see R. Bruce Elder, Harmony and Dissent. Film and Avant-Garde Movements in the Early Twentieth Century (Waterloo, Ont.: Wilfrid Laurier University Press, 2010), 346-350, 422-423.

See the chapter on cosmism by Marlène Laruelle in this volume. See also Michael Hagemeister, „Der ,russische Kosmismus - ein Anachronismus oder die ,Philosophie der Zukunft?," In: Anne Hartmann, Christoph Veldhues, eds., Im Zeichen-Raum. Festschrift für Karl Eimermacher zum 60. Geburtstag (Dortmund: Projekt, 1998), 169-201. One of the earliest sources for the term "Russian cosmism“ is Renata Gal'tseva's article on Vladimir Vernadskii in the $5^{\text {th }}$ volume of Filosofskaia entsiklopediia (1970) which became famous for its ideologically daring positions. For a good overview, see Aleksandr Ogurtsov, Russkii kosmizm (Obzor literatury i 
Feted by its advocates as a "philosophy of the future", capable of "solving the urgent problems of humanity" by paving the path toward the "divine stage of human development", ${ }^{5}$ and denounced by its opponents as "science mysticism", "gnosticism", "technocratic pseudo-religion"56 and the "occult shadow ideology" of Soviet Marxism, ${ }^{57}$ "Russian cosmism" elaborates an image of humanity, which spreads its "noocratic rule" over the universe, whence it can fulfill the "universal cosmic plan" of turning itself into an almighty immortal organism, thus attaining the status of God. Tsiolkovskii's fantasies appeared at the beginning of a century in which totalitarian doctrines of universal salvation made their way to power.

navigator po saitam Interneta), http://vox-journal.org/content/vox4-11ogurcov.pdf (accessed September 11, 2010).

55 Arsenii Gulyga, „Wir leben im Zeitalter des Kosmismus,“ Deutsche Zeitschrift für Philosophie, 40 (1992), 870-881, here 873-874.

56 Gavriushin, „Kosmicheskii put',“ 125; idem, „A byl li ,russkii kosmizm’?,“ Voprosy istorii estestvoznaniia i tekhniki, 1993, no. 3, 104-105 (in this article the Orthodox philosopher calls "Russian cosmism" a "Trojan horse" which served to hide "theosophists, occultists, Christian heretics, as well as mystic and positivistic natural philosophers").

57 Alexandre Douguine [Aleksandr Dugin], "Le complot idéologique du cosmisme russe," Politica hermetica, 6 (1992), 80-89. Dugin introduces himself as a "metaphysician, conspirologist and an expert in sacred geography”. See also Slavoj Žižek, In Defence of Lost Causes (London, New York: Verso 2008), 186. 


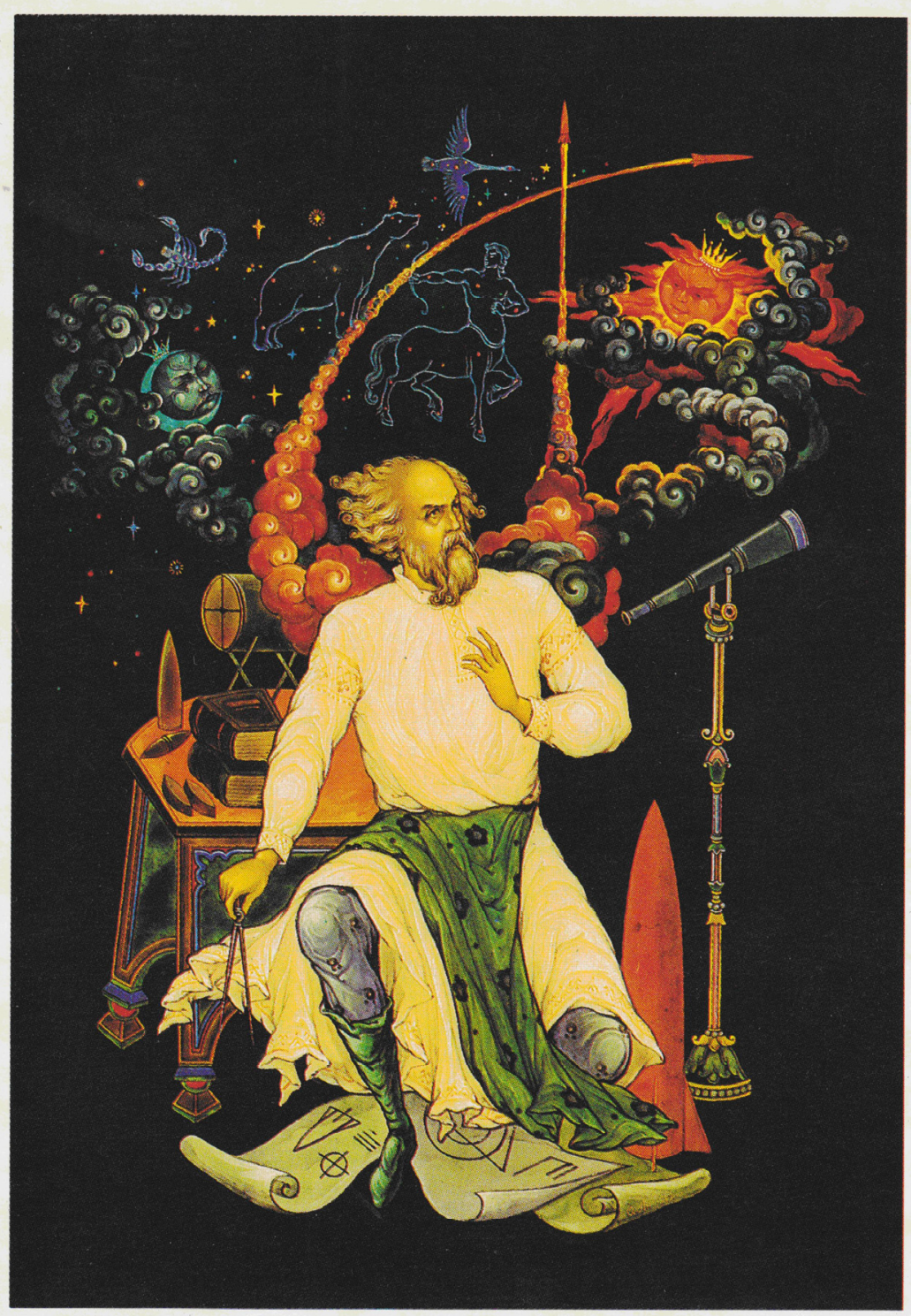

Konstantin Tsiolkovskii

Palekh lacquer miniature, ca. 1980

Michael Hagemeister and Birgit Menzel - 978-3-86688-198-3

Downloaded from PubFactory at 01/11/2019 02:22:40AM

via free access 


\title{
OCCULT AND ESOTERIC MOVEMENTS IN RUSSIA FROM THE 1960s TO THE 1980s
}

\author{
BIRGIT MENZEL
}

\author{
"...a whole level of culture almost unknown \\ to anybody outside of a closed circle." \\ (Grigorii Reinin)
}

The Stalinist project of creating a Soviet civilization based on work, empirical knowledge and "scientific atheism" suppressed occultism along with all metaphysical and cultural experimentation. The Khrushchevian Thaw brought political rehabilitations, a liberalization of culture, but also new atheist campaigns, since the revival of socialist ideals and cosmic enthusiasm refuelled the revolutionary dream of transforming society and nature by means of science. Since the Thaw, there was a marked reaction against the atheistic cult of the rational in both artistic practice and everyday life. In the late 1960s and 1970s, charismatic individuals, numerous mystical circles and sects emerged in the two capitals and in cities throughout the country, accompanied by experiments with drugs and transcendental practices intended to expand consciousness. According to Marxist-Leninist ideology the humanities were defined as part of the sciences, and their borders were much less strictly defined than in the West so that-paradoxically-phenomena excluded from the Western scientific paradigm were studied and supported within the Soviet academic system. Alongside with a highly secretive underground "occulture", ${ }_{1}^{1}$ works and ideas

I would like to thank Konstantin Burmistrov, Andrei Grib, Michail Iskrin, Vladislav Lebed'ko, Vladimir Montlevich, Evgenii Moroz, Sergej Moskalev, Arkadii Rovner, Valentin Nikitin, Sergei Pakhomov, Andrei Paribok, Andrei Terent'ev, and the respondents to my questionnaire for material, information and critical comments for this chapter. My special thanks go to Paul Hillery, without whom this book would not be here.

1 The term "occulture" has been introduced by Christopher Partridge to expand "the narrow technical definition of the term 'occult' to include a vast spectrum of beliefs and practices sourced by Eastern spirituality, Paganism, Spiritualism, Theosophy, alternative science and medicine, popular psychology, and a range of beliefs emanating out of a general interest in the paranormal." He also refers to it as "often hidden, rejected and oppositional beliefs and practices". Although Partridge has Western, mostly Anglo-American occulture in mind, his definition can also be applied to the situation in Russia described in this chapter. In Christopher 


\section{Birgit Menzel}

with topics and contents related to the occult and paranormal appeared in official publications. The wide range of esoteric quests and occult practices flourished along with a revival of utopian projects of the early $20^{\text {th }}$ century. The almost magical appeal of cybernetics ${ }^{2}$ inspired fantasies of omnipotent control and, combined with Eastern yoga practices, promised total body-transcending self-control. Mathematics and mysticism merged in a bizarre variety of the Orthodox cult of imiaslavie, a secret occult circle of Moscow mathematicians originating in the early 20 th century. ${ }^{3}$ Medicine, physics, and parapsychology mingled and opened new fields of research. All this, together with an unprecedented optimism on conquering nature and the cosmos under conditions of the Cold War, led to a highly paradoxical relationship between politics, science, religion and the occult. ${ }^{4}$

The full history of this metaphysical undercurrent of Soviet civilization still remains to be written. This chapter presents some of the most influential paths, teachings, people and movements, by which occult ideas, traditions and practices were rediscovered by Russian intellectuals between the Thaw and Perestroika. It aims at expanding the picture of Late Soviet culture by looking at metaphysical aspects which have been largely unknown or remained unnoticed.

Despite the massive repression of the Stalin era, the occult tradition of the early $20^{\text {th }}$ century never died. Theosophy and Anthroposophy helped shape the occult revival in the 1960s (along with specific features from the post-Stalin era to the post-Soviet present). The Russian occulture of the 1960s and 1970s

Partridge, The Re-Enchantment of the West. Alternative Spiritualities, Sacralization, Popular Culture, and Occulture, vol. I (London: T\&T Clark, 2004), 68; vol. II ( London: T\&T Clark, 2005), 2.

2 Slava Gerovich, From Newspeak to Cyberspeak: A History of Soviet Cybernetics (Cambridge, Mass., 2002).

3 For the cult of imaiaslavie in Russian mathematics see Loren Graham, Jean-Michel Kantor, Naming Infinity. A True Story of Religious Mysticism and Mathematical Creativity (Cambridge, Mass.: Harvard University Press, 2009). The philosophy of imiaslavie was developed mostly by the Orthodox priest and scientist Pavel Florenskii and the religious philosopher Sergei Bulgakov in the 1910-1920s. See Michael Hagemeister, „Imjaslavie - imjadejstvie. Namensmystik und Namensmagie in Russland (1900-1930), "In: Tatjana Petzer et al., eds., Namen. Benennung - Verehrung - Wirkung. Positionen der europäischen Moderne (Berlin: Kadmos, 2009), 78-98.

4 Julia Richers, Monica Ruethers, "Spirituality, Transcendence and Soviet Utopianism in Reflections of Space Travel," In: Eva Maurer, Julia Richers, Monica Ruethers, Carmen Scheide, eds., Soviet Space Culture - Cosmic Enthusiasm in Socialist Societies (Houndmills, Basingstoke: Palgrave Macmillan, 2011). 
emerged mostly from the rediscovery of Gurdjieff, Nicholas and Elena Roerich, Blavatsky's Theosophy, Eastern religions, ancient esoteric philosophy, Christian mysticism, and Sufism. It was also informed by Western occult classics, the contemporary New Age movement in the West, and by direct contacts with folk healers and teachers from indigenous Eastern peoples and within the Soviet Empire (Siberia, Buriatia, Central Asia, Caucasus).

\section{Gateways to Spiritual Paths}

In Russia since the 1950s, gateways to spiritual paths were provided by texts and, for practitioners, in certain places. Anyone who sought spiritual paths to individual self-transformation, had to pursue these paths secretly and alone. Access to knowledge about the occult was mostly provided by reading. Central State libraries such as Moscow's Lenin Library provided open access to numerous prerevolutionary publications for professional academics, which were obviously too alien for ideological scrutiny and therefore escaped the censorship's attention. Here, some of the pioneering occultists who later became gurus for the younger generation, Iurii Mamleev, Vladimir Stepanov, Evgenii Lazarev and Evgenii Golovin, discovered the Western occult classics. The writings of Eliphas Lévi (Alphonse Louis Constant), Papus (Gérard Encausse), Julius Evola, René Guénon and Carl du Prel. ${ }^{5}$ Writings by Elena Blavatsky, Petr Uspensky, Rudolf Steiner and Jakob Böhme began to circulate in Samizdat in the capitals in the late 1950s, either in prerevolutionary Russian translations or in original editions from the emigré press Tamizdat, followed later by publications of the contemporary Western New Age. Libraries became places to meet other surviving occultists of the older generation by tracking down the regular readers of the same rare books. ${ }^{6}$ There were also a few libraries and archives preserved in some private collections for decades. ${ }^{7}$

Thanks to the friendly relations of the USSR with India, many basic texts on Eastern religions, Buddhism, Hinduism, including yoga philosophy and practice were accessible to the general public. Examples include Romain Rolland's biography of Ramakrishna Paramakhamsu (1836-1886) and Swami Vivekananda (1863-1902), the founders of Neo-Hinduism and popularizers of

5 Iurii Mamleev, “Okkul'tizm v Sovetskoi Rossii," Okkul'tizm i ioga 63, 1976, 29-47; Vladimir Stepanov, In: Vladimir Lebed'ko, Khroniki Rossijskoi San’iasy. Iz zhizni Rossiiskikh mistikovMasterov i uchenikov 1960-1990kh), vol. II. (Moscow, 2000), 34-36 (www.sannyasa.narod.ru).

6 Recalled by Stepanov (Lebed'ko II, 34).

7 See Konstantin Burmistrov's chapter in this volume, Fn. 37, 42. 


\section{Birgit Menzel}

Indian religion to the West. Rolland's biography was published in 1936, in the midst of Stalinist repressions, as volume nineteen of the collected works of this French communist writer and foreign delegate at the First Congress of Soviet Writers in 1934. And in 1956, a new translation of the Bhagavad-Gita was published by Boris Smirnov by the Turkmenistan Academy of Sciences in Alma-Ata, as part of a grandiose one-man translation of the Mahabharata. This publication contained extensive comments, including detailed information about classical yoga practices and their philosophical context. ${ }^{8}$

Numerous articles on topics related to the occult and paranormal appeared in popular scientific journals such as Science and Life (Nauka i zhizn'), Knowledge is power (Znanie - sila), Science and Religion (Nauka i religiia) and Technology for the Youth (Tekhnika molodezhi). Literature also served as a source of inspiration. Daniil Andreev's novel Roza mira (Rose of the world) was one of the major influential sources circulating in the underground. ${ }^{9}$ In 1964 the wellknown author of science-fiction novels Ivan Efremov introduced yoga and Indian philosophy to a wide public in his novel Lezvie britvy (Razor's Edge). ${ }^{10}$

The discourse on anti-fascism allowed topics such as the connection between German Fascism and esoteric mysticism to be discussed in journals from the 1960s on. Among the earliest publications were excerpts from the international bestseller The Morning of the Magicians (Le Matin des magiciens [Paris, 1960]) by Louis Pauwels and Jacques Bergier in the journal Nauka i religiia, which described for the first time, in a sensational manner, the occult context of Hitler and Nazi politics. ${ }^{11}$

8 The neurosurgeon Boris Smirnov (1891-1967), who was politically exiled to Ashkhabad in the 1920s, translated 23.000 of the 100.000 verses of the Mahabharata. This fourth Russian translation of essential parts of the Indian epos-after several adaptations based on interlingual versions, by the theosophist Anna Kamenskaia (1916), the writer Semen Lipkin and the autodidactic translator Sergei Neapolitanskii-became particularly popular in the 1970s and 1980s. Smirnov became known to a wider public by a series of articles on Indian philosophy and yoga in Nauka i zhizn' (1987). Viktor Boiko, Istoriia jogi v Rossii (www.realyoga.ru). Parallel to Smirnov's there has been initiated a full Russian prose translation of the epic in Leningrad in 1939 by V. Kal'ianov (1908-2001).

9 See Mikhail Epstein, "Daniil Andreev and the mysticism of femininity", In: Bernice G. Rosenthal, ed., The Occult in Russian and Soviet Culture (Ithaca, London: Cornell University Press, 1997), 325-356.

10 Efremov's novel was printed in 116.000 copies. See Leonid Heller's chapter in this volume.

11 Luis Povel', Zhak Berzh'e, "Kakomu bogu poklonialsia Gitler?" Nauka i religiia, no. 9-10, 1966, 63-69; no. 11, 1966, 82-89. Louis Pauwels and Jacques Bergier's book Utro magiei was published in full in 1994 (Moscow: Enigma). See Iurii Stepanov, "Dikii chelovek v zheleznom stolbe," Literaturnoe obozrenie, no. 3-4, 1994, 63-68. The novel Le Matin des magiciens was 
For people who had learned to read between the lines, publications of atheist polemics against all kinds of so-called "mysticism" provided classical sources as well as publications on contemporary Western New Age movements. ${ }^{12}$ Such publications were available in central and even regional libraries. They were based on information from library-collections closed to the public and often contained detailed information in order to 'expose' these phenomena as ideologically dangerous.

For Russian occulture after the 1950s prominent places to encounter knowledge of esotericism were the academic Institutes for the Study of Eastern Religions and Philosophy at the Moscow and Leningrad Universities. In Moscow the Institute of Asian and African countries and in Leningrad the departments of Indology and Egyptology had long held an internationally approved high reputation, but Oriental Studies had also branches in other cities, like Novosibirsk. Leningrad had special ties with Buddhism since the early $20^{\text {th }}$ century. ${ }^{13}$ Buddhism, as well as Shamanism, had been acknowledged religions since the Russian Empire. In the Soviet period, even if the people following both religions were massively repressed and suffered from the consequences of atheist campaigns, they continued to be officially acknowledged by the Soviet government in Buriatia, Tuva and Kalmykia. ${ }^{14}$

translated into most European languages, discussed in the press, and had an impact on many writers and intellectuals of the 1960s generation.

12 An example for this is Valentina Pazilova, a historian of religion and atheism at Moscow University. A dedicated cosmist and disciple of Nikolai Fedorov since the 1970s, married to a practicing Buddhist, she published several critical attacks against Fedorov with the explicit intention of quoting as much as possible from her revered master's texts. In the 1990s, Pazilova became editor of the journal Science and Religion (Nauka i religiia), working with Viktor Pelevin and publishing a book on Blavatsky.

131909 the first Buddhist cathedral (datsan) outside of Tibet and the first in Europe was built in St. Petersburg, thanks to several influential mediators, especially the Buriat lama Agvan Dorzhiev (1859-1938), who had received his education in Tibet and represented the Tibetan government in St. Petersburg and after 1920 in Petrograd-Leningrad, and to the above mentioned Buriat orientalist and doctor Petr Badmaev. After Petr Badmaev's death in 1920, the practice of Tibetan medicine was continued by his nephew Nikolai (1879-1939). A special private clinic for oriental medicine was founded in 1923 in Leningrad where Nikolai Badmaev treated prominent authorities, among them Maxim Gorky. Support from political leaders of the Kremlin did not protect him from denunciations and attacks, however, and in 1938 he was arrested and shot. See Markus Osterrieder's chapter in this volume.

14 Marjorie M. Balzer, ed., Shamanic Worlds (New York: Sharpe, 1997); Valentina Kharitonova, Feniks iz pepla? Sibirskii shamanizm na rubezhe tysiacheletii (Moscow, 2006); See also Natalia Zhukovskaia's chapter in this volume. 
Other official institutions in which people with interests in the supernatural could meet in public, attain esoteric knowledge and find fellow-seekers for research and experimental practices were the Faculty of Psychology at Moscow University, institutions of health-care, alternative and complementary medicine.

A prominent source of detailed information on religious and spiritual matters and an attractive meeting place for people in search of esoteric knowledge was the Museum for the History of Religion and Atheism in Leningrad. It had a large collection of paintings and artifacts on religious topics, and a variety of cultic material in sections such as "Religions of the East", "Origin of religions" and "Science and religion." Andrei Teren'tev, a young indologist who later became an influential practicing Buddhist, worked in the Eastern section. Several occultists of the former underground refer to the museum as a place with access to literature which was forbidden elsewhere. ${ }^{15}$

\section{Teachings and Teachers-Connections with the Past}

For most people seeking spiritual orientation and experience beyond the dogmas of traditional religions, there was a great need for authorities and teachers, dead or alive. Together with Nicholas and Elena Roerich, Elena Blavatsky and Petr Uspenskii, Georgii Gurdjieff (1866 [?]-1949) became one of the leading authorities for the Late Soviet occult underground. Born in a Greek-Armenian family, Gurdjieff left Russia in 1920 and travelled extensively throughout Europe and America in the 1920-1940s, developed a syncretic, yet original teaching called the Fourth Way, ${ }^{16}$ a fusion of Eastern and Western esotericism, in which elements presented as being of Islamic Sufi origin, such as the theatrical-mystic art of Caucasian-Asian dervish-dance, merge with performance rituals of Caucasian table-talk, community, and elements of shock- and psychotherapy (e.g. the Enneagram). Gurdjieff, who was an artist and composer, had a particularly strong impact on artists and people in the creative professions. ${ }^{17}$

15 M. Burdo, Sergei Filatov, Sovremennaia religioznaia zhizn'v Rossii. Opyt sistematicheskogo opisaniia, 4 vols..(Moscow: Logos, 2006) on Terent'ev; Igor' Polianski,, Geister der Erinnerung. Das Atheismusmuseum als sowjetischer Gedächtnisort. ZeitRäume. Potsdamer Almanach des Zentrums für Zeithistorische Forschung 2008 ( Potsdam, 2009), 115-126. Sophia Wellbeloved, Gurdjieff. The Key Concepts (London: Routledge, 2003).

17 In the West Katherine Mansfield, Aldous Huxley, Peter Brook, Keith Jarrett, who recorded his hymns. James Webb, The Harmonious Circle. The Lives and Work of G.I. Gurdjieff, P.D. Ouspensky, and Their Followers (London: Thames and Hudson, 1980). 
Since the late 1950s some of Gurdjieff s disciples, Fedor Verevin (19011968 for example) were either released from the GULag or returned to the capitals from remote hiding places. They attracted young followers, such as Vladimir Stepanov and Boris Kerdimun, who became individual practitioners of the Fourth Way and instructed other young followers, like the writer Arkadii Rovner (b. 1940), the philologist Mikhail Meilakh (b. 1944) and the jazzmusician Boris Grebenshchikov (b. 1953), who spread Gurdjieff's influence further. At the same time, some of the most charismatic authorities of the occult underground, the poet and translator Evgenii Golovin (b. 1938) and the writer Iurii Mamleev (b. 1931), incorporated Gurdjieffs teachings in their ideas and behavior, in particular the elements of shock, provocation, and denigration. Sometimes the methods of breaking through the Iron Curtain for contact and information reflected Gurdjieff s eccentric masquerades. As Rovner recalls, Mikhail Meilakh would stand on his head in the breakfast-room of the Leningrad Interhotel for foreign guests and after a while would turn to each table and ask the puzzled or amused foreign businessmen or diplomats most politely in various languages if they could bring in any information or material about Gurdjieff on subsequent trips. ${ }^{18}$ Golovin and Mamleev introduced the teachings of René Guénon (1886-1951), ${ }^{19}$ founder of traditionalism, to Russia. Their fascination with Julius Evola and other philosophers of fascism, also served as inspirations for political occultism.

In the 1970s the situation changed, as several of the protagonists emigrated. But apart from the brain-drain, emigration also helped to link the Russian occulture to Western New Age. Arkadii Rovner, who went to New York taught mysticism at various colleges, edited numerous publications, and established personal contacts with Gurdjieffians in Western countries, especially in England, including the writer-historian Robert Graves, Idries Shakh and John Bennett. Writings and information about the Gurdjievist movement was smuggled into and distributed in Russia via Samizdat. After returning to Moscow in 1994, Rovner continued to teach the Fourth Way by founding the Insti-

18 Arkadii Rovner, Gurdzhievskoe dvizhenie v Rossii 1960kh i 1970kh. Vospominaniia i reflektsii uchastnika, www.harrimaninstitute.org/MEDIA/00713.pdf; Vspominaia sebia, Kniga o druz'iakh i sputnikakh zhizni (Penza, 2010). See also Mikhail Meilakh, Teoriia transmutatsii G.I. Gurdzhieva. Ratsional'noe i irratsional'noe $v$ sovremennom burzhuaznom soznanii, vyp. 2 (Moscow: INION, 1979), 139-172.

19 For a biography of René Guénon see Mark Sedgwick, Against the Modern World. Traditionalism and the Secret Intellectual History of the Twentieth Century (Oxford: Oxford University Press, 2004). 
tute for Cultivation of Inner States (ICIS), ${ }^{20}$ again mediating between East and West, linking generations in the Soviet past and post-Soviet present.

One of the most peculiar links between early and late $20^{\text {th }}$ century occultism is the journal Okkul'tizm i ioga. This small-size journal was probably one of the earliest and longest-lived emigré publications of the Soviet period. It was founded in 1929 by the Russian emigrant Aleksandr Aseev (1903-1993), ${ }^{21}$ who ran and edited it for more than four decades, first from Belgrade (1933-1936), then from Sofia (1937-1938) and Tallinn. From 1952 on he settled in Asuncion (Paraguay), from where the journal was published until 1977. Efforts in the early 1980s to transfer its edition to Israel, failed and publication ceased. Aseev had close ties with Elena and Nicholas Roerich, ${ }^{22}$ and, judging from the editors' notes, the range of authors and reader-responses, served as the center of an international network for Russian occultists beyond political borders, with distributors in England, France, the US, Australia and Uruguay. The journal, sixty six volumes in all, was issued irregularly, with several issues per year. The articles covered a wide range of topics, from surveys of classical esotericism (Rosicrucianism in Russia) to Theosophy, parapsychology and paganism (Druidry), as well as Russian or Slavic nationalism and "integral Christianity". It offered texts from Russian literature, from classical to symbolist poets, and extended writings by Nicholas and Elena Roerich. Contributions came also from Roerich-disciples in Soviet Russia, such as the writer Valentin Sidorov, ${ }^{23}$ who promoted Roerich's esoteric legacy openly in official thick journals. ${ }^{24}$ Mamleev, too, was a frequent contributor to Okkul'tizm i ioga. He presented his own philosophical essays, discussed Buddhism, Hinduism, and the Western New Age as well as occultism in Soviet Russia. ${ }^{25}$ The journal became a link between old and new emigrant and domestic Russian occultism, even though it was read by only a small number of intellectuals. (fig. 1)

20 www.sostoyanie.ru.

21 A selection of issues can be found in the New York Public Library. To my knowledge, the complete issues are preserved in only one private collection in Moscow.

Elena Rerikh, Nikolai Rerikh, Aleksandr Aseev, Okkul'tizm i joga. Letopis' sotrudnichestva, vol. I, II (Moscow: Sfera, 1996).

23 Valentin Sidorov, „Puti liubvi, Velikaia bitva,” Okkul'tizm i ioga 62, 1976, 2-6.

24 V. Sidorov, "Sem' dnei v Gimalaiakh," Moskva 8, 1982, 3-99; Sidorov, a member of the Russian nationalist Pamiat'-group, also became engaged in the project of re-establishing the Christ the Savior Cathedral in Moscow. 


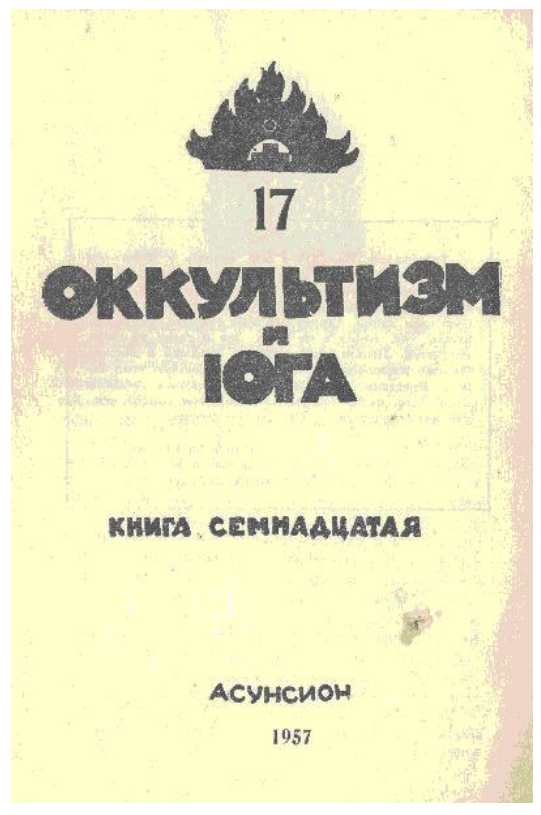

Fig.1: Cover of the Samizdat journal Okkul'tizm i ioga.

During Brezhnev's tenure, Russian intellectuals turned inward, and discovered religion, orthodoxy and mysticism, along with Russian nationalism. A situation of closed, secretive exclusiveness emerged, which intensified both risk and romanticism, and clandestine groups flourished around masters and gurus. The urge to join a spiritual teacher was so strong that many charlatans and manipulators took advantage of the gullible, sometimes resulting in paranoia or cynicism.

But there were also remarkable personalities who went beyond social, moral and psychological norms and limits in their self-experiments and who, by their radical exploring and realization of human potential became spiritual authorities, "masters" of self-made schools. Some of these seekers had a multiprofessional profile with qualifications in both the hard sciences and the liberal arts, practicing poetry, theatre, Oriental Studies, yoga, therapeutic and martial arts. ${ }^{26}$ Psychology and psychoanalysis were hotbeds of heterodox belief sys-

26 Grigorii Reinin was a biologist and karate-teacher; Aleksandr Voronov was a chemist and psychologist; the Gurdjievist Igor' Volodin was an engineer dealing with quantum-optics, Anatolii Ivanov held degrees in chemistry, mathematics, psychoanalysis, and physiotherapy. 
tems, and often a professional starting point. Student groups studying and challenging Freudianism in Moscow and Leningrad became laboratories of a Russian human potential movement, from where some, like Aleksandr Ėtkind, moved westward into academic cultural studies, and others, like Aleksei Mar'ianenko and Vladislav Lebed'ko, became part of the post-Soviet esoteric milieu. One of the goals was to take as many of the officially possible professional qualifications offered by the system of Soviet education. "Through scientific knowledge we wanted to break through to the realm of spirituality, boundless freedom, total self-transformation," said the biologist Igor' Chebanov, who after exploring Buddhism and Sufism discovered Christianity in the Caucasus and after years of ascetic retreats moved from Moscow to a village practicing Christian mysticism mixed with "spiritual drinking". ${ }^{27}$

Igor' Kalinauskas (b.1945), for example, a Russian-Lithuanian psychologist, theatre-director, musician, was introduced to Gurdjieff s teachings and Sufism by Arkadii Rovner, worked through an occultist private library, acquired eclectic knowledge of Freemasons, Theosophy, techniques of Roerich's Agni-yoga, and experimented with bioenergetics, Castaneda, and various altered states of consciousness. He became one of the leaders of the esoteric underground. Moscow student groups organized exchanges with Kiev and other cities. Inspired by Hinduism, yoga and Eastern philosophy, Kalinauskas for became a disciple of the Uzbek Sufi mystic Mirzabaj Kymbatbaev (1935-2006), ${ }^{28}$ and travelled to Central Asia, while working with his own experimental theatergroup, training and performing improvised vocal techniques. Later he also worked as a trainer in extreme psychotechniques with Olympic sportschampions and the clean-up crew of Chernobyl' in the Clinical Institute of Radiation Medicine in Kiev. ${ }^{29}$

Igor' Chebanov, Lebed'ko I.

28 Mirzabai was a charismatic Sufi-master whose reputation was, however, severely damaged, after he witnessed a brutal murder of the actor Talgat Nigmatulin by fanatic members of the group in Vil'nius without interfering. This murder-case with a ritual background stirred up similar outrage in both the official press and in the occult underground as the Kunta-yogagroup. See also Rovner, Vospominaia sebia, 268-312.

In the 1990s he developed an international career as an esoteric multitasking artist and performer. 


\section{Occult Milieus and Circles}

The Russian occult underground can be described as a "cultic milieu" (Colin Campbell), a term coined to define the "cultural underground of society" in the West, which can be equally applied to the situation in Russia.

It includes all deviant belief systems and their associated practices. Unorthodox science, alien and heretical religion, deviant medicine, all comprise elements of such an underground (...). Substantively, it includes the worlds of the occult and the magical, of spiritualism and psychic phenomena, of mysticism and new thought, of alien intelligences and lost civilizations, of faith healing and nature cure. This heterogeneous assortment of cultural items can be regarded despite its apparent diversity, as constituting a single entity-the entity of the cultic milieu (...). The cultic milieu is manifestly united by a common ideology of seekership which both arises from and in turn reinforces the consciousness of deviant status, the receptive and syncretistic orientation and the interpretative communication structure. ${ }^{30}$

From the 1960s to the 1980s, individual seekers aiming at mystical experience, gathered esoteric knowledge in solitude. Some of them went on geological or meteorological expeditions, settled in remote places far North or East in the Tundra or Taiga; others followed the example of the mystical and anchoretic tradition of Russian Orthodox monks (otshel'niki). But much more often, esoterics remained in the capitals, gathering in various small circles of writers, artists, philosophers, scientists. Each circle had its teacher and disciples.

Since the danger of being arrested was always high, and many members of the occult underground were sentenced to prison camps or psychiatric hospitals, all circles were intensely secretive. This did not exclude, however, a high range of social and spatial mobility. The wish to escape control and stagnation, a desire for an unbound inner freedom, independent of social strata and professional obligations led many nonconformist intellectuals to give up their professional status and survive on low-profile jobs such as furnace stoker or janitor, which gave them the necessary work-registration and a lot of free time. Seekers travelled all over the country looking for qualified teachers to follow or sacred places, such as Lake Svetloiar, where the legendary town of Kitezh, the Russian Atlantis, was buried, or Belovod'e, the Russian Shambhala (Shangri-la).

30 Colin Campbell, "The Cult, the Cultic Milieu and Secularization,” In: Jeffrey Kaplan, Hélène Lööw, eds., The Cultic Milieu (Oxford, 2002), 12-25, here 20 (first publ. A Sociological Yearbook of Religion in Britain, 1972, no. 5, 119-136). 
Tickets were cheap throughout the Soviet Union, and it was not untypical to give up a job and disappear for months or even years. Formal registration could be faked, student status kept, and in such a large territory it was possible to escape official control for a while. Although active practitioners were scattered all over the Soviet Union, mostly individuals lived under cover in their everyday life. ${ }^{31}$ "All San'iasins of the 1970s knew each other well," recalled Aleksandr Voronov, one if the masters. ${ }^{32}$ The following is an attempt to classify different milieus, although they often overlapped and could not always be clearly separated.

\section{Bohemian occulture}

Moscow probably had more eccentric bohemian circles than Leningrad, where specialists in science, psychology, and ascetic adepts of Oriental Studies seemed to prevail. The area of Sokol'niki-Cherkizovo became well-known for occult circles of poets, artists and philologists. Iurii Trifonov described some of the occult Moscow underground from a non-participant's perspective in his novella Drugaia zhizn' (Another Life, 1975). One of the most influential persons of the early Moscow underground was the above mentioned Iurii Mamleev, writer, mathematician and son of a well-known psychiatrist, who was among the first to study Eastern, especially Neo-Hindu philosophy. Mamleev introduced and translated into Russian the writings of the French occultisttraditionalist René Guénon. In the early years of the Thaw, Mamleev's underground circle, Iuzhinskii pereulok (named after the address of his apartment), became a meeting-point for eccentric intellectuals, engaged in readings of literary texts and conducting bizarre happenings. Explorations into the dark sides of the human nature beyond all moral and social norms, similar to some of Aleister Crowley's practices with the Golden Dawn, were part of experimenting with the boundaries of human behavior, to which the members contributed with alcohol and drugs and by calling themselves "the sect of sexual mystics" (seksual'nye mistiki):

Only in the depth of the total underground, behind closed curtains, a new free and independent consciousness will be born [... ] in this situation with all its deviances, despair and departure from everything out-

31 For a roman à clé, in which Vladimir Stepanov is turned into the main hero, see Konstantin Serebrov, Odin shag v zazerkal'e. Germeticheskaia shkola. Kniga pervaia (Moscow: Belye al'vy, 2001).

32 Aleksandr Voronov in Lebed'ko, II., 6 (2.10.1998). 
side-an impossible literature will emerge, a literature worthy of Russia! -even if it is monstrous at first sight! (...) From the depth of the deepest abasement it shall rise! ${ }^{33}$

This is how Mamleev described the Moscow underground in his autobiographical novel Moskovskii gambit, as a way down to hell and back into an enlightened state of higher consciousness. As the master of ceremonies, he offered his own philosophy of transgression and from this circle received stimulation for his writing, which later became known as "the aesthetics of monstrosity". However, apart from self-mystifications and denunciations, few reliable sources exist to reconstruct the history of this circle..$^{34}$ Most of the charismatic leaders of the Moscow occult underground (Evgenii Golovin, Evgenii Lazarev, Vladimir Stepanov) were attached to it at one time or another. Their occult practices remained secret, for the initiated; how much they outgrew or internalized remains unknown. After his emigration to Paris in 1973, Mamleev became one of the mediators between the Eastern and Western occulture by contributing to and helping smuggle the journal Okkul'tizm i ioga into Russia. With their theatrical and often provocative mysticism, the members of this circle influenced a whole generation of intellectuals, artists and occultists, from Gajdar Dzhemal and Aleksandr Dugin to Victor Pelevin.

In the 1970s more circles emerged, which were later ironically called the "Moscow School of Pseudo-Tibetan Esoterics" (Vladimir Danchenko). Studying mysticism from books in groups with romantic names like Gnozis, Artur and Iamskoe pole was one thing. Practicing experimental psychology was another: masters would often order members of the circle to perform unusual tasks to break their egos and test their capacity for radical self-transformation. Thus, a person could be ordered to go to a certain town in the South and found an esoteric underground circle. ${ }^{35}$ Sometimes Gurdijeff s shock-theatre was

33 Iurii Mamleev, Moskovskii gambit (Moscow: ZebraE, 2007), 277-278.

34 "Seksual'nye mistiki," A. Strelianyi, G. Sapgir, V. Bakhtin, N. Ordynskii, Samizdat veka (Moscow/Minsk: Polifakt, 1998), 438-39. For a polemical report see Aleksei Chelnokov, "Melkie i krupnye besy iz shizoidnogo podpol'ia. Vertep v Iuzhinskom," Zhurnal Litsa 8, 1997 (http://chelnokov-ac.livejournal.com/7987.html) (15.8.2011); Iurii Mamleev, "Okkul'tizm v sovetskoi Rossii," Okkul'tizm i ioga 63, 1976, 29-46; "Unio mistica. Beseda Viktora Kulle s Iuriem Mamleevym i Sergeem Riabovym," Literaturnoe obozrenie 268, 1998, 68-74.

35 For Svetloiar and Kitezh Vasilii Komarovich, Kitezhskaia legenda. Opyt izucheniia mestnykh legend (Moscow, Leningrad 1936 (http://www.svetloyar.eu/publishing/doccomarovitz.htm) and Leonid Heller, Michel Niqueux, Geschichte der Utopie in Russland (Bietigheim-Bissingen: Edition tertium, 2003) (first French, Paris: PUF, 1995). 
simulated or parodied, when, for example, one of the members, a well-known Moscow opera singer, was summoned to stand singing on a refrigerator in front of the whole group after stripping naked. ${ }^{36}$

One of the most eccentric masters of provocation in these circles was the artist Sergei (de) Rokambol' (pseudonym Grigorii Popandopulo), who established an unsavory reputation for cultivating mat (Russian foul language), and using it almost exclusively in his communication. He used his extraordinary intuition to break everybody's psychological self-defense with ruthless verbal attacks, even in public. Like many other occultists, Rokambol' used psychedelic mushrooms, which he found and experimented with in the woods around Leningrad. The all-prevailing drug, however, remained alcohol. "Vodka was the absolute key product to provide 'illumination'. Nothing went without vodka." ${ }^{37}$ In the 1970s alcohol was raised to a cult status, turned into a philosophy of dissent, ${ }^{38}$ and used for many reasons, among them to proceed to an altered state of consciousness for spiritual growth. It was consumed both to prove the maintenance of control under intoxication and to release inhibitions. Some esoterics declared themselves followers of an ancient tradition of "sacred drinking" 39

\section{Health and Alternative Medicine}

Unlike the Moscow bohemian circles, the milieu of spiritual healers, folk healers and practitioners of yoga following Eastern religious teachings was characterized rather by abstinence from alcohol and drugs. Larissa Honey identified three categories in the field of alternative health practice:

- external healers,

- non-traditional medicine,

- internal healers.

36 Vladimir Tret'iakov, in Lebed'ko I., 161. After this the singer was so embarrassed that she did not return to the circle for half a year.

37 Petr Mamkin, in Lebed'ko I., 3, 5.

38 "Alcoholism and drunkenness," In: The Cambridge Encyclopedia of Russia and the Soviet Union, ed. Archie Brown (New York: Cambridge University Press, 1982); Yvonne Pörzgen, Berauschte Zeit, Drogen in der russischen und polnischen Gegenwartsliteratur (Cologne: Böhlau, 2008).

39 Mamkin, in Lebed'ko I., 3, 5. For an interpretation of alcohol as debasing oneself within a Christian religious context see Dirk Uffelmann, "Exinanitio alcoholica [Selbsterniedrigung mittels Alkohol]. Venedikt Erofeevs Moskva-Petuški“. Wiener Slawistischer Almanach 50 (2002), 331-372. 
External healers use their own energy to cure other people. Non-traditional medicine includes Chinese medicine and ayurvedic medicine, as well as znakharstvo, traditional Russian folk healing. "Inner healing" emphasizes "self-help, the importance of thoughts and the mind and the development of innate human powers of self improvement." 40 In the 1960-1980s, healers of all three categories were active in Russia. "External healers" (narodnye tseliteli) were often uneducated wandering peasants, charismatic and mythologized figures ranging from "magicians" (kolduny) to "holy fools" (iurodivy). Beliefs and practices of traditional folk-healing and magic are deeply rooted in Russian culture and survived through the Soviet into the post-Soviet era. ${ }^{41}$ Folk healers used herbal medicine and knowledge passed on to them for generations in families or by old village wise men and women (babki/dedki). Many healers appeared to have psychic abilities and used magic spells in their treatments. ${ }^{42}$ Like the popular institutions for phytomedicine, "external healers" did not necessarily have esoteric beliefs, but for many the dvoeverie was characteristic, i.e. a mix of pagan nature religion and mystical Christian beliefs. ${ }^{43}$ Oriental medicine was different, because everything was spiritually defined, and no separation between body, mind and soul was made.

In the 1970s, the book of Tibetan medicine, together with a collection of traditional recipes, which included a wide range of folk remedies and therapies from herbal medicine to magic spells and incantation, circulated in Samizdat. The main treatise of Tibetan medicine, Chzhud-Shi, was translated into Russian by the Buriat doctor Petr (Zhamtsaran) Badmaev (1851-1920), who brought religious, cultural and medical traditions from Tibet to European Russia and applied methods of Tibetan medicine at the court of Tsar Nikolai

40 See Larissa Honey, Transforming Selves and Society: Women, Spiritual Health and Pluralism in Post-Soviet Moscow, unpubl. Diss. (New York: CUNY, 2006), 125. For the tradition of womens' folk healing in Russia see Eve Levin and Rose Glickman, Russia's Women: Accomodation, Resistence, Transformation, ed. Barbara Evans Clements (Berkeley: University Press, 1991). For traditional and non-traditional healing and magic in Russia see Galina Lindquist, Conjuring Hope. Healing and Magic in Contemporary Russia (New York, Oxford: Berghahn, 2006).

41 See Iuliia Sinelina, Izmenenie religioznosti naseleniia Rossiian. Pravoslavnye, musul'mane. Suevernoe povedenie Rossiian (Moscow: Nauka, 2006), 20, 33, 95-100; W.F. Ryan, The Bathhouse at Midnight. Magic in Russia (UniversityPark, Pa., 1999).

42 This practice has been typical for rural areas until recently, as I was told by a collegue from Khabarovsk from her own experience, and by the folk healer Aleksei Gladkov in St. Petersburg.

43 See, for instance, the folk healer P. Pipko (http://www.travolekar.ru/articles/pract/pipko.pdf). 
II. ${ }^{44}$ Some specialists, like the medical doctor Vadim Rozin, gave semi-public talks on Chinese folk medicine and biofield-theories, referring to a whole body of forbidden literature ${ }^{45}$ Spiritual healing was the project of those who directed their attention to the development of their inner nature. By practicing meditation, yoga, vegetarianism and various psychotechniques, these people aimed at transforming their Self and thereby developing their human potential.

The reception of yoga in Russia was ambivalent. After some popularity in the early $20^{\text {th }}$ century among intellectuals, which was part of the European wave of Orientalism, it disappeared in the 1930s. Only few individuals, mostly those involved with Oriental Studies, practiced it in private after the 1950s. In 1970, the Kiev studio for scientific films released a documentary film Indian yogis who are they? (Indiiskie yogi-kto oni?) which introduced the "Ancient Indian health-care-practice", by showing Indian yogis performing extraordinary physical actions, which contradicted all laws of human physiology. Fakirs lying on broken glass were driven over by a truck, others were dug out alive and healthy from inside the earth where they had been lying for months without eating and breathing, i.e. in a state of clinical death. The film was part of a State-promoted campaign for the mobilization of "hidden human resources" (skrytye chelovecheskie resursy) and caused a sensation. All over the country people began imitating these experiments.

But the official policy on yoga was contradictory, because conflicting interest-groups dominated the party-leadership at different times. Thus, right after the documentary film, yoga was severely criticized in the press, official voices warned that it would cause epilepsy, mental illness, and physical damage. Yoga was attacked as a means of ideologically undermining the Soviet mind and power, an instrument of hidden Cold War propaganda, as it was associated with the Western counterculture. In 1973, the Sports Committee of the Soviet Council of Ministers officially condemned yoga, which was declared incompatible with Marxist-Leninist ideology and called "a Trojan horse of Indian idealism." ${ }^{\prime 6}$

Nevertheless, yoga gained popularity and was both practiced and widely discussed as a fascinating phenomenon in popular science magazines. Science and Life (Nauka i zhizn'), Country Youth (Sel'skaia molodezh') and Science and Religion (Nauka i religiia) published extended series about yoga, which evoked

On Badmaev see Markus Osterrieder's chapter in this volume.

Larissa Honey, Transforming Selves, 199; Vadim Rozin, Ezotericheskii mir. Semantika sakral'nogo teksta (Moscow: URSS, 2002), 15.

Burdo, Filatov, Sovremennaia religioznaia zhizn', III, 353-355. 
a great deal of reader response. ${ }^{47}$ Defenders tried to legitimize yoga as a technique for physical exercise, body-control and health-care. It was promoted as an effective means for athletes, along with the martial arts of China and Japan which also became popular in the 1970s, and began to compete with traditional Russian boxing techniques. Just as Roerich's followers pointed to his proposed peace treaty in 1935 as a predecessor of the United Nations, to legitimize him, defenders of yoga pointed to it as a sign of the officially promoted SovietIndian friendship to justify its political meaning.

Behind the stage of public attacks, hidden human potential experiments with yoga were promoted by the highest orders in closed medical institutes. Scientists and the Party leadership were particularly interested in the techniques of anabiosis ${ }^{48}$ for possible use in Soviet space travel, and thus provided extended training for cosmonauts as well as prominent athletes. The biophysicist Aleksei Katkov became obsessed with yoga breathing techniques under conditions of extreme cold. From 1966 to 1973 he worked in the secret Moscow Pirogov Institute for Cosmic and Aviation Medicine. He even published several articles about anabiosis and yoga, which were followed by selfexperiments in radical esoterics. But shortly before he finished his dissertation about "Conquering pain and the resources of our organism", Katkov died in 1987, at the age of thirty seven, while fulfilling the order to hike the Caucasian Mount Elbrus without oxygen. ${ }^{49}$

One of the early promoters of yoga as a physical and spiritual practice of self-perfection was the professor of philosophy, indologist and cosmist Vasilii Brodov (1912-1996), who participated as an expert-consultant in the film Indiiskie yogi - kto oni? and became the head of the Soviet Association for Philosophical and Medical Problems of Yoga in Russia. ${ }^{50}$ Although he published articles about yoga in handbooks of atheism, Brodov's aim was to synthesize Russian and Indian cosmism. In the 1970s, several semi-public yoga-courses

47 Viktor Vorontsov, “Chata-Yoga: Chto my mozhem vziat' iz nego?” Nauka i zhizn'; Sensatsii ne budet, Sel'skaia molodezh' 1969-1970.

48 Anabiosis is a temporary state of extremely reduced metabolism, practiced by Indian yogis; the practice can cause near-death-experience. Experiments with anabiosis have a long tradition in Russia. For some utopian scientists in 1920s, anabiosis was connected with hopes of prolonging life and even achieving immortality. See Nikolai Setnitskii, "O smerti i pogrebenii," In: Vselenskoe delo, sbornik 2 (Riga, 1934), 141-146. Vladimir Maiakovskii parodied these experiments in his drama The Bedbug (Klop, 1930).

49 Burdo, Filatov, Sovremennaia religioznaia zhizn' III, 354.

50 Vasilii Brodov published about yoga in Nauchno-ateisticheskii slovar' (Moscow, 1969) and in the journal Science and Religion (Nauka i religiia). 
were offered in Moscow by the engineer Viktor Boiko, who was inspired by Ivan Efremov's science fiction novels, as well as by Anatolii Zubkov, an orientalistist from Moscow University, who had worked in India and qualified as a yoga teacher; and by Ian Koltunov, an ardent Roerich disciple, who in 1976 founded the popular yoga-club Kosmos, disguised as a sports-institute, which at times attracted over a thousand practitioners. After 1980, when another atheism campaign began, yoga was categorically forbidden, Kosmos was closed and Koltunov was expelled from the Communist Party for his activities.

Beyond the public discourse, members of the esoteric underground studied yoga seriously with a spiritual approach to life. More profound studies and sources from the Western counterculture circulated in Samizdat and were available in the institutes of Oriental Studies in both capitals. But in Russia, yoga seemed to remain mostly a challenge for the physiological limits of human potential. An example in the Leningrad underground is Anatolii Ivanov (b. 1951), who became both a charismatic yoga teacher and a scandalous eccentric. With multiple degrees in psychotherapy and applied mathematics from the Bekhterev Institute, and qualifications in physiotherapy and oriental medicine, Ivanov trained himself in various paranormal abilities and used yoga as a means to realize optimal control of the human organism. He experimented with various psychophysical healing-techniques, including anabiotic breathing. Illumination, he considered possible only beyond the physical limits of human potential. Ivanov also got involved with Tantric sexual practices. In order to prove that the supernatural is part of human potential as boundless male libido, he had a bizarre experiment organized in a medical academic institute. For fifty-five hours he performed uninterrupted sexual intercourse with eleven female medical student volunteers under the surveillance of a group of professional doctors. For his extensive teaching of yoga while at the same time successfully practicing external and internal healing, Ivanov was arrested in 1978 and sentenced to four years in a prison-camp. ${ }^{51}$

One of the most popular Russian yogis was the peasant Porfirii Korneevich Ivanov (1898-1983). At the age of thirty five, after a mystical healing experience, he dedicated himself to a radical back-to-nature way of life, rejecting any material property, refusing to wear clothes (except for shorts) or shoes and taking only a minimum of food. Despite numerous arrests, imprisonments and compulsory treatments in psychiatric hospitals in the 1960s, Ivanov continued his ascetic life as a wandering mystic and natural healer, following both Chris-

51 See the article on Anatolii Ivanov in the Samizdat-journal Chronicle of current events 48, 1978 (http://victor.sokirko.com/ecomomy/Zes2/II.1.htm) and Lebed'ko I., 118. 
tian and pagan beliefs, seeking to overcome the limits of the physical body and achieve immortality. Even though barely educated, he wrote diaries and didactic texts for the growing number of his followers. Especially after Ivanov's death, he became a cult-figure. Some took up his practice and philosophy of ascetic health, others chose to worship him as a mystical saint of Russian nature. In the post-Soviet present Ivanov, who the official Orthodox Church rejected as a neo-pagan schizophrenic, remains a real popular hero, massively promoted in the official mass-media, an icon in the internet, and an idol for the movement of his followers (Ivanovtsy)..$^{52}$

\section{Scientific occulture}

It was not only Marxist-Leninist ideology that determined what was to be considered rational and scientific in Russia. After Einstein, Heisenberg and the emergence of quantum physics, the general notion of science changed from a purely rational to a more intuitive interactive approach, and after World War II, psychology became a vital factor in warfare, prisons and psychiatry. So in both Russia and the West, the clear line between science and the Occult became blurred. In Russia these developments were embraced and repudiated at the same time. Research into paranormal, so-called "psycho-bio-physical" phenomena (such as Psi and ESP (Extrasensory Perception) in biophysics and astrophysics which, according to the dominant Western paradigm, had previously been considered a parascience or pseudo-science, were now promoted and supported in both East and West. In the Soviet Union it received a fair amount of institutional support, even while being publicly attacked or even prosecuted. Science itself became part of the Occult. Pioneering studies on telepathy and hypnosis in the Leningrad Institute for Psychoneurology in the early $1920 \mathrm{~s}^{53}$ which expanded into the Institute for Brain-Research under Vladimir Bekhterev (1857-1927), the "most prominent scientist to investigate occult aspects of mental activity," were officially banned after 1930. Nevertheless, research continued in secret laboratories and were quietly incorporated in Soviet science and even culture, because they "came to play an integral role in the creation of the theory of Socialist Realism, mainly by way of Maxim Gorky, its principal formulator." 54

52 Knorre, in Burdo, Filatov, 247-258.

53 See Konstantin Burmistrov's chapter in this volume.

54 Mikhail Agursky, "An Occult Source of Socialist Realism," In: Rosenthal, ed., The Occult, 247272 , here $247,262$. 
In the early 1930s, Bekhterev's disciple Leonid Vasil'ev (1891-1966) founded a commission for the "Study of secret phenomena of the human psyche" by order of Leningrad party officials, who were confronted with massive appeals for information about psychic phenomena by the public and material about personal experiences, and were searching for professionals to collect and explain this material. The commission had five members: the psychiatrist Arsenii Dubrovskii from the Bekhterev-Institute, Ivan Stepanov, a popular lecturer, the ethnographer Nina Nikitina, and as a secretary the young assistant of the Museum for the History of Religion at the Academy of Sciences, Mikhail Shakhnovich. From the 1930s to the1960s, the members of this commission, Shakhnovich in particular, collected a wide range of material based on personal interviews with astrologers, alchemists, palm-readers, psychographologists, occultists, Theosophists, spiritists, and fortune-tellers in Leningrad, but evaluations of their opinions differed considerably..$^{55}$ In the late 1950s, Vasil'ev was officially allowed to resume his research. In the 1970s, graduates of psychology and young psychoanalysts from Moscow and Leningrad University gathered in unofficial workshops on NLP (Neuro-linguistic programming) to write out and explore transcendental meditation or experimented with transpersonal psychology.

Vasil'ev's former secretary, Mikhail Shakhnovich (1911-1992), is an example of some rather tragic biographies of Russian specialists on mysticism. As a Jewish intellectual who also did research on the Protocols of the Elders of Zion, he was paradoxically tied to mysticism and the occult for most of his life, publishing his research in many publications, not with the hidden agenda of a spiritual seeker, ${ }^{56}$ but as an ardent fighter for atheism, a promoter of European rationalism and enlightenment. Shakhnovich began his career as an assistant of Leonid Vasil'ev in the Bekhterev Institute for Brain-Research in the 1920s, and was a sceptical opponent of Vasil'ev's "mystical" aspirations. He had also worked with Vladimir Bonch-Bruevich, Lenin's emissary to the sectarians. After Vasil'ev's institute was closed Shakhnovich, who, as a disciple of Vladimir Propp, had attained a doctoral degree in world folklore, became chief of the section of "heterodox" (vneveroispovednoi) mysticism (1932-1941) at the Museum for the History of Religion, which he helped re-establish after World War II. In the 1960s he published several polemical monographs on aspects of occultism, presenting extensive quotations and in-depth information about the

55 From the evaluation of $90 \%$ fraud in these practices by I. Stepanov to only $47 \%$ by L. Vasil'ev. Mikhail Shakhnovich, Peterburgskie mistiki, 12.

56 Like some of the authors and editors around the journal Nauka i religiia in the 1970s. 
history of the Occult and Western New Age. ${ }^{57}$ In a retrospective note from 1991, when his expertise was publicly requested again, Shakhnovich wrote:

It became ever more clear to me, that the "secret sciences" had not completely disappeared in our country, but that they had simply gone deeply underground, as if they wanted to prepare for their future reappearance. Sixty years passed, and I was right. ${ }^{58}$

In 1996, material he collected for three decades was posthumously published by his daughter, a professor of religious studies at St. Petersburg University. ${ }^{59}$ Experimental research on Psi-phenomena, ESP, and electromagnetic effects on the human bioenergy field ${ }^{60}$ resumed in several institutes of the Academy of Sciences: the Moscow Laboratory of Biophysics at the All Union Institute for Experimental Medicine (VIEM), which had been directed from 1934-1942 by the famous biogeophysicist and physiologist Petr Lazarev (1878-1942), an adherent of cosmism and various energy-theories; ${ }^{61}$ and at the Moscow Laboratory of Psychophysiology, where during the 1940s the well-known Polish psychic

57 Mikhail Shakhnovich, Sovremennaia mistika v svete nauki (Moscow, 1965); Mistika pered sudom nauki (Moscow, 1970). - Another example is the professor of Atheist studies at Moscow State University Evgenii Balagushkin (b. 1931). In 1978, he presented one of the first detailed accounts on the Western New Age movement, based on rich material from Western media and closed collections from the Moscow Lenin Library. Balagushkin introduced Wilhelm Reich's theories of sexual revolution and its impact on Western countercultureyouth. Today he recommends himself as an expert of "non-traditional religious movements". Evgenij Balagushkin, "Vliianie neofreidizma i teorii seksual'noi revoliutsii na nravstvennoe soznanie molodezhi Zapada," In: Molodezh', NTR, kapitalizm (Moscow, 1979), 189-244; Idem, Netraditsionnye religii v sovremennoi Rossii. Morfologicheskii analiz, vol. 1-2 (Moscow, 2002).

58 Mikhail Shakhnovich, Peterburgskie mistiki, ed. Marianna Shakhnovich (St. Petersburg, 1996), 246.

59 Shakhnovich, Peterburgskie mistiki,

60 G.K. Gurtovoi, "Nemnogo istorii," In: Liudmila B. Boldyreva, Nina B. Sotina, Fiziki v parapsikhologii. Ocherki (Moscow: Letnii sad, 2003), 6-14; Physicists in parapsychology (Moscow: Hatrol, 2002). In 1986 this section was renamed 'Section for organic matter of physical fields' (bioenergo-information).

61 See Michael Hagemeister, "Russian Cosmisn in the 1920s and Today," and Mikhail Agursky, "An Occult Source of Socialist Realism," In: Rosenthal, ed., The Occult, 194, 258. On the All Union Institute for Experimental Medicine which was established in 1932 by the Soviet authorities to conduct applied studies on the human brain, hypnosis, toxic poisons, and drugs and which also hosted a section of the occultist doctor Aleksandr Barchenko see Andrei Znamenski, Red Shambhala. Magic, Prophesy, and Geopolitics in the Heart of Asia (Wheaton/Ill.: Theosophical Publishing House, 2011), 82-88. 
Wolf Messing (1899-1974) ${ }^{62}$ demonstrated his telepathic abilities. From 1958 to 1968 experiments on "distant acting" were conducted in the Institute of Automacy and Electrometrics in the Siberian Academy of Sciences in Akademgorodok led by the Doctor of Technology Boris Petrov; and the Moscow Popov Association of Radiotechnology, Electronics and Communication (NTORES) became a place where "almost everybody met who was involved with such interests." ${ }^{13}$ In 1975, a special section for bioelectronic research, the first institute of bioenergetics, was founded within the Popov Institute, where young physicists with esoteric and alchemical interests investigated parapsychological phenomena.

Many scientific institutions had, apart from their publicly accessible sections, a second structure of completely independent secret sections. Those working on the Soviet nuclear and space-program in Institutes for Clinical, Radiational, Experimental and Trauma Medicine in Leningrad, Kiev and Novosibirsk, and the Pirogov Institute for Cosmic and Aviation Medicine in Moscow, had laboratories and ideologically unrestricted working conditions, following different rules and taking orders mostly from the top of the partynomenklatura or the KGB. ${ }^{64}$ These institutes provided a field of free experiments for people with psychic abilities and a place for research and experiments on expanded consciousness for occultists in the sciences.

Ectoplasma-photography which had become a popular and scientific concern among late $19^{\text {th }}$-early $20^{\text {th }}$ century spiritualists gained new attention with the work of Semen and Valentina Kirlian, two physiotherapists from Krasnodar. In 1939 or, according to other sources, 1949, by displaying visual radiation of a "human finger in a laboratory in Kiev, they discovered 'corona/or Gas

62 Wolf Messing established a popular mythologized image of himself in Soviet Russia which has been successfully promoted into the post-Soviet present. The publication of his memoirs in 1965 was considered a sensation. At least seven monographs on him were published after 1999, six in Russian, one in English translation (Tatiana Lungin) and one in German (Topsy Küppers, 2002). Four films about him were released since 2005. However, serious research has begun only recently, by which many of the popular myths especially

Messing's supposedly close relationship with Stalin, have been deconstructed. See N.N. Kitaev, "Kriminalisticheskii ekstrasens: pravda i vymysel," V zashchitu nauki 4, 2008, 102-144; Boris Sokolov, Wol'f Messing (Moscow: Zhizn' zamechatel'nykh liudei, 2010) and the Russian article on Wolf Messing in Wikipedia.

63 I. Voronov in Lebed'ko, I., 90.

64 Asif Siddiqi, The Red Rockets' Glare: Spaceflight and the Soviet Imagination, 1857-1957 (Cambridge: Cambridge University Press, 2010). 
discharge', also called 'electrographic'." ${ }^{65}$ The visualization of biofeedback supposedly proved the visible existence of fine-matter, the long-held thesis of a cosmic aura-energy claimed by Theosophists, Anthroposophists and all scientists hoping to prove the existence of a fourth dimension. ${ }^{66}$ Despite harsh criticism by many Russian scientists, their technique became famous under the name of Kirlian photography, and the couple was allowed to conduct officially approved research in their institute. Their controversial "electrographology"methods have been contested as paramedicine in the international scientific community, ${ }^{67}$ though in some fields of complementary medicine they are still being applied, and not only in today's Russia. Kirlian-photography has become extremely popular. In some countries it has been officially approved as a complementary medical-diagnostic technique. ${ }^{68}$

In Leningrad the academic institutes had always been closely connected, which sometimes facilitated interdisciplinary exchanges. The Fridman Institute of Mathematics and Cosmology at the Academy of Sciences had offices next to the orientalist Lev Gumilev's office. Gumilev is the founder of a bizarre theory of ethnogenesis. ${ }^{69}$ For some years, discussion groups emerged in which the quantum mathematician and specialist for cosmology Andrei Grib, Lev Gumilev and scholars of Eastern philosophy met. Sometimes foreign scientists would visit. Psychic experiences were shared and esoteric correspondences were explored. ${ }^{70}$

65 Valentina Kirlian, Semen Kirlian, V mire chudesnykh razriadov (Moscow, 1964). Kirlianovskie chteniia "Kirlian-2000". Sbornik dokladov i statei (Krasnodar, 1998).

66 On the fourth dimension see Linda Dalrymple Henderson, Computers, Art and the Fourth Dimension (Boston: Tony Robin/Fourfield, 1992).

67 See, for instance, the discussion by Tom Duerden in the British journal Complementary Therapies in Nursing \& Midwifery in 2003/2004 with further references.

68 G. Ermolina, „Mir budushchii, mir vysshii griadet v dospekhe luchei laboratornykh... (Ėffekt Kirlian uchenie zhivoi etiki), "In: Rerikhovskoe nasledie. Trudy konferentsii II (St. Petersburg, Vysshii Volochek: Rerikhovskii tsentr St. Peterburgskogo gos. universiteta, 2005), 630-633. Konstantin Korotkov, Osnovy GRV bioelektrografii (St. Petersburg, 2001).

69 A certain "biochemical energy of living matter in the biosphere" is, according to Gumilev, decisive in the formation and vitality of an ethnos. This energy, originally of cosmic origin, evolves into genetically transmittable biological energy that induces a variable percentage of individuals from the collective to an increased social, political, intellectual, or religious activity. For this irrational energy, which he contrasts with the 'sensible' instinct of self-preservation, he created the term passionarnost' (passionateness). In the context of neo-Eurasian ideologies and political occultism around Aleksandr Dugin Gumilev's theories have received considerable influence among intellectuals since the 1990s.

70 Andrei Grib, in an interview with me, October 4, 2008 in St. Petersburg. "Sovremennaia fizika i religioznoe otkrovenie," In: Dva Grada. Dialog nauki i religii. Vostochno- i Zapadno- 


\section{Birgit Menzel}

The popularity of parapsychology both in society and in the scientific community in the 1960s and 1970s is reflected not only in the fact that Leonid Brezhnev's sessions with the psychic and healer Evgeniia "Dzhuna" Davitashvili $^{71}$ became public knowledge, but also in a bibliography of publications related to paranormal phenomena in specialized and popular scientific books and journals between 1969 and $1981 .^{72}$ (fig. 2)

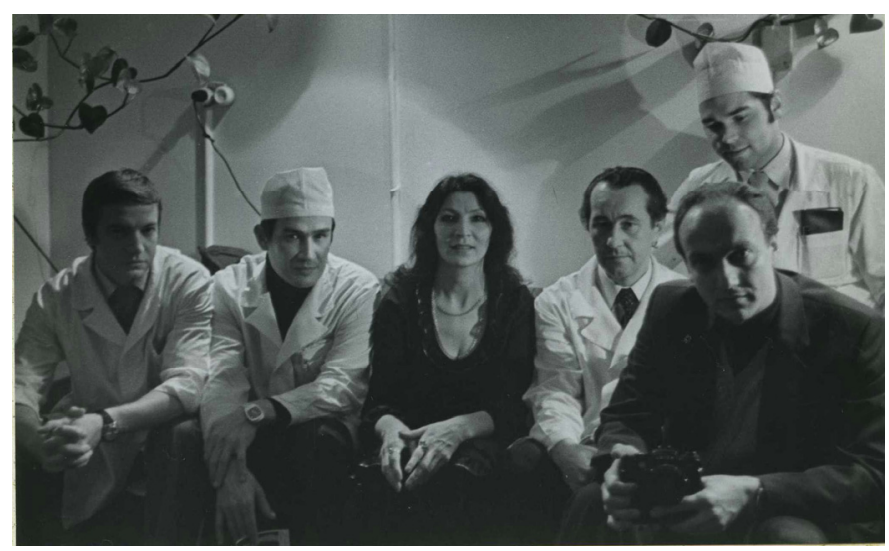

Fig. 2: Dzhuna Davitashvili in one of the special clinics in Moscow (early 1980s).

evropeiskaia traditsii (Moscow: RAN, 2002), 181-207; idem and A.Terent'eva, "Kosmos Drevnykh Dzainov," Ariavarta 1, 1996, 224-234.

71 For a reminiscence of a physicist participating in the secret research on extrasense with Dzhuna see: Aleksandr Torin (pseud. Taratorin), Nevydumannaia istoriia èkstrasensov $v$ Rossii (1997)

(http://torin.vasaros.com/extrasens_nevidumannaja_istorija/nevidumannaja_istorija.pdf)

72 E.K. Naumov, L.V. Vilenskii, N.K. Shpilev, eds., Parapsikhologiia v Rossii. Bibliograficheskii ukazatel' (Moscow, 1993). The bibliography contains 172 titles on telepathy, 237 on biolocation and bioenergy information, 58 on poltergeist, 33 on telekinesis and 261 on physical aspects of paranormal phenomena including Kirlian photography. 


\section{Eastern Religions: Tibetan Buddhism, Neo-Hinduism, and a Buriat Shaman in Leningrad}

Several charismatic professors, such as Iurii Roerich, Nicholas Roerich's son, Bidia Dandaron, a Buddhist lama-shaman from Buriatia, as well as the orientalist Lev Gumilev, had a strong impact on the study of ancient religions. They translated Tibetan, Indian (Sanskrit) and Chinese texts as basic sources and thereby conveyed Eastern mysticism into Russian. Some of these scholars lived a dual existence: as university professors on the outside and as initiated spiritual teachers for their disciples in the classical sense of esotericism: by secret transmission of sacred knowledge, by the idea of mediation, the teaching of universal correspondence and all knowledge aimed at a personal transformation as an ultimate goal.

One example of esoteric teaching directly from the East is Bidia Dandaron (1914-1974), who established the first, and for a long time, only Buddhist underground circle in European Soviet Russia. Born and brought up in Buriatia as an initiated monk of Tibetan Buddhism, he had been designated after 1917 as the reincarnated spiritual leader of the planned Buriat-Mongolian theocracy. After these plans failed, Dandaron studied aeronautics in Leningrad, but was arrested in 1937 for an alleged pan-Mongolian conspiracy and sent to prisoncamp for ten years. After being released, between 1956 and 1972, he received an affiliation as a lecturer of Indology and Tibetology at Leningrad University, and, still officially ostracized both in Moscow and Leningrad, gathered a secret circle of dedicated disciples, who were initiated by him. Among them were young, later internationally respected scholars, such as Aleksandr Piatigorskii, Boris Smirnov, Oktiabrina Volkova, Iurii Parfionovich and Linnart Miall'. Dandaron also established personal contacts with monasteries in Buriatia, Mongolia and Tibet, as a result of which monks regularly came to Leningrad in the 1970s and 1980s and held lectures in private apartments. The lama Dandaron himself was arrested three times for different reasons and spent fourteen years in the GULag, where he died from brutal beatings in 1976. Although most of his disciples also suffered repression, spending years in prison camps, he still has a dedicated following. In 2006, his disciple Vladimir Montlevich published Danderon's writings and material about him. ${ }^{73}$ Since in Buriatia Tibetan Buddhism has always been merged with traditional Shamanism, Dan-

73 Bidia D. Dandaron, Izbrannye stat'i. Chernaia tetrad' et al., ed. V. Montlevich (St. Petersburg 2006, first publ. 1995); Vladimir Montlevich, B.D. Dandaron. Buddist, uchenyi, podvizhnik, Unpubl. Ms. sent to me in December 2008. 
daron's influence also represented an influence of Shamanism, the religion of the indigenous people of Siberia.

Another example is Nicholas and Elena Roerich's second son Iurii Roerich, a professor and considered to be the founder of Tibetology; an internationally renowned indologist. Next to his brother, the painter Sviatoslav Roerich, ${ }^{74}$ the impact of Iurii Roerich on the Occult Revival in Russia cannot be overestimated. Together with other close disciples of Roerich, who was repatriated in Novosibirsk from Harbin ${ }^{75}$ Iurii returned to Russia from India in 1957 after his father's death, and during the last three years of his life was closely engaged with Bidia Dandaron. He, too, gathered a circle of dedicated initiated disciples around him. As his disciple Piatigorskii recalls, Roerich related to him in the same way as Buddha to a Brahmin. ${ }^{76}$ The legacy of Roerich's teachings ranges from so-called "noosferic ${ }^{77}$ environmental projects" in Siberia and India to research in bioelectrographic or Kirlian photography. ${ }^{78}$

In the 1970s, students especially of philology and oriental disciplines went on a spiritual quest and began to travel East, some to the Altai, searching for the mystical paradise of Shambhala, about which their teachers had written. Lev Gumilev's article Strana Shambala v legende $i v$ istorii $^{79}$ was a sensation at this time. Some people travelled to Central Asian Republics in search of Sufi teachers, or to the Buddhist republics for Tibetan lama-teachers. Some disguised their quest by joining geological expeditions, which was a frequent way

74 See Pavel Belikov, Sviatoslav Rerikh. Zhizn' i tvorchestvo (Moscow: Mezhdunarodnyi Tsentr Rerikhov, 2004).

75 For the reception of the Roerichs in Novosibirsk see John McCannon's chapter in this volume.

76 Aleksandr Piatigorskii, "O filosofskoi rabote Zil'bermana," In, Rossiia 4 (Torino: Einaudi, 1980), 278.

77 According to the Russian geologist Vladimir Vernadskii (1863-1945) the noosphere is the third in a succession of phases of developments of the Earth (after the geosphere, inanimate matter, and the biosphere, biological life), in which, just as the emergence of life fundamentally transformed the geosphere, the emergence of a unified human cognition fundamentally transforms the biosphere (Nauchnaia mysl' kak planetnoe iavlenie, Moscow, 1937). The concept of noosphere has been developed in the 1920 and 1930s by Vernadskii, Teilhard de Chardin and Édouard Le Roy, who taught and met at the Sorbonne in Paris. It has been applied by several Russian and Western scientists, incl. Marshal McLuhan and Eric Raymond. In postSoviet Russia it has become popular and in the West it is currently researched in the Princeton Global Consciousness Project. (http://noosphere.princeton.edu/)

78 See the materials from the International conference to celebrate Iurii Roerich's $100^{\text {th }}$ birthday in St. Petersburg in 2005, which in part reads almost as an encyclopedia of esotericism in Russia today. Rerikhovskoe nasledie. Trudy konferentsii (St. Petersburg: Irida, 2005).

79 Lev Gumilev, "Strana Shambala v legende i v istorii," Aziia i Afrika segodnja 1968, no. 5; idem, Sochineniia, vyp. 5 (Moscow 1994ff. DiDIK), 298-316. 
for members of alternative culture to explore unknown realms of nature and spirituality in the East. Others went on individual esoteric quests. Andrei Terent'ev, a student of orientalism from Leningrad University, established contacts with Tibetan Buddhist lamas in Buriatia. Lamas from the East began to visit Russia, such as the Tibetan monk Bakula Rinpoche, once a Mongolian ambassador in India, and later, in 1979, the well-known lama Namkai Norbu Rinpoche, who fled Tibet in 1959 and established himself as a professor at Naples University, visited Russia from Italy. Terent'ev founded a student association for the study of Buddhism, in which young orientalists like Evgenii Torchinov and Andrei Paribok, who later became academic teachers themselves, searched for deeper esoteric or, as they called it, mystical knowledge and experience than scholarly studies. ${ }^{80}$

In addition to Buddhism and Shamanism, Neo-Hinduism had an impact on the Russian occulture. As the least institutionalized Eastern religion, it had attracted Russian writers from Nikolai Novikov to Lev Tolstoy ${ }^{81}$ and influenced Elena Blavatsky and the Theosophists. One of her main followers, Annie Besant, declared her disciple, the Hindu Jiddu Krishnamurti (1895-1986) an avatar of the New Messiah. ${ }^{82}$ Neo-Hinduism had been a concept adapting the Old Vedanta Hindu teachings to modern civilization and classical teachings by Hindu mystics, like Ramakrishna Paramahamsa (1836-1886), had been transferred to the West by Swami Vivekandanda (1863-1902) that attracted many people in the Western counterculture in the 1960-1970s, because they embraced a certain ethical relativism, a pacifist, pantheistic worldview, a mystical eclecticism and a striving for ecstasy, liberating the unconscious from social and other norms. It was also connected to some practices, like yoga and meditation, which connected body and mind and could be applied as unsuspicious health-related methods. ${ }^{83}$ In the 1960s, followers and disciples of Nicholas Roerich (Iurii Mamleev, Aleksandr Piatigorskii, A. Syrkin, Tat'iana Elizarenkova, Vladimir Erman, Linnart Miall' and Oktiabrina Volkova) helped popularize Hindu teachings by translating classical sacred texts, which also circulated in Samizdat, and by publishing a Sanskrit-Estonian dictionary. Although most

80 Poresh, In: Burdo, Filatov, Sovremennaia religioznaia zhizn' (2005), 238-239. Terent'ev in an interview with me on 1 April, 2010.

81 Nikolai Novikov published the first Russian translation of the Bhagavad Gita (1788); Elena Blavatsky initiated a new translation in 1909.

82 Maria Carlson, "No Religion Higher Than Truth". A History of the Theosophical Movement in Russia, 1875-1922 (Princeton, NJ: Princeton University Press, 1993), 139.

83 Boris Knorre, "Induizm," In: Filatov, Burdo, Sovremennaia religioznaia zhizn' (2005) III, 335454. 
scholars opposed the popularization of neo-Hinduism, especially in the Western New Age, some influences began to migrate into Russia, too, and their work had an impact on the occulture.

\section{Traditionalism Reinvented: Kunta-Yoga}

One of the most bizarre groups representing the "pathogenic belief-system" (Grigorii Reinin) of that time was the Kunta-Yoga group around Vladimir Shuktomov (1957-1987) in Leningrad, who became legendary under the name of Tosha. (fig. 3)

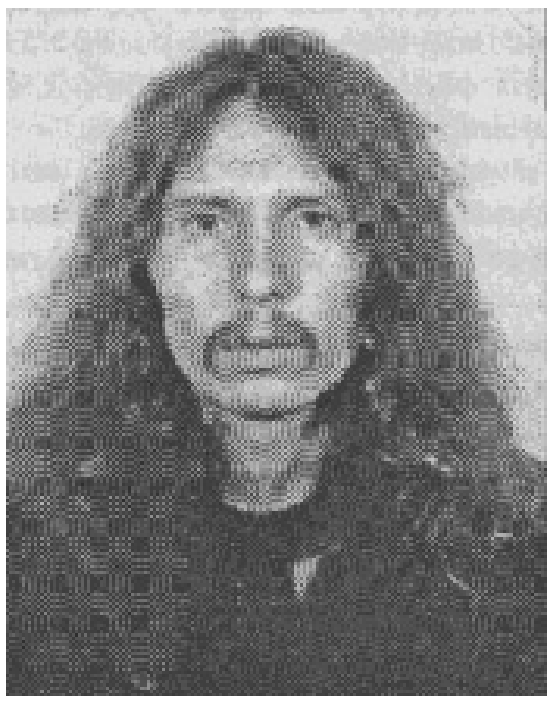

Fig. 3: "Tosha" (Vladimir Shuktomov (1957-1987))

In the late 1970s, when young nonconformists, rejecting the ideological rage of political dissidents, inspired by the rock-music of Boris Grebenshchikov, Viktor Tsoi and a hippie counterculture, ${ }^{84}$ the young student drop-out with psychic abilities Tosha, who had already practiced solitary survival-training in the tundra, developed a system of symbols and hieroglyphs (Dissa) which suppos-

84 Alexei Yurchak, Everything was Forever until it was no more. The last Soviet Generation (Princeton, 2006); Sergei Zhuk, Rock and Roll in the Rocket City: The West, Identity, and Ideology in Soviet Dniepropetrovsk, 1960-1985 (Woodrow Wilson Center Press, 2010). 
edly evoked magic powers in whoever was exposed to or controlled the psychotechnique of an extended consciousness. This system, he claimed, revived an ancient Indian yoga-technique, but in fact, his programmatic slogan "Only do what you really want!" 85 reminds one much more of Aleister Crowley's credo "Do what thou wilt!" A major task was to challenge the borders of life and death, to overcome the fear of death, thereby creating a perception of boundless power, invisibility, and the capacity of psychic healing. Tosha's magnetic personality offered a short-cut to ultimate liberation by accessing and controlling the occult powers of life and consciousness. Some twenty students of the faculty of chemistry, after going through some shock-therapy sessions, out-of-body experiences similar to shamanic travels, and spontaneous healing (one member was apparently cured of his tuberculosis), moved in together. When most of them were expelled from the Komsomol and lost their scholarships, and some of their apartments were searched by the KGB, they gave up their ordinary work and life and totally dedicated themselves to developing their project of self-transformation. Sometime in the early 1980s, a group of twenty-five students, including a family with a child, were ready to give up life in Leningrad to follow Tosha's suggested path anywhere. They moved first to a remote mountain area in Armenia where they made camp in the wilderness. Later, as conflicts emerged, some members dropped out or were chased away by the local police. Back in Leningrad, they were detected by the KGB, so the most dedicated ones went underground with Tosha. To escape arrest, he moved with a smaller group to the Karelian woods in the North. The experiment ended tragically. Denounced by local inhabitants, they had to flee again; some committed suicide, others were confined in psychiatric hospitals; only a few survived and emigrated. Tosha himself disappeared into the woods where he was denounced, arrested, released and finally found in a tent months after his death. The group became legendary, but the surviving members kept silent about their traumatic experiences and the occult symbols which supposedly caused this destruction. One of them, Sergei Beliaev, who emigrated and later returned to become a teacher of esoteric healing practices, wrote a memoir, which was translated into several languages, praising Tosha as a "Russian mystic." $" 86$

85 "Delai tol'ko to, chto ty deistvitel'no khochesh'!"

86 Sergei Beliaev, Ostrye kunty. Put' russkogo mistika (www.ark.ru); Tosha-russkii Budda (St. Petersburg, 2002); Tausha. The Life and Teachings of a Russian Mystic (Station Hill, Barrytown, New York, 2001). 


\section{East-West Connections}

Western New Age came to Russia in the 1960s by way of rock music, New Religious Movements, literature and personal encounters with prominent foreign leaders of the movement. The discovery of Transcendental Meditation with Maharishi Mahesh Yogi in India by the Beatles and other rock musicians in 1966, especially George Harrison, promoting the newly founded Krishna movement, and the official approval of the neo-Hindu guru Sri Chinmoy by UNESCO, all had their impact in Russia, where passionate student-fans spread their music by Magnitizdat and other inventive techniques and helped to organize a cult following. ${ }^{87}$ Some Russian rock musicians, like Boris Grebenshchikov, got involved with the New Age movement and later became mediators between East and West. The Peruvian-American anthropologist Carlos Castaneda's book Teachings of Don Juan, which had an enormous impact on the psychedelic New Age, was discovered by the esoteric biologist Vasilii Maksimov on a trip to Eastern Siberia in 1969 and immediately translated into Russian, as well as all the following volumes. ${ }^{88}$

Underground Krishna groups were founded in the early 1970s after the New York-based Indian founder of the International Society for Krishna Consciousness (ISKCON; Hare-Krishna, in Russian: Vaishnavy), Bkhaktivedanta Swami Prabhupada, visited Russia in 1971. Since in 1970 Sheila Ostrander and Lynn Schroeder, who had visited the first Soviet Congress of Parapsychology in 1968, stirred up considerable interest with their bestseller Psychic Discoveries Behind the Iron Curtain in the West, and American professional parapsychologists such as Stanley Krippner had established personal connections with Russian colleagues during trips to the Soviet Union, the founder of the leading Western New Age-Institution, the Californian Esalen Institute, Michael Murphy opened up a high-level connection by visiting Russia four times (1971, 1972, 1979, and 1980). The first two visits were privately organized, while on the last trip he came by invitation, indirectly, of the KGB, officially hosted by the faculty of American Studies at Moscow University. In 1971, Murphy entered the Soviet Union via Central European countries where he had previously met other esoteric scientists. Together with a group of friends, he settled in the central Moscow Intourist hotel and met scientists, psychics and parapsy-

87 See Knorre, Induizm, 410-420.

88 The first publication of Castaneda's works in Russia was edited by Viktor Pelevin, who, as a childhood friend of Rokambol', turned him into a literary persona (Volodin) in his novel Chapaev i pustota (1996). Maksimov, in Lebed'ko I. 
chologists for several months, until their visit threatened to have consequences for their Russian colleagues. ${ }^{89}$

To their surprise the enthusiastic American promoters of universal consciousness also discovered some differences, such as the strong impact of Christian mysticism and religious philosophy and a peculiar self-involvement with their own invention of an occultist vocabulary. ${ }^{90}$ Further encounters between Russian and American members of the New Age were facilitated by the US diplomat Arthur Hartmann, who, thanks to some personal contacts, was sympathetic to Esalen. When he became Ambassador in Moscow under President Reagan, he opened his house for numerous events and meetings with Russian Rock-musicians as well as psychic healers.

The reaction of the Russian occultic milieu to the embrace of American New Age was ambivalent. Forced into the isolation behind the Iron Curtain, aware of the highly selective and coincidental reception of Western sources, Russian intellectuals did not escape the general attitude of competition, as they

89 In the fall of 1979, Murphy attended the First Congresses on Psychoanalysis, 'Problems of the Unconscious', in Tbilisi. Other prominent members of Esalen joined him on visits to the Soviet Union in 1972 and 1979, met with Dzhuna Davitashvili, set up experiments with Russian psychics, later even in cross-continental telepathy, and visited scientists in Alma-Ata, Kazakhstan and Novosibirsk. Murphy's next visit in July 1980 took place in spite of frozen US-Soviet relations after the invasion of Afghanistan in December 1979, followed by the American boycott of the Olympic Games in Moscow. Murphy was invited as a featured speaker at the "International Conference on Sports and Modern Society," again in Tbilisi, with a talk on "The Future Evolution of the Body: Possibilities for Human Transformation Revealed by Sport and Other Disciplines." Murphy's talk was part of a US-Soviet section on "Sport and Maximum Human Performance." The Congress was attended by 1500 participants from forty-two countries. To their surprise the enthusiastic American promoters of universal consciousness also discovered, some differences, as for example the strong impact of Christian mysticism and religious philosophy and a peculiar self-involvement with its own invention of an occultist vocabulary. See Jeffrey J. Kripal, Esalen. America and the Religion of No Religion (Chicago, London 2007), 249-270.

90 Kripal, Esalen, 315-338. Peculiar terms only popular in Russia are for instance "psychotronics", "socionics", “egregor/ism", "torsionic field”, "noosphere”. After Murphy's visits to Russia, Esalen in 1980 founded the Soviet-American Exchange Program, which for sixteen years worked in favor of a Russian-American friendship, first publishing a series of English translations of Russian philosophical texts - from Vladimir Soloviev's "Smysl liubvi” to Nikolai Berdiaev's "Russkaia ideia." During the last tense years of Cold War, Esalen, with secret approval from Washington, since several government-officials had close connections to Esalen, "played its own part in the collapse of Soviet Communism" by their program of 'citizen diplomacy'. Thus, in the 1980s they sponsored the first American-Soviet satellite telebridge, and by way of citizen diplomacy several major encounters, such as the first visit of Boris Yeltsin to America in 1989. Kripal, Esalen, 
were torn between curiosity about similar movements in the West and selfcontained self-mythologizing. Visitors were often tested, provoked and challenged to prove their incompatibility compared to the maximum psychic powers and "hidden resources" of their Russian hosts. ${ }^{91}$ After the fall of communism, when many Russians travelled and the "imagined West" (Yurchak) was challenged by real encounters, disillusionment followed. And when the overwhelming wave of religious and esoteric sects from the West declined in the second half of the 1990s, and the Russian Orthodox Church reestablished its influence by creating a special section sektovedenie, ${ }^{92}$ most of the occult underground had ceased to exist. More than a few former leading 'masters' chose Orthodox Christianity as their belief, some dedicated themselves radically by becoming monks and disappearing into monastic life. Others chose emigration or established a transnational life between East and West for themselves.

\section{Conclusion}

Many of the ideas and experimental practices described here seem familiar to Western eyes and can be considered variants of the Western New Age. Michael Murphy was right in stating the similarities after his visit in 1980, in spite of his illusionary enthusiasm for an imminent universal transformation of consciousness:

There is a remarkable symmetry between Soviet and American interests in this field. The Soviet term 'hidden reserves', for example, is almost identical to the American 'human potential' as a guiding idea. Soviet concern with 'maximum performance' resembles American investigations of 'peak experience', Soviet studies of 'bioplasma', 'biophysical effects' and 'distant bioinformation interactions' resemble American studies of 'energy fields', 'dowsing', and 'remote viewing'. Training in 'psychical self-regulation techniques' is the Soviet equivalence of 'biofeedback' and 'stress management' programs in the U.S. In both countries these ideas have stimulated new approaches to education, healthcare, and sports. ${ }^{93}$

91 Rokambol' in Lebed'ko.

92 One of the most ardent fighters against occultism in and outside of the Orthodox Church is the diakon Andrei Kuraev (b. 1963) whose numerous books can be seen as almost encyclopedic collections of occult ideas and movements in post-Soviet Russia. See for instance Andrei Kuraev, Okkul'tizm v pravoslavii (Moscow: Blagovest, 1998).

Michael Murphy, quoted from the unpublished report (1980), In: Kripal, Esalen, 331. 
But the Soviet Union was a closed society. Although occultists were not political dissidents and therefore not prosecuted as fiercely, Russia still remained an authoritarian state. All social life was ruled by political repression, state control and ideological censorship. Esoteric attitudes in science were treated by the political leadership in paradoxical ways, since there were overlapping areas of interest which sometimes resulted in instrumental uses of the Occult by the State. It was perfectly possible to offer a course on Gurdjieff s Fourth Way in an officially sponsored institution, ${ }^{94}$ while at the same time people were being arrested for teaching yoga in their private apartments. All this made it very difficult for groups to communicate, build networks, and almost impossible to try out alternative life-styles.

As scientists looked into occult matters, many things that were considered occult now found a basis in science. Conversely, due to the secretive Cold-War politics of science, occult sciences could sometimes be legitimized by science no matter how fanciful they were. Finally, the system of central authority and ideology affected the underground itself by increasing fascination with the irrational. For some, the secrecy of the government created the potential for beliefs that things formerly incomprehensible might have scientific explanations, known or to be discovered. Others were attracted by things "totally alien, secret and incomprehensible," esoteric or mystic. According to the level and intensity of involvement, there were various directions in the Russian occulture of the Late Soviet period:

- For many people the occulture was no more than a transitory period in which they discovered various non-orthodox religious and spiritual teachings. After the fall of communism some of them turned either to traditional Russian Orthodoxy, as has been said, several former members of the occult underground later became monks and retreated to the numerous reopened monasteries, while some went back into the atheism or agnosticism which had shaped generations of Soviet peoples' minds.

- Others tried to find a fast and instant release from the omnipresent ideology and control by diving into esoteric knowledge and occult practices. By exercising their bodies and minds in extreme ways, including the use of drugs, they hoped for a breakthrough to ultimate individual

94 Mamleev, Okkul'tizm v Sovetskoi Rossii, 42-43.

95 Lebed'ko I., 21. 
freedom. Some of them failed to grasp the deeper levels of spirituality. ${ }^{96}$ Some of the most radical ones, however, failed tragically and were destroyed along the way.

- Only for a small group of people did occult or esoteric belief-systems determine their whole way of life. Some of these followed paths of traditional or Westernized Eastern religions, dedicating themselves to the Jewish Kabbalah, Sufi mysticism, Tibetan or Zen-Buddhism; others became teachers, healers or gurus in the New Age of Post-Soviet Russia.

Given the above mentioned parallels between East and West, a comparison of Russian occulture with basic elements of the Western New Age ${ }^{97}$ also reveals some significant differences, which, I argue, can be identified as specific features of Russia's New Age:

1. In Russia, esoteric knowledge was mainly transmitted by the intellectual elite. Highly qualified specialists provided direct access by translating a body of original classical esoteric texts, while in the West New Age was predominantly transmitted by popular culture.

2. Russian intellectuals, due to the geopolitical condition of the Russian/Soviet Empire, had the possibility of more direct connections with mystical teachings and traditions of the indigenous people of the East than in Western countries, by numerous personal contacts to spiritual teachers in Buriatia, Tibet, the Caucasus and Central Asia.

3. There were many research activities dealing with occult or paranormal phenomena within the official state-supported system of Soviet science which would be considered parascience in Western countries.

4. The most striking difference, however, is that eros and sexuality, which had become central issues of the Western New Age in the 1960s and 1970 s, played only a very marginal role in the almost exclusively maledominated Russian occulture. In spite of a few practical explorations in the realm of sexuality, the occult underground in Russia has been much more cerebral and much less corporeal than in the West. There has

96 Because of their urge for narcotic self-oblivion these people were called kaifisty (arab. kaif = idle). Mamleev, Okkul'tizm v Sovetskoi Rossii, 30.

97 I follow the definition by George Chryssides, "Defining the New Age," In: The Handbook of New Age, ed. Daren Kemp, James Lewis (Leiden, Boston 2007), 5-24. See introduction of this volume. 
been a greater emphasis on esoteric knowledge than on occult practice, more emphasis on mind and spirit than on the body.

The physical aspects included, for many, massive use of alcohol, which in fact worked, against any long-term psychological and spiritual transformation of consciousness. Despite often excessive self-experiments, there was a remarkable leaning towards asceticism, at least in the explicit statements of the male leaders. The ultimate goal was ridding oneself of the body, rather than unifying body, mind and soul..$^{98}$ In this one cannot help to find common traces with the general Soviet moral puritanism which was deeply rooted in the religious traditions of Russian orthodoxy, but also has elements in common with Russian Theosophy, even though it was dominated by females, and with various teachings of Eastern mysticism.

98 Even sex was practiced as body-control (Ivanov). 


\title{
AWAY FROM THE GLOBE. OCCULTISM, ESOTERICISM AND LITERATURE IN RUSSIA DURING THE 1960s- $1980 \mathrm{~s}$
}

\section{LEONID HELLER}

\author{
They spent a long time looking for us on the Globe, \\ We did not hide, we merely walked and walked \\ By different paths we left the Globe behind \\ And there, praise God, they stopped looking for us. \\ Grigorii Reinin, Songs of Lotus [Pesni Lotusa]
}

Before I begin my discussion let me make a few introductory remarks based on my previous research. ${ }^{1}$ The existing works on esotericism and occultism focus mostly on the second half of the $19^{\text {th }}$ century and the beginning of the $20^{\text {th }}$, and tend to simultaneously underestimate and overestimate the interaction of these traditions with the culture as a whole. They underestimate the interaction because scholars pay more attention to individual figures than to general trends. They overestimate because certain paranormal phenomena once constituted part of generally accepted scientific studies, then were dismissed as imaginary, then became staples of paracultural and/or religious activities, and today are once again being studied by serious researchers.

The difficulties facing the historian of ideas multiply for the historian of literature. Since ancient times the commonplaces, cosmological situations, and narratological motifs of esotericism have functioned inside the genre-creating modi of writing (the pathoi, to use the old terminology of Northrop Frye), i.e. utopia, satire, and exotic trips. I believe, for example, that the structure of the utopian idea is contingent on the tradition of "optimistic" occultism, among other things. I mean the assumption of the plasticity of the world, as well as the idea of a knowledge distinct from the "official canon" that envisions the possibility of radically changing and improving man, and the entire world through

1 For example “Ézotericheskie kody E. Zamiatina,” In: Larisa Poliakova, ed., Tvorcheskoe nasledie Evgeniia Zamiatina, vyp. XIV (Tambov: Izd. Tambov. un-ta, 2007); „Organoproektsiia: v poiskakh ochelovechennogo mira," Zvezda, 2006, no.11; "Ézotericheskie èlementy v sotsialisticheskom realizme," In: Rolf Fieguth, ed., Orthodoxien und Häresien in den slavischen Literaturen, Wiener Slawistischer Almanach, 1996, SBd. 41; "Mirozdanie Ivana Efremova," Vremia $i$ my, 1977, no. 24; Utopiia v Rossii (with Michel Niqueux) (St. Petersburg: Giperion, 2003, French edition 1995, German edition 2003). 
man. This knowledge enables the bearer to penetrate the secrets of the universe with the help of magic formulae; afterwards it can be used to subject the world to the will of "the one who knows." In this sense the utopianist is not offering anything that is not offered by the occultist or the gnostic, and this kinship is illustrated by the way in which many of the great utopian authors depend on the esoteric tradition, beginning with Campanella and Andreae and ending with Fourier. It is no accident that in Russia the utopian novel was born in Masonic circles.

Even more obvious are the links between esotericism and fantastic literature. One example of fantastic-esoteric literature is Jan Potocki's The Manuscript Found in Saragossa (Le manuscrit trouvé à Saragosse) (1794-1810), in terms of motifs one of the richest works of European literature, which talks not only about magic, the Kabbalah, heresy, occultism and its illusions, but also about the initiatory journey to the center of the world. In the caves and subterranean paths that link Europe to Africa and Asia we meet the members of an ancient community of Muslim sages, whose aim is the unification of all religions and peoples. There is no doubt: the Manuscript is in every regard an example of an esoteric novel, while its famous story-within-a-story narrative structure implements the esoteric principle of circles of secrets and corresponds to this principle's interweaving of motifs and topical patterns. I mention Potocki because both the novel and the myth that sprang up around him have had a more or less clear impact on Russian literature, beginning with Pushkin. Moreover, Potocki is important for our main topic: according to certain accounts, the publication of his novel in Russian translation and the release of Wojciech Has' film The Saragossa Manuscript in the Soviet Union in the 1960s were significant events for the "underground" (the unofficial cultural scene), ${ }^{2}$ while in the early 1980 s a poem by Viktor Sosnora, which was twice set to music by the guitar poets, became extremely popular. Its theme is the legend of Potocki's suicide with an enchanted silver bullet. ${ }^{3}$

Potocki's masterpiece can also easily be read as an attempt at "drawing the conclusions of the $18^{\text {th }}$ century," 4 a philosophical novel that synthesizes Enlightenment ideas, or as a novel about exotic travels and the relationship

2 Ian Pototskii, Rukopis', naidennaia v Saragose (Moscow: Nauka, 1968). See Stanislav Savitskii, Andergraund. Istoriia i mify leningradskoi neofitsial'noi literatury (Moscow: NLO, 2002), 112.

3 See Evgenii Slivkin, "Stikhotvorenie, naidennoe v Saragosse: funktsiia grammaticheskogo roda v stikhotvorenii Viktora Sosnory 'Ia ostavil posledniuiu puliu sebe...," NLO, 2008, no. 93.

4 See François Rosset, "Roman grotesque parce que roman-somme: Le Manuscrit trouvé à Saragosse de Jean Potocki, “ Colloquium Helveticum, 2004, 35. 
between East and West. But most importantly, in the novel the magical arts are presented with a healthy dose of irony; the gothic terrors are enveloped in the grotesque, and the reader is given the idea that he or she is reading a parody of occultism and that the author-a knight of the Maltese Order-is presenting the fruits of his own imagination as esoteric tradition. Whether this impression is correct or not is unimportant: Potocki teaches us to keep our distance when approaching the discourse of occultism and about occultism.

A recent collection of critical works about Russian literature in the first five years of the 21st century features two articles on the work of Iurii Mamleev, a leading figure of Russian esotericism. One researcher (Graham Roberts) reads his work exclusively through Lacan's theory of psychological archetypes, the other (Anne Coldefy), denies the psychologism of the same works, referring instead to their link with esotericism. ${ }^{5}$ The "occultness" or "esoteric character" of a given text, even if stated explicitly, is not compulsory for the reader, it does not have absolute meaning.

Science is constantly shedding concepts it has come to regard as false. Occultism, on the other hand, maintains its viability while incorporating scientific concepts, including those that are false, processing them and writing them into its own worldview. Occultism in art and literature, then, is related to them by the same dynamic correlation. It forms part of their history, and occultfantastic literature depends just as much on occultism itself as on literary evolution.

The limits of the period considered in this overview are set by two "critical moments," the post-Stalin Thaw and the collapse of the Soviet Union. This amounts to 35 years between 1956 and 1991, almost half of the entire Soviet era. The system opened itself to the past and the outside world hesitantly, but open it did, and that which had been proscribed and forgotten was discovered. The parallel culture made space for different forms of esotericism and occultism and for the activities of individual persons, groups and communities. ${ }^{6}$ But while this space was situated within the underground, it was isolated and for a long time noticed only very selectively. A few publications in the West (the

5 Graham Roberts, "CEdipe ou Frankenstein : vers une lecture lacanienne de la prose russe contemporaine”; Anne Coldefy, "Dans le miroir : sur la trilogie de Iouri Mamléïev," In: Hélène Mélat, ed., Le premier quinquennat de la prose russe du XXI siècle (Paris: IES, 2006).

6 See Birgit Menzel's chapter in this volume. It also provides a bibliography on this issue. 
journals Occultism and Yoga and Gnosis, the books of Iurii Mamleev and Arkadii Rovner) publicized the fact that there were active circles, first and foremost Mamleev's Iuzhinskii circle, and that there existed a certain "MoscowLeningrad metaphysical school", but no more than that. When Rovner, who had been publishing an esoteric journal in New York, sent out a questionnaire in 1979 with the aim of reviving this school, as the only positive phenomenon "in the field of contemporary Russian culture," Iurii Mamleev answered that "many of the authors belonging to this current preferred writing for more or less narrow elite groups." In the same questionnaire, Anri (Henri) Volokhonskii stated that there were three "different meta-social subcultures", Soviet, dissident and "metaphysical." Living as they were "on another plane," the esotericists did not consider themselves dissidents. Over the last ten years a number of memoirs on the life of the esoteric underground have appeared, providing us with a good depiction of the members of the movement, their energy and certain aspects of their creative activities, but unfortunately not of their work as a whole. The scale of what went on in this sphere is only now becoming apparent. It has not yet been described or evaluated as a whole, and its role within the literary process is poorly understood. ${ }^{8}$

Volokhonskii's thesis about three "subcultures" points to the heterogeneity of the parallel culture and the different function of its components. For example, few esoteric texts were circulated in dissident Samizdat (and only rarely published in Tamizdat, i.e. abroad). Most of what the esotericists produced remained confined to the brochures they published themselves and to the memory of eyewitnesses. Samizdat anthologies usually mention only two or three esotericists. A well informed history of $20^{\text {th }}$ century Russian literature, recently published in Poland, devotes many pages to Samizdat literature without mentioning the esotericists at all. ${ }^{9}$ The reason for this is obvious: most esotericists began to publish in the 1990s or later, which raises the difficult question of how to date the movement and establish its chronology.

The literary historian will have to complement Volokhonskii's thesis. Its secrecy notwithstanding, the esoteric scene interacted with all the other scenes. Daniil Andreev's The Rose of the World (Roza mira), one of the most outstanding manifestations of the new esotericism in Russia, circulated widely in Samizdat in the 1970s. And official culture was not monolithic either (our

7 See Gnozis VII-VIII (New York, 1979), 253, 254, 260.

8 I do not consider myself an expert on the esoteric underground, which is why a number of my remarks are hypotheses and mark areas deserving more thorough analysis.

9 Andrzej Drawicz, ed., Historia literatury rosyjskiej XX wieku (Warsaw: PWN, 2007). 
criterion for officialness is publication within Soviet edition structures). Two phenomena in censored literature show evidence of links to esotericism and will be discussed in this article: science fiction and the wave of mythological prose. The particularities of the science fiction genre sometimes made it possible to express the forbidden in official publications. Science fiction that ignored the proscriptions too blatantly ended up in Samizdat or Tamizdat. Mythological prose, on the other hand, was written by established writers and published in the usual channels.

If we are schematic we can imagine a certain "esoterosphere" within the literary field, which is divided, just like the field as a whole, into two parts-a Soviet part and an uncensored one. The border between these two parts is permeable, and each part comprises two sectors: on one side, science fiction and the mythological wave, on the other side, spiritual Samizdat and esoteric literature proper. These sectors function under different conditions and according to different rules, but they are in contact with each other. Their evolution looks approximately like this: the publication of Ivan Efremov's utopian fantasy Andromeda: A Space-Age Tale (Tumannost' Andromedy) in 1957 marked the beginning of the flowering of science fiction, which slowed down after 1968. The 1960 and 1970s were the high point of Samizdat (in their memoirs the esotericists insist that Samizdat existed at the end of the 1950s). The early 1980s saw the swell of a wave of literature that can be called mythological, and before the end of the 20th century members of the esoteric underground began to publish their books and carry out their activities in the open.

Let us have a brief look at the question of influence. During the Thaw it became evident that among the survivors of Stalinism were not just isolated disciples of Nikolai Fedorov and some anarchists, but also members of the esoteric societies of the 1920s. One who reports about the experience bequeathed to him by these people is Vladimir Stepanov. ${ }^{10}$ The Thaw also made it possible to identify their teachers, the esotericists of the early $20^{\text {th }}$ century. Gurdjieff and Uspenskii were especially important. Paradoxically, it was Soviet scholars themselves who pointed to still other trails that could be followed. Gothic novels proved to be a good source of information about alchemy, the Kabbalah, and occult traditions in the West. ${ }^{11}$ Naturally, acquaintance with the East fos-

10 See the interview with Stepanov in Vladislav Lebed'ko's book Khroniki Rossiiskoi San'iasy, vol. II. The first of the four volumes was published in 2000 by the Institut obshegumanitarnykh issledovanii, St. Petersburg. All volumes can be read online: http://sannyasa.narod.ru/, http://sannyasa.narod.ru/chronicles/vol2/stepanov.htm (accessed 8 August 2011).

11 For example, V.M. Zhirmunskii, N.A. Sigal, "U istokov evropeiskogo romantizma," In: Uolpol. 
tered a new form of esotericism. One of the first to tread this path was Efremov himself: his novel Razor's Edge (Lezvie britvy, 1963), about an inquiry into man's paranormal abilities and the mystical encounter between Russian and Indian wisdom provided a reminder of esotericism's link with India. Alongside the classics of the genre (Jules Verne, Herbert G. Wells, Jack London), translations of contemporary American science fiction furthered the evolution of science fiction in the Soviet Union. At the same time, the genre was also nourished by Soviet science fiction of the 1920s and by the fantastic tradition of Nikolai Gogol. A key influence was Stanislaw Lem, in particular his novel Solaris (translated into Russian as early as 1961) with its rich structure of irrational and metaphysical motifs, which can be read in a Gnostic vein. An important figure who emerged ten years later was Gabriel Garcia Marquez with his One Hundred Years of Solitude and after him, the entire Latin American school of "Magic Realism." The latter, together with Mikhail Bulgakov's The Master and Margarita, which was first published in 1966, established the coordinates for a new form of fiction, this time not science fiction, but "mythological fiction."

After the almost twenty-year break imposed by Stalin's censorship, the geologist and palaeontologist Ivan Efremov returned to Soviet literature the utopian and the space-trip novel in one book, Andromeda. In this book, he made the first attempt to create an integral world view, based on the concepts of scholars who would subsequently be labelled "cosmists"-Vladimir Vernadskii and Konstantin Tsiolkovskii-and on his own interpretation of history. In the novel we once again find motifs that belong to both traditions: the idea of the transfiguration of man through the attainment of physical and mental perfection; something akin to the mysticism of light (the tale is about the transformation of solar energy and an encounter with the dark forces of the cosmos); and the idea of a certain syncretic wisdom that mankind attains once it is unified. There is documentary evidence for Efremov's interest in esotericism: he was acquainted with the son of Nikolai Roerich, the creator of Living Ethics (Agni Yoga), a continuation of the Theosophy of Blavatsky, and with Blavatsky's system itself. While working on Andromeda he copied passages from Roerich's books, including quotations from dialogues between the characters. ${ }^{12}$

Although the adventures of the spirit take centre stage in Efremov's novel, he also sketches a narrative scheme for inter-stellar travel and encounters with

Kazot. Bekford (Walpole. Cazotte. Beckford). Fantasticheskie povesti (Leningrad: Nauka, 1967); Igor' Belza, "Posleslovie," In: Potocki, Rukopis', naidennaia v Saragosse.

12 See A. Iuferova, "Ivan Efremov i ,Agni Ioga ," Nauka i religiia, 1991, no.4. 
aliens, contrasting them with the scheme of the American space opera. In the sequel to Andromeda, the novel The Bull's Hour (Chas byka), Efremov synthesizes his experience of the cosmic and the communist utopia and of encounters with India-a synthesis of scientific and mystical knowledge. After the initial publication in 1968 the novel was banned and re-published only during Perestroika. It plays with the themes of David Lindsey's Voyage to Arcturus ${ }^{13}$ (which is mentioned in The Bull's Hour) and provides a comprehensive concept of the life of the universe. The main axiom is the infernality of all natural evolution, something akin to an inexorable principle of entropy, the reason for the pain and suffering of every living being, who is unable to escape from the mechanism of selection and the struggle for survival. Efremov calls the infernal tendency towards the increase of suffering, and consequently the evil in nature, "the arrow of Ahriman." An example of this is the tyrannical regime on the planet Tormance, a mixture of traits from the Soviet, Chinese, and capitalist systems. The path of initiation leading to man's inner enlightenment and liberation from animal feelings and instincts is identified as the only way to eliminate social problems and, over time, form a society without suffering. Subsequently, in a concerted effort similar to Nikolai Fedorov's "Common Cause", a pan-human project aimed at the ultimate abolition of death, Ahriman's arrow would be averted and the world improved. Here the Manichean motif of the eternal struggle between Good and Evil, the Gnostic idea of the suffering of all physical existence, and the esoteric approach to initiation and spiritual quest are combined with the alchemical faith in transmutation (the earthling starship is called the "Dark Flame") and the improvement of nature, as well as with the Hindu idea of karma.

Similar motifs can be found in the most monumental Soviet cosmic opera, Sergei Snegov's Men like Gods (Liudi kak bogi; a reference to H.G.Wells' novel). Its three volumes, crammed with adventures, encounters with a multitude of different worlds, and techno-magical transformations of time and space were published over a ten-year period between 1966 and 1977. It intertwines utopia, anti-utopia and futurology. The people of the future are allpowerful, like magicians. But unlike Efremov, Snegov introduces a hierarchy into his cosmic population: some of the inter-stellar races resemble snakes, others are invisible, still others look like angels; they are at different stages of development. There are inter-galactic giants, who are more ancient and more developed than the human race, and people are embroiled in a million-year

13 David Lindsay, A Voyage to Arcturus (London: Methuen, 1920; republished many times). Efremov took the name for the planet Tormance (torment + romance) from this book. 
long intergalactic war with the "evil-mongering demiurges," the incarnation of cosmic evil. Somewhere there is also a civilization that matches its powerful gods. The way in which Snegov's epic combines occult motifs is almost parodic, turning them into a genre stereotype.

The cosmic operas of Oles (Aleksandr) Berdnyk, the "Ukrainian Efremov", are hardly inferior to Snegov's work in terms of scale and the scope of adventurous fantasy. Written in Ukrainian, they were quickly translated into Russian, and became widely known. They presented an esoteric worldview without a hint of parody. Let us look at Berdnyk's tale about the end of Atlantis, The Heroic Deed of Vaivasvata (Podvig Vaivasvaty, 1965). The tyrannical state, led by very powerful magicians, unleashes a war against an island, the fairyland Shvet-Dvip, which is inhabited by immortals who are inter-stellar aliens from the planet Shakra. The immortals move matter by the power of thought, and it is they who gave fire and science to the inhabitants of the earth, two tools that the magicians from Atlantis turned into tools of power and oppression. As it turns out, the aliens oversee the development of inter-stellar civilizations. They defeat Atlantis, but except for a few chosen ones, Atlantis must perish, because it has transformed knowledge into evil and is able to harness the power of evil in order to drag other worlds in the same direction. "Every phenomenon has its higher manifestations in Infinity. Everything within the universe is connected. A feather dropping from a bird's wing can be heard as thunder in other worlds (...). Every movement, every thought and every action have an impact on the planet." This is because the force of nature's creation consists "in the magnet of unity, the Great Cosmic Magnet." Each atom, each cell of life has preserved the memory of unity. Each of them strives towards unification through evolution. "Primal substance itself, scattering into an infinite number of primary fractions, gives them the impulse to search for the lost unity." And reason, over the course of its development, tries to merge with matter, "to pour itself into the fiery primal substance, to vanish as a separate entity." ${ }^{14}$ It is already obvious that this story ostensibly paints an esoteric picture of the world, drawing on Theosophical and Hindu sources, and does so more openly than Efremov's work. Berdnyk's subjects, which recur in his other writings, are clearly esoteric: immortality, the interrelatedness of all elements in the world, a link between micro-and macrocosm, the striving for the reunification of all things into One, the Cosmic Magnet, and alien gods. In Sanskrit, the word Shakra, the name of the planet from which the aliens have come, means "the powerful" and is an epithet of the god Indra. Shvet Dvip is the island of the

14 Oles’ Berdnyk, "Podvig Vaivasvaty,“ Raduga, 1965, no. 10, 145, 146, 147. 
Light of the White Island mentioned in the Mahabharata and also described by Blavatsky. It is sometimes identified with the Tibetan Shambhala: a site in the centre of the Gobi Desert which is, according to legend, the place where the dwellers of Atlantis re-settled and ancient wisdom is preserved. ${ }^{15}$

We must add that Berdnyk developed his worldview in a labor camp after the war, just like Daniil Andreev. Berdnyk was arrested for the second time for his involvement with human rights causes. As a result, the print run of his main novel, The Star Warrior (Zorianii korsar; Zvezdnyi korsar, 1971) was confiscated, and it took twenty years for the novel to be translated into Russian. As a fighter for the national idea, Berdnyk was very well known in Ukrainian Tamizdat throughout the 1970s. He maintained contacts with India, Tibet and Roerich's heir, and for almost twenty years, until his death in 2003, he was leader of the movement for a Ukrainian Spiritual Republic, which was meant to be a member of the "Spiritual Nations" of the future. None of this was known in the 1960s, and Berdnyk's writings were often criticized, as their esoteric traits were interpreted either as evidence of a naïve idea about the future or as a declaration of his opposition to Marxism. ${ }^{16}$ This example clearly shows how views change as a result of shifts in temporal and critical perspectives.

The esotericism of Efremov or Berdnyk is easy to identify as it is selfevident. In other cases the indications are less obvious. For example, in Mikhail Emtsev and Eremei Parnov's story The World Soul (Dusha mira, 1963) the reader encounters a flower, created by accidental mutation, which begins to feed on the human energy field, keeps growing and eventually sucks into itself the souls of people, who lose their memory and self-awareness. The story is preceded by an epigraph from Goethe's neoplatonic poem Die Weltseele about life that separates from Unity for the sole purpose of returning to it. However, the collective soul is presented in a negative light, and the heroes of the story fight against its omnipotence. In another story by the same authors, nature is described as a "dog biting its own tail" (a variant of the Uroboros?): "Our distinction between the infinity of Micro and the infinity of Macro is artificial.

15 See, for example, Sergei Volkov, "Legenda o belom ostrove," Baikal'skaia zemlia, http://baikal. irkutsk.ru/index.php?rubr=13\&doc=13\#top1 (accessed 8 August 2011).

16 See for example Dmitrii Bilenkin, "Fantastika i poddelka" In: Fantastika 1965, vyp. II (Moscow: Molodaia gvardiia, 1965); Leonid Geller, Vselennaia za predelom dogmy (London: OPI, 1985), 177-178; Iwan Hrynioch, Oles Berdnyk - Utopist oder Charismatiker am Horizont des zweiten Jahrtausends des Christentums in der Ukraine (München: Ukrainische Freie Universität, 1981). 
(...) Nature is one and integral. (...) That means there must be a place or, maybe, a moment in which the two great infinities merge into one...."17

The conversation about contemporary science allows for recourse to esoteric formulae and motifs camouflaged as emotionally accentuated scientific discourse. Writers are either criticizing esotericism or (apparently) taking it seriously. We can assume that these vacillations are part of a strategy against censorship, especially when we know that later on Parnov would popularize occultism with the help of his status as a specialist in the struggle against occult prejudices. $^{18}$

References to Charles Maturin's gothic (and occult) novel Melmoth the Wanderer (1820) constitute an important leitmotif in the work of Gennadii Gor, a recognized master of intellectual fantasy. In his cycle of stories Uera, A Dweller in Two Worlds, The Electronic Melmoth (Ëlektronnyi Melmot, 1964), Larvef the Wanderer (Skitalets Larvef, 1966), The Great Actor Johns (Velikii akter Dzhons, 1966) we meet an alien from another planet who spends hundreds of years living on earth, travels through time and space many times and has the ability to be reincarnated. His immortality and his memory of his home planet mark time as contingent. Gor was the first Soviet writer to dare, in his story Ol'ga Nsu (1965), to remember Nikolai Fedorov with admiration and to call "great" his book on the "Common Cause". In the novel The Statue (Izvaianie, 1971) people turn into pictures and vice versa, as in the work of Maturin and Gogol, and one person amalgamates within himself different forms of memory, different characters and different viewpoints. Reality is not divided by strict lines; subject and object merge, as does the imagined and the real. The world is integrated and plastic, and it is plastic because it is integrated. We do not know about Gor's real attitude towards occultism, but his stories present the world as it could be seen by an occultist and a romantic.

The hero of Vladimir Savchenko's ${ }^{19}$ story Trial by Truth (Ispytanie istinoi, 1973), a scholar, is looking for a way to overcome the reductionism of science that is unable to embrace the world as a whole. According to his theory of world vibrations, the image of the world created in human consciousness, works like a model that can coincide in its oscillations with the "harmonics" of

17 Mikhail Emtsev, Eremei Parnov, Dusha mira, In: Uravnenie s Blednogo Neptuna (Moscow: Molodaia gvardiia, 1964), 57.

18 Eremei Parnov, Tron Liutsifera. Kriticheskie ocherki magii i okkul'tizma (Moscow: Izd. politicheskoi literatury, 1991).

19 Vladimir Savchenko is one of the writers who came to define the style and themes of Soviet science fiction in the 1970s. 
the environment, i.e. the universe. The energy accumulated inside consciousness is set free when the oscillations of the model and reality resonate, when "truth" is found. The scholar understands that "resonance-understanding" is attained outside theory and outside societal contingencies. He abandons his career and becomes a vagrant. And then comes the moment when he feels the impulse of the world rhythm. Then there is a flash and the scholar literally dissolves: "The environment took the Discoverer up into itself." ${ }^{20}$ Savchenko describes mystical experience and its limits, or rather, infinity, almost without covering his tracks-a rare case in Soviet literature, even in the science fiction genre. He presents this experience as gained outside the church and conventional religious forms, the preconditions being solitude and meditation. Without negating the rational image of the world, it demands the participation of all man's psychological and physical powers. The story lacks the motif of "passing on tradition" in order to be called esoteric in the direct sense of the word, but there is the figure of the Teacher, the birth of a knowledge which in the future will become tradition. ${ }^{21}$

Finally, if we look at mythological prose, let us put together a group "Tradition and History" from the stories about the cycles of time, the flowering and decline of ancient and exotic civilizations, earthly and cosmic versions of Atlantis, and the encounter between East and West. Naturally, under censorship the most important elements were kept under wraps. Contact with supernatural forces was subject to exposure and secret knowledge was not an open topic of debate. And yet many things were said, and the richness of the topics which science fiction incorporated in a comparatively short period, and which can be interpreted within the categories of esotericism, is astonishing. In the 1970s a practice from the 1920s returned to Soviet literature, with almost all mainstream writers trying their hand at fantastic literature. Leonid Leonov, one of

20 Vladimir Savchenko, Ispytanie istinoi, in Antologiia. Biblioteka sovremennoi fantastiki, vol. 25 (Moscow : Molodaia gvardiia, 1973), 329, 339, 336-337.

21 The vibration theory of the structure of the world and its implications, the theory of world rhythms and synaesthesia or correspondences (each one by itself, feelings perceive the cosmic vibrations which are one in their nature and therefore act together) had a strong impact on modernism and often went hand in hand with an interest in Theosophy (for Kandinsky, Skriabin, Kupka, Mondrian et al). See for example Serge Lemoine et al., eds., Aux origines de l'abstraction. 1800-1914. Catalogue de l'exposition (Paris: Réunion des musées nationaux, 2003). 
the Soviet classics, published in the almanac Fantastika 75-76 (i.e. 1975-76) a fragment under the title The Universe according to Dymkov (Mirozdanie po Dymkovu), a chapter from a metaphysical novel, colossal in concept and with strong Gnostic elements, in which post-revolutionary Russia turns into the arena for the struggle between the forces of good and evil, angels and demons, and the heroes wander about in search of a new religion. The novel finally appeared in 1994 Piramida (The Pyramid) and was acclaimed by Russian critics as one of the greatest literary achievements of the $20^{\text {th }}$ century.

The publication of Leonov's fragment coincided with the fashion for Latin American Magic Realism, books such as Hermann Hesse's The Glass Bead Game, the general excitement about Bulgakov's The Master and Margarita, and the sustained interest in topics that science fiction had raised but could no longer pursue after 1968. The result was that the realist canon made room for what we have called the "mythological wave." Myth, magic, extravaganza, and fantasy once again entered Russian literature in the works of Mikhail Ancharov, Vladimir Tendriakov, Chingiz Aitmatov, Vladimir Krupin, Vladimir Orlov, Anatolii Kim, Vladimir Makanin, Mikhail Kuraev and Liudmila Petrushevskaia. ${ }^{22}$ The wave lasted two decades and facilitated the entry, in the next century, of the grotesque and fantastic postmodernism of Viktor Pelevin, Tat'iana Tolstaia, Dmitrii Prigov, Anatolii Korolev, Andrei Kurkov and Vladimir Sorokin.

Naturally, not all the writers mentioned above use clearly recognizable esoteric motifs. But they are united by a will towards the poetics of myth, an understanding of myth as part of reality, a tendency to re-assess old myths and create new ones, and often also a striving to fit into the scope of the quest for a new faith that characterized the period of stagnation and the end of ideology. Makanin's The Forerunner (Predtecha, 1982) tells the story of a healer who, perhaps, laid the foundations for a new religion. In Aitmatov's novel The Day Lasts More than a Hundred Years (I dol'she veka dlitsia den', 1980), the new mythology of space flight meets the ancient myths of the Kirgiz people. In The Executioner's Block (Plakha, 1986), Aitmatov arguing with Bulgakov, brings up

22 For a discussion on post-Soviet occult revival as a phenomenon of popular culture see Valentina Brougher, "The Occult in Russian Literature of the 1990s," Russian Review 56 (1997), 111-24; Holly de Nio Stephens, "The Occult in Russia Today," In: The Occult in Russian and Soviet Culture, 357-376; Eliot Borenstein, "Suspending Disbelief: 'Cults' and Postmodernism in Post-Soviet Russia," In: Consuming Russia: Popular Culture, Sex, and Society since Gorbachev, ed. Adele Marie Barker (Durham: Duke University Press, 1999), 437-462; idem, "Survival of the Catchiest. Memes and Post-Modern Russia", Slavic and East European Journal 48 (2004), 462-483. 
the figure of Christ once again and sends his hero out to follow in His footsteps and to atone for the modern decline in faith, drug dependency, cruelty, and destruction of nature.

Let us now concentrate on one of the best and most characteristic works of the mythological wave: The Squirrel (Belka, 1980) by Anatolii Kim, a Russian writer of Korean origin. The framework of the novel is a message to the lost object of youthful love, written by a narrator whose childhood impressions are centered on a squirrel that has taken upon itself the role of his mother when the latter died of hunger in a Korean forest. The hero, brought up in Russia, develops an artistic talent and travels to Moscow to study; his life and the fate of his three artist friends provide the subject for the novel. The narration is organized in a non-linear way, with the action running ahead, looping, breaking into parallel episodes. This intricacy is motivated by the supernatural qualities of the hero (we never discover for sure whether these are real or imaginary), who is capable of transforming and transmutating himself. He explains:

I can from one moment to the next transform into a squirrel and back, take on human form during special moments that are marked by some strong emotion or fright. (...) These transformations happen to me while my bodily essence remains unchanged-it is just that my soul enters one or another human being, and not only human beings, but even a butterfly or a bee-and this doesn't depend on my will and happens totally unforeseen. (...) I can undergo hundreds of transformations in a single minute... ${ }^{23}$

When talking about his life, the hero describes this whirl of different consciousnesses. It happens that the viewpoint changes within a single paragraph and the narrating "I" moves from one character to another, sometimes fudging identification and forcing the reader to pay very close attention in order to guess who has stepped into the narrative focus. Such a stroboscopic perception is complex, but the hero's own perception is even more complex. Looking into the "mirror of time", he sees himself at different times, encounters incarnate allegories in the street-a flat man, death as an old woman-converses with the dead (his friend, who was murdered, is leading a life after death) and, what is most important, begins to see clearly the beasts under the human masks. Being a shape-shifter himself, he recognizes in the people around him the animals who make up their inner being. He sees fighting dogs in two editors at a publishing house who are embroiled in an argument, guinea pigs in the in-laws of

23 Anatolii Kim, Belka. Roman-skazka (Moscow: Sovetskii pisatel', 1984), 10. 
an acquaintance, and so on. In fact there are far more shape-shifters than human beings around. They are shown in their transformations, and sometimes in the coexistence of human and animal nature. Some of the animals are amenable, like the hero-squirrel himself, but the majority instils fear through its bestiality. They fight against human beings and convene congresses with the aim of organizing the takeover of the entire world. It turns out, then, that the main theme of this book, which is so permeated by love of nature and animals, is the struggle for humanity. The life of nature, the "green maya" of the Forest "is happening in the inviolable concord of mutual annihilation", we read at the end of the novel. "At this moment the thinking squirrel understood that man is called to proclaim the great replacement of death by immortality." Mankind will enter a new state, the "human ether." The world is renewing itself. "But the immutable higher precondition that must be fulfilled in order for death to transform into immortality is that everyone builds his life in a human fashion..."24

Other esoteric motifs, apart from transformation and transmutation, apart from life after death, not in the form of an eternal soul but in the form of a specter that is roaming the earth, are the very principle of the thinness of the material world, visible in the incessant leaps of a many-layered reality and the flickering of consciousness and appearance. The Fedorovian theme of immortality is present against the background of Eastern esotericism. It has been written about Kim that "the sequence of transformations his heroes undergo can be easily described in the categories of Buddhist philosophy," and his novel has been presented as the site of an encounter between Russia and the East. ${ }^{25}$ In contemporary Russian literature this novel about the sublimation of the beast in man constitutes probably the most successful variation on the topic of shape-shifters, and the one that is richest in meaning. ${ }^{26}$ Kim anticipated Pelevin's Life of Insects (Zhizn' nasekomykh) by ten years. In turn, The Squirrel is dependent on the poetic fantasy of Gor's metamorphoses, and the entire lineage that brought about Gor, a younger member of OBERIU-the line of Andrei Bely, Velimir Khlebnikov and Konstantin Vaginov. All the writers following this line had links to some forms of esotericism, from Anthroposophy to

24 Ibid., 269.

25 Lev Anninskii, “Posleslovie”, In: Anatolii Kim, Nevesta moria (Moscow: Izvestiia, 1987), cited after: Iurii Mamleev, Sud'ba bytiia, http://rvb.ru/mamleev/03philos/01sb/sb.htm\#9. (accessed 8 June 2011).

26 The analysis of The Squirrel was not included in my article on this topic, “Oboroten': iz natsional'nykh mifov," Slavic Almanac. The South African Journal for Slavic, Central and European Studies, 2006, vol.12, no. 2. 
Hermetism and neo-occultism. In their literary works they experimented profusely with stylistic and narrative conventions, and Kim is a worthy heir to this tradition.

As a rule, experiments of this kind in Russian literature of the 1960s-1980s reached the reader through Samizdat and Tamizdat. Many of them had no direct link to esotericism, but were preoccupied with comprehending literary models that had been suppressed in the Soviet system, from Bunin and Nabokov to Platonov and from Gumilev and Mandel'shtam to OBËRIU. And yet for many authors of both prose and poetry formal innovation, oneiric complexity of style, the prevalence of fantasy and the provocative infringement of linguistic decorum were directly related to a spiritual and metaphysical quest.

It is difficult to draw a definite line between these two areas, and exactly where it is drawn depends on the observer. If the reader so wishes, it is perfectly possible to read the guest from space in Andrei Siniavskii's story Pkhents (around 1964), who has become soiled by the grey everyday on earth, as an allegory to the Gnostic "inner man" who has been thrown into physical existence and remembers his heavenly origin less and less frequently. In Mark Kharitonov's story Ahasver (Agasfer, 1975) we can recognize the topical tradition of picturing the power of the (esoteric) book and its power over readers, and we might consider his longer story A Study of Masks (Etiud o maskakh, 1976) as a tract on the deceptiveness of the visible outside world. Both Siniavskii and Kharitonov became famous in Samizdat independent of any possible links to the esoteric underground. As mentioned before, a writer's decision to choose the fantastic or phantasmagoric convention automatically destroys the reliability of that which is depicted and affirms the multilayeredness of reality, thereby justifying an esoteric reading. This also applies to the greatest cult book of 1970s Samizdat, Venedikt Erofeev's abovementioned story- "poem" Moscow to the End of the Line (Moskva-Petushki). The characters constantly change their appearance, first assuming reality and then dissolving like spirits; among them we find servants of Evil. The delirious is on the same level as the real, the hero moves within real geographical space, but is surrounded by oneiric decorations. Everything in the book is motivated by the intoxicated state of the hero and his fellow travellers, but can just as successfully be interpreted as the description of a spiritual quest. The hero is in contact with another world and converses with the voices of mysterious beings only he can hear, with "angels", and when he keeps devising recipes for alcoholic drinks-magic potions-he behaves like a real occultist who is drawing up formulae for the study of secrets. 
Just like the "new sectarians" described by Mikhail Epstein ${ }^{27}$ and the heroes of Makanin's Forerunner and Aitmatov's The Executioner's Block, Venichka Erofeev is looking for a new religion. Aleksandr Zinov'ev, who recorded the ideological and intellectual, as well as emotional, atmosphere of the 1960s1970s, described the trial of the founder of such a religion. Below are a few sentences from the defendant's speech:

Our society engenders evil and is incapable of fighting it by official means. I wanted to teach people to oppose evil on their own initiative and with their own strength. (...) The beginning is a flash of inspiration-the realization that there is a certain (...) higher secret of being in which we are complicit and the state of suffering as a consequence of this. And then the state of compassion with that towards which the awareness of the higher secret is directed. For man, this state achieves the highest value in life, a value he is no longer prepared to exchange for any of the good things in the world. (...) My system is designed for a person living in our society, who is forced to go to work, to use public transport, to queue for things etc. The main goal of my system for training the body is to give the Soul the possibility of concentrating as fully as possible on its business. ${ }^{28}$

This scene, drawn with Zinov'ev's characteristic directness and strength, has echoes of the episode of the trial of Christ in The Master and Margarita, showing the new heresiarch as a conscious and rational fighter against the evil that is growing in the world. He is building a system for mastering the body and distinguishing between everyday physical routine and matters of the Soul. "Training the body" for the fight against evil, something that forms part of the tradition of the Manichean sects, places this system in the proximity of those mystics in the Soviet Union who are practicing yoga and Eastern martial arts for the sake of self-edification, meditation and spiritual perfection. From our point of view the figure of the heresiarch himself is important, too, as a contrast to the loners engrossed in dreams and "spiritual inebriation," such as Erofeev's Venichka. Venedikt Erofeev's poem constituted the height in Russian literature of an original frenzied style, which uses alcohol or psychological derangement as a means of entering the world of the spirit.

27 Mikhail Epshtein, Novoe sektantstvo. Tipy religiozno-filosofskikh umonastroenii $v$ Rossii (70-80 gg.) (Moscow: Labirint, 1998), engl.: Cries in the Wilderness (Philadelphia: Paul Dry Books, 2002).

28 Aleksandr Zinov'ev, V preddverii raia (Lausanne: L'Age d'Homme, 1979), 353-356. 
Vagrancy, seclusion, the collision with the darkest and most monstrous sides of life and its brutality constitute the range of themes evident in this original strand of spiritual fantasy, combined with gothic imagery, visions, and the untrammelled and out-of-order chatter of the "underground man" and the "ridiculous man." Metaphysics, including direct references to the Gospel, are framed in soteriological and apocalyptical tones. We find an early example of this style in the story Nobody: Or the Disgospel according to Maria Dementnaia (Nikto. Disangelie ot Marii Dementnoi, 1966) that was circulated anonymously. Its author, Nikolai Bokov, provided valuable comments in the appendix to the online Samizdat Anthology (Antologiia Samizdata). ${ }^{29} \mathrm{He}$ writes that in the Soviet world, "in a system in which only death is infinite" a new Christ is not possible, because what the spirit encounters is emptiness. "There are references, perhaps, to Buddhism or to the Kabbalah (as found by the translator of the story into English). This is not what is important. What is important is that both God and your neighbour are no longer there, there is only emptiness, and emptiness you must love." The remark of the Western translator, who was puzzled over which esoteric school the author followed, is a measure of the current distance between explanatory reading and the activity of the writer. When the journal Gnosis invited Bokov to fill in a questionnaire on the "metaphysical school" he replied "I am not sure that it existed. What existed were 'mutual influences'." Almost in the spirit of Viktor Shklovskii writing about Andrei Bely's Anthroposophy, Bokov added: "And anyway, why 'metaphysical'? A literary school is characterized by language, and 'metaphysics' or whatever else it may be can be an aesthetic idea, a theme, but it nevertheless remains the cart and cannot become the horse." 30

Spiritual fantasy provides an opening to postmodernism. Egor Radov's novel The Snake Sucker (Zmeesos, 1992), which was typical of the first stage of Russian postmodernism opens with the foreword of a prominent critic who affirms that

[In postmodernism] literature stops being art, turning into the glad tidings about another form of being, and subsequently into an unmediated magical act that transforms the world, returning it to its Origins. The

29 Published in the revue Grani, 1971, no. 82. See Nikolai Bokov, Nikto. Disangelie ot Marii Dementnoi (1966), In: Mark Barbakadze, ed., Antologiia Samizdata, http://antology.igrunov.ru /authors/bokov/1159693106.html (accessed 8 August 2011).

30 Nikolai Bokov, "Otvet na anketu," Gnoziz VII-VIII (New York, 1979), 257. Compare Viktor Shklovskii, „Andrei Belyi“ in his Gamburgskii shchet: stat'i, vospominaniia, èsse (Moscow: Sovetskii pisatel', 1990), 212-239. 
Gospel according to Sasha, Dmitrii, Valeriia, Egor (Sokolov, Prigov, Narbikova, Radov...). ${ }^{31}$

Such affirmations should not be understood too literally. Nevertheless they are characteristic. While the creative manner motivated by the spiritual quest of the underground writers acquired the status of a trademark of an artistic movement, this happened only in the second half of the 1980s and the 1990s, during Perestroika and the beginning of the post-Soviet era.

This was the time when Russian readers first came into unmediated contact with émigré culture and with works that had been forcibly excluded from literary history. Specialists in magical and mythological topics returned, such as Pavel Muratov and Aleksandr Kondrat' $\mathrm{ev}^{32}$ The researcher will find a fount of esoteric themes in the work of Sigizmund Krzhizhanovskii. And we must mention Aleksandr Barchenko, a doctor who began researching paranormal phenomena in the 1910s. He engaged in telepathy, collaborated with the famous physiologist and psychologist Vladimir Bekhterev, and in the early 1920s sought traces of ancient civilizations in the Russian North..$^{33}$ Before 1917, he wrote several occult short stories; his multi-volume novel Doctor Black (Doktor Chernyi) $)^{34}$ was published only in 1991, and is still awaiting its researcher. The prototype for the novel was Barchenko's guide to the esoteric sciences, Petr D. Uspensky, who was also the author of occult tales (some of which might have inspired Nabokov). ${ }^{35}$

From the standpoint taken in this article, the most important event of that time is the process by which the esoteric underground left the unofficial sphere behind. Only a short time ago, the conviction that "behind the iron curtain," literary occult motifs had disappeared, because there they were "not tolerated, just as religious and philosophical themes on the whole", was generally accepted. ${ }^{36}$ But religious and philosophical quests did not disappear despite attempts at suppressing them and were pursued in different and sometimes

31 Oleg Dark, "Strashnyi sud Egora Radova," in the volume Egor Radov, Zmeesos (Moscow, Tallinn: Gileia, 1992), 4.

32 See Aleksandr Kondrat'ev, Belyi kozel. Mifologicheskie rasskazy (St. Petersburg: Golike \& Vilborg, 1908); idem, Satiressa. Mifologicheskii roman (Moscow: Grif, 1907); idem, Na beregakh Yaryni. Demonologicheskii roman (Berlin: Mednyi vsadnik, 1930); Pavel Muratov, Magicheskie rasskazy (Moscow: Delfin, 1922); idem, Egeriia (Berlin, St. Petersburg: Grzhebin, 1922).

On Barchenko's life and his ties to the Cheka see Oleg Shishkin's chapter in this volume.

See: Aleksandr Barchenko, Iz mraka. Roman, povest', rasskazy (Moscow: Sovremennik 1991).

See note 55 .

D. Klenovskii, “Okkul’tnye motivy v russkoi poėzii nashego veka,” Grani, 1953, no. 20, 76. 
extreme ways. What is known about the esotericists does not tally with conventional ideas about life in the Soviet Union. Aleksandr Zinov'ev, Venedikt Erofeev and 'alcoholic' or 'frenzied' literature revealed the life of either straightforwardly marginal figures, new sectarians, or simply people who drown their everyday hopelessness in alcohol. But we are talking about a milieu that had a common network in which experiments with drugs, alcohol, training of the body (above we mentioned the practice of yoga and martial arts) and sex were defined by spiritual goals-experiments that distinguished Volokhonskii's metaphysical subculture or, to use contemporary terminology, the "schizoid paradigm." ${ }^{37}$ In brief, the appearance on stage of the esotericists retrospectively changed the picture of the Soviet era, as well as the image of the Samizdat milieu and the idea of how the culture functioned.

Beside Arkadii Rovner and Iurii Mamleev, whose work often reached the readers and was held in high esteem by the critics, who called them the "misty," ${ }^{8}$ there appeared the names of already two generations of adherents of secret knowledge: Evgenii Golovin, Vladimir Stepanov, Anatolii Arlashin, Valentin Sidorov, Valentin Provotorov, Vitalii Akhramovich, Igor' Kalinauskas, Sergei Riabov et al. ${ }^{39}$ Many of them are introduced in Vladislav Lebed'ko's book of interviews. The majority of them were writing in the 1960s and '70s, and continue to write today. In terms of quantity we are looking at an impressive body of works that have been published since Perestroika, but also include works that were written much earlier. This body of works is heterogeneous, including a large number of translations and also pragmatic texts-manifestoes and treatises which expound doctrines and behavioral rules without belletrization and poeticization. There is also a rich body of criticism and essays, and much documentary literature in the form of memoirs, travel logs etc. Finally there is belles-lettres, where the small forms play the main role, as in fairy tales and parables. The genre boundaries are not absolute. Andreev's tract The Rose of the World (Roza mira) can be read as a poetic work-the poetic and shamanistic qualities of his terminology and intonation are beyond doubt. But it is also clear that esoteric literature is differentiated and, while changing the scale,

See various interviews in Vladislav Lebed'ko's Khroniki Rossiiskoi San'iasy. idem, Tumany chernykh lilii (Moscow: Enneagon Press, 2007); Valentin Sidorov, Sem'dnei v Gimalaiakh (Moscow: Sovremennik, 1986); idem, Znaki Khrista. Rasskaz o dukhovnoi Rossii (Moscow: Kniga, 1992); Igor Kalinauskas, Zhit' nado! (St. Petersburg: Meduza, 1994); idem, Naedine s mirom (St. Petersburg: Liki kul'tury, 2002); Vitalii Akhramovich, "Skazki dlia magov", http://eurasia.com.ru/mystery/ahromovich/ (accessed 8 August 2011). 
reproduces the functional and genre structure of literary production overall. A case in point: the poetry of the esotericists, previously little known or not known at all, or incomprehensible outside the circle of the initiated (to give an example, hardly anyone recognized the esoteric allusions in the openly published poetry of Valentin Sidorov), has found special publishing outlets in the form of retrospective collections. ${ }^{40}$ Almanacs of "free Russian poetry" are now appearing as part of the project The Mystery of Infinity (Misteriia beskonechnosti). ${ }^{41}$

This entire continent of literature and esotericism has not yet been much explored, and in the period that interests us it consisted of an archipelago of islands under water. When we look back we can see interesting achievements among them, for example some of Valentin Provotorov's poems or the fables of Vitalii Akhramovich, who died in 1995 and was a talented stylist whose circle also included the author of fantastic prose Viktor Pelevin. In this sense the esoteric milieu continues to nourish literature today, one example being Vladimir Sorokin's popular trilogy Ice (Led, 2002), The Path of Bro (Put' Bro, 2004), and 23000 (2005). But we must also note that this trilogy does not introduce any fundamentally new motifs into the selection of science fiction and mythological fantasy themes mentioned above: there are space aliens, the arrival of a new man, supernatural abilities, transformations, initiatory wanderings. What drives the development of the genre is not new motifs, but a livelier narration. The same is true for the poems which can be classified as esoteric: it is difficult to consider them a new phenomenon in Russian poetry. Most of the time they are illustrative and express more or less provocative imagery, recognized as symbolic, within a traditional form of versification.

Люблю я пустынные гулкие улицы

из домиков ярких, узорчатых труб,

где в каждом за ставнями в кресле сутулится какой-нибудь вежливый, маленький труп.

Валентин Провоторов

I love deserted resounding streets of bright houses, patterned pipes where in each behind the blind in an armchair huddles

some small, polite corpse.
Нам нравится эстетика дома престарелых, Фейерверк проклятья разорванных губ, Когда рыдает на свалке опустелой Забытый смертью раскрашенный труп...

Евгений Головин

We like the aesthetics of old peoples' homes fireworks of curses from parched lips When on the deserted dump sobs

A colored corpse who death forgot.

40 See Sergei Riabov, ed., Unio mistica. Moskovskii ėzotericheskii sbornik (Moscow: Terra, 1997).

41 The project "Misteriia bezkonechnosti", http://eurasia.com.ru/mystery/mamleev.htm. (accessed 8 August 2011). 
Today we see the landscape of esoteric prose in the 1960s-1970s as dominated by Rovner and Mamleev. A characteristic feature of the new situation is that the old masters are very active, as if making up for the years they had to spend underground. They write, publish their own work and that of others, and are present in the mass media and the internet. Rovner is directing the Institute for the Cultivation of Inner States, ${ }^{42}$ and in recent years has published, beside a two-volume collection of prose, more than a half dozen novels, essays and memoirs. ${ }^{43}$ Mamleev is even more active: he founded the literary school of "metaphysical realism" and managed to arrange a special section on it in the Writers' Union of the Russian Federation. Mamleev is now considered a cult author; it seems that his role in Russian literature is significant. His stories and novels-the first of which, The Idlers (Shatuny, 1966), brought him fame and became the basis for a trilogy on which he worked until recently ${ }^{44}$-are populated by astonishing, monstrous characters, each of which passes through a terrible initiation and often undergoes a metamorphosis. They kill, rape, cannibalize and devour themselves. The physical world is holding them captive, death allows them to free themselves from the body, to break through into another world and the next incarnation. Mamleev combines Hindu teachings with the Gnostic perception of physicality as evil and a very strong experience of the "infernality" and illusory quality of the world. He is being compared to the authors of the Gothic school of horror tales, E.T.A. Hoffmann and Edgar Allan Poe. "It seems that the monstrous characters in the story "Tough Encounters" (Krutye vstrechi) came straight out of the etchings of Hieronymus Bosch and Francisco Goya: a body with two heads, a living corpse, a manbear." ${ }^{\prime 5}$ People are fond of comparing Mamleev to the Latin American Magic Realists. Distancing himself from the latter, Mamleev in an interview explains his poetics as follows: in his work he used.

not the genre of myth but the genre of traditional prose, but I infused the realia of this prose with "metaphorical fabric". Actually this is a new

42 See the site of the Institute: http://www.sostoyanie.ru/ (accessed 8 August 2011).

43 Arkadii Rovner, Izbrannaia proza, vol.1-2 (Moscow: Mif, 1998); idem, Veselye sumasshedshie ili Zaraiskie besedy (Kaunas: Gera Diena, 1998); idem, Pelenaia predka (Moscow: Nomos, 2005); Legkaia substantsiia sostoianii (Moscow: Zolotoe sechenie, 2009); idem, Vspominaia sebia. Kniga o druz'iakh i sputnikakh zhizni (Moscow: Zolotoe sechenie, 2010).

44 Apart from Idlers, the trilogy consists of the novels Wandering Time (Bluzhdaiushchee vremia, St. Petersburg: Limbus-Press, 2001) and The Other (Drugoi, Moscow: Ast, 2008).

45 Roza Semykina, 'Kto est' ia?' Metafizicheskaia antropologiia Iuriia Mamleeva," Oktiabr', 2003, n. 3, http://magazines.russ.ru/october/2007/3/se9-pr.html (accessed 8 August 2011). 
genre in which into the "body" of a realistic tale I introduce something metaphoric, metaphysical, symbolic. The result is a synthesis. ${ }^{46}$

To the literary historian it is clear that Mamleev's formula describes not a new genre, but an established tradition in Russian prose that is evident in the work of modernist writers such as Fedor Sologub. In 1922 Evgenii Zamiatin, a student of Fedor Sologub and Andrei Bely, advocated a new literary current he called "synthetism," which he defined as "a synthesis of fantasy and the everyday." "Almost forty years later Andrei Siniavskii would finish his famous essay on overcoming Socialist Realism with hidden quotations from Zamiatin, refer to Hoffmann, Goya, Dostoevsky, and Marc Chagall and confess: "I put my hope in fantasmagoric art with hypotheses instead of goals and the grotesques instead of descriptions of everyday life." 48 There can be no doubt that Siniavskii's three-legged visitor from space, the half-plant and half-man Pkhents, is a very close relative of Mamleev's monsters. The onereic characters of Moscow to the End of the Line with their changing contours are close to them as well. Even more obvious than the link to the tradition of Sologub, Bely and Zamiatin is Mamleev's relation to the tradition of the Russian absurdists Kharms and Andrei Platonov, which had a direct impact on the frenzied writers of the 1960s1970s. Mamleev, Rovner and other esotericists never tire of stressing the need to break free from the prison of rationality; this is the reason for their interest in alogisms, the absurd, the grotesque, the creation of new forms through mutation and accidental hybridization.

Mamleev insists, especially in his last public statements, ${ }^{49}$ that the source of his "metaphysical realism" is the encounter between two traditions, Russia and the East. He was enthusiastic about Kim's Squirrel, as proof that "life in the $20^{\text {th }}$ century is not entirely cut off from the bottomless Source of Eastern Wisdom." ${ }^{50}$ Let us not forget, however, that his metaphysical realism is also heavily indebted to West European Gothic and romantic phantastic tradition. In my view it is even more interesting to consider Mamleev's extreme schizoid physi-

46 Iurii Mamleev, "Metafizicheskii realizm pisatelia-optimista. Beseda s A. Voznesenskim," Nezavisimaia gazeta, 2000, May 25.

47 Evgenii Zamiatin, "O sintetizme“ (1922), in idem: Sochineniia (Moscow: Kniga, 1988), 416.

48 Andrei Siniavskii, "Chto takoe sotsialisticheskii realizm? "In: Fantasticheskii mir Abrama Tertsa (New York: Mezhdunarodnoe literaturnoe sodruzhestvo, 1967), 446.

49 Compare the web-resource "Arctogeia": http://www.arctogaia.com/public/mamleev (accessed 8 August 2011)

50 Iurii Mamleev, Sud'ba bytiia, http://rvb.ru/mamleev/03philos/01sb/sb.htm\#9 (accessed 8 August 2011). 
ologism (and, to a lesser degree, that of Rovner) in the context of the avantgarde experiments in art contemporary to him-Vienna Actionism, body art, and performance. These movements peaked right at the turn of the 1960s1970s and, in turn, can be traced back to Dadaism and often constituted Western artists' answer to the philosophical and aesthetic challenge of the East. In other words, such a position was not unique to Russia, and many of the things that appear to be a direct dialogue between the Russian esotericists-and Russian culture-with the East, are in fact an indirect argument with the West. ${ }^{51}$ It is no accident that almost everything that is listed as a specific trait of the work of esoteric authors-eclecticism, abundance of quotation, absurdism, oneirism, the aesthetics of cruelty and monstrosity, the struggle against norms-is at the same time construed as a postmodern quality, while the "schizoid paradigm" forms part of the more general paradigm of postmodernism. ${ }^{52}$

Shklovskii stated in 1924 that Bely in his prose was overcoming Anthroposophy, while fifty years later Nikolai Bokov called "metaphysics" in literature a cart that had been put before the horse. They both pose the same question about the interrelation of ideology and aesthetics, i.e. esoteric ideas and the poetics of esoteric works of literature. In other words, does the turn towards esoteric motifs and themes entail distinct poetic and formal consequences or do they function independently of their poetic realization? In the introduction I gave a partial answer: the fantastic, oneiric, fairytale, or more broadly, deformative mode of the writing clearly corresponds to the principle of "maya" that is characteristic of esotericism, i.e. an unsteady or plastic reality. Is that all? Let us move away from fantasy-and from poetry, too, which requires slightly different methods of analysis-and turn to our experience of reading those prose writers of the early $20^{\text {th }}$ century who were interested in esotericism (Bely, Briusov, Sologub, Kuz'min, Muratov et. al.), risking an approximate, by no means exhaustive description of "esoteric poetics". It is characterized by

- intellectualism (the clash between acknowledged and new or marginal concepts of the makeup of the world, a comedy of ideas);

- affectedness (the construction of situations that are attractive or very repulsive, with both of these cases requiring an emotional and aesthetic evaluation);

51 See i.e. Leonid Heller, "The Russian orientalism: an encounter with the West", In: Emanuel Waegemans, ed., Russia and the West: Missed Opportunities, Unfulfilled Dialogues (Brussels: Contactforum-Universa Press, 2006).

52 See Natalia Tamruchi, "Bezumie kak oblast' svobody," NLO 2009, no. 100. On the "schizoid paradigm" in painting see Viktor Tupitsyn, Kommunal'nyi (post)modernizm. Russkoe iskusstvo vtoroi poloviny XX veka (Moscow: Ad Marginem, 1998). 
- mythologization of rhetorical commonplaces and tropology: play with images derived from various myths, the investment of characters and situations with mythological potential, heroization (even in the paradoxical scale of the everyday, in inverse order);

- the principle of descriptive transgressiveness and provocation;

- a highly complex composition as a result of the struggle against conventions on the narrative level, too: multiplication of plot lines, deliberate discontinuity, involved chronology, shifts in and blending of viewpoints (the implementation of the principle of metamorphosis);

- stylistic tendencies: stylization (the reproduction of speech patterns of different eras or different discursive situations), multilingualness, parody and humor as devices for "making strange" (still the same action against the usual norms, the liberation of "discourse").

The majority of these particularities (though not necessarily simultaneously and to the same degree) is also inherent to the work of Mamleev, Rovner, Erofeev, Kim and the Strugatskii brothers, and it is a curious coincidence that they are all distinguished by Leonid Leonov's manner in The Pyramid (Piramida). One can of course point out that the writings of Efremov or Berdnyk cannot be described in these poetic terms. But this is natural as they function in the didactic mode and allegory that is characteristic of utopian discourse. It is more difficult to understand why Petr Uspenskii, in his time, chose poetic reductionism, a simple plot, and a direct style for his occult stories. ${ }^{53}$ One possible reason is that narrative situations such as scientific discovery, the megapolis, and time travel that had not yet been cultivated but would soon become staples, provided the required distance by making strange. Another explanation is also possible: against the background of normative narration, minimalism is perceived as a transgression-this is the style of Daniil Kharms, an adept of the study of secrets and thoroughly acquainted with the writings of Uspenskii. Sometimes the younger OBËRIU-writer Gennadii Gor approached a similar style.

We have seen that esotericism and occultism provide inspiration for literature in very different situations; and we have also seen that the territories of the

53 Petr Uspenskii, Razgovory s d'iavolom. Okkul'nye rasskazy (Petrograd: Izd. Brenchaninova, 1916); his Kinemodrama (ne dlia kinematografa), Okkul'tnaia povest' iz tsikla idei 'Vechnogo vozvrashcheniia' (Petrograd: Izd. Brenchaninova, 1918); another version of this novel was published in English as The Strange Life of Ivan Osokin (London: Stourton Press, 1947); see in Russian: Strannaia zhizn' Ivana Osokina (St. Petersburg: Komplekt, 1995). 
esoteric space in Russian literature that we have been able to identify do not just communicate with each other, but constitute an entity composed of complex elements. They are served by approximately the same complex of motifs and topics. But it is not just conditions that are changing, but also the vectors of writers' activities. After leaving Stalinism behind, and independent of where they were standing, most adepts of esotericism were busy searching for individual or small-group alternative solutions against the dominant, compulsory way of thought, life, and art. Approximately since the late 1960s they were influenced by several factors simultaneously: the turn towards nationalism of part of the party establishment, Orthodox Christian dissent, the encounter with the East and, paradoxically, the influence of such Western revilers of liberal culture as Julius Evola and René Guénon. As a result, many esoteric currents experienced a significant shift to the right. Followers emerged for the ideas of Grigorii Klimov, the author of a book about Satan's power over the world. ${ }^{54}$ Evgenii Golovin (for a short time) declared himself Reichsfuhrer of the "Black Order of the SS," while he and his student, Aleksandr Dugin, both took part in the formation of National Bolshevism and resurrected Eurasianism, adding a mystical component to both. Mamleev would create the Patriotic Teaching of Eternal Russia (Patrioticheskoe uchenie Vechnoi Rossii) and, having found support from the younger generation in the person of Dugin, become the leader, within the Eurasian movement, of the project The Mystery of Infinity and, more generally, of the cultural activities designed to cast Russia in the role of the "spiritual centre of the world." 55

Mystical wanderings became entwined with Russian nationalism, became equal to an obtrusive obsession with identity,-it seems that this evolution is what nowadays separates many Russian esotericists from the world of The New Age, which is based on the principles of tolerance and universalism.

54 See for example: Grigorii Klimov, Kniaz' mira sego (New York: Izd. Rossiia, 1972). Klimov's concept is radicalized to the limit by Vladimir Istarkhov, Udar russkikh bogov (Moscow: Institut èkonomiki i sviazi s obshchestvennost'iu, 2000).

55 See for example: Elena Seifer, "Naedine s Rossiei Iuriia Mamleeva: 'Ia shel ot ada k raiu...," Gazeta kz, 4.05.2009, http://articles.gazeta.kz/art.asp?aid=131197 (accessed 8 August 2011). 


\title{
GUESTS FROM OUTER SPACE. OCCULT ASPECTS OF SOVIET SCIENCE FICTION
}

\author{
MATTHIAS SCHWARTZ
}

\begin{abstract}
Many things in our science and techniques are secret, a whole lot of forbidden themes exist (...). Does this mean that we don't have to show people things which are at the limit of secrecy? No, in each question, even in the most complicated one, we can find the right way that the reader can feel how a task is solved, we can avoid vulgarization, can show how an idea is born. An idea never can be secret, even if the result of an idea is kept secret. (Boris Liapunov, 1951) ${ }^{1}$
\end{abstract}

\section{Introduction}

Although the topic of my article has long been neglected in the field of cultural studies, science fiction (SF), or, as it is called in Russian: scientific fantasy (nauchnaia fantastika) is of fundamental significance for the establishment of occult thought in Soviet and post-Soviet Russia: It is precisely this genre that offered one of the few areas in the Stalin period and afterwards in which it was possible to articulate occult thoughts and practices that differed from official party ideology. ${ }^{2}$ This astonishing phenomenon was facilitated by two circum-

1 Boris Liapunov at a discussion about SF in the Writers Union in April 1951, see Russian Archive of Literature and Art (Moscow, abbr. RGALI), f. 631, op. 22, ed. 41, 1. 41; The article is for the most part based on the research results of my dissertation, see Matthias Schwartz, Expeditionen in andere Welten. Sowjetische Abenteuerliteratur und Wissenschaftliche Fantastik (Berlin, 2010); I thank Diana Aurisch for polishing my English.

2 The term "occult" I use in the sense the editors have defined it, cf. introduction to this volume; For a general survey of Soviet science fiction, see Darko Suvin, "Significant Themes in the Criticism of Soviet Science Fiction to 1965, with A Selected Bibliography," Extrapolation 11:2 (1970), 44-52; idem, "The Utopian Tradition of Russian Science Fiction," The Modern Language Review 66:1 (1971), 139-159; Boris Liapunov, V mire fantastiki. Obzor nauchnofantastchčeskoi i fantasticheskoi literatury (Moscow, 1975); John Glad, Extrapolations From Dystopia. A Critical Study of Soviet Science Fiction (Princeton NJ, 1982); Leonid Heller, Vselennaia za predelom dogmy. Razmyshleniia o sovetskoi fantastike, (London, 1985); Patrick L. McGuire, Red Stars. Political Aspects of Soviet Science Fiction (Ann Arbor, 1985); Rafail Nudelman, "Soviet Science Fiction and the Ideology of Soviet Society," Science-Fiction Studies 
stances. On the one hand, after the First Soviet Writers' Congress in 1934, SF was subordinated to the realm of children's and popular scientific literature, a fact which meant less ideological pressure than in the field of "serious" literature for grown-ups. On the other hand, its focus on the "fantastic" possibilities of scientific progress predestined the genre to speculative border crossings that were open for para-scientific and occult thoughts and world models.

One of the most prominent, if not the most central, "medium" for occult belief systems in the Stalin period was the fictional engagement with extraterrestrial life forms and energies, which had been discussed under the label of "Guests from outer space" since the beginning of the 1950s. In the so-called Thaw period under the rule of Nikita Khrushchev, the engagement with close encounters with outer space due to the first sputniks and Gagarin's space flight developed into the central theme of Soviet SF. But other factors also influenced SF, for instance, the popular engagement with native cultures from the recently decolonized Third World. Thus, SF constituted an extremely popular genre that, until the end of the Soviet Union as a strictly materialistic and atheistic state, offered occult belief systems and thoughts in a fantastic estranged form. ${ }^{3}$ These stories functioned in a way, as the popular critic and science popularizer, Boris Liapunov, quoted above put it in 1951 in an internal discussion regarding science policy: Even if occult thoughts were forbidden in general, SF authors always found "the right way that the reader can feel how a task is solved".

\section{Communist Pinkertons: The anti-occult orientation of scientific adventure literature in the 1920s}

Early Soviet mainstream SF, full of suspense, action and entertainment, was far removed from occult belief systems. ${ }^{4}$ On the contrary, all sorts of religious or para-scientific models were ridiculed and vulgarized. This tendency had a long

16 (1989), 38-66; Richard Stites, "World Outlook and Inner Fears in Soviet Science Fiction," Science and the Soviet Social Order, ed. Loren R. Graham (Cambridge, Mass., London, 1990), 299-324; Vsevolod Revich, Perekrestok utopii. Sud'by fantastiki na fone sudeb strany (Moscow, 1998).

3 On the problematic implications of such an "allegoric" reading, cf. Elana Gomel, "The Poetics of Censorship. Allegory as Form and Ideology in the Novels of Arkady and Boris Strugatsky," Science Fiction Studies 22 (1995), 87-105.

4 "Elite," fin de siècle literary adoptions of scientific innovations and topics, however, often dealt with spiritual, magic and religious implications and readings of technological progress, see Anindita Banerjee, Genesis and Evolution of Science Fiction in Fin de Siecle Russia, 1880-1921 (Diss., Los Angeles, 2000). 
tradition, beginning with the appearance of popular commercial adventure literature in the last third of the $19^{\text {th }}$ century in Russia. These stories significantly shaped the images held by the Russian literate urban masses about the dangers and challenges of the modern world. ${ }^{5}$ In doing so, they were aiming not so much to intimidate and overwhelm the reader but rather-as Jeffrey Brooks has shown-, to make their readers familiar with the challenges of the new times. ${ }^{6}$ This literature reached its zenith in the years after the defeated revolution of 1905, and it entered cultural history under the term "Pinkerton" literature due to the widely received polemic of the prominent literary critic Kornei Chukovskii, who railed against it as trashy, lowbrow literature. ${ }^{7}$

After the caesura of war, revolution and civil war, this adventure literature enjoyed a second heyday in the 1920s during the time of the New Economic Policy, during which magazines, booklets, book series and publishing houses specializing in the genre made it into the most popular reading material of the early Soviet period. ${ }^{8}$ Nikolai Bukharin's challenge, first voiced in 1922, to create a "communist Pinkerton", was groundbreaking for the new ideological direction. ${ }^{9}$ The worldwide export of revolutions but also global world wars or

5 According to today's understanding, this included both historical stories of knights, romantic Gothic novels, crime novels, colonial jungle and sea adventures as well as "extraordinary travels" related to technology and science. See Jeffrey Brooks, When Russia Learned to Read. Literacy and Popular Literature, 1861-1917, (Princeton, NJ, 1988); Stephen Lovell, "Literature and Entertainment in Russia. A Brief History," Reading for Entertainment in Contemporary Russia. Post-Soviet Popular Literature in Historical Perspective, eds. Stephen Lovell and Birgit Menzel (Munich, 2005), 11-28; On modern commercial adventure novels in general, see Richard Phillips, Mapping Men and Empire. A Geography of Adventure (London, New York, 1997).

6 Brooks, When Russia Learned to Read, 246-268.

7 Kornei Chukovskii, "Nat Pinkerton i sovremennaia literatura" $\left({ }^{2} 1910\right)$, Sobranie sochinenii v 15 tomakh. Literaturnaia kritika 1908-1915, vol. 7 (Moskva, 2003), 25-62.

8 Nikolai Rybnikov, ed., Massovyi chitatel' i kniga (Moskva, 1925); Evgenii Dobrenko, Formovka sovetskogo chitatelia. Sotsial'nye i èsteticheskie predposylki retsepcii sovetskoj literatury (St. Petersburg, 1997); Mariia Cherniak, Fenomen massovoj literatury XX veka (St. Petersburg, 2005), 76-128.

9 See Nikolai Bukharin, "Kommunisticheskoe vospitanie molodezhi v usloviiakh NĖPa (5-j Vser. s”ezd R.K.S.M. Doklad t. Bukharina. Utrennee zasedanie 13-go oktiabria)," Pravda 232 (14.10.1922), 2; All scholars until now dated Bukharin's speech one year later, following Mariètta Shaginian's notion, that she read about Bukharin's claim for a "red Pinkerton" the first time in autumn 1923, see Mariètta Shaginian, "Kak ia pisala 'Mess-Mend' (1926)," Sobranie sochinenii 1905-1933, vol. 3 (Moscow, 1935), 375-382; Robert Russell, "Red Pinkertonism. An Aspect of Soviet Literature of the 1920s", Slavonic and East European Review 3:60 (1982), 406418; Carol Avins, Border Crossings. The West and Russian Identity in Soviet Literature 19171934 (Berkeley, 1983), 55. 
out of control laboratory experiments provided material for the stories. A huge number of stories also focused on the intellectual fashions of the creative and scientific avant-garde in Moscow and Petrograd. ${ }^{10}$ These had taken up the cause of carrying out the political revolution in the arts and sciences, which threw off the ballast of an anachronistic bourgeois concept of science and culture in support of a revolution of knowledge. ${ }^{11}$ Their "revolutionary dreams"12 rejected all established norms and principles, yet also anticipated diverse "occult" and parascientific concepts of the intelligentsia, associated with names such as Aleksei Gastev and Aleksandr Bogdanov, Vladimir Bekhterev and Bernard Kazhinskii, Nikolai Fedorov and Konstantin Tsiolkovskii. ${ }^{13}$

The "communist Pinkertons" took their ideas as material in order to parody and denounce the possible consequences in dramatic subjects. Thus the fantastical adventure literature of the 1920s served not so much as a popularizer of these occult ideas, but rather as a playful and often satirical adaptation and tabloidization of these intellectual hypertrophies. The most well-known of these authors is Marietta Shaginian, who (under the pseudonym of Jim Dollar), in the first part of her Mess-Mend trilogy Mess Mend or the Unusual Adventure of the Yankees in Petrograd, parodies, among others, biological and psychological concepts surrounding degeneration and mass suggestion, but also the Gastevist concept of labor. ${ }^{14}$ But Shaginian, as an author coming from the

10 Schwartz, Expeditionen in andere Welten, 172-221.

11 John E. Bowlt, Olga Matich, eds., Laboratory of Dreams. The Russian Avant-Garde and Cultural Experiment (Stanford, 1990); Daniel Beer, "Blueprints for Change. The Human Sciences and the Coercive Transformation of Deviants in Russia, 1890-1930," Osiris 22 (2007), 26-47; Yvonne Howell, "Eugenics, Rejuvenation, and Bulgakov's Journey into the Heart of Dogness," Slavic Review 65 (2006), 544-562.

12 See Richard Stites, Revolutionary Dreams. Utopian Vision and Experimental Life in the Russian Revolution (New York, Oxford, 1989).

13 See Michael Hagemeister's chapter in this volume; idem "'Unser Körper muss unser Werk sein.' Beherrschung der Natur und Überwindung des Todes in russischen Projekten des frühen 20. Jahrhunderts," In: Boris Groys and Michael Hagemeister, eds., Die Neue Menschheit. Biopolitische Utopien in Russland zu Beginn des 20. Jahrhunderts (Frankfurt a.M., 2005), 1967; Matthias Schwartz, Wladimir Velminski, Torben Philipp, eds., Laien, Lektüren, Laboratorien. Künste und Wissenschaften in Russland 1860-1960 (Frankfurt a.M., 2008).

14 Mariètta Shaginian [Dzhim Dollar], „Mess-Mend. Roman-trilogiia. Chast' I. Ianki v Petrograde," Sobranie sochinenii 1905-1933, vol. 3 (Moscow 1935), 105-374. On the novel cf. Anthony Vanchu, "Technology as Esoteric Cosmology in Early Soviet Literature," In: Bernice G. Rosenthal, ed., The Occult in Russian and Soviet Culture (Ithaca, London: Cornell University Press, 1997), 203-222, here 212-221; Muireann Maguire, Soviet Gothic-Fantastic. A Study of Gothic and Supernatural Themes in Early Soviet Literature (Diss., Cambridge, 2008), 61-65. However, the intention of this novel has been slightly misread by nearly all western scholars 
"serious" high culture, was rather an exception; the market was dominated by authors such as Mikhail Gireli, Viktor Goncharov or Vladimir Orlovskii, all mostly forgotten nowadays. The powerhungry villains of their stories, set in contemporary Russia or in capitalist foreign countries, are able, with the help of Indian yoga techniques, to read the thoughts of other people and to telepathically manipulate them, siphon the "psychic energy" of people with the help of special "psycho-machines", or use solar energy, accumulated in gigantic pyramid-like structures called "horror machines", to unleash mass epidemics among the panicking masses. ${ }^{15}$

Michail Girelis' (pseud. of Michail Osipovich Pergament) novel The Crime of Professor Zvezdochetov (Prestuplenie professora Zvezdochetova, 1926), for instance, is set in a location typical of the genre, a private provincial medical laboratory, in which the parody of "cosmistic" conceptions of the psyche are taken to a literally absurd extreme. ${ }^{16}$ With the help of Indian yoga practices as well as optical and chemo-physical apparatuses, the "astrology" professor (in Russian zvezdochet means "astrologer") here attempts to investigate the "cosmic energy" of the human origin. In order to do so, he first psychically infiltrates the soul of his assistant, and then of his wife, which provides him with a strongly erotically coded delight, but does not lead to secret knowledge or enlightenment of any kind. Rather, both women die due to his experiments, and for this reason the professor lands in front of the procurator at the end of the story, accused of a double murder. ${ }^{17}$

This "tabloidesque" attitude of popular adventure literature towards occult and scientific practices and models to explain the world did not change noticeably until 1928, when this literature became the focus of massive criticism a result of the "Great Upheaval". It was strongly attacked as unworldly entertainment literature and counter-revolutionary contraband. In the polemic

insofar as they worked with the completely reworked version of 1956, where Shaginian not only changed the names and some plotlines to a more "Socialist realist" style, but also the overall concept of the novel, which now is mainly directed against the manipulative capitalist and imperialist system. On this last aspect, see Avins, Border crossings, 55-60.

15 See Viktor Goncharov, Psikho-mashina. Fantasticheskii roman (Moscow 1924); Vladimir Orlovskii, Mashina uzhasa. Nauchno-fantasticheskaia povest' (1925) (Leningrad, $\left.{ }^{2} 1927\right)$. For an interpretation of these novels see Schwartz, Expeditionen in andere Welten, 191-204.

16 Michail Gireli, Prestuplenie professora Zvezdochetova (Moscow, 1926).

17 Ibid. Gireli also pursued this idea of psycho-energetic mind-reading in his second novel Eozoon. The Dawn of Life (Eozoon. Zaria zhizni (Leningrad, 1929); regarding the biography of Gireli see Igor'Chalimbadzha, "Gireli Michail Osipovich," Entsiklopediia fantastiki. Kto est' kto, ed. Vladimir Gakov (Minsk, 1995), 167. 
against the genre, the hitherto barely reflected and only occasionally used term "scientific-fantastical" became the focus of the debate. The defenders wanted to use this term to at least partially save this genre by portraying it as a literature of industrial development and scientific progress. But all these attempts to save the genre failed and the main magazines and publishing houses were closed down by 1932. At the First Soviet Writers' Congress the term played only a marginal role. ${ }^{18}$

\section{Necrobiotic rays and wonder generators: The occult beginnings of Stalinist Science Fiction}

On the eve of the First Soviet Writers' Congress in 1934, when the new conceptualization of Soviet literature was being discussed, the reformulation of entertainment literature and popular science literature had a central role. Yet, at the beginning, all forms of adventure literature and SF had already been rejected. However, this approach found no support among authors, publishing houses and readers, so that already in the middle of the 1930s, "Scientific Fantasy" was allowed within the framework of children's and youth literature. ${ }^{19}$ The genre thereby found itself in an odd intermediate position. On the one hand, in terms of Socialist Realism it was to popularize future social and especially scientific developments in the spirit of the socialist construction sites, while on the other hand, it was also expected that it would anticipate future developments in terms of Maxim Gorky's definition of myth and folklore. In his pioneering speech at the Writers' Congress, Gorky had attested that, in their antique myths and folklore, the common people were using fantastical objects such as flying carpets or seven league boots to articulate technical wishes that would serve to improve their miserable existence. ${ }^{20}$

It is precisely these seemingly fantastic "adventures of invention", as the influential critic and science popularizer Aleksandr Ivich wrote in a book that was published three times in the 1930s alone, that one should take as a model in order to anticipate qualitative jumps in scientific development, that seem impossible according to contemporary conceptions. ${ }^{21}$ According to him, it is

18 For a detailed reconstruction of this debate see Schwartz, Expeditionen in andere Welten, 235251.

19 Ibid., 323-331.

20 Maksim Gor'kii, "Doklad A. M. Gor'kogo o sovetskoj literature," Pervyj vsesoiuznyi s"ezd sovetskikh pisatelei 1934. Stenograficheskii otchet (Moscow, 1934), 5-18.

21 Aleksandr Ivich, Prikliucheniia izobretenii (Izdanie vtoroe, pererabotannoe, Moscow, 1935). 
seemingly the unchangeable laws of nature, that bourgeois science claims was God-given, which must be called into question. Precisely such a scepticism towards established knowledge was a gateway for occult explanations that claimed the existence of secret powers that humans could wrest from nature. ${ }^{22}$

In the 1930s such "scientific fantastic" fictional "adventures of invention" in Russia focused especially on the field of physics. ${ }^{23}$ Thus in 1939 and 1940, Iurii Dolgushin, who would later go on to become a decisive proponent of Lysenkoism, published his first "scientific fantasy novel" Generator of Wonders (Generator chudes) in installments in the popular science journal Tekhnika molodezhi. ${ }^{24}$ In the novel, biology and physics find themselves at the center of attention as models for explaining the human brain and life. They are represented by two scientists, the young radio engineer Nikolai Tungusov, who conducts physical experiments with electromagnetic waves in his private laboratory, and the renowned physiologist and surgeon Professor Ridan, who investigates electromagnetic manipulations of the brain in his private villa in Moscow.

During a coincidental encounter the two scientists discover that their research areas complement each other. Thus they begin to build the so-called Generator of Wonders. During this work they are described as typical "mad scientists" of the $18^{\text {th }}$ and $19^{\text {th }}$ centuries, who retreat from social life and secretly devote themselves to their private obsessions. ${ }^{25}$ Thus Tungusov, who lives alone at home without parents, a wife or children, only with an aunt, is

22 Ibid. Thus revolutionary successes in the field of the sciences, such as the one declared by Lysenko in regard to creative Darwinism in the field of biology in the post-war period, were often simulated as fictional intellectual games within Scientific Fantasy as early as the 1930s. For the Soviet post-war period see Igor J. Polianski, „Das Unbehagen der Natur. Sowjetische Populärwissenschaft als semiotische Lektüre, "Laien, Lektüren, Laboratorien, 71-113.

23 Petr Kapitsa, “O nauchnoi fantastike,” Detskaia literatura 4 (1940), 18-23.

24 Preprints appeared already in 1938, in 1941 Dolgushin additionally wrote a radio version of the novel. See Iurii Dolgushin, "Generator chudes. Nauchno-fantasticheskii roman," Tekhnika - molodezhi 1 (1939), 34-40; 2, 40-47; 3, 53-59; 5, 45-51; 6, 49-54; 7-8, 58-65; 9, 33-38; 1011, 59-67; 1 (1940), 36-42; 2-3, 61-66; 4, 46-52; 5, 50-57; 7, 50-56; 10, 50-58; 11, 43-50; 12, 2 cover , 51-58; idem: Generator chudes (Radiokompozitsiia $v$ dvukh chastiakh dlia detei starshego shkol'nogo vozrasta) (Moscow, 1941). On Dolgushins biography see Genadii Prashkevich, Krasnyi sfinks. Istoriia russkoi fantastiki ot V. F. Odoevskogo do Boris Shterna (Novosibirsk, 2007), 353-361.

25 For this topic see Barbara Benedict, "The Mad Scientist. The Creation of a Literary Stereotype", Imagining the Sciences. Expression of New Knowledge in the "Long" Eighteenth Century, eds. Robert C. Leitz, Kevin L. Cope (New York, 2004), 59-107. 
not at all interested in the labor in the factory, while he pursues the "sacred acts" of his research at home at night. ${ }^{26}$

Professor Ridan, who lives alone in a large villa with his daughter, is the same sort of strange loner. The two scholars, protected by the NKVD, threatened by German spies and curious rivals, abandon themselves with total passion to their "sacred acts":

The professor disappears into a dark corridor. Tungusov's workroom greets him with a large circle of light concentrated on the "Generator of Wonders" by the Vikling scale, which stands in the middle of the room [...] Ridan locks the door securely behind him. [...] It was already light when both emerged from the room, completely robbed of strength from the overabundance of experiences and from exhaustion. ${ }^{27}$

The reader is not told what kind of experiments the two of them carry out every night behind closed doors. The result is a "Generator of Wonders", which, through special receiving and sending machines, can not only receive and manipulate telepathic signals of the human brain across great distances, but also, with the help of "life rays", heals diseases and brings the dead back to life. $^{28}$ Thus, Dolgushin's novel actually does represent a cryptogram of real research that deals with electromagnetic brain waves and biophysical experiments on the revival of frozen creatures. After Bekhterev's death in 1927, research continued on the phenomenon of electromagnetic brain waves in various institutions in the Soviet Union. ${ }^{29}$

26 "All these works he judged as insignificant, and the word 'invention' only irritated him. The true matter started for him only at home, in the evening, when he felt himself completely free. Here started his sacred act." Dolgushin, "Generator chudes", Tekhnika - molodezhi 6 (1939), 49.

Ibid., 5 (1940), 57.

Dolgushin: Generator chudes, Tekhnika - molodezhi 5 (1940), 55-57; 11 (1940), 49.

Regarding the description of research institutions, the novel mainly referred to Bekhterev's Leningrad Brain Institute, where Leonid Vasil'ev (1891-1966) continued his work on "mental suggestion" (telepathy) from 1932 to 1937 . Without any official scientific exchange taking place, Sergei Turlygin simultaneously investigated the electromagnetic rays of the brain in the laboratory for biophysics of the Academy of Sciences of the USSR under the directorship of Petr Lazarev (1878-1942). See Leonid Vasil'ev, Vnushenie na rasstoianie. Zametki fiziologa (Moscow, 1962); Mikhail Agursky, "An Occult Source of Socialist Realism. Gorky and Theories of Thought Transference," In: Rosenthal, ed., The Occult, 247-272, here 258. The topic also regularly appeared in the mainstream science journals, including the publications by Dolgushin himself. See Iurii Dolgushin, "Luchi professora Gurvicha," Znanie - sila 10-11 (1939), 21-24. 
In contrast to the "communist Pinkertons" of the 1920s, the fictional adoption of ideas on telepathy and resuscitation of the dead no longer treats them simply as a means of entertaining and captivating the readers, but provide them with the aura of mythical-sacred knowledge that reveals a deeper understanding of humans. Thus it is not the possibilities of the "life rays" that captivate Prof. Ridan's "daydreams" (mechty), ${ }^{30}$ but specific "necrobiotic rays". These are sent out by the brains of the dying and transmit telepathic suggestive powers to the brains of relatives thousands of kilometers away: "The discovery of necrobiotic rays brings us closer to understanding one of the 'most secret' facts [...]. I mean the case of death, which can be 'felt' across a distance of thousands of kilometers and causes hallucinations in people who are close to the dying person." ${ }^{11}$ While one only consciously registers the "death signals" (signaly smerti) sent out by a person one is close to, as one is conditioned towards these as in a Pavlovian reflex, the signals sent out by people unknown to one can influence a person in the form of panic attacks, nervous breakdowns or simply an uncomfortable feeling, without the person being consciously aware of it. ${ }^{32}$

Thus the "most secret" facts about future scientific developments also represented a kind of knowledge, hidden, censored and forbidden in many ways, about the Soviet present during the "Great Terror" of the late 30s. The "necrobiotic rays" of deceased friends and relatives, which cause panic attacks, nervous breakdowns and feelings of discomfort, clearly point to the time in which the novel was created. Similarly, the topic of state surveillance and the manipulation of people via the media is not directly addressed, but Prof. Ridan's experiments aiming for the complete control of all thoughts clearly point in this direction. Thus the "occult" knowledge of the scientific-fantastical stories of the Stalin period comes to have very ambivalent meaning. On the allegorical level, this knowledge points to the forbidden sides of Stalinist society and, in its visions of the future, simultaneously offers an imaginary way out of the threat of death and states of fear of the present through the healing of psychic wounds promised by the resurrection of relatives and friends who died prematurely. While this political subtext can be found in the works of other authors of this time, such as Aleksandr Beliaev or Grigorii Grebnev, two authors, Ivan Efremov and Aleksandr Kazantsev, developed a decidedly occult poetics in the 1940s. ${ }^{33}$

\footnotetext{
30 Ibid. 5 (1940), 50.

31 Ibid., 57.

32 Ibid.

33 Aleksandr Beliaev wrote several novels in this sense, like the 1933 novel The Jump into the
} 


\section{From the Tunguska event to the atomic bomb: Alien encounters in the post-war period}

While scientific fantasy had found a niche for occult thought models within the field of children's literature during the pre-war period, as a result of the loosening of the censorship during the war, it was also discussed more often in the union-wide press such as the Komsomol'skaia pravda or the Literaturnaia gazeta. One reaction to this was that some branches of the Writers' Union began receiving manuscripts in the so-called "self-flow" (samotek), which were then forwarded to the main office of the Writers' Association in Moscow. One of these manuscripts was sent from the Kyrgyz branch of the Writers' Association in 1946 with a request for review, as there was no expert on location who was familiar with scientific-fantastical literature. ${ }^{34}$ The text was reviewed only after repeated requests from Kyrgyzstan, and was then given to association member Aleksandr Kazantsev in the fall of that year. However, he opposed accepting the fantastic novel Problems of Peace (Problemy mira) for publication. $^{35}$

The novel Problems of Peace tells the story of a prehistorical civilization from 35,000 years ago whose members live underground as protection from wild animals and that provides a model for today's society. However, according to Kazantsev's review, the novel and the social order it describes, which combines socialist ideas with Christianity, the separation of the sexes, the euthanasia of sick children, the honoring of ancestors and a collective council of elders, presents an ideologically dangerous mixture, moreover, the work is of poor literary quality and full of clichés. ${ }^{36}$

The author of the novel, Trofim Luk'ianovič Antonov, an "old engineer" from Frunze, did not accept this rejection, which was very understandable within the context of Soviet literary policy, and wrote a long letter to the "Patron of the defense writers", Marshall Kliment Voroshilov, asking for his

Void (Pryzhok v nichto), dedicated to the Soviet rocket pioneer and student of Tsiolkovskii, Fridrikh Tsander (1887-1933), The W Laboratory (Laboratoria Dubl've, 1938) about psychoneurological mind-expanding experiments or Ariel (Ariell', 1941). Grebnev published in 1937 for the first time his fantastic novel Arktaniia. The flying station (Arktaniia. Letaiushchaia stantsiia) about a communist future, where the resurrection of the dead and undead fascists played a crucial role. Schwartz, Expeditionen in andere Welten, 346-352, 392-395. Freedom 1946-1947, RGALI, f. 631, op. 22, ed. 11, 1. 1-11.

Ibid., 1. 2, 10-11.

Ibid., 1. 10-11. 
help. ${ }^{37}$ According to Antonov, the novel's rehabilitation of Christ as a "Great Humanist" was highly topical, Christ's message having only later been falsified by the state church. Antonov argued that Christ had fought against the Roman oligarchy and had been the first to advocate a "realm of happiness on earth", to which "the Great Humanist I. V. Stalin was leading humanity with an iron hand" today. ${ }^{38} \mathrm{He}$ maintained that the "uneducated critics of the Writers' Association" had also failed to understand the political message:

[...] at a time in which the Christian topic, in the way in which it is portrayed in 'The Problems of Peace', is for us Communists a highly important, I would even say, a profitable one, because it strikes at the hypocrisy of our worst enemy, the Christian caste of priests, and provides us with an advantageous position in comparison, through us shattering the foundation of our enemy's camp. ${ }^{39}$

In fact, the Council of Ministers of the USSR, of which Voroshilov was the chairman, saw itself obliged to intervene with the Writers' Union on the author's behalf by requesting that the Association rethink the rejection of the manuscript and get in touch with the author in order to save the novel through reworking. ${ }^{40}$

The Writers' Union refused this request, but the events show how insecure the status of Scientific Fantasy was, as this manuscript was by no means an anomaly. Fantasy seems to have been associated by many readers with arcane, secret knowledge that could provide one with explanations about one's own society, explanations that went beyond the official announcements and with decidedly religious connotations.

The fact that this perception was not simply an incorrect reception of the Soviet provinces can nowhere be seen more clearly than in the reviewer of the Writers' Union, Aleksandr Kazantsev (1906-2002). After studying at the Tomsk Polytechnical Institute, Kazantsev had worked in various places as a mechanic and inventor before beginning to write SF in the middle of the $1930 \mathrm{~s} .{ }^{41} \mathrm{He}$ simultaneously remained active as a scientific organizer, thus in

37 Ibid., 1. 3.

38 Ibid., 1. 5.

39 Ibid., 1. 6.

40 Ibid., 1. 8-9.

41 However, the only information about his actual work in the military-industrial sector are the autobiographical pieces of information that he himself labelled as fiction, which are to be 
1939 he worked as the chief engineer of the industrial sector of the Soviet Pavilion at the World's Fair in New York. ${ }^{42}$ During the war he was also involved in the defense and industrial sector in leadership positions and climbed to the rank of colonel before officially devoting himself entirely to literary pursuits after the war. Within the Writers' Union he became the reviewer responsible for SF within the section for scientific-fictional literature (nauchnokhudozhestvennaia literatura). ${ }^{43}$ He played a central role within literary policy in various functions within and outside of the Union into the 1970s, whereby, as an advocate of the "Stalinist" definition of the genre, especially due to his good contacts all the way into the Politburo of the CPSU, he developed into one of the most prominent opponents of the well-known Soviet SF authors, the brothers Arkadii and Boris Strugatskii. ${ }^{44}$

His first work consisted of a screenplay, entitled Arenida (Arenida), written together with the inventor and director of the Leningrad House of Scientists, Izraèl' Shapiro, which won the first prize for the best SF screenplay at a nationwide contest organized by the Houses of Scientists in Leningrad and Moscow and the film studio Mezhrabpomfil'm in February $1936 .{ }^{45}$ Arenida is set in the year 1940 and tells the story of a gigantic meteorite named Arenida that is

taken with a grain of salt. Aleksandr Kazantsev and Nikita Kazantsev, Fantast. Mnemonicheskii roman v dvukh knigakh, vol. 1 (Moscow, 2001), 264-269.

Britikov, Russkii sovetskii nauchno-fantasticheskii roman, 156.

43 The term "scientific-fictional" was shaped by Gorky in the beginning of the 1930s and became a controversial category in concurrence to the term "scientific-fantastic" prose until the early 1950s. For Kazantsev's biography, as well as for the pre-war period, one is dependent on his own statements, according to which he, obviously due to his knowledge of engineering and his political reliability, was engaged in special commissions during the war, which were to work behind the lines to secure secret defense and industrial projects of the Germans for the Soviet Union, and through which he, for example, was also involved with the German V-2 rocket. After the war, as Chairman he led the Commission for Dismantling of Industrial Facilities in occupied Austria before returning to his literary passions after the dissolution of the commission, Kazantsev: Fantast (vol. 1), 427-451.

44 Thus, he was essential to bringing about the ban of some works by Arkadii und Boris Strugatskii. Erik Simon, “The Strugatskys in Political Context”, Science Fiction Studies 31 (2004), 378406, here 394-397.

45 Kazantsev und Shapiro received the second prize. The first prize was not awarded as, according to the opinion of the jury, no author had successfully combined the scientific idea with its filmic realization Iurii Fedorov, "Fantastika v nauke i kino," Kino 8 (11.02.1936), 2. On the background Aleksandr Kolpakov, "Vtoroe dykhanie (Fantasticheskaia sud'ba fantasticheskikh knig),“ V mire knig 7 (1985), 54-56. 
speeding towards earth and threatening to destroy it. ${ }^{46}$ While panic breaks out among the people in the West and everyone is preparing for the end of the world, which leads to chaos, outbreaks of violence and escalating criminality, a tense work-oriented atmosphere reigns in the Soviet Union, for Soviet scientists have developed an energy accumulator that can release gigantic amounts of energy. Thanks to this invention, the Soviets build a titanic facility, for which all factories and firms of the country are forced to halt their work for 19 days in order to allow the facility to charge. Three days before the predicted collision of the meteorite, this gigantic amount of stored energy is fired towards the heavenly body with special canons and tears it into "hundreds of particles burning in yellow light", so that the end of the world is avoided: "An unbelievably magnificent firework spread across the sky, as if someone had hit a magic hammer against the sun. Lightning, fiery gushers and fountains light up the heavens." 47

As this scenario did not simply serve for pure scientific propaganda but also enabled a clearly religious-apocalyptic reading, it encountered both heavy public and internal criticism. In a Pravda article written in early 1938, the first secretary of the Komsomol, Aleksandr Kosarev (1903-1939), turned against several "sectants" who had prophecied, based on the screenplay, an imminent "end of the world" by a "stone from heaven" (nebesnyi kamen'). ${ }^{48}$ When Kazantsev as sole author later expanded the screenplay into the scientificfantastical novel The Burning Island (Pylaiushchii ostrov) in 1940/41, he was forced to make major changes in the plot. Now it is no longer a heavenly body falling to earth that causes panic and chaos in the West, but a magical weapon built by the capitalists themselves that is capable of causing a "nitrogen fire" in the atmosphere. ${ }^{49}$ But even if the occult subtext in this novel, published in 1941, has been largely eliminated, Kazantsev continued to be fascinated by this topic, and when the censorship rules were loosened as a result of the Second

46 After the publication of an excerpt in the newspaper of the Soviet for National Economics, $\mathrm{Za}$ industrializaciiu, this screenplay was published in complete form for the first time in 1937 in the Leningradskaia Pravda. A. Kazantsev and Izrael' Shapiro, "Arenida (Otryvki iz stsenariia i libretto fil'ma)," Za industrializatsiiu 243 (18.10.1936), 4.

47 Ibid., 4.

48 Kolpakov: "Vtoroe dykhanie," 55.

49 The Name Arenida no longer refers to a meteorite, but to an island in the Arctic Sea, which is completely destroyed during the test of a new weapon by the imperialistic military forces. While the capitalists pursue only military goals against the Bolsheviks, thanks to collective efforts the Soviet Union is able to avoid the outbreak of war at the last minute. A. Kazantsev, $P y$ laiushchii ostrov. Nauchno-fantasticheskii roman, (Moscow, Leningrad, 1941). 
World War, he once again took up his idea of an extraterrestrial heavenly body that influences human destiny. This time around it is not terrestial rayemitting weapons which successfully destroy the extraterrestrial invader, but it is "cosmic rays" that help humans to find a new understanding of themselves.

Not even half a year after the first atomic bomb was dropped on Hiroshima in August 1945, the popular science journal Vokrug sveta published Kazantsev's "hypothetical story" (rasskaz-gipoteza) The Explosion (Vzryv) as the cover story of then January 1946 issue. ${ }^{50}$ The story deals with the so-called Tunguska meteorite, which had crashed in the central Siberian mountain region Tunguska in 1908. The meteorite became well-known in the 1920s due to the reports by the magazine Vsemirnyi sledopyt about the Soviet meteorite researcher Leonid Kulik (1883-1942), who had searched in vain for the site of the meteorite in the Taiga. ${ }^{51}$

Kazantsev took this hitherto never found meteorite as the point of departure for his hypothetical story, which additionally mystified the event as an exotic riddle and occult awakening event. Thus the story begins with a magazine editor's childhood memories of a boat trip along the river of the same name through the Siberian Taiga in the year 1908, which had always remained in his memory as a parareligious experience. ${ }^{52}$ After this opening, the narrator receives a visit on 3 April 1945 from an ethnographer and a physicist who want to undertake an expedition into precisely that region in order to prove their different research hypotheses: The ethnographer wants to prove that the indigenous inhabitants of Siberia were descended from "African Negroes" while the physicist maintains that the meteorite exploded shortly before its impact in an atomic chain reaction. Only after the dropping of the atomic bombs on Hiroshima and Nagasaki does the narrator once again hear something about the completely "savage" researchers. ${ }^{53}$ As it turns out, the Evenks living in the region of the alleged meteorite crash have all died of a strange disease. The lone

50 Aleksandr Kazantsev, "Vzryv. Rasskaz-gipoteza," Vokrug sveta 1 (1946), 39-46. The Literaturnaia gazeta deemed their first public reading to be worth an individual report. [Anon.]: "Novyi rasskaz A. Kazantseva (V Soiuze sovetskikh pisatelei SSSR)," Literaturnaia gazeta 50 (08.12.1945), 4.

51 Leonid Kulik, Za tungusskim divom. Vmesto fel'etona (Krasnoiarsk 1927); [Anon.], "Sledopyt na pomoshch' L. A. Kuliku,” Vsemirnyi sledopyt 10-12 (1928), 782, 868-871, 947. Kulik died in 1942 in a German POW camp, also cf. on this topic E. Krinov, "Tungusskoe divo," Znanie sila 8 (1951), 12-14; F.Zigel', "Nerazgadannaia TAINA,” Ibid. 6 (1959), 40.

Kazantsev, "Vzryv," 39-41.

Ibid, 43. 
survivor is a completely dark-skinned female shaman clad only in a loincloth. ${ }^{54}$ When the physicist asks her about the Soviet plans for space travel, she suddenly breaks down but wants to impart a final message to the researchers as she lies dying, but she takes her secret to the grave. The researchers merely hear her last heartbeats, whereby they notice that her heart is located not on the left but on the right side of her body ${ }^{55}$ Thus the ethnographer rejects his hypothesis that the indigenous Siberians came from Africa, while the physicist ends the story with the conclusion: "It is not impossible that the explosion did not occur in a uranium meteorite, but in an interplanetary spaceship powered by atomic energy." 56

Kazantsev connects this SF subject matter with an occult concept in the character of the shaman woman, who possesses wondrous healing powers and sings "prehistoric songs". For the shaman with the strange anatomy not only has a secret connection to atomic rays and extraterrestrial existence, but the encounter with her is also a moment of spiritual awakening for the two researchers. ${ }^{57}$ One of the researchers describes their first meeting-which takes place at the same time as the dropping of the atomic bombs by the Americans on Hiroshima and Nagasaki-as follows:

The morning star shines, surrounded by a small aureole, above the black descending line of the forest. The shaman and her companions stand in the middle of the moor with arms upraised. Then I heard a deep, long tone. As if in response the distant echo of the forest was heard, repeating the note several octaves higher. Then an echo, getting already louder, continued the strange, unclear melody. I understood that she was singing there-the shaman. Thus began a non-repeatable duet between a voice and a forest echo, whereby they were often heard together, mixing in an incomprehensible but magical harmony. The song ended. I did not want to and could not move. ${ }^{58}$

The "strange, unclear melody" literally puts a spell on the listener who no longer can nor wants to move, and places him in another, cosmic or-in the

54 Thus, she is described by various witnesses as an "incomprehensible", "foreign" person in terms of physique and character. Ibid., $40,44$.

55 Ibid, 45-46.

56 Ibid, 46. According to some apocryphal writings and folk tales, which were common in Eastern Europe as well, vampires as reincarnations of the antichrist are supposed to have their heart on the right side (Dextrocardia). Thanks to Paul Hillery for this reference.

57 Ibid, 42-43.

58 Ibid, 44 . 
terminology of Mircea Eliade- "sacred time". At the same time, the scenery is clearly marked by Venus in the shape of the morning star, which in Christian symbolism represents both the light-filled appearance of Christ in the night of the world as well as Lucifer, the fallen angel. It is precisely this ambivalent interpretation that is delivered by Kazantsev's story of the atomic bomb explosion of Hiroshima in the form of the exploding spaceship, an event which, on the one hand, augurs the epiphanic appearance of the salvation of mankind, and on the other hand can also be read as Satan's plummeting to Hell, falling from the sky like lightning. ${ }^{59}$

It must be noted that Kazantsev was not the first in Stalin's time who imagined a connection between atomic rays and cosmic energies that constitute a holy time of enlightened wisdom. This idea can be traced back to Ivan Efremov, who dealt with the topic of transcendental cosmic effects of atomic energy in his Stories of the Unusual (Rasskazy o neobyknovennom), written during the war. Efremov, son of a wood merchant, had worked as a dock worker, sailor and member of the Red Army before embarking on a successful career as a paleontologist in the $1930 \mathrm{~s} .{ }^{60}$ In 1952, as a renowned professor he even received a Stalin Award for his paleontological work. He wrote his first stories during the war while evacuated to Middle Asia due to a long illness. These stories were soon published in the army magazines The Red Army Soldier (Krasnoarmeets) and The Red Navy Sailor (Krasnoflotets), in Tekhnika molodezhi as well as in the main literary magazine Novyi mir, and by $1946 \mathrm{had}$ already been published six times in book form.

Encounters with hitherto unknown "fantastic" secrets of nature that enable humans to experience spiritual cleansing and inner enlightenment play a central role in all of these stories. This concept of nature is mostly clearly portrayed in the story The Observatory of Nur-i-Desht (Observatoriia Nur-i-Desht, 1944), in which the internal narrator tells how he was sent as a wounded soldier to recover in Central Asia and by chance lands at an archaeological dig in

In addition, the story has a military political subtext as it implicitly points to the absolutely secret project to build an atomic bomb in Siberia.

60 For biographical details see Evgenii Brandis and Vladimir Dmitrevskii, Cherez gory vremeni. Ocherk tvorchestva I. Efremova (Moscow, 1963); [Evgenii Brandis], “Zhizn' uchenogo i pisatelia. Interv'iu s I. A. Efremovym (Materialy k tvorcheskoi biografii I. A. Efremova)” [1960], Voprosy literatury 2 (1978), 187-208; Petr Chudinov, Ivan Antonovich Efremov. 1907-1972 (Moscow, 1987); idem, "K portretu sovremennika," Ivan Antonovich Efremov. Perepiska s uchenymi. Neizdannye raboty, ed. N. V. Boiko (Moscow, 1994), 5-28; Prashkevich, Krasnyi sfinks, 408-426. For the hitherto most insightful and penetrative analysis of Efremov's prose see Heller, Vselennaia za predelom dogmy, 317-358. 
the middle of the desert, where an old professor and his young Uzbek assistant are excavating an ancient observatory called "Light of the Desert" (which is the Uyghur meaning of "Nur-i-Desht"). Strange states of exhaustion, happy evenings with the assistant by the campfire or at the nearby river as well as an antique vase that shines at night lead the narrator to conclude that the observatory must be built of radioactive material the rays of which cause both healing and euphoric effects on people as well as an unusually clear view of the starry sky: "And suddenly it turned out that the cause of all this was the radium - and only...That is, if the radium had not existed, [...] the wonderful enchantment of those days in the ancient observatory would not have occurred..." ${ }^{61}$ Thus the radioactive "Light of the Desert" not only heals the war wounds of the narrator but also brings to life the desert of his soul, so that in the end he can also "open" himself up towards Tania, the young assistant: "Tania, my love-I said-here my soul has come back to life, and she has opened herself towards you. Tania got up and ran towards me. The clear eyes of the girl reflected the ash-gray light of the stars. Above us the swan, his long neck extended in eternal flight, pierced the light clouds of the Milky Way." ${ }^{\prime 62}$ Here the radioactive rays are not portrayed as weapons of destruction bringing death, but quite the contrary, as a force that cleanses the soul. At the same time, the human mental states are depicted as a reflection of the "ash gray starlight" that already contains all options for action. ${ }^{63}$

A few years later Efremov formulated this cosmic influence of radioactive, cosmic rays on people even more clearly in his second scientific-fantastic novella, The Starships (Zvezdnye korabli, 1947). ${ }^{64}$ Regarding Kazantsev's and

61 Ivan Efremov, "Observatoriia Nur-i-Desht. Iz tsikla rasskazov o neobyknovennom," Novyj mir 11-12 (1944), 120-130, 130.

62 Ibid.

63 The fact that the swan constellation is well known to represent Zeus in ancient mythology, who seduces young women in this form, further underlines this "cosmic" semantics of the unusual love adventure in an exotic location. This "cosmic" semantics is formulated very explicitly by the narrator in a later version of the story: "Who knows, perhaps the influence of the radioactive substances on us will become even more understandable through further research successes. And who can guarantee that there aren't many other kinds of rays influencing us whether it is the cosmic rays or not. Right there - I stood and lifted my hand to the starry sky is perhaps the source of very different energies that send particles from distant star worlds from the black depths of space." Ivan Efremov, "Observatoriia Nur-i-Desht," Bukhta raduzhnykh strui. Nauchno-fantasticheskie rasskazy (Moscow, 1959), 55-83, 82-83.

64 The novella appeared in installments in the second half of 1947 in Znanie - sila before also being published as a book by Detgiz in 1948. This quote is taken from the magazine version, 
Efremov's prose from those years, we can thus state that, using researcher characters that portrayed recognized and valued professors of Soviet society, they developed a vision of thoughts about the universe and models for explaining the world quite distant from the official science policy and ideological conflicts of the Soviet presence. ${ }^{65}$ Without any regard for these conflicts, the topic of extraterrestrial visits to earth could continue to be dealt with in the popular scientific press. In 1950 the popular science journal Znanie - sila printed the sketch From the Depth of the Universe (Iz glubiny vselennoi) by Liapunov, who was quoted in the introduction to this article on the main topic, which confirmed the thesis of the Tunguska meteorite as a spaceship. ${ }^{66}$ Half a year later, Tekhnika - molodezhi published another scientific fantastical story by Aleksandr Kazantsev, "The Guest from the Cosmos" (Gost' iz kosmosa), which is also dedicated to that thesis. ${ }^{67}$ Detailed explanations on the possible life forms in the cosmos, the Mars Channels and possible human spaceflights accompanied this publication. ${ }^{68}$

Thus with the help of the "Tunguska Wonder" (Tungusskoe divo), within five years the topic of interplanetary travel and extraterrestrial, human-like intelligence had been made public in three main popular science journals. The response to these publications was considerable and led to a series of further texts on the topic of interplanetary spaceflights, rocket technology and intelligent life on other planets. ${ }^{69}$ A Soviet critic later wrote that these texts drew the

see Ivan Efremov, "Zvezdnye korabli. Nauchno-fantasticheskaia povest'," Znanie - sila 7 (1947), 25-30; 8, 4 supplement, 29-36; 9, 30-35; 10, 28-32, 4 cover.

65 For the official notion of science see Ethan Pollock, Stalin and the Soviet Science Wars (Princeton, Oxford, 2007).

66 Boris Liapunov, Iz glubiny Vselennoi, Znanie - sila 10 (1950), 4-7.

67 A. Kazantsev, Gost' iz Kosmosa. Nauchno-fantasticheskii rasskaz, Technika - molodeži 3 (1951), 28-34.

68 Aside from the achievements of the astronomer and president of the Armenian Academy of Sciences, Viktor Ambartsumian (1908-1996), who founded the astrophysical observatory of Biurakan in 1946 and rose to prominence in 1947 with the discovery of the so-called "star associations," it was above all the astronomer, co-founder of the Kazak Academy of the Sciences (1946) and popularizer of the self-created scientific discipline of "astrobotany," Gavriil Tikhov (1875-1960), who was deemed to have advanced Soviet astronomy "incredibly far". See A. Kazantsev et al., “Tungusskii meteorit. Est' li zhizn' na drugikh planetakh? Planeta Mars. Kanaly Marsa. Planeta Venera. Chto takoe astrobotanika? Kak mozhno reshit' zagadku Tungusskogo meteorita?," Tekhnika - molodezhi 3 (1951), 28-34. Gavriil Tikhov, Noveishie issledovaniia po voprosu o rastitel'nosti na planete Mars (Moscow, 1948).

69 E. Krinov, "Tunguskoe divo," Znanie - sila 8 (1951), 12-14. One of the readers of these articles was the young Polish author Stanisław Lem, who wrote his first great Science Fiction novel The Astronauts (Astronauci, 1951) based on the thesis of the Tunguska meteorite as an inter- 
"attention of millions of readers". ${ }^{70}$ Reports about extraterrestrials were not only taken up with interest by a broad circle of readers, but were seriously discussed even among professional scientists. ${ }^{71}$

The "collective investigation" of the "guests from the cosmos" became so popular among an interested audience of laypeople, established scientists and members of the academy, that the Meteorite Commission of the Academy of Science of the USSR saw itself obliged to turn to the Secretariat of the Writers' Association of the USSR and request that it immediately curb the popularization of this topic as the association was spreading "fantastical ideas" "under the guise of scientifically proven assumptions". This propaganda "of lies" had led to the fact that "the opinion had spread to wide circles among the population that Liapunov's guess was a proven scientific conclusion". Alarmed by this development, the Executive Committee of the Academy of Sciences and the scientific department of the Central Committee of the Communist Party of the Soviet Union intervened in the autumn of 1951 and banned any publications on the topic. ${ }^{72}$

If we look at these fictional and journalistic texts about extraterrestrial guests from outer space and damaged spaceships in a broader cultural historical context, they represent a strange phenomenon similar to the reports that began surfacing in the USA in 1947 about Unidentified Flying Objects, socalled UFOs, that allegedly came from space. While traumatic war experiences, fears about a world completely dominated by technology and circulating anticommunist conspiracy theories in the McCarthy era are possible reasons for the rise of these pop-culture narrations in the USA, similar arguments can be found for the Soviet Union under different conditions. ${ }^{73}$ However, the abduction motif that was so dominant in the USA did not play a role during the late Stalin period, but Efremov's and Kazantsev's works accentuate the motif of an imaginary escape and the parallelization of nuclear energy as a demonic tran-

planetary spaceship, which was the first German-Polish science fiction film ever released, in 1960, under the title The Silent Star (in the USA it ran in a substantially re-edited version under the title First Spaceship on Venus).

Thus, for example, for years lectures were given in the Moscow Planetarium on the "riddle" of the Tunguska meteorite. E.Brandis, "Puti razvitiia i problemy," O fantastike i prikliucheniiakh (Leningrad, 1960), 48.

71 [Anon.], “Iz glubiny Vselennoi (Nauka i fantastika)," Znanie - sila 8 (1951), 11.

72 Krinov, “Tungusskoe divo," 12-14; RGALI, f. 631, op. 3, ed. 210, 1. 339-349.

73 Bryan Appleyard, Aliens. Why they are here (London, 2007), 13-47; Roger Luckhurst, "The Science-Fictionalization of Trauma. Remarks on Narratives of Alien Abduction," Science Fiction Studies 25 (1998), 29-52. 
scendental force that, as "cosmic energy", connects humans with the universe in thought. ${ }^{74}$

From a cultural politics perspective, the appearance of "guests from outer space" in the post-war period is even more surprising considering that this time of the so-called Zhdanovshchina was ideologically extremely repressive. The fact that the topic could nonetheless be published until 1951 points out how fragile the official ideological stance was, not only among writers, but especially among the intelligentsia in the field of technology and among scientists. When during the Thaw period the Tunguska meteorite became a steadfast element of worldwide UFO literature and of the engagement with so-called SETI phenomena as an "unsolved mystery", ${ }^{75}$ the story of its creation in the first post-war years had soon been completely forgotten. ${ }^{76}$

\section{From Sputnik to Stalker: "Philosophical fantasy" since the Thaw period}

The launch of the first Sputnik satellite and the Soviet successes with manned spaceflights propelled the idea of an interplanetary spaceship onto the covers of the mainstream press. The search for extraterrestrial intelligence occupied an exceedingly large space in the popular scientific media of the time. Besides speculations about the true story behind the Tunguska Event, other topics surfaced in connection with "Guests from Outer Space". For instance, the search for extraterrestrial influence on human history afforded a perfect opportunity to engage a wide variety of religious and folkloristic texts. The questions of how to communicate with such beings and whether they would look

74 When looking at the broader reception of the topic, one can conclude that this "cosmic" subtext of the "Tunguska wonder" and of space travel played a decisive role not only in the works of Efremov and Kazantsev, but also in those by other authors. F. Zigel', „Nerazgadannaia TAINA,” Znanie - sila 6 (1959), 40-41.

Matthias Schwartz, Die Erfindung des Kosmos. Zur sowjetischen Science Fiction und populärwissenschaftlichen Publizistik vom Sputnikflug bis zum Ende der Tauwetterzeit (Frankfurt a.M., 2003)., 98-101. Only Vladimir Sorokin, who wrote a trilogy about the Tunguska phenomenon from 2002 to 2005, which, however, does not tell the story of extraterrestrial spaceships but of cosmic ice that provides enlightenment to a select group of people, adopts this connection of cosmic energy and spiritual enlightenment, as first conceived of by Kazantsev and Efremov, as the main idea of his cycle. Vladimir Sorokin, Trilogiia, (Moscow, 2005). Occultist interpretations and conspiracy theories around the "Tungusska phenomena" are popular in Russia to this day. See for instance Nikolai Vasil'ev, Tungusskii Meteorit. Kosmicheskii fenomen $1980 \mathrm{~g}$. (Moscow, 2004); Anatolii Maksimov, Nikola Tesla i zagadka Tungusskogo meteorita, (Moscow, 2009). The abbreviation SETI stands for "Search for Extra-Terrestrial Intelligence". 
like human beings or totally different were discussed heatedly. ${ }^{77}$ Striking in this debate was above all the wide variety of scientists from all disciplines who spoke out in support of the possibility of extraterrestrial contact. In 1965, the Armenian branch of the Academy of Sciences went so far as to organize an international conference on the matter. ${ }^{78}$

While the sciences provided arguments supporting the possibility of an encounter with extraterrestrial life forms, possible scenarios for the "First Contact" were played out in the SF of the Thaw period. Novels and stories that engaged with this topic were the most popular SF works of the period. Countless authors developed models to explain the world that diverged from Soviet ideology and that ranged from openly religious to clearly politically motivated, dissident visions. ${ }^{79}$ Efremov and Kazantsev were two of the most prominent representatives of occult codings of space travel, Kazantsev argued for a historical revision of the history of the earth and the gods as a cosmic history of intelligent life, while Efremov tends to focus on a "cosmic holistic" revision of the Soviet image of humanity. Instead of a generic history-like Kazantsev-he writes texts about individual epiphanies.

Kazantsev not only remained the most prominent representative of the spaceship thesis of the Tunguska meteorite, which now appeared in almost all of his novels, ${ }^{80}$ but also, similar to Erich von Däniken in Western Europe, in his texts he propagated the possibility that the human notions of the gods were actually stories about the visits of extraterrestrials to earth. ${ }^{81}$ From the "cosmonauts of antiquity", 82 he argued, one could see that mankind was descended

77 Zigel', "Nerazgadannaia TAINA," 40-41; Iu. Rall', "Razumnye obitateli Vselennoi," Nauka i zhizn', 11 (1960), 32-34; A. Guliaev et al. (1960), “Zhizn' vokrug solntsa," Tekhnika molodezhi, 1 (1960), 36.

78 See Akademiia nauk Armianskoi SSR (ed.), Vnezemnye tsivilizatsii. Trudy soveshchaniia. Biurakan, 20-23 maia $1964 \mathrm{~g}$. (Erevan, 1965).

79 Matthias Schwartz, "A Dream Come True. Close Encounters with Outer Space in Soviet Popular Scientific Journals of the 1950's and 1960's," In: Eva Maurer, Julia Richers, Monica Ruethers, Carmen Scheide, eds., Soviet Space Culture - Cosmic Enthusiasm in Socialist Societies (Houndmills, Basingstoke, 2011), 232-250.

80 In 1956 he also rewrote the novel Pylaiushchii ostrov in this regard, so that the spaceship landing of the Tunguska meteorite became the point of departure for the plot. This version of the novel was published in five editions until 1966, before Kazantsev rewrote the novel again.

81 Erich von Däniken, Chariots of the Gods? Unsolved Mysteries of the Past (1968) (New York, 1999).

82 The term of the "cosmonauts of antiquity" was first popularized by Kazantsev in 1961, when he advocated an until then unknown young author, before it became a widespread buzzword. 
from a "solar race of intelligent beings" spread across the universe. ${ }^{83}$ One example of this is the most prominent Soviet SF film of the Thaw period to have dealt with a cosmic journey, The Planet of the Storms (Planeta bur'), directed by Pavel Klushantsev in 1961, and based on a novel with the same title by Kazantsev. The film depicts a space mission to Venus in the near future, during which a Soviet scientist discusses with his American colleague the possibilities of an extraterrestrial visit beginning with the mystic Atlantis, before a young anthropologist continues his argumentation concluding: "The migration of life is as natural as seed swept by the wind on Earth. And branches of a single tribe of living beings are developing in the solar system. The solar tribe..." 84

Ivan Efremov, on the other hand, became the one to help the breakthrough of Soviet SF in 1957 with his novel The Andromeda Nebula (Tumannost' Andromedy), which described a communist interplanetary utopia in the $34^{\text {th }}$ century. ${ }^{85}$ With this reference to a higher wisdom of the East and other older nonEuropean cultures, Efremov in the end also followed a fashion that was generally spreading in Europe as a result of the 1960s movements, which also influenced the urban intelligentsia in the Soviet Union. ${ }^{86}$ While this so called "philosophical fantasy" ${ }^{87}$, represented by authors such as Arkadii (1925c1991) and Boris Strugatskii (b.1933), Mikhail Emtsov (1930-2003) or Eremei Parnov (1935-2009), had been regarded by the political side with suspicion since the beginning of the Brezhnev period and was repeatedly limited by bans and censorship measures, it nonetheless continued to be published. Thus, for example, Emtsov and Parnov first wrote a series of SF stories together in which the

A. Kazantsev, "K stat'e M. Agresta 'Kosmonavty drevnosti'," Na sushe i na more. Povesti, rasskazy, ocherki, vol. 2 (1961), 526-528: M. Agrest, "Kosmonavty drevnosti," ibid., 528-542.

83 A. Kazantsev, "Planeta bur'. Nauchno-fantasticheskaia povest'," Gosti iz Kosmosa. Povesti i rasskazy (Moscow, 1963), 469-608, here 596.

84 Planeta bur', dir. Pavel Klushantsev, Leningradskaj kinostudiia nauchno-populiarnykh fil'mov 1961; Evgenii Kharitonov, "Kosmicheskaia odissea Pavla Klushantseva," Na èkrane - chudo. Otechestvennaia kinofantastika i kinoskazka (1909-2002). Materialy k populiarnoi ènciklopedii, Kharitonov and Andrei Shcherbak-Zhukov (Moscow, 2003).

85 I. Efremov, "Tumannost' Andromedy. Nauchno-fantasticheskii roman," Tekhnika - molodezhi, 1 (1957) 26-31; 2, 25-29; 3, 22-27; 4, 22-27; 5, 22-27; 6, 27-32; 7, 28-33; 9, 30-35; 11, 4, 25-29.

86 See interviews of the author with Mikhail Emtsev (Moscow, 22.05.2003) and Eremei Parnov (Moscow, 18.09.2003). On occult and esoteric mysticism in Soviet SF of the time see Birgit Menzel, "Russian Science Fiction and Fantasy Literature," Reading for Entertainment in Contemporary Russia, 117-150, here 132.

87 The term "filosovskaia fantastika" was first used in debates since 1962, Schwartz, Die Erfindung des Kosmos, 128-130. 
heroes embark on quests for secret knowledge of spiritual insights of Native Americans of Latin America, such as The last travel of colonel Fosset (Poslednoe puteshestvie polkovnika Fosseta, 1964) or The tear of the great waterfall (Sleza bolshogo vodopada, 1969) ${ }^{88}$ After their split in 1970, Emtsov turned towards dissident milieus and a private Christian-Buddhist search for God, ${ }^{89}$ while Parnov became a successful foreign correspondent in Vietnam and India for Pravda and Literaturnaia gazeta and developed into an expert on all sorts of secret knowledge, mysticism, freemasonry and alternative religions, on which he published journalistic articles as well as fiction. ${ }^{90}$ Yet, despite his emphasis on the battle against charlatans and superstition, which earned him influential positions in the Writers' Union and an award from the Interior Ministry, his works themselves are in certain ways influenced by Buddhist philosophy of cyclical world processes and a transcendental determination of fate. ${ }^{11}$

Also heavenly "guests from the cosmos" remained a central medium for religious salvation fantasies, of which Andrei Tarkovskii's film Stalker (1979), based on Arkadii and Boris Strugatskii's novel The Roadside Picnic (Piknik na obochine, 1972), is probably the example most well known in the West. ${ }^{92}$ As in

88 But also substances coming from space or produced in chemical laboratories and capable of inducing hallucinations repeatedly provide Emtsev's and Parnov's heroes insight into other states of being. Matthias Schwartz, „Diktatur als Drogentrip. Rauschfantasien in sowjetischer Science Fiction," Rausch und Diktatur. Inszenierung, Mobilisierung und Kontrolle in totalitären Systemen, eds. Árpád von Klimó, Malte Rolf (Frankfurt, New York, 2006), 255-280.

89 He published only one more novel in SF until 1990, Bog posle shesti. Pritvoriashki (God after six. The Hypocrites, 1976), in which he articulated his true belief in God against false rituals and manipulations using the case of a sect. In his legacy there is a series of texts in which he articulated his views on spirituality and religion. M. Emtsev, Dusha mira. Izbrannoe (Moscow, 2004).

90 His most famous trilogy of detective fiction about inspector Liusin dealt with the ban on the Knights Templar in the $14^{\text {th }}$ century and how the persecuted friars remained secretly active until nowadays (Larets Marii Medichi, The wreath of Mary Medici, 1972); it re-evaluated Hindu und alchemist knowledge of the middle ages (Tretii glaz Shivy, The third eye of Shiva, 1975) and dealt with ancient experiments in the search of a mysterious "elixir of immortality" The Maltese baton (Mal'tiisiskii zhezl, 1987).

91 Beginning with his book At the crossroad of eternity (Na prerekrestke beskonechnosti, 1967) Parnov started to write educative documentary books with fictional elements on occult and religious themes. The most controversial and popular one was his bestseller The Throne of Lucifer. Critical views on magic and occultism (Tron Liutsifera, 1985), followed by a series of books on similar topics like Rulers and mages (Vlastiteli i magi, 2 vol., 1996), The secret signs of Gods (Tainye pis'mena bogov, 2007) or Satanic deals. Secrets of the Second Worldwar (Sataninskie sdelki. Tainy Vtoroi mirovoi voiny, 2009).

92 While Arkadii and Boris Strugatskii engaged with religious themes and apocalyptic scenarios 
the works of Efremov and Kazantsev, supposed secret relics from the cosmos are clearly associated with radioactive rays, which in Tarkovskii's work wield magical power over intellectuals from the capital city and promise the fulfillment of their secret wishes.

One can regard Tarkovskii's film as a symptomatic turn in the engagement with the topos "guests form outer space" as it marks the crossing over of the topic out of the niche of SF and of the engagement with occult topics, especially by the technological-scientific intelligentsia, into the broader mainstream of "serious" high culture. After this, religious and occult topics were to an ever lesser extent directly associated with the human cosmic journey into the universe and rather took on the older religious narrative model again, which had always located spiritual experiences, gods and angels in the heavens. ${ }^{93}$ The human hubris, dominant in the works of Efremov and Kazantsev and generally in occult approaches, which posit that thanks to the "light of intellect" humans will themselves rise to possess "divine" wisdom, once again follows classic religious, mostly Christian Orthodox narrations.

\section{Conclusion}

If we try to summarize the occult aspects of Soviet SF since its emergence at the peak of the so-called Great Terror in the midst of the Stalinist scientific intelligentsia, we can highlight some common elements. First of all, all texts about some sort of secret or hence unknown knowledge offer a technical and scientific explanation that serves as a medium of contact for extraterrestrial experiences. These encounters take place, for the most part, in the Soviet present or in the near future and are, in this way, accessible and comprehensible for readers based on their everyday experiences. At the same time, these cosmic contacts are never described in literature as collective encounters, but rather as experiences of individuals or small groups, which remain outside of the public sphere and are not institutionalized. Instead, they are reduced to the level of singular, personal experiences. These fictional contacts with "secret" extraterrestrial entities offered not only new insights into the nature of humanity, but

starting with their novels It is Hard to be a God and Monday begins on Saturday, they always remained within the scope of materialistic, humanistic explanations of the world, whereas Tarkovskii in his films dealt with religious belief systems. SeeYvonne Howell, Apocalyptic Realism. The Science Fiction of Arkady and Boris Strugatsky, (New York, 1994); Daniel Kluger, "Fables of Desire," Science Fiction Studies 31 (2004), 415-417.

93 See Nadya Peterson, Subversive Imaginations. Fantastic Prose and the End of Soviet Literature, 1970s-1990s (Boulder, Colorado, 1997). 
also challenged materialistic explanatory models of human history and society. In this sense, "guests from outer space" are not presented as a classical instrument of exoneration, confession or projection, but often allow the formulation of secret or forbidden desires that can be interpreted as a fictional realization of occult practices or belief systems. ${ }^{94}$

In the context of the Cold War period, the personalized "guests from outer space" were, at the same time, aimed against the popular myths of the West: The extraterrestrials were conceived as friends and not as hostile invaders, not as colonizers intending to remain on the earth, but rather as temporary visitors, who possibly had a positive influence on human history and always signaled hope for the future. ${ }^{95}$ Naturally, comparable phenomena can also be observed on the other side of the "iron curtain". The wave of UFO hysteria that gripped America in the post-war period is one prominent example. Furthermore, the enthusiasm for cosmic issues by the hippie movement or the fascination with outer space by African-Americans since the 1950s represent similar popular fashions. ${ }^{96}$ However, whereas para-science and "astrofuturism" were pushed to the margins of societal discourse in the West, this division was not present in the Soviet Union: science was the legitimating principle of society. In this way, occult and fantastic theses could be supported by prominent experts in the central institutions of society.

In summary, the following can be noted about cosmic themes, as they were present in Soviet SF since the middle of the 1930s: The project of enlightenment, which was intended to give common knowledge and universal truth to the people to get rid of false gods and to organize society according to strictly secular criteria, was fundamentally challenged with the establishment of Stalin's dictatorship. This challenge enabled the emergence of occult notions of natural sciences, which aimed at a qualitative, dialectical leap of knowledge. SF texts offered fictional settings that would ultimately change our previous worldview. As early as the prewar era, SF drew "forbidden" connections be-

94 It can be assumed that this fictionalization of occult knowledge was, at least to some extent, the result of targeted cultural policymaking. It offered alternative models for the creation of meaning, which satisfied certain religious needs while following the party line set by the Soviet regime regarding technical and scientific issues. At the same time this phenomenon worked distinctly against the Russian Orthodox belief system.

95 On this difference, see Menzel, "Russian Science Fiction and Fantasy Literature," 135-136.

96 De Witt Douglas Kilgore, Astrofuturism. Science, Race, and Visions of Utopia in Space (Philadelphia PA, 2003); Marina Benjamim, Rocket Dreams. How the Space Age Shaped Our Vision of a World Beyond (New York, 2003); Mark Bould, "The Ship Landed Long Ago. Afrofuturism and Black SF," Science Fiction Studies 34 (2007), 177-186. 
tween secret scientific and technical innovations, cosmic occurrences and possible contacts with extraterrestrial beings. This disposition of "guests from outer space" was to become a central topic of popular scientific and "scientific fantastic" literature in the postwar period, which, as I have argued in this article, can be characterized as a specifically Soviet occult discourse.

In considering the longer-term cultural-historical consequences of Soviet SF for the post-Soviet occult revival, one has to take into consideration the following two aspects. On the one hand, as the print media and television began during the Glasnost period to report on topics that had long been subject to tight censorship, the public was above all fascinated by stories about parapsychology and the New Age. This media success of occult and new-religious movements in post-Soviet Russia can be only partially explained as a simple adaptation of western entertainment culture and zeitgeist trends. ${ }^{97}$ To a greater extent, these movements can be traced back to a deeply seated occult interest: namely, the decades-long engagement with this topic in Soviet SF texts and popular scientific journals. ${ }^{98}$

On the other hand, the continuity of religious and occult discourses certainly also had an important impact on post-Soviet fantasy literature, which is even today, along with crime fiction, the most popular genre of "light" fiction. ${ }^{99}$ In asking why this type of literature is so successful one answer is that, possibly, the function of fantastic devices nowadays has changed significantly. Whereas Soviet "scientific fantasy" can be partly interpreted as a movement seeking to promote forbidden religious or occult ideas and aiming against the official ideology of an atheist society, in post-Soviet fantasy these alternative worlds no longer claim the authority of the sciences, but proceed in another direction: Post-Soviet fantasy, claims the multifaceted authority of spiritual and folkloristic interpretive models in order to cope by literary means with the idiosyncrasies of Putin's and Medvedev's Russia in a globalized world. The fantastic description and occult explanation of the Soviet past and Russian present, as it dominates many texts of so-called "alternative histories" or "crypto histories", continue explanatory models developed in Soviet SF. ${ }^{100}$ At the same time, these

97 See Birgit Menzel, "The Occult Revival in Russia Today and Its Impact on Literature," The Harriman Review 16 (2007), 1-14.

98 Which again took its origins in the Silver Age of Fin-de-Siècle Russia, cf. Rosenthal, "Introduction," In: The Occult in Russian and Soviet Culture. 1-32.

99 Menzel, „Russian Science Fiction and Fantasy Literature, “ 118.

100 Vitalii Kaplan, "A Look Behind the Wall. A Topography of Contemporary Russian Science Fiction," Russian Social Science Review 2 (2003), 82-104; Elena Kovtun et al., eds., Russkaia fantastika na prekrest'e épokh I kul'tur. Materialy Mezhdunarodnoy nauchnoy konferentsii 21- 
stories present an attractive alternative to new political ideologies as well as to Russian Orthodoxy by devising an entire collection of extraterrestrial and mythic beings and phenomena for all circumstances. Hence they offer imaginary worlds that promote all sorts of esoteric thinking, conspiracy theories or para-scientific knowledge, but in their playful hybrid assemblage of these discourses, similar to the "communist Pinkertons" of the 1920s, simultaneously vulgarize and defuse them. Post-soviet fantasy thus often constitutes a counterdiscourse to the actual occult revival in Russia rather than enforcing it.

23 marta 2006 goda (Moscow, 2007); Matthias Schwartz, „Postimperiale Erinnerungsbilder. Zum Umgang mit der Geschichte in der russischen Populärkultur, "In: Geschichtspolitik und Erinnerungskultur im neuen Russland, eds. Lars Karl, Igor J. Polianski (Göttingen, 2009), 215234. 


\title{
TOTALITARIAN UTOPIA, THE OCCULT, AND TECHNOLOGICAL MODERNITY IN RUSSIA: THE INTELLECTUAL EXPERIENCE OF COSMISM
}

\author{
MARLÈNE LARUELLE
}

Cosmism is a movement of thought-whose boundaries and founding fathers may vary-that is relatively unrecognized in Western scholarship and yet had important ramifications in the Soviet Union. These ramifications began in the 1920s, as emphasis was being put on the sciences of the future, and were later reinforced by the conquest of space. Cosmism is part of the romantic and organicist tradition that rejects divisions of knowledge, presupposes that scientific progress and spiritual quest go hand-in-hand, and believes in an intrinsic link between micro- and macrocosm. Calling for the voluntarist transformation of nature by humankind, mainly by the mastery of space, cosmism tried to synthesize Gnostic beliefs and scientific progress. It therefore illustrated, in a rather unique way, an occult experience of modernity, founded on the idea that technological knowledge is power, in all its senses: the power to change humanity, to master nature, to abolish temporality and the relation to the body, and to transform the relations between states. A study of cosmism, therefore, calls for the seemingly obvious configuration between the rational and the irrational to be put into question. This configuration can be shown not to be a given but instead a social construction that belongs to a time and a place. Indeed, the status of non-conventional narrative of cosmism did not prevent it from operating as a framework-sometimes underground, sometimes recognized-for $20^{\text {th }}$-century scientific interrogations in Soviet Russia. ${ }^{1}$

\section{Genesis of Cosmist Thinking: a Contextualization}

Cosmism drew many of its philosophical precepts from the great currents of thought preceding it, and tried to put forward an original and innovative synthesis of the relations between science and faith. It is rooted in Romantic ideology of the late $18^{\text {th }}$ and early $19^{\text {th }}$ centuries and organicist theories that assume the existence of laws of harmony between humankind, nature, and the cosmos. Similarly, it also drew inspiration from the scientism of the turn of the $19^{\text {th }}-20^{\text {th }}$ century and the nomogenetic precepts used to challenge Darwinism. Lastly,

1 I thank Michael Hagemeister for his very helpful comments on the first version of this text. 
cosmism is inspired by the messianic statements of Soloviev and Dostoevsky concerning the reconciliation of humanity over and above its division into different nations.

Rooted in the German Naturphilosophie elaborated from the end of the $18^{\text {th }}$ century, Romantic ideology appeals to a new model of intelligibility in which primacy is given to the human factor. It asserts that human beings retain their essential singularity, are irreducible to numerical analysis, and that science goes hand-in-hand with faith: the organization of phenomena is explainable by recourse to providence. Hence, Romantic ideology does not challenge the facts and laws established by experimental research, but rather their placement in the general scheme of knowledge. Though it accepts the encyclopedic knowledge of the Renaissance, it dismisses that of the Enlightenment, which it apprehends as a sum of unrelated pieces of knowledge which rejects faith. Romanticism aims, in fact, at promoting a lost unity by endorsing a science that is total and transdisciplinary. It endorses a return to a philosophy that recognizes the rights of imagination and emotion, and rejects the dry. For the Romantics, the value of an event appears only when it is placed in a meaningful context. As such, they maintained the necessity of constructing a higher level of knowledge, a philosophy of humanity encompassing both faith and science. ${ }^{2}$

This Romantic thinking is strongly marked by the birth of a general theory of biology which encompasses animals and the vegetal in the same processes as humans. Nature is no longer considered a mythological divinity but an internal economy subject to regulations accessible to human intelligence. Accordingly, Lebenskraft, or vital force, became the major theme of the era. It is not mere chance that Naturphilosophie had great success in both the medical milieus and the fields of earth science and vegetal biology. The mechanicist revolution had assured the triumph of an analytic representation of the universe. However, machines have no self-consciousness, and therefore the mind that creates them must be of another order. Organicism thus sought to re-establish a previously dominant mode of knowledge, wherein instead of placing limits on its ambitions to decipher the superficial organization of phenomena, it strove to forge an alliance with the "essence" of reality. Against the artificial construction of mechanicism, it substitutes a living growth, obeying not abstract rules, but an immanent inspiration. Organicism founded the possibility of understanding the world on the principle of analogy. It proposed a vitalist schema of growth whose dynamism progresses from birth to death, and which maintains, between the elements that it assembles, an intimate solidarity, in which mecha-

2 On Romanticism as ideology, see George Gusdorf, Le romantisme (Paris: Payot, 1993). 
nisms are subordinated to the government of finality: the part cannot be realized without the whole, or the whole without the parts. Multiplicity and unity do not stand in contradiction. ${ }^{3}$

However, while Romanticism had wanted to "put Newton on trial"4 and asserted that a mechanistic and clockwork-like vision of the human automaton would lead straight to an industrial hell, cosmism affirmed exactly the opposite. In so doing, it drew on the scientist revival of the late $19^{\text {th }}$ and early $20^{\text {th }}$ centuries. This revival rejected positivism, interpreted as a resignation of the mind which considers that science has no say in the inner meaning of the phenomena whose sequences it sketches. For the scientists, on the contrary, science aimed to provide the response to the great questions-religious and moral-of humanity, those to which religion also responds. As Jules de Gaultier explained in 1911,

scientist belief repeats the sum of petitions comprising the program of human hope in its messianic and moral forms. It restores the theme of the always reborn and unfulfilled dream of human consciousness on the search for better futures among the perspectives on a development that is inestimable in duration. ${ }^{5}$

Cosmism is based wholly on this scientist precept, which it pushes to its extreme. It can therefore be understood as a vitalist theory indirectly inspired by Bergsonian thought. Already convinced, thanks to its organicist influences, about rehabilitating the alchemy of the Renaissance, cosmism also drew inspiration from the para-scientific quests of its time, such as spiritism, hypnotism, somnambulism and telepathy, the discovery of animal magnetism (mesmerism), palingenesis, and metempsychosis. All these challenges to the limits of science encouraged the belief that there are some parts of scientific knowledge still inaccessible to the human mind. The discovery of the atom, the gene, and the idea according to which every living cell registers and reacts to natural phenomena, came to influence cosmism profoundly.

Cosmism also based itself on some Russian intellectual traditions. In the second half of the $19^{\text {th }}$ century, several thinkers, challenged-whether positively or negatively - by the discoveries of Darwinism, set out to investigate the

3 On Organicism, see Judith Schlanger, Les métaphores de l'organisme (Paris: L'Harmattan, 1995).

4 Title of a chapter of Gusdorf, Le romantisme, vol. 1, 197.

5 Jules de Gaultier, Revue philosophique de la France et de l'étranger, 1911. 
relations between science and faith, as well as the epistemology of science. ${ }^{6}$ The embryologist Karl Ernst von Baer (1792-1876), whose theories were very popular in Europe, objected, for example, to the idea that natural selection suffices to explain evolution. Heralding the theory of mutations that Hugo de Vries (1848-1935) will later develop, Baer subscribed to immanentism and was a supporter of so-called ontogenetic evolution, conceived as fulfilling a plan. Similar notions can be found in the famous Pan-Slav theoretician Nikolai Danilevskii (1822-1885). In his, Darwinism: A Critical Study (Darvinizm: Kriticheskoe issledovanie) published in 1885 and 1889, he postulates that Darwinism is not a matter of botany or zoology, but a philosophical interrogation into the origin of humanity and the organicity (tselesoobraznost') of nature. $\mathrm{He}$ therefore acknowledged a positive point in Darwin's theory, which is that it puts the naturalist back into nature insofar as it proves the need to study forms of life in their environment and not to classify them once dead: it is harmony that must be explained and not each living thing taken individually. ${ }^{7}$ Nevertheless, for him, the idea of systematizing chance in the mechanisms of evolution amounted to a negation of the existence of God: how, from a series of chance events without any coordination between them, could a harmonious order emerge? If humans are only descendents of the ape, then nihilist and atheist thinking is justified: Danilevskii judged the idea of the struggle for survival, in which the strongest only survive eminently anti-Christian. Here, he based himself on the German Theodor Eimer (1843-1898), who promoted the idea of inner predetermined evolution, an idea ignored by Darwin who instead privileged external causality. ${ }^{8}$

In the early $20^{\text {th }}$ century, Lev Berg (1876-1950) pursued Baer's and Danilevskii's claims that there existed an alternative nomogenesis to Darwinism in his work Nomogenesis, published in $1922 .{ }^{9}$ His nomogenetic theory of evolution postulates that evolution obeys laws, for example, that it is a development of pre-existing rudiments or potentialities, rather than a series of adap-

6 On this topic, see Alexander Vucinich, Darwin in Russian Thought (Berkeley: University of California Press, 1988); Loren R. Graham, Science in Russia and the Soviet Union: A Short History (Cambridge, Cambridge University Press, 1993).

7 "N. Ia. Danilevskii: Codification of Anti-Darwinism," In: Vucinich, Darwin in Russian Thought, 118-150.

8 Patrick Sériot, "Aux sources du structuralisme: une controverse biologique en Russie," Etudes de Lettres, 1994, 89-103.

9 Lev S. Berg, Nomogenez (Évoliutsiia na osnove zakonomernostei) (St. Petersburg: Gosudarstvennoe izdatel'stvo, 1922), translated in English: Nomogenesis or Evolution Determined by Law (Cambridge: MIT Press, 1966). 
tive responses by organisms to their environment. Berg, however, rejected all vitalist approaches. For him, conformity to a goal was a property of the living and not a mysterious force. In the same line, Boris Chicherin (1828-1904), anticipating Bergson, spoke of an inner, goal-oriented vital force and believed that the only explanatory principle of evolution was teleology. ${ }^{10}$ Similar approaches also emerged with Vladimir Vernadskii (1863-1945), a geochemist by training and director of the biochemistry laboratory of the Soviet Academy of Sciences from the late 1920s until his death. ${ }^{11}$ Renowned throughout Europe, he was especially interested in the energy of living matter. In the 1920s, he developed the notions of the "biosphere"-positing as his hypothesis that the earth was formed by a geological force he called life-and of the "noosphere", or sphere of thought, presented as the next level of development of humankind. The terrestrial envelope, he claimed, would soon be the object of regulation by human reason, which was itself beginning to appear as a form of energy, as it had the ability to change hitherto material processes. ${ }^{12}$

Last but not least, Cosmism can also be considered as an inheritor of the Silver Age and the revival of Russian philosophy embodied by Semen Frank, Nikolai Berdiaev, Nikolai Grot, Pavel Florenskii, Sergei Trubetskoi, or Lev Karsavin. The philosophers of the Russian Silver Age pursued the Romantic will for synthetic knowledge in order to give meaning to the world. They wanted philosophical reflection to be meta-systematic and to provide essential responses to their interrogations. They saw the much-awaited realization of the union between science, faith, and poetry in a renewed philosophy. The cosmists are particularly indebted to Vladimir Soloviev ${ }^{13}$ (1853-1900), who himself had borrowed the notion of "integral knowledge" (tsel'noe znanie) from Ivan Kireevskii (1806-1846), and had been influenced by his combination of mystical intuitions and interest in the "Russian question." ${ }^{14}$ Soloviev's philoso-

10 On Baer and his successors, see the works of Patrick Sériot, Structure et totalité. Les origines intellectuelles du structuralisme en Europe centrale et orientale (Paris: PUF, 1999).

11 Kendall E. Bailes, Science and Russian Culture in an Age of Revolutions: V.I. Vernadsky and His Scientific School, 1863-1945 (Bloomington: Indiana University Press, 1990).

12 The term noosphere was employed for the first time by a disciple of Bergson, Edouard Le Roy, in his courses at the Collège de France in 1927, as well as by Pierre Teilhard de Chardin. Cf. Svetlana Semenova, ed., Russkii kosmizm. Antologiia filosofskoi mysli (Moscow: PedagogikaPress, 1993).

13 On his life and thought, see Dmitri Stremooukhoff, Soloviev et son ceuvre messianique (Lausanne: L'âge d'homme, 1975).

14 The Russian Idea (russkaia ideia) conventionally refers to late nineteenth and early twentiethcentury debates in the Russian intellectual world, centered on the notion that the essence of 
phy comprises a meeting between the three approaches that, according to him, led humanity on the path to wisdom: theosophy (thought), theurgy (emotion, art), and theocracy (will). The philosopher believed that only Orthodoxy can imbue with Christian principles this new philosophy, to which he assigned the task of re-establishing the unity of the intelligible world. Nevertheless, Byzantium had moved away from the real Christian spirit while sticking only to the letter, and the Russian Church, since Nikon, had become corrupt by becoming secular. Orthodoxy could therefore be revived only by its reunion with Rome which had preserved the notion of a central authority. Soloviev's philosophy therefore places the concept of all-unity (vseedinstvo) at the core of its reflections: it defined the much-awaited Ecumenical synthesis in terms of a belief in humankind's intuition of the organicity of humanity and the universe.

To Soloviev's concept of totality it is necessary to add other messianic precepts, such as those developed by Fedor Dostoevsky, notably in his Journal of a Writer (Dnevnik pisatelia), published between 1873 and 1881. Dostoevsky remained a Christian thinker who was more interested in faith and evil than merely in the future of Russia. His messianism, however, is ambiguous, being at once religious and national. He thought that the Russians had been called upon to save the world because they were the body of Christ, the people of freedom, and of social justice. "We Russians have two homelands: Russia and Europe-even in cases when we call ourselves Slavophiles (...). The greatest of all the great missions that the Russians realize lies ahead of them is the common human mission." ${ }^{15}$ Accordingly, the national idea of Russia is a universal one, Russian genius being close to the other peoples throughout the world. Russian messianism is also universal in its biblical filiation. "Europe is almost as dear to all of us as is Russia: Europe is the home of the whole tribe of Japheth, and our idea is the unification of all the nations of this tribe and, eventually, in the distant future, of the tribes of Shem and Ham as well." 16 This Russian messianism is often adorned with eschatological characteristics. The prevailing theme of the imminent end of the world, or of massive upheavals, is traditional in Russian popular thinking, for instance in the famous legend of

the Russian nation could be characterized by certain timeless features including messianism, Orthodox spirituality, and a sense of symphony or community (sobornost'). However, the concept of the Russian Idea has been gradually expanded to encompass all debates on identity, extending from those among the first Slavophiles of the early 1830s to contemporary doctrines on how the nation can re-assume a sense of its mission.

15 Fedor Dostoïevski, Journal d'un écrivain, 1873-1881 (Paris: Gallimard, 1972), 505-506.

16 Ibid., 833. 
the submerged town of Kitezh and the various movements of old-believers who wandered as far as Siberia and Chinese Turkestan. ${ }^{17}$

From these multiple influences, cosmism tries to forge a reconciliatory synthesis of opposites. ${ }^{18}$ Its main theoreticians, each in their own way, militate for the rebirth of holistic knowledge, in the manner desired by Romanticism, but without subscribing to the idea of humanity's decadence. Of the organicism, they retain the claim about the ontological unity between Man and nature, and the need to converge the forms of knowledge of man, and the cosmos. Like the anti-Darwinian Romantic biologists, they believe that the evolution of life is based not on the idea of random selection, but on a predestined designnomogenetic-which remains to be discovered. However, they never undermine science in itself, on the contrary: cosmism is fundamentally optimistic, futurist, and believes firmly in the idea of humanity's progress through science. Lastly, the cosmists are part of the great currents of messianism to have developed in Russia: they think that their country is destined to accomplish, in one way or another, a form of reconciliation of humanity.

\section{The Founding Fathers: \\ From Christian Exegesis to the Conquest of Space}

A great herald of the cosmist movement, Nikolai Fedorov (1828-1903) struck as an original, if marginal, figure in Russia at the start of the $20^{\text {th }}$ century. ${ }^{19} \mathrm{~A}$ famous librarian of the Rumiantsev Museum, he refused to publish while he was alive and expounded his ideas only orally to small groups of loyal supporters. ${ }^{20}$ His sole work, titled Philosophy of the Common Task (Filosofiia obshchego dela), was published posthumously by his two disciples, Nikolai Peterson and

17 Viacheslav Shestakov, Eskhatologiia $i$ utopiia. Ocherki russkoi filosofii i kul'tury (Moscow: Vlados, 1995).

18 On the links between Romanticism and the cosmos, see Jean Clair, ed., Cosmos: From Romanticism to the Avant Garde (Quebec: Montreal Museum of Fine Arts, 1999).

19 The main work on him is Michael Hagemeister, Nikolaj Fedorov: Studien zu Leben, Werk und Wirkung (Munich: Sagner, 1989). See also George M. Young Jr., Nikolai F. Fedorov: An Introduction (Belmont: Nordland Publishing, 1979), and Stephen Lukashevich, N.F. Fëdorov: A Study in Russian Eupsychian and Utopian Thought (Newark: University of Delaware Press, 1977).

20 George M. Young Jr., "Fedorov's Transformations of the Occult," in Bernice G. Rosenthal, ed., The Occult in Russian and Soviet Culture (Ithaca, London: Cornell University Press, 1997), 172. 
Vladimir Kozhevnikov. ${ }^{21}$ This long and complex work can be understood as a scientific exegesis of Christianity, strongly inspired by Soloviev and Dostoevsky. Fedorovism maintains that there is only one real goal of humanity, the resurrection of the dead. It claims that all of humanity's intellectual, spiritual, and scientific activity is directed, wittingly or not, toward this accomplishment. Death is held only to be one state of humanity, which arises from our imperfect character, and is by no means a destiny. This quest for immortality and for liberation from suffering, Fedorovism maintains, will be achieved through faith, but also through technological knowledge. This first cosmism, or Fedorovism, is thus conceived as a practical and technological implementation of Christianity, construed primarily as a religion of resurrection. Created in the image of God, man must learn to resurrect that which is dead. Fedorovism thus considers the conscious re-creation of all our ancestors as a moral duty of the living toward the dead.

For Fedorov, the conquest of space is intrinsically linked to the question of the resurrection of the dead. "[The] conquest of the path to space is an absolute imperative, imposed on us as a duty in preparation for the Resurrection. We must take possession of new regions of space because there is not enough space on Earth to allow the co-existence of all the resurrected generations." ${ }^{22}$ In fact, humanity does not cease to be when dead. Simply it assists in a transformation of its corporeal state, marked by the parcelization of bodies into atoms. With the conquest of the Moon, the planets, and the stars, humanity will be able to recover the set of particles and begin a vast undertaking of reconstituting the ancestors' bodies, perhaps in different physical forms. In its last stage, humanity will therefore be all-knowing; not limited in time or space, it will simultaneously be one and plural (mnogoedinstvo) and solve the contradiction between the individual and the collectivity. Fedorov tried to formulate some first technical possibilities for the conquest of space and the mastery of nature. He believed strongly, for example, in gaining control of atmospheric processes and in the colonization of other planets (as a Malthusian, he was concerned about the growing demographic pressures exerted on the Earth), and wrote about humankind's genetic transformations. However these topics elicited strong

21 Filosofiia obshchego dela was published posthumously, the first volume in 1906 at Vernyi (future Alma-Ata), and the second in 1913. His texts have been republished in Anastasiia Gacheva and Svetlana Semenova, eds., N.F. Fedorov: Sobranie sochinenii v chetyrekh tomakh, (Moscow, 1995-2000).

22 Jean Clair, "From Humboldt to Hubble," In: Clair, ed., Cosmos, 25. 
distrust even among those who shared his philosophical and religious conceptions.

Inspired by the utopian socialism of Fourier, Saint-Simon or Bellamy, Fedorov appealed to an immanent universal resurrection. Such resurrection, he claimed, would by no means be reserved to a small circle of the elect, since there are no privileges in accessing higher knowledge: ideal reality is accessible only through pan-human labor, consciously organized. However, humanity's victory over nature, he argued, remained inextricably linked to Russia, since it would be the country to lead the world on the path to salvation. Russia would be the key country to produce great advances in terms of mastery of the cosmos, interplanetary travel, transforming nature and climates, and establishing agriculture in space. Fedorov also believed that the nature of Russia's ideocratic political regime was a further sign that it heralded the resurrection of humanity. For only autocracy, which tends toward the completion of man, but also toward the worship of ancestors, constitutes the apogee of a people's maturity faced with capitalism and constitutionalism, deemed immature insofar as they proclaim that sons are superior to their fathers. Fedorov claimed that the territorial success of the Russian Empire, its immense advances into Asia, won without encountering great resistance, was the heralding sign of its destiny to conquer spaces of another nature, those of the cosmos. ${ }^{23}$

Fedorov's world history is founded on a dialectical principle between civilizations that exploit the earth on the one side, and nomad and mercantile civilizations, on the other. In this world history, Russia is said to play a major role since the obshchina embodies the principle of the earth-the only regenerator able to contend with the commerce and luxury which will lead to humanity's downfall. The tradition of the peasant commune had therefore prepared the Russian people for the cosmic control of nature. It is also destined to help all major agricultural civilizations, particularly Indian and Chinese, to become aware of their salvational role in countering the world of the steppes. The Russian autocracy is to bring about the sedentarization of the nomads, but also the passage of urban dwellers to the countryside: indeed, as a disciple of the first socialist utopians, Fedorov hoped that all people would live in fields in summer and in small-size factories during the winter. Russia purportedly rested on a twin mission: anti-colonialist, since it took up the defense of exploited peoples

23 Nikolai Fedorov, "Filosofiia obshchego dela," In: Semenova, ed., Russkii kosmizm, 70. More in Olga Lavrenova, "Filosofiia prostranstva v russkom kosmizme," In: Ivan Mitin and D.N. Zamiatin, eds., Voobrazhenie prostranstva, prostranstvo voobrazheniia (Moscow: Agraf, 2009), 82-93. 
against the colonizing West, but also messianic, since it is compelled to work towards world peace between the "white" and "yellow" races. In this combat, China is seen as one of Russia's main allies: through this alliance, a renewed Orthodoxy would introduce the ancestral worship present in Confucianism, something that Fedorov was especially appreciative of, since, for him, ancestors and god were synonyms. ${ }^{24}$ Hoping that, in the long term, the Middle Kingdom would convert to Christianity, he was delighted at the discoveries of Nestorian steles in Chinese Turkestan. For him, this proved that Orthodoxy-as the majority of Russian intellectuals assimilated it to Nestorianism-was not foreign to China, but had formerly been its national religion. ${ }^{25}$

Despite his ambiguous attraction to China, Fedorov's attention was actually commandeered by India. In 1899, he went to Turkestan from Krasnovodsk, the departure point of the Transcaspian railway, and visited Pamir (today in Tajikistan), which the Tsarist Empire shared with the British Empire at the time by an agreement that gave rise to the buffer state of Afghanistan in 1895. The Pamir heightened his interest for the Indian question and came to have a fundamental place in his cosmogony: though Constantinople had announced Christianity, the Pamir symbolized the birth of the Aryan race and the first steps of the Indo-European languages. According to Fedorov, it is no coincidence if the Russo-British border had stabilized in Pamir, since it contains "the forgotten ancestors of all the Aryan and non-Aryan peoples, Japhet, Shem and Ham. ${ }^{26}$ Pamir thus showed that the two colonial powers had a common origin and that this called for peace: should they prefer to make war here, he claimed, then the "cradle of the human species will also be its tomb." 27 The desire for a Russo-Indian alliance, however, was not directed against the West in itself: on the contrary, Fedorov was persuaded that a rapprochement would occur in the future between Germany and Russia, since, he alleged, both peoples shared the common roots of "all peoples of Aryan origin." ${ }^{28}$ Nature itself would call for the presence of the Tsarist Empire in India: the Russian rivers need an opening to the southern seas and one could even foresee an "exchange of air" between the Siberian cold and the Indian monsoon, enabling the creation of a temperate climate in both countries. ${ }^{29}$

24 Nikolai Setnitskii, Russkie mysliteli o Kitae. V.S. Solov'ev i N.F. Fëdorov (Kharbin, 1926).

25 Nikolai Fedorov, "Po povodu khristianskikh pamiatnikov v Kitae," Russkii vestnik, no. 1, 1901, 151-66.

26 Nikolai Fedorov, Filosofiia obshchego dela (Lausanne: L'Âge d'homme, 1985), vol. 1, 268.

27 Ibid.,268.

28 Ibid., 262.

29 Cited without precise references in Lukashevich, N.F. Fedorov, 270. 
As the first step toward the reconciliation of humanity, Fedorov proposed organizing a Russian-British scientific expedition-a form of Aryan pilgrimage - to search for the original language of humanity on the high summits of the Pamir. ${ }^{30}$ Once found, the first ever Aryan would then be brought back and buried in a "museum of the human species" to be located in Moscow, which would again become the capital of Russia and would take up its place as the world center of awareness of the paternity, and therefore of the fraternity, of Aryan humanity. In this vein, his disciple Nikolai Peterson argued in 1899 that the $12^{\text {th }}$ Russian Archeological Congress should be held in Central Asia, in Tashkent, Samarkand or Merv, in order to affirm Russia's Aryan nature: according to him, research conducted on Pamir and other presumed sites of the general patrimony of Aryan peoples would "reconcile Slavophilism and Westernism into a higher unity, Ariophilia (ariosofil'stvo)." ${ }^{31}$ Paying respect to the original Aryan remains would bring about global salvation since "the discovery of the bones of the ancestors of all peoples must work towards a goal of pacification, of unification." ${ }^{32}$ Fedorov assigned a major importance to the army, in which he saw the ideal prototype of a collectivized humanity working to master nature. Russia would then put together a Christian army (khristoliubivoe voisko) to provide protection to any peoples that asked for it.

By organizing a world conference of linguists in order to recreate humanity's original language as it existed prior to the division of Babel, Russia would announce a sort of eschatological return of humanity to itself and the muchawaited "end of history." National divisions would disappear and schools set up where the entirety of world knowledge would be taught. Fedorov thus sketched future society as a form of totalitarian psychocracy, in which the idea of "returning to the earth" is combined with that of a world of science-fiction resembling Fourier's phalanstère but placed under the patronage of an Orthodox "Big Brother." ${ }_{33}$ Fedorov's thought had its main success after a Revolution that many intellectuals saw as the second coming of Christ, one that implied not only social, but also metaphysical changes. However, after him, the theme of overcoming death was understood less and less as a religious phenomenon, linked to a Christian awareness of the world, and more and more as a mechani-

30 Young, "Fedorov's Transformations of the Occult," 181.

31 Protokoly Turkestanskogo kruzhka liubitelei arkheologii (Tashkent), vol. III, 1899, 99-103.

32 Fedorov, Filosofiia obshchgo dela, vol. 1, 270.

33 Accordingly, each member of the commune would note down his dreams and thoughts, would be called before a psychological council, and would benefit from the therapies proposed by the council, under the supervision of the Orthodox Church; brides and grooms would be chosen in accordance with a selection made in terms of "psychogenetic" criteria etc. 
cal reality. In the first years of the new Soviet regime, the main theoreticians of cosmism merely oriented toward a more technical and practical vision something that had been originally deployed as a religious philosophy.

In the emigration, Fedorov's thought gave rise to a movement laying claim to him in Kharbin, Mandchuria, centered around Nikolai Setnitskii (18881937), and played a key role in the crystallization of National-Bolshevism by Nikolai Ustrialov (1890-1937), as well as in so-called leftist Eurasianism, whose views were expressed in the Evraziia newspaper, published in Paris at the end of the 1920s. ${ }^{34}$ Fedorov's disciples in the Soviet Union, the so-called Fedorovtsy, led by Aleksandr Gorskii (1886-1943), were organized in Moscow and Kaluga. At the time, they focused chiefly on the technical elements that Fedorov had evoked in the struggle against humankind's mortality, rather than on his Christian philosophy, which no longer suited the ideological presuppositions in Russia after the Revolution. According to them, the cosmos is a machine, certainly one of extreme complexity, but nonetheless one that can be correctly deciphered in order to find the reverse process which will enable the passage from disaggregation to recomposition. Many groups that were stamped by revolutionary eschatology were particularly fascinated by the Fedorovian metaphysics of technology, including the famous god-building movement (bogostroiteli) of Anatolii Lunacharskii (1875-1933) and Aleksandr Bogdanov (1873-1928), the lesser known groups of biocosmists and immortalists, ${ }^{35}$ but also central personalities of Soviet history, such as Lev Trotskii (1879-1940) and Maxim Gorky (1868-1936).

Following more or less strict definitions of cosmism, it is possible to present Fedorov either as its founding father, or as the founder of Fedorovism, leaving the paternity of cosmism, properly speaking, to Konstantin Tsiolkovskii (1857-1935). ${ }^{36}$ Soviet propaganda sought not to highlight Tsiolkovskii's philosophical presuppositions, which diverged from the regime's atheist ideology, and a number of his writings have thus remained in the archives. However, in a second phase of his life, the thinker no longer revisited the technical

34 Dmitri Shlapentokh, "Bolshevism, Nationalism and Statism: Soviet Ideology in Formation," Cahiers du monde russe, no. 4 (1996), 429-466.

35 On Cosmist societies, see Michael Hagemeister, "Russian Cosmism in the 1920s and Today," In: Rosenthal, ed., The Occult, 195-196; James T. Andrews, "In Search of a Red Cosmos: Space Exploration, Public Culture, and Soviet Society," In: Steven J. Dick, and Roger D. Launius, eds., Societal Impact of Spaceflight (Washington DC: National Aeronautics and Space Administration, 2007), 43-44; Asif A. Siddiqi, "Imagining the Cosmos: Utopians, Mystics, and the Popular Culture of Spaceflight in Revolutionary Russia," OSIRIS, vol. 23 (2008), 268-271.

36 See Michael Hagemeister's chapter in this volume. 
elements linked to the construction of rockets and largely emphasized the religious background of spatial conquest. Since the 1960s he has been called a "disciple of Fedorov" even if Tsiolkovskii always denied this influence. Both men knew each other in the 1870s, but Fedorov's influence on him occurred not so much on the theme of the conquest of space, ${ }^{37}$ as on that of the transformation of bodies: "And the Earth, and we other humans, and all contemporary organic life on the planet, were material of the sun. We have always lived and we always will, but each time in a new form and, of course, without memories of the past." 38 Tsiolkovskii seems to have been a fervent believer, and sought to make the events described in the Bible compatible with modern science. For him, it was evident that the conquest of space is not an end in itself, but a technical means to fulfill humanity's self-perfection and the search for happiness.

Tsiolkovskii's belief in pan-psychism differs from Fedorov's materialism. The world, he claimed, was guided by a "cause" (prichina), and the universe was a living being endowed with a mind, since the intellect is located in each atom. ${ }^{39}$ Like Fedorov, he advocated a monist approach to the cosmos. In his Monism of the Universe (Monizm Vselennoi), published in 1925, he states that we must think earthly life and the beyond in terms of unity. Humankind is only an assemblage of cells, which themselves are mere assemblages of liquids and gas: since all is divisible down to the level of the atom and humankind is part of an eternal whole, it cannot be conceived autonomously from the cosmos. "I am not only a materialist, but a pan-psychist, who recognizes the sensitivity of the whole universe. I consider this property [sensitivity, ML] to be inseparable from materiality." 40 Tsiolkovskii also seems to have been inspired by the German philosopher Carl du Prel (1839-1899), author of Die Philosophie der Mystik (1885), which had been translated into Russian. Du Prel was famous for drawing a link between cosmic and biological evolution, stating that Darwinian natural selection applied to planetary bodies just as it did to living organisms. ${ }^{41}$ An inhabitant of Kaluga, Tsiolkovskii was also probably up

37 On the differences between these two thinkers, see Vladimir Kaziutinskii, "Kosmizm i kosmicheskaia filosofiia," In: Boris Raushenbakh, ed., Osvoenie aerokosmicheskogo prostranstva: Proshloe, nastoiashchee, budushchee (Moscow, IIET RAN, 1997). This point is confirmed by Siddiqi, "Imagining the Cosmos," 266-267.

38 Konstantin Tsiolkovskii, Grezy o zemle i nebe: nauchno-fantasticheskie proizvedeniia (Tula: Priokskoe izd., 1986).

39 "Nauchnye osnovaniia religii", "Étika ili estestvennye osnovy nravstvennosti," "Nirvana," etc.

40 Kontantin Tsiolkovskii, “Monizm Vselennoi,” In: Semenova, ed., Russkii kosmizm, 266.

41 See Michael Hagemeister's chapter in this volume. 
to date with the theosophist publications of the Lotus publishing house. ${ }^{42}$ Many of his texts thus seem based on theosophist conceptions of a "secret doctrine". Tsiolkovskii also believed in extra-terrestrial intelligence (ETI ${ }^{43}$ and in the existence of superior "ethereal" (efirnyi) beings, like angels or spirits, who live in space and help humans to decipher celestial messages. ${ }^{44}$

Among his disciples, Aleksander Chizhevskii (1857-1964)—who also lived in part in Kaluga and was a member of the group of biocosmists and a personal friend of Tsiolkovskii-played a special role. ${ }^{45}$ Chizhevskii's career was more or less type of an original researcher in the Soviet period, in the sense that it alternated between recognition and repression. In 1924, Chizhevskii published an introduction in German to Tsiolkovskii's monograph, and this played a key role in the launching of the first Soviet space experiment as well as this issue's fashion among the general public. ${ }^{46}$ In 1926, both men participated in the world's first experiment in the field of space biology. In the 1920s-1930s, Chizhevskii worked at the Medical Department of Moscow University, at the Institute of Biological Physics at the Ministry of Health, and then at the ZooPsychology Laboratory of the People's Commissariat for Education of the Russian Federation. His main book, Physical Factors of the Historic Process (Fizicheskie faktory istoricheskogo protsessa), published in 1924, earned him a rebuke from Stalin, who demanded that he retract his theories concerning the role of the sun on human activity. A self-proclaimed sun-worshiper and poet of his time, Chizhevskii refused and was repressed, spending eight years in the Gulag between 1942 and 1950, and then being imprisoned in Karaganda until 1958. Afterwards he was permitted to return to Moscow, where he ran an aeroionification laboratory under the USSR State Planning Organization. Not until 1995 was the most complete version of his manuscript, The Earth in the Embrace of the Sun (Zemlia v ob"iatiiakh solntsa), finally published. ${ }^{47}$

Similar to Tsiolkovskii, Chizhevskii was actively in favor of the Soviet space program and hoped to see the conquest of other planets, since "in subjugating

42 Maria Carlson, No Religion Higher than Truth: A History of the Theosophical Movement in Russia, 1875-1922 (Princeton: Princeton University Press, 1993).

43 Vladimir Lytkin, Ben Finney, and Liudmila Alepko, "Tsiolkovsky - Russian Cosmism and Extraterrestrial Intelligence," Royal Astronomical Society Quarterly Journal, 36 (1995), no. 4, 369-376.

44 See Michael Hagemeister's chapter in this volume.

45 See his memoirs: Aleksandr Chizhevskii, $\mathrm{Na}$ beregu vselennoi: gody druzhby s Tsiolkovskim. Vospominaniia (Moscow: Mysl', 1995).

46 Siddiqi, "Imagining the Cosmos," 284

47 Available on http://www.chizhevski.ru/zemla 
nature and our victory over it, the goal of the final triumph of human knowledge will be realized." 48 Above all, he contributed to developing two scientific domains that he called heliobiology - the study of the impact of solar flare cycles on human history-and heliotaraxy-the study of the effect of solar activity on the biosphere. ${ }^{49}$ According to him, the Earth's physical fields, variations of solar activity, solar magnetism, and dependent geomagnetic oscillations, all impact on human life. "It is not the earth, but the cosmic spaces that will become our homeland, and we are just starting to feel the importance of radiation, in all its authentic immenseness, for terrestrial existence and the displacement of remote celestial bodies." ${ }^{\text {50 }}$ Analyzing sunspot records and proxies as well as battles, revolutions, riots and wars for the period 500 BCE to 1922 $\mathrm{CE}$, he found that 80 percent of the most significant events occurred around the sunspot maximum. The history of humankind, he therefore claimed, responded to cosmic regularities (zakonomernost'), notions that were developed later by Lev Gumilev (1922-1992). In his "historiometric" works, Chizhevskii states that human history is shaped by 11 year cycles in the sun's activity, as manifest in political events (revolts, wars, revolution), and other events such as power shortages or plane crashes. He therefore marked a new threshold in the evolution of cosmist theories in that he was more removed from Fedorovism than Tsiolkovskii, and was more distinctly focused on the sole topic of spacein particular toward sun-centered theories-rather than on the question of humanity's overcoming the state of death; moreover, he emphasized a sort of cosmic determinism which did not exist in Fedorov's works.

\section{Cosmism, a Paradoxical Reading of the Occult}

Cosmism is stamped by the historical context in which it emerged. The October Revolution provided fertile ground for futurist utopias, which seemed thus to be shifting from the status of dream to that of possibility. The Bolshevik Revolution gave a new lease of life to a secular millenarism that was founded on ancient utopian traditions present in Orthodoxy. God-building, biocosmism, theories of rejuvenation with blood (Bogdanov), Lenin's embalming... all constituted part of this intellectual kaleidoscope, which the Revolution had

48 Aleksandr Chizhevskii, "Kolybel' zhizni i pul'sy Vselennoi," Zemnoe èkho solnechnykh bur'.

49 Boris Vladimirsky, and N.A. Temuryants, Solar Activity \& The Biosphere: Heliobiology. From A.L. Chizhevsky To The Present (Moscow: Russian Academy of Natural Sciences, 1999).

50 Aleksandr Chizhevskii, “Kolybel’ zhizni i pul'sy Vselennoi," In: Semenova, ed., Russkii kosmizm, 319 . 
awakened. ${ }^{11}$ These universalist utopias emerged in the early 1920s, but were liquidated during the "great turn" of 1929. Stalinism no longer wanted to hear of dreams about humanity's potentialities; it wanted to change nature and society by force. It was no longer committed to a transformation of humanity as a whole, but sought to prove the superiority of Russian-Soviet science in its competition with the capitalist world. As a maximalist ideology par excellence, cosmism was the only futurist current of the early 1920s to survive this "great turn". Its totalitarian features and the importance it assigned to technological modernity were in agreement with the ambitions of "total realization" that were operative in the Bolshevik years and then again under Stalin. Cosmism was thus able to find some common ground with Stalinism, permitting the latter to instrumentalize it as part of the victory of Soviet science. Later, cosmism also found common ground with Khrushchevian détente over the conquest of space. It therefore managed to navigate in the "grey" and troubled waters of the informal Soviet world: it was neither completely reduced to an instrument of state propaganda, nor was it open dissidence. It found its place in the various niches of intellectual freedom permitted in the Soviet society.

Cosmism, however, cannot be reduced to a specifically Russian phenomenon, able to be explained completely by its local cultural context. It also has to be placed in larger intellectual traditions such as occultism-though the issue here is not to distribute labels of belonging, but instead to inquire into parallelisms, mimetisms, and intellectual hybridizations.

Cosmism shares very many features with the so-called classic occultist traditions, such as Kabbalah, astrology, alchemy, etc. Its main presupposition is that the separation, formulated during the Renaissance, between metaphysics - either institutionalized religions or arcane sciences-and the modern sciences is a confusion of human thought, a negation of the multiplicity of the dimensions of human existence. Cosmism, therefore, like occultism, appeals to the recreation of holistic forms of knowledge, forms which would reconcile mind and matter, metaphysics and science. These holistic forms of knowledge are supposed to provide access to a higher reality, a hidden and ideal world. This presupposition is common to both intellectual traditions, although they differ as regards the interpretation they give of the relation between reality and

51 Richard Stites, Revolutionary Dreams: Utopian Vision and Experimental Life in the Russian Revolution (Cambridge: Oxford University Press, 1991); Irene Masing-Delic, Abolishing Death: A Salvation Myth of Russian $20^{\text {th }}$-century Literature (Stanford: Stanford University Press, 2002); Boris Groys, Michael Hagemeister, eds., Die Neue Menschheit. Biopolitische Utopien in Russland zu Beginn des 20. Jahrhunderts (Frankfurt a. M.: Suhrkamp, 2005). 
the hidden world. For occultism, this higher reality is parallel to the real world in which humanity lives, whereas cosmism maintains that the real world is destined to become a higher one: for the former, there are two co-existing worlds, while, for the latter, they are one and the same world, but they occur at different times. For the former, the difference between both worlds is of essence, while for the latter it is uniquely temporal.

Both traditions meet up again, however, in the idea that holistic knowledge, which enables the passage to another world, must be founded on a certain connectedness and the recreation of a lost link. For occultism, this connectedness between the different levels of reality is materialized in the secret doctrines that humanity has inherited from a time when it could still feel the unity of itself and the cosmos, a premonition that is lost today and that contemporary humans must seek in ancient texts, whose meanings are concealed or occulted. In cosmism, however, connectedness materializes with the rebirth of the past, properly speaking, since the return of the dead, in various physical forms, heralds the reconciliation of humanity with itself and its environment. Where occultism views connectedness from an intellectualized angle-that of lost forms of knowledge to be rediscovered and relearned-cosmism does seek out intermediaries: it is the dead themselves who will return to symbolize the vanished link, not the texts or the practices of the living. The idea of a living knowledge (zhivoe znanie), so dear to occultist thinking, thus finds in cosmism a practical implementation-that of the resurrection-pushed to its extreme. Another trait that dissociates both movements is probably that of moralism: cosmism calls for the redemption of humanity-the Christian theme par excellence-and therefore brings a moralizing judgment on the contemporary failure of humanity - a feature that is very noticeable in Fedorov in particular. This trait, however, is largely absent from the occult traditions, even though it is found in some currents, such as Guénonian Traditionalism. ${ }^{52}$

One of the major differences distinguishing cosmism from the other occult traditions is its socialism: according to cosmism, hidden reality will become obvious to all of humanity, not for a small group of the privileged. The secret character of the activities of connectedness, as a sort of "lodge" for the initiated, does not comprise part of the intellectual and organizational apparatus of cosmism which, on the contrary, likes to speak of the greatest number. For Fedorov, humanity as a whole must participate in the "common tasks" of resurrecting the dead and conquering space. This socialism, however, is not with-

52 Mark Sedgwick, Against the Modern World. Traditionalism and the Secret Intellectual History of the Twentieth Century (Oxford-New York: Oxford University Press, 2004). 
out its totalitarian background: it amounts to an obligation, since the resurrection it heralds will not be individual but collective. Individual refusal therefore cannot be tolerated, and nobody will escape the military brigades working toward the transformation of the cosmos. Here, cosmism is far from the individualist features of other occult traditions, which instead tend to emphasize the personal nature of the quest towards spiritual awakening, and put value on belonging to an elite. With the cosmists, the transformation of man into superman is to eventuate through the authoritarianism of an enlightened state and a certain measure of physical violence, both features that are pushed to their extreme in the eugenicist theories of Tsiolkovskii. In the other occult traditions, which do not have a totalitarian character but, on the contrary, emphasize the individuality of each person's path, the idea of violence against humanity in the name of its obligatory awakening is absent. Cosmism awaits the re-animation of humanity into a single universal organism - and the conjunction between two adjectives, single and universal, is a sign of totalitarian thought-whereas occultism sketches a world of awakening filled with multiple, diverse, specific individualities, each one having formed its consciousness, via different paths, of the harmony of man and the cosmos.

In terms of practice, cosmism proves much poorer than occultism. Its calls to connect body, mind and soul did not give rise to any precise practices, applicable in the everyday, even if Tsiolkovskii, for example, claimed he spoke to angels. For Fedorov, it might be noted that man's harmony with the cosmos is created through a specific agriculturally-based economic system: inspired by the Slavophiles, he actually saw agriculture as the economic sector that was most harmonious. Tsiolkovskii, on the contrary, was more directed toward "cosmic industry" than toward "cosmic agriculture." The nationalist character of cosmism also distances it from the occult traditions, which do not lay claim to the superiority of one nation over another. According to them, the quest is at once individual and universal, but not national, even if Elena Blavatsky and Nicholas Roerich (Nikolai Rerikh) have commented the uniqueness of the "Russian way" too. In cosmism, in particular with Fedorov, Russian messianism is an intrinsic part of the utopian message. This nationalism is expressed differently with Tsiolkovskii, which stresses more particularly the progress of Soviet science on matters of spatial conquest. This nationalist narrative is today being heavily revised by the Russian neo-cosmists, according to whom Russia alone, through its awareness of the religious bases of all scientific progress, is able to show the future path to a humanity in perdition. ${ }^{53}$

53 For example, see the texts of Evgenii Troitskii (born 1928), founder and president of the 
While nearly all occult traditions deem that higher knowledge had been better preserved in the East than in the West, this Orientalist fascination is practically absent from cosmism. With the exception of Fedorov's texts in which he points up Zoroastrianism as a precursor of Eastern Christianity,$^{54}$ and his fascination for the Pamir mountains, the other currents of Eastern thought are not underscored, and neither Tsiolkovskii, nor Chizhevskii were oriented toward the Orient. However, the presence of the main Soviet cosmist theoreticians at Kaluga, the "capital" of theosophy in Russia, is surely not a geographical coincidence and can lead us to suppose that there had been direct influences, but probably not concerning this "Eastern" feature. The cosmists of the Soviet era such as Tsiolkovskii are closer to the western ufologists, than they are to the great classical strands of occultism. For them, the space of selfrealization has evolved; it is no longer situated in a mystic East of Egyptian or Babylonian wisdoms, of Brahmanic or Buddhist knowledge, nor on the high plateaus of the Himalayas, as it was for Blavatsky and Roerich. Instead, it is located in the extraterrestrial world: thanks to space flight, human liberation from the Earth has geographically shifted the future of humanity from the East toward the cosmos.

The complex relation of cosmism towards temporality, however, links it partly to occultist traditions. Cosmism's complexity in this relation comes from the fact that it can, paradoxically, be read simultaneously as turned toward the future-the quest for a new mankind-and toward the past-the resurrection of the dead. In much the same way that the cosmists expected science to fight against the decomposition of bodies, and to enable the displacement of humans in time and space, the alchemists of the Renaissance also sought methods by which to transform living bodies and objects, and to travel through the corridors of space and time. For the cosmists, the magical knowledge of alchemy was supposed to evolve into simple scientific and technical prowess. The cosmists, then, participated in Gnosticism insofar as they believed in a magical power to transform the world, but they concentrated this power in technology.

Association for the Complex Study of the Russian Nation (Assotsiatsiia po kompleksnomu izucheniiu russkoi natsii), such as Russkaia ideia, slavianskii kosmizm i stantsiia Mir (Kaluga: Oblizdat, 2000), or those of Vladimir Dudenkov, chair of philosophy at the Technical University of Saint-Petersburg, such as Filosofiia kosmizma v Rossii rubezha 19-20 vekov (St. Petersburg, 1998).

54 Young, "Fedorov's Transformations of the Occult," 176. 
Despite its technologizing obsessions, cosmism has continued to think that the mastery of technology was only a means to attain a higher degree of humanity, and not an end in itself. Such mastery necessarily had to be accompanied by humanity's spiritual transformation, as machines have utility only in order to help humans develop their physical and psychic potentialities. For cosmism, the human control of nervous-energy flows will make it possible to change reality over the long-term. As such Fedorov, Tsiolkovskii, and Chizhevskii all developed pan-psychic theories: as thought is lodged in atoms and these atoms occupy the entire universe, the universe itself is considered a living and thinking being. Human transformation thus depends on the inherent active teleological forces and the supreme-nomogenetic-causality which brings the world forward. The cosmists are, however, marked by an anthropocentric reading of this interaction: humans must, through an active and conscious process, integrate themselves into the whole ambient cosmos. Some see this anthropocosmism as a Russian tradition that has been stamped by the personalism of Russian philosophy, according to which the person (lichnost'), who lives in harmony with the collectivity, is emphasized, while the individual, cut off from the group, is criticized. However, Chizhevskii's theories point toward a strong determinism: they no longer exult humankind's capacity to transform nature, including its own, but conceive humans as beings subjected to cosmic activities over which they have little control. Despite this deterministic presupposition, which does not exist in either Fedorov or Tsiolkovskii, all cosmist theoreticians share with occultism the idea that the ultimate knowledge is that of awareness.

\section{Conclusion}

Cosmism belongs to those non-conventional spiritual traditions, combining strong allusions to Christianity (redemption via resurrection) - albeit an absence of interest in Eastern religions-a pan-psychic reading of the universe, belief in still unknown cosmic forces and in an extra-terrestrial future for humanity. Its complexity resides in its twofold scientific aspect. It is both a science of spatial conquest, construed as conventional, legitimate science and endorsed as the embodiment of progress; and a science of the ability to change material realities by the force of the spirit, perceived as illegitimate. Without the success of spatial conquest, which did indeed broaden the limits of human possibilities, cosmism's scientific pretensions would have remained marginal. It would not have been able to present itself as anything other than a pseudoscience or a para-science. But its ability to predict, and then to accompany, the 
message sent with the conquest of space multiplied its power of expression and reception tenfold. Responding to the fashion for a "science with a conscience," cosmism presented itself as a scientific religion, a mysticism of technology, and a finalism able to speak to Soviet society, which was torn between exulting its industrial exploits, ecological concerns, and spiritual interrogations outside the channels of the institutionalized Churches. Buoyed by many occult convictions, of which it offers a modern reading, cosmism advanced holistic responses and aimed to rethink, fundamentally, the boundaries of the visible skies. Reprising an archetype of human thought according to which the physical sky above our heads is the place of the divine, it tried to find novel formulations for human interrogations into the meaning of life and humanity's place in the universe. 


\title{
OCCULT AND ESOTERIC DOCTRINES IN RUSSIA AFTER THE COLLAPSE OF COMMUNISM
}

\author{
DEMYAN BELYAEV
}

After the collapse of the communist system it was not only the established denominations (the Russian Orthodox Church, various Protestant churches) that experienced a boom in Russia, as people tried to fill the spiritual and ideological vacuum left behind by the previous system. ${ }^{1}$ Numerous religious and spiritual movements, which current scientific classifies as occultism, esotericism or alternative religion have been offering ways of coping with life to a population that is looking for meaning.

As early as 1988 the national newspapers ran the first articles on UFOs, yoga and parapsychology that showed none of the aggressive and "unmasking" features previously characteristic of publications on these topics. Now these areas were presented as merely "insufficiently researched" and "full of open questions". The pioneer of this process was the national newspaper Komsomol'skaia pravda, whose target audience was mostly the generation of 20-30 year olds. Soon after the newspapers had broached the subject, books using the same neutral popular-scientific approach with regard to contentious issues began to appear. ${ }^{2}$

The first newspaper exclusively specializing in this subject area appeared in 1990 under the title Anomaliia. Publisher and editorial board, who had set themselves the goal of providing unbiased reports on enigmatic phenomena, chose the following epigraph for their newspaper: "The miracle is not incompatible with nature but with what we know about nature". In the first two years the paper's print run reached 250,000 copies per issue. However, shortly afterwards the number of copies sold fell quickly, probably because of the emergence of a large number of rival publications on the same subject.

1 The author gratefully acknowledges the financial support provided by the Deutsche Forschungsgemeinschaft (DFG) to the research project that led to the findings presented here. Some of them also appeared in Demyan Belyaev, "Heterodox Religiosity in Russia after the Fall of Communism: Does it Challenge 'Traditional' Religion?” Religion, State \& Society 2010, no. 38 (2), 135-151.

2 Aleksandr Vengerov, Predskazaniia i prorochestva: za i protiv (Moscow, 1991). 
This newspaper still exists, if in significantly modified form. However, the highest number of copies (up to 550,000 copies per monthly issue) has been reached by other specialized esoteric newspapers and journals, including Oracle, UFO, Secret Power, The Age of Aquarius, and Paranormal News (Orakul, NLO, Tainaia vlast', Era Vodoleia, Anomal'nye novosti). The largest of these, Oracle, belongs to the German media corporation Bauer and, unlike the abovementioned pioneering publications, has a strong commercial focus and relies heavily on advertising. The newspaper is sold in Russia, Ukraine and other countries. However, it is marketed not as a yellow-press paper but a worldview-specific publication with an orientation towards popular science. ${ }^{3}$

Political liberalization was followed by a rapid growth in publications on all kinds of topics related to occult knowledge. The books of Blavatsky, Roerich, Gurdjieff, Andreev and other Russian and Western esotericists of the past came out in huge print runs. The number of publically acting healers, magicians and astrologers grew exponentially. Healing with the help of magic techniques was especially popular. ${ }^{4}$ Moreover, other movements that the author of this article considers to be at the margins of the esoteric subculture, such as Slavic neo-paganism and the concomitant Russian nationalism ${ }^{5}$ or traditional shamanism in Siberia ${ }^{6}$ and certain other Russian regions, have also seen an upturn.

TV played a special role in the process of spreading esoteric knowledge and skills in the years of Perestroika. The uniqueness of this historic moment probably consists in the fact that the mass media were still highly centralized when the Soviet Union collapsed, while state control over the information presented in these media suddenly disappeared. This is why those who managed to gain prominence on TV as esotericists during this time quickly acquired country-wide fame.

The first popular subject was healing. On 31 March 1988 the Ukrainian doctor Anatolii Kashpirovskii (b. 1939) performed a live operation on the show Vzgliad, using a kind of hypnosis as an anaesthetic. On 9 October 1989 the public channel Ostankino, which can be received all over Russia, began broadcasting Kashpirovskii's healing séances. In 1989 the Muscovite Allan Chumak

3 Interview of the author with Ol'ga Monachova, Moscow, 23/08/2007.

4 Galina Lindquist, Conjuring Hope: Healing and Magic in Contemporary Russia (London, 2006).

5 Marlène Laruelle, "The Two Faces of Contemporary Eurasianism: An Imperial Version of Russian Nationalism," In: Nationalities Papers 2004, no. 32(1), 115-136.

6 Marjorie Balzer, Shamanic Worlds. Rituals and Lore of Siberia and Central Asia. (New York, 1997). 
(b. 1935), a trained sports coach and journalist, appeared with similar séances for the first time. While live on TV he charged water, food and other items with healing energy, solely by gesticulating, unlike Kashpirovskii, who pronounced some formulae. ${ }^{7}$

The next vogue was astrology. In January 1989 the astrologist Pavel Globa (b. 1953), a trained historian and archivist, and his wife Tamara made their first appearance on the Leningrad channel The Fifth Wheel (Piatoe koleso). Pavel Globa had been teaching astrology underground since the late 1970s, for which he was charged for anti-Soviet agitation and imprisoned. The Globas have made a significant contribution to the popularity of astrology among the broad masses of the Russian population, mostly by propagating astrology as a form of ancient esoteric knowledge with links to Zoroastrianism. Their prognoses for the future, including politics, which they regularly presented on TV, also became popular with ordinary Russians.

The third very popular area of applied occultism was magic. In the late 1980s-early 1990s, also on TV, the Ukrainian Iurii "Longo" Golovko (19562006) gained notoriety as a practitioner of white, practical magic. The phenomena demonstrated included levitation and even the resurrection of the dead. Later on, he switched to individual consultations. In the last years of his life Longo spoke frequently about his plans to found a "practical religion" that would help people to do the right thing in various situations. ${ }^{8}$

Although these individuals were national celebrities in the late 1980s, they no longer have the same influence on the population as they used to, but they remain active to the present day, mostly in the esoteric milieu. Kashpirovskii, for example, has been on several short tours throughout Russia since 2005, even though his performances no longer draw large audiences and there have been a number of protests against his "charlatanism" in several towns (Novgorod, Petropavlovsk-Kamchatskii). Allan Chumak toured Germany for a month in 2005, giving séances in various towns. Just like Kashpirovskii, he seems most popular among Russian émigrés who left in the late 1980s-early 1990s and maintain links to aspects of Russian culture that were prominent during that historical period (e.g. pop singers who have long since fallen into oblivion in Russia itself). Pavel Globa still reads the horoscope every morning on one of the commercial TV channels and publishes articles in newspapers and journals. He also advises politicians and businessmen. ${ }^{9}$

\footnotetext{
7 See, e.g., http://www.peoples.ru/medicine/psychology/anatoliy_kashpirovskiy/index.html

8 Jurii Longo, Éntsiklopediia samoistseleniia i tainykh znanii (Moscow: Ėksmo, 2004).

9 See e.g. www.globa.ru
} 
During the market reforms of the 1990s the range of esoterically oriented materials and activities grew so large that now there is a large number of active magicians, astrologers and healers. However, what they all have in common is that their practice is usually limited to a single service to a single customer ("client"). This service can entail information or advice (in the case of astrologers and tarot readers) or healing and/or health promotion (the two kinds of healers most common in Russia are called celiteli and ekstrasensy). ${ }^{10}$ These representatives of the esoteric sub-culture in contemporary Russia are not organized in institutions (associations etc), which makes establishing their true number next to impossible. Representatives of the esoteric subculture often advertise in free magazines, complete with photos.

Due to the overall lack of both institutional organization and written sources, providing a structural overview of this part of the Russian esoteric milieu is possible only to a very limited degree. In addition to the first differentiation according to specialization - astrologers, tarot readers, magicians etc first attempts have been made in the literature to divide, for example, those esotericists who engage in various kinds of healing practice into subgroups according to the main method of healing they use. ${ }^{11}$ Perhaps the same approach could be used in order to structure the milieu of magicians, wizards and fortune-tellers.

However, the scene in contemporary Russia is not limited to those representatives of the esoteric subculture we have subsumed under the term "suppliers of exclusively applied esotericism". Next to them we find those who specialize mostly in the dissemination and/or teaching of different schools, training systems and practices. These systems and practices offer different focal points to their followers, e.g. influence on the human body (like Malakhov's Cleansing of the Organism, (Ochishchenie organizma), Levshinov's How to get a Perfect Figure (Kak sdelat' figuru velikolepnoi) or Norbekov's Path towards Youth and Health (Tropinka $k$ bodrosti $i$ zdorov'iu), the development of certain abilities that the majority of people do not possess (Zolotov, Klein, the "late" Norbekov and Bronnikov) or how to bring about fundamental changes in the relationship between man and his surroundings (Lazarev, Sinel'nikov und Sviiash).

This theoretically founded section of the esoteric subculture includes bioenergetics (often also called psychics), the development of psychic abilities, as well as several approaches from the field of practical psychology as long as they

10 This is not the same as "psychics" known in the West as the alleged principle of their work is different.

11 Evgenii Panov, Naidi svoego tselitelia (Moscow, 2000). 
appeal to the existence of supernatural forces or laws. Some the most important forms of knowledge transfer for the representatives of this second section of the esoteric subculture are the so-called "seminars for personality development". One of the first such seminars was held in 1988 in Southern Siberia by Boris Zolotov and his closest disciples, Nikolai Denisov and Aleksandr Klein. Zolotov (b. 1947) is a native of the city of Odessa and from the family of a military rocket engineer and member of the Soviet Academy of Sciences. He calls himself a "specialist in complex systems". According to the participants in his seminars, Zolotov allegedly possesses healing - and other unusual abilities. During the 1990s Zolotov regularly held seminars in different cities in the Ukraine (Kiev, Kherson, Krivoi Rog), Bulgaria, Hungary and Russia. A large Zolotov-seminar took place from 10 July-10 September in Evpatoriia (Crimea). Zolotov's methods for working with his disciples resemble the ones used by the Sufis: knowledge is transferred not directly (verbally) but must reveal itself to the disciple, without further action from the teacher, during the process of living through certain situations in which his teacher has placed him. Zolotov himself says he is teaching "expert-operative interaction".

Another important way of communicating esoteric knowledge in contemporary Russia, both theoretical and practical, is through books. The pioneer in this field was Gennadii Malakhov (b. 1954), who published his first book on this topic, Cleansing of the Organism and Diet (Ochishchenie organizma i pitanie), in 1991 in the small southern town of Staryi Oskol. This book was followed by several others and, according to Book Market Survey (Knizhnoe obozrenie), by 1995 Malakhov (b. 1954) had sold more than four million copies of his highly esteemed four volumes. He still lives in his native town of KamenskShakhtinskii in the Rostov area in southern Russia. He regularly travels the country, meets his followers, publishes a newspaper, has his own TV show and owns the publishing house Genesha.

Mirzakarim Norbekov (b. 1957) came to Moscow in 1993 and began to hold health promotion séances on various stages, just like Andrei Levshinov (b. 1957) in St. Petersburg. Later they both turned to writing books, trying to gain a bigger audience for their ideas and healing methods, in the same way as Malakhov. First they both collaborated with experienced female authors - Levshinov with Valentina Travinka in $1995^{12}$ and Norbekov with Larisa Fotina ${ }^{13}$ in 1996. Later they each wrote bestsellers that made them famous throughout

12 Andrei Levshinov, Valentina Travinka, Isprav'sud'bu svoiu! (Moscow, 2001).

13 Larisa Fotina, Mirzakarim Norbekov, Doroga v molodost' i zdorov'e. Prakticheskoe rukovodstvo dlia mushchin i zhenshchin (Moscow, 2002). 
Russia. ${ }^{14}$ Norbekov organized a network of courses for the restitution of sight. Subsequently he began offering courses for the development of intuition, which he presents as a necessary prerequisite for founding one's own company and improving one's financial situation. Levshinov taught yoga and Qi Gong and held outdoor training sessions abroad, which he called "grand master classes".

At the end of the 1990s, Aleksandr Sviiash (Sviiash), Valerii Sinel 'nikov und Viacheslav Bronnikov appeared on the Russian scene. Chronologically they belong to the "third wave" of esotericism. Sviiash's first book, How to design events in your life with the power of thought (Kak formirovat' sobytiia svoei zhizni s pomoshch'iu sily mysli) came out in 1997 and became the cornerstone of his doctrine and his training center called The Sensible Way (Razumnyi put'). Sviiash told me that he began to study esotericism seriously in 1990 and that he attended Boris Zolotov's seminars among others. Although he painstakingly avoids esoteric terminology in his latest works, he explains the laws of the world that surrounds us using concepts such as "astral bodies of man" (ton'kie tela), "egregore" etc, which clearly identifies him as a propagator of esoteric knowledge rather than, for example, conventional psychotherapy. ${ }^{15}$ The same applies to Sinel'nikov, who became popular only when his book Love your Illness (Vozliubi bolezn'svoiu) came out in 2000. Over the course of a kind of ideological drift, Sinel'nikov gradually moved away from orthodox medical training to homeopathy, modern Western psychotherapy and hypnosis and finally towards an esoteric worldview. ${ }^{16}$

Bronnikov claims to have discovered a phenomenon of "direct vision" via the brain or rather, with closed eyes. He calls the alleged capacity of the brain to function in such mode the "biocomputer", a skill which, according to him, can be trained in many people. ${ }^{17}$ But whether the "biocomputer" is the brain or the phenomenon of direct vision, or the brain's capacity to function in this mode is not clear.

Some of Bronnikov's disciples have been examined at the Institute for Brain Research in St. Petersburg, which is part of the Russian Academy of Sciences. Allegedly the scientific Director of the Institute, Natalia Bekhtereva, confirmed

14 Andrei Levshinov, Taina upravleniia sud'boi (Moscow, 2002); Mirzakarim Norbekov, Opyt duraka, ili kliuch' k prozreniiu. Kak izbavit'sia ot ochkov (Moscow, 2003).

15 Aleksandr Sviiash, Razumnyi mir (Moscow, 2006).

16 Valerii Sinel'nikov, Tainy podsoznaniia (Moscow, 2006).

17 This is not the same as "remote viewing" known by some Western psychics. "Direct vision" is the literal translation of Bronnikov's term, which is preferred here given that the technique he teaches is peculiar in itself. 
the existence of the phenomenon of "direct vision". In 2003 Bronnikov began to sell video recordings of his training sessions, and in 2005 he founded the first regional training centers for teaching the "Bronnikov Method." Just like Norbekov, Bronnikov is one of those esotericists who seek recognition from traditional science, which is why he gave his doctrine the scientific-sounding term "Cosmo-psycho-biology". Still relatively unknown esotericists also frequently give their doctrines scientific-sounding names; examples include Tonkov's "biosensoric psychology" or the "spiritual psychocybernetics" by Gennadii Mir (Miroshnichenko) from Tula.

In addition to the abovementioned esotericists, this subculture also has a large number of activists who are not seeking a large audience but prefer to concentrate on teaching relatively small groups. Examples include Zolotov's disciple Nikolai Denisov (school The Golden Ray (Zolotoi luch)), Sergei Romasenko and Aleksandr Klein, the main proponent of Russian Zen. In 2005 Klein organized twelve different seminars in a holiday center near Moscow on Second Logic (Vtoraia logika), as he calls his system. Others include Sergei Rozov and Artur Razumov in St. Petersburg, Vasilii Goch in Tallinn and Vladimir Lermontov in Bolshoi Utrish. Less influential esotericists often have no institutionalized schools of their own but sometimes use "Centers for Spiritual Development" such as The Other World (Drugoi mir) in St. Petersburg or Help Yourself (Pomogi sebe sam) in Moscow as their platforms, or open air festivals such as Inlakesh in the summer. Esoteric bookshops such as White Clouds (Belye oblaka) in Moscow are other venues that attract these figures.

There are some clear cases of fraud where people pretending to represent the esoteric subculture are looking only for financial gain. Notorious is the case of Grigorii Grabovoi from Kazakhstan in 2006, who offered to resurrect, for a fee, the school children killed during the attack by Chechen separatists in Beslan. He was subsequently given a prison sentence. ${ }^{18}$ However, such cases are for the most part exceptions. On the whole it is noteworthy that those who are now recognized as bearers and disseminators of esoteric knowledge began to engage with this subject matter well before the fall of the Soviet Union. Thus it is very hard to accuse them of having chosen esotericism simply as a convenient way of making money in the financially difficult transitional period of the 1990s.

Andrei Levshinov told me that he has been interested in yoga, karate and psychology since 1978. Gennadii Malakhov was the director of the Alertness (bodrost') club for natural healing as early as 1984. Sergei Lazarev began his

18 „Grabovogo vziali po-chernomu,“ Nezavisimaia gazeta, 07.04.2006. 
research in the field of bioenergetics around 1980. Sinel'nikov met his karate teacher Vladimir Zhikarentsev when he was 14, a meeting that was, according to him, decisive for his later wish to become an unusual doctor. Most of these esotericists were born in the 1950s and are therefore presently at the height of their creative careers. All these observations suggest that what intensified significantly after the collapse of the Soviet Union was not the interest in esoteric knowledge as such, but merely the scope of this interest and the intense communication of this knowledge to broad groups of the general population.

Different scientific approaches have been used to examine the recent developments in the religious panorama in Russia (among which esotericism and occultism are usually counted); they have led to a variety of conclusions.

On the one hand, doubt is cast on the profundity of the beliefs of those Russians who today refer to themselves as believers. In view of the widespread belief in astrology and miracles, some people say, it is an exaggeration to speak of a religious renaissance in Russia, since such a mixture of beliefs ought to be interpreted as a sign of rejection of all definite religious convictions. ${ }^{19}$ However, some scholars say that religiosity in Russia was never very high and the Orthodox Church, it is suggested, never had a monopoly on religious belief even in the $18^{\text {th }}$ and $19^{\text {th }}$ centuries. ${ }^{20}$ Others insist that in Russia even communism was turned into a religion. ${ }^{21}$ According to these people the view that the country underwent a process of secularization in the Soviet era is erroneous, as is the view that a de-secularization took place during the 1990s. On the contrary, the dogmatic and quasi-religious atheistic system had nothing to do with secularization, and only today are we witnessing secularization, in its postrational, adogmatic-eclectic form. Russia's spiritual evolution is like a pendulum moving between different kinds of religiosity, that is, from Orthodox Christianity to communism and atheism towards post-rational eclecticism. ${ }^{22}$

19 Kimmo Kääriäinen, "Religiousness in Russia after the Collapse of Communism," Social Compass 1999, no. 46(1), 35-46.

20 Stefan Plaggenborg, „Säkularisierung und Konversion in Russland und der Sowjetunion, “ In: Lehmann, H., ed., Säkularisierung, Dechristianisierung, Rechristianisierung im neuzeitlichen Europa (Göttingen: Vandenhoeck \& Ruprecht, 1997), 275-292.

21 Sam McFarland, „Communism as Religion," International Journal for the Psychology of Religion 1998, no. 8 (1), 33-48; Edgar Wunder, Religion in der postkonfessionellen Gesellschaft. Ein Beitrag zur sozialwissenschaftlichen Theorieentwicklung in der Religionsgeographie (Stuttgart, 2005).

22 Dmitrii Furman, „Religion and Politics in Mass Consciousness in Contemporary Russia, “ In: Lehmann, ed., Säkularisierung, 291-303. 
Some scholars even apply this theory to all of Eastern Europe and argue that the atheization of Eastern Europe in the $20^{\text {th }}$ century was a myth. ${ }^{23}$

In the early 1990s it was not only Marxist ideology that was in a very weak position. Orthodox Christianity had been compromised by decades of collaboration with the Soviet authorities ("spiritual bankruptcy"24) and as a result the main rivals of Orthodox Christianity, traditionally the dominant religion in Russia, were those religious doctrines whose adherents "believed not in God but in supernatural forces." The adherents in question can identify with Orthodox Christianity as well as with Christianity in general and even with atheism; typical for this group is an interest in Eastern religions, spiritism, parascientific and para-religious mythology. The latter is seen as a movement "towards an amorphous, eclectic consciousness that is not denominational and not even Christian or anti-Christian." ${ }^{25}$ Religion in Russia has turned into a folkloric belief system based on science, para-science and Theosophy. Magic, occultism and elements of Eastern religions are combined with traditional Christian dogmas. This, they say, points to the existence of a wholly private religiosity, the main criterion of which is the ability to construct a worldview of one's own. ${ }^{26}$

Therefore, it is claimed, the "real" religion of Russia is "not Orthodoxy, and not paganism, shamanism or atheism either", but rather "a popular religion combining many elements of different origin." Only on the surface is there a thin layer of Orthodox Christian practices, or a Muslim one in post-Soviet Central Asia, which is home to a "popular religion based on shamanism, Zoroastrianism, Islam and other sources. ${ }^{27}$ The public consciousness of Russia is seen as dominated by "spiritual entropy", while within the paradigm of "occultism-after-atheism" Orthodox Christianity no longer serves as a source of beliefs and values, but rather as the "public religion", that is, a source of the national ideology and identity that is sought by society. ${ }^{28}$ Two conflicting ten-

23 Irene Borowik, "Between Orthodoxy and Eclecticism: On the Religious Transformations of Russia, Belarus and Ukraine," Social Compass 2002, no. 49 (4), 497-508.

24 Jerry Pankhurst, "Religion in Russia Today," In: Dmitrii Shalin, ed., Russian Culture at the Crossroads: Paradoxes of Postcommunist Consciousness (Boulder/Co., 1996), 127-156.

25 Dmitrii Furman, Religion and Politics.

26 Irene Borowik, Between Orthodoxy and Eclecticism.

27 David Lewis, After Atheism. Religion and Ethnicity in Russia and Central Asia (London, 2000), 295.

28 Alexander Agadjanian, "Russian Religion in Media Discourse - Entropy Interlude in Ideocratic Tradition,” In: M. Kotiranta, ed., Religious Transition in Russia (Helsinki, 2000), 251-288. 
dencies are said to exist in Russian post-communist society: "a syndrome of missed modernity" and simultaneously "a postmodern framework" which together result in a "hybrid picture". The reasons for this hybrid mixture are identified as a "weak civil society" and "lack of experience in independent public treatment of religious questions in a pluralistic context." 29

The third line of argument derives from cultural studies, rather than the sociology of religion. Scholars point out that occultism normally flourishes "during hard times". ${ }^{30}$ Its present flourishing is interpreted as a reaction to the "pseudo-scientific worldview previously propagated as part of the general atheistic teaching" ${ }^{31}$ and a result of "Russia's own historical and spiritual heritage" - a comforting alternative to the rational worldview prescribed by scientific materialism..$^{32}$ It is even claimed that there is a connection between the occult ideas that circulated in Russian society at the beginning of the $20^{\text {th }}$ century and the later Stalinist regime. ${ }^{33}$ New Age worldviews in post-communist states are seen as deeply rooted in utopia and socialism and as means of transporting the central ideas of socialism into the post-socialist age. ${ }^{34}$

Among the reasons Russian scholars give for the present growth of esotericism, mysticism and occultism in Russia and the world are the disintegration of the motivational principles of the former cultural mainstream of Western civilization, ${ }^{35}$ the collapse of faith in science, ${ }^{36}$ the complexity of human life which science is not always and not everywhere capable of ordering, ${ }^{37}$ the real

29 Alexander Agadjanian, "The Search for Privacy and the Return of a Grand Narrative: Religion in a Post-Communist Society," Social Compass 2006, no. 53 (2), 169-184.

30 Sidney Monas, "Review of 'The Occult in Russian and Soviet Culture' by Bernice G. Rosenthal," The Journal of Modern History 1999, no. 71 (2), 517-518.

31 H. Heino, What is Unique in Russian Religious Life, In: Matti Kotiranta, ed., Religious Transition in Russia (Helsinki, 2000), 289-304.

32 Holly DeNio Stephens, "The Occult in Russia Today," In: Bernice G. Rosenthal, ed., The Occult in Russian and Soviet Culture (Ithaca, London: Cornell University Press, 1997), 357376.

33 Bernice G. Rosenthal, "Political Implications of the Early Twentieth-Century Occult Revival," In: eadem, ed., The Occult, 379-418.

34 Barbara Potrata, "New Age, Socialism and Other Millenarianisms: Affirming and Struggling with (Post)socialism," Religion, State \& Society 2004, no. 32 (4), 365-379.

35 A. Jurkevich, “'Ezoterizm' kak sotsial'no-kul'turnyi fenomen v Kitae i na Zapade," In: L. Fesenkova, ed., Diskursy ėzoteriki (filosofskii analiz) (Moscow: Editorial URSS, 2001), 148-168, here 163.

36 V. Vizgin, "Nauka, religiia i ėzotericheskaia traditsiia: ot moderna k postmodernu," Ibid., 7999, here 94.

37 Evgenii Balagushkin, "Ėzoterika v novykh religioznykh dvizheniiakh,” Ibid., 214-239, here 217. 
nature of the human psyche, ${ }^{38}$ the need for self-affirmation, the striving towards the creation of a perfect society and the desire of intellectuals who consider the traditional religious worldviews slightly primitive to find patterns for interpreting the world that have a stronger rational or science-like appearance. $^{39}$

Is it thus true that the present esoteric subculture in Russian could turn into a rival of traditional (Christian) religiosity and even aspire to a dominant position in the religious consciousness of the population? This question motivated me to carry out my own opinion poll among the Russian population in 2006. For this poll I presented 1,600 persons from all over Russia with a questionnaire on belief in occult ideas and their experience with occult practices. This poll has so far been the only scientifically founded quantitative investigation in Russia specifically designed to analyze the proliferation of occult worldviews in the Russian population. ${ }^{40}$

According to the results of the poll the majority of respondents agreed with thirteen of the examined esoteric worldviews, and even those ideas that were rejected by or viewed in a sceptical light by the majority were approved by a relatively large minority.

38 O. Baksanskii, "Psikhologicheskie osnovaniia ėzotericheskikh uchenii (v svete analiticheskoi psikhologii K. Iunga)," Ibid., 131-146, here 143.

39 L. Fesenkova, “Teosofiia segodnia," Ibid., 10-35, here 26-30.

40 Demyan Belyaev, „Heterodoxe' Religiosität auf dem Vormarsch in Russland? Zur empirischen Untersuchung des religiösen Synkretismus im postsozialistischen Raum, "Zeitschrift für Religionswissenschaft 2008, no. 16, 177-202. 
Tab. 1 Attitude towards the examined elements of esoteric worldviews

\begin{tabular}{|c|c|c|c|}
\hline Agreed with the following statements: (\%) & $\begin{array}{c}\text { Yes } \\
\text { or likely } \\
\text { yes }\end{array}$ & $\begin{array}{l}\text { Hard } \\
\text { to say }\end{array}$ & $\begin{array}{c}\text { No } \\
\text { or likely } \\
\text { no }\end{array}$ \\
\hline There is a higher power such as God, providence or others & 69 & 21 & 10 \\
\hline $\begin{array}{l}\text { There is a higher instance of justice that rewards or } \\
\text { punishes people's acts }\end{array}$ & 61 & 25 & 14 \\
\hline It is possible to predict the future & 58 & 27 & 15 \\
\hline Humanity today is facing a global crisis & 56 & 27 & 17 \\
\hline Jesus Christ really was the son of God & 53 & 37 & 10 \\
\hline It is possible to influence other people's life by magic & 53 & 24 & 23 \\
\hline $\begin{array}{l}\text { Some healers can cure diseases that traditional medicine } \\
\text { cannot cure }\end{array}$ & 52 & 27 & 22 \\
\hline $\begin{array}{l}\text { Human beings have a soul that can exist independent of } \\
\text { the body }\end{array}$ & 51 & 31 & 18 \\
\hline $\begin{array}{l}\text { There is a correlation between a person's zodiac sign and } \\
\text { character }\end{array}$ & 49 & 30 & 21 \\
\hline Angels, demons and ghosts do exist & 44 & 36 & 20 \\
\hline $\begin{array}{l}\text { Luck and misfortune are influenced by supernatural } \\
\text { powers or laws }\end{array}$ & 44 & 33 & 24 \\
\hline It is possible to read other people's mind (telepathy) & 44 & 31 & 25 \\
\hline Talismans can be effective & 43 & 29 & 28 \\
\hline $\begin{array}{l}\text { Governments keep knowledge about the supernatural } \\
\text { secret ("conspiracy") }\end{array}$ & 34 & 45 & 22 \\
\hline Aliens have visited planet Earth already & 32 & 44 & 24 \\
\hline This is not my first life & 29 & 34 & 37 \\
\hline It is possible to move objects by the power of thought & 24 & 37 & 39 \\
\hline Contact with ghosts is possible & 19 & 44 & 37 \\
\hline
\end{tabular}

Source: Own calculations, representative poll of Russian population in September 2006.

In addition, the respondents were asked about their practical experience with esotericism or its representatives. We distinguished between several different kinds of experience. According to our results, over 22\% of Russians have had some contact with a spiritual healer, with a subjective success rate of almost 
$56 \%$; almost $35 \%$ of Russians over 18 have read some kind of esoteric literature and around $50 \%$ believe they have profited from the advice given in this literature.

The worldviews we analyzed (see Table 1) can be divided into two groups. Ideas such as the belief in a soul, God, higher justice, angels and Jesus ${ }^{41}$ can be summarized under the label "traditional-religious". The second, esoteric, group comprises ideas such as predicting the future, telepathy, moving of objects, healing, talismans, magic, astrology, and contact with ghosts. ${ }^{42}$ There is a strong correlation between these eight ideas, which is not as obvious for the remaining ideas (also listed in Table 1 but not allocated to either group).

According to our calculations the proportion of convinced non-believers (i.e. those who do not believe in any of the ideas from the two groups) is relatively low at just under $10 \%$. Around $15 \%$ of the population adheres to traditional religious beliefs (i.e. most of the elements of the first group but not of the second). In comparison, around $20 \%$ of the population have a predominantly esoteric worldview (believing most of the elements of the second group but not of the first). Another $27 \%$ are both traditionally religious as well as believers in esoteric ideas (they believe in most ideas from both groups) and around 30\% ostensibly have no consistent convictions in the field of religious or esoteric belief.

This quantitatively founded result allows us to draw the following conclusions: in contemporary Russia esoteric worldviews are more common than traditional forms of religiosity. They apply consistently to at least $45 \%$ of the population, compared to $40 \%$ who hold traditional Christian ideas and $10 \%$ who adhere to scientific materialism.

It is hardly possible to reduce the complexity of societal relations that have led to this situation to a few social causes. But we can point to a few specific conditions that may have encouraged the flourishing of esoteric beliefs. Above all there is the fact that esoteric and occult doctrines have a long-standing tradition in Russia, in particular among the intellectual elite, both before the Bolshevik Revolution and after. Secondly, the fast rejection of Marxist doctrines in public consciousness in the early 1990s furthered the reception of everything new, including all kinds of occult and esoteric doctrines. Thirdly, one can say that perhaps the Russian consciousness ("mentality") remains less influenced by the West European Enlightenment. However, this proposition ought to be proven or refuted with the help of specialized research into mentality.

41 For complete wording see Table 1.

42 For complete wording see Table 1. 
As someone who grew up in Russia and has engaged in extensive research into Russia during different historical periods, I would like to point out that I regard any talk about a "break" with the "rational" Soviet past as erroneous. The Russian people have always been merely human, with all the traits inherent to human nature, including irrationality. Soviet "civilization" was only superficially "rational" or "different". Therefore I see no causal relation between the present rise in esoteric ideas and Soviet civilization, with the potential exception of the freedom of the press, which did not exist in the Soviet Union.

It would likewise be a gross exaggeration to talk about a "cult of humanism" in the Soviet Union as opposed to a "cult of nihilism" in present-day Russia. The Soviet cult of humanism was nothing more than a phenomenon of the belief in science and progress, which was also apparent in the West during this time. Likewise, the "cult of nihilism" has been known since the days of Nietzsche and today constitutes a phenomenon of international mass culture, imported to Russia from the West and consumed there. The fact that certain Russian writers and other producers of cultural goods are active in this field does not tell us anything about the genuine worldview of the Russian people, but merely about their openness to manipulation by the "gatekeepers" of mass literature, which characterizes the populations of Western countries in much the same way.

For these reasons it might be more appropriate to regard contemporary Russian esotericism as part of the development of global society rather than a reaction to the Soviet past. 


\title{
OCCULT DISSIDENT CULTURE: \\ THE CASE OF ALEKSANDR DUGIN
}

\author{
MARK SEDGWICK
}

Aleksandr Dugin (b. 1962) is perhaps best known as the leading exponent in contemporary Russia of Eurasianism, an increasingly fashionable political doctrine, referred to by scholars such as Marlène Laruelle as "neo-Eurasianism." He is also, however, one of Russia's leading exponents of Traditionalism, a school of thought of early twentieth-century French origin which might be classed as a philosophy, but has occult roots and is usually seen by scholars as a form of esotericism. A form of Traditionalism that is both distinctively Soviet and distinctively Russian, this article will argue, lies at the heart of Dugin's politics. This form of Traditionalism is, in important ways, a continuation into the post-Soviet era of one aspect of Soviet civilization, occult dissident culture. Dugin and his activities are generally regarded with alarm in some circles in Russia and the West, where he is regarded as a dangerous "neo-fascist." Whether or not the Dugin phenomenon is dangerous, and if so to whom, are questions this article will not address. Neither will it address the relationship between the Dugin phenomenon and neo-fascism.

\section{The Dugin phenomenon}

Since 1967, Aleksandr Dugin has been involved in what is at first sight a bewildering array of groups and positions, starting at the margins of Russian political and intellectual life, and becoming ever more prominent. The "Dugin phenomenon," however, becomes comprehensible if analyzed on three levels: the public, the political, and the intellectual. ${ }^{1}$

Dugin is at present most widely known in Russia at the public level, as a frequent commentator on foreign (and sometimes domestic) affairs in the Russian media. The fall of the Berlin wall was "a shameful event" for Russia, Dugin tells km.ru. ${ }^{2}$ The West is using "new ways of trying to impose their vision

\footnotetext{
1 My thanks to Mischa Gabowitsch for suggesting this approach to the analysis of Dugin.

2 Sergei Makarov, "Krushenie Berlinskoi steny kak tragediia Rossii," Km.ru November 9, 2009, news.km.ru/krushenie_berlinskoj_steny_kak_t.
} 
of a unipolar world on all humanity," he tells ITAR-TASS. ${ }^{3}$ Protest rallies in Moldova have been organized by the USA, he explains in Komsomol'skaia pravda. ${ }^{4}$ At this public level, Dugin's views and comments are plentiful, but not especially remarkable. They might be described as Great Russian nationalist, anti-American, or Soviet-imperial nostalgic, positions that have become increasingly common in recent years. There is much more to Dugin's views than this, however.

At the political level, Dugin is at present the leader of the Eurasian Movement, and thus the leading spokesman for Eurasianism, a political philosophy which promotes Eurasian solidarity against the Atlantic world, and which thus fits well with currently fashionable nationalist and anti-American positions. Its declared objective is "to draw people together to work for prosperity and peace throughout the [Eurasian] continent, to build and care for our common Eurasian home."

The Eurasian Movement, established in 2001, is the successor, as Dugin's main organizational vehicle, of the National Bolshevik Party (NBP), which he established in 1993 with the novelist Eduard Limonov (b. 1943) and the musician Egor Letov (1964-2008), ${ }^{6}$ but left in 1998 as a result of various disappointments, and a split with Limonov (Letov was never particularly active). ${ }^{7}$ The central political positions of the Eurasian Movement and the NBP organizations are quite different, as is their status. In other ways, however, they are quite similar.

The NBP was defined more by what it stood against-President Yeltsin's Russia and the liberalism that was then popular-than by what it stood for. It was colorful, but marginal. ${ }^{8}$ The Eurasian Movement is defined by what it stands for, and is loyal to today's Kremlin, with which it seems to enjoy good relations. ${ }^{9}$ It includes such establishment figures as the television journalist

3 "Lider mezhdunarodnogo Evraziiskogo dvizhenia Aleksandr Dugin v Ekaterinburge," ITARTASS February 11, 2010, www.tass-ural.ru/presscentre/94884.html.

4 Ol'ga Vandysheva, “Aleksandr Dugin, politolog: Kishinev podzheg Obama," Komsomol'skaia pravda April 7, 2009, www.kp.ru/daily/24273/469785.

5 “Manifest Mezhdunarodnogo Evraziiskogo Dvizheniia," Evrazia.org, www.evrazia.org/mod ules.php?name=News\&file=article\&sid=1571 (accessed March 7, 2010).

6 Of Grazhdanskaia Oborona (Civil Defense).

7 The NBP under Limonov has since taken very different directions.

8 Mark Sedgwick, Against the Modern World: Traditionalism and the Secret Intellectual History of the Twentieth Century (New York: Oxford University Press, 2004), 230-232.

9 Many rumors circulate concerning these. The central point, however, is that Dugin could hardly enjoy his current public prominence without some significant support in the Kremlin. 
Mikhail Leont'ev and Mufti Talgat Taj al-Din. ${ }^{10}$ It also differs from the NBP in having branches (some more important than others) in the West. The Eurasian Movement resembles the NBP, however, in attracting activist youth, though to the Eurasian Youth Union rather than the Eurasian Movement proper, in Russia and in the former Soviet space. ${ }^{11}$ Members of the Eurasian Youth Union have engaged in a variety of "direct actions" outside Russia, ranging from destruction of a Ukrainian national symbol ${ }^{12}$ to paramilitary activities on Russia's fringes, such as Transnistria and South Ossetia. ${ }^{13}$ The Eurasian Youth Union, then, continues the activist traditions of the old NBP, and despite differences in central political positions, the Eurasian Movement stands, as the NBP stood, against American-style liberalism.

At the intellectual level, Dugin is at present a professor of sociology at Moscow State University, where he is director of the Center for the Study of Conservatism and editor of the Center's journal, Russian Time (Russkoe vremia, since 2009). ${ }^{14}$ The Center is in a sense an organizational vehicle, but is more a forum for the promulgation of Dugin's intellectual positions, and in this sense is the immediate successor to a lecture series called the "New University," to individual lectures given to members of the NBP before that, and ultimately to lectures given by Dugin to members of Pamiat' in 1987, ${ }^{15}$ discussed below The journal is the successor of Dear Angel (Milyi Angel), Dugin's first journal, es-

10 "Vysshii Sovet Mezhdunarodnogo Evraziiskogo Dvizheniia," Evraziia.info, evrazia.info/ modules.php?name=News\&file=article\&sid=1908 (accessed February 23, 2010).

11 Nataliia Ludanova argues that Eurasianism has in effect become the official Kazakh state ideology, and has close links with Dugin (Kasachische Mission: Das eurasische Konzept in der Konstruktion der nationalen Idee in Nursultan Nazarbaevs Kasachstan, unpublished thesis, University of Mainz, 2009/10). There seems, however, to be no significant esoteric content in Kazakh Eurasianism. An interesting form of Chechen Eurasianism, in contrast, does seem to have esoteric content, even though the author of an excellent recent study, Eduard ten Houten, argues against this (Blood, Power, Islam: The Life and Opinions of the Exemplary Chechen Khozh-Akhmed Noukhaev, unpublished thesis, University of Amsterdam, 2009). For my response to Ten Houten, see Mark Sedgwick, "Is Hanifi Traditionalism Traditionalist?" Traditionalists, February 16, 2010, traditionalistblog.blogspot.com/2010/02/is-hanifi-traditionalismtraditionalist.html.

12 Mark Sedgwick, "Dugin Accused of Terrorism," Traditionalists, November 7, 2007, traditionalistblog.blogspot.com/2007/11/dugin-accused-of-terrorism.html.

13 "Associates of Dugin filed a lawsuit against Grigol Vashadze," Expert Club, January 29, 2010, eng.expertclub.ge/portal/cnid_3311/alias_Expertclub/lang_en/tabid_2546/default.aspx.

14 Russkoe vremia 1 (August 2009), 1, haxe.d2.gfns.net/videos/pavel_ak/russkoe_vremya_Layout 1.pdf.

15 For these lectures, Dugin, interview, Moscow, August 1999. 
tablished in 1991, and to Elements (Élementy), established in $1993 .{ }^{16}$ These journals were and are supplemented by a number of major websites, well designed and with copious archives, that carry many of Dugin's articles as well as videos of his more recent lectures. ${ }^{17}$ The topics treated and authors referred to in all these lectures, journals and websites have developed over the years, but have not changed fundamentally, and contain significant esoteric content. The intellectual level of the Dugin phenomenon, then, shows the greatest continuity over the years.

Dugin has published 28 books between 1990 and 2010, some of which are collections of his lectures. These can be allocated to both the political and the intellectual levels, but not to the public level, as none are aimed at a mass readership. The book which first brought him to serious public attention in 1997, Geopolitical Foundations: The Geopolitical Future of Russia (Osnovy geopolitiki: geopoliticheskoe budushchee Rossii), for example, belongs to the political level, and contains little that is properly esoteric. Other books, however, belong to the intellectual level, for example The Metaphysics of the Gospel (Metafizika blagoi vesti, 1996) and The Philosophy of Traditionalism (Filosofiia traditsionalizma, 2002), and contain much that is esoteric.

The relationship between these three levels of the Dugin phenomenon might in theory be that the public creates the political, and that the political creates the intellectual. However, given that the intellectual has remained consistent over the years while the political has changed somewhat and the public has changed even more (from slight visibility at the margins to definite visibility in the mainstream), it makes more sense to understand the intellectual as giving rise to the political, and the political to the public.

This is Dugin's own understanding of the relationship. After a period of "ultimate despair" in the 1980s, he has written, events (evidently those attending the collapse of the Soviet Union) led him to the conclusion that political and public action was necessary for the sake of the intellectual or, as he put it, that "it was necessary to strengthen the Traditionalist spirit, to clarify metaphysical positions, to consolidate the forces that could-intentionally or notdefend the sacred." 18 The "Traditionalist spirit" (which will be explained below) and metaphysical positions relate to the intellectual level, and are where the esoteric is to be found. The consolidation of forces relates to the political

16 For these journals, see Sedgwick, Against the Modern World, 233.

17 At present, the most important are Arktogeia (arcto.ru), Informatsionno-analiticheskii portal Evraziia (evrazia.org) and the MSU site (konservatizm.org).

18 Aleksandr Dugin, Filosofiia traditsionalizma (Moscow: Arktogeia, 2002), 547-548. 
and public levels, where the esoteric is not so central, and where others may serve Dugin's intellectually defined objectives "intentionally or not."

This article, therefore, understands the intellectual-including the esoteric - as the basis of the political and the public, and so will focus on the intellectual. It will now examine the origins of Dugin's former despair, and then the Traditionalist metaphysics from which his conception of the sacred derives.

\section{Dugin's despair: The Iuzhinskii Circle as a Soviet phenomenon}

Dugin's despair was of Soviet origin. Dugin was born in 1962, allegedly into the Soviet nomenklatura as the son of a general in the GRU (military intelligence). ${ }^{19}$ At the age of 18 , however, he encountered occult dissident culture in the form of the "Iuzhinskii Circle," ${ }^{20}$ so-called because it originally met in an apartment in Iuzhinskii Lane. The Iuzhinskii Circle was an informal group that had been established in the 1960s by the poet Evgenii Golovin (1938-2010), the novelist Iurii Mamleev (b. 1931), and a graduate of the Moscow Institute of Philosophy, Vladimir Stepanov. By 1980, when Dugin entered the circle, Mamleev had emigrated to America, and Golovin no longer attended much; leadership had passed to Stepanov. ${ }^{21}$ It is not clear that it was still referred to as the Iuzhinskii Circle at this point, but the label is anyhow used in this article, since no better label is available.

The Iuzhinskii Circle had originally been established in search of all forms of occult knowledge, starting with yoga and Sufism, but had gradually come to concentrate on the work of Georgii Gurdjieff (1866 [?]-1949), ${ }^{22}$ the GreekArmenian who, after an early career in the Russian Empire, had emigrated to Paris and there established one of the most enigmatic and important alternative religious movements of the twentieth century. ${ }^{23}$ The Iuzhinskii Circle was not, however, an "authentic" Gurdjieff group, which, as Arkady Rovner argues, would have been impossible in "the environment of cultural isolation of Soviet

19 “Doktor Dugin," Literaturnaia Rossiia 15, no. 13 (April 2007), www.litrossia.ru/2007/15/ 01412.html. When I first interviewed him, Dugin identified his father simply as "an army officer" (interview, Moscow, August 1999).

20 Ibid.

21 Arkady Rovner, "Gurdzhievskoe dvizhenie v Rossii 1960-kh i 1970-kh: Vospominaniia i refleksii uchastnika," paper given at the conference on "The Occult in 20th Century Russia: Metaphysical Roots of Soviet Civilisation,” European Academy, Berlin, March 11-13, 2007.

22 Ibid.

23 Although much has been written on Gurdjieff, there is still no good scholarly history of this movement. 
Russia." It, like other such occult dissident groups, necessarily developed its understandings on the basis of the limited material its members could find (normally in the Lenin Library), ${ }^{24}$ often developing this material in idiosyncratic ways. Its interpretation of the Gurdjieff "work" was somewhat different from that known at Gurdjieffs own Institute for the Harmonious Development of Man outside Paris, for example, and included a strong emphasis on the use of "shock," "tests" of obedience (such as going out for a week wearing one brown shoe and one black one), ${ }^{25}$ and prolonged bouts of drunkennessincluding, allegedly, a party for Golovin's birthday that lasted for five months. ${ }^{26}$

By the time that Dugin joined the circle, "excess in all forms" had become the norm, according to Dugin also a form of revolt. ${ }^{27}$ As well as the consumption of significant quantities of alcohol, this excess included sexual experimentation. Dugin's first wife, Evgeniia Debrianskaia (b. 1953), whom he met in the Iuzhinskii Circle, was later one of two co-founders of the Association of Sexual Minorities, ${ }^{28}$ which became the Moscow Gay and Lesbian Union. Excess, however, was matched by serious discussion and by reading, carried out in a variety of languages, which members of the circle often taught themselves. ${ }^{29}$ Dugin, for example, is an accomplished linguist, said to read nine or ten languages. ${ }^{30}$

Dugin's encounter with occult dissident culture in the form of the Iuzhinskii Circle changed his life in several ways. Its immediate effect was to turn him into a dissident, one of those arrested by the KGB in 1983 after a party in a painter's studio during which he had sung what he describes as "mystical antiCommunist songs." As a result, he was expelled from the Institute of Aviation, where he had been studying. For some years after this he worked as a street sweeper. ${ }^{31}$ Another effect was to introduce him to people with whom he would

Rovner, "Gurdzhievskoe dvizhenie."

Rovner, interview, Berlin, March 2007.

Vladislav Lebed'ko, Khroniki Rossiiskoi San'iyasy" (St. Petersburg: Tema, ND) vol. 2, ch. 3, sanyasa.narod.ru/chronicles/vol2/stepanov.htm. Accessed March 1, 2010.

Dugin, interview, Moscow, August 1999.

"Evgeniia Debrianskaia," Proekt People's History, www.peoples.ru/state/statesmen/ evgeniia_debrianskaya/index.html, accessed March 1, 2010.

Dugin, interview, 1999.

Nine languages according to Dugin's entry in the Russian Wikipedia (accessed March 7, 2010), and ten according to an earlier version of his biography, www.evrazia.org/modules. php? name $=$ News\&file $=$ article\&sid $=1882$ (accessed November 11, 2006). As well as Russian, he certainly knows French and English very well, and evidently also German, though I have not interviewed him in German.

Dugin, interview, 1999. 
remain in contact until today, including Gaidar Dzhemal (b. 1947), with whom Dugin took his first political steps during the closing years of the Soviet Union, when both men joined Pamiat', the first non-Party mass political organization in Soviet history, and one opposed to perestroika. ${ }^{32}$ Dzhemal, like Golovin and Mamleev, lectured for Dugin's "New University" in the late 1990s and early $2000 \mathrm{~s},{ }^{33}$ despite by then having adopted political positions that were different from Dugin's. Dzhemal, for example, became one of Russia's best known Islamists, and despite an early interest in Traditionalism, no longer describes himself as a Traditionalist. ${ }^{34}$

The most important effect on Dugin of the Iuzhinskii Circle, however, was to introduce him to a wide range of occult writers and thought. These, the origin of Dugin's Traditionalist metaphysics, and thus of his political and public positions, will be considered below.

The Iuzhinskii Circle, the location of Dugin's "ultimate despair" and of his discovery of the metaphysics that would remain central to the fundamental intellectual level of his later activity, was a phenomenon characteristic of late Soviet culture. Circles of friends exist everywhere, but late-Soviet circles such as the Iuzhinskii Circle differed from those found elsewhere in two important respects: the talent and intellectual quality of their members, and their compactness and thus their significance for their members. Systems such as the contemporary Western one afford talented and clever people many opportunities for a variety of activities, with the result that such people tend to be busy, and so meet only occasionally, and do not generally form significant circles of close friends, at least after they leave university. Post-university circles, then, have little impact on them. The late Soviet system, in contrast, rewarded only certain types of talent, leaving other types of talent unoccupied, and thus providing unusually talented recruits for circles such as the Iuzhinskii Circle. The late Soviet system also ensured, through the activities of the state security apparatus, that such circles were compact. The Iuzhinskii Circle is reported by Rovner not to have been too worried about informers because of a conviction that "informers do not read [Jakob] Böhme." ${ }^{35}$ This was probably true, but isolating the Circle from all those who did not read Böhme necessarily resulted in a high bar to entry. Circles of friends in systems without an intrusive security apparatus have lower bars to entry, and so are less compact. The late Soviet circle,

\footnotetext{
32 Ibid.

33 List of lectures at nu.evrazia.org/archives, accessed February 21, 2010.

34 Dzhemal, interview, Moscow, January 2006.

35 Rovner, "Gurdzhievskoe dvizhenie."
} 
then, was an instance of a very special social formation, similar to a religious sect. One characteristic of a sect is that it is of great significance for its members' lives. Another is that the mental world within it tends to develop with little reference to society in general, ${ }^{36}$ and so-unrestrained-can easily go in unusual and surprising directions.

The Iuzhinskii Circle was also a distinctly late-Soviet phenomenon because of its eclecticism-the very wide variety of occult and esoteric writings in which it was interested. Esoteric groups in the West, for example, commonly follow one particular line. Western followers of Gurdjieff generally read Gurdjieff, P. D. Ouspensky, and other writers of the "Fourth Way." They do not generally read the Traditionalist writers whom Dugin encountered via the Iuzhinskii Circle, as in the West the two movements do not overlap. To the extent that they do have any relations, those relations are generally hostile. In late Soviet Russia, however, only some of the works of the writers of the "Fourth Way" were available. The Lenin Library did not intentionally stock esoteric or occultist works in foreign languages, and had a somewhat random collection of them. Anything that could be found, then, was valuable, was read, and was discussed, not only in the Iuzhinskii Circle but also in the wider group of readers in the Lenin Library who were interested in the occult. Many of these knew each other, and met and talked there; Rovner describes such readers as almost living in the Lenin Library. ${ }^{37}$ Dugin remains remarkably eclectic to this day, ${ }^{38}$ and this eclecticism is a continuation of Soviet occult dissident culture.

One further way in which the Iuzhinskii Circle was a phenomenon characteristic of late Soviet culture was the prior intellectual formation of its members. Though all were clever and talented-Jakob Böhme is not easy reading, after all-few if any were trained in the rigorous application of critical and analytic skills. Dugin, for example, was almost entirely self-taught: he received no formal higher education in the humanities. The doctorate that later allowed him to become a professor of sociology was awarded in 2004 by the Rostov

36 For a recent successful application of the sociology of the sect to the analysis of the political, see Marc Sageman, Understanding Terror Networks (Philadelphia: University of Pennsylvania Press, 2004).

37 Rovner, interview.

38 He has also incorporated Herman Wirth (1885-1981) into his Traditionalism, which no Western Traditionalist has. Filosofiia traditsionalizma, 135-165. Wirth does not, however, seem to have had a major impact on Dugin's final conceptions. 
Institute of Law in Rostov-on-Don, ${ }^{39}$ not one of Russia's leading academic institutions. Although others in the Iuzhinskii Circle had received higher education, Soviet higher education did not encourage the questioning and critical analysis that are the marks of a good education in the humanities in the West.

There was also a difference between the scope of acceptable knowledge in the late Soviet Union and the West. One of the standard definitions of "esoteric" used by social scientists is, of course, "rejected knowledge." ${ }^{\prime 0}$ Such definitions are usually followed by examples that illustrate the rather narrow scope of rejected knowledge in the West: the study of flying saucers is often given.$^{41}$ The scope of rejected knowledge in the Soviet Union, however, was rather wider. Esoteric authors were not just in the same category as flying saucers, but in the same category as Adam Smith and Isaiah Berlin.

This is one explanation for a striking difference between the reception of occult and esoteric works in the Iuzhinskii Circle-and indeed in Russia as a whole-and in comparable environments in the West. In the West, esoteric and occultist writers are not taken seriously in mainstream intellectual life, while in Russia they may be. This is partly a question of fashion-it is hard otherwise to explain why René Guénon (discussed below) is not acceptable in the footnotes of Western academic papers, though Mircea Eliade and Frantz Fanon are-but it is also a question of Soviet circumstances: less training in intellectual rigor and critical skills, and a far wider scope of "rejected knowledge."

Late Soviet circumstances, then, encouraged the formation of circles such as the Iuzhinskii Circle, and determined their nature. In contrast to Western norms, such circles collected more talent, were more compact (and so more sectarian) but also more eclectic. If they had much higher barriers to entry for individuals than the Western norm, they also had much lower barriers to entry for ideas, partly by necessity, and partly as a consequence of the prior intellectual preparation of their members and partly as a consequence of the wider scope of "rejected knowledge."

39 Dugin, "Transformatsiia politicheskikh institutov $i$ struktur $v$ protsesse modernizatsii traditsionnykh obshchestv (Unpublished dissertation: Rostov-on-Don, 2004), science.dugin.ru/ avtodisser-2.htm.

40 Deriving from Colin Campbell's famous "The Cult, the Cultic Milieu and Secularization," A Sociological Yearbook of Religion in Britain 5 (London: SCM Press, 1972), 119-136.

41 For example, by Michael Barkun, "Conspiracy Theories as Stigmatized Knowledge: The Basis for A New Age Racism?”, in Nation and Race: The Developing Euro-American Racist Subculture, Jeffrey Kaplan, Tore Bjørgo, eds. (Boston: Northeastern University Press, 1989), 62. 


\section{Dugin's metaphysics: Traditionalism as a Western phenomenon}

The single most important writer Dugin encountered through the Iuzhinskii Circle was René Guénon (1886-1951), whose work had been introduced to the Circle—along with that of another Traditionalist, Julius Evola (1897-1974)_ by Stepanov. Guénon was, Dugin wrote in 2002, "the most important man of the twentieth century." 42 Students at Moscow State University who took Dugin's course on the sociology of Russian society in 2009 found five books by Guénon and four books by Evola on their readings lists, along with more standard titles by Émile Durkheim, Claude Lévi-Strauss, and Jean Baudrillard. ${ }^{43}$

René Guénon is the founder of the Traditionalist movement. ${ }^{44}$ His early career in Paris during the belle époque was typical of activities in the esoteric milieux of his time. As a young man, he joined the Martinist Order of "Papus," Gérard Encausse (1865-1916). This was a quasi-Masonic order which derived ultimately from the Theosophical Society, and enjoyed considerable-if briefsuccess, mostly in France, but also in late-imperial Russia. ${ }^{45}$ After the First World War, Guénon distanced himself from these milieux, became a severe critic of the occultism of the period, and attracted Roman Catholic patronage. He continued to develop various ideas of esoteric origin, notably perennialism (discussed below), and so lost Catholic patronage. He later dismissed contemporary Christianity as esoterically bankrupt. His mature philosophy was expressed in several books, many articles by him and his followers, and a longrunning journal, Études traditionnelles.

There are three crucial elements in Traditionalism. Taken individually, none of these are unique to Traditionalism; what is unique is their combination. The first and most widespread element is perennialism, a belief in the existence of a single original $U r$-religion known as the Tradition, from which Traditionalism takes its name. This perennial Tradition is a major theme in Western esotericism. It dates back to the work of Marsilio Ficino (1433-1499) and Agostino Steuco (1497-1548) at the time of the Renaissance, and is found thereafter not only in occultist and esoteric writings, but also in the more

42 Dugin, Filosofiia traditsionalizma, 21

43 Reading list, konservatizm.org/konservatizm/sociology/060909141416.khhtml (accessed February 22, 2010).

44 This summary and subsequent summaries are drawn from the first chapters of Sedgwick, Against the Modern World.

45 Marie-Sophie André, Christophe Beaufils, Papus, biographie, la Belle époque de l'occultisme (Paris: Berg international, 1995), 171. 
mainstream work of the philosopher Gottfried Wilhelm Leibniz (1646-1716). ${ }^{46}$ The second element is a conviction that progress is an illusion, and that the real dynamic of history is relentless decline. Modernity is the lowest stage of decline, when the Tradition has been almost entirely lost. Traditionalism, then, is fiercely anti-modernist. The third element is a conviction that something can and should be done about this, either by following a traditional esoteric path within a traditional exoteric framework-Guénon's solution-or by spiritually motivated political activity_Evola's solution. For Guénon, the model was the brahmin priest, and for Evola, the model was the kshatriya spiritual warrior. Evola is sometimes described as a fascist, but was never a member of the Fascist Party, which he saw as insufficiently radical, and with which he was sometimes in conflict.

By the start of the Second World War, Guénon had moved to Egypt and converted to Islam, the exoteric framework within which he pursued the esoteric, Sufism. His followers by then included French Freemasons, European Sufis, and Rightists in Italy and Romania, inspired also by Evola. After the end of the Second World War and Guénon's death, these streams diverged. There is relatively little information about Traditionalist Freemasons. Several groups of Traditionalist Sufis came into being, none of which were large but some of which were influential, given that their members were often persons of importance in European and American cultural and intellectual life. Traditionalist Rightism developed most in Italy where, during the 1970s, the works of Evola became the chief inspiration for activists who were at one point responsible for an average of 80 terrorist incidents a month. ${ }^{47}$

As an anti-modernist philosophy, Traditionalism has most appeal to those with problematic experiences of modernity. In the West, it has generally appealed to intellectuals whose understanding of modernity has led them to disenchantment with it and alienation from it. In the Islamic world, it has more general appeal in Turkey and Iran, the two countries with the most problematic experiences of modernity: Turkey because Kemalist modernity is simultaneously nationalist and in opposition to Turkey's cultural and historical past, and Iran both because the Shah's modernity was similarly in opposition to Iran's culture and recent history, and because of the problematic experience of the disappointing consequences of the Islamic Revolution. In the Arab world,

46 Charles B. Schmitt, "Perennial Philosophy: From Agostino Steuco to Leibniz," Journal of the History of Ideas 27 (1966), 505-532.

47 There were some 2,000 incidents in 1977. It can be assumed that half of them were the work of Rightists. 
where experience of modernity has been much more superficial, Traditionalism is popular only in limited circles, notably among the Moroccan Francophone elite-which, of course, has its own problematic experience of modernity. ${ }^{48}$

The Soviet Union in some ways defined modernity, and Russia's experience of that modernity was certainly problematic. Guénon condemned modernity for its loss of the sacred, its cult of the technical sciences, and its illusory cult of progress. Nowhere was the loss of the sacred more dramatic than in the officially atheist Soviet Union, and nowhere else were the two substitute cults of science and progress more assiduously advanced, and nowhere else was the cult of progress more obviously illusory. Guénon condemned the materialism that underlay modern life; in the Soviet Union, materialism was not an underlying factor that was visible only to those who looked carefully, as it was in France, but rather a major and official part of the dominant world view. In one of his most important books, The Reign of Quantity, Guénon contrasted the "modern" emphasis on quantity, with its attendant atomization, and the "traditional" emphasis on quality, understood in a metaphysical sense. ${ }^{49}$ Quantity (in this sense, not in the sense of abundance) rather than quality was characteristic of Soviet life, again perhaps more than anywhere else.

One of Traditionalism's major points of appeal has always been its condemnation of modernity. Traditionalism has always had limited appeal in the West, because Guénon's characterization of modernity corresponds so little to most Westerners' experience of modernity that it can easily seem a caricature. For those with experience of Soviet modernity, however, Traditionalism could very easily seem to present an entirely accurate analysis.

\section{Traditionalism as a Russian phenomenon}

Traditionalism in Russia followed two lines of development, one unusual (in international terms) under Dugin, and one more usual under Iurii Stefanov (1939-2001) and then Artur (Arsenii) Medvedev (1968-2009). This second line is a post-Soviet development, and so does not show the influence of Soviet occult dissident culture. The differences between the first and second lines, then, are instructive.

48 These observations, like some of those following, are distilled from the relevant sections of Sedgwick, Against the Modern World.

49 René Guénon, Le règne de la quantité et les signes des temps (Paris: Gallimard, 2003). 
Stefanov discovered Guénon in the Library of Foreign Languages, ${ }^{50}$ rather as Stepanov discovered him in the Lenin Library, but was a well-regarded translator of French literature, not a dissident, and not a member of a circle such as the Iuzhinskii Circle. Immediately after the collapse of the Soviet Union in 1991, Stefanov published a number of articles on Guénon in the journal Questions of Philosophy (Voprosy filosofii), a serious philosophical journal published by the Russian Academy of Sciences but with a somewhat wider readership than such journals normally have. A number of Russian intellectuals who read this journal became interested in Traditionalism, including Artur Medvedev, then a young history graduate from the Russian State Humanities University. After Stefanov's death, Medvedev became Russia's most prominent non-political Traditionalist, ${ }^{51}$ as founder and editor of the journal Magic Mountain (Volshebnaia gora), which has published one or two issues each year since $1993,{ }^{52}$ each containing around 300 pages.

Magic Mountain acts as a focus for non-political Russian Traditionalism, following a pattern well established in the West, where Guénon's own journal Etudes traditionnelles formed the initial focus for the development of Traditionalism, and where similar journals have been established in every country where Traditionalism has become established..$^{53}$ Like its Western equivalents, Magic Mountain contains translations of classic Traditionalist texts, translations of classic non-Traditionalist spiritual writers such as Mullah Sadra, new articles, and book reviews. Most of the new articles are by Russian or Russianspeaking Traditionalists, but Magic Mountain also translates articles by contemporary Western Traditionalists, linking Russian Traditionalism with that elsewhere. ${ }^{54}$ Medvedev estimated that over the years he has published some 200

50 Artur Medvedev, interview, Moscow, January 2006.

51 This article uses "non-political Traditionalist" in the sense in which I use "spiritual Traditionalist" in Against the Modern World.

52 Medvedev, interview. Where no other source is given, information on Medvedev and his group comes from Medvedev. This journal, named after Thomas Mann's novel, was initially intended to be a literary and philosophical publication, a summit where intellectuals of various persuasions might meet, but from its second issue it became increasingly Traditionalist.

53 In 2010 there are similar journals in several languages, of which the most important are Connaissance des religions and La Règle d'Abraham (in French), Sophia and Sacred Web (in English, published in the United States and Canada, respectively), Symbolos and Revista de Estudios Tradicionales (in Spanish, published in Spain and Argentina, respectively), and Rivista di Studi Tradizionali (in Italian, 1961-2003).

54 Comments based on a review is issues 9 to 11 of Volshebnaia gora. The Western authors do not always know they are being translated (I myself did not at the time). 
different authors. ${ }^{55}$ Medvedev did not in general accept purely political articles, but did publish Golovin and some followers of Dugin and Dzhemal. ${ }^{56}$

The non-political Traditionalist circle around Magic Mountain also resembles Western models with regard to the type of person who contributes to it, though perhaps with a heavier than usual emphasis on poets and academics, probably as a result of the lower bar to entry for ideas into Russian intellectual life noted above. Like non-political Traditionalists in the West, many of Magic Mountain's authors also publish books on various subjects which are not Traditionalist, but in which Traditionalist perspectives are reflected. ${ }^{57}$

Post-Soviet Russia, then, provides conditions in which Traditionalism can flourish in much the same way that it has flourished in the West. Where the Magic Mountain circle differs from Western models, however, is that it is not associated with a Sufi order or any other distinct spiritual community. In the West, such groups normally follow Guénon's example in matching their intellectual interests with spiritual activity, most frequently in the form of a Sufi order, but sometimes also in the form of a Masonic lodge. This is not the case for either line of Russian Traditionalism, that associated with Magic Mountain or that associated with Dugin. Only very few Russian Traditionalists have converted to Islam over the years, and they have in general have been drawn to Shi'ism rather than Sufism, largely as a result of the influence of Dugin's associate from the Iuzhinskii Circle, Dzhemal, who is himself Shi'i ${ }^{58}$

Both Dugin and Medvedev explain this difference between Russian and Western Traditionalism in terms of Russian Orthodoxy. According to Medvedev, Stefanov was interested in Kabbalah and Gnosticism, but always saw himself as an Orthodox Christian. Similarly, the spiritual consequences for Medvedev himself of his encounter with Guénon and Stefanov were that he began regular Orthodox Christian practice (at baptism he assumed the name Arsenii).$^{59}$ Dugin too follows Orthodox Christian practice, though as an Old Believer, of the Edinoverie. ${ }^{60}$ He argues in Metaphysics of the Gospel that the

55 Medvedev, interview.

56 Dzhemal, for example, first published what is generally considered his most important spiritual work- Orientatsiia Sever (now available at kitezh.onego.ru/nord) - in Volshebnaia gora.

These comments are based on a review of the tables of contents of several issues, and discussions with Medvedev about the various authors.

58 Ali Turgiev, interview, Moscow, January 2006.

59 Medvedev, interview.

60 Vladimir Karpiets, interview, Moscow, January 2006. Edinoverie, unlike most varieties of Old Belief, recognizes the authority of the Patriarch, and is in return recognized by the mainstream 
Christianity that Guénon rejected was Western Catholicism. Guénon was right in rejecting Catholicism, Dugin argues, but wrong in rejecting Eastern Orthodoxy, of which he knew little. Orthodoxy, unlike Catholicism, had never lost its initiatic validity and so remains a valid tradition to which a Traditionalist may turn. ${ }^{61}$

This emphasis on Russian Orthodoxy is the one way in which both lines of Russian Traditionalism differ from Western norms, and the explanation seems to be Russian (rather than Soviet). This is suggested partly by the fact that it is common to Dugin's Soviet-era Traditionalism and to Magic Mountain's postSoviet Traditionalism, and partly by parallels outside Russia. Traditionalist Sufism is also unknown in Turkey, where its absence is explained by the abundance of pre-existing non-Traditionalist Sufi orders, ${ }^{62}$ and in Iran, where Sufism has a different history, and where the absence of Traditionalist Sufism ${ }^{63}$ is explained by the abundance of pre-existing alternative expressions of Islamic esotericism. $^{64}$ In the West, pre-existing Catholic alternatives have attracted only a tiny handful of Traditionalists, and pre-existing Protestant alternatives have attracted none. There have been a number of Traditionalists in the West who have turned to Christianity rather than Sufism, but in its Russian or Greek Orthodox forms. One of these, the French writer Jean Biès (b. 1933), has made much the same arguments as Dugin, and was evidently a source for the first version of Dugin's The Metaphysics of the Gospel. ${ }^{65}$ The implication seems to be, then, that Western Traditionalists create Traditionalist Sufi orders because they cannot find a pre-existing religious practice that satisfies them, but that when a satisfactory esoteric religious practice does already exist-in Turkey, Iran, and evidently also in Russia-this need does not arise. The substitution of Russian Orthodoxy for Sufism, then, reflects Russian conditions.

Orthodox church. Dugin's political action may be inspired by Traditionalism, but it takes place within Russia, and is facilitated by good relations with the Church.

61 Dugin, Metafizika blagoi vesti (2000) chapter 22, arctogaia.org.ru/modules.php?name=News $\&$ file $=$ article $\&$ sid $=270$.

62 Turkish informant, Istanbul, April 1999.

63 Apart from one very small branch of the Maryamiyya.

64 Shahram Pazuki, interview, Tehran, January 2001.

65 The original URL of Dugin's "La Métaphysique de la bonne nouvelle" was web.redline.ru/ $\sim$ arctogai/bies.htm (accessed May 31, 1997). 


\section{Dugin's Eurasianism as a post-Soviet phenomenon}

Traditionalism, then, is of Western origin, but its unusual emphasis on Russian Orthodoxy is of Russian origin. The Magic Mountain circle is of post-Soviet origin, and in other respects close to Western Traditionalist norms. Dugin's Traditionalism, in contrast, differs from those norms, and reflects the characteristically late-Soviet circumstances of the Iuzhinskii Circle.

The distance between Dugin's Traditionalism and Western norms were justified by Dugin in his 2002 Filosofiia traditsionalizma. In the first chapter of this book, Dugin argues that what Guénon really developed was a form of language, a "meta-language" - in fact, though Dugin does not use the word, a sort of dialectic. Guénon's distinction between modernity and tradition is, Dugin argues, as fundamental as Marx's distinction between labor and capital, but "even more fundamental, even more radical." Guénon's dialectic has to be used, however, not merely repeated, and Dugin is highly critical of Western Traditionalists for simply repeating Guénon with "very small deviations," which he sees as "a kind of intellectual hobby" like stamp-collecting, or a form of sadomasochism. ${ }^{66}$ Dugin's style, incidentally, sometimes shows something of the "literary shock tactics" found in Mamleev's work, which Rovner ascribes to Gurdjieff. ${ }^{67}$

Dugin argues instead for what he calls "Post-Guénonianism," the application of Guénon's dialectic to changing and developing circumstances, which is necessary since "the modern world is degrading. As a set of anomalies, it is going from bad to worse." This application allows, for example, the realization that "Soviet or Chinese communism contains more elements of the language of Tradition (however paradoxical and contradictory in expression) than modern Protestant theology." ${ }^{68}$ Post-Guénonianism is, according to Dugin, essential:

All the events around us (the crash of the ruble, military conflict, a government's resignation, new discoveries in archeology) are the struggle between two opposing camps. One pole: a tiny Post-Guénonian camp, almost non-existent, like a grain of sand in the desert. The other: a giant liberal camp, the language of modernity, which claims global supremacy. ${ }^{69}$

Dugin, Filosofiia traditsionalizma, 43.

Ibid., 49-50. 
As a result:

Implementation of the Post-Guénonian program is the single main state, national, social and cultural challenge. We have only one author, who must be read: René Guénon. We have only one objective: to understand what he meant to do. His thinking is our way of thinking, his language is our language... Without this, any change of government, any disaster and any social changes (even if positive) are metaphysically zero, because without Post-Guénonianism there is no spirituality, no social justice, no life-nothing. ${ }^{70}$

The principle vehicle for the implementation of "the Post-Guénonian program" is his Eurasianism. Eurasianism was originally developed in Prague, Berlin and Paris during the early 1920s by Russian emigré intellectuals, notably the geographer Petr Savitskii, the linguist Prince Nikolai Trubetskoi, and Nikolai Alekseev, a legal philosopher, ${ }^{71}$ building on the nineteenth century Slavophiles and Pan-Slavists. The Slavophiles defined a Slavic identity by contrast with that of Europe, emphasizing the Slavs' religion and social solidarity in contrast to the supposed dry rationality and moral decadence of Europe, drawing on Romantic critiques of early modernity. ${ }^{72}$ The Eurasians of the $1920 \mathrm{~s}$ extended their criticisms of Europe, and replaced the Slavs with Eurasia, defined as Russia and the peoples of the Eurasian steppe..$^{73}$ Dugin modified this definition of Eurasia in line with the work of two non-Russian interwar intellectuals, the British geographer Sir Halford Mackinder and the German geopolitical theorist Karl Haushofer, which pitted a "Eurasian heartland" consisting of Germany and Russia against an Atlantic world comprising maritime nations predisposed toward free trade and democratic liberalism. ${ }^{74}$

Dugin's Traditionalism, which had already embraced Russian Orthodoxy, fitted well with this Eurasian-Atlantic model. Eurasia, as defined by Mackinder and Haushofer, and led by Russia, could be identified with Tradition and the sacred, building on the original Slavophile conception of the Slavic identity. The Atlantic world, in contrast, could be identified with decline, modernity, and the absence of spirituality, building on the original Slavophile conception

70 Ibid, 50.

71 Marlène Laruelle, L'ideologie eurasiste russe, ou comment penser l'empire (Paris: L'Harmattan, 1999), 62.

72 For the Slavophils and Pan-Slavists, Laruelle, L'ideologie eurasiste russe, 34-39.

73 Ibid., 39.

74 Sedgwick, Against the Modern World, 226. 
of an "other" characterized by dry rationality and moral decadence. The result of this combination was the geopolitical philosophy underlying Dugin's 1997 Geopolitical Foundations, the book which—as has been noted-first drew public attention to him. The same geopolitical revision of Traditionalism forms the basic creed of the Eurasian Movement, which has been modified further to accommodate perspectives associated with the Western New Right, and especially with the French writer Alain de Benoist (b. 1943). ${ }^{75}$

One reason why Geopolitical Foundations and Dugin's Eurasianism have enjoyed such success is that the definition of the opposing Atlantic and Eurasian blocs reflects well-established pre-Soviet Russian and, especially, Soviet models. The identification of America as the chief representative of modernity, and so as Russia's chief adversary, is a comfortable continuation of Cold War realities. The Eurasian bloc is a continuation of the old Soviet Union and Warsaw Pact, changed principally by Dugin's inclusion of Iran and Turkey, a change in which Dugin follows a long-established trend, since Russian rulers from Catherine the Great to Stalin have seen these two countries as natural appendages to the Russian sphere.

Eurasianism provides, to those who want it, an ideological explanation of the continuation of a pattern of confrontation that has lost its original, Sovietera ideological justification. It is also well adapted to post-Soviet conditions because of one feature it takes directly from Guénonian Traditionalism, the belief in the existence of a single original and perennial $U r$-religion. This is an excellent basis for religious pluralism, and religious pluralism is urgently needed in post-Soviet Russia. One of the most popular forms of Russian nationalism has always been based in, or at least expressed in terms of, Orthodoxy. This, however, necessarily excludes Russia's non-Orthodox inhabitants, and thus easily becomes a force towards fragmentation-the precise opposite of what most nationalists seek. Traditionalist perennialism, however, provides the solution. On the basis of a shared perennial truth, Dugin can easily include Muslims and Jews in his Eurasian Movement (as he does), and propose an Orthodox alliance with Muslim nations, whether former Soviet republics or neighboring states such as Iran and Turkey. The Eurasian approach to Jews is complex, welcoming "traditional" Jews while rejecting "cosmopolitan" ones, concerning whom established anti-Semitic discourse may be used.

This seems to be one reason for the adherence to the Eurasian Movement of Mufti Talgat Taj al-Din, the shaykh al-Islam of European Russia and Siberia,

75 Anton Shekhovtsov, “Aleksandr Dugin's Neo-Eurasianism: The New Right à la Russe,” Religion Compass 3/4 (2009), 697-716. 
an office first established by Catherine the Great in 1789, and then reestablished in 1942. Some of Taj al-Din's views are close to perennialism, possibly for political reasons. He suggested in 1992, for example, that the Tartars' pre-Islamic worship of Tengri (Tengriianstvo) should be regarded as an early form of monotheism, and was instrumental in the 1998 construction of a mosque adorned with stained-glass windows bearing the image of the cross and of the Star of David. ${ }^{76}$ Other reasons for Taj al-Din's participation in the Eurasian movement include the characterization of Salafism (what he calls "Satanic Wahhabism") as modernist which Dugin shares with most other Traditionalists, and Dugin's anti-Americanism, which Taj al-Din shares. He announced after the American invasion of Iraq in 2003, for example, that resistance to the Americans constituted jihad and was thus a religious duty. This caused some consternation in the Kremlin, which for a while boycotted him. ${ }^{77}$

A further feature of Dugin's Eurasianism that may be a response to postSoviet conditions is its apocalypticism. All Traditionalists are apocalyptic in some sense, since the decline that they see as producing modernity is irreversible and marks the start of a new cycle. Dugin's work (if not his public media pronouncements), however, has an unusually strong emphasis on the apocalypse, from the title of his 1997 hit radio program "Finis Mundi," to remarks made in conversation. ${ }^{78}$ The reasons for this are not clear, but may well be related to Russia's traumatic history since the collapse of the Soviet Union. As Dugin wrote in Geopolitical Foundations, these events "are difficult to understand unless interpreted as a sign of the times, announcing the proximity of the climax.".79

76 Marlène Laruelle, "L’appartenance à l'Islam comme critère politique? La politisation des directions spirituelles et la constitution de partis musulmans en Russie, "In: Islam et politique en ex-URSS (Russie d'Europe et Asie centrale) eds. Marlène Laruelle, S. Peyrouse (Paris: L'Harmattan, 2005).

77 Ibid.

78 For example, in January 2006, Dugin commented on the common ground between him and American Neo-Conservatives, and I suggested that his views were hardly likely to encourage good relations with them or with America. Dugin's response was "You forget that I am an apocalyptic."

79 Dugin, Osnovy geopolitiki, 97, quoted in Marlène Laruelle, "Aleksandr Dugin: A Russian Version of the European Radical Right?” Woodrow Wilson Center Occasional Paper \#294 (2006), 6 . 


\section{Conclusion}

Dugin's public positions, then, may seem unremarkable, but are informed by political positions that are more remarkable, and which themselves derive from central intellectual positions of Western origin, modified partly in accordance with Russian and post-Soviet conditions, but still bearing the stamp of Soviet occult dissident culture. Soviet occult dissident culture produced the hothouse atmosphere of the Iuzhinskii Circle within which the young Dugin read an unusually eclectic variety of occultist works of Western origin, including Guénon and Evola. The intellectual preparation of the members of that Circle made such authors more acceptable than they would have been in the West, and the highly problematic Soviet version of modernity may have made them especially appealing.

After the collapse of the Soviet Union, with access to both a wider range of sources and a wider public, Dugin developed his Soviet-era Traditionalism into post-Guénonian Eurasianism, bringing in pre-Soviet Russian elements such as the Eurasianism of the 1920s emigration and Russian Orthodox practice. The result was then adjusted to post-Soviet conditions by the definition of Eurasian and Atlantic blocs that reproduced the battle lines of the Cold War.

Dugin is also a product of Soviet culture in one other way: the extent to which he attributes power to ideas. When I first met Dugin, he described Guénon to me as "an undiscovered Marx," ${ }^{" 0}$ borrowing (I later learned) from the French Traditionalist René Alleau. ${ }^{81}$ Soviet Marxism embodied the power of the idea, if not in quite the way that had originally been intended. Dugin's belief in the potential power of another idea, in the power of correct analysis, is not without parallel outside Russia, but is still redolent of Soviet culture.

80 Interview, Moscow, August 1999.

81 René Alleau, "De Marx á Guénon : d’une critique 'principielle' des sociétés modernes," in René Guénon (Les dossiers H, vol. 3), eds. Pierre-Marie Sigaud, Jean Tourniac (Paris: L'Age d'homme, 1984), 192-202. 


\title{
THE RODNOVERIE MOVEMENT: THE SEARCH FOR PRE-CHRISTIAN ANCESTRY AND THE OCCULT
}

\author{
MARLÈNE LARUELLE
}

As in Western Europe, over the past two decades many "new religious movements" have been developing in Russia. The alternative spirituality, interest in Eastern religions, esotericism, occultism, astrology, and research on aliens has been fashionable among Soviet urban elites since the 1970s; alternative therapies, which promote holistic and psychological medicine, have also grown. ${ }^{1}$ As in Germany, Scandinavia, England, Ireland, and France, groups inspired by Wicca, New Age, Druidism, Heathens, Tolkienism, and Satanism have appeared on the Russian religious scene. Among these the Rodnoverie, or ethnic faith, movements seek to restore the pre-Christian religion of the Slavs, and are among the most visible and numerous. They have benefited from the conjunction of spiritual quests, questions about Russian national identity after the Soviet experience, the rediscovery of traditions and folklore of the Russian peasantry, and paranormal scientists being in vogue. Like other non-conventional spiritual practices, this ethnic faith movement believes in a concealed wisdom that institutionalized religions would seek to erase. While propagating exoteric beliefs, the Rodnoverie movement attaches importance to certain esoteric practices, namely mythology, holistic body exercises, symbolism, rituals associated with seasons and deities, and harmony with nature-all elements of occult belief that allow one to glimpse into higher worlds and interact with motherEarth and her gods, but also to find ones place among ancestors and therefore in the national community.

\section{The Kaleidoscope of Rodnoverie:}

\section{A Wide Range of Beliefs and Practices}

Many movements in Russia now claim the "Mother Faith" (rodnoverie), a generic term comprising a large variety of groups, objectives, and practices, sometimes contradictory. Rodnoverie is an internal term used by supporters to self-define. They reject the external designation of "neo-pagan" because they do not consider themselves "new" and paganism often has a negative connota-

1 Massimo Introvigne, Le New Age des origines à nos jours. Courants, mouvements, personnalités (Paris: Dervy, 2005). 
tion vis-à-vis Christianity. Rodnoverie seeks to be broader than a neo-pagan religious practice and more inclusive than just adherence to a pantheon of preChristian gods. Another commonly used internal term is Vedic Faith (vedizm, vedicheskaia vera), which refers to ancient Indo-Iranian Vedism texts (Avesta and the Rig-Veda), Ancestrism (rodianstvo), or natural faith (prirodnaia vera). Rodnoverie cannot necessarily be defined as a religion in the strict sense. Some of its followers prefer to speak of spirituality (dukhovnost'), wisdom (mudrost'), or a form of philosophy or worldview (mirovozzrenie). ${ }^{2}$ According to Kaarina Aitamurto, it is fairly safe to say that there are at least 10,000 rodnovers in Russia, even if the calculation is difficult to demonstrate and boundaries between groups are often fluid. ${ }^{3}$

The Rodnoverie phenomenon was not born from the collapse of the Soviet regime in 1991. Since the Russian interwar emigration, some searches for national identity have become radical and certain exiles came to deny the conventional place of Orthodoxy as the key element of "Russian soul". In the émigré journal Zhar-Ptitsa, published in the 1950s in San Francisco, several authors were interested in a so-called manuscript dating from the first centuries before the Common Era. The Book of Veles (Vlesova kniga) describes the bravery of the ancient Slavs and their authentic faith. ${ }^{4}$ The probable forger of this manuscript, Iurii Miroliubov (1892-1970) was the first to use the term "Vedism" to designate this neo-paganism..$^{5}$ As early as the 1960s, the Book of Veles was established as an authentic manuscript by Russian émigré nationalists as well as by some exiled Ukrainians, particularly in the circles close to another great propagandist of the book, Sergei Lesnoi (i.e. Sergei Paramonov, 1898-1968). Despite the absence of any first edition assessed by experts, these groups present the book not only as an indisputable historical source concerning Slavic antiquity, but also as a set of prayers and hymns to ancient gods that can be "put into practice."

2 Oleg Kavykin, "Rodnovery". Samoidentifikatsiia neo-iazychnikov v sovremennoi Rossii (Moscow: Institut Afriki RAN, 2007).

3 Kaarina Aitamurto, "Russian Rodnoverie. Negotiating Individual Traditionalism," Globalization, Immigration, and Change in Religious Movements. The 2007 International Conference, June 7-9, 2007, Bordeaux, France, www.cesnur.org/2007/bord_aitamurto.htm\#_ftn1.

4 This book was supposedly discovered during the Russian Civil War by White Army officer, F. A. Izenbek, but the original wooden boards on which the text was written would have been lost during the Second World War. However, one of Izenbek's friends, Iuri Miroliubov, would have had the time to study and copy them.

5 Maya Kaganskaya, "The Book of Vlas: the saga of forgery," Jews and Jewish topics in Soviet and East European publications, vol. 4, Winter 1986-1987, 3-18. 
It also seems that in the Soviet Union itself, the rebirth of Russian nationalism, supported by Stalin since the second half of the 1930s, may have made possible the consolidation of Vedic discourses. Stalin took a keen interest in the research carried out on Slavic antiquity and hoped he could demonstrate the ancient communism of the Russian people. Some researchers, among them the academician Boris Rybakov (1908-2001), former head of the Institute of Archaeology, then provided the first scientific arguments to support the neopagan doctrine. In the 1960s, the renewal of atheist activism organized by Nikita Khrushchev also presupposed the re-rendering of certain pre-Christian or pre-Islamic traditions. ${ }^{6}$ From this time through the 1980s, Russian intellectuals were disturbed by what they viewed as an eradication of traditional Russian culture and the loss of a distinctive Russian identity. According to Viktor Shnirel'man, the first manifesto of Russian neo-paganism was the letter "Critical remarks by a Russian man on the patriotic newspaper Veche" (Kriticheskie zametki russkogo cheloveka o patrioticheskom zhurnale Veche), published anonymously in 1973 by Valerii Emelianov (1929-1999), an expert on the Middle East who was then close to Khrushchev. ${ }^{7}$ In this text, Emelianov clearly expressed the idea that Christianity is simply an expression of Jewish domination and serves the interests of Zionism, much disparaged in the Soviet propaganda of the time.

The Pamiat' nationalist movement, which emerged at the very beginning of the 1980s, constituted one of the meeting places of personalities attracted to this "Vedic component" of Russian identity. In 1983, Pamiat' organized a session devoted to the Book of Veles headed by Valerii Skurlatov (b. 1938), who assumed the arguments put forward by the Russian émigré groups. Until 1985, the association was openly neo-pagan, but after that date became more traditionally Orthodox and close to monarchist circles. Both religious trends coexisted for some time within Pamiat', but the neo-pagans eventually left the movement. Vedic sensibility was also expressed much more officially in certain Soviet academic circles. In 1988, Apollon Kuzmin (1928-2004), the leader of neo-Slavophile historiography, claimed in The Fall of Perun (Padenie Peruna) that the true Russian national faith was paganism, as Orthodoxy had led to subjugation by the Mongols. Discourses on the rehabilitation of paganism could also be found in the last books of Boris Rybakov-in particular The $\mathrm{Pa}$ ganism of the Ancient Slavs (Iazychestvo drevnikh slavian), published in 1981,

\footnotetext{
6 Viktor Shnirel'man, Intellektual'nye labirinty: ocherki ideologii v sovremennoi Rossii (Moscow: Academia, 2004), 229.

7 Ibid., 231.
} 
and The Paganism of Ancient Russia (Iazychestvo drevnei Rusi), from 1988and in the literary writings of several important figures of village prose (derevenshchiki), such as the writer Petr Proskurin (1928-2001) and the poet Iurii Kuznetsov (1941-2003). ${ }^{8}$

Since the 1990s the Rodnoverie movement has expanded and diversified. It has reached wide audiences in large part due to the publications of Aleksandr Asov (b. 1964), whose books on the philosophy of pre-Christian Slavs have sold millions of copies. The Rodnoverie movement is in principle largely decentralized, with hundreds of groups coexisting without submission to any central structure that would include the entire Russian territory. Many groups exist only in a city or region and have horizontal, rather than hierarchical, relations to other groups with similar affinities. The societal and political views espoused by adherents are extremely broad, ranging from extreme pacifism to militarism, from complete de-politicization or semi-anarchism to far right groups defining themselves as National-Socialists. Very few groups are registered as religious movements and most exist as cultural associations or without legal status. The most politicized Rodnoverie are the most popular because they demonstrate their beliefs in the media and on the internet, are known for their anti-Christian propaganda, and sometimes participate in violent acts, up to crime in the name of their racist or anti-Christian beliefs, even if it is always difficult in the case of murders to measure the actual weight of religious beliefs in the act.

The most well known of the politicized Rodnoverie movements are Viktor Bezverkhii's (1930-2000) Union of the Veneds ${ }^{9}$ (the former Society of the Magi), based in Leningrad; the Church of Nav, founded by Il'ia Lazarenko and openly referring to German Ariosophy and the Ku Klux Klan; the small group $K$ bogoderzhaviiu, which tried to campaign during elections and lobby the Duma; Aleksandr Sevast'ianov's (b. 1954) National Party of the Russian Great Power, which has also some connections with politicians close to the mayor of Moscow Iurii Luzhkov; and the Party of Aryan Socialism run by Vladimir Danilov. For all of these groups, religious arguments are only one element of national identity, among others. ${ }^{10}$ Their ideology is radical in its nationalism,

8 Yitzhak Brudny, Reinventing Russia. Russian nationalism and the Soviet State, 1953-1991 (Cambridge-London: Harvard University Press, 2000), 94-131.

9 "Vened" was the name given by Germans to an ancient Slavic people that lived in Central Europe, also called Wends. Subsequently, the term was applied to all Slavs.

10 Marlène Laruelle, "Alternative Identity, Alternative Religion? Neo-Paganism and the Aryan Myth in contemporary Russia," Nations and Nationalism 14 (2008), no. 2, 283-301. 
racism, and anti-Semitism. Some members are violently anti-Soviet, but more defend socialist theories and others are even nostalgic for Stalinism, seeing it as a successful political expression of paganism. Many skinhead groups also defend Vedic ideas, which are often spread by heavy metal groups. Nevertheless, one cannot consider them religious followers in the sense that ideological references play an instrumental role in the youth counter culture, which defines itself above all through a protest-driven way of life, the rejection of adult life, and a sense of community. ${ }^{11}$

Other groups are more centered on religious revival, even if they also call for Russians to reclaim and defend their ethnic identity. Aleksandr Belov's martial arts club (the Association of Slavonic-Goritsa Wrestling) had an impressive 40,000 members in its heyday in the mid-1990s, even though not all of them were followers of Slavic Vedism. Among the most numerous Rodnoverie groups, each having hundreds of members, are the very nationalistic Union of Slavic Communities of Native Faith led by Dobroslav; ${ }^{12}$ the Circle of Pagan Tradition, which unites several dozens of groups from various Russian towns; the Ancient Russian Ingliistic Church of Orthodox Old Believers-Ingliists (ARICOOBI), often considered one of the most sectarian and authoritarian Rodnoverie movements; ${ }^{13}$ Viatichi's Koliada, one of the oldest traditionalist groups and a regular participant in the World Congress of Ethnic Religions; and the Circle of Veles led by a charismatic leader, Veleslav, who is said to refuse nationalist rhetoric and be open on principle to tolerance. ${ }^{14}$ They form communities for whom religious practice requires a ritual of deChristianization, the adoption of a pagan name, and wearing traditional Russian clothes. These groups are among the main producers of Rodnoverie knowledge, posing works and articles on their websites that analyze their philosophy and links to original Indo-European religions, give explanations of the rituals of their organizations and the holidays of the Vedic calendar, and organize commemorative gatherings and seasonal festivals in the cities where they are based. Even though priority seems to be given to faith over national

11 Hilary Pilkington, Anton Popov, "Understanding Neo-paganism in Russia: Religion? Ideology? Philosophy? Fantasy?,” In: C. Williams, E. Ramanauskaite, G. McKay, M.Goddard and N. Foxlee, eds., Subcultures and New Religious Movements in Russia and East-Central Europe (Frankfurt a.M.: Peter Lang, 2009), 253-304.

12 www.rodnovery.ru

13 V. B. Iashin, “Tserkov' pravoslavnykh staroverov-inglingov kak primer neoiazycheskogo kul'ta," In: Viktor Shnirel'man, Neoiazychestvo v prostorakh Evrazii (Moscow: BibleiskoBogoslovskii institut, 2001), 56-67.

14 http://www.velesovkrug.ru/ 
identity, the two are seen as being inextricably linked. An adherent of Rodnoverie must be a good Russian who respects national traditions, is conscious of his ethnic traditions and the history of his ancestors.

But there also exist groups for which political affiliation and identity matters little or not at all. They conceive of Rodnoverie as one movement among others in the mix of new religions: spiritualism, theosophy, anthroposophy, cosmism, Satanism, neo-Eastern religions, New Age groups, and extraterrestrial beliefs. ${ }^{15}$ These groups recruit among young people, especially in student circles. They seek to reclaim the ancient rituals described in historical and ethnological sources on the Russian countryside. They are based on a general need for the public to rediscover the national past and culturally rehabilitate regional folklore. Thus public interest in the history of Slavic antiquity, folk oral traditions, regional cultural specificities, and the rediscovery of ancient peasant rites and superstitions related to the worship of Mother Earth (witchcraft, folk beliefs, and the practices of Old Believers), including "double faith" (dvoeverie, a mixture of Christian and pagan practices documented in ethnological sources) promote the union of folk revival and nationalist theories. Solstice rituals in particular attract thousands of people for whom the reference to an ancient and natural religion is devoid of political links. ${ }^{16}$ Some small groups seek to live in a financially independent manner by producing traditional handicrafts or rehabilitating ancient pharmacy, which they sell at markets or folk fairs. It should be mentioned that this Rodnoverie style is also a commercial product. All major groups have a shop where they sell "typically Slavic" jewelry and ornaments, musical instruments, posters and calendars illustrated with reproductions of pagan imagery, and designs inspired by science fiction and Tolkien, and regularly participate in markets and craft fairs. ${ }^{17}$

Russian Rodnoverie has started to develop international contacts with other European movements with similar religious precepts. Their pan-Slavic sensibilities invite them to collaborate mainly with Ukrainian, Belorussian, and Serbian movements. The same forged manuscripts often inspire them, in particular of the Book of Veles, and they make similar references to Slavic identity. ${ }^{18}$ For instance, the All-Slavic Council of Native Believers gathers Rod-

15 Holly DeNio Stephens, “The Occult in Russia today," In: Bernice G. Rosenthal, ed., The Occult in Russian and Soviet Culture (Ithaca: Cornell University Press, 1997), 357-376.

16 Viktor Shnirel'man, "Nazad k iazychestvu? Triumfal'noe shestvie neoiazychestva po prostoram Evrazii," In: idem, Neoiazychestvo, 28-30.

17 "Runnyi posokh," http://runposoh.clan.su

18 A. V. Gurko, "Neoiazychestvo v Belarusi: predposylki i usloviia vozniknoveniia, organizatsionnye formy, perspektivy,” In: Shnirel'man, Neoiazychestvo, 68-79. 
noverie followers from the countries of Central and Eastern Europe. Some have developed relations with German and Scandinavian groups. The Baltic countries are also known for their neo-pagan movements, which played an important role in the struggle for independence of these republics in 1990 and 1991. In Latvia, the Dievturiba association, founded in 1990, includes about one thousand people. It draws its inspiration from the association of the same name, which was founded in the 1920s with the objective of bringing back the ancient Latvian religion, but the Soviet authorities repressed the movement when they occupied the republic. ${ }^{19}$ In Lithuania, the Romuva movement emerged as a cultural association as early as 1967 at the occasion of the summer solstice. Headed by Jonas Trinkunas but having only a few hundred members, the movement advocated the rediscovery of national faith by the rehabilitation of popular songs, practices, and rituals. ${ }^{20}$ As in the case of Russian Rodnoverie, the Baltic movements are split between far right activists and partisans of a national rebirth that would be expressed in religious and cultural terms.

\section{Rodnoverie Worldview and Faith}

Rodnoverie is not lacking in tensions in its conception of faith. It is an "open source religion" 21 and thus follows in part New Age movements according to which the world experiences different levels of reality. It also calls for adherence to tradition, composed of the legacy of Slavic ancestors for whom the strictest possible respect is owed. However, some groups admit that what they know about the authentic Slavic religion is very fragmented and therefore its reconstruction is personal. According to the majority of Rodnoverie followers, neither a unique dogma nor a supreme authority exists. They insist on the direct link, with no interference, between man and the divine. Rodnoverie is a faith without a prophet, a sacred text (even if some treat the Book of Veles as a text of prayers), any institutionalized place of worship (with the exception of some minority groups who support the construction of temples, worship is done in nature), clergy (priests exist, but they do not have the authority to

19 S. I. Ryzhakova, “Dievturiba. Religiozno-natsional'naia ideia i ee realizatsiia v Latvii,” In: Ibid., 80-113.

20 Donatas Glodenis, "La situation religieuse en Lituanie - Entretien avec Donatas Glodenis," Religioscope, January 29, 2003, http://religioscope.info/article_65.shtml.

21 An "open source religion" emphasizes individual participation and doctrinal evolution, and calls for the personal creation of religious belief systems. 
intervene with god, as in Orthodoxy or Catholicism), without dogma and interdicts, or mandatory rites and prayers. ${ }^{22}$

The search for meaning can only be an individual one and each human is entitled to establish his or her own pantheon of beliefs in diverse combinations. Individual interpretations and sensations dominate over any institutionalized ideas. This assertion often comes with a discourse on the democratic nature of the faith. Rodnoverie is presented as a religion devoid of any social exploitation, power relations, or financial and institutional reality. ${ }^{23}$ Human freedom is thus expressed through the equality of men in their access to the divine. Social justice is therefore an important element of reference. Christianity is denounced as a hierarchical, centralized power that defended the rich throughout its history, accepted the enslavement of man by man, and legitimized a slave mentality. Although certain Rodnoverie groups founded by charismatic leaders are prone to relatively authoritarian visions of power and cultivate the image of a head guru, the majority call for the rejection of power relations, and the autonomy and responsibility of the individual, actively campaigning against drinking, smoking, and drugs. ${ }^{24}$

Followers do not perceive eclecticism and syncretism of religious inspiration as contradictory. It is therefore difficult to determine whether neo-pagan followers think of their faith in monotheist, polytheist, or pantheist terms. Some of them assert the existence of a unique superior principle (Rod or Svarog), while others advocate the existence of multiple gods with dissociated functions. Some insist on a dual conception, with Belbog representing the good principle and Chernobog embodying the evil; others prefer to believe in a trinity consisting of the Creator, the Destroyer, and the Harmonizer. The general precepts are based on the idea of a trinity with Iav (the visible world), Nav (the world of beyond), and Prav (the world of laws), which represent different levels of reality. Even the Russian pantheon mentioned by all Rodnoverie movements is not unified. Several gods from ancient Slavic mythology like Svarog (god of the sun), Veles (god of the earth), Perun (god of thunder), Dazhbog, and Khors are in mutual competition, with each movement giving preference to one or

22 Kaarina Aitamurto, "Russian Paganism and the Issue of Nationalism: A Case Study of the Circle of Pagan Tradition," Pomegranate: The International Journal of Pagan Studies 8 (2006), 2, 184-210.

23 Mariya Lesiv, "Glory to Dazhboh (Sun-god) or to All Native Gods?: Monotheism and Polytheism in Contemporary Ukrainian Paganism," Pomegranate 11 (2009), 2, 147-164.

24 See for example the strict rules Krivichi put forward on the use of alcohol and cigarettes, and respect for nature, http://www.krivichi.3dn.ru/index/0-2 
the other. Others refer to ancient Germanic gods such as Thor and Odin, inspired by Western traditions, especially Scandinavian ones. The majority has several dozen gods; gods of fire, fertility, fisheries, the Earth, the moon, animals, and the dead complement the gods of the natural elements.

In addition, all movements invite their members to add their own ancestors to the pantheon, since the worship of one's lineage (rod) is considered a basic principle. ${ }^{25}$ Everyone can create his own religious combinations. "Each of us can choose objects to worship," announced the group Slavia; however, while respecting a minimal framework in which the idea of national tradition dominates. ${ }^{26}$ Each movement, for example, produces its own calendar and organizes festivities around the passage of seasons, the memory of the dead, and the natural elements. ${ }^{27}$ They help make popular ancient Russian peasant festivals (Ivan Kupala, Koliada, and Maslenitsa) and celebrations of the solstice, which succeeded in bringing together wide audiences more interested in the festive and folkloric, rather than religious, aspects of the event. ${ }^{28}$ Some Rodnoverie movements draw their inspiration in part from oriental religions, following the popular propensity toward Eastern spirituality within the Russian intelligentsia during the last decades of Soviet Union. They mention Buddha, Zarathustra, and Manu, as well as many Hindu divinities and the holy text of the Krishnas, the Bhagavad Gita. Within these trends, there has been widespread reading of Elena Blavatsky (1831-1891), Sri Aurobindo (1872-1950), and Carlos Castaneda (1931-1998), the last two translated into Russian in the 1990s. The same applies to the work of George Gurdjieff (1873-1949), Petr Uspenskii (18781947), Nicholas Roerich (Nikolai Rerikh, 1874-1947), and theoreticians of Cosmism. The practice of energetic healing, Asian medicine, martial arts, and diverse versions of yoga are integral parts of this Oriental-inspired Rodnoverie. Some of them are focused on the ideas of bio energy, karma, reincarnation, telepathy, and stories about UFOs and the mysteries of the cosmos. The most politicized movements prefer to refer to the German and Austrian ariosophists of the early twentieth century, and Traditionalist thinkers like Julius Evola or René Guénon.

Rodnoverie presents itself as post-modern and attempting to rehabilitate the spiritual to the detriment of the material. Institutionalized religions grant too much importance to their ritual and theological aspects, while Rodnoverie

\footnotetext{
25 See for example the importance the group Rodstvo accords to genealogy, http://rodstvo.ru/

26 "Nasha vera. Osnovanie," http://www.slavya.ru/vera.htm

27 "Prazdniki," http://www.rodnovery.ru/prazdniki.html

28 "Nasha vera. Osnovanie," http://slavya.ru/vera.htm
} 
would put morality, ethics, and spirituality at the center of its message. Eschatological patterns and problematic relations to modernity are recurrent in Rodnoverie. Its followers often think that mankind is on the road to ruin by denying religious values in favor of material well-being. The development of technology and knowledge of natural science has given men the illusory idea of control over nature. The modern world has thus embarked on a dead-end path that would lead the whole of mankind to its downfall, while the Soviet experience confirmed the impossibility of man dominating nature. This denunciation of industrial modernity represents a recurring element of Rodnoverie discourse in which what is at stake is not material comfort, but the meaning given to life. According to them, the origin of the current technological madness could be found in the great historical religions. As a result, they condemn Christianity and other Abrahamic religions as anthropocentric. By asserting that man was created in the likeness of God, and by suggesting that the latter could have been incarnated as a man (Christianity) or could have transmitted his message through a man (Islam), these religions distort the place of mankind within nature. Only nature could be considered representative of the divine on earth, with man occupying a more modest position in this hierarchy.

Presenting itself as a natural religion, Rodnoverie insists on the need to "return" to nature and defend ecological claims. The group Slavia thus regularly posts on its website virulent critiques of the 2014 Winter Olympics in Sochi, which will have a significant impact on deforestation and has been denounced by groups like Greenpeace and the World Wildlife Fund..$^{29}$ Rodnoverie imagery often evokes the countryside as "typically Russian" - birch and fir forests, lakes, and wooden villages in the snow, relying on old references worked by nineteenth century Romantic painting and national folklore artists like Ivan Bilibin (1876-1942). Since the nineteenth century, the idea that the "Russian soul" is fundamentally marked by the landscape of the country has constituted a classic element in discourse on the "Russian idea." This discourse belongs to the most persistent clichés, according to which Russian identity would not fit the Western schemes: the vastness of the territory, and the flat, dull, and dreary nature of the great Russian plain would invite one to withdraw to family life, religious meditation, and contemplation, but not to political or social commitment. Moreover, as early as the 1960s, environmentalist sensibilities have constituted one of the main sources of demands coming from Russian national circles, which were opposed to the Soviet willingness to submit nature to the

29 “Olimpiada v Sochi. Ubiistvo prirody," http://slavya.ru/rings/viewtopic.php?t=1924 
industrial needs of the regime. Some Rodnoverie groups take for themselves the ancient Russian traditions of the cult of Mother Earth by claiming that the Slavs, children of the forest, will be the first to rediscover harmony with nature. $^{30}$

\section{Occult Concepts and Practices in Rodnoverie}

In this conceptual framework, occult theories and practices constitute an important part of Rodnoverie; however, it cannot be completely considered an occult movement. Some of its practices like readings and prayers are rather exoteric and public, fully disclosed to everyone. The initiatory character may be significant, but it differs between groups and the leadership's viewpoint on this exoteric versus esoteric question. Some seek to combine the "natural Slavic faith" with a belief in alchemy, arcane science, and forms of white or black magic, while others insist on the exoteric, popular, and folk character of their faith. Furthermore, as Rodnoverie conceptions vary among individuals, the level of commitment of members plays a key role in links to the occult. Thus, the least invested members and the most open communities tend to spread exoteric knowledge, which is accessible to many people and insist on folklore (for example, organizing large celebrations for the solstice). But more closed groups, for which the commitment required by individuals is more stringent, advocate for esoteric practices such as complex initiation rituals, including references to a kind of Kabbalah, prayers and belief in magic. Rodnoverie being more a worldview than a practice, the occult appears primarily at the level of discourse in three main areas: the feeling of having hidden or secret knowledge, accessible only to a limited group of insiders, the belief in superior knowledge that gives access to the supernatural world, and the idea of having, through this connection with a higher world, a power over human beings, world events, and even mind control.

All Rodnoverie groups are based on the idea that religion is a hidden knowledge that only those who are "awake" to the true faith can understand. This vision of self is common in all new religious movements, which paint in heroic terms their small size compared to major institutionalized churches. This is reinforced by the idea that for two millennia, Christianity has deliberately destroyed the pagan memory, denied its presence in the popular consciousness, and done everything possible to prevent a new awareness of the

30 Adrian Ivakhiv, "Nature and Ethnicity in East European Paganism: An Environmental Ethic of the Religious Right?," The Pomegranate 7 (2005), 2, 194-225 
original faith of the Slavs. ${ }^{31}$ This secret understanding is accessible through myths, tales, and legends, which are thought of as relics transformed over centuries into ancient knowledge that one must now decipher and reinterpret, since the original meaning is no longer apparent. ${ }^{32}$ As stated by Aleksandr Belov: "Myths are the subconscious of humanity. There was a time when they were reality. Time has transformed them into tales, the original links to the heroes having been lost." 33 Among the most common and successful of Rodnoverie myths, the myth of Belovod'e, or the kingdom of white water, is an update of an eighteenth century belief from the culture of Old Believers. A Russian version of Atlantis, Belovod'e expresses the belief in an ancient esoteric world that disappeared from the face of the Earth, but not from the memory of mankind. ${ }^{34}$ However, unlike some readings of Atlantis, Belovod'e did not disappear by its own fault (the claim of human civilization to control nature), but due to eschatological natural events.

Through its militant atheism, as well as the conspiracy theories to which it has indirectly given birth, the Soviet period accentuated this sense of secret knowledge waiting to be discovered. Although some Rodnoverie groups insist on their tolerance for all beliefs as a basic principle of the Native faith, most publications have a tendency to explain the world in very Manichean terms, with minority forces of good struggling against the majority forces of evil. They apply methods of alternative history, which refers to a broad editorial genre that encompasses many fields, including the paranormal, especially the mysteries of ancient civilizations and the study of parallel worlds, the analysis of history "that did not happen", and conspiracy theories against Russia. While alternate history in Western Europe is often devoid of nationalist pretexts, this is not the case in Russia. Allusions to mysterious or parallel worlds that could have existed on Russian territory are often influenced by Aryan assumptions or claims on the superiority of Russian civilization, which supposedly inspired all great ancient cultures. The majority of books exploring hypothetical political regime change are based on the idea of a Jewish or Masonic conspiracy against Russia, whether explicitly expressed or implied. Jewish and Christian conspir-

31 See Aleksandr Asov, Slavianskie vedy (Moscow: Fair-Press, 2003), Sviato-russkie vedy. Kniga Veleseva (Moscow: Fair-Press, 2007), in which he presents himself only as a translator and commentator of ancient texts, and his personal website, http://acov.m6.net/ where he renders several texts and explains his methods for reconstructing ancient knowledge.

33 Aleksandr Belov, Ariiskie mify rusov (Moscow: Amrita-Rus', 2010), back cover.

"Belovod'e," http://www.svet.sva.name/belovodie.html 
acy theories against the original faith are particularly numerous and spread for example in Rodnoverie, the journal published by the Union of Slavic Communities. ${ }^{35}$ Some minority movements inspired by apocalyptic expectations tend to promise their members survival after the events threatening the future of the Earth. ${ }^{36}$

The precepts of Rodnoverie are secrets not only because they are held by a chosen few, but also because they provide access to higher knowledge. Heavily influenced by Eastern religions, Buddhism, Shintoism, and Hinduism, Rodnoverie revalues esotericism as a higher knowledge, even though it is conventionally held in lower regard in Christianity. This knowledge is generally accessible in two non-contradictory ways. One stresses the need for a holistic world view that connects body, mind, and soul through physical practices inspired by yoga or the martial arts. The Association of Slavonic-Goritsa Wrestling was, in the 1990s, the best known of these groups. This method is not limited to Rodnoverie movements, but is common to all "patriotic" groups. Thus many military-patriotic clubs for children and adolescents now commonly offer a Russian version of martial arts called rukopashnyi boi and updated versions of socalled Slavic sports, which are often similar to judo or boxing. ${ }^{37}$

For practitioners of these "national" sports, physical exercise allows the human mind to become aware of its inner strength and the intrinsic link that binds one to ancestors, thereby gaining access to a higher level of consciousness. The classic martial arts are said to favor a Buddhist background, which would be dangerous for Russian identity, while the national sports accentuate a Slavic consciousness, whether Vedic or Orthodox. ${ }^{38}$ For the majority of Rodnoverie, physical training, often militarized, plays a key role. At festivals, demonstrations of men's physical strength in tournaments where teams symbolically compete are a sign of courage and the superiority of the Aryan/white race. ${ }^{39}$ It is also a metaphor for nature, such as the victory of spring over win-

35 “Teoriia zagovora," Rodnoverie 1-2, 2010, http://rodnoverie.org/002/index.html

36 "Kul'tura Russkogo Apokalipsisa," http://apocalypse-cult.org/about/

37 "Russkie voinskie iskusstva" (The Russian military sport arts), http://rusvoin.msk.ru/view page.php?page_id=21

38 Interviews conducted by the author in 2009-2010 with those responsible for "Russian sports" in patriotic clubs for teenagers.

39 Kaarina Aitamurto, "Modern Pagan Warriors. Violence and Justice in Rodnoverie," In: James R. Lewis, ed., Violence and New Religious Movements (Oxford: Oxford University Press, 2011), 231-249. 
ter. ${ }^{40}$ The idea that access to supernatural forces is a source of power over society is present in some texts, particularly among the most politicized groups that claim to exercise mind control and thus influence political decisionmaking, for example the $K$ bogoderzhaviiu. ${ }^{41}$ However, even if extrasensory phenomena are implicitly evoked, one cannot then consider Rodnoverie as a movement entirely oriented toward the paranormal.

Other groups give preference to symbolism; traditional animals such as wolves, ravens, and the phoenix are associated with specific gods, and prayers to their image allows one to intercede with the deity in question. ${ }^{42}$ Some ancient symbols, like geometric shapes or runic writings found during archaeological excavations, have also been reclaimed and endowed with new meanings. Finally, the six or eight branch swastika remains a key component of the accession to the upper world. For many Rodnoverie groups, the Orthodox cross is the Slavic version of the swastika (also called kolovrat in Russian), which can be found in Hinduism and Buddhism. Some Russian nationalists have been pushing this claim since the 1970s. Archaeological excavations suggest an association between the swastika and Svarog, the ancient Slavic god of the sun, which can justify this overlap. This interpretation is especially popular in groups for which Orthodoxy is not considered a single branch of a universal Christian religion, but the national religion of the Russian people, close to the authentic faith. ${ }^{43}$

Certain groups engage in magical thinking, in particular the assumption of a link between language and cosmos, in an unacknowledged similarity to Kabbalah. This idea partly inspired the revival of the cult of names (imiaslavie), an old Orthodox tradition present until the beginning of the twentieth century in Orthodox monasteries on Mount Athos; it claims that the repetition of the name of God allows one to come closer to him. In Russian, the terms for pagan (iazychnik) and language (iazyk) have the same roots. ${ }^{44}$ This observation rein-

40 “Obriadovye boi," http://www.svet.sva.name/boi.html

41 Evgenii Moroz, Istoriia "Mertvoi vody" - ot strashnoi skazki k bol'shoi politike. Politicheskoe neoiazychestvo $v$ postsovetskoi Rossii (Stuttgart: Ibidem, 2005).

42 Stan Stepanic, "The Symbolism of Russian Neo-Paganism," Paper presented at the Southern Conference on Slavic Studies, Charlottesville, March 26-28, 2009.

43 "Izvednik russkogo iazychestva" (The Testimony of Russian paganism), http://www.arya.ru/ kap/inf/izved/izvednik.htm; "Khram Svargi", http://slavsoyz.clan.su; Entsiklopediia svasticheskikh simvolov, vol. 2, http://www.aworld.ru/mc/335.html.

44 Similar phenomena can be found in many Romance languages. For example, in French pagan (païen) and peasant (paysan) derive from the same word. 
forces the convictions of some groups regarding the magical character of the Cyrillic alphabet, and its predecessor, the Glagolitic alphabet. ${ }^{45}$ The group Vseiasvetnaia gramota (Pan-Universal Charter) for instance thinks that the Cyrillic alphabet, in particular liturgical Old Slavonic, is endowed with a transcendent reality: certain Slavic letters could be keys to the cosmos or to extraterrestrial civilization, or endowed with supernatural powers that could be used by initiates. ${ }^{46}$ For the essayist Aleksandr Pleshanov, the Cyrillic alphabet is a way to communicate with heaven, as the letters have a hidden meaning that could predict major global disasters. ${ }^{47}$

Occult principles also mark ritual practices. The main rites of Rodnoverie feature gestures and encoded chants that allow participants to enter into communion with the divine world, especially in rites of passage such as baptism with a pre-Christian name (imianarechenie), entry into the brotherhood (bratanie) marriage, and death. These rituals all take place in forests on specific sites that the group has previously sanctified. On the occasion of rituals dedicated to the gods (the days of Veles, Perun, and Svarog), some Rodnoverie groups like the Slavic Community of Briansk carve into wooden faces representing these gods and enter into communion with them, which is substantiated by the presence of an energy beam they claim to have photographed. ${ }^{48}$ The rituals of sacrifice (prinesenie treby), mainly agricultural products and kvas, also have hidden meanings, as does the lighting of fire (vozzhiganie ognia). The search for the occult enables group members to create their own codes, preferences, and borders, thus strengthening the sense of community among insiders.

Rodnoverie ideology is strongly influenced by the ideas of European Romanticism, specifically that cultural boundaries were born from nature and geography. Ethnicity must therefore be understood as territorialized, henceforth the importance accorded to the reconstruction of a Slavic/Aryan/Russian identity. ${ }^{49}$ However, some groups seem inspired by the other native faiths,

\footnotetext{
45 "Proiskhozhdenie Kirillitsy," http://zagadki.dlia.vsekh.ru/Zagadki_istorii/Proishozhdenie_ Kirillicy.html

46 "Obshchestvennaia organizatsiia Vseiasvetnaia gramota," http://www.vgramota.ru/vctuplenie. php

47 See for instance Aleksandr Pleshanov, Russkii alfavit. Kod obshcheniia cheloveka s kosmosom (Moscow: Novyi tsentr, 2004), and Russkii alfafit kak instrument nauchnogo poznaniia (no date of publication), www.soznanie.info/ezo_pleshan.html

48 "Lik Svaroga," http://www.svet.sva.name/lik.html

49 Ivakhiv, "Nature and Ethnicity in East European Paganism," 202-203.
} 
mainly those from the Uralic and Siberian populations. As such, shamanism benefits from a privileged status since it is considered as the best preserved and the most demonstrative ritual practice and enjoys international prestige outside Russia. The occult movement Belovod'e based in Barnaul describes for instance its provisions as a mix of traditions referring to "the mysterious studies of the people of Siberia, the Altai, and Central Asia, the hidden esoteric side of Russian pre-Christian beliefs and Shamanism. It teaches ancient magic, the art of healing, and the understanding of trees, animals, and Shamanism." ${ }^{50}$ The Circle of Veles also tries to develop a kind of cult around white stones found in nature, probably inspired by the cults of anthropomorphic stones of TurkicMongolian peoples. ${ }^{51}$

This animism insists on the sanctity of Earth and nature, and on the continuum between man and nature, but also has the territorialization of ethnicity as one of its political foundation. The re-sacralization of earth indeed enables indigenous movements to fight on their own ground, in Russia and elsewhere, asking for their rights as original inhabitants. Thus, the pioneer peoples who arrived late on already inhabited lands have a need to appropriate the cults of the earth of the peoples they dominated. The movements that are the most interested in this type of borrowing have tried to take part in the World Congress of Ethnic Religions (formerly the World Pagan Congress). One of the purposes of this association is precisely to gather in one association the contemporary movements coming from the United States and Europe, which are reconstructions, with the ancient religions of the "original peoples" such as Native Americans, African religions and Hinduism. As in the United States, some Russian ethnic faith movements try to draw on the religious arsenal of the rituals of the native peoples and old cosmogonies linked to the cult of the Mother Earth.

However, in contrast with Western New Age movements, in which female participation is dominant, Rodnoverie in Russia is not marked by feminine symbols. Despite the cult of "Mother Earth" and of fertility rituals, the Russian movements are mostly made up of men. Virility and masculine symbols are particularly visible, and some currents exalt warrior values. In addition, the narrative of Rodnoverie is very conservative in terms of its mores: its calls for heterosexuality, fidelity, and procreation. The sexual liberation dimension of the Western New Age is totally absent from it, and even disparaged.

50 See the website Belovod'e, http://www.vav.ru/belovod/.

51 "Belyi kamen," http://bely-kamen.ru.mastertest.ru/ 


\section{Conclusions}

Rodnoverie is a contradictory, complex, and multifaceted phenomenon, but these adjectives should not be viewed as negative connotations. They are a sign of the vitality of the movement and its cultural resonnance in contemporary Russian society. Rodnoverie presents itself as eminently postmodern and in the forefront of individualism and environmentalism. But at the same time, its followers demand a "return" to tradition, which has been marginalized by Russian-Soviet modernity, and they display their quest for cultural and religious "authenticity," which could be rediscovered by purely and simply erasing the last millennium. Rodnoverie is thus simultaneously the willingness to "go back" and a kind of religious millenarianism turned toward the future. This paradoxical conjunction also joins the process of ethnicization of the divine, with ambiguous political consequences. Indeed seeking the rediscovery of a lost harmony between man and nature, or within a community, can easily drift towards xenophobic theories if the conception of this harmony is built on the exclusion of certain individuals or groups.

The underlying tensions are therefore intrinsic to Rodnoverie. It both celebrates natural multiplicity, because each nation is invited to cultivate its natural faith or ancestry, but also holds Slavic/Aryan characteristics in the highest regard; Rodnoverie condemns globalization that would erase cultural roots, but anchors itself in increasingly internationalized networks; ${ }^{52}$ it calls for the respect of nature, harmony between man and Earth, and a healthier life, as it flirts with occult practices of accession to superior and supernatural knowledge. The legacy of Soviet atheism can probably partly explain the Rodnoverie. Some of its arguments against historical religions are borrowed from Soviet anti-religious propaganda, for example that Christianity and Islam justified the exploitation of the lower classes and wars between nations. A portion of Russian society is interested in the revival of faith that emerged since perestroika. But traditional Orthodoxy, which is very institutionalized, moralistic, and somewhat out of tune with the modern world, is not appealing because it expects its faithful to comply with normative beliefs without room for interpretation.

On the contrary, Rodnoverie permits affirmations of faith without any regular ritual observance, or any theological background. It is limited to praise of

52 Anastasia Koskello, "Sovremennye iazycheskie religii Evrazii: Krainosti globalizma i antiglobalizma," In: Aleksei Malashenko, Sergei Filatov, eds., Religiia i globalizatsiia na prostorakh Evrazii (Moscow: Carnegie Tsentr, 2009), http://www.portal-credo.ru/site/?act=lib\&id=2448. 
Mother Earth, and leaves large areas of autonomy to the individual. This likely explains its success among educated young people and the cultivated middle classes, who find an answer to their spiritual needs, but to also their environmental concerns, individualism, and willingness to rebuild social networks based on a sense of community and brotherhood. The occult then plays a key role in rebuilding a relationship with lost traditions: the reconstitution of mythological knowledge, holistic mind and body exercises in order to access higher levels of consciousness, visual symbolism associated with ancestors, and prayers and rituals performed in nature in order to speak to the gods. The reference to anti-rational sources within occult traditions, already present in Soviet civilization but now in new forms, is very similar to ethnic revivals of faith in Western Europe. Rodnoverie therefore testifies to the vibrancy of esoteric quests in modern societies and undermines the idea that modernity signals the end of belief; the questioning by individuals of the hidden interactions between man, the cosmos, and a higher power via all kinds of initiatory practices is not about to disappear. 


\title{
THROUGH AN OCCULT PRISM: THE BOLSHEVIK REVOLUTION IN THREE POST-SOVIET NOVELS
}

\author{
MARINA APTEKMAN
}

The revival of occult motifs in contemporary Russian literature of recent years has been highlighted time and again by both Russian and Western critics, particularly Eliot Borenstein, Valentina Brougher, Birgit Menzel and Holly DeNio Stephens. ${ }^{1}$ Scholars differentiate among occult, esoteric, and mystical, but in the novels to be discussed in this chapter, these terms are used interchangeably, as in most post-Soviet literature addressed to a non-specialized readership.

Contemporary Russian authors turn to occultism for various reasons. For some it is simply a literary device which allows them to give the story a certain vivid, mysterious quality; and, in some cases, to provide a logical explanation for discordant elements in the storyline (as for example in Tat'iana Ustinova's novel A Shadow for Two (Odna ten' na dvoikh). For those postmodernist authors, occultism is a sort of aesthetic conundrum, an intellectual game with the reader (Victor Pelevin's novels Buddha's Little Finger (Chapaev i pustota) and The Sacred Book of the Werewolf (Sviaschennaia kniga oborotnia) are examples of this approach). Nationalist, patriotic authors such as Sergei Alekseev often give a political interpretation to occult motifs. And for just a small percentage of contemporary authors-compared to early $20^{\text {th }}$ century Russian literaturethe occult theme is directly related to the author's world-view, a desire to know the unknown and to give expression to his or her own mystical quest in their works.

According to a common belief, ${ }^{2}$ the current popularity of non-rational and mystical trends in Russian culture is a direct reaction to the decades-long ban on religious and mystical practice in the Soviet Union and particularly reflects a radical break with Soviet society's supposedly rational past. However, this analysis does not explain why, in that case, one of the most popular genres of post-Soviet literature is "counter-history": historical narrative constructed on

The author would like to thank Mark Lipovetskii and Nancy Pollak for their help and advice in the process of writing this chapter.

1 See, for example, Valentina Brougher, "The Occult in Russian Literature of the 1990s," Russian Review 56 (1977), 111-124; Birgit Menzel, “The Occult Revival in Russian Today and Its Impact on Literature," Harriman Review 16 (2007), 1, 1-14.

2 See the introduction to this book for a definition of terms. 


\section{Marina Aptekman}

the combination of historical facts and fiction, that is, "what was" and "what might have been". Important events in Soviet history are interpreted mythologically, and a complete or partial change in the course of history is an indispensable element of the plot. The use of Soviet mythology is a central theme of post-Soviet literature, which carries on an endless dialogue with the past in an ongoing search for identity, using Soviet history and Soviet literature as meta-text and meta-style.

Almost every work that comes under the heading of counter-history contains certain magical, mystical or fantastic features. These range in classification from pseudo-folktales (Pavel Pepperstein's novel The Mythogenic Love of Castes (Mifogennaia liubov' kast) is one example) to esoteric mysteries (Vladimir Sharov's novel Be Like Children (Bud'te kak deti). Even so, not all counterhistory novels can be called "occult”. For example, Holm Van Zaichik's Eurasian Mystery story series, although it makes use of the folk tale genre and is full of wondrous events, cannot be defined as an "occult novel". Neither can such (now cult) works as Vasilii Zviagintsev's novel Odysseus Leaves Ithaca (Odissei pokidaet Itaku) or Sergei Luk'ianenko's Watch series, even though magical and esoteric themes are broadly represented in these inherently fantastic novels.

Accordingly, the present article does not aim to analyze the counter-history genre per se, nor the specific use of magical or mystical themes in works of this genre; only those counter-historical works which have been defined by their authors either as "mystical/occult" or "esoteric", and only where the concept of "occultism" is a central theme of the novel. This article centers on an analysis of three novels, all of which interpret the early $20^{\text {th }}$ century (a turning point in Russian history) through an occult and esoteric lens. This choice is no accident. From the late 1980s to the present, dozens of articles (not only academic, but often pseudo-academic and highly polemical) have appeared in the Russian mass media to the effect that both the theory and practice of Soviet ideology in the 1920s - the early period of its development-actively employed the mythologems of various esoteric practices, while outwardly rejecting all mysticism. It could be argued that, in the last twenty years, the Russian mass media has developed a myth of the "occult side" of the Bolshevik Revolution: a myth arising both from the real history of the USSR and from contemporary popular culture. ${ }^{3}$ Simultaneously, the events of the Russian Revolution and Civil War

3 See Bernice G. Rosenthal, "Introduction," In: eadem, ed., The Occult in Russian and Soviet Culture (Ithaca, London: Cornell University Press, 1997), 26. For example, see James von Geldern, "Nietzschean Leaders and Followers in Soviet Mass Theater: 1917-27", In: Bernice G. Rosenthal, ed., Nietzsche and Soviet Culture (Cambridge: Cambridge University Press, 1994), 
are to some extent the "sore spot" of Russia today, an indicator of the social discomfort and socio-cultural malaises of modern Russian society. Soviet history was made in the 1920s; correspondingly, the chance to "replay" that exact period allows for a replaying of the entire corpus of Bolshevik historiography.

The choice of works to be discussed below is also influenced by the fact that, on one hand, the occult interpretation of historical events-primarily the Civil War and Lenin's death-is identical in every novel. Moreover, this interpretation is characteristic and highly representative of the majority of contemporary novels dealing with the subject of "occultism and Revolution". At the heart of each novel analyzed here is the idea of immortality and eternal life, refracted through the mythology of the Lenin cult and the idea of the "new man": an individual created by the Revolution who possesses radically new physical and psychological abilities. The authors of these novels interpret the Revolution not as a political act but as an occult one, originating in sects and secret societies and completed with the aid of magical forces. On the other hand, each novel is an example of a given sub-genre that is representative of the broad mass of contemporary Russian literature. Il'ia Masodov's novel The Devils (Cherti) is an example of the postmodern novel, largely aimed at that section of the readership that was the target audience for Sorokin and Pelevin in the 1990s. Vladimir Sharov's Be Like Children, short-listed for the prestigious Russian Booker-the highest literary prize in Russia-was called an "esoteric mystery" by its author. Finally, Polina Dashkova's The Source of Happiness (Istochnik schast'ia) trilogy is presented as an esoteric crime novel, aimed at fans of popular literature. This selection represents, at least in degree, the typology of "counter-history" texts and explains the role that occult symbols and themes play in these works. Finally, another common factor in these novels is that the language and style are not original, but consciously and deliberately modelled on the style of the Silver Age and 1920s modernist writers: Fedor Sologub, Mikhail Bulgakov, Andrei Platonov and to a lesser extent Isaak Babel' and Evgenii Zamiatin. ${ }^{4}$

127-148; Jay Bergman, “The Image of Jesus in Revolutionary Movement," International Review of Social History 35 (1990), vol. 2, 241.

4 For example, take the opening of The Devils: "In the twilight, two Red armored trains approached the town and fired resounding shots from their cannons into the silence that would otherwise have descended for the first time after the long cannonade of the spring battles. Behind the fence of the city park, a vertical blizzard of blooming lilacs wilted in fear. The trains had stopped coming two weeks ago... and the day before yesterday, the troops began to retreat, although until the very last nobody believed that they would go. But they went, noiselessly, like 
Lev Trotskii defined revolution as the creative unity of conscious and unconscious, when the masses break down the doors of societal routine with a spontaneous thrust and give victorious expression to the most profound needs of historical development. This is precisely how Il'ia Masodov defines the Revolution: as the mass unconscious breaking through into the consciously established world order. ${ }^{5}$ At the heart of the novel is the story of three children-Klava, Varvara and Pet'ka-and their half-real, half-metaphysical journey to Moscow and to Lenin. All three children have lost their parents in the hell of the Civil War. All three have undergone physical and mental torture, which has awakened the slumbering magical powers in their souls and finally transformed them into shades, strange half-alive half-dead creatures. ${ }^{6}$ Thus, the Revolution and the Civil War are an instrument of metaphysical liberation for the children, but Bolshevism-releasing all the monsters which slumber in the Russian soul-is presented as a terrible occult power which must be fought. ${ }^{7}$ The meta-style of the novel is unquestionably the style of Andrei Platonov. Masodov consciously employs Platonov's language, at once parodying and deconstructing both the idea of communism and the mystical and super-

stagehands bringing new scenery onto the stage." Il'ia Masodov, Cherty (Tver': Mitin Zhurnal; Kolonna Publications, 2003), 9.

5 Very little indeed is known about Masodov himself. According to the publisher, Masodov was born in 1966, worked as a teacher of mathematics, and currently lives in Germany. Moreover, the subject matter of Masodov's prose, which is almost always founded on the aesthetic of violence-physical and sexual-and the proximity of the author's style to the postconceptualist tradition has led to the theory that Masodov's surname is a pseudonym. On the back cover of The Devils is a line from a review which is difficult to get around: not clear what you mean "It is hard to rid oneself of the impression that the author is not a real person but a literary project, and that even his name is a composite. 'Ma' is for Mamleev: the novel's main characters are zombies, the walking dead. 'So' is for Sorokin, and ' $\mathrm{D}$ ' is for others (drugie)." Also, in the context of his works, the name Masodov certainly raises an association with the term Sado-Maso.

6 Il'ia Kukulin considers that Death of a Pioneer Girl, the famous poem by Eduard Bagritskii, is the source for the character of Klava, the heroine of the novel. However, it seems to me that Klava is more likely a reincarnation of Nast'ia from Platonov's Kotlovan. All of Klava's relatives- "representatives of the bourgeoisie"-are killed. Klava is created by the new reality, and her half-living, half-dead shadowy being is a reflection of Nast'ia, whose mother was also a "bourgeois", and whose principal entertainment is to play with her toys in a wooden "kulak" coffin. Pionerka Bagritskogo prinosit otvetnyi udar, Novoe literaturnoe obozrenie 71 (2005).

7 As Dmitrii Bavil'skii observed in his review of The Devils, "Previously it would have been written that the novel presents 'a broad panorama of revolutionary reality', but as if turned inside out and written from the viewpoint of a ghoul or a nedotykomka." Bavil'skii, "Zapiski pokoinika. Il'ia Masodov, Cherty. Roman,” Topos, 28/02/03, http://www.topos.ru/article/935, (Last accessed November 1, 2011). 
human nature of the project, as well as its techno-occult concepts; for example, the deification of machines widespread among Proletkul't authors, especially Bogdanov and Gastev. In Masodov's novel the deification of the steam engine image, which is central to Platonov's prose, takes on a morbid, Gothic fantasy quality:

Trifon did not believe in God, but in the relentless power of the steam engine. This faith originated in him from exhaustion before the rapid movement of the massive iron mechanisms. He could find no equivalent to this in nature, and this meant that there was no God. So Trifon rejected the idea of God as an obsolete opiate, and ipso facto came spiritually closer to the Communists, who also recognized that the steam engine was more important than God. ${ }^{8}$

Masodov reduces Platonov's techno-utopian ideas to an absurdity by laying bare their subconsciously magical and occult subcontext. For example, Masodov employs one of Platonov's central images: "the all-powerful locomotive which will run on light". ${ }^{9}$ In The Devils, the armoured train Comrade Sverdlov, created by the "proletarian genius" Ladov, is such a machine:

The steel giant was assembled in the first hard years of the new life, when swarms of White Guards occupied the Republic and prevented it from breathing the free air of forests and fields. Only the sun continued to cross into Soviet territory, despising imperialism; and out of respect for its loyalty, Ladov decided to take the sun itself as a pattern. ${ }^{10}$

Ladov puts a piece of sun into the train's heavy duty armour and sets "the resulting mass on the class enemy": "A nuclear armored train did not need rails, only a Sovnarkom plan, but in the meanwhile it travelled across the land, burning the life out of it, and not stopping for a moment because a real heart beat within it." 11 Masodov gives the hackneyed metaphor of Bolshevik narrative, the "fiery Bolshevik heart", a literal interpretation. At night, his armoured train recharges itself from the energy of the Bolshevik heart, drawn from Iakov Sverdlov's speeches. Sverdlov's words are absolute nonsense: they are just scraps of slogans and of hysterical ideological speeches, but in the context of the novel they become magical invocations which infuse power into the tech-

8 Masodov, The Devils, 151.

9 See, for example, Rosenthal, "Introduction," 26.

10 Masodov, The Devils, 97.

11 Ibid., 98. 
nology of the Revolution. ${ }^{12}$ Masodov's image of the "magical-scientific armored train" is doubtless a paraphrase of yet another Platonov idea: the "death machine" which will "rework the living, turning them into the dead". The armored train draws its terrible power not just from the sun and the power of Bolshevik hearts, but from the living souls which, should they stray into its path, it consumes and converts into solar energy. ${ }^{13}$

At first, the reader is convinced-like the young Klava-that the new Russia is under the rule of the wicked and the ghoulish. When Klava sees the Reds for the first time, "their eyes were lit with a dull, bloody flame, and while they looked like the drunkards who used to patrol the margins of the workers' quarters, Klava instantly realized that they were zombies". ${ }^{14}$ Even the title The Devils (Cherti) is doubtless a paraphrase of Dostoevsky's The Demons (Besy). Klava's friend Varvara confirms her impression of the Bolsheviks: "The Bolsheviks are pure evil. And Lenin is their chief sorcerer. He can levitate, and he doesn't pronounce his 'r's; he's a real demon. They're all like that, because Satan can't create them properly." 15 The resurrection of the dead-one of the major ideas of Russian Cosmism-is a central theme in The Devils. In Masodov's interpretation, the Revolution turns Russia into the kingdom of the dead-a metaphysical battle between otherworldly forces of good and eviland historical figures take on a new, occult interpretation. The ghosts of dead soldiers from a White Guard regiment annihilated by the Reds continue to battle the magical armored train. "All the dead power killed by the Bolsheviks" prepares to attack the demon Lenin, led by the witch doctor Old Man Kolchak, "who rose from the earth, and he's taller than a tree. And his name isn't that at all, nobody knows his real name, but they called him that after the prophetic words the angel whispered to him: kol-chak."16 It is to "Old Man" Kolchak that hundreds of dead kulak troops, bloated with starvation, swim the freezing

12 On the occult role of language in the poetics of LEF and the Proletkul't see Rosenthal, New Myth, New World: From Nietzsche to Stalinism (University Park: Pennsylvania State University Press, 2002), 221; Irina Paperno and Joan Grossman, eds., Creating Life (Stanford: Stanford University Press, 1994); Rolf Hellebust, Flesh to Metal: Soviet Literature and the Alchemy of Revolution (Ithaca: Cornell University Press, 2003); Irina Gutkin, “The Magic of Words: Symbolism, Futurism, Socialist Realism”, In: Rosenthal, ed., The Occult, 225-246.

13 The result of this experiment is clearly observed in a review in Weekend magazine, stating that The Devils could have been written by Platonov were he bitten by juvenile vampires. (Weekend, $12 / 10 / 2002,14)$.

14 Masodov, The Devils, 24.

15 Ibid., 156.

16 Ibid., 105-106. 
river; an image, once again, from Platonov's Kotlovan.

The principal apocalyptic figure in Masodov's book is the Commissar, initially introduced to the reader as the Horse Rider. The main symbol of the Reds, the Rider seems to resemble the four Riders of Apocalypses. He is covered with blood, and is inherently otherworldly (being already dead), but "the infernal joy did not leave his terrible face." The Rider gallops into the town at full speed, and while galloping, decapitates Klava's friend, the boy Pet'ka. A local sorcerer, Rogatov, finds Pet'kas hat on the pavement, sews the head of a dead dog onto Pet'ka; and the boy lives on like that. "The head of a dog" sewn onto a human being refers, of course, to Bulgakov's Heart of a Dog. Like Sharikov, Pet'ka behaves like a half-human, half-dog: he talks like a human, but snaps his jaws to catch snowflakes, like a dog. But the image of the dog-headed boy, artificially put together from half a dead human and half a dead dog, is linked not only to the Russian fantastic tradition of the 1920s but also to Egyptian mythology which, as we shall see below, is extremely important in this novel.

At the beginning, the reader, like Klava, is in no doubt as to Bolshevism's demonic nature. However, as the novel goes on, the reader begins to sense the clear dualism of the author's relationship to the Revolution. Pavel Alekseevich, an academic and Fedorov scholar who takes Klava in soon after the death of her family, is convinced that the Civil War and Revolution are necessary: they will destroy all life on Earth and establish a single universal Death, through which and after which the rebirth of a new, immortal and all-powerful human being, capable of taming the Universe, will begin. Even Klava, who hates the Bolsheviks at the beginning, gradually forgets her past and realizes that Lenin and Trotskii are creating something immense and holy to which she, Klava, is called. And precisely because of this, in the new world-the world of the dead, created by the Revolution-the Revolutionary leader Lenin turns out to be not a demon, but a saint.

Masodov's Lenin has all the characteristics of the "Lenin myth". ${ }^{17} \mathrm{He}$ is omnipotent, and at the same time "helpless and defenceless as a child". Lenin's speech has the "Leninian" burr; he can levitate with the help of magical forces concealed in his cap, and "his whole figure is bathed in a barely distinguishable electric glow". ${ }^{18} \mathrm{He}$ is telepathic: "he squinted cunningly, and Klava realized that he knew about her what she did not know herself." Lenin's thought is "a

\footnotetext{
17 For more detail on the development of the Lenin myth in Soviet literature and ideology see Nina Tumarkin, Lenin Lives (Cambridge, MA: Harvard University Press, 1983); Rosenthal, New Myth; Olga Velikanova, Making of an Idol: On Uses of Lenin (Göttingen, 1996).

Masodov, The Devils, 55.
} 
great wonder, an epiphany, the victory of human reason over the universe." $\mathrm{He}$ outlaws lies with a grand Decree on Truth. Lenin is convinced that Man will "definitely collide with and penetrate the universe."19

At the end, Klava and the Commissar, whom she hates, unexpectedly become one in a final alchemical transformation: "I [the Commissar] was you and you were me, and I had no voice, because time was not yet time or air, air." ${ }^{20}$ Hatred, which ruled the world from the Revolution to Lenin's death, gives way to conciliation and unity; and at the centre is the ever living Lenin, who guards the world order, and the dead children, who will guard the ever living Lenin forever.

The stylistics of The Devils, based on Platonov and Bulgakov, carry a distinct echo of the symbolism of Egyptian mythology. However, it is extremely important to clarify that the novel is not about Egyptian mythology per se, but about its occult interpretation, prevalent in the Masonic rites of the time and particularly the symbolism of the Memphis-Misraim rite. ${ }^{21}$ Practically all of the characters in the novel are temporal incarnations of the Egyptian occult myth. ${ }^{22}$ A meeting of the All-Russian Central Executive Committee (VTsIK) plays out like a meeting of a secret lodge, in a room with Venetian plaster wallpaper on which "were depicted columns of fish, birds and insects": Egyptian hieroglyphs. The same "familiar letters" are also written on the inner walls of the Mausoleum and on the dead Lenin's forehead: "herons and some kind of rods" ${ }^{23}$ Trotskii also writes the minutes of the VTsIK meeting in hieroglyphs. The nuclear sun of the "Red" armored train, devouring everything in its path, is the Egyptian sun of the dead, devoured every night by the evil spirit Apop, depicted in ancient Egyptian mythology as an enormous snake embodying darkness and evil, the eternal enemy of the sun god $\mathrm{Ra}^{24}$ The river across which the bloated corpses swim towards Old Man Kolchak is a metaphorical

Ibid., 55, 103.

Ibid., 221.

On the Egyptian initiation rites of the Memphis-Misraim Rite see Calvin C. Burt, Egyptian Masonic History of the Original and Unabridged Ancient and Ninety-six 96th Degree Rite of Memphis (Kessinger Publishing, 1997).

22 In this interpretation, Masodov does not claim originality; he simply starts out with Soviet symbols and reduces them to absurdity. Shchusev, the architect of Lenin's mausoleum, deliberately provoked an Egyptian association in the mind of the viewer, and the very idea of embalming Lenin's body is obviously associated with Egyptian mythology. Moreover, the name of the Memphis-Misraim masonic rite originates in the Hebrew word for Egypt: "Misraim".

Masodov, The Devils, 220.

Mythology. Encyclopedia (Moscow: Belfaks, 2002), 86. 
Nile, across which the dead swim to eternal life. As for the boy with the dog's head, who-as Klava says-has become God and who is shown at the end of the novel as a guard at Lenin's tomb, holding "a carbon rod terminating in an icy hook;" 25 he is without a doubt Anubis, the Egyptian god of the dead and one of the fundamental symbols of "Egyptian" Freemasonry. The final lines of the novel indubitably demonstrate the unity of Pioneer and occult Egyptian symbolism in a kind of initiation:

Varvara walked away and stood at Lenin's head. [The children] surrounded him, and [their] strength was once more united. [Klava] stretched out [her] left hands, meeting over Lenin's sleeping face. Blood dripped from her palms and fell on Lenin's broad forehead, and the dark symbol flared up and disappeared back into the head of the dead leader.

"And you shall become a stone", said Varvara, "locking the gates of darkness. Forever and ever."

And Pet'ka placed his rod on Lenin's corpse, and it lies there to this day, where Pet'ka laid it. And you children raised your hands to block your faces, so that posterity would not know them and nobody could break your spell. Nobody knew, then, that millions of boys and girls would soon lift their hands before their faces just like that, beneath the flame of red flags, repeating your sacred gesture and blocking the way of any deadly gaze into their radiant, joyful eyes. They will draw you like that one day, engrave you on some massive stone wall: two girls, standing over the sarcophagus of a charmed and incorruptible light, and the boy with the head of a dog. ${ }^{26}$

Masodov interprets the hand lifted in the Pioneer salute as an occult sign of "protection", and the founders of the Pioneer movement turn out to be ancient Egyptian guardian priests of the ever living Lenin; dead children killed by the Revolution, living forever. ${ }^{27}$

25 Ibid., 221.

26 Masodov, The Devils, 222.

27 The sacralization of the Lenin myth and the transformation of Lenin's tomb into an occult symbol-a kind of amulet-appears in Pavel Pepperstein's fantasy novel The Mythogenic Love of Castes. The Fascist soldiers in the novel are convinced that "the Soviet infidels believe that Lenin's mummy gives them strength and magically promotes success in business." However, Pepperstein's novel is a fantastic, fairy-tale work. Occult and esoteric themes are not central to it. 
It would be easy to see Masodov's novel as a parody of the utopian Soviet modernist narrative, close in spirit to Vladimir Sorokin's experiments in The Blue Fat. Indeed, it is hard to take seriously the image of the dead members of the requisition brigades, hung up to "cure" by villagers whom hunger has driven to cannibalism, discussing - as if alive-the question of "whether Lenin has a dick, or just electricity." However, in my opinion, Masodov's aim is quite different from Sorokin's. I agree with Il'ia Kukulin, who states that Masodov's principal aim is a kind of research into the subconscious of early Soviet literature. Masodov's Satanic-Communist aesthetic is not so much parodicalalthough undoubtedly parody plays a considerable role in The Devils-but lyrical and even metaphysical. In giving The Devils a completely apocalyptic storyline, Masodov deconstructs not so much the early Soviet narrative of the Revolution as the contemporary occultization of Lenin and the Bolshevik Revolution; and where myth, the grotesque and sincere lyricism meet, the author creates his own text.

The magical interpretation of the "Lenin and children" theme which appears in Masodov's novel is also central to Vladimir Sharov's Be Like Children. ${ }^{28}$ At the heart of the novel is Sharov's fictional invention, the "children's crusade": a mystical crusade for secret knowledge, eternal happiness and everlasting life. The action takes place in the mid-1920s when, on the orders of Lenin and Trotskii, thousands of dispossessed children have to walk to Jerusalem (many of them walking across the sea). As soon as the first child reaches Jerusalem, "the lame walk, the blind see, and the deaf hear. Even the dead rise again" ${ }^{29}$ However, the same images which are portrayed as occult in Masodov's novel can be read as mystical in Sharov's. Like Masodov's prose, Sharov's language is constructed in the style of Platonov. As with The Devils, Fedorov's ideas about the resurrection of the dead- "those who died before the victory of Communism" - is central to Sharov's novel. ${ }^{30}$ However, the element of parody which is fundamental to an understanding of The Devils is entirely absent in Be Like Children. The Civil War and Revolution appear in Sharov's novel not as a

28 A similar mystical and occult interpretation of early Soviet history appears in Sharov's earlier works, for example his novels The Resurrection of Lazarus (2003) and Rehearsals (1992), but Be Like Children is a more striking example of the author's treatment of this theme.

Vladimir Sharov, Bud'te kak deti (Moscow: Vagrius, 2008), 129.

30 It is worth noting that Fedorov's philosophical ideas and their influence on Platonov's work are central to an understanding of Sharov's own creative philosophy, most vividly expressed in his literary and philosophical essay "Between two revolutions: Andrei Platonov and Russian history", published in the collection Tempted by Revolution: the Russian leadership (Moscow: Arsis, 2009), 12-54. See, for example, 40-44. 
battle between good and evil, but rather as Lenin's "inner path" to his own personal spiritual enlightenment. The stroke which afflicts him in the last years of his life is portrayed by Sharov as a kind of initiation, opening the door to a secret world in which language has magical powers and humans can see the invisible "that which is accessible only to innocent little children." 31

Like Masodov, Sharov stresses the role of language in the Revolution; primarily Lenin's use of language. According to Sharov, Lenin's language and his "revolutionary" speeches are in a way invocations, magical "seals". Moreover, Sharov claims that in the last years of his life Lenin became entirely convinced that human language was imperfect, originating from "cunning"; that "after Adam's expulsion from Paradise, people began to use a conditional and deceptive language," 32 and that only Communism could restore the real, esoteric and magical nature of words, which would help people to reach a state of eternal grace and eternal life. Sharov himself defines his novel as an "esoteric mystery" and the Revolution as an unsuccessful attempt at a new and mystical quest in the search for universal happiness.

Accordingly, if The Devils can be called an "occult" novel, Sharov's work, which uses practically the same mythologems and symbols as Masodov's, presents the reader with a mystical text. However, it is not a mystical text, as it is constructed on individual magical reasoning; accordingly, it is an esoteric text and not one belonging to the Christian mystical canon. Sharov interprets the processes of the Revolution, and those taking place in Lenin's soul in the last years of his life, as a secret "inner path" to a mystical experience, whichalthough it might be considered close to Christian in nature-is rather antiChristian. Hence he regards Leniniana not as an opponent to Christianity but rather a counterbalance: the secret personal religion of Bolshevism and the Bolsheviks.

Neither The Devils nor Be Like Children can be considered popular literature. Both novels are constructed in the style of a literary and linguistic experiment aimed at a fairly narrow, although influential audience: the wellgrounded reader with a literary education. By contrast, Polina Dashkova's The Source of Happiness trilogy is aimed at the general reader, ${ }^{33}$ and Dashkova has produced an occult, conspiracy-based mystery novel incorporating elements of

\footnotetext{
31 Masodov, the Devils, 128.

32 Ibid., 127.

33 By way of comparison, the print run of The Devils (2003) was only 1,000 copies; that of Be Like Children (2008) was 4,000, while, the combined print run of Dashkova's trilogy in 2010 was over 50000 copies.
} 
mystery, fantasy, historical and open adventure narrative, catering to the tastes of that audience. However, the principal "real" protagonists of The Source of Happiness are all the same: the Bolshevik leadership, Lenin, Sverdlov et al. The time period of the action, which unfolds from the first years of the Civil War to Lenin's death, also remains unchanged. As with Masodov and Sharov, all three of Dashkova's novels are strongly anti-Bolshevik in character, while displaying a dualist attitude to Lenin. Dashkova defines Bolshevism as a dark, demonic force, in which "evil is elevated into valor and the cruellest instincts of the masses are raised to the heights of a new religion." ${ }^{34}$ Dashkova's protagonistslike those of Masodov and Sharov-are convinced that the Civil War and Revolution are an apocalypse; an allegorical death which Man must undergo for resurrection into eternal life. ${ }^{35}$ Dashkova styles her narration after the "classical" modernist narrative of the Silver Age and early Soviet period. However, unlike Masodov-whose novel is an example of conscious and strikingly purposeful imitation of a modernist text, teetering on the brink of parodyDashkova's trilogy is not a conscious imitation. Rather, as the author of a recent review in the Literaturnaia gazeta correctly observed, Dashkova's text "reiterates those literary stereotypes describing the revolutionary era which have come to replace the Soviet stereotypes;" 36 that is to say, she does so quite unconsciously in an attempt to write a text capable of immersing the reader in the era of the 1920s, both in content and in style. In this sense, we can assert that Dashkova's trilogy is an example of that literature which originated in post-Soviet popular culture, but cleverly disguised as "high" literature.

The plot of the novel is fairly simple. A year after the Revolution, the Moscow professor Mikhail Sveshnikov is carrying out experimental operations in the transplant of rat epiphyses - the rounded ends of a long bone of a brain, when he unexpectedly discovers a rejuvenating effect linked to the action of an unknown worm on the brain; a parasite discovered by chance in the pineal gland of a donor rat. Sveshnikov invents a drug with the cysts of the mystery parasite as the main component, and so creates the "elixir of immortality". As we later discover, Sveshnikov is not the first to find the parasite. In 1547, the

34 Polina Dashkova, The Source of Happiness: Book Two. Misterium Tremendum: the Fear-Inspiring Mystery (Istochnik schast'ia: kniga vtoraia)(Moscow: AST, 2010), 160.

35 It is also noteworthy that, like Masodov, Dashkova could to some degree be called a literary project. The combination "Polina Dashkova" is a pseudonym, and the author's real name, Tat'iana Poliachenko, was for a long time kept strictly secret. Even now, despite the dissemination of this information on the internet, the author does not welcome the popularization of her real name.

Ol'ga Shatokhina, “The doomed dolls," Literaturnaia gazeta, 10-16 March, 2010, 6. 
German artist, doctor and alchemist Alfred Plut (a fictional character probably based on the Renaissance occultist and physician Paracelsus) discovered the parasitic worms with the aid of a diamond microscope of his own invention, carved in the form of a crystal skull. He includes the worms in his famous picture "Misterium Tremendum". The action of the novel unfolds in two parallel time frames: 1920s Russia and 2007 in both Russia and Germany; however, the narrative centres on Sveshnikov and his biologist granddaughter Sonia.

Subject matter drawn from Bulgakov, primarily Heart of a Dog, is central to The Search for Happiness. The reader can easily discern Bulgakov's Professor Preobrazhenskii in the character of Sveshnikov. ${ }^{37}$ However, if Bulgakov aims to dissect the myth of the creation of the new "ideal" man of "Communist formation" from the lumpenproletariat, Dashkova's aim is to denounce the Bolshevik melodrama of mastery over the secrets of nature and control over the unknown.

Finding out about the drug, the Bolsheviks aim to obtain it. They consider Sveshnikov not so much a doctor as one who possesses arcane powers and the techniques of ancient priestly magic. In contrast to Masodov's Bolsheviks, who are genuinely "wicked" and possess the real magical powers of demons and ghouls, Dashkova's characters are to some extent ordinary people, albeit with extraordinary parapsychological abilities. However, their aim is to create a new world, and they need occult science in order to achieve that aim. As one of the characters states, "today's materialism is a colossal, profoundly elaborated and meticulously organized magical act." 38 The Bolsheviks are creating their own myth, and in order to sustain that myth they require iron health and, ideally, immortality. Therefore, in Dashkova's version, the Bolshevik leaders-who do not have real magical powers or occult knowledge-lay down their lives in order to acquire that knowledge and power. According to Dashkova, the Bolshevik leaders and especially Gleb Bokii are closely linked to Gurdjieff and his sect, study the writings of Blavatsky and are members of the Imhotep Masonic lodge. ${ }^{39}$ They want to become superhuman, and they seek all means to that

37 Dashkova specially incorporates a reference leading the reader to the protagonist of Bulgakov's novel. Under the influence of Sveshnikov's discovery, a Moscow professor transplants a human pituitary gland into a monkey. Although this case involves a monkey rather than a dog, the transplant of a human pituitary gland into an animal unequivocally reminds the reader of Preobrazhenskii's experiments.

38 Dashkova, The Source of Happiness: Book Three. The Sky Above the Abyss (Istochnik schast'ia: kniga tret'ia. Nebo nad bezdnoi) (Moscow: AST, 2010), 431.

39 Similar ideas can be traced in other contemporary works dedicated to the links between the GPU and occult and esoteric circles, for example the pseudo-factual novels of Oleg Shishkin, 
end, carrying occult artefacts and demanding an injection of the wonder drug from Professor Sveshnikov.

Dashkova's description of the Bolshevik regime and its leaders constantly teeters on the brink of the fantastic; however, the author always tries to keep that balance, letting the reader decide whether the novel is really about occult powers or about the accomplishments of science. In this it also works from the Russian modernist tradition, in which science is usually perceived as the heir and successor of magic. However, Dashkova constantly insinuates that the main culprits in the nightmare of the $20^{\text {th }}$ century, Stalin and Hitler, were not real people, but shapeshifters, demons with a human face and created by "darkness;" infernal, demonic forces. ${ }^{40}$ Dashkova accords a considerable role to hypnosis and mesmerism, using examples of mesmerism in order to emphasize the demonic and infernal nature of the Bolshevik regime. ${ }^{41}$

Reading the text, it is difficult not to think that Dashkova's novel embodies all the myths about the Bolsheviks and Silver Age occultism thrown up by 1990s Russian popular culture. According to Dashkova, the leading Bolshevik figures were adepts of secret societies, primarily the international Masonic lodge Narcissus. Like Masodov's characters, they dispose of and use Egyptian occult symbolism, especially the image of the ancient Egyptian priest, doctor and alchemist Imhotep, the architect of the first pyramids, and they consider themselves priests. Dashkova's narrator (like Dashkova herself, to judge by the

The Battle for the Himalayas (Bitva Gimalaiakh) and Red Frankenstein (Krasnyi Frankenshtein). In Dashkova's work, the Imhotep lodge is fictional. However, it is worth noting that the Imhotep Masonic lodge really exists today in Russia, as part of the Memphis-Misraim rite. (See http://www.memphis-misraim.ru/) It is also worth noting that the image of Imhotep-the ancient Egyptian god of medicine-has often been used in Western popular culture in recent years, primarily in the popular films The Mummy (1999) and The Mummy Returns (2001), which undoubtedly played a role in Dashkova's choice of this image.

40 Ibid., 320-321.

41 At times the wealth of such details - incorporated without even a hint of parody or deliberate stylization-can make the reader smile. For example, Sveshnikov's assistant Valia practices hypnosis during operations when there is not enough anaesthetic available in the hospital or when the anaesthetic is dangerous to the patient. During one such operation a female Cheka agent suddenly begins to ventriloquize in a male voice: "Suddenly, Karaseva opened her eyes and grinned widely. There was a giggle, and then the vibrating hum resumed. It made the head ache. Then there was a squelch, and a voice sounded: a male voice, low and hoars. "Recognize me? Want to play with me?" "Not with you," said Valia slowly, "You're nothing. Empty." The patient's heart stopped, and the voice kept resounding. "Are you praying? Well, go on and pray. Only I will listen. No other but me!” (221). - Clearly the infernal dybbuk who speaks from the dead woman's womb demonstrates the genuinely infernal soul of Karaseva the Cheka agent, "who loved shootings and torture". 
statements she has made in numerous interviews) is convinced that the Revolution was the doing of a secret mystical order which:

has long been trying to destroy the old, unjust world and build a new, just one. It has many subdivisions in the form of Masonic lodges and other mysterious organizations. The order supports the Bolshevik party and leads it. Il'ich is an adept of the order. ${ }^{42}$

Like Masodov and Sharov, Dashkova constantly emphasizes that the speeches of the Bolsheviks do not carry a logical message, but constitute a kind of psychological mumbo-jumbo: "Il'ich fills his speeches with utter nonsense. But the crowd listens enthusiastically. In fact, he uses coded language. It is not the words that work, or the logical connections, but the signs and symbols." ${ }^{43}$

The character of Alfred Plut-who, it emerges in the third book of the trilogy, has lived for over 400 years-plays a parallel role to Lenin throughout. Lenin appears as the primary symbol of "Bolshevik alchemy". Thus, Plut's crystal skull-through which one can see a human skull in the picture "Misterium Tremendum"-echoes the following statement by one of Lenin's comrades in arms: "Lenin's brain is an astounding cupola of forehead in sculptural contours; and, observe, it glows. A physical emission of light; the inexhaustible energy of the supreme, universal intellect." ${ }^{44}$ However, at the same time Dashkova actively implements the idea that the disease of the brain which afflicted Lenin at the end of his life was not the result of atherosclerosis, but was brought about by hallucinogens and ritual exercises "directed at the intensive stimulation of certain parts of the brain," to which Lenin was exposed during his occult initiation, which he underwent as a young man. ${ }^{45}$

Over the last two decades, Russian popular culture has elaborated and popularized an occult interpretation of events relating to the making of the Lenin myth and the period of the 1920s, thus creating an "occult mythology"

42 Ibid., 547.

43 The Source of Happiness: Book Two. Misterium Tremendum: the Fear-Inspiring Mystery, 299.

44 The Source of Happiness: Book Three. The Sky Above the Abyss, 172.

45 Ibid., 432. It is noteworthy that, in contrast to the character of Lenin, Dashkova interprets the character of Stalin solely negatively. Having first met Stalin, Sveshnikov emphasises that he "consisted entirely of special traits: webbed toes, the left arm shorter than the right... even his pupils seemed rectangular, not like other people's." Sveshnikov observes that all these traits made Stalin "some kind of not quite human being, rather a strange half-human, half-devil" (The Sky Above the Abyss, 14). Thus it can be argued that, like Masodov's Lenin, who did not pronounce his 'r's, Dashkova's Stalin is indubitably one of those "shapeshifters" whom "Satan could not properly create." 
incorporating rumors, information from the now accessible archives, numerous real historical discoveries and pop-academic speculation. The works considered above are an expression of this mythology in contemporary Russian literature. At the same time, if the popular relationship to Soviet mythology was extremely negative at the beginning of the 1990s, the instability of Russian society in the 1990s and the dissatisfaction of the general public with the social and political situation in the country led to a certain renaissance and "neoromanticization" of Soviet symbolism, creating that dualist attitude towards the fundamental Soviet myth - the Lenin myth - which is clearly manifested in Masodov, in Sharov and in Dashkova. All three novels-The Demons, Be Like Children and The Source of Happiness - portray the Revolution not as a historical process but as an occult and creative one, an alchemical Magnum Opus aimed at reworking mortal material into an immortal synthesis of the soul, eternal matter and renewed consciousness. In this sense, it could be argued that these texts to some degree continue the tradition of early Soviet literature, which also portrays the Revolution as a great metaphysical transmutation. ${ }^{46}$ In each of these novels, the everyday events surrounding the Revolution take on mythical, not to say cosmic qualities.

However, in some cases it could be argued that history undergoes either a purely occult interpretation (as for example in Masodov) or that the interpretation of events has a more vividly expressed mystical and esoteric character (Sharov's work is an example of such a novel). Taking into consideration that both Sharov and Masodov's novels are more literary, and are not aimed at a general audience, then accordingly one could argue that a complete erosion of the boundaries between these terms is more characteristic of popular than of "elite" literature. In my opinion, this results from the stereotypical perception of the term "occultism" in contemporary Russian popular culture.

The absence of a single version of historical events is superimposed on the broad religious crisis in modern Russian history, creating a situation in which people who grew up in a society propagandizing rationalism and negating any mysticism not only become easily enthused for mysticism and the occult, but try to interpret the well known version of events through an occult and mystical lens, negating theses events and changing them. Although the action of the novels analyzed above unfolds entirely or mostly in the 1920s, in our view

46 For more about this, see Rosenthal, "Introduction," 11; George M. Young, "Fedorov's Transformations of the Occult," In: Rosenthal, ed., The Occult, 171-185; Anthony Vanchu, "Technology as Esoteric Cosmology in Early Soviet Literature," ibid., 203-222; Rosenthal, New Myth; Hellebust, Flesh to Metal. 
these books are clearly a product of the end of the $20^{\text {th }}$ century and the beginning of the 21st, and their subject matter-to paraphrase Vladimir Sharov-is rooted in dissatisfaction with real history, with their historical fate, and in a very strong desire to replay it all and make human life as experimental as, say, physics. ${ }^{47}$ In the texts discussed above, the Soviet past functions not as an object of historical research, but as an attempt to fill the conditional symbolic space of the culturological "black hole" with new thought and new interpretations, in which the established materialist course of history is transformed into a symbolic quest for power and becomes a secret path to awakening and realising the supernatural essence in human life.

47 Sharov, "The final rounds are always happening here and now," Knizhnaia vitrina, 23/29/2008, http://www.bigbook.ru/smi/detail.php?ID=5360 (Last accessed June 8, 2011). 


\title{
SHAMANISM IN THE RUSSIAN INTELLIGENTSIA (POST-SOVIET SPACE AND TIME)
}

\author{
NATALIA ZHUKOVSKAIA
}

\section{Shamanism and Occultism: the Question of Correlation}

Scientific literature associates the concept of occultism with a wide range of adjoining concepts that aspire to the mastery of secret knowledge, both individually and in aggregate with the others. These concepts include mysticism, spiritism, astrology, and alchemy, which are sometimes given the collective label the occult sciences. At some point in the history of human civilization, all of them together, and each one by itself, enjoyed the status of scientific knowledge and were studied as such in secular educational institutions. Religion on the other hand, while itself using occult methods which were, in varying degrees, present in all Eastern and Western religious systems, officially condemned occult practices and punished severely those suspected of using them, often to the extent of capital punishment. Examples include the witch hunts, and the stakes of the Inquisition.

However, while there exists a large body of literature on occultism and its relation to various religions that recognize mystical experience, few have directed their attention to the search for its possible roots in Shamanism, which can rightfully be called if not a world religion, then at least the first supranational religion to emerge, although different peoples know it under different names. The term Shamanism in scientific literature emerged much later than the phenomenon it describes. To date, no one single definition of the nature of shamanism has yet been agreed upon. Some researchers perceive it as a religion, others as a worldview, still others as a practice. This does not change the essence of the matter from the point of view of the subject under study.

The definitions of occultism that can be found in philosophical, psychological or religious encyclopedias, as well as in specialized literature, stipulate its main features as the following: the possession of higher psychic or spiritual abilities; the possession of secret knowledge available only to the initiated; the ability to establish contact with the netherworld and the ability to receive from the dwellers of this world answers to questions posed by the living; the ability to use these answers in order to predict the future and influence its course. For the researcher into shamanic cultures in any part of the world these indicators 
represent the standard qualities that characterize the ordinary shaman and without which he cannot be considered a shaman. There are still other highly important qualities the shaman possesses: the ability to heal a fairly large number of diseases and afflictions, including mental conditions, to induce mass hypnosis in the participants in the rituals he is carrying out and the ability (if we may use contemporary language) to "scan" the brain and psyche of his client and to re-create his "portrait" in the past (including his past life), present and future. And finally, the ease with which the shaman crosses the border between the worlds of the living and the dead, continuously receiving information from his deceased ancestors (who often double up as his spirits and helpers) about what might happen, what must be avoided and, most importantly, how to escape seemingly unavoidable misfortune and even death. I am not convinced that the carriers of occult knowledge today really can do all these things. But then it is possible that in the early days of occultism they could.

\section{Research on Shamanism}

The literature on the nature of the shamanic gift and Shamanism as a phenomenon of human culture comprises more than a thousand titles, as people started writing about it in the $17^{\text {th }}$ century. There is no need to expound on the basics of Shamanism here, since almost every serious encyclopaedia and reference work on the religions of the world contains relevant articles. ${ }^{1}$ Towards the end of the $20^{\text {th }}$ - beginning of the $21^{\text {st }}$ century, the research on regional forms of Shamanism, as well as on theoretical aspects, has reached such dimensions that we can state the following: one can find books on Shamanism of the indigenous populations of practically all countries of Asia, America, Africa, Australia and even Europe. We can talk about Shamanism studies as an independent discipline that emerged at the intersection of several subjects, including religious studies, philosophy, psychology, history and medicine. There are centers for the study of Shamanism in Europe, Asia and the USA. I want to mention several authors whose works are key to the study of this culturalhistorical phenomenon: Mircea Eliade, ${ }^{2}$ Áke Hultkranz, ${ }^{3}$ Vilmos Diószegi, ${ }^{4}$

1 See for example Encyclopaedia Britannica, vol. 16, 1974, 638-641; Shamanism: an Encyclopedia of World Beliefs, Practices and Culture, ed. by Mariko Walter, Eva Fridman Neumann (Santa-Barbara-Denver-Oxford, 2004), vol. 1-2; Severnaia éntsiklopeidiia (Moscow, 2004).

2 Mircea Eliade, Shamanism. Archaic Techniques of Ecstasy (Princeton University Press, 1974).

3 Ake Hultkranz, "Ecological and Phenomenological Aspects of Shamanism," In: idem, Shamanism in Siberia, (Budapest, 1978), 27-58. 
Anna-Leena Siikala, ${ }^{5}$ Anna -Leena Siikala/Mihály Hoppal, ${ }^{6}$ Mihály Hoppal, Roberte Hamayon, ${ }^{8}$ Piers Vitebsky, ${ }^{9}$ Caroline Humphrey/Urgunge Onon, ${ }^{10}$ Marjorie Balzer, ${ }^{11}$ and Eva Fridman, ${ }^{12}$ among others. Each of these authors has several books and dozens of articles to his or her name. Moreover, they have organized international conferences on Shamanism and edited the collected volumes that were published after these conferences.

Since this article is based on Russian materials on Shamanism, some of the scholars who were the founders of Shamanism studies as an academic discipline in Russia should be introduced, namely Sergei Shirokogorov, ${ }^{13}$ Vladimir Bogoraz, ${ }^{14}$ Lev Shternberg, ${ }^{15}$ Nadezhda Dyrenkova, ${ }^{16}$ Andrei Anokhin, ${ }^{17}$ and

4 Vilmos Diószegi, Shamanism. Selected Writing of V. Diószegi, ed. by Mihály Hoppal, Bibliotheca Shamanistica, vol. 6 (Budapest, 1998).

5 Anna-Leena Siikala, The Rite Technique of Siberian Shaman (Helsinki, 1978).

6 Anna-Leena Siikala, Mihály Hoppal, Studies of Shamanism (Budapest, 1992).

7 Mihály Hoppal, Otto Sadovsky, eds., Shamanism. Past and Present, 2 parts (Budapest, 1989); M. Hoppal, Schamanen und Schamanismus (Augsburg, 1994); idem. Shamans and Traditions, Bibliotheca Shamanistica, vol. 13 (Budapest, 2007).

8 Roberte Hamayon, La chasse à l'âme. Esquisse d'une théorie du chamanisme sibérien (Nanterre, 1990).

9 Piers Vitebsky, Dialogues with the Dead (Cambridge University Press, 1993).

10 Caroline Humphrey, Urgunge Onon, Shamans and Elders. Experiences, Knowledge and Power among the Daur Mongols (Oxford: Clarendon Press, 1996).

11 Marjorie Mandelstam Balzer, „Ot bubnov k skovorodam: povoroty sud'by shamanizma v istorii Sakha (iakutov)," In: Shamanizm i rannie religioznye predstavleniia:k 90-letiiu doktora istoricheskikh nauk, professora L.P. Potapova. Sbornik statei (Moscow, 1995), 25-36; idem, "Sovremennyi sakha-shaman' in "Izbranniki dukhov" - "izbravshie dukhov". Traditsionnoe shamanstvo i neoshamanizm. Pamiati V.N. Basilova (1937-1998). Sbornik statei (Moscow, 1999), 183-193.

12 Eva Fridman Neumann, Sacred Geography: Shamanism among the Buddhist Peoples of Russia, Bibliotheca Shamanistica, vol. 12 ( Budapest, 2004).

13 Sergei Shrirokogorov, "Opyt issledovaniia osnov shamanizma tungusov," Uchenye zapiski istoriko-filologicheskogo fakul'teta, vypusk 1 (Vladivostok, 1919), 47-108; Sergei Shirokogoroff, Psychomental Complex of the Tungus (London-Shanghai, 1935).

14 Wladimir Bogoraz, "The Chukchee: Jesup North Pacific Expedition Memoir," American Museum of Natural History, vol. 7, pt. 2 (Leiden, New York, 1907), 277-536, pt. 3 (Leiden, New York, 1909), 537-733.

15 Lev Shternberg, Pervobytnaia religiia v svete ètnografii (Leningrad 1936).

16 Nadezhda P. Dyrenkova, 'Materialy po shamanstvu u teleutov' in: Sbornik Muzeia antropologii i ètnografii. T. X. (Leningrad, 1949), 107-190.

17 Andrei Anokhin, „Materialy po shamanstvu u altaitsev, sobrannye vo vremia puteshestviii po Altaiu v 1910-1912 gg," In: Sbornik Muzeia antropologii i ètnografii, t. IV, vyp. 2 (St. Petersburg, 1924). 
Gavriil Ksenofontov. ${ }^{18}$ The latter fell victim to political repression in 1938 and his work began to appear in print only in 1992. These authors produced the first, rather divergent, definitions of Shamanism. They were not theorists confined to their offices, but experienced field researchers who knew the languages of the indigenous peoples and collected their material from various peoples (Tungus, Chukchi, Giliaki, Altai, Yakut) even before the Russian Revolution in 1917. As a result their work reflects the classical period of Shamanism before it came under the tremendous pressure of Soviet government ideology.

The new generation of Shamanism scholars who replaced them - Leonid Potapov, ${ }^{19}$ Andrei Popov, ${ }^{20}$ Sevian Vainshtein, ${ }^{21}$ Taras Mikhailov, ${ }^{22}$ Dashinima Dugarov, ${ }^{23}$ Vladislav Kulemzin, ${ }^{24}$ Anatolii Mazin, ${ }^{25}$ Vladimir Basilov ${ }^{26}$ and many others, worked under the conditions dictated by the mass atheization of the population and repressions of priests and ordinary believers. As a result, much of what they wrote was their own reconstruction of how they thought things had looked or should have looked during the time of classical Shamanism.

In the 1980s and 1990s those who were interested were inundated with material on Shamanism and on what some people decided to consider Shamanism, from news items to art works whose hero was a shaman, and from websites and blogs to documentary films shot in different regions of Russia by amateurs, as well as professionals. Two scholars, both of them members of the staff at the Institute of Ethnology and Anthropology of the Russian Academy of Sciences, stood out among this flood that called all kinds of things "Shamanism." Their works became pillars of support and lode stars for all admirers of the shaman genre in science and in life. These scholars are Vladimir Basilov

18 Gavriil Ksenofontov, Shamanizm. Izbrannye trudy (Iakutsk, 1992).

19 Leonid Potapov, Altaiskii shamanizm (Leningrad, 1991).

20 Andrei Popov, Kamlaniia shamanov byvshego Viliuiskogo okruga (teksty) (Novosibirsk, 2006).

21 Sevian Vainshtein, Tuvintsy-todzhintsy. Istoriko-ètnograficheskie ocherki (Moscow, 1961); idem, Mir kochevnikov Tsentra Azii (Moscow, 1991).

22 Taras Mikhailov, Iz istorii buriatskogo shamanizma (s drevnikh vremen do XVIII v.) (Novosibirsk, 1980); idem, Buriatskii shamanizm:istoriia, struktura i sotsial'nye funktsii (Novosibirsk, 1987).

23 Dashinima Dugarov, Istoricheskie korni belogo shamanstva na materiale obriadovogo fol'klora buriat (Moscow, 1991).

24 Vladislav Kulemzin, "Shamanstvo vasiugansko-vakhovskikh khantov (konets XIX-nachalo XX vv.)” in: Iz istorii shamanstva (Tomsk, 1976), 3-154.

25 Anatolii Mazin, Traditsionnye verovaniia i obriady èvenkov-orokhonov (konets XIX-nachalo XX vv.) (Novosibirsk, 1984).

26 Vladimir Basilov, Izbranniki dukhov (Moscow, 1984), 208p.; idem, Shamanstvo u narodov Srednei Azii i Kazakhstana (Moscow, 1992). 
and Valentina Kharitonova. Each of them is the author of dozens of articles on the topics and can be called the leaders of the two main currents in contemporary Russian Shamanism studies.

Vladimir Basilov, who died in tragic circumstances in 1998, defended the classics of the genre and unceasingly wrote about what ought to be considered Shamanism, ${ }^{27}$ not distinguishing between the two Russian terms shamanstvo and Shamanism, and defining which religious ideas and practices could be considered shamanist. ${ }^{28}$ Valentina Kharitonova, on the other hand, is monitoring the largest possible number of groups in different regions and across different professional strata of society who hold that they represent classical Shamanism and frequently take offence when considered neo-shamans, pseudoshamans, or not associated with the phenomenon at all. ${ }^{29}$ Kharitonova's main focus is on the medical aspect of this research.

\section{Shamanism in the Soviet Era}

During Soviet times it could be dangerous to write something positive about any religion at all. The only writings on religion to be approved and published were those that took a harshly critical stance. The ideological construct of the USSR considered religion in all its forms, from early forms of belief to world religions, as "vestiges," sometimes even specifying which social order had left the vestiges behind, e.g. feudalism, capitalism or the early class society. Shamanism was allocated a place at the very bottom of this scale, as a vestige of the early class society, and sometimes of feudalism, too, although the people of Siberia has failed to experience any feudalism, passing from the early class society directly to Soviet socialism. On the other hand, writings on the Shamanism of peoples in faraway countries, such as the Malay and Indonesians, received every possible encouragement. ${ }^{30}$ These works made it possible to talk of Shamanism as a cultural phenomenon, and their print runs quickly sold out.

It would be incorrect to claim that there was no research on Shamanism in Soviet Russia whatsoever, of course there were scholars working on the topic; however, these works focused on Shamanism in the past. They included two

27 Vladimir Basilov, „Chto takoe shamanstvo?” Étnograficheskoe obozrenie, 1997, no 3, 3-16, 3.

28 Ibid., 7-9.

29 Her book, Kharitonova 2005, and many articles, are dedicated to this topic.

30 Elena Revunenkova, Narody Malaizii i Zapadnoi Indonezii (nekotorye aspekty dukhovnoi kul'tury) (Moscow, 1980). 
books by Taras Mikhailov, ${ }^{31}$ one of the leading specialists on the Shamanism of the Buriats. Mikhailov himself descended from one of the shamanic clans of the Buriats of Irkutsk and knew many of the things he described in his monographs from the tales of his ancestors and those shamans who practiced in secret, as well as drawing heavily on the material on Shamanism already published in the three-volume work of the first Buriat ethnographer, Matvei Khangalov (d. 1918). ${ }^{32}$

In order to protect himself against the wrath of the Party leaders, he called his book From the History of Buriat Shamanism (from antiquity to the $19^{\text {th }}$ century) (Iz istorii buriatskogo shamanizma (s drevneishikh vremen do XVIII v.)). His books were detailed and profound studies, but when the very same leaders ordered that Shamanism must be strongly condemned, he wrote brochures such as Buriat Shamanism and its vestiges (Buriatskoe shamanstvo i ego perezhitki). ${ }^{33}$ This approach corresponded to the demands of the times in which he lived and made clear that somehow Shamanism no longer existed, that all that remained were its vestiges.

The beginning of the revival of religion during Perestroika, and especially afterwards, failed to stimulate the writing of either general works or regionally focused research about the fate of Shamanism during the Soviet era. Everyone immediately began to write about the process of revival, which is entirely understandable: the revival happened live, right before the eyes of the researchers, and changed itself in every concrete segment of time. As such it was much more interesting than the past. The persecution of Shamanism and the repressions against shamans were merely mentioned in the context of other negative phenomena of the Soviet era. But while Russian scholars talked about this subject in passing, merely stating a fact, ${ }^{34}$ European and American researchers

31 T. Mikhailov 1980, 1987.

32 Matvei Khangalov, Sobranie sochinenii, vol. I (Ulan-Ude, 1958); vol. II (Ulan-Ude, 1959); vol. III (Ulan-Ude, 1960).

33 Taras Mikhailov, Buriatskoe shamanstvo i ego perezhitki (Irkutsk, 1962).

34 See for example: Galina Galdanova, "Buriatskii shamanizm: proshloe i nastoiashchee," In: Sibir': ètnosy i kul'tury (traditsionnaia kul'tura buriat), vyp. 3 (Moscow, Ulan-Ude, 1998), 546; Taras Mikhailov, Shamanizm, Istoriia i kul'tura buriatskogo naroda. Uchebnoe posobie dlia uchashchikhsia i studentov (Ulan-Ude: Izdatel'stvo BGU, 1999), 180 p.; Tat'iana Skrynnikova, "Traditsionnoe mirovozzrenie buriat i shamanism," In: Metodologicheskie i teoreticheskie aspekty izucheniia dukhovnoi kul'tury Vostoka, vyp. 2 (Ulan-Ude: Izdatel'stvo BNTs. ,1997), 319; Marina Mongush, "Religiia v istorii i sovremennoi kul'ture tuvintsev," In: Religiia $v$ istorii $i$ kul'ture mongloiazychnykh narodov Rossii (Moscow: Izdatel'stvo Vostochnaia literatura, 2008), 215-241; Ol'ga Khomushku, Religiia v kul'ture narodov Saiano-Altaia (Moscow: Izdatel'stvo RAGS, 2005). 
who chanced to be in Russia at this time and even carried out field research, were attracted by the matter. ${ }^{35}$

And yet, every researcher into Shamanism in either its classical or contemporary forms had firsthand experience of interaction with shamans in the Soviet Union. I am no exception. I would not call this interaction very successful, since it carried the imprint of the time when it took place. But it allows me to make a certain number of generalizations.

In 1959, when I was a student of the Faculty of Ethnography of Moscow State University, I went to Buriatia for the first time and began the research in which I am engaged to the present day. As the object of my research I chose the Tunka region where, as I knew, Shamanism had become entwined with Buddhism and Orthodox Christianity. I knew that there were several shamans in the region and carefully looked for opportunities to meet them. Sometimes I was successful, but more often than not the shamans tried to avoid these meetings. I understood their reasons. In the young girl (i.e. me) who had come from faraway Moscow they saw not a researcher, but a threat to their existence, even more so since they were forced to carry out their shamanic activities in secret.

By this time the Soviet government had been fighting them for around forty years. The shamans had been among the first to experience this government's iron hand. When the repressions began against those who did not correspond to the new ideological standards and were not convinced of the imminent advent of the bright communist future, the shamans were among the first to suffer. Those who managed to avoid exile and forced labor camps remained in their native villages, but were now living under the vigilant eyes of the local powers. Their vocation and activities had been banned. Reluctance, and sometimes fear of putting themselves at risk, and even more so those who were seeking their help and advice, meant that the entire repertoire of shamanic rituals was moved from daytime, which had been the norm, into the night, which was considered a violation of the rules - the shamanic spirits were more responsive to the shaman's appeal for help when it was light and disliked acting in the dark. Moreover, when a ritual was carried out at night, a guard consisting of young people was positioned at some distance from the scene, whose task was to warn the shaman of the approach of unwanted guests with the help

35 Marjorie Mandelsam Balzer, "Shamans in All Guises: Exploring Cultural Repression and Resilience in Siberia," Curare: Zeitschrift für Ethnomedizin, vol. 22, no. 2, 1999, 129-134; Caroline Humphrey, Marx Went Away - But Karl Stayed Behind. Update edition of Karl Marx Collective: Economy, Society and Religion in a Siberian Collective Farm (Ann Arbor: The University of Michigan Press, 1998), 373-432; Fridman 2004, 139-150. 
of pre-agreed signs (whistling, the cry of a bird or animal). It is possible that this practice was not followed everywhere, but the late Dar'ia Tankhaeva, who lived in the village of Kyren and spent her youth in the Tory steppe, told me that between the age of 15-17 she was often told to stand guard while her uncle carried out shamanic rituals. She now found it funny to remember, but at the time was terribly afraid.

Thus in the Soviet era the shamanic tradition was preserved in secret. The shamans rarely made their activities public and their clients also kept silent for fear of both the authorities and researchers who were studying the local religious situation. They were even afraid of people who were inappropriately curious. This led to the impression that the Soviet powers had been successful, or nearly successful, in uprooting Shamanism and that Shamanism had practically self-liquidated by the 1960s. Fortunately it was not so. The shamanic tradition survived the Soviet government, and during the boom revival of traditional cultures and religions that began in Russia towards the end of the 1980s it quickly gathered strength. ${ }^{36}$

\section{The Renaissance of Shamanism and its Manifestations}

The post-Soviet period and space presented to the scholarly community and the whole world a huge boom in the most divergent religions - from world religions (Christianity, Islam, Buddhism and their national forms) to narrowly local pagan cults, some even unknown to those outside a certain village or region. Shamanism occupies a place in between these two extremes.

The revival of Shamanism gave rise to a huge wave of scholarly research into this process that was accompanied by publications in the media that lacked any scholarship and thoroughly confused the picture of what was happening. An analysis of the publications of the last 25 years (the sample begins in 1985, the year Perestroika began) allowed scholars to conclude that the processes that were going on in the shamanic world were not homogenous. ${ }^{37}$ The concept of the revival of Shamanism included a number of phenomena that were independent of each other and united under the label Shamanism

\footnotetext{
36 Natalia Zhukovskaia, "Mir traditsionnoi mongol'skoi kul'tury," Seriia Rossiiskie trudy po vostokovedeniiu, vol 11, (Lewiston-Queenston-Lampeter: The Edwin Mellen Press, 2000), 157-158; eadem, "Respublika Buriatiia: religiia v kul'turnom prostranstve ètnosa," In: Étnokul'turnoe vzaimodeistviie v Evrazii, kniga 1 (Moscow: Nauka, 2006), 332-345.

37 Valentina Kharitonova, Feniks iz pepla? Sibirskii shamanizm na rubezhe tysiacheletii (Moscow: Nauka, 2006), 234-243.
} 
solely because it is widely known and understood by many of those who are interested in various forms of esotericism.

And in fact, traditional shamanic cult sites (holy mountains, mountain passes, groves, ancestral graves et al) that had been destroyed or consigned to oblivion during Soviet times were reinstated and shamans began to perform the necessary rituals, but at the same time we also saw the formation of associations and unions of shamans within ethnically more or less homogenous regions.

The emergence of shamanic associations, which Valentina Kharitonova, who specialized in Shamanism of the post-Soviet period, wittily referred to as a "party-trade union form of socialist vestige" 38 - this was a clear deviation from the classic Shamanism of former times, which valued individuality rather than collective approaches in these matters.

Shamanism, emerging from the underground to which it had been confined from the 1920s-1980s, appeared in the most divergent spheres. Shamans began to not just perform rituals, which had always been part of their function, but to make public appearances in the mass media and propagate the shamanic worldview, to feature frequently in documentaries, to leave their native villages to travel to the large Russian cities and subsequently abroad, to Europe, America and Asia. There they began to do something of which the classic shamanic tradition categorically disapproves, namely carry out shamanic acts or heal people on alien territory, far away from their own helper spirits (which are often the spirits of their ancestors) who had remained behind. Often they simply demonstrate their extrasensory abilities without any particular reason and ask for payment.

In the context of the newly emerged associations and unions the shamans began to engage in publishing and education, which no longer bears any relation to Shamanism as a form of religious activity. Instead, it was related to Shamanism as a form of knowledge-whether religious, worldview-related, practical or natural depends on how one looks at Shamanism-but knowledge for certain.

To this category belong the maps of the sacred sites of Buriatia, re-published several times, and the now annually appearing calendars that indicate the dates for performing shamanic rituals in honor of the spirits of one's ancestors in the places where they need to be honored. ${ }^{39}$ It is clear that the traditional shamans could not have coped with these undertakings. But the new generation of sha-

38 Idem, 156.

39 Sviashchennye gory Baikal'skogo regiona. Kalendar' tradtsionnykh obriadov. (no place given, 2005); Traditsionnye shamanskie obriady (Religioznyi kalendar') (Ulan-Ude, 2001). 
mans, who were in demand in the new Russian reality, coped well. And now we have finally arrived at the topic mentioned in the title of this paper: Shamanism and the intelligentsia in Russia in the post-Perestroika period.

I want to mention straight away that my analysis is mostly based on the material from Buriatia that I know well, because I am a specialist in this area, travel there every year to go on expeditions and try to keep up with events taking place there. The generation of shamans that has appeared in Buriatia over the last two decades can be called the shamanic intelligentsia, which of course does not apply to each and every individual shaman. Realizing the somewhat conditional character of this concept I want to explain what I mean. First and foremost, this is a young generation of shamans, not in terms of age (many of them are well over forty and some are much older) but in terms of the relative recency of their vocation to perform shamanic tasks. It seems that Perestroika, and in particular the years after it, had a profound influence on the shamanic spirits too, giving them an incentive to extend the "call" to Shamanism to representatives of a new, young generation who harbor contemporary ideas. Typically, these people hold a degree from a secular higher education institute and have experience in working in different secular establishments, such as higher education institutes, schools, libraries or public administration, which can be easily combined with the performance of shamanic duties. It turned out that it is perfectly possible to pursue a secular career and belong to the regional intelligentsia while also being a shaman, without experiencing any ideological or practical discomfort.

A particular interesting example of this kind of synthesis we find in the biography of Iurii Kharaev (d. 1996). He was a distinguished cultural figure in the Republic of Buriatia and worked for almost twenty -five years as the director of the Republic's national library. At the same time he was a well-known shaman whose clientele included not only his kinsmen, but also members of the government apparatus of the Republic of Buriatia and the Republic's higher technical and cultural intelligentsia. His former clients and "colleagues" in the shamanic trade remember him with great warmth and respect. There is no doubt that he was one of the most outstanding representatives of the Buriat intelligentsia in general and a just as outstanding representative of the shamanic intelligentsia in particular. After his death Pravda Buriatii, the main print organ of the Buriat government, published an obituary that listed all his secular achievements and appointments and ranked his activity as a shaman alongside them. The obituary was signed by the republic's highest-ranking officials. This was the first time the achievements of a member of the intelligentsia as a shaman were publicly acknowledged. 
Another example of this combination is Nadezhda Stepanova, a graduate of the library section of the Institute of Culture in Ulan Ude (today the East Siberian State Academy of Culture and Art). For a few years she taught "The Principles of Shamanic Practice" at the department of Ethnology and Folklore at this Academy. Since 1993 she has been the president of the Shamans' Association of Buriatia, and since 2001 also the president of the Shamans' Association of Central Asia. She has visited Italy, France, Brazil, the USA and other countries and there shared her own experience with members of the public who are interested in esoterism in its various forms. The Italian documentary filmmaker Constanzo Aleone has shot a documentary on Stepanova, and a book has been published in Italy with her stories about herself, how she became a shaman, how she became aware of her shamanic gift and tried to ignore it, what miseries befell her family as a result and how she had to become a shaman after all. Today she is the best-known representative of the Buriat shamanic circles in the international arena.

And another example from the same sphere. In the Soviet period, EshinKhorlo Tsybikzhapova was a teacher and lecturer at the regional centre for public education and later a member of staff member at the Buriat Institute for the Enhancement of the Qualifications of Staff in Education. Since the early 1990s she has been practising as a shaman who is known for her special healing gift-she can heal with the help of sound, song, tunes to the words of nonexistent but nevertheless phonetically recognizable languages with which she, like a painter with his brush, "paints" a picture of her client, in the course of which she discovers the diseases that have befallen him or her and heals them through her song. After leaving Buriatia, where there are many shamans fighting for space in a relatively small republic, for Novosibirsk oblast', where there are practically no shamans at all, she began giving courses on the perfection of the psychological and physical nature of the human being. Most of her clients are young and middle-aged women who are, for various reasons, experiencing a high degree of stress. She helps them rediscover their faith in their own strength and potential and find inner harmony.

At some point she understood that her psychological knowledge was insufficient and graduated from Novosibirsk University's correspondence course program. Now she is herself teaching psychology at Buriatia State University, but has not given up her shamanic practice. Yet she no longer calls herself a shaman, believing that she has outgrown this label and requesting to be called a psychologist or even psychotherapist instead. ${ }^{40}$ To her patients it does not

40 N. Zhukovskaia, "Buriatskie shamanki na mezhdunarodnoi konferentsii (tunkinskii opyt, iul' 
matter what she calls herself, what matters is that she has preserved her healing gift, which is shamanic in its essence, and that she uses it for the good of others.

Stepanova and Tsybikzhapova are urban shamans. Caroline Humphrey has produced an interesting description of their shamanic biographies and their trajectory from being ordinary members of the secular urban intelligentsia to becoming shamans. Humphrey recorded detailed and rather open stories about their shamanic experience from both women. ${ }^{41}$

In 1993 the Society of Buriat Shamans was founded, at first under the name Khese khengereg (literally Clanging Tambourine), subsequently renamed Bee murgel (literally Shamanic faith). This society, a fundamentally new phenomenon, unites the old and new generations of professional shamans and was brought into being by the characteristic features of social and public life in Russia in general and in Buriatia in particular. The Society is registered with the Ministry of Justice of the Buriat Republic and has the same status as more than hundred other denominational organizations in the republic, such as Buddhist monasteries (datsany), Orthodox churches, Old Believers' (the so called "semeiskie") communities, new religious centers (the Bahai, the Hare Krishnas, Protestant missions that emerged in the mid- $20^{\text {th }}$ century et al). According to the Ministry of Justice, there were 228 religious communities registered in the Buriat Republic at the end of 2009. Among them are three shamanic ones-Bee murgel (Shamanic faith), Lusad (Water Spirits) and Téngeri (The Heavenly World). The two latest ones emerged fairly recently and unite shamans who stem from Irkutsk oblast' and the Aginsk steppe but who are living in the Buriatia Republic. Yet another shamanic organisation was founded in 2009-Khukhè Munkè Téngèri (Eternal Blue Sky).

Why do shamans choose to form organizations? New times dictate new rules. There are several reasons for the legalization of shamans. The law "On religious activity on the territory of the Republic of Buriatia", which names Shamanism as one of four traditional religions in Buriatia, protects the sacred cult sites and allows the performance of certain rituals at these sites, but also demands that the shamans register their cult sites as special protected objects. This is required to avoid conflict with the representatives of other denominations who claim the same sacred site, or any agricultural organizations that might decide to use the site and damage it. One shaman on his or her own

2004 g.), In: Zhenshchina i vozrozhdenie shamanizma'. Etnologicheskie issledovaniia po shamanstvu $i$ inym verovaniiam i praktikam, vol 11 (Moscow: IEA RAN, 2005),142-145.

41 Caroline Humphrey, Postsovetskie transformatsii v aziatskoi chasti Rossii. Antropologicheskie ocherki (Moscow: Natalis, 2010), 364-380. 
would hardly be able to gain justice; this can only be achieved by an organized community of shamans.

The shamans' organizations have yet another objective, and that is to block the way of pseudo-shamans, of whom there have been quite a few recently. According to the shaman Dugar D. Ochirov in an interview with Mihály Hoppal, the president of the International Society for the Study of Shamanism, "our shamanic society was created to stop charlatans from performing rituals; and whoever considers himself a shaman must demonstrate his abilities and perform rituals - this is one of the preconditions of admission to the Society of Shamans." ${ }^{42}$

The Society is also active in other fields. We can list a number of "events" (if this word can be applied at all to shamanic practice and cultural tradition) the society either organized or that took place with its knowledge and the participation of its members. They include a series of tailgan (ancestral sacrifices) in honor of the "Thirteen lords and masters"- personages from the shamanic pantheon of the Baikal Buriats. These lords are considered the ancestors and forefathers of various ethnic subdivisions on which the prosperity of the entire Buriat people depends, according to the shamans. In our age this idea is more than timely. It testifies to the fact that the shamans are concerned about the fate of the people as a whole and are trying to exert beneficial influence with the help of traditional methods.

The planned tailgan were held for the first time in July and August 1993: the first was held in honour of the lord of the island of Ol'khon-Oikhoni buural-babay; the second was in honour of the lord of the mountain Baragkhan in Barguzin; the third in honour of the forefather of the Bulagaty Bukha-noion, who was also the patron and defender of all Buriats; the fourth in honour of Burin-khan, the spirit of the mountain of Munku-Sardyk, the highest point of the range of the Eastern Saian Mountains etc.

In the last years, Tailgan in honour of the patron spirits of local mountains, wells and passes have been held entirely officially, and the participants have included not only representatives of the Society of Shamans, but also of the authorities (in some cases even the heads of the regional administration). The heads of the regions thus publicly display their loyalty to the traditional religious culture of the population, which is particularly important during election campaigns. In 2002 a Tailgan was held on the occasion of the $840^{\text {th }}$ anniversary

42 N. Zhukovskaia, "Buddhizm i shamanizm kak faktory formirovaniia buriatskogo mentaliteta," In: Religiia $v$ istorii $i$ kul'ture mongoloiazychnykh narodov Rossii, (Moscow: Izdatel'stvo Vostochnaia literatura, 2008), 9-36, 28-29. 
of the birth of Genghis Khan, perceived by the population of Central Asia, especially in Mongolia and Buriatia not, as in Russian historical science, as a conqueror, oppressor and destroyer but, conversely, as the great creator of the Mongol empire, god-patron of all Mongol peoples and Man No 1 of the second millennium. The participants comprised shamans not just from Buriatia, but from Mongolia as well, alongside representatives of various ethnic groups and, naturally, representatives of the authorities on republican level.

The next area in which we see an interpenetration of the spheres of shamans and intellectuals is scientific conferences, either on Shamanism or more broadly, on the cultural history of the peoples of Central Asia and Southern Siberia, who are sometimes compared to the indigenous cultures of North America. The participation of shamans in scientific conferences is one of the most interesting phenomena of the post-Soviet stage in the development of Shamanism. I would define it as the fusion of Shamanism with Shamanology (Shamanism studies), that is, the fusion of a cultural phenomenon and the scientific study of it. In it, two streams converge. The first stream features shamans who are striving towards science, while the second consists of scholars of Shamanism who desire to be initiated into Shamanism. The latter are most often scholars of Shamanism from regions where Shamanism is part of the national tradition and/or scholars who have shamans among their ancestors and who think that their knowledge of Shamanism gives them a right to be initiated into Shamanism.

At first the shamans strictly opposed these ambitions. However, the devaluation of various kinds of values in societies that have lost their moral criteria, to which Russia unfortunately now belongs, took its toll here, too. I am aware of several cases in which scholars of Shamanism, or even of subjects other than Shamanism, received the desired initiation. Also known is the sum they paid for this- $\$ 300$ US. The fact that this sum is the same in all cases tells us that yet another unwritten rule of shamanic ethics has been violated, which stipulates that the shaman does not name a sum, but waits until the person who has ordered the ritual pays of their own accord the sum they can afford or consider appropriate.

But let us return to the subject of scientific conferences that are attended by shamans. The first such conference took place in August 1992 in Yakutsk and was called "Shamanism: Genesis, Reconstruction, Traditions." After this first attempt such conferences became a regular feature and were held every two or three years in Buriatia, Tuva, Khakassia and even in Moscow. The last of them, defined as the International Interdisciplinary Symposium "Psychophysiology and Social Adaptation among (Neo) Shamans in Past and Present," took place 
on 2-8 August 2010 in the town of Arshan in the Tunka region of Buriatia. It had a rather varied programme and demonstrated that the field of questions under debate had become much wider since the first conference in Yakutsk. At the conference in Arshan scholar-theoreticians and shaman-practitioners jointly discussed the following issues: 1) The psychophysiology and social adaptation of (neo) shamans; 2) The changed state of consciousness in the practice of (neo) shamans and storytellers and issues of creative self-expression; 3 ) (Neo) shamans in the human world and the spirit world; the phenomenon of personality; 4) The shaman and the pagan priest: limitations and specifics of practice, their role and place in the social medium. The programme of the symposium included a Tailgan at the foot of the sacred mountain which is considered the residence of Bukha-noion, the personage from the shamanic pantheon that is respected by all Buriats. The Tailgan attracted more than one hundred participants who had travelled from all over the Baikal region. The Tailgan was led by shamans who were members of the religious organization Téngeri and who had attended the symposium, giving papers and speeches. There were also showings of films on Shamanism and shamans that had been shot by scholars in many different countries.

While in Yakutsk I focused on the question of what attracts shamans to scientific conferences where scholars, using their professional language, give papers that are hardly accessible to anyone outside the scholarly community. However, it has turned out that the language of scholars is very accessible to contemporary shamans, most of whom hold higher degrees, but they do not agree with the things scholars write about Shamanism and shamans, considering the research on themselves to be "incorrect" and think that they are better equipped to talk about themselves at scholarly conferences. This is not surprising, given that the shamans have inside knowledge of their art and profession, while the task of the researcher is by definition external. This is the reason why I find the desire of shamans to fuse their gift with the ability to explain it well so interesting. It means that a new source for the study of Shamanism is emerging. What is even more important, it concerns contemporary Shamanism, giving us the opportunity to contrast the contemporary situation within and around Shamanism with the one that has been studied by subsequent generations of scholars from the mid- $19^{\text {th }}$ century onwards.

There is already some experience in this field. One example are the books of the shaman and healer Nadezhda Angaraeva, who recently also rejected the title of "shaman" and now considers herself a priestess of the Tèngrian cult. ${ }^{43}$

43 Nadezhda Angareva, Vremia ognia (Ulan-Ude,1996); eadem, Vetochka verby s bubentsami 
Another example is the Sacrament and Practice of Shamanism (Tainstvo i praktika shamanizma) by Boris Bazarov, a shaman from Barguzin. ${ }^{44}$ Yet more examples are the shaman Nadezhda Stepanova's book of short stories about herself, edited and translated by the Italian journalist D'Arista, ${ }^{45}$ and Eshin-Khorlo Tsybikzhapova's books that are not even about Shamanism, but about the heroic epos Geser in the light of philosophy and cosmic harmony. ${ }^{46}$ These works prepare the ground for considerations about the nature and depth of shamanic sacraments, with the authors prepared to facilitate the grasp of these sacraments in every possible way, although they also warn of the danger secret knowledge presents to the uninitiated and the overly curious. Working in direct contact with them, I received several warnings that I was approaching a dangerous border which I, as an uninitiated person, was not meant to cross. As a scholar I was upset by this, but as a human being I was very grateful for the warning.

There is yet another field of activity in which shamans, scholars and professional ecologists put up a united front, and that is the preservation of the environment and landscape features (mountains, lakes, rivers, forests etc) and of cultural objects, created by human hands throughout history (archaeological monuments dating from different epochs, cult buildings etc). In Siberia, this field of activity has been very important during the last three decades because of the unchecked actions of oil and gas companies who are exploiting oil and gas reserves and building pipelines in areas which are protected as natural and cultural sites by a number of federal laws ("On the guaranteed rights of indigenous small peoples", adopted in 1999; "On the preservation of the environment", adopted in 2002; "On the animal world, adopted in 1998; "On the objects of cultural heritage (monuments of history and culture) of the peoples of the Russian Federation", adopted in 2002). All these laws are being deliberately ignored and constantly violated with the connivance of the central and local authorities, who are receiving sizeable amounts of money from the abovementioned companies for not meddling in their affairs.

The ones who struggle for the "small fatherland", for the preservation of hunting grounds and pasture, are the local population together with ecologists

(Ulan-Ude), 1997; idem (Наёхан), Krasota beskorystnoi liubvi (Ulan-Ude, 2002).

44 Boris Bazarov, Tainstva i praktika shamanizma. Kniga 1 (Ulan-Ude, 1999); Kniga 2 (UlanUde, 2000); Kniga 3 (Ulan-Ude, 2009).

45 Nadia Stepanova, L'Invocatrice degli Dei. Storie di vita di una Sciemana Buriata. Raccontata C. D’Arista (Milano, 1998).

46 Eshin-Khorlo Tsybikzhapova, Kosmicheskaia èvoliutsiia v geroicheskom épose ,Geser' (UlanUde, 1998). 
from NGOs; often they also attract the local shamans to their cause. The most potent means of protest the shamans have at their disposal is to perform traditional rites at these sacred sites, addressing the local spirits and asking them to protect the sacred sites of the ethnic territories.

Unfortunately this does not always help. The best-known case where it did is the confrontation in 2002 between the Tunka National Park and the international oil company YUKOS, where the involvement of shamans (supported, by the way, by other economic and political measures) helped avert the destruction of more than twenty sacred sites and four villages in the Tory steppe with their epibiotic vegetation. This topic has been covered in scientific literature. ${ }^{47}$

However, science is not the only way of putting one's knowledge into practice that attracts the shamans. They also take an interest in the theatre, as the shamanic and the theatrical performances are related and thus the theatre also represents a world that allows the shaman to display his or her talent. I am only giving one example here.

In May-June 2001, the Second World Theatre Olympics took place in Moscow. Apart from theatre companies from different countries, and above all from Russia, there were also shamans from Buriatia, Tuva, Khakassia and Moscow (!?). The shamans from Buriatia were represented by Bair Ts. Rinchinov (accompanied by three of his helpers), a representative of the Aginsk Buriat, who is considered a very strong shaman in his region. In the context of the shamanic master-class that took place at the Olympics, he performed a nightly shamanic ritual which, although it took place on the stage of the new building of the Theatre School for Dramatic Art (director Anatolii Vasil'ev), made a very strong impression on those present.

Shamans of the type described above are often referred to as neo-shamans or urban shamans, which is not quite the same. ${ }^{48}$ However, the name is not the most important element. It has fallen to these people to re-establish and develop an important cultural, psychological, moral and medicinal tradition which is a constituent element of the people's mentality and was interrupted for seven decades during the Soviet era.

Everything cited above refers to the representatives of the intellectual stratum who became aware of their shamanic gift and were initiated as shamans in

47 See N. Zhukovskaia, "Heritage versus Big Business: Lessons from the YUKOS Affair," Inner Asia, vol. 11, no. 1, 2009, 157-167. Shapkhaev 2008, 55-60.

48 Valentina Kharitonova, Anna Ozhiganova, Nadezhda Kupriashina, "V poiskakh dukhovnosti i zdorov'ia (novye religioznye dvizheniia, neoshamanizm, gorodskoi shamanism)," In: Issledovaniia po prikladnoi i neotlozhnoi ètnologii, no 207 (Moscow: IEA RAN, 2008). 
the post-Soviet era, having either come from a position in the state apparatus or pursued a free profession. However, there was also the educated rural or urban intelligentsia, the members of which considered themselves far removed from the traditional views of their ancestors and did not believe in any spirits or their ability to influence peoples' lives. One example I encountered during my expeditions in the 1990s demonstrates the degree to which this applied.

During these years a woman called Vera Khromtsova worked as a schoolteacher of biology and chemistry in the village of Tory in the Tunka region of Buriatia. Her father was Buriat, her mother Russian, she considered herself Russian. When I asked her about her religion she answered "atheist"; she did not believe in any gods, whether Christian or Buddhist, and even less so in shamanic spirits. Priests she contemptuously referred to as frauds and swindlers, no matter of which religion. In her lessons and excursions she acquainted her pupils with the nature of their native region and taught them how to observe it. All her actions were evidence of a practical mindset devoid of any tendency towards exalted views.

Once we met in the street of the village and began a conversation on some topic. We were interrupted by her neighbour who walked past and asked:

- Vera, why did you pull the sacks out from the cellar yesterday? The conversation carried on:

- Well, Badma came-Vera began, but her neighbour interrupted her.

- Which Badma?

- Badma Tsyrenova.

- But she died two years ago.

— That's what I'm saying. Badma came and said "Take the sacks out from the cellar."

- And you didn't ask her why?

- I didn't have time, she left immediately.

Three days later the upper end of the Tunka valley saw very strong rainfalls, which led to the groundwater rising and flooding all cellars, destroying the food reserves that many people kept there. Those who had been "visited by Badma" and "warned" to take out the food reserves (sacks of potatoes, carrots, cabbages, turnips, jars of jam and pickles-all that which can be destroyed by water in the cellar) did not suffer damage from the elements.

The following moments render this everyday episode from the Buriat village interesting. No one was surprised to see the recently (or not so recently?) deceased Badma in the flesh, not even the atheist schoolteacher. Many families have their own "Badma", as a rule a deceased relative whose appearance usually warns them of some impending misfortune. However, in order for this to hap- 
pen one condition must be fulfilled-the graves and souls of the deceased ancestors must not be neglected and forgotten by their descendants. Only when this memory is present and regular sacrifices of food and drink are made to the souls of the ancestors, when they are remembered and called to the ancestral sacrificial offerings (tailgan) can a thread emerge that links descendants and ancestors and enables the latter to assist their living kinfolk.

\section{Shamanic Practice in Moscow}

However, matters were not limited to the regions only. In the years following Perestroika the intelligentsia in the capitals, too, caught the Shamanism bug. This bug has even been given the scientific name "experiential Shamanism", from the English term "experience". Its initiator is Alina Slobodova, a professional psychologist, graduate of Moscow State University and student of Michael Harner, an American scholar of Shamanism who set up the Center for the Development of Shamanic Practice in California and subsequently branches of the Center in many countries. Using his methods, Slobodova in the early 1990s founded a school seminar in Moscow which she called Moscow Shamanic Center.

By the end of the $20^{\text {th }}$ century she had hundreds of followers who honestly thought that what they were doing in this school was real Shamanism. Michael Harner believed that everyone can become a shaman if he receives the appropriate training according to a certain methodology and masters a certain amount of practice. The firm belief that this is possible and that it is not necessary to have a long line of ancestors who were shamans (and how could a Muscovite have one, whose ancestors always lived in central Russia and had no relation to the shamanistic world), have made this center extremely popular. Alina Slobodova herself maintains that her students and the students of her students who have graduated from the Center and its branches number one thousand. ${ }^{49}$ It is likely that by 2011 they have become much more numerous. The circle of followers of experiential Shamanism includes members of the intelligentsia working in different professions, representatives of small and medium-sized business, women who do not work (the wives of wealthy men who need not worry about money and how to feed their families).

49 Valentina Kharitonova, “Alina Leonidovna Slobodova," In: Zhenshchina i vozrozhdenie shamanizma, Etnologicheskie issledovaniia po shamanstvu i inym verovaniiam i praktikam, vol. 11 (Moscow: IEA RAN, 2005), 349-358. 
What is it that attracts members of the creative intelligentsia and businesspeople to shamanistic centres and unions? There are several reasons, although in some cases a single reason is probably sufficient, while in others all the reasons were at work. First of all, many associate the interest in non-traditional forms of medical practice first and foremost with Shamanism. Secondly, there is the search for ways to counteract stress, which affects so many people in our day. Thirdly, there are various forms of the search for oneself, one's roots, one's talents and ways of realizing these talents. Fourthly, the activity of shamans, which was banned for many decades, like all banned things attracted the interest of many of those who came in contact with it or at least heard about it. As soon as the bans were lifted, Shamanism became some kind of fashion, and initiation into this world, often accidental and without understanding of the inherent dangers, was seen as a token of belonging to an elite, a prestigious token that offered an "immersion" into this virtual world.

There are possibly other reasons too, but the four I listed above explain the overwhelming majority of cases of immersion into Shamanism by members of the intelligentsia.

One has to add that the founder of the Moscow Shaman Center, Alina Slobodova, does not insist on being called a shaman, or on calling her activity Shamanism. It was the press who christened her a shaman. She refers to herself as a psychologist and psychotherapist who is using shamanic practices. ${ }^{50}$ And now, having founded several schools in different Russian towns that are headed by her disciples she considers that she has outgrown all this, that she is going further while maintaining shamanic spiritual practices (contact with spirits, immersion in trance, "flights" through different worlds, reception of energy from a helper animal) and holding training events, but already at a different level. At the same time she admits that the interest in these practices is falling, although those who mastered them with the aim of health improvement and self-perfection would most probably not abandon them. ${ }^{51}$

50 Idem, 2005, 354.

51 Idem, 2005, 357-358. 


\section{COMPETING LEGACIES, COMPETING VISIONS OF RUSSIA: THE ROERICH MOVEMENT(S) IN POST-SOVIET RUSSIA}

JOHN MCCANNON

In Ten Days That Shook the World, his classic account of the Russian Revolution, journalist John Reed noted dryly that, in Petrograd, the year of 1917 was "a particularly active season for Theosophists." Reed's implication-that alternative belief systems flourish in times of social and political instability-holds just as true for Russia's post-Soviet aftermath as it did for the period of tribulation that preceded the USSR's birth. During the long transition that began with the glasnost' campaign of the late 1980s and continues to the present day, a combination of excitement, curiosity, uncertainty, and frustration has sparked a widespread spiritual revival among contemporary Russians, causing many to embrace not just conventional religion in the form of Orthodox Christianity, but a tangled variety of mystical, esoteric, and occult practices.

Of these, among the most successful, and yet most controversial, has been the movement-more precisely, the cluster of movements-dedicated to the teachings of Nikolai Roerich [Rerikh] (1874-1947), the prominent Silver Age painter who, in emigration, gained fame for his peace activism and his artisticarchaeological expeditions to Asia, and, with his wife Helena [Elena], created the Theosophically-derived doctrine of Agni Yoga, known also as the "system of living ethics." Roerichism draws advantage from its association with a versatile, internationally-known celebrity, as well as its exceptional doctrinal elasticity, which allows the views and enthusiasms of a wide variety of adherents to be accommodated. ${ }^{2}$ In particular, Roerich's vision of a morally pure Russia, connected organically to Asia and the Christian world by virtue of its geographic position, holds enormous appeal for those who seek a belief system that sustains them spiritually and reinforces their sense of self-worth as Russians, but who, for whatever reason, derive little satisfaction from Russian Orthodoxy. Also, the Roerich family's ambiguous relationship with Soviet power has made

1 John Reed, Ten Days That Shook the World (London: Penguin, 1986), 38.

2 I use the term "Roerichism" as an umbrella term to include all spiritual outlooks that involve a meaningful degree of admiration for Roerich. I interpret "Agni Yogist" to mean someone pursuing a narrower and more dedicated commitment to the "living ethics" (zhivaia étika) outlined in the Roerichs' 14-volume "Agni Yoga" series. 
it unusually, if not uniquely, viable for Roerich to be adopted as an object of admiration by Russians who reject the country's Marxist-Leninist past and by those who mourn communism's demise.

On the other hand, that same ambiguity contributes to the many controversies that have surrounded Roerich movements since the collapse of the Soviet regime. Astoundingly for someone so famous, some of the most basic facts of Roerich's life story remain the subject of intense debate, none more so than the question of his poorly-understood collaboration with the Soviet regime, and whether this involved espionage or, as seems far likelier, a more tentative and less successful interchange. Not only have these debates affected Roerich's reputation among the Russian public, they have caused rifts among those actively dedicated to Agni Yoga. Other issues bedeviling the Roerich movements include disputes over institutional and doctrinal authority, competition over custodianship of Roerich's art and the family's personal effects, public condemnation of the Roerichs by the Russian Orthodox Church, and, most profoundly, a failure to arrive at a unified understanding of Roerich's vision for Russia, its future, and its place in the world. This essay will trace the explosion of public interest in Roerich that began in the late 1980s and early 1990s, along with the rise of Roerichite groups and circles, including the International Center of the Roerichs (MTsR) in Moscow. It will also address the controversies outlined above, especially the unceasing struggle to resolve competing articulations of Roerichism.

\section{The Roerich Revival and Russia's Transition from Communism}

As described in Markus Osterrieder's chapter, Roerichite currents flowed through the Soviet Union following the artist's rehabilitation-and the return of his older son, the orientalist George, or Iurii-in the late 1950s. ${ }^{3}$ Roerich was restored to the canon of great Russian artists; during the Cold War, he served as a useful symbol in depictions of the USSR as committed to world peace and to fraternal relations with Asia, thanks to his lifelong advocacy of the Banner of Peace Pact (also known as the Roerich Pact), whose purpose was to protect art

3 At the invitation of Nikita Khrushchev, Iurii Roerich returned to the USSR and took up a position as a Tibetologist with the Russian Academy of Sciences. In 1958, a major exhibition of Roerich père's paintings was held in Moscow, and cautiously sympathetic reviews such as $\mathrm{N}$. Dmitrievna, "Vystavka proizvedenii N. K. Rerikha," Iskusstvo 8 (1958); and N. Sokolova, "Rerikh,” Oktiabr' 10 (1958), signalled his artistic rehabilitation. Also see Birgit Menzel's chapter in this volume. 
in times of war, and to the many years he and his family resided in India. ${ }^{4} \mathrm{Be}$ tween the 1960s and the 1980s, key centers of Roerich-related activity cropped up in Riga, Tallinn, Izhevsk, and Novosibirsk, and the 1974 centennial of Roerich's birth unleashed a flood of commemorations and publications dedicated to him, including a library of standard biographies and collections of his writings. ${ }^{5}$

Still, if Roerich's influence flowed readily, it did not do so with complete freedom. His expeditions were portrayed as strictly artistic and scholarly endeavors, and allusions to the political motivations underlying them were risky - as was open discussion of Roerich's mysticism, which had to be kept as rarefied and abstract as possible, with emphasis on "universal profundity" and "keen insight" into the philosophies of the east. There was no room for talk of the Roerichs' past as Theosophists and mediums, nor was it safe to study Agni Yoga as an esoteric doctrine, as demonstrated by the 1979 crackdown visited upon Academy of Sciences scholars in the Novosibirsk suburb of Akademgorodok, where a subgroup of the city's large Roerich circle tried to promote Nicholas's and Helena's thesis from the 1920s about the reconcilability of Agni Yogist mysticism and Marxist-Leninist communism. "Your Blavatskian tendencies have placed our institute in a difficult situation," the authorities thundered as they forced recantations all around. "If you wish to continue being considered communists, you had better rethink your position." 6 The state responded similarly in Izhevsk, where, in 1983, a member of the local Roerich group claimed to be receiving psychic sendings from Shambhala. ${ }^{7}$ At roughly the same time, poet Valentin Sidorov stirred up a public storm by publishing his Roerich-inspired travelogue Seven Days in the Himalayas (Sem' dnei v Gimalae) in the journal Moskva.

All this changed in 1987, when sponsorship from the highest levels of

4 On the Roerich Pact, see Mark Boguslavsky, "Legal Aspects of the Russian Position in Regard to the Return of Cultural Property," In: The Spoils of War, ed. Elizabeth Thompson (New York: Abrams, 1997); and Karl Meyer, "Limits of World Law," Archaeology 48 (July-August 1995), 51. Many works, including biographies of Indira Gandhi and various collections of letters, attest to Roerich's friendship with prominent Indians, including Jawaharlal Nehru and the poet Rabindranath Tagore.

5 See, for example, N. K. Rerikh, Iz literaturnogo naslediia (Moscow: Izobrazitel'noe iskusstvo, 1974); idem, Izbrannoe (Moscow: Sovetskaia Rossiia, 1978); A. D. Alekhin, Nikolai Konstantinovich Rerikh (Moscow: Znanie, 1974); and Katalog khudozhestvennykh proizvedenii N. K. Rerikha s 1885 po $1947 \mathrm{gg}$. (Novosibirsk, 1974).

6 Igor' S. Kuznetsov, Inakomyslie v Novosibirskom Akademgorodke: 1979 god (Novosibirsk, 2006), passim.

7 Roman Lunkin, "Rerikhovskoe dvizhenie," In: Sovremennaia religioznaia zhizn' Rossii, vol. 4, ed. Michael Burdo and Sergei Filatov (Moscow: Logos, 2006), 20. 
Soviet leadership raised Roerich's prestige to unprecedented levels. That year, after a May 14 meeting with Roerich's younger son, the artist Sviatoslav, Mikhail Gorbachev began speaking with approval about the "Roerich idea," praising the Roerich family as "cultural pillars" and "outstanding representatives of our country." "Gorbachev and his wife Raisa enjoyed a warm relationship with Sviatoslav, and Raisa, who grew up in the Altai region (where Roerich's memory is particularly well preserved) and greatly admired Indian thought, is rumored to have sympathized with Agni Yoga, speaking in her own autobiography of Roerich's "wisdom." More than that, Gorbachev wished to use the "Roerich idea" to revitalize a Soviet ideology whose symbolic force had been exhausted by overuse and public cynicism dating from the stagnation (zastoi) of the Brezhnev era. ${ }^{10}$ Gorbachev appears to have calculated that Roerichite thinking, properly packaged, would infuse the Soviet worldview with a potent combination of aesthetically-appealing and exotic imagery; a pride in Russia that was neither chauvinistic nor at odds with the multiethnic nature of the Soviet state; an associative link between the USSR and respect for the ideals of peace, culture, and beauty; and the possibility of spiritual enrichment without the need for conventional religious faith. In October 1989, Gorbachev, supported by Sviatoslav and the academician Dmitrii Likhachev, the government's chief adviser on cultural affairs, allocated funds for the creation of a Soviet Roerich Foundation to locate and gather Roerich's art, manuscripts, and belongings, and a Center-Museum to stimulate Roerich studies.

The driving force behind both bodies' work was the Center-Museum's head, Liudmila Shaposhnikova, an indologist and journalist with powerful connections among the Soviet elite and a personal acquaintance with Sviatoslav Roerich dating back to 1968. In 1990 and 1991, Shaposhnikova established cooperative ties-for the moment-with Roerich societies throughout the USSR and in Bulgaria, Australia, Mexico, Canada, Germany, and Switzerland, as well as with India's International Roerich Memorial Trust (which held responsibility for maintaining the family's former residence in the Kulu valley village of Naggar) and the Nicholas Roerich Museum in New York. In May

8 Pravda (May 15, 1987). Also Bernice G. Rosenthal, "Introduction," In: The Occult in Russian and Soviet Culture, ed. Bernice G. Rosenthal (Ithaca/NY: Cornell University Press, 1997), 29.

9 Raisa M. Gorbacheva, Ia nadeius' (Moscow: Kniga, 1991), 135-140. Also Sylvia Cranston, HPB: The Extraordinary Life and Influence of Helena Blavatsky (New York: Putnam, 1993), 551-152; and Newsday (December 5, 1989).

10 On the weakening appeal of Soviet symbology under Brezhnev, see Christel Lane, The Rites of Rulers: Ritual in Industrial Society - The Soviet Case (Cambridge: Cambridge University Press, 1981), passim. 
1990, with the aid of Iurii Vorontsov, the USSR's deputy minister of foreign affairs, and with Sviatoslav's apparent blessing, Shaposhnikova scored a major coup by recovering from the Roerichs' home in Bangalore, India, a treasure trove that included 432 paintings, several tons of books and letters, numerous objets d'art, and at least a portion of Nicholas's and Helena's funerary ashes. ${ }^{11}$ These materials were formally presented to the Soviet people on October 9, 1990 , the $116^{\text {th }}$ anniversary of Roerich's birth.

But by this time, the Roerich revival, as with so many glasnost' initiatives, was going farther, and in different directions, than Gorbachev had intended. In keeping with the general interest in New Age practices that blossomed during the last years of the Soviet period, many of Roerich's admirers became more boldly and openly occultist-as witnessed, for example, by the strong Roerichite orientation of the Russian Theosophical Society, reconstituted in 1990-1991 after a seven-decade hiatus. Also, conceptualizations of Roerich diversified, making it difficult to settle on the single "Roerich idea" that Gorbachev had originally envisioned. Certain leaders had connections with the Roerichs that rivalled Shaposhnikova's and could therefore claim equal right to interpret the family's teachings and desires. The founders of the Siberian Roerich Society, Natalia Spirina and Boris Abramov, had studied with Roerich himself in Harbin, Manchuria, during the 1930s, and Pavel Belikov, the longtime head of the Estonian Roerich Society, had corresponded with him during the 1940s. Prominent members of the Moscow Roerich Society, founded in 1990-1991, had similar ties: the artist Boris Smirnov-Rusetskii had been a member of the Amaravella school inspired by Roerich in the 1920s and 1930s, and had met Roerich in 1926, while the indologist Natalia Sazonova had known Sviatoslav Roerich almost as long as Shaposhnikova had. Finally, in ways that presaged the quarrels of the post-Soviet 1990s and 2000s, institutional imperatives threatened to clash: leaving aside the works held by collectors and galleries in America, India, and Europe, many of Roerich's paintings, designs, and belongings were held by various museums in Russia, including the Tretiakov Gallery, the State Russian Museum, the Bakhrushin Theatrical Museum, numerous regional museums (especially the Novosibirsk Picture Gallery),

11 Irma Mamaladze and Liudmila Shaposhnikova, "Nasledie Rerikha," Literaturnaia gazeta 22 (May 30, 1990). Also see Maria Carlson, 'No Religion Higher Than Truth': A History of the Theosophical Movement in Russia, 1875-1922 (Princeton/NJ: Princeton University Press, 1993), 196, 246; and the foreword to K. N. Riabinin, Razvenchannyi Tibet (Magnitogorsk: Amrita-Ural, 1996), 22-25. According to Rae Barkley of the Institute for Visionary Leadership, a Roerich-oriented retreat in Northfield, Vermont, some of the Roerichs' ashes remained in India (interviews with the author, winter 1998-1999). 
the Izvara Estate-Museum outside St. Petersburg (the country retreat owned by Roerich's family during his childhood), and, most important, the State $\mathrm{Mu}$ seum of Oriental Art (MOOA, today the Museum of the East). Each had its own stake in how the Roerich revival worked out.

All the same, it appeared in 1990 and 1991 that some degree of coherence and cooperation would prevail, with the Soviet Roerich Foundation and its Center-Museum providing leadership and coordination. In March 1991, the first All-Union Meeting of Roerich Societies-attended also by foreign representatives, including from the Nicholas Roerich Museum (NRM) in New York-agreed to transform the Center-Museum into the International Center of the Roerichs, which would manage a new Roerich Museum and a charitable fund to be named after Helena Roerich. The MTsR's first president was Iurii Vorontsov, who used his UN connections to have the Center named an associate organizational member of UNESCO. Shaposhnikova took the posts of MTsR director and Roerich Museum head, and also the presidency of the Helena Roerich Fund. Over the course of the year, the MTsR acquired as its home base the sumptuous Lopukhin Estate on Malyi Znamenskii Lane, only a short distance from the Kremlin Embankment and the Pushkin Museum of Fine Arts. All this transpired against the backdrop of the USSR's final disintegration, and it was only in December 1991, on the very eve of the Soviet Union's final disbandment, that the MTsR formally registered itself as a legal entity.

\section{Uncertainty and Diffraction:}

\section{Roerich Movements during the Yeltsin Years}

One of the most vivid manifestations of early post-Soviet Roerichism involves the famous Altai pilgrimages that began in 1991 and peaked in 1992, sparked by expectations that a great flood was soon to engulf Eurasia, leaving only the Altai Mountains unscathed. To ensure humanity's survival into the next cosmic era, a number of Roerichite communes established themselves in the Altai, although few lasted for long. Not only did the awaited deluge fail to occur, but the pilgrims were constantly divided by arguments about the nature of their mission-particularly about whether the "radiant city" of Zvenigorod that Roerich had wished to build in the Altai would miraculously appear if their faith were strong, or whether they would have to erect it themselves before the flood poured down. ${ }^{12}$

12 NRM director Daniel Entin, interviews with the author (October 1999). Also see Lunkin, "Rerikhovskoe dvizhenie," 24. 
This episode illustrates not just how dedicated to Roerichite ideas many Russians were during the 1990s, but also how difficult they found it to arrive at a consensus about those ideas. In many ways, this was a function of the problem that arises whenever one tries to gauge the nature and intensity of a spiritual belief: as William James outlined multiple varieties of the religious experience in his classic 1902 book of that title, we can recognize many varieties of the occult experience, ranging from casual dabbling to dogmatic adherence to a single discipline. Four to five hundred Roerichite groups and circles (many of them small and loosely organized) formed in Russia during the 1990s; unspecified thousands practiced on an individual basis, and scholarly estimates of those "captivated" in some way by Roerich's "unique philosophy" have run to "the millions." ${ }^{13}$ Especially in the last case, it is hard to determine how much Roerich's popularity rested on non-spiritual factors, such as interest in his uniquely-styled art, patriotic admiration for him as a historically significant Russian, or popular perception of him as a Gandhi-like symbol of transcendent humanitarianism. But even looking strictly at those to whom Roerich appealed on spiritual grounds, we see a huge diversity, both in their level of commitment to Roerichism and in what form their Roerichism took. As in the West, there emerged in post-Soviet Russia an "increasingly complicated cacophony of spirituality," to borrow from a New York Times discussion of contemporary American religion ${ }^{14}$-and, for many Russians, Roerichite spirituality was merely one item for purchase in the growing marketplace of esoteric practices, often blended syncretically with Zen, yoga, Theosophy, astrology, and Vedanta, not to mention indigenous or conventional faiths like shamanism or Christianity (despite the Orthodox Church's constant denunciation of New Age trends). Simply to revere Roerich did not necessarily make one an actual Roerichite.

Even when it did, there was never anything clear about what it meant to practice Roerichism. Like the Theosophy from which it sprang-frequently described by scholars as "intellectually undisciplined" and "promiscuous[ly] hospita[ble] to symbols"15-Agni Yoga is a sprawlingly eclectic and protean system of belief, complicated all the more by the way the Roerichs themselves

13 Rosenthal, "Introduction," 29; quote from Roman Lunkin and Sergei Filatov, "The Rerikh Movement: A Homegrown Russian 'New Religious Movement'," Religion, State and Society 28, no. 1 (2000), 136.

14 Charles Blow, "Paranormal Flexibility," New York Times (December 12, 2009).

15 Carlson, "No Religion", 22-25; and John Ransom, speaking of Theosophy in The Permanence of Yeats, ed. James Hall and Martin Steinmann (New York: Collier, 1961), 90. 
constantly changed their political and philosophical views. It is often observed that Agni Yoga can adapt to "any school of thought," be it "ecology, astrology, vegetarianism... Buddhism," and so on-but so can many alternative belief systems, and the question goes beyond that. ${ }^{16}$ Roerichism is so riddled with inconsistencies and so susceptible to selective, decontextualized readings that, out of it, numerous lines of thought can be spun, few having much to do with each other, and many in direct opposition. This certainly took place during the perpetually shifting and often disheartening sociopolitical circumstances of the Yeltsin years, when Russians turned in any and all directions for psychological and spiritual comfort. Depending on how it was tailored, Agni Yoga could appeal to the right or the left, to Russophile chauvinists or peace-loving internationalists. It spoke to savior-seeking messianists, pantheists wishing to perceive divinity in the natural world, intellectuals who agreed with Roerich's emphasis on the societal importance of culture and the arts, and atheists looking for a more philosophically austere metaphysics. It resonated with those who expected the future to unfold apocalyptically and with those who expected it to do so noospherically.

A broad church indeed was needed to bring together so many different outlooks, and yet the only body with a chance of succeeding - the International Center of the Roerichs-failed in that task, thanks largely to doctrinal and institutional high-handedness. With unyielding zeal, MTsR director Liudmila Shaposhnikova insisted on the Center's exclusive right to codify and publish the Roerichs' writings; by compiling fresh editions of Nicholas's and Helena's essays, letters, and diaries-the "Great" and "Small" Roerich Libraries (Bol'shaia Rerikhovskaia biblioteka and Malaia Rerikhovskaia biblioteka)-the MTsR sought to control the production of a new canon that would have the authority of scripture. Most of all, Shaposhnikova claimed that the line of Agni Yogist authority descended directly to her from the departed Roerichs and their masters, Morya and Koot Hoomi. Those who refused to accept this "truth," she maintained, were not legitimate Roerichites. ${ }^{17}$ Not surprisingly, such fiats sat poorly with many others in the Roerich community, including some otherwise inclined to agree with Shaposhnikova on questions of interpretation.

16 Lunkin, Filatov, “Rerikh Movement," 147-148.

17 These views are set out and periodically updated on the MTsR's website (www.icr.su), particularly in the "Zashchita imeni i naslediia Rerikhov" section, as well as the MTsR journals Mir ognennyi and Kul'tura i vremia. See also Daria Kucherova, "Art and Spirituality in the Making of the Roerich Myth," (Ph.D. dissertation, Central European University, 2006); and Lunkin, "Rerikhovskoe dvizhenie," 36-37. 
A canny and well-connected operator, Shaposhnikova worked on several levels to define the "Roerich idea" to her liking and to the MTsR's advantage. Among committed Roerichites, she asserted as dogma the status of Nicholas and Helena as ascended masters, saint-like entities in a pantheon of prophets and teachers similar to that found in Blavatskian Theosophy and the Baha' $i$ faith. Building on the artist's own claim that his paintings had healing powers, she proclaimed that Roerich's art was imbued with a positive, life-giving force. Helena received greater attention than during the Soviet period as the primary author of the Agni Yoga books, and Shaposhnikova, emphasizing the physical suffering Helena endured during her lifetime, in the form of migraine headaches, back pain, and cardiac palpitations, depicted her as a martyr who allowed rays of energy to pass through her-virtually as though she had been crucified- "in order that the normal balance of energy on our planet might be restored."18 Shaposhnikova purported to be in psychic communion with the Roerichs' spirits, making her the earthly executor of the couple's will: a high priestess in all but name. She promoted the same eschatological scheme that Helena had preached after Roerich's death and right before her own, according to which the battle of Armageddon had been fought during World War II and had ended with the withdrawal of Lucifer from the solar system in October 1949. Maitreya, Buddha of the Future, was enthroned in Shambhala; at some point in the coming century, he would reveal himself, ending the epoch of Kali Yuga, the age of discord, and inaugurating the bright era of Satya Yuga. No discussion of political scandal, or of any topic that might call into question the MTsR's carefully-cultivated image of the Roerichs as invariably virtuous, was permitted.

In the public sphere, Shaposhnikova concentrated less on esoterica and more on Roerich's stature as a great Russian. The MTsR made no secret of his mysticism-several rooms in its museum are quite shrine-like, including the entryway, with a plastic "crystal" lit from within by an electric "fire," and the Hall of Living Ethics-but defined it in vague and beatific terms, not cultish ones, and pointed out how he fit into Russia's long tradition of cosmist and supernaturalist thought, with reference to Kandinsky's On the Spiritual in Art, and to Silver Age thinkers like Vladimir Soloviev and Nikolai Berdiaev. Stress was placed on Roerich's intellectual versatility (with frequent comparisons to

18 Quotation from Zashchitim kul'turu (Moscow, 1996), 83, as translated by and cited in Lunkin, Filatov, "Rerikh Movement," 144. 
Leonardo da Vinci ${ }^{19}$ ); his profound insight into nature's inherent sacrality (he was touted as an early environmentalist, and Anatolii Boukreev, the finest Russian mountaineer of his generation, spoke with feeling about his ability to "sing of Himalayan beauty"20); the scholarly value of his 1925-1928 and 19341935 expeditions, which were portrayed as "bedrock" contributions to archaeological and ethnolinguistic understandings of Asia (even though academically useful results were meager and in fact belonged to Iurii, not Roerich senior) ${ }^{21}$; his pronouncements about the role of culture in bringing humankind closer to its cosmic destiny (presented as desperately-needed wisdom in a world overrun by materialism); and, most of all, his abiding love for Russia, along with his conviction that it was the messiah among nations (although Shaposhnikova continued the time-honored strategy of keeping silent about Roerich's everchanging feelings for Soviet Russia).

In many respects, this approach paid off. Public regard for Roerich grew. One particular bonus was the deep and longstanding respect for him that Iurii Roerich had managed to foster among the USSR's scholarly elite upon returning to work for the Soviet Academy of Sciences in the 1950s and 1960s. This, combined with the generally greater open-mindedness of Russian academics and public intellectuals to paranormal speculation and noospheric theorization, as described by Birgit Menzel in her chapter of this volume, ensured Roerich a higher degree of credibility among Russia's scientists and literati than he has tended to have in the West. Another asset was Shaposhnikova's network of connections among the press and in the government. A Communist Party stalwart dating back to her student days at Moscow State University, Shaposhnikova had been a member of the Union of Soviet Writers and the Union of Soviet Journalists, and her orientalist studies acquainted her with many who went on to become highly-placed diplomats and ambassadors in the Ministry of Foreign Affairs. Owing to the incomplete turnover of political elites following the collapse of the USSR, this left her with extensive contacts within the Yeltsin regime, most notably Evgenii Primakov, who served the new government as head of foreign intelligence, foreign minister, and prime minister.

19 For example, Evgenii Matochkin, Kosmos Leonardo da Vinchi i Nikolaia Rerikha: khudozhestvennye paralleli (Samara: Agni, 2002).

20 Anatoli Boukreev, Above the Clouds (New York: St. Martin's, 2001), 111, which is adorned throughout with Roerich's Pax Cultura symbol and epigraphs from his book Shambhala.

21 The "bedrock" quotation comes from the Times Atlas of World Exploration (New York: HarperCollins, 1991), 222. On the Atlas's board is Gennadii Leonov, curator of Tibetan and Mongolian art at St. Petersburg's Hermitage Museum, and the most likely source for this overdone assessment. 
Shaposhnikova could count on positive media coverage from many outlets as well. Raising Roerich's profile became all the easier with such useful friendships at one's disposal.

Not for long, however, did the MTsR stand unopposed. While Roerichite groups in the majority of Russian cities remained loyal, as did foreign partners in Bulgaria, Latvia, Ukraine, and Belarus, resentment of Shaposhnikova flared up in key centers, for three main reasons. First, the MTsR's campaign to enlarge its collection of Roerich's art brought it into conflict with other museums, particularly the Museum of Oriental Art, which, thanks to a 1974 gift from the Nicholas Roerich Museum in New York (and other bequests in the 1980s) owned nearly 300 paintings by Roerich and his son Sviatoslav, including Roerich's prized “Architectural Studies” from 1903-1904. Argument about these works began in 1991 and continued throughout the decade, causing MOOA director Vladimir Nabatchikov to oppose the MTsR institutionally, and a number of Roerichites associated with the MOOA, among them Ol'ga Rumiantseva, Ekaterina Sheveleva of the "Roerich House" cultural center, poet Valentin Sidorov, and Natalia Sazonova of the Moscow Roerich Center, to ally with him. The MTsR lobbied the Yeltsin government intensely and received vocal support from Moscow mayor Iurii Luzhkov, but the Russian Ministry of Culture upheld-and continues to uphold-the MOOA's position (this caused the MTsR's museum to erect a "wall of shame," castigating all of Yeltsin's ministers of culture, especially the long-serving Evgenii Sidorov; only in the following decade was this odd display taken down). ${ }^{22}$ In the process, the MTsR antagonized the Nicholas Roerich Museum in New York, as well as the deputy

22 The MTsR has based its argument principally on a claim that Sviatoslav Roerich, who died in January 1993, had bequeathed his family's "legacy" (nasledie) to the Soviet Roerich Foundation, whose work the MTsR was continuing. However, Sviatoslav's widow, the Indian film star Devika Rani Roerich (d. 1994), stated in 1993 that her husband had wished the inheritance to go to a state-run museum in Russia or be returned to India-and the museum of the MTsR had never been recognized as an official state institution. Not only was the MOOA a state museum, the MTsR was relying on a highly dubious claim of "moral right" in insisting that Sviatoslav's wishes had any bearing on art bequeathed to the MOOA in the 1970s and 1980s. Complicating the question further were questions about whether the Soviet Roerich Foundation had violated Indian law by airlifting so many of the Roerichs' possessions to Moscow in 1990 (the 1972 "Antiquities and Art Treasures Act" forbade the export of any artifacts owned by the family that were more than one hundred years old, and, because Roerich had been declared a "National Treasures Artist" by the Indian government in 1979, export of his art was likewise against the law), as well as the appearance of Devika Rani's relatives from an earlier marriage as possible heirs. See interviews with NRM in 2002; and Lunkin, "Rerikhovskoe dvizhenie," 22-23. 
director of the Russian Academy of Sciences' Institute for Oriental Studies, Rostislav Rybakov.

A second source of friction was the MTsR's reaction to the appearance during the 1990s of previously unknown or unpublished manuscripts that promised to shed new light on the Roerichs' lives and careers, including the journals of several people who followed or traveled with the family, including Sina Fosdick (Zinaida Lichtmann), Dr. Konstantin Riabinin, Pavel Portniagin, and Colonel Nikolai Kordashevskii. ${ }^{23}$ The emergence of these texts caused the MTsR a great deal of anxiety, revealing as they did a number of personal and practical details that contradicted the Center's image of Nicholas and Helena as politically-innocent saints. That anxiety helps to explain the fury with which the MTsR waged its next struggle, which had to do with the right to publish the diaries of Helena Roerich. Written down in nearly fifty notebooks, Helena's diaries ended up in America, with the original held by the Amherst College Center for Russian Culture, but with photocopied and electronic versions widely available. By the mid-1990s, plans were in place for the Sfera publishing house, led by Dmitrii Popov, formerly of the reestablished Russian Theosophical Society, to annotate and publish the diaries with assistance from the NRM in New York. Shaposhnikova took legal action, blocking publication for more than ten years (it is proceeding now under the editorship of the Museum of the East's Vladimir Rosov) and embroiling Sfera and the NRM in a barrage of lawsuits that were accompanied in the early 2000s by political pressure and, according to rumor, behind-the-scenes threats. The Sfera affair reinforced the growing impression that the MTsR was prepared to interfere at will with academic work on Roerich, and it wedged the Center even farther apart from the MOOA, the RAN's Institute of Oriental Studies, and the NRM; by 2002, it caused a rupture between Shaposhnikova and Nataliia Spirina of the Siberian Roerich Society, who had tended earlier to be more or less in line with Shaposhnikova on matters of belief. ${ }^{24}$

Thirdly, opposition to Shaposhnikova arose not just among Roerichites who found her too fundamentalist, but also among those who considered her

23 Zinaida G. Fosdik [Sina Lichtmann], Moi uchitelia: po stranitsam dnevnika, 1922-1934 (Moscow: Sfera, 1998); Konstantin N. Riabinin, Razvenchannyi Tibet (Magnitogorsk: Amrita-Ural, 1996); Pavel K. Portniagin, "Sovremennyi Tibet. Missiia Nikolaia Rerikha. Ėkspeditsionnyi dnevnik, 1927-1928," Aryavarta 2 (1998): 11-106; Nikolai Kordashevskii, Tibetskie stranstviia polkovnika Kordashevskogo (s èkspeditsiei N. K. Rerikha po Tsentra'noi Azii) (St. Petersburg: Dmitrii Bulanin, 1999).

24 For Spirina's complaints, see Nataliia Spirina, "Skazhem pravdu!” Na voskhode (November 24, 2002). 
not fundamentalist enough. Many of these complaints came from groups who based their theology on the pro-Soviet writings of the 1920s, when Nicholas and Helena penned paeans of praise to Marx and Lenin and foretold the synthesis of Buddhism and Soviet communism. Roerich societies in Tomsk, Volgograd, Lenin's birthplace of Simbirsk, and Vladivostok (where, much to the MTsR's consternation, Roerichite leader Mikhail Lunev claimed to be in psychic contact with the Roerichs) took Shaposhnikova to task for downplaying this aspect of Roerich ideology, and all of them became active in the 1996 presidential elections, supporting Gennadii Ziuganov and the Communist Party. ${ }^{25}$ Other organizations felt that they should be more forthright about the supernaturalist side of Agni Yoga. This was the case with the Karelian circle led by the cosmist Iurii Linnik and the Crown of the Heart movement in Barnaul, although the most outspoken of the independent movements has been the Bazhov Center headquartered in Cheliabinsk and led by Vladimir Sobolev, who considers himself the reincarnation of Confucius and has several times predicted not just the return of Zoroaster (who will be enthroned in the ancient temple site of Arkaim), but the outbreak of a third world war that will destroy Europe and America, leaving Russia to rule the earth. ${ }^{26}$

As if all this were not enough, the MTsR had to contend with outside pressures that made it increasingly difficult to manage Roerich's public image. Shaposhnikova might prefer to remain silent about the political side of Roerich's career, but a host of revelations from formerly-inaccessible Soviet archives, in combination with the new sources described above, confirmed what had already been suspected or partly-known for years: namely, that Roerich's 1925-1928 expedition involved an attempt to convince the USSR to support the artist's "great plan" of creating a pan-Buddhist confederation encompassing Tibet, Mongolia, and parts of Siberia (in exchange, he offered to gather intelligence and propagandize the virtues of communism among the Buddhist peoples of Asia), and that his 1934-1935 expedition-and much of the acclaimed work he did on behalf of the 1935 Banner of Peace Pact-had to do with trying to sway either Japan or the U.S. to help him do the same thing, but now with an anti-Soviet slant. Western scholars had mooted these possibilities for decades, but Russian authors shied away from them until the early-to-mid1990s, when an array of works touching on these themes began to burst onto

25 Lunkin, "Rerikhovskoe dvizhenie," 38-40, 50-52; Lunkin, Filatov, "Roerich Movement," 144146. For an MTsR complaint about Lunev's insistence that he was in communication with the Roerichs, see “Ostorozhno, Lunev!” Mir ognennyi 19 (1998).

Lunkin, "Rerikhovskoe dvizhenie," 40-50. 
the Russian scene. The most dramatic was the series of articles published by Oleg Shishkin in the newspaper Segodnia in the autumn of 1994 and later expanded into book form, arguing that Roerich had become an agent for the USSR as early as 1919-1920 and that the rest of his career was tied up with service as a Soviet spy in the full sense of the word. ${ }^{27}$ Shishkin's maximalist interpretation was based on incautious readings of sources that call out for careful interpretation (such as confessions extracted from prisoners interrogated by Stalin's secret police), and many particular points have been called into question or disproven. Still, the process of inquiry he helped open up has been carried on by formidable researchers like Aleksandr Andreev and Vladimir Rosov, and has brought much valuable information to light. ${ }^{28}$

It also had a potentially electrifying effect on public perception of Roerich, especially in conjunction with another bombshell of the mid-1990s: the Orthodox Church's war on Agni Yoga. This was part of a larger effort on the part of the Church, which had anathematized all forms of occultism in 1932 and again in 1944, and which found itself appalled at the upsurge of New Age and occultist trends in Russia during the 1990s. ${ }^{29}$ Starting in 1993 and 1994, the Church

27 Oleg P. Shishkin, “N. K. Rerikh v ob”iatiakh 'naglogo monstra', Segodnia 208 (October 29, 1994), 13; idem, “N. K. Rerikh: ne schest' almazov v kamennykh peshcherakh,” Segodnia 222 (November 19, 1994), 13; idem, “N. K. Rerikh: moshch' peshcher," Segodnia 237 (December 10, 1994); idem, Bitva za Gimalai. NKVD: magiia i shpionazh (Moscow: OLMA, 1999). Among those following Shishkin's line are Anton Pervushin, Okkul'tnye tainy NKVD i SS (Leningrad: Neva, 1999); and Richard Spence, Red Star over Shambhala." New Dawn Magazine 109 (July-August 2008). The MTsR's response to Shishkin's work has been blistering; see its website, as well as A. Stetsenko, "Byl li Nikolai Rerikh sotrudnikom spetssluzhb?" Pravda (June 6, 2003).

28 Works on (or dealing in part with) Roerich informed by non-partisan and/or in-depth archival research include Vladimir Rosov, Nikolai Rerikh: Vestnik Zvenigoroda, 2 vols. (Moscow St. Petersburg, 2002-2004); Aleksandr Andreev [also publishing as Alexandre Andreyev], Vremia Shambaly (St. Petersburg: Neva, 2004); idem, Soviet Russia and Tibet: The Debacle of Secret Diplomacy (Leiden: Brill, 2003); Karl Meyer, Shareen Blair Brysac, Tournament of Shadows: The Great Game and the Race for Empire in Central Asia (Washington, D.C.: Counterpoint, 1999); Andrei Znamenski, Red Shambhala. Magic, Prophecy, and Geopolitics in the Heart of Asia (Wheaton: Theosophical Publishing House, 2011); Markus Osterrieder's chapter in the present volume; John McCannon, "By the Shores of White Waters: The Altai and Its Place in the Spiritual Geopolitics of Nicholas Roerich," Sibirica: Journal of Siberian Studies 2 (October 2002), 167-190, among other articles; and Anita Stasulane, Theosophy and Culture: Nicholas Roerich (Rome: Pontifica università gregoriana, 2005).

29 As the Osterrieder chapter in this volume notes, the Roerichs themselves were hard-pressed to cope with the Church's hostility to occultism. Aside from the fact that they cherished Russian Orthodoxy as an essential aspect of "Russianness" and as a legitimate reflection of the higher 
included Agni Yoga in its attacks on "pseudo-Christian, neo-pagan, and occultist sects," undermining the Roerich movement's attempt to portray Nicholas's and Helena's teachings as culturally and spiritually compatible with Russian Orthodoxy. ${ }^{30}$ Wielding the heaviest cudgel was deacon Andrei Kuraev, whose many anti-Roerich publications include the 1,000-page Satanism for the Intelligentsia: On the Roerichs and Orthodoxy, from 1997, which charged Roerich with espionage, quasi-Nazism, and the production of bad art. ${ }^{31}$ In January 1999, a Church conference on "Totalitarian Sects in Siberia," held in the Altai town of Belokurikha, declared that "the dissemination of the Roerichs' Agni Yoga that has taken place with the support of state leaders evokes our horror... we declare that Roerich's teachings are not only incompatible with Christianity but directly inimical to it." 32

With clockwork predictability, the MTsR responded by becoming more combative than ever. Adopting as its motto the catchphrase "we shall defend the Roerichs' legacy," the Center lashed out at all who spoke of the Roerichs in less than ideal terms, denouncing any criticizm, be it scholarly or ecclesiastical, as defamation and libel. The term "legacy" took on a twofold meaning, referring not just to the art and heirlooms that the MTsR was so determined to acquire and control, but to the Roerichs' good name, which the Center was prepared to safeguard with Cerberus-like vigilance. In her most strikingly successful exploitation of government connections, Shaposhnikova persuaded Evgenii Primakov to transfer Roerich's secret police file from the archives of the former KGB to the MTsR. And to Shishkin, Rosov, Andreev, and other authors writing about the Roerichs without the Center's imprimatur, she threw down the gauntlet, declaring it an "abomination" to speak of Nicholas and Helena without reverence, as if they were "mere historical figures." 33

truths revealed in the "true religion" they believed themselves to be espousing, they sought White Russian backing for their "Great Plan" between 1928 and 1935-one of their antiCommunist phases-and did not wish to alienate any potential supporters. Accordingly, during these years in particular, Roerich placed special emphasis on St. Sergius as a motif in his art and essays, and was anxious to portray himself as devoutly Orthodox.

30 Proceedings of the Bishops' Council of November-December 1994, as recorded in Arkhiereiskii sobor RPTs (Moscow, 1995).

31 Andrei Kuraev, Satanizm dlia intelligentsii: o Rerikhakh i Pravoslavii (Moscow: Otchii dom, 1997). Also see idem, Vse li ravno kak verit'? (Moscow, 1994); idem, Ob otluchenii Rerikhov ot Tserkvi (Mstitslav': Prosvetitel', 1995); and idem, Khristianstvo i okkul'tizm (Moscow, 1997). Also see Rachel Polonsky, "Letter from Peryn," Times Literary Supplement (June 7, 2002): 5. "News about Religion in Russia," www2.stetson.edu/ psteeves/ relnews/ 9903a.html

See the "Zashchita imeni i naslediia Rerikhov" section of the MTsR website; as well as Kucherova, "Art and Spirituality," 309-311. 


\section{Imperfect Consolidation: Roerichism in the Twenty-First Century}

Whether or not the dictum holds true that bad publicity is better than no publicity at all, the abovementioned scandals did not prevent Roerich's fame and popularity from soaring even higher in the 2000s than they had during the 1990s. The number of active Roerichites is estimated to have grown, with the quantity of circles and groups rising to several thousand, and that of individual followers to at least the tens of thousands. ${ }^{34}$ More than that, though, the level of generalized and informal admiration for Roerich skyrocketed in the new century.

Much of this had to do with the booming international market for fin-desiècle Russian art over much of the decade. As part of this overall trend, Roerich's paintings fetched unprecedentedly high prices at Sotheby's, Christie's, and elsewhere, a fact that redounded to his credit at home. ${ }^{35}$ Many Roerich works were repatriated, as in 2007, when the famed RostropovichVishnevskaia collection-which included Roerich's Treasure of the Angels (1905) - was purchased by tycoon Alisher Usmanov and installed in St. Petersburg's Constantine Palace. ${ }^{36}$ Beyond that, in what might be termed an M. C. Escher or Maxfield Parrish effect, Roerich's unique, eye-catching style continued to earn him a much higher degree of popular recognition among the wider public than any number of artists from his time who are treated with greater seriousness by art historians.

Much more crucial was the way Roerich became linked in the public mind with the confidence of an economically healthier and more assertively nationalistic Russia-due somewhat to general circumstances, but also to assiduous image maintenance on the part of Roerichite institutions throughout the country, especially the MTsR. Roerich centers in Moscow and St. Petersburg became steadily more entrepreneurial in making themselves part of Russia's expanding tourist infrastructure; starting in 2001, a state museum-institute dedicated to the Roerich family was established in St. Petersburg, with the assistance of St. Petersburg University and Liudmila Mitusova, daughter of Helena Roerich's favorite cousin, the composer Stepan Mitusov. ${ }^{37}$ MTsR activ-

34 Lunkin, "Rerikhovskoe dvizhenie," 52.

35 In 2006, Roerich's Lao-tse (1924) went for \$2.2 million at Sotheby's New York, making it the top earner in a 589-lot sale of Russian art that brought in \$54 million total. See Russian Life 49 (July-August 2006), 11.

36 St. Petersburg Times (May 16, 2008). The Guardian (September 18, 2007), referred to Treasure of the Angels, valued at $£ 1.2$ million, as one of the collection’s "star pieces."

37 Ironically, the St. Petersburg State Museum-Institute of the Roerich Family is located in the 
ism helped to ensure that Roerich's name appeared as far and as wide as possible: on the hull of a naval vessel in Russia's Pacific Fleet, as the designation of planetoid \#4426, and as the name of a peak in the Altai. Roerich's Banner of Peace flag, with its symbol of three crimson orbs, was carried to the top of Mount Everest, flown into space by the shuttle Columbia, and displayed aboard the Mir International Space Station. The Center also continued its cozy relationship with Russia's state authorities. Moscow mayor Iurii Luzhkov remained an ally, and President Vladimir Putin has spoken frequently and effusively about Roerich's importance as an artist and philosopher. Also, during the first half of the decade, the federal procuracy took up the MTsR's case against Sfera, and the Administration for the Prevention of Economic Crimes (UBEP) charged Dmitrii Popov and Daniel Entin with conspiring to cause economic harm. ${ }^{38}$ The prominent Master Bank, which uses Roerich-inspired logos, bankrolls much of the MTsR's publishing activities.

Not that the MTsR was completely triumphant. More and more, regional groups found it in their best interest to conform to the MTsR's line, but not always. Tensions persisted between the MTsR and the Siberian Roerich Society, and outright war continued between the Center and the Museum of the East (as the MOOA renamed itself); the MTsR's animosity toward the NRM still burned as well. Externally, the Church's campaign against Roerichism took its toll, despite the ironic fact that the two worldviews increasingly converged during the decade in their Russophilia and, as cultural critic Rachel Polonsky puts it, in their insistence that "the West has defiled Russia's sacred space and led her away from salvation." ${ }^{39}$ The irony is physical as well: the reconstructed Cathedral of Christ the Savior, the most visible symbol of Orthodoxy's postSoviet resurgence, stands a two-minute walk from the MTsR-close enough for the two institutions quite literally to hurl imprecations at each other. (Church criticism remains a sore point with Roerich admirers, even less pugnacious ones; the response is generally to argue that Nicholas and Helena remained Christian, but, like Tolstoy in his later years, had a purer understanding of the faith than did the Church, or to maintain-as does the St. Petersburg Museum-Institute of the Roerich Family-that the family never abandoned

former home of Mikhail Botkin, Roerich's worst enemy during his years as an employee of the Imperial Society for the Encouragement of the Arts. The museum's website is www.roerich. spb.ru.

38 Author's interviews in October 2002 with staff of the Nicholas Roerich Museum. Lunkin, "Rerikhovskoe dvizhenie," 23, mentions how the MTsR also turned to Putin, with less success, for help in its dispute with Moscow's Museum of the East.

Polonsky, "Letter from Peryn." 
Orthodoxy at all. ${ }^{40}$ ) The MTsR created an additional firestorm between 2005 and 2007, when Vladimir Rosov, whose penetrating examinations of Roerich's political ambitions had caused the Center great embarrassment since the 1990s, completed the dissertation "Nicholas Roerich's Russian-American Expeditions to Central Asia in the 1920s and 1930s," in fulfillment of his higher doctoral degree. Even though Rosov had the backing of thirty academicians and doctors of historical science, the MTsR, joined by a host of other Roerichite organizations, launched fierce attacks on him in the press, seeking to discredit the October 2005 defense of his dissertation with accusations of "deficient scholarship" and deliberate "slander."41 For more than a year, the furor over Rosov's dissertation became a cause célèbre of nationwide proportions; in the end, Rosov's foes failed to block him from a successful second-stage defense in the spring of 2007.

To some extent, the MTsR's shrillness of tone and the continuous rehashing of the oddities and mysteries surrounding Roerich's career have damaged the artist's credibility; there are plenty who roll their eyes or shake their heads at the mention of his name, and the slang term rerikhnut'sia, coined during the 1990s and punning on the verb rekhnut'sia ("to go crazy") shows every sign of surviving into the new century. All the same, the prevailing view of Roerich is in many ways as the MTsR and its allies would have it. Followers ignore anything unflattering about Roerich, and non-followers, even when they are aware of such things, tend not to dwell on them. The MTsR's signal accomplishment during the Putin years has been to formulate in the public mind an equation of Roerich with "Russian-ness" (russkost') without sacrificing his usefulness as a symbol of universal peace and multicultural tolerance. Roerich's paintings are held up as testaments to the unique virtue of the Russian land, and even his mysticism, properly framed, plays well to the longstanding Slavophile stereotype that many Russians have of themselves as spiritually richer and more intellectually flexible than close-minded, narrowly empirical materialists in the

40 The latter point is made in the display notes-and was pressed upon me vehemently by a tour guide-at the St. Petersburg Museum-Institute (interview of May 2008, name withheld).

41 Note that Rosov already possessed a kandidatskaia degree, the equivalent of a Ph.D. in the West; the Russian doktorskaia degree carries greater weight. A sampling of attacks on Rosov, or discussion of those attacks, can be found on the MTsR website; "Kul'tura, ne politika... K voprosu o neudachnoi dissertatsii o Nikolae Rerikhe," Literaturnaia gazeta (September 26, 2006); "Ėtika lzhenauki" and "Staroe pod maski novogo," both in Novaia gazeta (November 23, 2006); and "Zaiavlenie Sibirskogo Rerikhovskogo obshchestva po povodu doktorskoi dissertatsii V.A. Rosova," Voskhod 156, no. 4 (2007): 15-18. 
West. ${ }^{42}$ In this context, any questioning of Roerich's worth as an artist or a thinker, or of his wider motivations (especially by foreigners, or based on research done in foreign archives), could be construed as an insult to Russian pride-a discursive approach that served Roerichites well in a Russia governed by a more openly nationalistic regime than before, and eager to reject the perceived humiliations heaped upon it by the West during the years of shocktherapy transition to capitalism. Some Roerichites have taken this line of reasoning to egregious, if not disturbing, extremes: the Roerich society in Sochi blames "anti-Russianism" in the West on the influence of Jews and Masons, and Roerichite cultural critic Ksenia Mialo has named J. R. R. Tolkien, the Catholic Church, the "judaic media," "global capital, NATO, and the Internet" as "implacable enemies of the pure 'Russian soul'." ${ }^{43}$ On a related note, neoEurasianists such as Aleksandr Dugin have encouraged a free-floating association between Roerichite thought and their own quasi-millenarian vision of a Russia rising to glory over the "Atlantic" West, although this is not an association sought by the MTsR or Agni Yogists in general. ${ }^{44}$

And yet Roerichism can also be used to buttress Russia's self-presentation as a nation with natural ties to cultures in the east, most particularly the Buddhist peoples of Central Asia and the Russian Federation itself, not to mention India. Whatever scholars may say about the authenticity or inauthenticity of Roerich's Buddhist pretensions, or of his affinity for other Asiatic belief systems, it is true that certain non-Russians have gone some way toward embracing Roerich, either as an exemplar of friendly relations between faiths, or even recognizing him as one of their own. Roerich is a figure of respect among the Buddhists who worship at the famed Kalachakra Temple in St. Petersburg's northern suburbs (Roerich himself was one of the artists who helped design the temple's interior during its 1909-1915 construction). Farther afield, Roerichism is popular among the indigenous peoples of the Altai, where it is often associated with or incorporated into shamanistic or Ak Jang (Burkhanist) practices, and a similar dynamic has been observed among Kamchatka's native

42 See, for example, G. Sviatokhina, “Zhivaia ètika-aktual'noe uchenie sovremennosti," Vestnik Rossiiskogo filosofskogo obshchestva 38, no. 2 (2006): 138-141.

43 Lunkin, Filatov, "Roerich Movement," 144, on the Sochi group. Mialo's essay "Christ in the Himalayas" paraphrased in Polonsky, "Letter from Peryn."

44 On Dugin, see Alexander Rahr, "'Atlanticists' vs. 'Eurasians' in Russian Foreign Policy," RFE/RL Research Report 1, no. 22 (1992); Vera Tolz, "The Burden of Imperial Thinking," RFE/RL Research Report 1, no. 49 (1992); David Kerr, "The New Eurasianists: The Rise of Geopolitics in Russia's Foreign Policy,” Europe-Asia Studies 47, no. 6 (1995). See also Mark Sedgwick's chapter in this volume. 
Itelmen. The Roerich group in Kazan is engaged in an interesting hybridization of Agni Yoga and Sufism, and, outside the country, Roerich's 1926-1927 residence in overwhelmingly Buddhist Ulan Bator has recently been commemorated by the transformation of his quarters into a house-museum, with support from the Mongolian government.

This sort of receptivity is most prominent and heartfelt in India, where the Roerichs' connections with the Nehru-Gandhi and Tagore clans are still remembered fondly, and where Roerich, in 1979, became one of only nine individuals - and the only non-Indian - to be named a "National Treasures Artist." As noted before, the USSR had stressed these ties during the Cold War, and the Putin regime lost no time in exploiting them as part of its larger strategy of asserting a more muscular presence on the world stage than the Yeltsin government had managed to do. Russia's ambassador to India, Alexander Kadakin, long an admirer and promoter of Roerich, has served as the deputy director of India's International Roerich Memorial Trust, and, with the assistance of no less than President Putin's wife Liudmila, he played a mammoth role in organizing a December 2002 exhibition of Roerich's work in New Delhi, at the National Museum of India.

Putin himself has referred to Roerich as an example of "the spirit of closeness that binds all people": an excellent illustration of how those who praise him as a paragon of russkost' are often just as ready to use him as a symbol of "boundless internationalism" when it suits their purposes. ${ }^{45}$ This is not always cynicism-the Roerichs' own writings, after all, provide ample backing for both views-although the contrast with nationalist strains of Roerichite ideology is sometimes jarring. Whatever the case, Roerich's name has appeared with surprising frequency in civic and academic discussion of international relations and new directions in foreign policy. Mainly, he has been cited by political scientists and strategic thinkers in Russia looking for models of "multipolarity" and "global pluralism" to counter U.S. hegemony and seemingly triumphalist or confrontational political theories from the West, such as Francis Fukuyama's "end of history" thesis or Samuel Huntington's "clash of civilizations"; here, Roerich appears in the same company as other "internationalist" thinkers, such as Pitirim Sorokin, Sun Yat-sen, and Pierre Teilhard de Chardin. ${ }^{46}$

45 Putin quote from India Today cited in Markus Osterrieder's chapter in this volume; "boundless internationalism" comes from Lunkin, Filatov, "Roerich Movement," 142.

46 See Andrei Tsygankov, Whose World Order? Russia's Perception of American Ideas after the Cold War (South Bend/Ind.: Notre Dame University Press, 2004), 94-95, 87-112, 163. 
(As noted above, Roerich has, paradoxically, been claimed as a kindred spirit by neo-Eurasianists whose aspirations are decidedly less ecumenical).

These internationalist views have generally been voiced outside the confines of the Roerich movement. Still, anything that earns the artist more approbation works to his followers' benefit, and most Roerichite organizations have echoed this rhetoric whenever possible. On numerous occasions, the MTsR has taken advantage of its UNESCO status to boost Roerich's visibility at the United Nations, trying to have him acknowledged as a humanitarian and peacemaker on par with Dag Hammarskjöld or Albert Schweitzer. This exercise has yielded meager results, as Roerich continues to be poorly known or perceived as an oddity by those outside his natural constituency. With evident pride, the MTsR displays a large photograph of UN General Secretary Kofi Annan being presented with a flag stamped with Roerich's Banner of Peace emblem. How justified that pride is, though, remains open to question: although it may be a trick of the camera, the non-Roerichite viewer cannot help but be struck by the nonplussed look on Annan's face-a small amusement illustrating a more significant dilemma.

\section{Concluding Remarks}

All signs indicate that, for the foreseeable future, the Roerichs' fame will continue to flourish in Russia. The celebration of Nicholas and (to a lesser extent) Sviatoslav as artists of note is unlikely to abate, nor is there much chance that George's scholarly reputation as an orientalist will dim. A casual survey of Russian bookstores, whether in Moscow and Petersburg or in Novosibirsk and Irkutsk, shows right away the wide acceptance Helena has gained as an author of ezoterika and, increasingly with the passing years, as a philosopher in her own right. ${ }^{47}$ Even Roerich's poetry, particularly his Flowers of Morya collection (1907-1921), is working its way slowly into the Russian literary canon. ${ }^{48}$

By no means, however, does renown in a generalized sense translate automatically into religious appeal, and the future of the Roerich movement is more difficult to predict. Over the course of almost two decades, the MTsR has

47 For instance, Mikhail Maslin, ed., Russkaia filosofiia (Moscow: Algoritm, 2007), 468-469, is one of several encyclopedias or general histories that give Helena Roerich serious consideration as a member in the canon of Russian thinkers.

48 Verses from Roerich's Flowers of Morya (Tsvety Morii) poems can be found in Russkaia poeziia. XX vek: Antologiia (Moscow: OLMA, 1999), 61-62, while N. K. Rerikh, Pis'mena (Moscow: Profizdat, 2006), was released as part of a major "Poetry of the Twentieth Century" series. 
turned itself into Russia's, if not the world's, single most powerful Roerichite institution-and yet its goal of monopolizing control over Roerichite doctrine and practice remains far out of reach: various and sometimes radically different strains of Agni Yoga exist throughout Russia and the regions neighboring it, some outright hostile to the MTsR and many feeling no need to pay allegiance to it. Especially now, in an era so enormously shaped by information and social-networking technology, diversity and individualized syncretism appear to be the wave of the future for Roerichism, as for most New Age systems of belief. Nor is it particularly clear which conception of Agni Yoga will prove dominant in the end. Will Russophilia win out over universalism, or vice versa? Or will the coexistence of both continue?

At certain points throughout his career, Roerich appears to have anticipated such unpredictability, posing the following question in his 1935 essay The Builder (Stroitel'):

Can the sower know for certain how the seeds he has sown will grow? The sower may suppose, but it is not given for him to know. The builders of wondrous temples and fortresses never knew whether they would be destined to complete their work. ${ }^{49}$

One would dearly love to have the opinion of Roerich himself on the MTsR, and on all the many disputes that have been fought in (and over) his name for so long. About such things we can only speculate, but the sole certainty is that, when Roerich dreamed of the temple he hoped someday to leave behind, he dreamed of one, not many. Unfortunately for him, the probability that a true and single church of Agni Yoga will ever materialize in Russia remains just as remote now as it did in his and Helena's lifetimes. ${ }^{50}$

49 N. K. Rerikh, “Stroitel'," Listy dnevnika (1931-1935) (Moscow: MTsR, 1999), 536.

50 Such a development may be more likely in the Baltic states, where, according to researcher Anita Stasulane, public discourse regarding the Roerichs and their spiritual views has become increasingly orthodox and dogmatic, with significant support from the state and its educational institutions. July 2009 conversation between Birgit Menzel and Anita Stasulane, relayed to the author in September 2010. 


\title{
ON THE WAY FROM BORDER CONFLICTS: TRANSPERSONAL PSYCHOLOGY IN RUSSIA
}

\author{
BORIS FALIKOV
}

One of the recent attempts to define Transpersonal Psychology (TP) was made by a well-known practitioner in the field, Mariana Caplan. "Although Transpersonal Psychology is relatively new as a formal discipline [...], it draws upon ancient mystical knowledge that comes from multiple traditions. Transpersonal psychologists attempt to integrate timeless wisdom with modern Western psychology and translate spiritual principles into scientifically grounded contemporary language."1 It's exactly the concern with spirituality which makes the definition of TP so difficult, because everybody seems to interpret spirituality in one's own way nowadays and there hardly will ever be consensus reached on it. As for the goal of TP the same author says: "Transpersonal psychology addresses the full spectrum of human psychospiritual development-from our deepest wounds and needs, to existential crisis of the human being, to the most transcendent capacities of our consciousness." ${ }^{2}$ Evidently, such a wide scope doesn't make it easier to define TP. However, if we try to put it into historical and cultural context of the last three decades of the $20^{\text {th }}$ century things become more understandable for us.

TP started to form in the United States in the 1960s as an outgrowth of humanistic psychology. However, it became obvious very soon that there were differences between them. Humanistic psychology was oriented towards selfactualization but transpersonal psychology was aimed at the achievement of ultimate states of consciousness. ${ }^{3}$ In other words, it wanted not only to study mystical experience but also to participate in it. As the founder of the Transpersonal Psychology Association (TPA) Anthony J. Sutich readily admitted, the therapist or counselor in the new field was supposed to be on his (her) own spiritual path. ${ }^{4}$

The founding fathers of TP (Anthony Sutich, Stanislav Grof, Ken Wilber

1 Mariana Caplan, Eyes Wide Open. Cultivating Discernment on the Spiritual Path (Boulder/Co.: Sounds True, 2009), 231.

2 Ibid., 231.

3 Anthony Sutich, “Transpersonal Psychotherapy: History and Definition,” In: Transpersonal Psychotherapy, ed. Seymour Boorstein (Palo Alto/Ca.: Science and Behavior Books, 1980), 10.

4 Sutich, "Transpersonal Psychotherapy," 10. 
and others) often cited among their predecessors William James, but if the latter in his famous Varieties of Religious Experience (1902) researched the mystical states empirically, they insisted on these states being experiences of ultimate personal truth and based TP on this ontological ground. It is this peculiarity of TP that let Wouter J. Hanegraaff define it as "an openly religionist psychology" and include it in his study of New Age movements. ${ }^{5}$

Hanegraaff also writes that TP is divided into practical and theoretical parts. The former explores altered states of consciousness and the latter makes "cartographies of consciousness which distinguish a hierarchy of levels of the psyche." Psychoanalysis, behaviorism and humanistic psychology explore the lower layers of the psyche and TP studies the highest one where transpersonal experience takes place. This hierarchy allows TP to position itself as a synthesis of western science and spiritual wisdom both of oriental and occult origin. Such image of itself is typical for the New Age movement as a whole and it makes obvious its inherent ties with TP.

These ideas let TP find its place alongside traditional branches of psychology. However, at the same time, they put it into a precarious situation on the border of science and religion. For more than forty years, its adepts have been talking about the coming of the new paradigm where this border will not exist any longer, but it still does. And it creates a lot of theoretical and practical problems for them.

A few years ago a group of leading American transpersonal psychologists quite openly discussed their difficulties. ${ }^{7}$ The major ones had to do with TP relationships with traditional psychology and society and culture at large. Were they right in fighting for a place in the American Psychological Association (APA)? Alternatively, would the niche of spiritual coaching or even religious ministry be better suited for them? Some of the participants of the conversational forum have chosen the latter, and they seemed to be quite content with it. This debate made obvious two things. First, American transpersonalists still find themselves in the situation of a border conflict. Second, political and cultural pluralism of American society helps them to deal with their problems. In Russia, the situation of the border conflict was less obvious in the first decade

5 Wouter J. Hanegraaff, New Age Religion and Western Culture: Esotericism in the Mirror of Secular Thought (Leiden, New-York, Cologne: Brill, 1996), 51.

6 Ibid., 51.

7 Mark Schroll, Stanley Krippner, Miles Vich, James Fadiman, Valerie Mojeiko, "Reflections on Transpersonal Psychology's 40 $40^{\text {th }}$ Anniversary, Ecopsychology, Transpersonal Science, and Psychedelics: Conversational Forum," The International Journal of Transpersonal Studies 29 (2009), 39-52. 
of TP's open existence in the 1990s, but now it is getting more evident than in the US. It is exactly the growing deficit of political and cultural pluralism in Russia, which makes the conflict stronger.

\section{From Underground to the "Romantic Period"}

TP found its way to Russia soon after its inception in the United States. In the very beginning of the 1980s Michael Murphy, the founder of the Esalen Institute and one of the godfathers of TP in California, came to the USSR and discovered that New Age there was in full bloom. However, it was mostly underground as the atheist communist ideology did not like Soviet people to have mystic experiences and altered states of consciousness. However, it did not prevent Murphy from meeting some of its representatives. He shared his impressions with the New Age Journal on his return back home. Murphy spoke about "the cultural awakening" very similar to that in the USA but somewhat quieter and about "the developing subculture" much involved with esoteric religion, new kinds of psychotherapy, alternative medicine, flying saucers and parapsychology. ${ }^{8}$ Murphy made a few trips to the USSR and discovered that "the developing subculture" also numbered some people in Soviet academic circles.

He made friends with a dynamic young man named Joseph Goldin whose title sounded typically for the huge Soviet bureaucratic machine-Scientific Secretary of the Commission for the Complex Study of Man. But in reality his commission was a cover for a group of intellectuals who studied semi-officially what they dubbed "hidden human resources." Their very eclectic field of study included such things as "psychology of creativity, cybernetics, sexology, architecture, film, music, nontraditional healing, parapsychology and sports performance." The goal of this research was to demonstrate that the supernatural did exist whatever materialistic communist ideology had to say on this subject.

Murphy, his energetic friend Jim Hickman and Joseph Goldin, who had a real gift of convincing hardened Russian officials to participate in his wildest projects, started the exchange program between Esalen Institute and the Academy of Sciences of the USSR. "We bring Soviet scientists over here and take American scientists over there," explained Murphy to an overwhelmed American journalist in an interview. "The Soviet buzz-word is 'hidden human re-

8 Michael Murphy, New Age Journal, March 1982, 33.

9 Jeffrey J. Kripal, Esalen. American Religion of no Religion (Chicago, London: The University of Chicago Press, 2007), 327. 
sources' and ours is 'human potential' [...] There's ESP, mystical experience, bodily transformation and evidence of super-normal capacities that the culture simply defines out of existence." ${ }^{10}$ An official Soviet atheistic materialism "defined it out of existence" in a more ruthless way but it may have made Russian scientists more open to new vistas of spiritual realm than their American colleagues. The forbidden fruit is always sweeter.

When the communist regime started to erode in the second half of the 1980s the idea of synthesis between Western science and spiritual wisdom became rather popular among Russian intelligentsia. Those who read Samizdat translations of the works by Grof, Wilber, Charles Tart and other American transpersonalists were eager to see their idols alive and the changed political situation made it possible. In the Easter week of 1989, Michael Murphy brought to Moscow Stanislav Grof and his wife Christina who held a short seminar on holotropic breathwork. ${ }^{11}$ They developed this technique as an adjunct to medical use of LSD but when the latter was forbidden the former became an independent way of access to alternative states of consciousness. This group method included hyperventilation of lungs by intensive breathing accompanied by tribal and meditative music and self-expression through drawing. Soon after the visit, two books by Grof were officially published for the first time at the Academy of Sciences Publishing House in a limited edition of five hundred copies. It was a real break-through. The underground period of TP in Russia was over and the first leaders of it made themselves known to a wider public.

Among them was the well-known mathematician Vasilii Nalimov (19101997), who worked in the academician Andrei Kholmogorov's team. In his youth he belonged to the underground esoteric group of Russian Templars and was imprisoned in Stalin's camps. He always combined his scientific research with spiritual quest and when TP came to Russia, he was one of the first to cooperate with it. Nalimov co-authored with his wife Zhanna Drogalina an article on the closeness of their views to TP. ${ }^{12} \mathrm{He}$ also published his articles in the International Journal of Transpersonal Studies and in spite of his advanced age actively participated in TP international conferences and symposiums.

10 Mark Vaz, "On the Psychic Frontier with Michael Murphy," Yoga Journal, January/February, $1983,24$.

11 The term "holotropic" is derived from two Greek words- "holos" (whole) and "trepein" (to turn to something) and might be translated as "moving to wholeness." Holotropic Breathwork is a method of psychotherapy that combines ancient yoga practices and modern research in human consciousness.

12 Valerii Nalimov, Zhanna Drogalina, "Naukometricheskii analiz zhurnala 'International Journal of Transpersonal Psychology," Psikhologicheskii zhurnal, vol. 13 (1992), no. 3, 130-139. 
Meanwhile a younger generation of Russian transpersonal psychologists came to the scene. One of its leaders was Vladimir Maikov. He graduated from the prestigious Moscow Institute of Physics and Technology in 1980, but went on with his post-graduate studies at the Institute of Philosophy, the Academy of Sciences of the USSR, where he got his Ph.D. in 1988. Alongside with his official education he got involved in 1980 into transpersonal studies in the underground Moscow group Kontext under the leadership of Vitalii Mikheikin (1938-1990). The members of the group translated for Samizdat the books by John Lilly, Carlos Castaneda, Ram Dass, Chögyam Trungpa and Stanislav Grof and "learned spiritual and transpersonal practices" from them. ${ }^{13}$

In the spring of 1990, Maikov with some of his friends founded the Russian Association of Humanistic Psychology and became the vice-president of its transpersonal section. "The romantic stage" of TP in Russia started, as Maikov and one of his close associates Vladimir Kozlov called it later, probably meaning their youthful enthusiasm for it. ${ }^{14}$ In the summer of 1990, Maikov went to the United States and visited the major centers of TP there. The close cooperation between Americans and Russians resulted in two conferences in 1991 and 1992. The American side was represented by the well known Saybrook Graduate School and Research Center in San Francisco. It was at this time that Maikov began to take holotropic breathwork lessons under the guidance of Stanislav and Christina Grof and became a certified instructor of this transpersonal discipline.

The "romantic period" in the history of TP in Russia can be characterized by two major features. First, American TP literature was translated and published profusely. Sometimes the quality of translations was good (as in the publishing project Teksty transpersonal'noi psikhologii initiated by Maikov) but more often, it was rather poor. There was a huge demand for things occult in the 1990s and translations of TP works were practically lost in "the spring torrents" of occult and esoteric books of all kinds, which filled the shelves of Russian bookshops. Russian readers interested in the supernatural did not differentiate between these books. Secondly, the New Age movement presented in Russia by such centers as "The Way to Oneself" (Put' $k$ sebe) practically merged with TP, selling its books and holding seminars on its practices. On the one hand, it made the TP approach widely popular (the journal $P u t^{\prime} k$ sebe was published in more that 100,000 copies), but on the other hand, the public image of it became rather

13 Vladimir Maikov, Vladimir Kozlov, Transpersonalnyi proekt: psikhologiia, antropologiia, dukhovnye traditsii, vol. 2 (Moscow: Teksty transpersonal'noi psikhologii, 2007), 147. Ibid., 151. 
vague. This vagueness was exacerbated by the fact that numerous psychic healers and magicians of all kinds freely used TP literature and practices to make themselves look more "scientific" and respectable. ${ }^{15}$

\section{The Export Package}

The "romantic stage" of TP, with its obvious danger of getting lost among the numerous Western imports in the field of popular spirituality, made its Russian leaders look for their own identity. They attempted to discover a TP lineage in the history of Russia. In his essay published in the International Journal of Transpersonal Studies Maikov made a short sketch of such lineage. He discovered three layers underlying Russian transpersonal tradition: a) Shamanism, b) Celtic paganism, and c) the modern layer. ${ }^{16}$ The modern layer is divided into seven areas: Orthodox hesychasm; Russian religious philosophy of the Silver Age; Theosophy, founded by Elena Petrovna Blavatsky (1831-1891); Anthroposophy; writings of Lev Tolstoy and Fedor Dostoevsky; the teaching of Georgii Gurdjieff (1866 [?]-1949) and, finally, Russian Cosmism with Nikolai Fedorov (1829-1903), Konstantin Tsiolkovskii (1857-1935) and Vladimir Vernadskii (1863-1945). ${ }^{17}$ Maikov also mentions some names of those who carried transpersonal tradition in the dark night of Soviet oppression: Mikhail Bakhtin (1895-1975), Aleksei Losev (1893-1988), Merab Mamardashvili (1930-1990), Aleksandr Piatigorskii (1929-2009), and Vitalii Mikheikin.

This lineage of Russian TP raises many questions. It is clear why the author mentions Shamanism and paganism. The shamanic experience represents the most ancient and direct way to altered states of consciousness (ASC) - the major object of study and practice of transpersonalists all over the world. More or less the same goes for paganism with its ecstatic rituals. But why include these things present in many other parts of the globe in the Russian transpersonal tradition? There is nothing particularly Russian in it. However, Siberian shamans and exotic pagan rituals are part of the image of "mystic Russia" abroad.

The tradition of hesychasm is also not of Russian but of Greek origin. It is rather the heritage of Orthodoxy and can be practiced by Orthodox ascetics

\footnotetext{
15 Ibid., 153.

16 Frankly speaking, I do not know about any vestiges of Celtic paganism in Russian culture but the author might have meant Slavic paganism.

17 Vladimir Maikov, "The Transpersonal Tradition in Russian Culture," International Journal of Transpersonal Studies, 24 (2005), 78.
} 
anywhere. The most well known Hesychastic exercise, "the Jesus prayer," called sometimes "Orthodox yoga" is indeed associated with Russia in the West due to the anonymous Russian book of the second half of the $19^{\text {th }}$ century, translated into English almost a century later and popularized by J. D. Salinger in his novel Franny and Zooey. ${ }^{18}$

Theosophy is a typical product of the Western occult revival of the $19^{\text {th }}$ century and the Russian origin of one of its founders did not influence its teaching very much. However, the name of HPB (as Blavatsky is called by her adepts) is indeed well known in the West as an example of the enigmatic l'Âme Slave. As for the Anthroposophy of Rudolf Steiner, it has not very much to do with Russia, though some of the great Russian writers and actors were involved in it. The names of Andrei Bely and Mikhail Chekhov come to mind, the latter being well known in the United States as the acting coach of many Hollywood stars.

The first impression one gets from this lineage is its arbitrariness but then a certain logic of it becomes clear. Those who are included into it are popularly associated with Russia in the West. The names of Dostoevsky and Tolstoy certainly fit into the picture as well as such names of Russian religious philosophers as Nikolai Berdiaev and Sergei Bulgakov who were exiled to Europe by Bolsheviks and became famous there. Georgii Gurdjieff (though not Russian, he was half-Armenian and half-Greek) is one of the best known Russian gurus in the West. Russian cosmists like Vernadskii are mentioned on many name lists popular in the New Age movement. As for the names of those who held the banner of TP in the Soviet years, the choice of some of them follows the same logic. The philologist and philosopher Mikhail Bakhtin, whose works on medieval "carnival culture" are translated into many European languages as well as the indologist and dissident Aleksandr Piatigorskii who immigrated to England in the 1970s evidently reveal the author's personal taste. (The expert on Greek and Renaissance aesthetics Aleksei Losev, and the Georgian philosopher Merab Mamardashvili were very popular among post-War Soviet intelligentsia). The name of Vitalii Mikheikin, practically unknown either in Russia or the West, is included because he happened to be the one who acquainted the author with TP.

18 "Otkrovennye rasskazy strannika dukhovnomu svoemu otsu," "The Way of a Pilgrim: And the Pilgrim Continues His Way. “ Transl. by R. M. French (New York: Harper, 1954). See, Michael Hagemeister, "Imjaslavie - imjadejstvie: Namensmystik und Namensmagie in Rußland (19001930), “ In: Tatjana Petzer, et al., eds., Namen: Benennung - Verehrung - Wirkung. Positionen der europäischen Moderne (Berlin: Kadmos, 2009), 77-98. 
The conclusion seems to be clear. Whatever the author's intentions were, the lineage looks as if it is meant for foreign readers, its conscious (or subconscious) purpose is to present an export package of Russian TP. It is hard to believe that Maikov wanted to introduce the Russian version of TP to Western customers who have plenty of their own teachers. The reason seems to be that Russia's image as a mystical "land of wonders" plays a certain role in the modern New Age mythology. We might compare it with the roles Egypt and India played for the $19^{\text {th }}$ century Western occult revival. It is exactly how many Western transpersonalists look at Russia nowadays and what makes people like Michael Murphy and Stanislav Grof come to Russia repeatedly. It is not accidental that Russian transpersonal psychologists being loyal followers of their American "gurus" look at Russia through their eyes. However, it does not help much to root TP in Russian culture.

\section{TP as a New Profession}

TP, being by definition a synthesis of spiritual wisdom and Western science, tried also to find its Russian identity as a legal branch of scientific psychology. In 1991 a close associate of Vladimir Maikov, Vladimir Kozlov, who was a professional psychologist by training, read a course of lectures, "The theory and practice of TP", for the students of the Psychology Department at the Iaroslavl' State University. The department approved the course and TP was officially included into an educational system of the USSR. Kozlov also held a session of holotropic breathing at the university as a practical seminar for his students. ${ }^{19}$

In the end of the 1990s Vladimir Maikov, Andrei Gostev, Evgenii Faidysh and Nikolai Kudriashev trained a group of ten transpersonal psychologists at the "College of Psychology" in the "Institute of Psychology" of the Russian Academy of Sciences. They became the first students who got higher TP education in Russia. In the spring of 2002 groups of TP followers in Moscow, St. Petersburg, Iaroslavl', Novosibirsk, Taganrog and Rostov-on-the-Don decided to found their professional association. In May 2002, the constituent conference of the Association for Transpersonal Psychology and Psychotherapy (ATPP) took place.

The number of professional organizations of TP began to grow in Russia: "The Institute of Integrative Psychology" led by Vladimir Kozlov in Iaroslavl'; "The Foundation of Transpersonal Psychology" of Faidysh and Gostev in Moscow; "The Transpersonal Institute" of Maikov also in Moscow; "The Baltic Asso-

19 Maikov, Kozlov, Transpersonal'nyi proekt, 152. 
ciation of Transpersonal Psychology" in St. Petersburg and many smaller local organizations. They publish professional journals, hold domestic and international conferences and participate in other academic activities. However, the process of TP's integration into Russian culture as a solid science has been coming across serious difficulties lately and the criticism of it by traditional psychology becomes stronger.

In the 1990s, Western transpersonalists coming to Russia were surprised and delighted at the reaction of Russian scientists towards TP. I have already mentioned Michael Murphy's optimism, but Stanislav Grof also fell in love with Russian openness. In his interview to a popular Russian website Pravda.ru he favored the Russian TP situation above the American one:

Another reason for growing popularity of TP in Russia is that under Soviet power psychology and psychiatry were permitted only a small number of philosophical approaches, for example, those based on Ivan Pavlov's works. When the old system fell, a spiritual vacuum has appeared and Russian specialists were sincerely eager to follow the last achievements in the consciousness studies. That is why there are much more scientists in Russia who accept TP than in American universities where departments of psychology have been filled with conservative supporters of biological, neo-Freudist and behaviorist approaches. I felt this during my trip to St. Petersburg in the summer of 2001."20

However, Grof was angered and disappointed when the respected Moscow newspaper Kommersant published an article on him, calling him "the father of psychedelic revolution" and stating that, he "continued experiments with psychedelic preparations in cancer patients and narcotic drug addicts (...) as an underground activity." The Russian journalist Alena Antonova confirmed, "He has been in Russia several times but these were private visits, because many of Grof's treatment methods are illegal in our country and they attract the interest of the special services." ${ }^{21}$ As it is well-known, Grof used LSD as the instrument of reaching ASC quite legally during his psychiatric research in Czechoslovakia and at the Maryland Psychiatric Research Center in Baltimore and replaced it with the holotropic breathwork method when the powerful hallucinogen became an illegal substance in the US. As for his trips to Russia, they were quite official and it was the Ministry of Health, which invited him. It was the article's

20 Stanislav Grof, "Liud'mi upravliaiut matritsy." www.pravda.ru/science/mysterious/human/1201-2007/209514-grof-3/ (accessed 24 August 2011).

21 Alena Antonova, "V stranu priekhal propagandist LSD," Kommersant, July 2, 2001. 
reference to "special services" whose influence was becoming stronger after Vladimir Putin's ascent to power that was symptomatic. The political climate in Russia was changing rapidly.

In modern Russian history short intervals of political and cultural freedom used to change into longer periods of authoritarian rigidity. This pattern started to reappear again when Putin's Ordnung replaced Gorbachev's perestroika and Yeltsin's democracy at the very end of the 1990s. Cultural change accompanied the political one. The non-rational wave of mysticism, which fascinated Murphy, Grof and other American transpersonalists in new Russia and made them nostalgically remember the years of their countercultural youth, has changed for a different mood. The rationalistic ethos began to dominate in official Russian culture and academia was eager to pick it up. That is why the spirit of acceptance of TP by academic Russian psychology, which surprised and delighted its Western adepts, was replaced by criticism. The attempts of Russian TP to achieve professional recognition were consequently snubbed.

\section{The Stigma of Pop-psychology}

In January 2007, the corresponding member of the Russian Academy of Sciences, the deputy director of the Institute of Psychology of RAS, Andrei Iurevich, published an article in one of the most respected academic journals Voprosy psikhologii. ${ }^{22}$ It was analyzing a phenomenon which the author, one of the leading Russian scientists in the field, named "pop-psychology." He regarded it as a new way of interaction between psychological science and mass consciousness. In his opinion, it was as different from academic science as from psychological practice. At the same time it was based on both, plus two other sources-esotericism and common sense. One of the leaders of TP in Russia, Professor Vladimir Kozlov, was put under scientific scrutiny in the article as the typical representative of pop-psychology. He was not happy with it, as the response on his personal website has shown. ${ }^{23}$

The major feature of pop-psychology, according to Iurevich, is the complete lack of borders between scientific knowledge verified by empiric experience and things, which have nothing to do with it. The author admits that in our time of postmodernist methodologies, scientific criteria are becoming less rigid, but pop-psychology is too "omnivorous" even for this situation. Pop-psychology

22 Andrei Iurenich, “Pop-psikhologiia," Voprosy psikhologii 1, 2007, 3-14.

23 V.V. Kozlov, "Nekotorye utochneniia: akademicheskaia, prakticheskaia i pop-psikhologiia," www.zi-kozlov.ru/articles/1144-pop 
finds a place not only for doubtful psycho-technologies like Neuro-Linguistic Programming (NLP), but for all kinds of esotericism. Pop-psychologists do not hesitate to place such concepts as "chakras", "karma", and "aura" alongside scientific data and do not consider whether there is any reality behind these concepts. The lack of borders results in texts scientific in form but very strange as far as their content is concerned. The author gives many examples of this approach taken mostly from the works by Vladimir Kozlov. The phrases such as "holotropic states of consciousness let us get the experience of eternity and immortality" can hardly be called scientific, in his view. ${ }^{24}$

Pop-psychology does not bother itself with differences between myth and science because its major goal is not scientific but practical. It wants to make itself attractive for clients and help them solve their psychological problems by any means. That is why it is so universalistic. Pop-psychologists easily break barriers between different academic schools and include esoteric elements into their synthesis. However, such an integrative approach demonstrates the absence of a critical position. The scientific method is based on the Cartesian credo-“doubt everything"-but pop-psychologists, so Iurevich, definitely prefer Paul Feyerabend's one- "anything goes".

The "cognitive omnivorousness" of pop-psychologists makes their writing style a mixture of science and fiction where phrases like "the universe is pregnant with human consciousness" (this is borrowed from Kozlov's texts) are common. They also love to refer to their personal experience, which is replete with spiritual revelations and extraordinary states of consciousness. These people look more like showmen than scientists, concludes the author and it is not surprising at all, as showmanship is a major feature of modern civilization. ${ }^{25}$

Iurevich states that he does not want to stigmatize pop-psychology as a new type of obscurantism and degradation of science. He even tries to find in it some positive sides like making psychology popular among a wider public. Iurevich admits it can give help when its practitioners share with clients the real fruits of their self-reflection (that is why he names common sense among poppsychology sources) but his general conclusion is far from optimistic. Making pseudo-scientific concepts out of mythologems is no good for modern Russian society as irrationality is wide spread there as it is. "Pop-psychology facilitates 'belief in everything' and it is a very dangerous state of mind because it opens limitless possibilities for manipulation of the mass consciousness." ${ }^{26}$

24 Iurenich, „Pop-psikhologiia,” 9.

25 Ibid., 11.

26 Ibid., 13. 
However, Iurevich thinks that the direct confrontation of psychology with its pop-version will not be useful for the former. Parapsychology is another marker and the attitude to it should be definitely negative, as science cannot share any ground with "pure mysticism." However, pop-psychology being a mix of science and esotericism is a very interesting phenomenon of modern civilization and should be studied as such. Psychology should know what is going on in people's minds; it is its job after all.

But the role of a guinea pig cannot be satisfactory for Vladimir Kozlov or any other Russian transpersonalist. They see themselves as leaders of psychology of the 21st century who will make it a great science of the future. In his response to Iurevich's article, Kozlov shares practically all statements of his opponent but reaches opposite conclusions. The main goal of TP (Kozlov prefers to speak of integrative psychology as an advanced version of it) is to unite all branches of modern psychology plus esoteric and religious teachings, but it is far from being bad. Quite the contrary is true. We can properly understand human beings only as a whole, so that a holistic approach is the one that is needed. It is exactly integrative psychology that supplies one with it. Indeed, new psychology does not trust analysis, but this does not mean it is not scientific as the basic feature of the new scientific paradigm is synthesis. Moreover, integrative psychology is not going to discard the academic one because the latter also makes part of the synthesis. Kozlov finishes his response in that flowery style, which makes his opponent so uneasy:

If our mental glance is able to unite various psychologies into one mandala of science and all psychologists suddenly are filled with strength in order to overcome great opposites and their eyes become wide open for different interpretations of psychology's subject as a child's eyes are open to the doings of life, then we meet the (real) psychologist. And integrative psychology! $!^{27}$

Russian TP continues with its attempts to find a common language with academic science. In June 2010, the $17^{\text {th }}$ World Transpersonal Congress took place in Moscow where Stanislav Grof was supposed to discuss the "new paradigm in science" with a Russian philosopher, Viacheslav Stepin. Stepin is not only a prominent thinker, he is also a full member of the Russian Academy of Sciences and scientific head of the Moscow Institute of Philosophy. The discussion between one of the founding fathers of TP and a high level representative of Russian academic science was planned by the Congress organizers to underline the

27 Kozlov, "Nekotorye utochneniia." 
scientific status of Russian TP. But academician Stepin didn't attend the discussion. There was only one well-known Russian scholar, Sergei Khoruzhii, who participated in the work of the Congress. He is a world authority on hesychasm and combines it with research in mathematics, but unlike Stepin, Khoruzhii is not a functionary in academia. The attempt of TP to establish "an official dialogue" with Russian science seems to have failed this time.

It is clear that Russian TP nowadays finds itself in the situation of a cultural border conflict, which has become more severe lately. In the 1990s Russian transpersonalists were envied by their Western colleagues but in the 2000s the situation has reversed. American transpersonalists can afford to discuss their strategies about whether they should establish themselves in APA in a more formal way or try to find alternative ways of existence. In Great Britain TP has firmly established itself as a section within a professional body of the British Psychological Society. However, after the breakthrough of the 1990s Russian TP comes across difficulties as far as its professional status is concerned. Its area for maneuvering in finding a proper modus vivendi is definitely limited. Of course, there is a huge difference from Soviet times when the official ideology ostracized unorthodox views and repressed its adepts. However, the situation of TP is exacerbated by the fact that it is not only the rationalist opponents who criticize its esoteric leanings; the latter come under the fire of non-rational critique as well.

\section{The Monopoly on Non-Rational}

In its studies of mystical experience, TP covers a wide range of religious phenomena from archaic Shamanism to oriental religions, occultism and Christianity. Its basic methodological premise is the equality of all kinds of mysticism. The shamanic flight, Hindu yoga and unio mystica of St. Theresa are considered no different in essence as they all represent altered states of consciousness. Moreover, TP makes no difference between natural and artificial ways of getting ASC such as psychedelics, holotropic breathwork, rebirthing, etc. The leaders of TP do not conceal their negative attitude to organized forms of religion, which, in their view, always tried to limit the mystic search of their followers. Stanislav Grof insists on the difference between spirituality and religion. The former involves a relationship between the individual and the cosmos and is a personal thing. The latter is an institutionalized activity that relies on appointed officials who not necessarily have spiritual experience. That is why organized religion easily loses its spiritual connection and becomes an institution that rather tends to exploit spiritual needs rather than satisfy them. 
It is quite clear that Grof's attitude to spirituality is positive but that to religion is strongly negative.

Organized religions tend to create hierarchical systems focusing on the pursuit of power, control, politics, money, possessions, and other secular concerns. Under these circumstances, religious hierarchy as a rule dislikes and discourages direct spiritual experiences in its members, because they foster independence and cannot be effectively controlled. ${ }^{28}$

The leaders of Russian TP, as a rule, do not share Grof's anti-clericalism openly but they include Orthodox mysticism in the lineage of Russian transpersonal tradition alongside with Shamanism, occultism and oriental religions. However, in the first decade of this century the Russian Orthodox Church (ROC) began to strengthen its leading role in Russian religious life. It is ready, to a certain extent, to share its spiritual monopoly with other "traditional religions" (Islam, Judaism and Buddhism) but strongly opposes all kinds of esoteric and occult teachings. Under such circumstances, it regards a highly eclectic TP, regarding all things occult as a direct challenge to itself. It is not accidental, in my view, that it was not only academician Stepin who failed to appear at the last World Congress of TP in Moscow but also another scholar mentioned in its program, Oleg Genisaretskii. He is a well-known layman of the ROC and actively participates in its social and cultural activity.

The Orthodox critique of TP can be divided into two types -- fundamentalist and conservative. For fundamentalists, TP is an outrageous Devil's attack on Russian culture, which they identify with the Orthodox tradition. It is a vanguard of dark forces, coming from the West, an enemy of all things good and should be eliminated without any delay by the Russian state and its glorious special forces. ${ }^{29}$ The conservatives' criticism is more subtle. It might even recognize a limited therapeutic value of TP but it affirms at the same time that real Orthodox believers do not need it.

In his work "Religious aspects of Transpersonal Psychology of S. Grof" the archpriest Konstantin Gipp concludes that TP is "a syncretic religious teaching containing elements of oriental religions, occult doctrines, kabbalah, astrology, shamanic practices and also certain non-traditional kinds of Christian mysticism." 30

28 Stanislav Grof, M.D. “A Brief History of Transpersonal Psychology," www.stanislavgrof.com.

29 Soiuz pravoslavnykh khorugvenostsev, www.pycckie.org (accessed 24 August 2011)

30 Protoierei Konstantin Gipp, "Religioznye aspekty transpersonal'noi psikhologii S. Grofa," www.hram-pokrov.ru/work2.html (accessed 24 August 2011). 
Consequently, from the Orthodox point of view, TP is to be divided into three parts. The first part contains ideas, which are unacceptable for an Orthodox Christian. They have to do with TP Weltanschauung. Above all, it is the monistic pantheism of TP, which posits the merging of the human soul with the non-personal Absolute as a goal of human life. The second part includes TP concepts, which can be interpreted within the framework of Orthodox teaching. For example, Jungian archetypes might be understood through the idea of anima mundi, borrowed by Orthodox theologians like Maximus the Confessor from neo-platonic philosophy. But a Christian believer should keep in mind that certain images awakened by TP practices are nothing else but daemonic temptations called 'seductive attraction' (prelest') in Orthodox ascetic literature. And, finally, the third part of TP contains elements, which can be interpreted in Orthodox terms and be useful for Orthodox psychology. Grof's concept of systems of COEX (condensed experience) is similar to the Orthodox one of passions and his teaching on prenatal states is similar to the Christian idea of original sin.

All in all, the evaluation of TP by archpriest Konstantin Gipp is rather negative. He refers to Pavel Florenskii's (1882-1937) belief, that spiritualism is a worse enemy of Christianity than positivism. The famous Russian theologian considered spiritualism to be an improved positivism, which used the same empirical method but accepted the spiritual dimension of life. However, its belief system was so different from Christianity that there could not be any reconciliation between the two. ${ }^{31}$ In the same vein, the modern orthodox critic regards $\mathrm{TP}$ as a combination of science and eclectic spirituality and finds irreconcilable differences between it and Orthodox faith.

Another Orthodox archpriest, Vladimir Parkhomenko, goes even further in his criticism of TP. He compares it to the Elysian mysteries of ancient Greece, which gave its adepts the mystical experience of death and rebirth close to that by experienced TP followers. Perhaps the latter would not object much to such comparison. However, they would hardly share the conclusion their Orthodox critic makes out of it; the Elysian mysteries gave way to Christianity because their knowledge of life and death was inferior to the faith in the resurrected Christ conquering death. "Transpersonal psychology wants to be called 'psychology of the future' but we can easily foretell that it will have the same future as Elysian cults of the past." ${ }^{32}$

31 Pavel Florenskii, "Spiritizm kak antikhristianstvo," In: idem, Sobranie sochinenii v chetyrekh tomakh, vol. 4 (Moscow: Mysl', 1994), 214.

32 Protoierei Vladimir Parkhomenko, "Vozvrat k elevzinskim misteriam ili khristianskii vzgliad na 
Father Parkhomenko ironically plays with the title of Grof's major work translated and published in Russia, but the leaders of the ROC prefer action to irony and do not play games with their ideological opponents. Three years ago a group of leading members of the Academy of Sciences, including two Nobel prize winners, the late Vitalii Ginzburg and Zhores Al'ferov, signed a letter of protest against the clericalization of Russian society by the ROC. ${ }^{33}$ They addressed it to the then president Vladimir Putin but he did not respond. Instead, the newly elected patriarch of the ROC Kirill, a very able and strong-willed politician, made the Ministry of Education and Science introduce theology to universities as a scientific discipline. ${ }^{34}$ It was exactly the thing members of the Academy had been fighting against. Now academicians prefer to behave very friendly to the ROC and its influential head, making him recently the Doctor honoris causa of the Moscow Institute of Physics and Engineering, the chief Russian center of nuclear research. ${ }^{35}$ In the same vein, another member of the Academy, Vladimir Fortov, has declared recently that Church and science should fight together against parascience and occultism as a threat to both:

Church and science have a large field for cooperation. I mean fighting with mysticism, magic, sorcery, astrology, para-science, all those things that flowed over our society. People started to believe in primitive answers thrust on them by charlatans. In such matters church and science are of the same mind. ${ }^{36}$

There are signs that the Russian TP community becomes aware of the situation and tries to find a compromise with the ROC. One of the leading Russian transpersonalists Andrei Gostev, who often represents Russia on international forums of TP and together with J.C. Tucker co-authors the Russian-American project "Zemlianin-The Emerging Global Citizen", ${ }^{37}$ has been researching the ascetic heritage of Eastern Christianity for the last few years. Other Russian transpersonalists might be also interested in such things but they are just ex-

religiiu budushchego," www.weren.ru/texts/02_true/04_modern/elevsin.html (accessed 24 August 2011).

33 "Politika RTPs: konsolidatsiia ili razval strany?", Novaia gazeta, Nauchno-populiarnoe prilozhenie Kentavr, no. 3, July 23, 2007.

34 “Teologiia stanet naukoi v aprele," www.grani.ru/Society/Science/m.174972.html (accessed 24 August 2011).

35 Elena Iakovleva, "Iadernaia vera. Patriarkh Kirill posetil znamenityi MIFI," Rossiiskaia gazeta, March 5, 2010, no. 5125 (46).

36 “Tserkov' i nauka - est' li konflikt: mneniia akademikov”, www.pravmir.ru/printer_2193.html

37 zem.org 
amples of mystic experience for them alongside the other ones. However, Gostev's approach seems to be different. He treats Orthodox ascetic tradition as an exclusive one and admits that those altered states of consciousness that do not conform to it might be of danger to the patients. He also uses the Orthodox ascetic term prelest' for describing them. ${ }^{38}$ His approach seems to be closer to that of Orthodox critics of TP than to that of his colleagues. Of course, we can always say that it is not a compromise but a matter of faith and Gostev has simply converted to Orthodoxy. But, whatever his subjective motives might be, his exclusionary approach objectively makes a sharp difference with the inclusive ethos of TP.

\section{The Escape into Popular Culture}

The ROC's monopoly on the non-rational is useful to Russian authorities. It corresponds to their ideal of "Law and Order", which seriously limits political, cultural and religious pluralism in the country. The TP seems to fall easy victim to this lack of pluralism. Besides, its position on the very border of science and religion is rather suspicious to both secular and religious participants of the politico-cultural process. Under such circumstances, TP's search for a proper place in Russian society becomes a real problem for it.

Meanwhile there is a large cultural area in Russia, which is practically free. I mean the domain of mass culture. It is based on the principle of entertainment and market laws govern it. In addition, it is very resistant to any kind of pressure. Lately the authorities have tried to control it in order to make it more decent, but all in vain. In the Soviet time things, which were rejected by the state used to go underground, now they tend to join the kingdom of popular culture. However, as they do so they become vulgarized and commercialized. This is what has been happening to esoteric and occult subcultures in Russia for some time, now it seems to be TP's turn. ${ }^{39}$ This process is typical for the modern world in general, but in Russia it is sped up by the growing stiffness of official culture. The more TP is criticized by mainstream institutions, the more it is tempted to escape into the "free world" of popular culture, which accepts it gladly.

When one looks at the activity of Russian transpersonal psychologists nowadays one notices that the majority of them is involved in numerous seminars

38 Andrei Gostev, Psichologiia i metafizika obraznoi sfery cheloveka (Moscow: Genesis, 2008), 294.

39 Boris Falikov, "Kakovy èlity, takova i ėzoterika; v usloviakh massovoi kul'tury okkul'tnye znaniia prevrashchaiutsia v razvlecheniia”, Nezavisimaia gazeta-religii, September 19, 2008. 
and sessions, selling people all kinds of TP techniques. Pop-culture entertainment presupposes a thorough knowledge of the public demand. Consequently, Vladimir Kozlov has posted on his personal website a survey, asking the viewers what they expect of him. In the period of half a year from September 2009 to April 2010, he got the following results.

The majority of $27.7 \%$ want him to teach shamanic practices; $23.7 \%$ expect to be taught different types of breathwork (rebirthing, vivation, holotropic methods, free breathing); Buddhist meditation is demanded by $15.8 \%$; art therapy is asked for by $10.7 \% ; 9.6 \%$ of the respondents look for body-oriented practices; $7.9 \%$ want to be taught dance movements; and, finally, $4.5 \%$ expect Kozlov to teach them visualization techniques. ${ }^{40}$ The high interest for shamanic practices is shared by Russian occult milieu today, which means that the border between occult practices per se and TP is getting more transparent now.

Other Russian transpersonalists follow Kozlov's example. The President of Russian ATPP, Vladimir Maikov and his wife Kristina, hold a program of Grof Transpersonal Training (GTT) in Moscow, teaching holotropic breathwork. The price list is attached to the program schedule on the website of ATPP. The cost of a one-day seminar is 2,500 rubles (about 84 US doll.), if prepaid, and 3,000 roubles (about 100 US doll.), if paid on the spot. For two-day seminars, the prices are 5,000 and 6,000 (about 167 and 200 US doll.respectively. Five-day seminars cost 10,000 and 11,500 rubles.(about 333 and 383 US doll.) These seminars are held at clubs and centers such as "Loft, Open World" (Otkrytyi mir), and "Sanskrit". These are typically New Age places, which operate on a commercial basis. For example, the program of "Open World" features such popular offerings as yoga classes, shamanic practices, tea ritual lessons, Taoist sexual practices for women alongside with TP sessions of all kinds. The ads for these fashionable and entertaining activities are placed on a special page in the popular Live Journal social network. ${ }^{41}$

The TP community exploits another mass fashion, pilgrimages to exotic places which are becoming very popular among Russians. Consequently, the leading Russian transpersonalists include TP into exotic package-tours. In the summer of 2009 the project "Spiritual Wanderings" (Dukhovnyie stranstviia) headed by Kozlov included trips to practically all places in Siberia highly valued by occult lore from "places of power" in Altai (like mountain Beluha and Uimon valley) to the "divinely pure" Lake Baikal. The professor taught practically every-

\footnotetext{
40 Opros. Kakie tekhniki vy by khoteli videt' na treningakh professora Kozlova? www.zi-kozlov.ru (accessed 24 August 2011).

41 www. open-w.livejournal.com/
} 
thing during the trips from "archaic techniques of ecstasy" to the newest methods of "integrative psychology." In his diary of the trips, published later on his site Kozlov, he admitted that the participants had to struggle with bad weather and overcome the temptations of good weather. Other tourist joys like feeling beauty of nature and developing real group spirit are also mentioned. ${ }^{42}$ It is obvious that exotic tourism as a popular cultural fashion proved to be a convenient means of escape for TP from its cultural border conflict with religion and science.

In 2010, Professor Kozlov provided his exotic tours with an international dimension. In February, his schedule included a 15 days trip to Sri Lanka, which cost each participant 1,850 US dollars. The program of the trip covered sacred Buddhist sights and was not very different from usual tourist tours to such far away and exotic places. TP training was to be conducted by Kozlov in the evenings and it is rather difficult to imagine how the exhausted tourists could follow the professor's instructions. In April, another trip to Israel and Jordan was held, which covered practically all the tourist's attractions of both countries.

The "Open World" club in Moscow also gives the public an opportunity to attend yoga classes in exotic surroundings. In May 2010, it was the Egyptian Red sea-resort Dahab. The trip to the Mount Sinai was also included in the package, which cost 11,000 roubles (about 370 USD). ${ }^{43}$ International trips with their obvious commercial element help New Age practices find a good niche in the domain of popular culture. Now TP follows suit and does it quite energetically. The price for such "spiritual packages" are not much higher than those for ordinary tourist trips and can easily compete with them. As for the Russian new rich they prefer to hire individual gurus and coaches.

As Russia has entered a period of authoritarian rigidity, the hopes of TP to become a part of academic science are thwarted and it is sharply criticized by the ROC, claiming the monopoly on all things spiritual while fighting the occult. Under such circumstances, TP looks for a new way of existence in the thick of popular culture. This latest period of its history in Russia resembles, to a certain extent, the situation of the 1990s in the sense that TP's closeness to New Age and occult milieu in general is growing, but there is one big difference. In its romantic period, TP was much less commercialized and much more idealistic.

42 Dukhovnye stranstviia 2009 (www.zi-kozlov.ru/trainingdescriptions/1198-ds2009) (accessed 24 August 2011).

43 Maiskie prazdniki - yoga v Dahabe (ww.open-w.livejournal.com/19443.html\#cutid4) (accessed 24 August 2011). 
The same is true for Russian New Age and esotericism as well. Moreover, the "Cult of the Golden Calf" seems to attract more and more adepts in practically all spheres of Russian life. 


\title{
OCCULTISM AS A RESPONSE TO A SPIRITUAL CRISIS
}

\author{
BERNICE GLATZER ROSENTHAL
}

Occultism surges in periods of spiritual crisis, periods when the idea that encapsulates a society's core values and beliefs loses its luster. Nietzsche called this idea the "myth." I use "myth" to apply to ideology as well. Nietzsche did not use "myth" as the antonym of "truth" because he believed there is no absolute truth.

The "myth," which can be religious or secular, informs a society's laws and institutions, permeates the culture, endows life with meaning, and helps shape personal and national identity. When the "myth" fades, long-held values and moral norms are challenged; established institutions are called into question, identity issues come to the fore, and people feel anxious, or confused, or insecure. Many of them turn to the occult for certainty, or guidance, or solace. Occultism can supplement the "myth" or replace it.

Of course, in any society, some people will be going through a spiritual crisis, for reasons that vary from one person to another, and some people will be drawn to the occult. This chapter is not about them. It is about periods of widespread spiritual crisis when occultism becomes pervasive. In such periods, the occult ideas and doctrines of previous periods are recycled; new elements that address contemporary concerns are added; and new doctrines are constructed. Occultism subsides when a new "myth" is established.

In Russia, occultism surged in the revolutionary and early Soviet periods (1890-1927) and subsided when Stalin became the new god. It (occultism) revived in the wake of de-Stalinization (the 1960s and '70s), and surged in late Soviet and post-Soviet Russia (1985-2000). Occultism also surged in the United States during and after the 1960s. The "myths" were different and they faded for different reasons, but in each case, their fading precipitated a spiritual crisis to which people responded by turning to the occult. 


\section{Prerevolutionary and Early Soviet Russia}

The spiritual crisis in prerevolutionary Russia was an extreme version of a panEuropean crisis brought on by secularization, dissatisfaction with rationalism, positivism, and materialism, and (in some cases) distaste for the emerging mass society. In Russia, the spiritual crisis was intensified by the obsolescence of Autocracy, the destabilizing effects of the industrialization drive of the 1890s, and modernization in general. Modernization undermined established elites and institutions and fostered new values_-individualism, self-fulfillment, and enjoyment of life-that contradicted the values of the Orthodox Church and of the intelligentsia. The spiritual crisis included a moral crisis propelled, in part, by Nietzsche's call for a "revaluation of all values" and his attack on Christianity.

The tendency of the Russian intelligentsia to seek an all-encompassing idea (or "myth") by which to live is well known. In the 1870s and '80s, the "myth" was populism (narodnichestvo), an agrarian socialism based on the peasant commune (the mir), and on the assumption that the peasant is a socialist by nature. So if the Autocracy and the aristocracy are removed, Russia would pass from the commune to full socialism, by-passing the capitalist stage of development. Rapid industrialization worked to the detriment of the agricultural sector and undermined the peasant commune. Searching for a new "myth" by which to live, some intelligenty turned to Marxism, others to Symbolism, a literary aesthetic imported from France that was based on the esoteric idea of correspondences- "as above so below" in the words of Hermes Trisgmegistos, the legendary Egyptian priest. French Symbolism was in turn informed by the occult revival spawned by Eliphas Lévi (pseudonym of Alphonse Louis Constant, 1810-1875) soon after the failure of the Revolution of 1848. Before that Revolution, Lévi had been a political radical.

Russian Symbolism was born in the early 1890s with Dmitrii Merezhkovskii's lecture, On the Causes of the Decline in Russian Literature and on the New Trends in Poetry (O prichinakh upadka v russkoi literature i o novykh techeniiakh $v$ poezii, 1892, published 1893), which became the manifesto of Russian Symbolism. In that lecture, he maintained that people of his generation were experiencing a spiritual crisis unprecedented in its intensity, because never before has the need for faith and the impossibility of faith (due to reason and science) been so great. Lambasting the "arid" rationalism and "soulless" materialism and positivism propagated by the intelligentsia, Merezhkovskii accused it of stifling creativity, hampering the development of individuality, and ignoring the "inner man" (the soul or the psyche). He predicted that Symbolism 
would lead to "higher truths" because it explores the depths of the human soul and "other worlds than ours," and, eventually, to a new faith that would become the basis of a new culture of creativity, beauty, and emotional freedom.

Merezhkovskii (1866-1941) made Symbolism into a surrogate religion that exalted artistic creativity as a metaphysical activity and rejected the asceticism, self-denial, and humility preached by the Orthodox Church and (in secular form) by the intelligentsia. But art alone did not quench Merezhkovskii's "spiritual thirst" nor did it assuage his fear of death. So in 1896, he posited two eternal principles-Christianity and Paganism, personal immortality and enjoyment of worldly pleasures-and set out to reconcile them. In 1899, he "turned to Christ." A year later, he concluded that "historical Christianity" (the Christianity preached in the churches) is obsolete because the Second Coming is imminent. Jesus Christ Himself would grant humankind a Third Revelation (a Third Testament) that would reconcile all contradictions: Christianity and paganism, spirit and flesh, East and West, and so on.

In 1901, Merezhkovskii co-founded the Religious-Philosophical Society of Saint Petersburg (1901-1903, 1906-1917) as a forum for discussing such issues as Lev Tolstoy's excommunication by the Orthodox Church, Christian attitudes to sex, whether new Christian dogma is needed and if so, who has the power to create it. The members were clergymen and lay intellectuals. The latter, mainly philosophers and poets, were dubbed God-seekers, even though most of them were already believers. They were seeking new, specifically Christian answers to the problems of modern life, as opposed to what they called the "mechanical world view" of the West, which stemmed from Newton and became the epistemological basis of the Enlightenment. Their religious quest encompassed the occult as a supplement to Christianity, not a substitute for it. The hitherto unprecedented spectacle of clergymen and lay intellectuals debating one another on equal terms attracted capacity audiences. Similar societies were founded in Moscow, Kiev, and other cities. The Moscow Religious-Philosophical Vladimir Soloviev Society (1905-1918) was named after the philosopher, Vladimir Soloviev (1863-1900). These societies helped inspire a religious revival. Maria Carlson considers occultism its "illegitimate offspring."

The Symbolists were carriers of occult ideas. They believed that earthly phenomena are but symbols of a higher reality, invisible to ordinary people but accessible to the artist's intuition. Most Symbolists also believed that art has theurgical qualities and that the Word can generate a new reality. Symbolist

1 Maria Carlson, No Religion Higher than Truth: A History of the Theosophical Movement in Russia, 1875-1922 (Princeton, 1993), 3. 
poetry emphasized the sound of a word rather than its meaning, by-passing the intellect. Female Symbolist poets drew on folk spells, incantations, and divination because they conferred "a special right to command the spiritual world through the power of language."2 Andrei Bely (real name Boris Bugaev, 18801934) wrote an essay titled "The Magic of Words" (1909). His novel The Silver Dove (Serebrianyi golub', 1909) is replete with Theosophical terms and images and the protagonist, like Bely cast his own horoscope. Valerii Briusov was interested in Spiritualism, not for its supernatural qualities but as a mode of nonrational cognition. ${ }^{3}$

The Symbolists' "revaluation of all values" included a fascination with the devil and demons. The Symbolist journal Golden Fleece (Zolotoe runo, 19061909) announced a competition for the best literary and pictorial depiction of the devil. Mikhail Vrubel's paintings of "The Demon" were inspired by Lermontov's demon, which was in turn inspired by Milton's Satan, who would rather rule in Hell than serve in Heaven. Some Symbolists regarded the Devil as a tragic figure, who defied divine authority and conventional morality. Briusov glorified "the Lord and the Devil alike." His novel, The Fiery Angel (Ognennyi angel', 1907), which is set in 16th century Germany, depicts erotodemonic possession, devil-worship, black magic, and witchcraft.

The Symbolists were apolitical until the Revolution of 1905-1907. Merezhkovskii concluded that the revolution was the harbinger of the apocalypse, that all revolutions are essentially religious, and that the Decembrist Revolt (1825) was inspired by mystical freemasonry (he was himself a mason). Georgii Chulkov (1879-1939), a minor Symbolist poet, declared that Russia is in the grips of an "all-pervasive crisis (...) the entire culture is breaking up." Viacheslav Ivanov (1866-1949) proclaimed that individualism is obsolete and would be superseded by sobornost'; in his view, a society cemented by love (eros, not agape), myth, and sacrifice. The myth would be a synthesis of Christian, occult, and Nietzschean elements. ${ }^{5}$ Between 1906 and 1908, he supported Chulkov's doctrine, Mystical Anarchism, which purported to reconcile unlimited indi-

2 Faith Wigzell, Reading Russian Fortunes: Print Culture, Gender, and Divination in Russia Since 1765 (Cambridge/UK, 1998), 193.

3 For details on the Symbolists and the occult, see Nikolai Bogomolov, Russkaia literatura nachala veka i okkul'tizm (Moscow: NLO, 1999).

4 Georgii Chulkov, "Khronika kul'turnoi zhizni," Voprosy zhizni 1905, no. 9, 245-246.

5 Viacheslav Ivanov, "Krizis individualizma," reprinted In: Idem, Po Zvezdam (St. Petersburg, 1909), 95; English translation in: Bernice G. Rosenthal and Martha Chomiak, eds., A Revolution of the Spirit (New York, 1990), 245-256. O misticheskom anarkhizme (St. Petersburg, 1906, Reprint Letchworth, England, 1970), 43, excerpt in: A Revolution of the Spirit, 177-186. 
vidual freedom with being part of a loving community, and which rejected all forms of dogmatism, whether in religion, philosophy, morality, or politics. Bely opposed Mystical Anarchism because he considered it amoral. Nevertheless, between late 1908 and 1910, he joined Ivanov and Anna Mintslova, a Theosophist, in a "mystical triangle" dedicated to "saving" Russia.

Occultism increased in popularity after the Revolution due to the recent turmoil, eased censorship laws, and fewer legal restrictions on organizations. The Russian Theosophical Society was chartered in 1908. Some intelligenty, disappointed with the results of the Revolution, abandoned politics and turned inward.

A new aesthetic movement, Futurism, emerged around 1909 and came to public notice in 1912 with its manifesto A Slap in the Face of Public Taste (Poshchechina obshchestvennomu vkusu). Paradoxically, some of them were interested in alchemy and shamanism. Velimir Khlebnikov (1885-1922) was enthralled by the ancient Egyptian concept of the ka (the Egyptian concept of the spiritual essence), was interested in occult botany, and developed numerological formulas for divination. He also believed that changing the letter of a word actually changes reality and in the existence of a fourth dimension. ${ }^{6}$

Occult themes and motifs permeate Russian literature, including popular literature, from the 1890s to the mid 1920s. ${ }^{7}$ Faith Wigzell reports a "vigorous revival" in the sale of occult books, especially dream-books, in the 1890s. ${ }^{8}$ Why the 1890s? Modernization broadened the scope of personal choice and created new opportunities and new dangers. In the burgeoning cities, people were very much on their own. Some of them turned to astrology to know their future, or to gain or regain health, wealth, and love, and/or navigate the new order by guiding their actions by the stars. The spread of literacy (itself a product of modernization) created a market for new publishing firms and enabled people to read about astrology in "how to" manuals, pamphlets, and articles in penny newspapers and popular journals. The well-to-do had their horoscopes cast. Also popular were articles on how to cultivate one's will-power, by hypnosis for example, other forms of fortune-telling such as palm-reading and numerology, séances, and demonstrations of mental telepathy as entertainment. Popular occultism filled a spiritual void as neither conventional religion nor the

6 For Khlebnikov's language, see the articles in: O Khlebnikove: Konteksty, istochniki, mify (Moscow, 2002).

7 See, Nikolai Bogomolov, ed., Russkaia literatura rubezha vekov (1890-nachalo 1920kh godov), 2 vols. (Moscow, 2000 and 2001).

8 Wigzell, 17. 
new ideology of science and technology became dominant. (See Julia Mannherz's chapter)

The famous (or infamous) Rasputin was the last of a series of faith-healers summoned to cure the Tsar's hemophiliac son. Rasputin did not cure him; but he did stop the bleeding, which gave him enormous influence over the royal couple, especially the German-born Empress, whom he seemed to control. Opponents of the government used Rasputin to discredit it. A group of aristocrats assassinated him in December 1916, too late to stave off the revolution that broke out the following February (March by the Western calendar). ${ }^{9}$

The occultism of prerevolutionary Russia is important, firstly because aspects of the most popular doctrines-Spiritualism, Theosophy, and Anthroposophy-became embedded in the wider culture; secondly because occultists who emigrated after the Bolshevik Revolution gained European and American admirers who disseminated their ideas; and thirdly because ideas drawn from the above doctrines were recycled (with some modifications) in the 1960s and after in both the Soviet Union and the West.

Spiritualism had the most adherents. The modern Spiritualist movement was born in upper New York State, on March 31, 1848, when the Fox sisters, Maggie and Kate, ages 12 and 14, claimed to have spoken with the spirit of a murdered peddler. ${ }^{10}$ In only a few years, Spiritualism swept the United States and Europe, including Russia, because it "proved" that life continued after death and "enabled" the living to communicate with the dead with the aid of a medium. Spiritualism soothed religious anxieties and it empowered women (most mediums were women). Some Spiritualists claimed their doctrine was a science and conducted experiments in thought transfer and hypnosis.

Spiritualism reached Russia in the 1850s. Séances were held at the royal court and in private homes. One factor in its appeal was the Crimean War, "which was accompanied by a sense that history was on the march and that great change was about to come."11 Spiritualism became widespread in the 1860 s, due in part to the social and economic dislocations induced by the emancipation of the serfs in 1861. Moreover, Spiritualism could counter the intelligentsia's atheism.

9 See e.g. Enid Goldberg, Grigory Rasputin: Holy Man or Mad Monk? (New York, 2008)

10 See Eberhard Bauer, "Spiritismus und Okkultismus", In: Okkultismus und Avantgarde. Von Munch bis Mondrian, 1900-1915 (Frankfurt: edition tertium, 1995), 60-80.

11 Ilya Vinitsky, Ghostly Paradoxes: Modern Spiritualism and Russian Culture in the Age of Realism (Toronto, 2008), 8. 
In Russia, as in other countries, Spiritualism evoked a great deal of controversy inside and outside the movement, and it took on national characteristics. Some Russian Spiritualists regarded their faith as the new all-encompassing idea, because it reconciled faith and science. In an extreme expression of the Russian cult of great writers, certain Spiritualists summoned Pushkin's ghost. ${ }^{12}$

American Spiritualists perpetuated the optimism ${ }^{13}$ and individualism of their culture; they believed in perpetual progress, even after death. The spirit ascends a ladder of perfection. This is the same spirit; they did not believe in reincarnation. ${ }^{14}$ The popularity of Spiritualism peaked in the 1860 s and '70s, because people desired to communicate with loved ones killed or missing in action during the Civil War. (More American soldiers were killed in that war than in all other American wars combined.) Abraham and Mary Lincoln held séances in the White House in an attempt to communicate with their favorite son, Willie, who died at the age of eleven.

Spiritualism peaked again during and after World War I and II. The escape-artist and magician Harry Houdini denounced Spiritualism as a fraud and berated mediums for profiting from other people's grief. During World War II, people sought news of loved ones in the armed forces in séances or by turning to a Ouija board, "Spiritualism's most popular innovation." ${ }^{15}$ In the 1960 s and '70s, Ouija boards became a fad among adolescents. For some it was merely a game; for others, its secret messages and intimate communiqués made it a "youthful rite of rebellion, ${ }^{16}$ presumably because Ouija boards were considered a "dangerous portal to the other side."

In Russia, Spiritualism "remained constantly within the field of vision of the cultural elite." 17 Vladimir Soloviev sought out Spiritualist circles when he went to London and he was interested in the occult generally, as was his older brother Vsevolod (1849-1903). The latter was friendly with Elena Blavatsky (founder of Theosophy), but then turned against her.

12 Vinitsky, Ghostly Paradoxes, 65.

13 Many observers have noted American optimism. By contrast, a powerful strain in Russian culture idealizes suffering; it stems from the image of the kenotic Christ. See Natalia Gorodetsky, The Humilitated Christ in Russisan Thought (New York, 1938) and Dirk Uffelmann, Der erniedrigte Christus. Metaphern und Metonymien in der russischen Kultur und Literatur (Cologne, Weimar: Boehlau, 2010).

14 I am grateful to Jenna Silvers for this information.

15 Mitch Horowitz, Occult America (New York, 2010), 65.

16 Ibid., 72-73.

17 Vinitsky, Ghostly Paradoxes, 20. 
Blavatsky (1831-1891) started out as a Spiritualist medium. In 1875, she and Colonel Henry Olcott, also a former Spiritualist, founded the Theosophical Society in New York City. In 1878, they moved to Adyar, India. By 1900, Theosophy had become a world-wide movement.

Blavatsky taught that Theosophy is a universal religion, based on one eternal truth, The Secret Doctrine, which Mahatma Morya, of the Lodge of the Great White Brotherhood in the Himalayas, transmitted to her astrally. Theosophy was primarily Buddhist and Hindu, but it incorporated the Gnostic rejection of matter, the legend of Atlantis, mystery religions, neo-Platonism, and the "vast body of Western Occultism, both ancient and modern, with interpolations from the natural and social sciences, comparative religion, archaeology, medicine, and evolutionism." ${ }^{18}$ Her version of evolution included seven root races, each of which had seven branches. The Slavs were the youngest branch of the Aryan race.

Blavatsky regarded the individual as a microcosm of the macrocosm, and the soul as an emanation of the Divine, so each "human monad is more than a mirror of God, it is God." ${ }^{19}$ She denied the existence of a personal God and of the Devil, and rejected the Christian concepts of heaven and hell in favor of karma, the "law of retribution," the "one universal law." Her interpretation of karma allowed the individual to shape his or her future lives.

Many artists and writers were drawn to Theosophy, at one time or another, because it offered means to explore psychic and spiritual states that defy rational interpretation and a new vocabulary for discussing these states. Moreover, it offered a structured worldview that was amorphous enough to accommodate other forms of mysticism, occultism, and religion. ${ }^{20}$

Theosophy was so popular that the St. Petersburg Religious-Philosophical Society devoted its entire November $24^{\text {th }} 1909$ meeting to it. The discussion revolved around whether Theosophy and Christianity are compatible. Merezhkovskii said they are not, because Theosophy lacks a personal God. (Vladimir Soloviev had said much the same thing.) Other speakers argued that since both doctrines reject materialism and egoism, they are ethically compatible.

Even certain Marxists were interested in Theosophy. Anatolii Lunacharskii (1875-1933), future Commissar of Enlightenment, and Maxim Gorky (18681936), a personal friend of Lenin's and a future formulator of Socialist Realism, appreciated Theosophy's denial of a personal god, its condemnation of egoism

18 Carlson, No Religion Higher than Truth, 114-115.

19 Ibid., 116.

20 Ibid., 29-30. 
and individualism, and its tenet of universal brotherhood. They thought that the macrocosm/microcosm paradigm could be accommodated to socialism. Gorky recognized the proselytizing potential of thought transfer and hypnosis. Ardent admirers of Nietzsche, both men recognized the importance of myth.

Anthroposophy was founded by Rudolf Steiner, a prominent German Theosophist who left the Society after Annie Besant, its leader after 1907, proclaimed a young Hindu boy, Jidda Krishnamurti, an avatar of Christ. Besant posited an "esoteric Christ" as one of a series of Divine manifestations, an Adept, a Mahatma, a Master, but not the one Messiah or a unique historical figure. She considered Buddha superior to Christ. Anthroposophy attracted people who thought that Theosophy had become too Buddhist.

Steiner taught that the birth of Christ was the central event in cosmic evolution, which he portrayed in both spiritual and physical terms. Before the birth of Christ, divine Being existed only outside man in the cosmos. With Christ's birth, divine Being descended to earth as a human body, thus creating an inner bond between earthly mankind and divine Being. Christ's sacrifice at Golgotha introduced a new spiritual mystery into the evolution of the cosmos; at that point, Christ's spirit entered into man, hence, Anthroposophy rather than Theosophy. Steiner called Anthroposophy "spiritual science" and "the science of the invisible," and claimed that it reconciled religion, philosophy, and science. ${ }^{21}$

Theosophy spawned other offshoots as well. Petr Uspenskii (1878-1947), a leading Russian Theosophist, wrote about the Fourth Dimension, originally a mathematical concept that came to be associated with mysticism and the occult. Trained as a mathematician, he "proved" his theory of dimensions with a mystical mathematics of space. Seeking a new all-encompassing idea, he wanted to unite Asian mysticism, Christianity, science, and Western philosophy. Uspenskii taught that the higher dimensions of reality were accessible only to a "new man" who has developed supersensible (occult) powers. His "new man" united the Theosophist concept of a "higher man" with Nietzsche's Superman and Soloviev's God-Man (Jesus). Uspenskii's major works, The Fourth Dimension (Chetvertoe izmerenie), Tertium Organum (Tertium organum), and Symbols of the Tarot (Simvoly taro) were published in Vestnik teosofii (Herald of Theosophy, the journal of the Russian Theosophic Society). In 1915, he became a disciple of Georgii Gurdjieff (1866 [?]-1949). They emi-

21 Renata von Maydell, “Anthroposophy in Russia," In: The Occult in Russian and Soviet Culture, 153-167; eadem, Von dem Thore: Ein Vierteljahrhundert Anthroposophie in Russland (Bochum, Freiburg: Projekt, 2005). 
grated (separately) after the Bolshevik revolution and worked together in France in the 1920s. Then Uspenskii went his own way.

Gurdjieff taught that human beings are essentially asleep and must be awakened by working on themselves individually and in a group setting according to his principles and instructions. "The Work" featured the development and integration of mind, body, and emotions, and included music, sacred dances, self-discipline, and obedience to the Master (Gurdjieff). For example, at his command, students had to stop whatever they were doing and hold that position until he released them. Gurdjieff had American and British admirers who propagated his ideas. His thought became important in Russia in the 1960s.

Nicholas Roerich (1874-1947) and his wife Elena Shaposhnikova-Roerich (1879-1955) claimed a karmic tie to Blavatsky by way of Mahatma Morya. They emigrated soon after the Bolshevik Revolution. In the 1920s and ' 30 s, they constructed Agni-yoga, named after the Hindu god of fire, who mediates between the gods and mortals. Agni-yoga combines eastern and western esotericism and includes discussion of diet, health, education, daily life, and human relations. Again, we find the typically Russian desire for an all-encompassing idea.

Theosophy and Anthroposophy were compatible with a long-standing Russian messianism. Blavatsky believed that the Slavs had a mission: to create a more spiritualized humanity. Steiner predicted that the Russians would play a special role in evolution because they had kept themselves open to the "Christ impulse."

The above doctrines were also compatible with the apocalypticism that permeated Russian culture from 1900 on. The Symbolists assumed that the end of their world would be the end of the world. Their apocalypticism was not all doom and gloom, however. They expected the Apocalypse to be followed by the establishment of the Kingdom of God on Earth.

Blavatsky taught that alternating manifestations of the seven root races are separated by periods of obscurantism and chaos (Kali-Yuga in the Hindu religion). The approach of such a period is signaled by cataclysms of fire and water, eschatological signs, and a general feeling of apocalypse. Humanity is now in such a period, Blavatsky claimed.

Steiner predicted that The Second Coming would not be the resurrection of Christ's physical body but of the "divine being" within man. Humanity, having attained supersensory powers through cosmic evolution, the "etheric Christ" (His living spirit) will be visible to all. He thought this would occur in the twentieth century, in the sixth post-Atlantean age. 
The Bolsheviks vaunted reason and science and condemned "superstition" (religion and the occult). They banned dream-books in 1918, ${ }^{22}$ Rudolf Steiner's writings in 1923, expelled the God-seekers from Russia in 1922-1923, and founded The League of Atheists (Soiuz bezbozhnikov) in 1925. The word "militant" was added later. Despite these measures, the Bolsheviks constructed a quasi-religion, the Lenin Cult, and worked with occultists for their own purposes. In the 1920s and early '30s, the secret police worked with the occultist Barchenko and the government funded Roerich's search for Shambhala. In the 1960s and '70s, the government denounced yoga as spiritual contraband, even while studying yogic breathing techniques, that could help the astronauts, and it supported research on parapsychology. (See the chapters by Oleg Shishkin, Markus Osterrieder, Birgit Menzel and Boris Falikov).

The "myths" were Marxism-Leninism, then Stalin's interpretation of it, and then Leninism. Throughout these changes, Soviet citizens were supposed to forget their personal concerns and devote their energies to "building socialism."

Occultism retained its appeal after the Bolshevik Revolution, because it helped people explain, or at least cope with The Dictatorship of the Proletariat (really of the Communist Party), hunger, epidemics, a bitter and bloody civil war, the "red terror," and economic collapse. The Religious-Philosophical Societies of St. Petersburg and Moscow reopened as the Free Philosophic Association (Vol'fila, Petrograd 1919-1923), and the Free Academy of Spiritual Culture (Vol'naia akademiia dukhovnoi kul'tury, 1918-1922). The members discussed Theosophy, Anthroposophy, and other esoteric doctrines, frequently mingling them with references to Golgotha, Armageddon, and Resurrection, which tie into the Russian belief in redemption through suffering. Vol'fila was a haven for Anthroposophists.

Occultism persisted during the NEP period (New Economic Policy, 19211927), partly because the partial restoration of capitalism dismayed some people and confused others; partly because important issues, such as how to implement Marxism in a "backward" country, how to present Marxism to the masses, and who would succeed Lenin had yet to be resolved. For many people, life was a struggle and its outcome depended on forces they could not control. Some people, even some Communists, hoped to use occult forces to achieve their goals. Early Soviet literature is permeated with occult ideas, old and new. ${ }^{23}$

22 Wigzell, Reading Russian Fortunes, 53.

23 For some examples, see Rosenthal's introduction in: The Occult in Russian and Soviet Culture, 227. 
Cosmism, a new occult doctrine, incorporated the Soviet faith in science and technology. Its sources include Nikolai Fedorov and Konstantin Tsiolkovskii (father of the Soviet space program). (See Michael Hagemeister's and Marlène Laruelle's chapter on Cosmism in this volume).$^{24}$ By contrast to prerevolutionary occult doctrines, which emphasized personal spiritual growth, cosmism was impersonal. The emphasis was on transforming man and nature.

The line between science and magic disappeared as Soviet writers transferred hopes formerly vested in magic and religion to science and technology, which the government considered essential to the transformation of life. ${ }^{25}$ Andrei Platonov (1899-1951) treated the engineer as a prophet and magus. Marietta Shaginian's novel Mess-Mend (1924) depicted an occult conspiracy in which the Communist's technological magic defeats the magic employed by the capitalist West. Before the Revolution she was part of Merezhkovskii's circle.

New occult groups responded to drastically changed conditions. Some groups supported the Revolution and tried to convince the Bolsheviks that the occult could be used to build socialism. Other groups opposed Bolshevism but could not say so openly. (See Konstantin Burmistrov's chapter).

In 1928, Stalin, the victor in the battle to succeed Lenin, instituted the first Five Year Plan, also known as the Great Break (Velikii perelom) because it was supposed to transform Soviet society. The Stalin Cult emerged on Stalin's fiftieth birthday (December 21, 1929). Its creators praised Stalin's "wise and firm" leadership and referred to him as the "Lenin of our day." Stalin's interpretation of Marxism became the only permissible interpretation. Subsequent versions of the Cult endowed Stalin with divine powers (omniscience, omnipotence, and omnipresence) and called him the object of his people's boundless devotion and love. Stalin became the personification of the Soviet "myth." He determined how the "myth" would be presented in literature and the arts, and in history and biology as well, and had his critics purged. The Great Purge began in 1934 and escalated into the Great Terror (1936-1939).

Between 1934 and 1939, known occultists were arrested and sent to the GUlag. Other occultists saved themselves by going underground. Occultism

24 Also see, George Young, Nikolai Fedorov, An Introduction (Belmont, MA, 1979); idem, Fedorov's "Transformations of the Occult," in: The Occult in Russian and Soviet Culture, 171-183; Michael Hagemeister, "Russian Cosmism in the 1920s and Today," ibid., 185-202; idem, Nikolaj Fedorov: Studien zu Leben, Werk und Wirkung (Munich: Sagner, 1989), and Irene MasingDelic, Abolishing Death (Stanford, 1991).

25 Anthony Vanchu, "Technology as Esoteric Cosmology," in: The Occult in Russian and Soviet Culture, 203. 
contradicted the Soviet faith in reason and science, but there might have been other reasons as well. Stalin may have feared that occultists might make negative predictions that could demoralize the population, or that they had special powers and might use them to sabotage the Plan. A.A. Menialov contends that Stalin had contacts with shamans and soothsayers during his early exiles in Siberia and utilized his knowledge to construct the Stalin Cult. ${ }^{26}$

In any case, on the surface, occultism disappeared. Science fiction was an exception. Matthias Schwartz suggests that science fiction was popular because it had a religious/apocalyptic component and also because it was believed to contain a coded explanation of the Great Terror (See his chapter).

\section{Late Soviet and Post-Soviet Russia}

By 1939, Stalinism was ensconced as the Soviet "myth," so Stalin's death, in March 1953, came as a great shock. But it was Nikita Khrushchev's "secret speech" to the $20^{\text {th }}$ Party Congress in February 1956, followed by de-Stalinization that triggered a spiritual crisis. Khrushchev exposed Stalin's crimes against "honest communists," accused Stalin of desecrating Lenin's memory, and called for a return to Leninist norms. In 1961, he had Stalin's remains removed from Lenin's tomb and Stalingrad renamed Volgograd. All this, of course, was very unsettling to people who had idolized Stalin.

Leonid Brezhnev's tenure (1964-1982) has been called the "era of stagnation," but it was also an era of intellectual ferment and spiritual quest, as more and more people lost faith, not just in the leadership but in the communist ideal and, in some cases, in the materialism on which it was based.

Occultism revived, often as part of a larger search for meaning and for recognition of the spiritual dimensions of life. (For occultism in this period see the chapters by Birgit Menzel and Leonid Heller). By the 1970s, the Godseekers' writings and classic occult texts were being published in samizdat, and contacts between Russians and Americans interested in transpersonal psychology began (see Boris Falikov's chapter). The Helsinki Accords (1975) permitted foreign travel and facilitated cultural exchange, enabling some Russians to learn about the West.

Occultism came out in the open during Mikhail Gorbachev's tenure (19851991) thanks to his policy of glasnost' (openness), which was in turn a response to the nuclear explosion at Chernobyl' in April 1986. Acknowledging a wide-

See Taina Val'kirii (Moscow, 2006). I am grateful to George L. Kline for calling this book to my attention. 
spread withdrawal from public life, spreading alcoholism and drug addiction, the growth of crime, a "weakened respect for work," pessimism, and cynicism, Gorbachev declared that the Soviet Union was facing a spiritual crisis (dukhovnyi krizis), as well as an economic one, so both structural and spiritual reconstruction (perestroika) were needed. ${ }^{27}$ To curb alcoholism, he limited purchases of vodka and had several vineyards in Georgia destroyed. Glasnost' had unexpected consequences. By allowing a torrent of criticism, it helped set in motion a process that led to the collapse of the Soviet Union in December, 1991.

The collapse was followed by the stresses (during Boris Yeltsin's tenure) of a flawed privatization, which enriched a few and impoverished ordinary people. Demyan Belyaev refers to a spiritual vacuum that occultism filled. John McCannon observes that Russians "turned in any and all directions for spiritual comfort." (See their chapters). Identity issues came to the fore in new religious movements such as rodnoverie (see Marlène Laruelle's chapter) and in the nationalist turn of intellectuals such as Aleksandr Dugin. (See Mark Sedgwick's chapter).

Disillusion with reason and science fostered interest in shamanism (see Natalia Zhukovskaia's chapter), alternative medicine, spiritual healing, and intensified interest in yoga. Novelists rewrote the history of the Bolshevik Revolution and the Early Soviet period to emphasize the power of occult forces. (See Marina Aptekman's chapter).

\section{Spiritual Crisis in the United States}

Occultism was by no means new in the United States, but its extent and intensity from the late 1960 s to the present is unprecedented. ${ }^{28}$ This is because Americans were experiencing a spiritual crisis brought on by the fading appeal of the American civil religion, also known as the American Dream: the belief that hard work and delayed gratification would result in happiness and prosperity. ${ }^{29}$ This is, of course, a secular version of the Protestant Ethic. Many baby-

27 Nicholas Riasanovsky, History of Russia (Oxford, 2005), 583, 586.

28 Previous occult revivals were more limited in scope. For a history of occultism in the United States, see Mitch Horowitz, Occult America. We know that tabloid newspapers began to publish horoscopes during the Great Depression, and that Roerich had Henry Wallace's ear, but more research on the 1930s is needed. There was not a spiritual crisis during World War II because, except for isolationists, most Americans regarded the war as a fight against evil.

29 The influential sociologist Robert Bellah famously argued that the United States has an unofficial civil religion in an article titled "Civil Religion in America," Journal of the American Academy of Arts and Science (Winter 1967) 96, 1-21. 
boomers found the civil religion sexually repressive and spiritually unfulfilling. Defying parental and societal authority, these baby-boomers sought selfrealization and insisted on doing their "own thing" (Ralph Waldo Emerson's term)..$^{30}$ They refused to participate in the "rat race" for higher incomes and better jobs, and disdained material acquisitions. Many of them were indifferent or hostile to organized religion; they were spiritual, they said, but not religious.

Other factors in the spiritual crisis were fear that the Cold War would turn into a nuclear war, the inconclusive Korean war (1950-1953) which was called a United Nations "police action," the discovery of Soviet spies in high places, McCarthyism, and the first Sputnik (1957) which punctured Americans' technological hubris. Even before the Sputnik, Americans had been fascinated by the possibility of life on other planets and space travel. Science fiction was very popular. The sightings of Unidentified Flying Objects (UFOs) near Roswell, New Mexico in 1947 triggered several investigations. Some people believed that the UFOs were occupied by gods or semi-divine beings from an extraterrestrial civilization. The 1951 hit film, The Day the Earth Stood Still featured an erudite looking alien who comes to earth, is immediately shot by troops, escapes and lives with a family, learning about humans and finally announces to the entire world that he is a policeman, sent to deliver a simple warning: now that humans have nuclear weapons, they must get their warlike nature in check and put their petty political differences aside, because others are watching and will not allow this violent tendency to spread. This was ten years before the Cuban Missile Crisis. Aliens came in other forms, such as the insidious seed pods in The Invasion of the Body Snatchers (1957) which would break open under the bed and slowly absorb memories and features, leaving a soulless duplicate (no anger, no joy), answerable to a central will. This metaphor for communism would be repeated over and over in books and films.

Still other factors in the spiritual crisis were the decline of scientism (the belief that science can solve all problems); rejection of rationalism, positivism, and materialism (which are basic to both classic liberalism and classic Marxism), and the revelation of the Nazi death camps, which negated the Enlighten-

30 Ralph Waldo Emerson (1803-1882) embraced the Hermetic concept of man as a microcosm of the universe, praised Hinduism and Buddhism, believed in the transformational power of ideas, and celebrated freedom and individuality. He familiarized the reading public with esoteric ideas that prepared the ground for Theosophy and other occult movements. In addition, he was a major influence on the New Thought movement, which in turn helped inspire books on the power of positive thinking. For the New Thought movement, see Horowitz, passim. 
ment belief that human beings are by nature rational and good and which led some people to ask "where was God?" 11

The cultural mainstream idealized the nuclear family and suburban life, extolled the superiority of capitalism over communism, mandated conformity, and was characterized by fixed gender roles, and a double standard in sex. "Nice girls" were supposed to wait for marriage. Homosexuals were in the closet. Television programs promoted "togetherness," which some people found stifling. This was the era of "behaviorism", when there was great faith in psychiatry and pharmaceuticals. Paradoxically, Americans extolled their individuality, as opposed to the supposedly brainwashed communists of Russia and China. Advertising created the term "lifestyles" to categorize individuality into marketing niches.

The "beats" were the first to drop out of the mainstream. Allen Ginsberg, author of Howl (1956) and Jack Kerouac, author of On the Road (1957) protested conventional values, preached and practiced sexual freedom, and were interested in Zen Buddhism. Ginsberg was openly homosexual and he objected to both capitalism and communism, the latter as currently practiced. He visited several communist countries to promote free speech but was expelled as a troublemaker. For example, in 1965, he was deported from Cuba for publicly protesting persecution of homosexuals. The Cuban government sent him to Czechoslovakia, where one week after being named the King of May (a student festival), the Czech government labeled him an "immoral menace" because of his open expression of radical views and deported him. Václav Havel considered Ginsberg an important inspiration in striving for freedom. Rock and roll was also a liberating force. ${ }^{32}$

Many hippies appreciated the "beats." In fact, the terms were used interchangeably until 1967. The hippies were the first baby-boomers to turn to the occult. Hippie enclaves developed in big cities and college towns. There, people could have their horoscope cast, their palms read, tarot cards interpreted, and purchase amulets for good luck and crystals with special powers. College and university students discovered astrology, the I Ching (for divination), Nietzsche, Hinduism, and Buddhism, and picked up aspects of a "natural" and sexually

31 Also important was the debate about the morality of dropping the atom bomb on Hiroshima and Nagasaki; and works of social criticism such as David Riesman's The Lonely Crowd (1950), William Whyte's The Organization Man (1956), C. Wright Mills' The Power Elite (also 1956), and Vance Packard's The Hidden Persuaders (1957).

32 See the chapter "Zappa and Vaclav," In: Paul Berman, A Tale of Two Utopias (New York, 1996), 195-223. 
free life-style. After the "Howl" obscenity trial (1956), censorship relaxed and free speech was thought of as a major difference between America and Russia or China. College kids avidly read sexually explicit authors such as de Sade, Wilhelm Reich, James Joyce, and William Burroughs, along with Marx and Mao. Many baby-boomers tried to combine individual freedom with belonging to a close-knit and loving community, ${ }^{33}$ and dreamed of the coming Age of Aquarius (around 2,000 CE.) to be achieved by love. ${ }^{34}$

Other factors came into play in the middle and late '60s. The official account of the assassination of President John F. Kennedy (November 22, 1963) was disputed, undermining confidence in the government, which was further undermined by the war in Vietnam, which escalated in December 1964. By the late ' 60 s, a counterculture had developed; it featured sex, drugs, and rock and roll, and rejected reason and empirical knowledge in favor of mysticism, especially Asian mysticism, and the occult. The Gay Rights movement began in June 1969, after the Stonewall riots in New York City. Some women embraced Wicca (witchcraft) a nature-religion, because it empowered them. ${ }^{35}$ In the 1970 s and ' 80 s aspects of the counterculture, including mysticism and occultism, became mainstream. But of course, not all hippies were big city kids into sex, drugs and rock and roll, rejecting work ethics. Many escaped their cities and parents, formed communes or ashrams and created the Back-to Nature Movement, embracing the lifestyle of Thoreau's Walden (1854) or of Jesus the Carpenter. They grew organic food, made music, arts and crafts, used natural medicines and practiced communal childrearing. Their reaction to the fading myth was to start their own utopia, tolerant and responsible to the group. While at the same time, saving the world, as well as the whales. They were pioneers of the Ecology Movement, with Stewart Brand's Whole Earth Catalogue as their guidebook. Sam Peckinpah's groundbreaking Western film, The Wild Bunch showed (for the first time) shoot-outs with bodies blown apart, because, as Peckinpah said, he had fought in Korea and knew those boys in Vietnam were not dying the bloodless sanitized Hollywood way, and that people should see it. The body bags were on the news each night. The hippies'

33 The search for such a community recurs in American history. Many utopian communities were formed in the $19^{\text {th }}$ century, when much of the U.S. was "unspoiled" wilderness.

34 The term stems from the progressions of the zodiac: from Gemini to Taurus in 4000 BCE, from Taurus to Aries in $2000 \mathrm{BCE}$, from Aries to Pisces in $1 \mathrm{CE}$ (the birth of Christ), and from Pisces to Aquarius around $2000 \mathrm{CE}$.

35 See Margot Adler, Drawing Down the Moon. Witches, Druids, Goddess Worshippers, and Other Pagans in America Today, (New York, 1979, 1986). 
abhorrence to violence had many factors and many of their parents accepted them and were loved by their kids.

The hippies were apolitical until the mid-1960s, when some joined the Left (the old Left and the new Left) in opposing the war in Vietnam. The new Left objected to the authoritarianism and dogmatism of the old Left, inadvertently creating a space for mysticism and the occult. Some Leftists rejected the American Dream altogether; others wanted to extend it to Blacks and (later on) to Native Americans, Chicanos, and women. The mantras of the anti-war movement were "peace and love" and "make love, not war," and its symbol was an inverted $\mathrm{Y}$ inside a circle, which Jungians regard as a kind of mandala (an aid to meditation used by Hindus and Buddhists). Roerich's Banner of Peace (1935) has a similar inverted triangle composed of circles, but the now standard symbol of peace is a 1958 design by a British artist (Gerold Holton) for a nuclear disarmament demonstration in London. Allen Ginsberg chanted Hindu phrases at anti-war rallies. Martin Luther King's non-violence melded Gandhi and Jesus. But some Blacks rejected Christianity saying that it inculcated a slave mentality. A back-to-African roots movement gained adherents, even among church-going Christians, as Blacks sought a new identity. Some Blacks changed their name. The poet LeRoi Jones became Amiri Baraka; Stokely Carmichael, former leader of SNCC (Student Non-Violent Coordinating Committee), became Kwame Ture, and renounced non-violence in favor of self-defense. Malcolm Little became Malcolm X (the X stands for the African family he never knew) and joined Louis Farrakhan's Nation of Islam. Farrakhan's sermons include Masonic symbolism, numerology, and references to UFOs. Some Black nationalists advocated racial separatism, espoused a vehement anti-Semitism, and invented a glorious African past.

In 1967, Ginsberg and Abbie Hoffman, the future "Yippie" (an acronym for Youth International Party, an urban guerilla group), organized hundreds of demonstrators to levitate the Pentagon. By chanting and singing outside it, they would perform an exorcism and end the war. This event was part of a larger demonstration that drew thousands of people and resulted in over 700 arrests. In August 1968, the Yippies were involved in a riot at the Democratic Convention in Chicago that was carried live on TV.

John Lennon and his wife, Yoko Ono, were active in the anti-war movement. They were fans of Maharishi Mahesh Yogi, founder of Transcendental Meditation, and of the British occultist and magician Aleister Crowley (18751947). Crowley was an influential member of the esoteric Hermetic Order of the Golden Dawn Ordo Templi Orientis (O.T.O.), one of the greatest influences on $20^{\text {th }}$ century Western esotericism, before founding a religious com- 
mune in Cefalu, Italy, known as the Abbey of Thelema. His picture is on the cover of Sergeant Pepper's Marching Band. Lennon once said: "Do what thou wilt, as long as it doesn't hurt somebody," a variant of Crowley's tenet, "Do what thou wilt shall be the whole of the law." Crowley is an extremely controversial figure because of his use of both black and white magic, his advocacy of "sex magic" (tantric sexual practices) and his fondness for shocking statements, especially an often-quoted one that seems to advocate human sacrifice and ritual cannibalism. ${ }^{36}$ The British tabloids called him the "wickedest man in the world" and "the Beast 666."

The 1960s and early '70s were full of violence as well as love. Civil rights workers were murdered in the Deep South. Riots in the Watts area of Los Angeles in the summer of 1965 lasted six days. Over one hundred thousand "flower children" flocked to the Haight-Ashbury district of San Francisco in 1967, to participate in the "summer of love." But that same summer, sections of Newark, Detroit, and other cities were torched by Blacks angry at continued discrimination. The assassination of Martin Luther King (on April 24th, 1968) sparked riots and arson in Washington D.C. and other big cities. Robert F. Kennedy was assassinated the following June. Black Panthers and White Supremacists formed para-military groups. Streets became unsafe as violent crime skyrocketed. Rock and roll concerts often ended in riots. A Left radical group called the Weathermen bombed government buildings in the late 1960s and early 1970s. They took their name from Bob Dylan's line "you don't need a weatherman to know which way the wind is blowing." To some hippies, the "natural" life style meant living off the land and rejecting commerce and industry. For these reasons, and also to be safe from the bomb, they set up agricultural communes. Most of them were short-lived.

Half a million baby-boomers converged at the Woodstock festival (in upstate New York) for music, peace, and love on August 15-18, 1969. Nevertheless, by the end of the ' $60 \mathrm{~s}$, violence outweighed love. A week or so before Woodstock, the Manson Family, a cult-group of California hippies, committed a series of gruesome murders and used their victims' blood to write, "kill the pigs" on the walls. Charles Manson, the leader of the cult, called the murders "helter skelter," the title of a song in the Beatles White Album (1968), which

36 To give one example, "It would be unwise to condemn as irrational the practice of devouring the heart and liver of an adversary while still warm. For the highest spiritual working one must choose that victim which contains the greatest and purest force; a male child of perfect innocence and high intelligence is the most satisfactory." This is from the section "Of the Bloody Sacrifice and Matters Cognate," in: Magick Book 4, Part III, chapter 12. 
Manson interpreted as a prophecy of an apocalyptic race war. The Family would survive by hiding in "the bottomless pit," a secret city underneath Death Valley, which they would reach through a hole in the ground. When the victorious Blacks proved unable to rule, the Manson Family would emerge and become the new rulers. The "bottomless pit" (Revelation 9: 1-2,11) is ruled by Apollyon, a name for the devil or the angel of death. Apparently, Manson identified with him. When the murderers were discovered there was a revulsion against cults and hippies, even though Manson denied being a hippie and poked fun at the naïve flower children. Some extreme elements of the counterculture thought the murders were "cool."

The following December, a young Black man was murdered at a Rolling Stones concert in Altamont, California that was intended to be Woodstock West. The murderer was a drunken Hell's Angel (a notorious motorcycle gang) who was hired as a security guard. At the same concert, there was a riot in which scores of people were injured and extensive property damage. Meanwhile, the carnage in Vietnam continued and was broadcast live on television. In 1974, the Symbionese Liberation Army kidnapped heiress Patricia Hearst and got her to take part in a bank robbery.

The occult explosion of the '70s was an escape from all this, a turn inward, a concentration on the self. Housewives and hippies, celebrities and bureaucrats, practiced Transcendental Meditation because it promised inner peace. Also in vogue were programs that promised self-transformation and personal empowerment. Werner Erhard's EST (Erhard Seminars Training, late 1971 to late 1984) taught that we create our own reality. He became a millionaire and a patron of a group of hippie physicists (see below).

Astrology became an integral part of popular culture. Jesse Stearn's A Time for Astrology (1971) and Linda Goodman's Sun Signs (1975) became best sellers. People would open a conversation by asking, "What's your sign?" A survey taken in the early '70s revealed that at least 5 million Americans planned their lives according to astrological predictions, roughly two thirds of daily newspapers had a daily horoscope column, and there was enough business to keep 10,000 full time and 175,000 part time astrologers busy. ${ }^{37}$ Their clients included "Yuppies" (young, upwardly mobile affluent professionals), who retained aspects of the hippie ethos of their youth.

Opposition to the counterculture increased in the late 1960s and early 1970s, and increased again in 1978-1979, because of stagflation, the hostage

37 Mircea Eliade, Occultism, Witchcraft and Cultural Fashions: Essays in Comparative Religion (Chicago, 1976), 59. 
crisis in Iran, which began in November 1978 and lasted 444 days, and the mobilization of the "religious right" by activists such as the Reverend Jerry Falwell, who founded the Moral Majority in 1979.

Contributing to the growing conservative mood was the murder (or forced suicide) of 909 people, 303 of them children, in Jonestown, Guyana, in November 1978, around a year before the hostage crisis began. Jonestown was the home of the People's Temple Agricultural Project, a Christian cultic community that Jim Jones founded and led. A communist, Jones used the trappings of religion to recruit members and infiltrate the church. ${ }^{38}$ The members were by no means hippies, but the People's Temple was a cult as well as a commune dedicated to what Jones called "apostolic socialism." The members had to sign over all their assets, including welfare payments and social security checks, to the People's Temple. The estimated wealth of the Temple in late 1978 was $\$ 26$ million. Jones saw Jonestown as a means to create a "socialist paradise" and a "sanctuary" from media scrutiny and from the bomb. ${ }^{39}$

He started to build Jonestown after defectors from the cult and concerned relatives of present members complained about police-state conditions and demanded a government investigation. As pressure for one mounted, Jones considered relocating the cult to the Soviet Union and was in contact with Soviet diplomats in Guyana. One diplomat visited the commune and praised it for being a socialist haven.

After he had an investigating committee, headed by Congressman Leo Ryan, murdered, Jones felt cornered, so he ordered the cult members to commit "revolutionary suicide" by drinking a Kool-Aid like drink mixed with poison and committed suicide himself. Before doing so, he told the cult members that a flying saucer, hiding behind a comet, was waiting to take them to

38 The Agricultural Project was the last incarnation of the People's Temple. The first People's Temple, founded in Indianapolis, Indiana, in 1951, was an urban community. In the 1970's Jones moved the cult to Northern California, first Redwood City, and then San Francisco, where he became politically active. Unlike other cult leaders, Jones enjoyed public support and contact with some of the highest level politicians in the U.S., including Walter Mondale, Governor Jerry Brown, and George Moscone, Mayor of San Francisco. Moscone rewarded The People's Temple for helping him get elected by appointing Jones Chair of the San Francisco Housing Authority. For details on the People's Temple, see John Hill, Gone From the Promised Land: Jonestown in American Cultural History (New Brunswick/NJ, 1987), and Tim Reiterman, Tom Reiterman, and John Jacobs, Raven: The Untold Story of Reverend Jim Jones and His People (New York, 1982).

39 In the early 1960s, Jones considered moving the cult to a remote location in Brazil to be safe from the bomb. 
heaven. Jonestown was the largest mass murder in American history until September $11^{\text {th }}, 2001$, so the media covered it extensively. In 1987, a book titled The Jonestown Carnage: A CIA Crime was published in the Soviet Union\$\$.

Reagan has been credited for revitalizing the American Dream, after the malaise of the Carter years. Reagan envisioned the United States as "a beacon of light to freedom loving people everywhere." His idea of freedom was "small government" as opposed to "big government" and the welfare state, and the end of the "evil empire" (the Soviet Union). He urged Gorbachev to tear down the Berlin Wall.

Reagan's private beliefs included astrology. That became public knowledge in May 1988, when Donald Regan, former White House Chief of Staff, revealed that Nancy Reagan regularly consulted a San Francisco astrologer, Joan Quigley, and that almost all presidential travel, press conferences, and even his cancer surgery was based on information that Nancy Reagan received from her. ${ }^{40}$ Many movie stars had a personal astrologer. There were even investors who timed their moves by astrology. By the mid-1980s, astrology had so pervaded the culture that The New York Times and The Wall Street Journal published articles about it. ${ }^{41}$

The New Age movement began in the '60s and grew steadily thereafter. ${ }^{42}$ Marilyn Ferguson, author of The Aquarian Conspiracy (1980), maintained that a leaderless but powerful network is working to bring radical change to American life; a new era of personal fulfillment and limitless potential is at hand. Once again, we find American optimism.

The New Age movement has no organizational structure, no centralized leadership, and no sacred text. It can be regarded as an outgrowth, or a maturation, of the counterculture, or put differently, as the counterculture for

40 Quigley was not the Reagans' first astrologer. Her predecessor, Jeanne Dixon, predicted that Reagan would be Governor of California and eventually President of the United States, but not in 1976. Unhappy with Dixon's prediction (which turned out to be correct), the Reagans dropped her. The astrologer Sidney Omarr claimed (without offering proof) that Nixon and Kissinger consulted astrologers too.

41 A few examples. "Thinking of Buying or Selling a House? Ask Your Astrologer" (Wall St. Journal, October, $\left.1^{\text {st }}, 1986\right)$; "Investors Turn to Tarot Cards" (New York Times, November $3^{\text {rd }}$, 1985); "Spiritualism has a Place in the Age of Disbelief" (New York Times, February $13^{\text {th }}$, 1986); "Missed the Train? Lost Your Wallet: Maybe it was all Mercury's Fault" (New York Times, November $\left.11^{\text {th }}, 2006\right)$. On October 16, 1998, the New York Times published an op-ed article, "Bush's Lucky Stars, Dukakis's Destiny," by Jeanne Dixon, assessing their chances of being elected President.

42 Details in Wouter J. Hanegraaf, New Age Religion and Western Culture (Leiden: Brill, 1996). 
adults. Loss of confidence in Western ideas and in conventional ways of doing things fostered a willingness to try out anything new, including Asian medicine and Asian belief systems, in a search for alternatives. William James talked about a "will to believe." People who turned to the occult wanted to believe in something. The New Age movement incorporates aspects of Spiritualism and Theosophy. New Agers refer to "channellers" rather than "mediums," and they concentrate on self-discovery and self-realization, rather than on speaking to departed loved ones.

Other sources of the New Age movement include American Indian spirituality (a rough parallel to contemporary Russians' interest in shamanism) and Carlos Castaneda's The Teachings of Don Juan (1969), about a Mexican Indian shaman able to reach an alternate reality by using hallucinogenic plants, which was translated into Russian. Castaneda's eleven books sold more than eight million copies and were translated into seventeen languages. And there was the proclaimed prophet, trance-healer and psychic, Edgar Cayce (1877-1945), a devout Christian who believed in karma and reincarnation.

Occultism has become an intrinsic part of American popular culture. In Out on a Limb (1983) and in subsequent books, Shirley MacLaine described her experience in recovering her past lives and her beliefs. Out on a Limb and Dancing in the Light (1985) were on The New York Times Best-seller list for several months. ${ }^{43}$ Like Blavatsky, MacLaine considers the soul an emanation of the Divine and contends that we are all gods, and that we can control our present and future lives, but she goes far beyond Blavatsky in asserting that we choose our parents and siblings. The emphasis on choice is quintessentially American.

MacLaine popularized an occultism that includes esoteric Christianity, the belief that "The man Jesus studied for eighteen years in India before he returned to Jerusalem. He studied the teaching of Buddha, became an adept himself, had complete control over his body, and understood that the body is only the house for a soul. He believed in karma and reincarnation, but the Nicene Council altered His teachings." ${ }^{44}$ In Dancing in the Light (1985), MacLaine repeats what a trance-healer told her, "there is only one spiritual law (...). Everyone is a god. Everyone." ${ }^{45}$ MacLaine visited Peru and reported that sightings of UFOs occur regularly. Some New Agers believe that Peru is an

43 According to an article in Money magazine, September $1^{\text {st }}, 1987$, as of that date, Out on a Limb had sold 3 million copies and Dancing in the Light, 2.2 million.

Shirley MacLaine, Dancing In the Light (New York, 1985), 412. 
energy knot of the universe (like the Pamir knot for some Russians) ${ }^{46}$ and that Machu Picchu and the mysterious Nazca lines (which are visible only from the air) were created by extra-terrestrials. Erich von Däniken promulgated this theory in Chariots of the Gods (1968).

Self-healing is a prominent feature of the New Age Movement. Louise Hays, author of You Can Heal Your Life (1984), refers to "dis-ease" and counsels "affirmations", a kind of mind-control or faith-healing that perpetuates the American insistence on "the power of positive thinking," a staple of the New Thought movement. In the same positive spirit, New Agers talk about wellness rather than sickness.

Hays runs a publishing empire. Her clients include Wayne Dyer, author of self-help books, including Change Your Thoughts: Change Your Life: Living the Wisdom of the Tao (2007); Deepak Chopra, an Indian physician who writes about spirituality, nutrition, and well-being; Ruth Montgomery, who calls herself a Christian psychic, and Sylvia Brown, author of Confronting your Spirit God and Sylvia Brown's Book of Angels. "Angelology" is the study of angels, demons, and Satan, but the New Age movement talks only about angels, another example of American optimism. Satan and his minions are prominent in "hellfire and brimstone" Christianity, which the New Age movement rejects.

The New Age movement was not just an aspect of popular culture; an intellectual and cultural elite was seriously involved in it as well. Their center was the Esalen Institute, a retreat co-founded by Michael Murphy and Richard Price in 1962 and incorporated as a non-profit institute in 1967. It became the center of the human potential movement and in David Kaiser's words, an "incubator of all things new age." ${ }^{\prime 7}$ Located in Big Sur, California, on a site of striking scenic beauty and naturally occurring hot springs (the famous coed hot tubs), the Institute is sometimes described as a playground, even though path-breaking intellectual work was going on. What makes Esalen "new age" is its blending of eastern and western thought, its optimism, its advocacy of "experiential learning" (as opposed to abstract intellectualism), its appreciation of

46 See George M. Young, "Fedorov's Transformations of the Occult," In: Rosenthal, ed., The Occult, 181-183. The Pamir knot is in what is now Kirghistan and Tadzhikistan, in the high border country where the former USSR meets Afghanistan and China. Other Russians believe that the Altai Mountains were an ancient power center. The Altai mountains are in Central Asia where Russia, China, Mongolia, and Kazakhstan come together. See Andrei Znamenski, Red Shambhala. Magic, Prophecies, and Geopolitics in the Heart of Asia, (Wheaton/Ill.: Theosophical Publishing House, 2011).

47 David Kaiser, How the Hippies Saved Physics: Science, Counterculture, and the Quantum Revival (New York: Publisher 2011), xvii. 
sexuality, its emphasis on the emotions, the senses, and the body, and its embrace of mysticism and occultism.

Murphy defines mysticism "as any altered state of consciousness that is revelatory of some deeper truth or reality," and occult "as related to the exalted contemplative states of the mystical life, but with a heavy accent on [what he calls] the supernormal powers, that is the psychic and physical phenomena of mysticism (precognition, clairvoyance, bodily transfiguration, reported levitation, and so on." 48 He distinguishes between the supernormal and the paranormal. What is considered paranormal in western culture is perfectly normal, he says. It refers to unconscious abilities that appear supernatural because they are not yet under conscious control. The supernatural is the paranormal that has come under conscious control. ${ }^{49}$

Both Murphy and Price had "life-altering 'break-out experiences"” in 1955$56 .{ }^{50}$ Murphy lost faith in the Episcopalianism in which he was raised, but was rescued from his "faith crisis" (Jeffrey Kripal's term) by Frederick Spiegelberg, professor of comparative religion and Indic studies at Stanford University, and by Sri Aurobindo, "an Indian saint." It was under Spiegelberg's influence that Murphy read Sri Aurobindo's book, The Life Divine, and was so impressed that he visited Aurobindo's ashram in Pondicherry and stayed for sixteen months. Aurobindo posited a bipolar reality similar in many respects to Nietzsche's Dionysian and Apollonian impulses and he believed in an occult evolution that will reunite the spiritual and material dimensions of reality within the human soul that will eventually result in a Superman, Aurobindo's term for a diversely gifted race of "gnostic beings" or "cosmic individuals" who consciously embody a full integration of Matter, Mind, and Spirit. ${ }^{51}$ Note the Nietzschean terminology. Aurobindo's philosophy was deeply indebted to the Tantric traditions of India, which affirm the world and the erotic body, and which have much in common with Nietzsche's thought. In prerevolutionary Russia, Nietzsche helped spur a "revaluation of all values." His thought had a similar effect on Esalen in the 1960 s. $^{52}$

Price's "break-out experience" was a psychotic breakdown, followed by institutionalization, during which he received fifty nine insulin shock treatments, ten electroshock treatments, and large doses of phenothiazine. The effects, both

Jeffrey Kripal, Esalen: America and the Religion of No Religion (Chicago, 2007), 471.

Ibid.

Ibid., 82.

Ibid., 65.

Ibid., 21. 
psychological and physiological, were brutal and long-lasting. ${ }^{53}$ Years later, the memory of his suffering motivated his co-founding of a Spiritual Emergency Network within Esalen that operated from 1980 to 1989. But the real crisis, Price concluded, was often a hermeneutical or cultural one. Westerners were undergoing intense spiritual experiences that could not be understood, much less appreciated, within their own cultural frames. They were thus experiencing tremendous cognitive, religious, and emotional dissonance. ${ }^{54}$ In other words, they were experiencing a spiritual crisis induced by the inadequacy (to them) of rationalism, empiricism, and materialism, and of what the Godseekers called "the mechanical world view." But while Murphy favored Tantrism, Price was drawn to Theravedic Buddhism, Zen Buddhism, and Taoism.

Esalen challenged established verities in psychology and physics, helped popularize alternative and complementary medicine, experimented with parapsychology and with new life styles, and held two conferences on UFOs, a topic shunned by conventional academia. The gurus of the counterculture-Norman O. Brown, Allen Ginsberg, Alan Watts, Timothy Leary, Paul Goodman, and Herbert Marcuse-all had strong indirect connections to Esalen. Aldous Huxley never taught there (he died in 1963) but his intellectual and personal influence was enormous. Other members of the intellectual or cultural elite who taught at Esalen, or were connected to it in some other way, include Joseph Campbell, Frederic (Fritz) Perls, Abraham Maslow, Fritjof Capra, Rollo May, Susan Sontag, Harvey Cox, Deepak Chopra, Ida Rolf, Michael Harner, and Andrew Weil.

The Institute's very first brochure listed "psychical research" and work on "mind-opening" (by means of psychedelic drugs, such as LSD, and consciousness altering plants) as two of its three major foci; the third was psychology, the study of the mind itself as the basis of the other two. Maslow was a key figure in Esalen's attempt to create a humanistic psychology as an alternative to Freudian reductionism and the behavioralism of John B. Watson and B. F. Skinner. Esalen's fourth seminar, on "drug-induced mysticism," was based on the assumption that certain drugs give access to unconscious layers of the mind. ${ }^{55}$ That seminar became one of the most popular and most frequently offered.

The longest running seminar was on the "physics of consciousness" (197678). Among the participants was the Fundamental Fysiks Group, hippie physicists interested in metaphysical questions ignored by most physicists at the

53 Ibid., 80.

54 Ibid., 267.

55 Ibid., 117 
time. ${ }^{56}$ After the job market in physics collapsed in the early '70s, the hippie physicists pursued their interests in ontology, parapsychology, and the physical effect of mystical experiences. Funding for their research came from the CIA, NASA and other government agencies worried that "Psychic Discoveries behind the Iron Curtain," the title of a book published in 1970, meant that the Soviet military and the KGB could leap ahead of the United States in telepathy, mind control, and psychokinetics. They also got funding from businessmen such as Werner Erhard, who was interested in Zen and in expanding consciousness.

The Fundamental Fysiks Group attempted to meld quantum mechanics with parapsychology and Eastern metaphysics in the hope that quantum mechanics could be harnessed to convey psychic powers. The scientific basis of their attempt was Bell's theorem, which offered experimental confirmation that once two entities (such as electrons) have interacted with one another they remain connected. Bell also proved that quantum mechanics implies nonlocality-that is, a measurement of particle A would instantaneously affect particle B, even if they are a galaxy apart. ${ }^{57}$ Non-locality, the hippie physicists hypothesized, could collapse space and time, thereby allowing instant signaling and faster than light communication. Today's encryption technology is based on quantum mechanics.

The hippie physicists championed an organic or holistic world view, rather than the Cartesian dualism prevalent in western philosophy since the $17^{\text {th }}$ century, and the "mechanistic fragmented" world-view of classical physics. They concluded that while mind and matter are different ontological orders they are inherently connected. In addition, they claimed that our impressions of the world arise, not from reality per se, but from our mental filters and habits, or what in ancient Hindu, Buddhist, and Taoist teachings are called illusions. Their stance challenged the Enlightenment belief (or "myth") that objective truth exists and can be discovered by reason and science.

Wishing to broaden physicists' range of approaches and methods, to push beyond what they considered a narrowness of vision, "they laced their investigations with more of the Dionysian spirit than the strictly Apollonian. As [Jack] Sarfatti put it in 1976, physicists needed more "'Mythos' to leaven the 'Logos." 58 The hippie physicists were not entirely Dionysian; they did not deny the need for experimental proof. 
They took mind-altering drugs, including LSD, in their search for a quantum-physics based explanation for such phenomena as telepathy and extrasensory perception, which they assumed existed, and experimented with remote viewing and precognition. If matter can affect consciousness, they asked, can consciousness affect matter? They were interested in the Israeli psychic Uri Geller, who claimed not only clairvoyance but psychokinetic powers as well. His most famous feat was apparently bending metal objects by sheer energy. ${ }^{59}$

Books written by hippie physicists reached a huge popular audience. Fritjof Capra's The Tao of Physics, (1975) and Gary Zukav's The Dancing Wu Li Masters (1979) were best sellers. $W u L i$ is the Chinese word for physics; literally translated, it means patterns of organic energy. Capra's book came out at a time of tremendous spiritual thirst, a widely shared striving to find some meaning in the universe that might transcend the mundane affairs of here and now, so it became a catalyst, triggering an enormous reaction." ${ }^{\prime 60}$ At least as important, the hippie physicists interacted with more conventional physicists, challenging long-held assumptions and asking fresh questions, thereby propelling further study of quantum mechanics.

\section{Russia Revisited}

In the 1980s, Esalen tried to end the Cold War and prevent a nuclear war by practicing "citizen diplomacy," private-sector initiatives between Soviets and Americans that were called Track Two. Track One was formal diplomacy. Based on the assumption that actual or potential conflict can be resolved or eased by appealing to common human capabilities to respond to good will and reasonableness, "Citizen Diplomacy" was a natural outgrowth of the Institute's faith in human potential and its long-standing interest in psychology and parapsychology (see Boris Falikov's chapter). On a previous trip to Russia, Murphy discovered a government-supported equivalent of the human potential movement. Now he wanted to know more about "psychic discoveries behind the iron curtain," and to meet Soviet psychics.

The decision to found a Soviet-American Exchange Program was made in 1980. A host of initiatives followed. ${ }^{61}$ In 1989, Esalen was chosen (out of a list

59 Ibid., 72-73; see also 82.

60 Ibid., 155

61 To give a few examples. In 1981, Esalen sponsored the first of six conferences on Citizen Diplomacy. In 1982, Esalen pioneered the first space bridge, which allowed Soviet and American citizens to speak to each other via satellite, a new technology at the time. In 1983, Esalen 
of fifteen organizations) to host Boris Yeltsin on a nine day tour (September $9^{\text {th }}$ to $17^{\mathrm{t}}$ ) of the United States. He converted from communism to capitalism in a Houston supermarket; returned to Moscow "furious at the lies of Soviet propaganda, quit the Party, and helped lead a revolution that would eventually help topple Soviet communism." ${ }^{62}$ Esalen's influence on Soviet-American relations continued after Yeltsin's visit. In late 1991, a few days before Gorbachev resigned, Jim Garrison, the Executive Director of the Soviet-American Exchange Program, convinced him to visit the United States.

Subsequent initiatives include the establishment of a Library of Psychological Literature at Moscow State University (this gave Russians access to Western psychology, which had been banned in the Soviet Union since the 1930s), publication of a series of monographs titled Future Scenarios on Russian American Relations; conferences, ${ }^{63}$ and publication of a Library of Russian Philosophy, that featured books by Soloviev, Berdiaev, and Bulgakov. ${ }^{64}$ At the back of some of the books is a capsule history of Russian philosophy, in which Murphy limns what he considers its most valuable characteristics:

...epistemological realism, integral knowledge (knowledge as an organic all-embracing unity that includes sensuous, intellectual, and mystical intuition), the celebration of integral personality (tsel'naia lichnost') which is at once mystical, rational, and sensuous, and an emphasis upon the resurrection or transformability of the flesh [preobrazhenie, BGR] (...) It is bol'shaia, big as philosophy should be. It is broad and individualistic, bearing within it many different perspectives (...). Above all it is universal. The principle of sobornost' or all-togetherness (human catholicity) is of paramount importance to it. And it is future oriented, expressing a

instituted a series of symposia on the political psychology of Soviet-American relations and co-sponsored a conference on the subject. In 1985, Esalen helped create the Association of Space Explorers. In 1988, Esalen hosted a second delegation of eminent Soviet writers who toured the U.S. and met with prominent American writers in order to facilitate Soviet writer's entry into the International PEN Club, which monitors government censorship and freedom of expression around the world. The initiative was successful: the Soviet Writers Union joined the PEN Club soon after the meeting. PEN is an acronym for Poets, Essayists, and Novelists. In 1989, Esalen organized a delegation of Americans to participate in the inaugural conference of the USSR Association of Peace Through Culture, formed in honor of Nicholas Roerich A complete list of initiatives is on the web.

62 Kripal, Esalen, 316, see also 396-397.

63 These include a conference on "Russia in Crisis," (1998) held, by coincidence, just after the ruble collapsed, and conferences on health issues, ethnic conflict, sports, and religious fundamentalism.

64 A complete list of the books published is in Kripal, Esalen, 528. 
philosophy of history passing into metahistory, the life-of-the-world-to come-in the Kingdom of God. ${ }^{65}$

Preobrazhenie is better translated as "transfiguration," a Russian Orthodox doctrine that is closely linked with the Orthodox concept of deification. Just as the flesh of Christ had been transfigured, so would the flesh of the redeemed. Or, as was said at the first Nicene Council: "God became man that we might be made God." Deification is roughly compatible with Blavatsky's idea that since our souls are emanations of the Divine, we are all Gods, except of course that the Christian ideal is to become like Christ.

The surge of occultism in Russia and in the United States in the time periods treated in this chapter was a response to a widespread spiritual crisis precipitated by the fading of the "myth." The "myths" were different and they faded for different reasons, so the occultism of each period reflected contemporary problems and issues.

In prerevolutionary Russia, the official ideology (Autocracy, Orthodoxy, and Nationality) was undercut by modernization, as was populism, the "myth" of the intelligentsia. Some intelligenty tried to quench their "spiritual thirst" by extolling creativity; their "myth" was Symbolism, which was based on the esoteric idea of correspondences. Some Futurists perpetuated a different set of occult ideas. Astrology attracted people seeking guidance in a rapidly changing world. New occult doctrines-Spiritualism, Theosophy, and Anthroposophygained adherents.

After the Bolshevik Revolution, the "myth" was Marxism-Leninism, but details of implementation had yet to be worked out, and people had to adjust to The Dictatorship of the Proletariat and to other drastic changes such as the institution of NEP in 1921. The government combated "superstition" (religion and the occult), but belief in them persisted. Cosmism, a new occult doctrine, incorporated the Soviet faith in science and technology as a world-transforming force.

Occultism subsided after Stalin, but it revived (clandestinely) in the 1960s, partly because of the unsettling effects of de-Stalinization, partly because the "era of stagnation" eroded faith in the communist ideal and in the materialism on which it is based. Gurdjieff s teachings became popular; occult classics were published in samizdat, and there was great interest in Asian religions in general and in yoga in particular.

65 Nikolai Berdyaev, The Russian Idea, trans. R. M. French (Hudson, NY, 1992), 286. 
Gorbachev instituted far-reaching changes, including an almost unlimited freedom of the press and freedom of speech, so a mish-mash of occult ideas came out in the open. Gorbachev himself endorsed the "Roerich idea." Occult classics and Western New Age books were published legally in English and in Russian translation. Some of Gorbachev's critics attributed Russia's woes, past and present, to a Judeo-Masonic conspiracy. A new religious movement, rodnoverie, glorified Russia's pre-Christian past. Glasnost' inadvertently set in motion a process that culminated in the collapse of the Soviet Union at the end of 1991.

During Yeltsin's tenure, a flawed privatization left people without a safety net and turned their world upside down. Not surprisingly, occultism surged. Whether it will subside, now that order has been restored, the Soviet Union is once again recognized as a great power, Orthodox Christianity is the de facto official religion, and high prices for oil and natural gas buoy the economy, remains to be seen.

As for the United States, in the 1960s "beats," "hippies," and many babyboomers found the unofficial civil religion spiritually unsatisfying and emotionally repressive, opposed the war in Vietnam., and supported the struggle for civil rights. They created a counterculture that featured sex, drugs, and rock and roll, back-to-nature and self-sufficiency, and that rejected conventional rationalism and empiricism in favor of mysticism, especially Asian mysticism, and the occult. The counterculture morphed into the New Age movement. In the 1970s and ' 80 s, occultism became part of the cultural mainstream, while opponents of the counterculture mobilized against it. Since then, the nation has been polarized. On one side are advocates of "small government" and cultural conservatives opposed to abortion and same-sex marriage. On the other side are supporters of "big government" and cultural libertarians. Neither side is monolithic; there are divisions within each one. As of this writing (August 2011), neither side has a governing majority. So the spiritual crisis continues, and no reconciling new "myth" is in sight. 


\title{
ON READING RUSSIAN MYSTICAL LITERATURE UPSIDE-DOWN
}

\author{
JEFFREY J. KRIPAL
}

\begin{abstract}
This is no clever allegory of communist idealism gone wrong, or even a parody of Aryan Übermenschen, ... . Sorokin is not being ironic about Bro's membership in the children of the Light; he is, to channel Bro's voice, dead serious. Not that 23,000 cosmic rays incarnated as humans exist anywhere outside his own imagination, of course, but rather that experiential mysticism is a real phenomenon whose personal, social, and spiritual implications deserve to be examined and critiqued.

-Victoria Nelson, "Meat and Light," on Vladimir Sorokin's Ice Trilogy
\end{abstract}

In her essay for this volume, Birgit Menzel describes how "Mikhail Meilakh would stand on his head in the breakfast-room of the Leningrad Interhotel for foreign guests." After a while, he "would turn to each table and ask the puzzled or amused foreign businessmen or diplomats most politely in various languages if they could bring in any information or material about Gurdjieff on subsequent trips." There is a parable in there somewhere. We are, after all, each upside-down to the other-often literally, on this spinning cosmic ball-but many of us are all also listening, in our own ways and terms, for the circulating rumors, the astonishing story, perhaps even, strangest of all, that gold nugget of scholarship on these secret teachings and astonishing stories that will throw new light on our own individual questions.

The little story also speaks volumes about the travelling, global character of esoteric movements. Religions are often primarily local phenomena whose main function is to build and maintain stable communities and clear religious identities, but esoteric movements are almost never simply local and, let us admit it, they are usually very bad at maintaining stable communities and forming clear, clean religious identities. We might better speak here of global networks of intellectuals, writers, and seekers who are questioning, and largely denying, the very notion of a single community or religious ego.

The Theosophical movement, to take one obvious example, may have been born in American Spiritualism around New York City in the 1870s, but it quickly became a force from England to India and Russia, and its tendencies to include just about anything and everything within its metaphysical embracefrom an imagined ancient Egypt and Tibet to the astral plane itself-are well 
known. It also seems relevant here, as the present essays explore in rich detail, that the Roerichs claimed to have met Master Morya not in the Himalayas but in London's Hyde Park, and that they dreamed of a Buddhist superland embracing everything from Tibet to Siberia; that Gurdjieff was a Greek Armenian whose career spanned the Russian Empire to Parisian society; that Russian science fantasy was inspired by both Euro-American science fiction and Latin American magical realism; that a figure like Aleksandr Dugin thinks of all of Eastern Europe and Asia as a single cultural block; that Henry A. Wallace was probably inspired by a Russian occultist (Roerich again) when, as Secretary for Agriculture, he proposed in 1934 to put the Great Pyramid on the American dollar bill; or, finally, that the entire earth is too small for the dreams of Russian cosmism. Are there any more apt symbols for the global reach of esoteric movements than the dollar and outer space?

One can see similar, if more academic, global networks in the psychical research tradition, which in its beginnings (not accidentally in those same Spiritualist 1870s), was largely an elite intellectual club moving between London, Cambridge, and Harvard. The friendship, for example, between Cambridgetrained Frederic Myers and Harvard's William James was real and deep. More dramatically still, when Myers died, women around the world soon claimed little bits of channeled English, Latin, and Greek from him - the famous "crosscorrespondences" that crisscrossed the globe like some occult Internet. Similar intellectual and global currents are apparent in the modern human potential movement. It may have begun in northern California in the early 1960s and expressed a distinct individualism and American "democracy of the soul," but it always relied for its vision and direction on cosmopolitan writers and intellectuals-from the Cambridge trained Bengali Sri Aurobindo, the exiled German theologian Frederic Spiegelberg, and the British-American writer Aldous Huxley to the globe-hopping Fritz Perls and the Czech psychiatrist Stanislav Grof. No Indian and European intellectuals, no American human potential movement.

One wonders if this tendency to downplay national boundaries and develop global networks is a function of the esoteric/exoteric structure of these movements, with local culture and religion falling into the exoteric half of the equation. One wonders if this is a function of the often learned and bookish nature of those attracted to such movements; books, after all, travel exceptionally well, and cosmopolitanism and education often go together. One wonders, more radically, if the same tendencies to downplay the local for the universal might be a function of the phenomenology of the mystical states out of which these esoteric movements claim to flow. One wonders. 
There are numerous exceptions and qualifications to make, of course. The present essays, for example, treat non-conformist spiritual seekers who often display both these global networks and a very distinct sort of nationalism, localism, even messianism, with Russia commonly portrayed as "the spiritual center of the world." One thinks here of Roerich's "New Country," which may embrace huge chunks of Asia but looks more than a little like an expanded Soviet Union; of the conservative, Eurasian Movement of Aleksandr Dugin; and of the anthropological and personal fascinations with local Russian shamanic traditions. Similarly, the explicitly nationalist and communal character of cosmism has been noted, and contrasted sharply, with the individualist and transnational directions of occultism. All fair enough.

Exceptions and qualifications aside, my comments here emerge from an interest in these learned global networks, mystical phenomenologies, and-my own particular soap-box-the manner in which the latter esoteric forms of mind have helped produce particular types of comparative practice, including the modern comparative study of religion. ${ }^{1}$ Although I work on movements and ideas that clearly participate in the same cosmopolitan conversations (North American guru traditions, American metaphysical religion, the human potential movement, and popular cultural expressions of the paranormal), I do not possess any expertise in this or that body of Russian literature. One might say, then, that I read, listen, and ask questions upside-down, rather like Mikhail Meilakh. Put less playfully, one might say that my questions are comparative ones in the sense that they seek to understand the Russian material in the mirror of the American material and the American material in the mirror of the Russian material.

What can be seen in this double mirror? Other than oneself, of course. Let me conclude by making just two observations. Both involve the historical production of gaps, silences, and secrets.

\section{How Gaps Become Secrets}

The first thing that I see in this double mirror is that mystical literature-by which I mean literature that claims to encode secret teachings about the true relationship of the human condition to a more fundamental transcendent or sacred order-presents very similar promises and problems to the reader,

1 I will not pursue this idea here, as I have developed it elsewhere at some length. See my The Serpent's Gift: Gnostic Reflections on the Study of Religion (Chicago: University of Chicago Press, 2007). 
wherever such teachings are found. The challenge confronted by the historian of mystical literature of any sort-be it from medieval Hindu India or Christian Europe, Soviet Russia, or contemporary North America-boils down to this: how does one read the relationship between a presumed mystical event and the text it helped to produce? Like the relationship between the mundane and the transcendent orders that it replicates and re-enacts, this relationship between event and text is inevitably a complex one, as many of these mystical experiences do not and cannot be neatly slotted into the cultural narratives of the place and time.

More importantly still, these events are often even mysterious and finally unspeakable to the psyches in which they occur. We might say that the mystical event cannot be spoken because it cannot be "languaged" or reasoned at all. It is, quite literally, beyond language and any linear logic. It is not a product of the left brain, the cognitive scientist would say (okay, I would say). That is, the mystical event may not only be culturally or politically dissident; it may also be cognitively and epistemologically dissonant.

Sometimes, moreover, this cultural and epistemological ineffability is radicalized further by what we might call psychological, religious, and political factors, say, because the event is heavily sexualized or morally problematic (as we saw with the Tantric experiments of Anatolii Ivanov or with the esoteric embrace of "sacred drinking"), or doctrinally heretical (as we saw with the Orthodox condemnations of Roerich and transpersonal psychology), or appears to undermine the reigning political ideology (well, where to begin?). For all these reasons, and more, it is most appropriate to name these kinds of events and their subsequent literatures "mystical"-literally, secret or hidden. They are.

Saints or mystics doctrinally committed to a particular religious tradition have handled this gap between the mystical event and their own cultural and psychological surrounds in one way. Nineteenth-century British or French occultists handled it another. Contemporary American New Age writers in still another. But in each case, the challenge is the same: how to bridge the gap between an experience and what can be said about the experience to those who have not experienced it, or, and this is where it gets especially complicated, to those who have known a similar, resonating but finally different sort of altered state. There is, then, a fundamental gap between what happened and what can be said about what happened, and the basic hermeneutical challenge is to bridge that gap through interpretation of some kind, be it traditionally religious, occult, or academic. Which is another way of saying that the saint, the occultist, and the historian share a great deal. 
What the historian can see and say that the saint or occultist generally cannot is that the textual articulations of previous mystical events often inform the phenomenology of later mystical events in profound and exquisite ways. There is a kind of "loop" mechanism going on here, then, whereby earlier texts help inform later experiences, which help produce further texts, which help inform further mystical events, which help ... you get my point. The historian of mystical literature enters this stream (which we call a "tradition") at some point and tries to locate some of those gaps, processes, earlier influences, present shapes, and so on.

Finally, let me also observe that the historian of esoteric literature must also deal with an entire barrage of gaps and silences, if not actual silencings, and these from multiple sides. He or she does not only have to deal with the facts that the sources have usually been heavily censored or suppressed by the political and religious climate under study, and that any scholarly discovery or interpretation that challenges these political and religious forces is likely to be vigorously rejected and framed as "blasphemous," "slanderous," or, my personal favorite, "Western" (consider the case of Vladimir Rosov's dissertation on Roerich discussed in two of the essays here ${ }^{2}$ ). He or she also has to deal with the censoring and suppressing ideologies of the modern-day academy, which we might describe as materialist and contextualist in orientation. Any open discussion of a mystical event or figure that implies some transcendent or universal dimension (which is all of esoteric literature) is, in principle, deemed inappropriate and so must be immediately reduced to a local "discourse," a "historical construct," and so on.

Orthodoxies (of all sorts) aside, I cannot help but think that these mystical literatures force metaphysical questions, and that we will never really understand these texts and events until we allow our own ontological assumptions to be questioned by these same questions. I also wonder, deep down, if our general failure to compare across cultures and times is not really a product of this basic ontological timidity. I mean, once we insist on everything everywhere being flattened out into purely material, local, surface processes, what is there to compare about esoteric movements, whose very raison d'être is to point beyond this material, mundane historical, surface realm? Our lenses focus

2 American Indologists saw the exact same attempts to conflate their historical-critical methods with Western imperialism/colonialism among right-wing Hindu propagandists seeking to actively suppress and censor professional scholarship in the late 1990s and turn of the millennium. These moves are clearly from the same playbook. I suspect historical influence here, from the Hindutva ideologues to the Rosov-Roerich case. 
expertly and efficiently on the historical detail and the social functions of what we study. We can talk forever about political circumstance and historical influence. All well and good. But this very focus blinds us to other aspects, including and especially the central claims of the texts and figures themselves. We ourselves are silenced by the rules of our own game.

Victoria Nelson has traced this fundamental hermeneutical problem beautifully in a recent essay on the Ice trilogy of Vladimir Sorokin, whose gnostic sensibilities we do not have to guess at. In 2008, Sorokin told an interviewer this: "I believe that humanity is not yet perfect, but that it will be perfected, that contemporary humans are thus far imperfect beings, that we still do not know ourselves or our potential, that we have not understood that we are cosmic beings. We are created by a higher intelligence, and we have cosmic goals, not just comfort and reproduction. We are not 'meat machines."'3 Potential. Cosmic goals. These are the watchwords of every modern evolutionary mysticism.

Nelson's essay, appropriately titled "Mean and Light," traces these convictions through the trilogy, demonstrating in the process that one cannot fully appreciate these three sci-fi novels without being challenged by Sorokin's Gnostic Transcendentalism. The Children of Light of the trilogy, all 23,000 of them, are beings of light incarnated as paranormally gifted human beings all over the planet (there is that global network again). They eventually all seek reunion with a huge chunk of divine cosmic ice that has crashed into Russian soil (the famous Tunguska event).

Are these Children of Light simply fictitious tropes for Sorokin, or reflections of his real convictions about the deeper esoteric nature of the human condition? Nelson gives the correct, basically fantastic answer. They are both. "Sorokin himself splits the difference," she writes, "and this is what I think his 'metaphor' amounts to: The children of the Light are us. We humans, all of us, are part meat machine, part cosmic ray." "The Ice trilogy then, is, in the end, not just another piece of Russian literature. It is also a metaphysical challenge of the deepest sort. "Let it be noted," Nelson observes, "that these days, presenting transcendental experience as real is a far more subversive and unsettling proposition than any of the conveniently shifting positions taken inside the boundaries of late-twentieth-century postmodernism. ${ }^{\text {"5 }}$ Indeed.

3 Victoria Nelson, “Meat and Light: Vladimir Sorokin's Ice Trilogy Considers Gnostic Transcendentalism, the Potential of Human Collective Energy, and the Changing Russian Sociopolitical Landscape," REF, 25.

4 Ibid., 26.

5 Ibid., 21. 
In short, it is not just the Russian esotericist who has a problematic relationship to a militant atheism and official materialist culture. So do professional historians, anthropologists, and literary critics. Little wonder, then, that we have invented so many new shiny categories-the mystical, the occult, the psychical, the paranormal, and now the esoteric-to name and try to understand these historical processes of silencing and occultation. These, after all, are not just secrets. These are secrets within secrets within other secrets. And they are ours as well.

\section{A Most Instructive Silence}

The second thing I see in the double mirror of the Russian and American materials is that this multiple censoring of the mystical takes on especially excessive forms in the Russian materials, and that these extend far beyond anything we can find in the American literatures. In the Russian case, it is obviously the fact that mystical writers had much more to deal with than, say, cognitive ineffability, internal psychological censors, or academic respectability. They had real censors to deal with. They had threatening intelligence officers and secret police to worry about. They were working in an immense and intricate Soviet system that rigorously denied claims concerning anything beyond the material realm as deluded, dangerous, and, in some cases, punishable. These were no gaps to bridge with a few metaphors or a tenure case. These were yawning abysses to fear for one's livelihood, if not one's life. One did not end up in cognitive dissonance or joblessness here. One ended up in Siberia.

Or dead. "Almost all of them were physically annihilated during the Great Terror in 1937-1938." So writes Burmistrov on the Russian Templars. “Almost all members of the secret society, United Workers' Brotherhood, were captured and shot. Bokii was the first to perish. He was to receive a bullet in the back of the head on 15 November 1937." So writes Shishkin on Barchenko's research and colleague.

This overwhelming political and social fact appears to have produced what is one of the most marked features of this volume's essays for me personally: their almost total silence in regards to any first-person accounts of mystical, occult, or esoteric experiences. Where are the experiences? I ask the question not to criticize the authors, but to underline the super-secrecy of modern Russian mystical literature, and to catalyze a discussion about how we might read these literatures in relationship to other forms of esoteric literature that are not as politically fraught. I mean, what would we get if we put, say, Euro-American ufological literature in conversation with Russian cosmist literature? There are 
plenty of secrets in both, to be sure, but the political lines drawn around, say, unknown aerial phenomena are quite different, and so too are what can and cannot be said. Could one set of literature be used to plumb and scan the other, and vice versa, like a kind of double radar scan? And what would such a scan reveal?

Experiences are hinted at, for sure, in the present volume. Burmistrov, for example writes about how the founders of occult groups in the 1920s and 30s created their movements out of a double source: earlier occult literature and their own paranormal experiences. They then constructed new initiation rituals, manufactured lineages, and invented traditions in order to support and pass on the implications of their original paranormal experiences. We might say that the fiction of tradition was wrapped around the fact of experience, but that this fact of experience was formed by an earlier literary tradition, and so on. Still, we get no descriptions of these initiating paranormal experiences, probably because we do not have them in the historical record.

Osterrieder, it seems to me, asks exactly the right question in his careful essay on the Roerichs and their experience of channeling occult wisdom. "On the other hand," he writes, "if one assumes that 'communication' actually took place - which the Roerichs perceived as their reality and as the motivating source of their actions -, did the medium (i.e. Elena Roerich) then distort the 'messages' through personal defaults or ambition? Or did the 'communicator' have a concealed identity and a quite different agenda from what was transmitted to the Roerichs?" Note here how the questions themselves depend on the factuality of the original channeling events. We cannot even ask these questions, much less try to answer them, if we assume that the communications did not take place, that they were simply inventions or clever ruses.

I have worked with channelers in the States. In many cases, and almost certainly in the Roerich case, we can just remove Osterrieder's careful "if." Which of course does not answer how we are to understand these historical events: as unconscious phenomena to be interpreted psychologically; as sincere subjects unknowingly acting out a social structure or script; or, the impossible option, as human beings channeling discarnate beings. Still, the point remains the same: however we choose to interpret these experiences, they remain actual historical events that deserve our attention and analysis, and we will get nowhere by simply denying that they happened. They happened.

Similarly again, Laruelle describes "the intellectual experience of cosmism," but we hear of no actual cosmist experience, say, an encounter with an alien intelligence or a mystical experience in space on the part of a cosmonaut. We certainly hear of Tsiolkovskii talking to angels, but in the end we get no angels. 
Part of this is no doubt due to what Laruelle identifies as the movement's socialism: "according to cosmism, hidden reality will become obvious to all of humanity, not for a small group of the privileged. The secret character of the activities of connectedness, as a sort of 'lodge' for the initiated, does not comprise part of the intellectual and organizational apparatus of cosmism which, on the contrary, likes to speak of the greatest number." This certainly goes a long way in explaining the silences around individual cosmist experiences, but does this mean that there were or are no such experiences?

Two American comparisons might be instructive here, again as radar scans of sorts. We encounter a very similar "cosmist" or mystical evolutionary worldview (with significant differences, of course) among American sciencefiction writers, ufologists, and alien abductees. Indeed, we even have multiple instances of the alien body, at once spiritual and physical, being seen with or around dead acquaintances or loved ones of the visionary. We are very close here to the resurrected dead. And if we take these accounts as a whole now, we have thousands, if not hundreds of thousands, of reports and detailed descriptions of individual experiences. Indeed, the historian of religions who ventures into this realm is positively swimming, or drowning, in psychological data. To take a single dramatic case, when the horror and sci-fi writer Whitley Strieber published his Communion in 1986, on his own dramatic (and erotic) experience of abduction, he put an address at the back of the book for readers to write him. As a result, he received half a million letters from all over the world, mostly from people who recognized the alien face on the cover or saw their own abduction experiences mirrored and scanned in his.

My point is this: virtually all of these half-million experiences would have been completely invisible to any practicing historian, but they were, and still are, there nonetheless. Moreover, these half million historical documents were invoked by a fiction writer writing about his own esoteric experiences in a book one of whose central features is the blurring of the fictional and the factual in such paradoxical events (Strieber is very conscious, and very clear, about the ways that the religious and cultural imagination shapes these sorts of encounters). The cognitive and cultural loops here between fiction and fact, between literature and the occult, between private and public, between the physical and the spiritual are nearly unimaginable in our present block-headed materialist epistemologies. And, once again, we can only begin to trace and track them if we take the original experiences as historical facts.

Or consider Apollo XIV astronaut Edgar Mitchell. While floating in space on his way back to earth, Mitchell experienced an overwhelming yogic union or "samadhi" (his term) involving what he calls the "dyadic" unity of matter 
and mind within an evolving conscious universe. This event changed everything for him. He later founded a still thriving scientific research institute to study psychical phenomena (the Institute of Noetic Sciences, in Petaluma, California) and wrote a detailed autobiography about his adventures in the "material" and "mystical" worlds. He has also, by the way, gone on record stating that he believes in the reality of UFOs. As with the Strieber case, the fact and the fiction merge and mirror one another here. The Institute of Noetic Sciences, originally inspired by Mitchell's outer-space event, was prominently featured in a work of esoteric pop-literature, Dan Brown's The Lost Symbol. There is the feedback loop again. ${ }^{6}$

We do have at least one reported individual experience in the essays above. It involves an atheist science schoolteacher by the name of Vera Khromtsova and the author of the essay, Natalia Zhukovskaia. A neighbor asks Vera why she pulled sacks out of her cellar the previous day. She replies that "Badma came" and told her to do so. Badma had been dead for two years. But Badma knew what she was saying:

Three days later the upper end of the Tunka valley saw very strong rainfalls, which led to the groundwater rising and flooding all cellars, destroying the food reserves that many people kept there. Those who had been "visited by Badma" and "warned" to take out the food reserves (sacks of potatoes, carrots, cabbages, turnips, jars of jam and pickles all that which can be destroyed by water in the cellar) did not suffer damage from the elements.

This is exactly the kind of narrative we need to forward the interpretive project. Once we have such a narrative, we can then ask new questions. Like whether "Badma" was an actual discarnate spirit, or some aspect of Vera's psyche transmitting a very useful piece of precognition in the only way it knows how-through the folklore of the culture; or, or what?

It seems relevant, to me anyway, that the only clear occult experience we have described in this volume was preserved as such only because the researcher-scholar was present and was willing to write about it. In other words, the scholar, i.e., Zhukovskaia, played a major role here in invoking, recording, and passing on this precognitive narrative to us. In the process, she teaches us about Russian anthropologists and intellectuals taking on the practices and

6 I discuss both the Strieber and Mitchell cases at some length in Mutants and Mystics: Science Fiction, Superhero Comics, and the Paranormal (Chicago: University of Chicago Press, 2011). 
roles of the shaman themselves, in essence, going native. This is where it gets especially interesting and, as I have argued elsewhere, especially fruitful. ${ }^{7}$

7 Jeffrey J. Kripal, Roads of Excess, Palaces of Wisdom: Eroticism and Reflexivity in the Study of Mysticism (Chicago: University of Chicago Press, 2002). 


\title{
SELECT BIBLIOGRAPHY
}

\author{
MICHAEL HAGEMEISTER
}

Agursky, Mikhail, "An Occult Source of Socialist Realism: Gorky and Theories of Thought Transference," In: Bernice G. Rosenthal, ed., The Occult in Russian and Soviet Culture (Ithaca, London: Cornell University Press, 1997), 247-272.

Aitamurto, Kaarina, "Modern Pagan Warriors: Violence and Justice in Rodnoverie," In: James R. Lewis, ed., Violence and New Religious Movements (Oxford, New York: Oxford University Press, 2011, 231-248.

Andreev, Aleksandr, Gimalaiskoe bratstvo: Teosofskii mif i ego tvortsy (St. Petersburg: Izd. S.-Peterburgskogo Universiteta, 2008).

-, Khram Buddy v Severnoi stolitse (St. Petersburg: Nartang, 2004).

-, Okkul'tist Strany Sovetov: Taina doktora Barchenko (Moscow: Eksmo-Iauza, 2004).

-, Soviet Russia and Tibet: The Debacle of Secret Diplomacy, 1918-1930s (Leiden: Brill, 2003); Tibet v politike tsarskoi, sovetskoi i postsovetskoi Rossii (St. Petersburg: Izdat. S.-Peterburgskogo universiteta, 2006).

-, Vremia Shambaly. Okkul'tizm, nauka i politika v Sovetskoi Rossii (St. Petersburg: Neva, Moscow: Olma-Press, 2002).

—; Berezhkov, Vasilii, Okkul'tisty Lubianki. (Moscow: Bystrov, 2006).

Antic, Oxana, "The Spread of Modern Cults in the USSR," In: Sabina Petra Ramet, ed., Religious Policy in the SU (Cambridge: Cambridge University Press, 1993).

Aptekman, Marina, Jacob's Ladder: Kabbalistic Allegory in Russian Literature (Brighton, MA: Academic Studies Press, 2011).

-, "Kabbalah, Judeo-Masonic Myth, and Post-Soviet Literary Discourse: From Political Tool to Virtual Parody," Russian Review 65 (2006), 657-681.

-, "Fantasticheskaia kabbala i ee rol' v istorii russkogo okkul'tizma: velikoe tainoe uchenie ili uspeshnoe sharlatanstvo?," Kontinent 107 (2001), 325-337.

Balagushkin, Evgenii, Netraditsionnye religii v sovremennoi Rossii. Morfologicheskii analiz, 2 vols. (Moscow: RAN, 1999-2002).

Balzer, Marjorie M., ed., Shamanic Worlds (New York: Sharpe, 1997).

Basilov, Vladimir, Izbranniki dukhov (Moscow: Politizdat, 1984).

-, Shamanstvo u narodov Srednei Azii i Kazakhstana (Moscow: Nauka, 1992).

Belotsvetov, Nikolai, Kommuna proletarskikh missionerov (Berlin, 1921).

Belyaev, Demyan, Geographie der alternativen Religiosität in Russland. Zur Rolle des heterodoxen Wissens nach dem Zusammenbruch des kommunistischen Systems (Heidelberg: Geographisches Institut, 2008).

Berry, Thomas, Spiritualism in Tsarist Society and Literature (Baltimore, 1985). 
Bogdanov, Alexej, Dmitrii Andreev and the Mystical Tradition in Literature (Diss. Colorado, 2002).

Bogomolov, Nikolai, Russkaia literatura nachala XX veka i okkul'tizm. Issedovaniia $i$ materialy (Moscow: NLO, 1999).

-, "Gumilev i okkul'tizm. Prodolzhenie temy," Novoe literaturnoe obozrenie 26, 1995, 181-200.

Bonetskaia, Natal'ia, „Russkaia sofiologiia i antroposofiia, “ Voprosy filosofii, 1995, 7, 7997.

Borenstein Eliot, "Suspending Disbelief: 'Cults' and Postmodernism in Post-Soviet Russia,” In: Adele Marie Barker, ed., Consuming Russia: Popular Culture, Sex, and Society since Gorbachev (Durham: Duke University Press, 1999).

Bowlt, John E., "Esoteric Culture and Russian Society," In: Maurice Tuchman, et al., eds., The Spiritual in Art: Abstract Painting 1890-1985 (Los Angeles: County Museum of Art and Abbeville Press, 1986), 165-183.

Brachev Viktor, Chekisty protiv okkul'tistov (Okkul'tno-misticheskoe podpol'e v SSSR) (Moscow: Iauza, 2004).

-, „Leningradskie masony i OGPU (protokoly doprosov, veshchestvennye dokazatel'stva)," Russkoe proshloe. Istoriko-dokumental'nyi al'manakh, kn. 1 (Leningrad, 1991), 252-279.

—, Masony, mistiki i bogoiskateli v Rossii. XX vek (St. Petersburg: Stomma, 2003).

-, Okkul'tisty sovetskoi épokhi. Russkie masony XX veka (Moscow: Bystrov, 2007).

—, Okkul'tnye istoki revoliutsii. Russkie masony XX veka (Moscow: Bystrov, 2007).

—, „Peterburgskie martinisty 1910-1925 godov. Dokumenty Arkhiva Ministerstva bezopasnosti Rossiiskoi Federatsii,“ Otechestvennaia istoriia, 1993, no. 3, 177-192.

—, “Tainye masonskie obshchestva v SSSR," Molodaia gvardiia, 1994, 3, 140-158.

Brougher, Valentina G., "The Occult in the Prose of Vsevolod Ivanov," In: Bernice G. Rosenthal, ed., The Occult in Russian and Soviet Culture (Ithaca, London: Cornell University Press, 1997), 299-322.

-, "The Occult in Russian Literature of the 1990s," Russian Review 56 (1997), 1, 110124.

[Bourdeaux, Michel] Burdo, M.; Filatov, Sergei, Sovremennaia religioznaia zhizn'v Rossii. Opyt sistematicheskogo opisaniia, 4 vols. (Moscow: Logos, 2004-2006).

Burmistrov, Konstantin, „Andrei Belyi i kabbala (O roli evreiskoi mistiki v mirovozzrenii russkikh simvolistov)," Jews and Slavs 13 (Jerusalem, 2006), 265-278.

-, "Christian Orthodoxy and Jewish Kabbalah: Russian mystics in the search for perennial wisdom," In: Kocku von Stuckrad, Olav Hammer, eds., Polemical Encounters: Esoteric Discourse and Its Others (Leiden: Brill, 2007), 46-77.

-, "The Interpretation of Kabbalah in early $20^{\text {th }}$-century Russian Philosophy: Soloviev, Bulgakov, Florenskii, Losev,” East European Jewish Affairs 37:2 (2007), 157-187.

Butkowsky-Hewitt, Anna, Gurdjieff in St. Petersburg and Paris (London: Routledge, 1978). 


\section{Bibliography}

Carlson, Maria, "Armchair Anarchists and Salon Supermen: Russian Occultists Read Nietzsche," In: Bernice G. Rosenthal, ed., Nietzsche and Soviet Culture. Ally and Adversary (Cambridge: Cambridge University Press, 1994), 107-124.

—, "Fashionable Occultism: Spiritualism, Theosophy, Freemasonry, and Hermeticism in Fin-de-Siècle Russia," In: Bernice G. Rosenthal, ed., The Occult in Russian and Soviet Culture (Ithaca, London: Cornell University Press, 1997), 135-152.

-, "No Religion Higher Than Truth." A History of the Theosophical Movement in Russia, 1875-1922 (Princeton NJ: Princeton University Press, 1993).

Chistov, Kirill; Sokolova, Vera, Russkie narodnye sotsial'no-utopicheskie legendy XVIIXIX vv. (Moscow: AN SSSR, 1967).

Debol'skii, Diodor, K poznaniiu Dukhovnoi opyta iudiiskikh i khristianskikh mistikov, ed. A.L. Nikitin (Moscow: Semeinyj arkhiv/Integraf Servis, 1996).

Decter, Jacqueline, Nicholas Roerich. The Life and Art of a Russian Master (London: Thames and Hudson: 1989).

DeNio Stephens, Holly, "The Occult in Russia Today," In: Bernice G. Rosenthal, ed., The Occult in Russian and Soviet Culture (Ithaca, London: Cornell University Press, 1997), 357-376.

Dimitri, Francesco, Comunismo magico. Leggende, miti e visioni ultraterrene del socialismo reale (Rome: Alberto Castelvecci, 2004).

Douglas, Charlotte, "Beyond Reason: Malevich, Matiushin, and Their Circles," In: Maurice Tuchman, et al., eds., The Spiritual in Art: Abstract Painting 1890-1985 (Los Angeles: County Museum of Art and Abbeville Press, 1986), 185-199.

Drayer, Ruth A., Nicholas and Helena Roerich: The Spiritual Journey of Two Great Artists and Peacemakers (Wheaton, Ill.: Quest Books, 2005).

Dubrov, Aleksandr; Pushkin, Veniamin, Parapsikhologiia i sovremennoe estestvoznanie (Moscow: Sovaminko, 1989).

[Dugin, Aleksandr] Douguine, Alexandre, "Le complot idéologique du cosmisme russe," Politica hermetica 6 (1992), 80-92.

-, Filosofiia traditsionalizma (Moscow: Arktogeia, 2002).

-, Konspirologiia (nauka o zagovorakh, tainykh obshchestvakh i okkul'tnoi voine) (Moscow: Arktogeia, 1993).

Epshtein, Mikhail, "Daniil Andreev and the Mysticism of Femininity," In: Bernice G. Rosenthal, ed., The Occult in Russian and Soviet Culture (Ithaca, London: Cornell University Press, 1997), 325-355.

-, Novoe sektantstvo. Tipy religiozno-filosofskikh umonastroenii v Rossii (70-80 gody XX veka) (Holyoke: New England, 1993; Moscow: Labirint, 1994).

Falikov, Boris, Kul'ty i kul'tura. Ot Eleny Blavatskoi k Rona Khabbarda (Moscow, 2007). Fedjuschin, Victor, Russlands Sehnsucht nach Spiritualität. Theosophie, Anthroposophie, Rudolf Steiner und die Russen (Schaffhausen: Novalis Verlag, 1988).

Fesenkova, Larissa, ed., Diskursy ėzoteriki. Filosofskii analiz (Moscow: URSS, 2001).

-, Russkii kosmizm i sovremennost' (Moscow, IFAN, 1990). 
Flerow, Wladimir, „Die neue ,Parapsychologie-Welle‘ in der Sowjetunion, “ Zeitschrift für Parapsychologie und Grenzgebiete der Psychologie 32 (1990), 3-4, 242-249.

Fridman, Eva Jane Neumann, Sacred Geography: Shamanism among the Buddhist Peoples of Russia, Bibliotheca Shamanistica. vol. 12 (Budapest: Akadéimiai Kiado, 2004).

Fumagalli, Nicola: Cultura politica e cultura esoterica nella sinistra russa (1880-1917) (Milano: Barbarossa, 1996).

Gaidukov, A., "Molodezhnaia subkul'tura slavianskogo neoiazychestva v Peterburge," In: Molodezhnye dvizheniia i subkul'tury Sankt-Peterburga, ed. V.V. Kostiushev (St. Petersburg: Norma, 1999), 24-50.

Gavriushin, Nikolai, „A byl li ,russkii kosmizm’?“" Voprosy istorii estestvoznaniia $i$ tekhniki, 1993, no. 3, 104-105.

—, 'Kosmicheskii put' k, vechnomu blazhenstvu'. (K. É. Tsiolkovskii i mifologiia tekhnokratii)," Voprosy filosofii, 1992, no. 6, 125-131 (English: Nikolai Gavriushin, "The Cosmic Route to 'Eternal Bliss'. K. E. Tsiolkovskii and the Mythology of Technocracy," Russian Studies in Philosophy, 1995, no. 34, 36-47).

—, "Mistik-tekhnokrat (K. E். Tsiolkovskii)," In: Vladislav Lektorskii, ed., Filosofiia ne konchaetsia. Iz istorii otechestvennoi filosofii. XX vek (Moscow: ROSSPÉN, 1998), 702-717.

G.O.M[ebes], Kurs èntsiklopedii okkultizma chitannyi G.O.M. v 1911-1912 akademicheskom godu v gorode Sankt-Peterburge, 2 vols. (St. Petersburg, 1912).

-, Meditatsii na Arkany Taro. Dopolneniia k Éntsiklopedii okkul'tizma: lektsii 1921 goda (Moscow: Aenigma, 2007).

Gordin, Michael D., "Loose and Baggy Spirits: Reading Dostoevskii and Mendeleev," Slavic Review 60 (Winter 2001), 756-780.

Gostev, Andrei, Psikhologiia i metafizika obraznoi sfery cheloveka (Moscow: Genesis, 2008).

Graham, Loren; Kantor, Jean-Michel, Naming Infinity. A True Story of Religious Mysticism and Mathematical Creativity (Cambridge, Mass.: Harvard University Press, 2009).

Grib, Andrei, Sovremennaia fizika i religioznoe otkrovenie, Dva Grada. Dialog nauki $i$ religii. Vostochno- $i$ Zapadnoevropeiskaia traditsii (Moscow: RAN 2002).

Grigor'eva, Nadezhda, „Tekhnomagicheskii roman tridtsatykh,” Wiener Slawistischer Almanach 49 (2002), 173-211.

Gris, Henry; Dick, William, The New Soviet Psychic Discoveries (Englewood Cliffs, N.J.: Prentice Hall, 1978).

Groberg, Kristi A., “The Shade of Lucifer's Dark Wing': Satanism in Silver Age Russia,” In: Bernice G. Rosenthal, ed., The Occult in Russian and Soviet Culture (Ithaca, London: Cornell University Press, 1997), 99-133.

Grof, Stanislav, Za predelami mozga. Rozhdenie, smert' i transtsendentsiia $v$ psikhoterapii (Moscow, 1993). 
Groys, Boris, „Elemente des Gnostizismus im Dialektischen Materialismus (sowjetischen Marxismus),“ In: Peter Koslowski, ed., Gnosis und Mystik in der Geschichte der Philosophie (Zurich, Munich: Artemis, 1988), 352-367.

Gutkin, Irina, “The Magic of Words: Symbolism, Futurism, Socialist Realism,” In: Bernice G. Rosenthal, ed., The Occult in Russian and Soviet Culture (Ithaca, London: Cornell University Press, 1997), 225-246.

Hagemeister, Michael, „Das Dritte Rom gegen den Dritten Tempel - Der Antichrist im postsowjetischen Russland,“ In: Mariano Delgado, Volker Leppin, eds., Der Antichrist. Historische und systematische Zugänge (Fribourg: Academic Press, Stuttgart: Kohlhammer, 2011), 461-485.

—, „Die Eroberung des Raums und die Beherrschung der Zeit: Utopische, apokalyptische und magisch-okkulte Elemente in den Zukunftsentwürfen der Sowjetzeit,"In: Jurij Murašov, Georg Witte, eds., Die Musen der Macht. Medien in der sowjetischen Kultur der 20er und 30er Jahre (Munich: Fink, 2003), 257-284.

—, „Imjaslavie - imjadejstvie. Namensmystik und Namensmagie in Russland (19001930),“ In: Tatjana Petzer et al., eds., Namen. Benennung - Verehrung - Wirkung. Positionen der europäischen Moderne (Berlin: Kadmos, 2009), 78-98.

—, "Russian Cosmism in the 1920s and Today," In: Bernice G. Rosenthal, ed., The Occult in Russian and Soviet Culture (Ithaca, London: Cornell University Press, 1997), 185-202 (in Russian: “Russkii kosmizm v 20-e gody i segodnia," Stranitsy 3 (1998), 2, 182-198).

—, „Der 'russische Kosmismus' - ein Anachronismus oder die 'Philosophie der Zukunft'?," In: Anne Hartmann, Christoph Veldhues, eds., Im Zeichen-Raum. Festschrift für Karl Eimermacher zum 60. Geburtstag (Dortmund: Projekt, 1998), 169201.

Hamayon, Roberte, La chasse à l'âme. Esquisse d'une théorie du chamanisme sibérien (Nanterre: Soc. d'Ethnologie, 1990).

Heller, Leonid: Vselennaia za predelom dogmy (London : OPI, 1985).

-: „Ėzotericheskie èlementy v sotsialisticheskom realizme,“ in: Rolf Fieguth, ed., Orthodoxien und Häresien in den slavischen Literaturen (Munich: Sagner, 1996).

-: „Ėzotericheskie kody E. Zamiatina,“ in: Larisa Poliakova, ed., Tvorcheskoe nasledie Evgeniia Zamiatina, vyp. 14 (Tambov: izd. Tambovskogo Universiteta: 2007).

-; Niqueux, Michel, Geschichte der Utopie in Russland (Bietigheim-Bissingen: Edition tertium, 2003).

Henderson, Linda Dalrymple, "Mysticism, Romanticism, and the Fourth Dimension," In: Maurice Tuchman, et al., eds., The Spiritual in Art: Abstract Painting 1890-1985 (Los Angeles: County Museum of Art and Abbeville Press, 1986), 219-237.

Hoellwerth, Alexander, Das sakrale eurasische Imperium des Aleksandr Dugin. Eine Diskursanalyse zum postsowjetischen russischen Rechtsextremismus (Stuttgart: ibidem, 2007).

Honey, Larissa, Transforming Selves and Society: Women, Spiritual Health and Pluralism in Post-Soviet Moscow, unpubl. PhD Diss. (New York: CUNY, 2006). 
Huneeus, Antonio, ed., A Study Guide to UFOs, Psychic and Paranormal Phenomena in the USSR (s.l.: Abelard Productions, 1991).

Ivakhiv, Adrian, "The Revival of Ukrainian Native Faith," In: Modern Paganism in World Cultures. Comparative Perspectives, ed. Michael F. Struicka (Santa Barbara: ABC Clio, 2005), 209-240.

Ivanits, Linda J., "Three Instances of the Peasant Occult in Russian Literature: Intelligentsia Encounters Narod," In: Bernice G. Rosenthal, ed., The Occult in Russian and Soviet Culture (Ithaca, London: Cornell University Press, 1997), 59-74.

Kasinec, Edward; Kerdimun, Boris, “Occult Literature in Russia,” In: Maurice Tuchman, et al., eds., The Spiritual in Art: Abstract Painting 1890-1985 (Los Angeles: County Museum of Art and Abbeville Press, 1986), 361-365.

Kasten, Erich, ed., Schamanen Sibiriens. Magier - Mittler - Heiler (Berlin: Dietrich Reimer Verlag / Linden-Museum Stuttgart, 2009).

Kharitonova, Valentina, Feniks iz pepla? Sibirskii shamanizm na rubezhe tysiacheletii (Moscow: Nauka, 2006).

Khram Buddy v Severnoi stolitse (St. Petersburg: Nartang, 2004).

Kirlian, Valentina; Kirlian, Semen, V mire chudesnykh razriadov (Moscow 1964).

Kirlianovskie chteniia "Kirlian-2000". Sbornik dokladov i statei (Krasnodar 1998).

Knorre, Boris, „Mariiskoe iazychestvo: sokhraniaetsia li mestnaia traditsiia v globalizirovannom mire?" In: Materialy po issledovaniiu religioznoi situatsii na Severozapade Rossii $i$ v stranakh Baltii, vyp. V (St. Petersburg: Ross. Gos. ped. univ. im. Gertsena, 2009), 59-64.

Kolpakidi, Aleksandr, Okkul'tnye sily SSSR (Moscow: Biblioteka Al'debaran, 2005).

Kornblatt, Judith Deutsch, "Russian religious Thought and the Jewish Kabbala," In: Bernice G. Rosenthal, ed., The Occult in Russian and Soviet Culture (Ithaca, London: Cornell University Press, 1997), 75-95.

Korotkov, Konstantin, OHuman Energy Field. Study with GDV Bioelectrography (Fair Lawn, NJ: Backbone, 2002).

Kotiranta, Matti, ed., Religious Transition in Russia (Helsinki: Kikimora, 2000).

Krippner, Stanley, “Soviet Parapsychology: Fiction or Reality?" Psi News. Bulletin of the Parapsychological Association 4 (April 1981) (German: "Sowjetische Parapsychologie: Fiktion oder Realität," Zeitschrift für Parapsychologie und Grenzgebiete der Psychologie, 26 (1984), nos. 1-4).

Kuraev, Andrei, Okkul'tizm v pravoslavii (Moscow: Blagovest 1998).

-, Uroki sektovedeniia (Kak uznat' sektu. Na primere dvizheniia rerikhovtsev (St. Petersburg: Formika, 2002).

[Laqueur, Walter] Laker, Uolter, „Chernaia magiia, okkul'tnye nauki i natsionalizm,“ Novoe vremja, 38, 1992, 17-19.

Laruelle, Marlène, “'The White Tsar': Romantic Imperialism in Russia's Legitimizing of Conquering the Far East," Acta Slavica Iaponica 25 (2008), 113-134.

-, Mythe aryen et rêve impérial dans la Russie du XIX siècle (Paris: CNRS Editions, 2005). 
—, "La question du ,touranisme" des Russes. Contribution à une histoire des échanges intellectuels Allemagne - France - Russie au XIX ${ }^{\mathrm{e}}$ siècle," Cahiers du monde russe 45/1-2 (2004), 244-266.

—, L'ideologie eurasiste russe, ou comment penser l'empire (Paris: L'Harmattan, 1999).

Lavrov, A.S., Koldovstvo i religiia $v$ Rossii (Moscow, 2000).

Lazarev E.S., „Gnosticheskaia obraznost' v nasledii russkikh tamplierov XX veka,“ Rossiia i gnozis. Materialy konferentsii (Moscow: VGBIL, 1996), 69-75.

Lebed'ko, Vladimir, Khroniki Rossiiskoi San'iasy. Iz zhizni Rossiiskikh mistikov - Masterov i uchenikov 1960-1990kh), 4 vols. (Moscow 2000).

Lindquist, Galina, Conjuring Hope. Healing and Magic in Contemporary Russia (New York, Oxford: Berghahn 2006).

Lövgren, Håkan, “Sergei Eisenstein’s Gnostic Circle,” In: Bernice G. Rosenthal, ed., The Occult in Russian and Soviet Culture (Ithaca, London: Cornell University Press, 1997), 273-297.

Luzianin S.G., Vostochnaia politika Vladimira Putina: Vozvrashchenie Rossii na Bol'shoi Vostok (2004-2008 gody) (Moscow: AST, Vostok-Zapad, 2007).

McCannon, John, "By the Shores of White Waters: The Altai and its Place in the Spiritual Geopolitics of Nicholas Roerich,” Sibirica 2 (2002), 166-189.

-, "Mother of the World: Eurasian Imagery and Conceptions of Feminine Divinity in the Works of Nikolai Roerich," in Russian Art and the West, ed. R. Blakesley and S. Reid (DeKalb: NIU Press, 2006).

-, "Passageways to Wisdom: Nicholas Roerich, The Dramas of Maurice Maeterlinck, and Symbols of Spiritual Enlightenment," Russian Review 63 (2004), 449-478.

-, "In Search of Primeval Russia: Stylistic Evolution in the Landscapes of Nicholas Roerich, 1897-1914.” Cultural Geographies 7 (2000), 271-297.

Maikov, Vladimir; Kozlov, V., Transpersonal'nyi proekt: psikhologiia, antropologiia, dukhovnye traditsii, vol. 2 (Moscow: Teksty transpersonalnoi psikhologii, 2007).

Malmstad, John E, „Andrei Bely i antroposofiia,” Minuvshee 6 (1992), 337-450; 8, 409471; 9, 409-488.

Mamleev, Iurii, Okkul'tizm v Sovetskoi Rossii, Okkul'tizm i ioga 1976, no. 63, 29-47.

Mandelstam Balzer, Marjorie, "Izbranniki dukhov" - "izbravshie dukhov". Traditsionnoe shamanstvo i neoshamanizm . Pamiati V.N. Basilova (1937-1998). Sbornik statei (Moscow, 1999), 183-193.

Mannherz, Julia, „Geistererscheinungen und ihre Zeugen: Geschichtenerzählen zwischen Positivismus und Spiritismus im späten Zarenreich, "WerkstattGeschichte, 44 (2006), 81-96.

-, Modern Occultism in Fin-de-Siècle Russia (Chicago: Northern Illinois University Press, 2012).

-, „The Supernatural and Claims of Scientificity in Russian Popular Culture 18751914," In: The Role of Magic in the Past: Learned and Popular Magic. Popular Beliefs and Diversity of Attitudes (Bratislava, 2005), 227-244. 
Maurer, Eva, et al., eds., Soviet Space Culture - Cosmic Enthusiasm in Socialist Societies (Houndmills, Basingstoke: Palgrave Macmillan, 2011).

Maydell, Renata v., "Anthroposophy in Russia," In: Bernice G. Rosenthal, ed., The Occult in Russian and Soviet Culture (Ithaca, London: Cornell University Press, 1997), 153-167.

-, "Dornach als Pilgerstätte der russischen Anthroposophen," in: Karl Schlögel, ed., Russische Emigration in Deutschland 1918 bis 1941. Leben im europäischen Bürgerkrieg (Berlin: Akademie Verlag, 1995), 295-303.

-, Vor dem Thore. Ein Vierteljahrhundert Anthroposophie in Russland (Bochum, Freiburg: Projekt, 2005).

Mejlakh, Mikhail, Teoriia transmutatsii G.I. Gurdzhieva. Ratsional'noe i irratsional'noe $v$ sovremennom burzhuaznom soznanii, vyp. 2 (Moscow: INION, 1979), 139-172.

Menzel, Birgit, "The Occult Revival in Russia Today and Its Impact on Literature," Harriman Review 16 (2007), 1, 1-14.

Mistiko-ėzotericheskie dvizheniia $v$ teorii i praktite. Istoriia, psikhologiia, filosofiia (Esoterica Mystica), Vtoraia mezhdunarodnaia nauchnaia konferentsiia, ed. S. Pakhomov (St. Petersburg: Russkaia khristianskaia gumanitarnaia akademiia, 2009).

Moore, James, Gurdjieff. The Anatomy of a Myth. A Biography (Shaftsbury, Rockport, MA,1991).

Moroz, Evgenii, Istoriia "Mertvoj vody" - ot strashnoi skazki k bol'shoi politike. Politicheskoe neoiazychestvo v postsovetskoi Rossii (Stuttgart: ibidem, 2005).

Naumov, Evgenii, et al., eds., Parapsikhologiia $v$ Rossii. Bibliograficheskii ukazatel' (Moscow: Vsemirnaia Parapsichologiia, 1993).

Nefed'ev, Georgii, „Russkii simvolizm i rozenkreitserstvo,” Novoe literaturnoe obozrenie 51, 2001, 167-195; 56, 2002, 149-178.

Nemirovskii, Aleksandr; Ukolova, Viktoriia, Svet zvezd, ili poslednii russkii rozenkreitser (Moscow: Progress-kul'tura, 1994).

Nikitin, Andrei, Ezotericheskoe masonstvo v sovetskoi Rossii. Dokumenty 1923-1941 gg. (Moscow: Minuvshee, 2005).

-, Mistiki, Rozenkreitsery i Tampliery v Sovetskoi Rossii (Moscow: Minuvshee, 1998).

-, Orden rossiiskikh tamplierov, 3 vols. (Moscow: Minuvshee, 2003).

-, Rozenkreitsery v sovestskoi Rossii. Dokumenty 1922-1937 gg. (Moscow: Minuvshee, 2004).

-, Tainye ordeny v Sovetskoi Rossii. Tampliery i rozenkreitsery (Moscow: Veche, 2006).

Novye religioznye ob"edineniia Rossii destruktivnogo i okkul'tnogo kharaktera. Spravochnik. Missionerskii otdel Moskovskogo Patriarkhata Russkoi Pravoslavnoi Tserkvi. (Belgorod, ${ }^{3} 2002$ ).

Novye religioznye organizatsii, sekty $i$ dvizheniia $v$ Rossii, ed. Trofimchuk, N.A., Osvienko, F.G., Odintsov, M.I. (Moscow: RAGS, 1997).

Obskurantizm v postsovetskuiu épokhu, ed. E. Krugliakov. Vestnik Rossiia: Tret'e Tysiacheletie. Vestnik aktual'nykh prognozov, No. 8, tom II. spec. vyp., Nauka v Rossii. Stsenarii razvitiia (Moscow, 2005). 
Okkultismus und Avantgarde. Von Munch bis Mondrian 1900-1915. Katalog der Ausstellung in der Schirn Kunsthalle Frankfurt 1995 (Ostfildern: edition tertium, 1995).

Osterrieder, Markus: "Ex Oriente Lux? Russland als eurasisches Imperium und das Reich Shambhala. Spirituelle und mentale Grundlagen des Eurasiertums von Petr Badmaev bis Aleksandr Dugin (1890-2004)," Die Drei 74, 2004, 13-27.

-, Das Land der Heiligen Sophia. Das Auftauchen des Sophia-Motivs in der Kultur der Ostslaven, Wiener Slawistischer Almanach 50, 2002, 5-62.

Ostrander, Sheila; Schroeder, Lynn, Psychic Discoveries (London: Souvenir Press, 1997). Panchenko, Aleksandr, Khristovshchina i skopchestvo. Fol'klor i traditsionnaia kul'tura russkikh misticheskikh sekt (Moscow: OGI, 2002).

Parvulesco, Jean, Putin i Evraziiskaia imperiia (St. Petersburg: Amfora, 2006).

[Pauwels, Louis; Bergier, Jacques] Povel', Luis; Berzh'e, Zhak, Utro magiei [Le matin des magiciens] (Moscow: Enigma, 1994).

Physicists in parapsychology (Moscow: Hatrol, 2002); Fiziki v parapsikhologii. Ocherki (Moscow: Letnii sad, 2003).

Polianski, Igor J., „Geister der Erinnerung. Das Atheismusmuseum als sowjetischer Gedächtnisort“, In: ZeitRäume. Potsdamer Almanach des Zentrums für Zeithistorische Forschung 2008 (Göttingen: Wallstein, 2009), 115-126.

Potapov, Leonid, Altaiskii shamanizm (Leningrad: Nauka, 1991).

Prilutskii, A.M., „Mifologicheskie èlementy i proiavleniia sinkretizma v diskurse narodnoi religii,“In: Materialy po issledovaniiu religioznoi situatsii na severo-zapade Rossii $i$ v stranakh Baltiki, vyp. IV (St. Petersburg: Rossiiskii gos. ped. universitet im. Gertsena, 2007), 189-205.

Proskurina, Vera: “'Cor Ardens': Smysl zaglaviia i èzotericheskaia traditsiia,” Novoe literaturnoe obozrenie 51, 2001, 196-213.

Rerikhi. Mify i fakty. Sbornik statej (St. Petersburg: Nestor-Istoriia, 2011).

Rerikhovskoe nasledie. Trudy konferentsii (St. Petersburg: Irida, 2005).

Reyner, John H., Ouspensky: The Unsung Genius (London: Allen \& Unwin, 1981).

Rock, Stella, Popular Religion in Russia: 'Double Belief' and the Making of an Academic Myth (New York: Routledge, 2007).

Roerich, Helena et al., Okkul'tizm i ioga. Letopis' sotrudnichestva, 12 vols. (Moscow: Sfera, 1996).

Rosenthal, Bernice Glatzer, "Introduction," In: eadem, ed., The Occult in Russian and Soviet Culture (Ithaca, London: Cornell University Press, 1997), 1-32.

-, "The Occult in Modern Russian and Soviet Culture. An Historical Perspective," Theosophical History 4 (1992-1993), 252-259.

-, "Political Implications of the Early Twentieth-Century Occult Revival," In: eadem, ed., The Occult in Russian and Soviet Culture (Ithaca, London: Cornell University Press, 1997), 379-418.

—, "Russia's Occult Revival," East-West Church and Ministry Report, August 1, 1999.

-, ed., New Myth, New World: From Nietzsche to Stalinism (University Park: Pennsylvania State University Press, 2002). 
-, ed., The Occult in Russian and Soviet Culture (Ithaca, London: Cornell University Press, 1997).

Rosov Vladimir, Nikolai Rerikh: Vestnik Zvenigoroda. Ékspeditsii N.K. Rerikha po okrainam pustyni Gobi. Kniga 1: Velikii plan (St. Petersburg: Aleteiia, 2002), Kniga 2: Novaia strana (St. Petersburg, Moscow: Aleteiia, Ariavarta, 2004).

Rovner, Arkadii, Vspominaia sebia. Kniga o druz'iakh i sputnikakh zhizni (Penza 2010). Rozin, Vadim, Ezotericheskii mir. Semantika sakral'nogo teksta (Moscow: URSS, 2002).

Ryan, William F., The Bathhouse at Midnight. Magic in Russia (University Park, Pa., 1999).

-, "Magic and Divination: Old Russian Sources," In: Bernice G. Rosenthal, ed., The Occult in Russian and Soviet Culture (Ithaca, London: Cornell University Press, 1997), 35-58.

Sarkisyanz, Emanuel, "Communism and Lamaist Utopianism in Central Asia," Review of Politics, 20 (1958), 4, 623-633.

-, Rußland und der Messianismus des Orients (Tuebingen: Mohr, 1955).

—, "Milleniarism in the Soviet Revolution," Filosofskii vek. Al'manakh. Vyp. 13: T.V. Artem'eva, M.I. Mikeshin, eds., Rossiiskaia utopiia épokhi Prosveshcheniia i tradicii mirovogo utopizma (St. Petersburg: Sankt-Peterburgskii Tsentr istorii idei, 2000), 307-319.

Savelli, Dany, ed., Présence du bouddhisme en Russie, Slavica Occitania no. 21, Toulouse, 2005.

Schamanen Sibiriens. Magier, Mittler, Heiler, ed. Kasten, Erich (Stuttgart: Reimer, 2009).

Sdobnov, V.V., Russkaia literaturnaia demonologiia: ètapy razvitiia $i$ tvorcheskogo osmysleniia (Tver', 2008).

Sedgwick, Mark, Against the Modern World: Traditionalism and the Secret Intellectual History of the Twentieth Century (New York: Oxford University Press, 2004).

Serkov, Andrei, Istoriia russkogo masonstva, 3 vols. (St. Petersburg: Izd. N.I. Novikova, 2009).

—, Russkoe masonstvo 1731-2000. Éntsiklopedicheskii slovar' (Moscow: ROSSPÉN, 2001).

Setzer, Heinz, "Die Bedeutung der Energielehre für die Literaturkonzeption Maksim Gor'kijs nach der ersten russischen Revolution,” Die Welt der Slawen 25 (1980), 394-427.

Shaglanova, Ol'ga; Konagaia, Yuki, Annotirovannyi katalog arkhivnykh materialov po buriatskomu shamanizmu (Osaka: National Ethnological Museum of Japan, 2009).

Shakhnovich, Mikhail, Sovremennaia mistika v svete nauki (Moscow: Nauka, 1965).

-, Mistika pered sudom nauki (Moscow: Znanie, 1970).

—, Peterburgskie mistiki (St. Petersburg: Nevskii glashatai, 1996).

-, Primety vernye i suevernye (Leningrad, 1984).

-, Sotsial'nye korni spiritizma (Moscow, 1931). 
Shamanizm narodov Sibiri. Etnograficheskie materialy XVIII-XX vekov. Khrestomatiia. Sostavitel' Tatiana Yu. Sem (St. Petersburg, 2006).

Shaumian, Tatiana, Tibet: The Great Game and Tsarist Russia (Oxford: Oxford University Press, 2000).

Shekhovtsov, Anton, “Aleksandr Dugin's Neo-Eurasianism: The New Right à la Russe," Religion Compass 3/4 (2009), 697-716.

Shevkunov, Georgii, Pravoslavnaia tserkov ob èkstrasensakh, NLO, teletseliteliakh $i$ okkul'tnykh iavlieniiakh (Moscow: Izd. Donskogo monastyria, 1992).

Shishkin, Oleg, Bitva za Gimalai: NKVD - magiia i shpionazh (Moscow: Olma-Press, 1999, $\left.{ }^{2} 2000\right)$.

—, Krasnyi Frankenshtein. Sekretnye èksperimenty Kremlia (Moscow: Ul'tra-Kul'tura, 2003).

Shnirel'man, Viktor, ed., Neoiazychestvo na prostorakh Evrazii (Moscow: BibleiskoBogoslovskii Institut Sv. Apostola Andreia, 2001).

Siddiqi, Asif A., "Imagining the Cosmos: Utopians, Mystics, and the Popular Culture of Spaceflight in Revolutionary Russia," Osiris, 23 (2008), 268-271.

-, The Red Rockets' Glare: Spaceflight and the Soviet Imagination, 1857-1957 (Cambridge: Cambridge University Press, 2010).

Sidorov, Valentin, “Sem’ dnej v Gimalaiakh,” Moskva 1982, no. 8, 3-99.

Siikala, Anna-Leena, The Rite Technique of Siberian Shaman (Helsinki: Suomalainen Tiedeakatemia, 1978).

Sinelina, Iuliia, Izmenenie religioznosti naseleniia Rossii. Pravoslavnye $i$ musulmane. Suevernoe povedenie rossiian (Moscow: Nauka, 2006).

Snelling, John, Buddhism in Russia: The Story of Agvan Dorjiev Lhasa's Emissary to the Tsar (Shaftsbury, Dorset; Rockport, Ma.: Element Books, 1993).

Sokolov, Boris, Vol'f Messing (Moscow: Zhizn' zamechatel'nykh liudei, 2010).

Spence, Richard, “The 'Bloody' Baron von Ungern-Sternberg - Madman or Mystic?," New Dawn, no. 108, 2008.

-, "Red Star Over Shambhala. Soviet, British and American Intelligence and the Search for Lost Civilisation in Central Asia," New Dawn, no. 109, 2008.

Stasulane, Anita, Theosophy and Culture: Nicholas Roerich (Rome: Pontificia Università Gregoriana, 2005).

Tseizer, Elena L., Psi-fenomeny kak proiavlenie psikhicheskoi real'nosti (Barnaul: Izd. Altaiskogo Universiteta, 2006).

"Unio mistica. Beseda Viktora Kulle s Iuriem Mamleevym i Sergeem Ryabovym", Literaturnoe obozrenie 1998 , no. $268,68-74$.

Vanchu, Anthony, “Technology as Esoteric Cosmology in Early Soviet Literature,” In: Bernice G. Rosenthal, ed., The Occult in Russian and Soviet Culture (Ithaca, London: Cornell University Press, 1997), 203-222.

Vasil'ev, Leonid: Experiments in Mental Suggestion (Church Crookham: Institute for the Study of Mental Images, 1963). 
Vilenskaia, Larisa, "Chudesa i tragedii chernogo iashchika. Chto proiskhodit s parapsikhologiei v SSSR," Grani 40 (1985), 253-275.

Vinitsky, Ilya, Ghostly Paradoxes: Modern Spiritualism and Russian Culture in the Age of Realism (Toronto, 2008).

-, "Table Talks: The Spiritualist Controversy of the 1870s and Dostoevsky," Russian Review 67 (2008), 88-109.

-, "Dukhovnyi kartser: Nikolai Leskov i 'Palata nomer 6' Antona Chekhova," Voprosy literatury 4, 2006, 311-322.

Volkova, A.N., Fenomenologiia misticheskogo opyta (St. Petersburg: Uchebnometodicheskii tsentr komiteta po obrazovaniiu, 2002).

Waldberg, Michael, Gurdjieff. An Approach to His Ideas (London, 1989).

Waldenfels, Ernst von, Nikolai Roerich. Kunst, Macht und Okkultismus (Berlin: Osburg, 2011).

Warth, Robert D., "Before Rasputin: Piety and the Occult at the Court of Nicholas II." The Historian: A Journal of History, 47, May 1985, S. 323-337.

Washton-Long, Rose Carol, "Expressionists, Abstraction, and the Search for Utopia in Germany," In: Maurice Tuchman, et al., eds., The Spiritual in Art: Abstract Painting 1890-1985 (Los Angeles: County Museum of Art and Abbeville Press, 1986), 201207.

Watts, Harriet, “Arp, Kandinsky, and the Legacy of Jacob Boehme," In: Maurice Tuchman, et al., eds., The Spiritual in Art: Abstract Painting 1890-1985 (Los Angeles: County Museum of Art and Abbeville Press, 1986), 239-255.

Webb, James, The Harmonious Circle. The Lives and Work of G.I. Gurdjieff, P.D. Ouspensky, and Their Followers (London: Thames and Hudson, 1980).

—, The Occult Establishment (La Salle, Ill.: Open Court, 1976).

-, The Occult Underground (LaSalle, Ill.: Open Court, 1974).

Wellbeloved, Sophia, Gurdjieff. The Key Concepts (London: Routledge, 2003).

Wigzell, Faith, Reading Russian Fortunes (Cambridge: Cambridge University Press, 1998).

Williams, Robert C., "Mysticism and Money: Nicholas Roerich," In: idem, Russian Art and American Money. 1900-1940 (Cambridge, Ma.: Harvard University Press, 1980), 111-148.

-, "Theosophy and the Fourth Dimension: Malevich's Suprematism," In: idem, Artists in Revolution. Portraits of the Russian Avantgarde, 1905-1925. (Bloomington, Ind.: Indiana University Press, 1977), 101-127.

Wünsche, Isabel, Harmonie und Synthese. Die russische Moderne zwischen universellem Anspruch und nationalkultureller Identität (Munich: Fink, 2008).

Young, George M. Jr., “Fedorov's Transformations of the Occult,” In: Bernice G. Rosenthal, ed., The Occult in Russian and Soviet Culture (Ithaca, London: Cornell University Press, 1997), 171-183.

Zdorovets, Ia.; Mukhin, A., eds., Konfessii i sekty v Rossii. Religioznaia, politicheskaia $i$ èkonomicheskaia deiatel'nost' (Moscow: Tsentr politicheskoi informatsii, 2005). 


\section{Bibliography}

Zhemchuzhnikova, M.N., „Vospominaniia o Moskovskom antroposofskom obshchestve (1917-1923),“Minuvshee. Istoricheskii al'manakh, vyp. 6 (Moscow, 1992), 7-53.

Zhuk, Sergei, Russia's Lost Reformation. Peasants, Millenarism, and Radical Sects in Southern Russia and Ukraine 1830-1917 (Washington, 2004).

Zhukovskaia, Natalia, "Buddizm i shamanizm kak faktory formirovaniia buriatskogo mentaliteta," In: Religiia $v$ istorii $i$ kul'ture mongoloiazychnykh narodov Rossii (Moscow: Vostochnaia literatura, 2008), 9-36.

Znamenski, Andrei, Red Shambhala: Magic, Prophecy, and Geopolitics in the Heart of Asia (Wheaton, Ill.: Quest Books, 2011). 


\section{ABOUT THE CONTRIBUTORS}

Birgit Menzel is Professor of Russian Literature and Culture and Chair of the Slavic Division at the Johannes-Gutenberg University Mainz, Germany. Her relevant publications include Civil War on Words. Russian Literary Criticism of the Perestroika (in German: Bürgerkrieg um Worte, Cologne 2001, St. Petersburg, 2006); Reading for Entertainment in Contemporary Russia. Post-Soviet Popular Literature in Historical Perspective, ed. with Stephen Lovell (Munich, 2005); “The Occult Revival in Russia Today and its Impact on Literature" (Harriman Review, 2007).

Michael Hagemeister is an independent historian. He has published widely on Russian philosophy and history. Together with Boris Groys he edited a book on biopolitical utopias in Russia in the early $20^{\text {th }}$ century (Die Neue Menschheit. Biopolitische Utopien in Russland zu Beginn des zwanzigsten Jahrhunderts, Frankfurt a.M., 2005). In his current research he concentrates on the origins of the "Protocols of the Elders of Zion" and the Russian religious and apocalyptic writer Sergei Nilus. Hagemeister was employed at the Universities of Marburg, Bochum, Basel, Innsbruck, Frankfurt (Oder), Berlin, and Munich.

Bernice Glatzer Rosenthal is Professor of Russian/Soviet History and European Intellectual History at Fordham University, Bronx, New York. Her relevant publications include: New Myth, New World: From Nietzsche to Stalinism (University Park, PA, 2002, 2004); The Occult in Russian and Soviet Culture (Ithaca, 1997), editor and contributor; Nietzsche and Soviet Culture, Cambridge, 1994, 2010) editor; Nietzsche in Russia (Princeton, NJ, 1986) editor and contributor; A Revolution of the Spirit: Crisis of Values in Russia, 1890-1924 (New York, 1990, with Martha Bohachevsky Chomiak) coeditor and co-author; and D. S. Merezhkovsky and the Silver Age: The Development of a Revolutionary Mentality (The Hague, 1975).

Marina Aptekman is Assistant Professor of Russian Literature at Hobart and William Smith Colleges in Geneva, NY (with a Ph.D. from Brown University). She is the author of the monograph Jacob's Ladder: Kabbalistic Allegory in Russian Literature (Boston, 2011). Her other publications include articles on problems related to Kabbalah, JudeoMasonic Conspiracy, Magic Science, and Russian Literature. 
Demyan Belyaev is research fellow at the Territory, Culture and Development Research Centre (TERCUD) of the Lusophone University of Humanities and Technologies (ULHT) in Lisbon. He holds a Ph.D. in human geography from the University of Heidelberg, a Master's in public policy from Harvard University and a B.A. in international relations and European studies from the State University of St. Petersburg. His dissertation was entitled The Geography of Alternative Religiosity in Russia. The Role of Heterodox Knowledge after the Collapse of the Communist System (Heidelberg, 2008, in German). His current research interests are in the area of social and cultural geography.

Konstantin Y. Burmistrov is Research Assistant in Jewish Philosophy and Mysticism at the Institute of Philosophy, Russian Academy of Sciences, and Chief Librarian of the Oriental Department, The Russian State Library. The main fields of his research are: the place of Kabbalah in Russian culture; Jewish Kabbalah and Jewish and Christian alchemy; Kabbalah and freemasonry; European Christian Kabbalah of the seventeenth century; the problem of name and language in Jewish and Christian mysticism. He is the author of the monograph For He is like a Refiner's Fire: Kabbalah and Alchemy (Moscow, 2009, in Russian) and more than 40 articles on the history of Christian and Jewish Kabbalah.

Boris Falikov is Associate Professor of Religious Studies at the Russian State University for the Humanities (Moscow) and columnist for gazeta.ru. He got his Ph.D. at the Institute of American and Canadian Studies, Russian Academy of Sciences, on Buddhist and Hindu based movements in the U.S. (1987) and researched modern Hinduism at the Institute of Oriental Studies, Russian Academy of Sciences. He is the author of several books on contemporary religion such as Neo-Hinduism and Western Culture (Moscow, 1994, in Russian) and Cults and Culture (Moscow, 2007, in Russian).

Leonid Heller is Honorary Professor of Russian Literature at Lausanne University (Switzerland). His publications include Vselennaia za predelom dogmy (London, 1985) and, together with Michel Niqueux, A History of Utopia in Russia (Paris, 1995, in French; Bietigheim-Bissingen, 2003, in German; St. Petersburg, 2003, in Russian). He has published widely on Russian and Soviet Science-Fiction and utopian genres, Socialist Realism, the literary and artistic Avant-garde, libertarian and libertine traditions, and edited several anthologies and collected volumes. Recent subjects include representations of exoticism and animal in the Russian culture.

Jeffrey J. Kripal holds the J. Newton Rayzor Chair in Philosophy and Religious Thought at Rice University, where he is also the Chair of the Department of Religious Studies. He is the author of Mutants and Mystics: Science Fiction, Superhero Comics, and the Para- 
normal (Chicago, 2011); Authors of the Impossible: The Paranormal and the Sacred (Chicago, 2010); Esalen: America and the Religion of No Religion (Chicago, 2007); The Serpent's Gift: Gnostic Reflections on the Study of Religion (Chicago, 2007); Roads of Excess, Palaces of Wisdom: Eroticism and Reflexivity in the Study of Mysticism (Chicago, 2001); Kali's Child: The Mystical and the Erotic in the Life and Teachings of Ramakrishna (Chicago, 1995). His present areas of interest include the revisioning and renewal of the comparative method, the comparative erotics of mystical literature, American countercultural translations of Asian religious traditions, and the history of Western esotericism from ancient Gnosticism to the New Age.

Marlène Laruelle is Research Professor at the Institute for European, Russian and Eurasian Studies, The Elliott School of International Affairs, George Washington University. In Paris, she is a associate scholar at Sciences Po (Institute of Political Studies), and at the French Center for Russian, Caucasian and East-European Studies at the School of Advanced Social Sciences Studies. Her main areas of expertise are political philosophy, nation and nationalism, citizenship and migration in Soviet and post-Soviet Russia and Central Asia. Her English-language publications include Russian Eurasianism: An Ideology of Empire (Washington, DC, 2008), and In the Name of the Nation: Nationalism and Politics in Contemporary Russia (Basingstoke, 2009).

Julia Mannherz is Lecturer and a tutorial fellow in Modern History at Oriel College, University of Oxford. Her research interests are in Russian history, particularly in Russia's cultural history of the nineteenth and twentieth centuries. Her book Modern Occultism in Fin-de-Siècle Russia will be published by Northern Illinois University Press in 2012.

John McCannon teaches Russian and European History at Southern New Hampshire University. He has written about Russian exploration, aviation, and culture. His publications include Red Arctic: Polar Exploration and the Myth of the North in the Soviet Union, 1932-1939 (New York, 1998); and several articles about Nicholas Roerich and related topics. He is currently completing a biography of Nicholas Roerich.

Markus Osterrieder is an independent historian, lecturer and writer. He graduated in East European History, Slavonic Studies and Political Science at the University of $\mathrm{Mu}-$ nich and was a research fellow of the Osteuropa Institut Munich, specializing in Russian, Ukrainian and Polish history. He has published and lectured on a wide range of topics related also to the History of Esotericism and lectured in many European countries and in Russia. His monographs include Sonnenkreuz und Lebensbaum: Irland, der Schwarzmeer-Raum und die Christianisierung der Europäischen Mitte (Stuttgart, 1995/ 2010); Durchlichtung der Welt: Altiranische Geschichte (Kassel, 2008). 
Matthias Schwartz is a research fellow and lecturer for East-European Studies and Comparative Literature at the Freie Universität Berlin. His research interests include the interplay of science and arts in Russia, Soviet and post-Soviet popular culture; Polish, Russian and Ukrainian literature in a globalized world. His publications include Die Spur des Sputnik. Kulturhistorische Expeditionen ins kosmische Zeitalter (ed. with Igor Polianski, Berlin/New York, 2009), Die Erfindung des Kosmos. Zur sowjetischen Science Fiction und populärwissenschaftlichen Publizistik vom Sputnikflug bis zum Ende der Tauwetterzeit (Frankfurt a. M., 2003). His book Aufbruch in andere Welten. Sowjetische Abenteuerliteratur und Science Fiction 1917-1957 will be published in Vienna, 2012.

Mark Sedgwick is Professor in the department of Culture and Society at Aarhus University, Denmark. He is the author of the first major academic study of Traditionalism, Against the Modern World: Traditionalism and the Secret Intellectual History of the Twentieth Century (New York, 2004). His recent books include Muhammad Abduh (Oxford, 2011), Islam and Muslims (Boston, 2006) and Saints and Sons: The Making and Remaking of the Rashidi Ahmadi Sufi Order, 1799-2000 (Leiden, 2005). He also published articles on sectarianism and on terrorism.

Oleg Shishkin is a playwright and independent scholar in Moscow, who has specialized in topics related to the Occult in Early Soviet time. Among his publications are Fight for the Himalayas. The NKVD: Magic and Espionage (Moscow 1999/2003, in Russian), Kill Rasputin (Moscow 2000, in Russian); Red Frankenstein (Moscow 2003, in Russian), and Dawn of the Magi. Gurdjieff and Others (Moscow 2005, in Russian). He is monitoring the programs Enigmas of history (Zagadki istorii) and The Magic of Cinema (Magiia kino) on the TV-Kanal Kul'tura.

Natalia Zhukovskaia is Professor and Chairman of the Center of Asian and Pacific Studies, Russian Academy of Sciences. As a historian and a cultural anthropologist, she is an expert in the Mongolian-speaking nomads in the steppes of Eurasia, specializing in religious traditions, Shamanism and Buddhism. Zhukovskaia has spent numerous field work seasons, mainly in Central Asia (Mongolia, Buriatia, Kalmykia). She is the author of seven books and more than 200 scholarly and popular scientific articles. 
ccult and esoteric ideas became deeply embedded in Russian culture long before the Bolshevik Revolution. After the Revolution, occult ideas were manifested in literature, the humanities and the sciences as well. Although the Soviet government discouraged and eventually prohibited metaphysical speculation, that same government used the Occult for its own purposes and even funded research on it. In Stalin's time, occultism disappeared from public view, but it revived clandestinely in the post-Stalin Thaw and became a truly popular phenomenon in post-Soviet Russia. From cosmism to shamanism, from space exploration to Kabbalah, from neo-paganism to science fiction, the field is wide. Everyone interested in the occult and esoteric will appreciate this book, because it documents their continued importance in Russia and raises new issues for research and discussion.

Worldwide Distributor:

\section{KUBON \& SAGNER}

Servicing libraries since 1947

ISBN: 978-3-86688-197-6

ISBN (eBooK): 978-3-86688-198-3

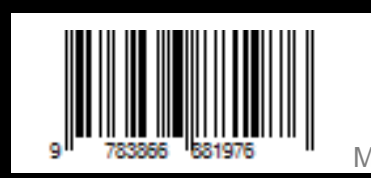

